

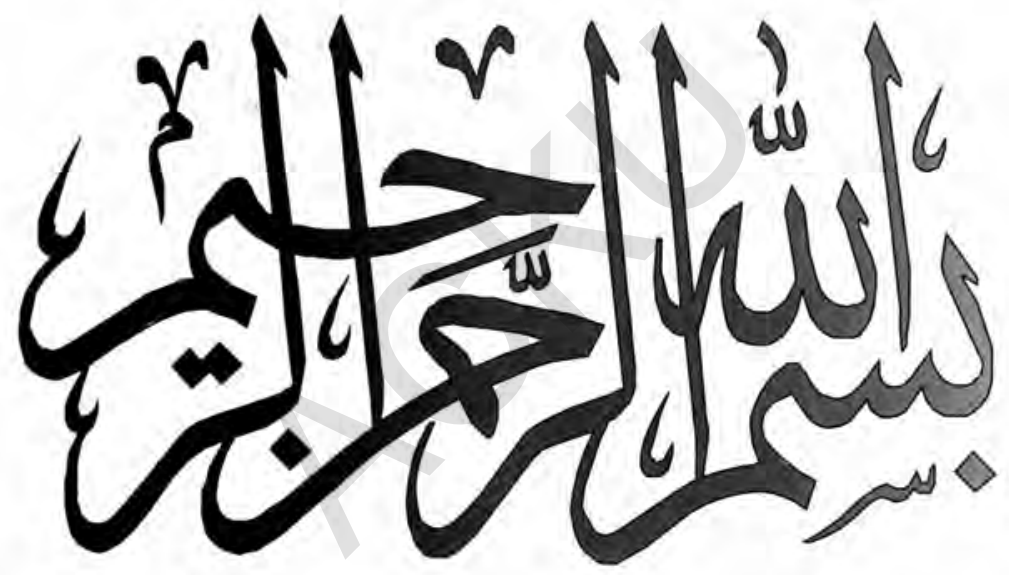


a

هي

$1 \% 91 / 15 / 10$

د وردكو مشاهير

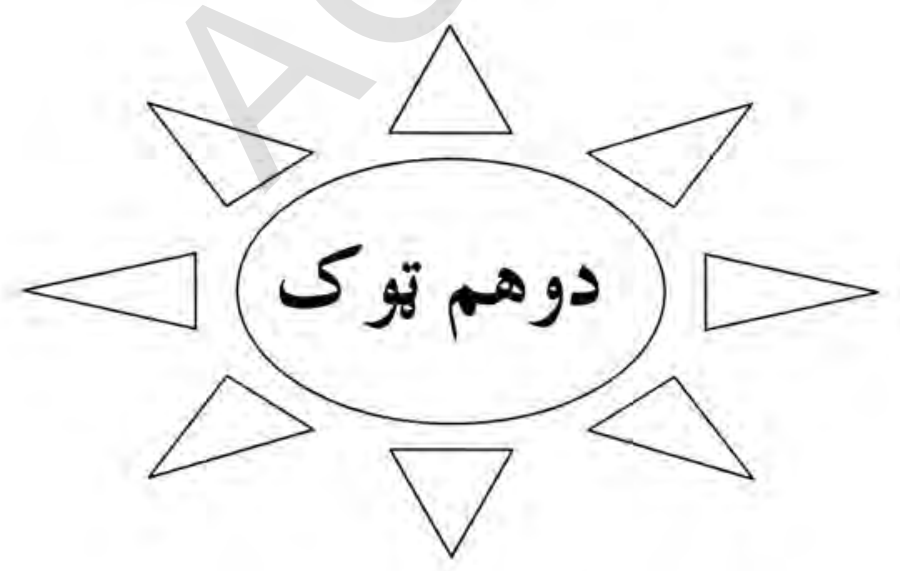




$$
\begin{aligned}
& \text { دكتاب مشخصات } \\
& \text { دوردكو مشاهير } \\
& \text { حيات الله حليم } \\
& \text { دوهم توكى } \\
& \text { حليم } \\
& \text { |rq| } \\
& \text {.... } \\
& \text { د كتاب نوم: } \\
& \text { ليكوال: } \\
& \text { د كتاب لرئ: } \\
& \text { خيروونكى: } \\
& \text { د جاب كال: } \\
& \text { د بحاب شميره: } \\
& \text { نقيب الله همت وردكى نئ } \\
& \text { ديزاين: } \\
& \text { بهير جاب خونه } \\
& \text { جاب: }
\end{aligned}
$$

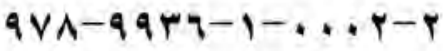

$$
\begin{aligned}
& \text { ISBN } \\
& \text { حيات الله حليم: Vq9F\%.vFV. } \\
& \text { 2 إريكو شميره: }
\end{aligned}
$$


منكئه

,

$\Delta$

ir

$+1$

ro

rA

is

$\Delta q$

vT

A.

Ar

(1)

47

1.

1.

it

17.

irt

$1+9$

irt

ITV
سرليك

احسـان الله مايار.

احسان الله آرينزى الهياري

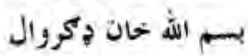

بسم الله خحان ـ ملكى

تأج محمد خان - بـ وزير جمال الدين خان ـ ق قوماندان

جمعه خان همدرد - والي حسان حبيب الله مايار - خحدابي خحمثيكار رحت الله رؤوفى ـ ـ والي ربسول داد خحان - مستوفى رؤى زرجان بها - رييس زمرك (ياسر) - ملي مبارز سخيداد فا يز - وزير سيد عبد الغنى خحان ـ فرقه مثير سبع جان شيرز اده - سناتور سيد كمال خان - ملدير شير جان خحان - قومي مشر شرين شجاعت مولوي - مولايتي امير

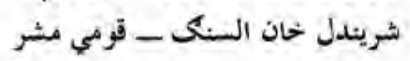

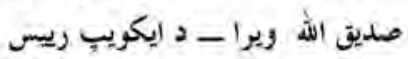

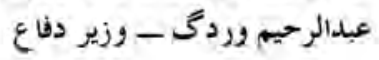




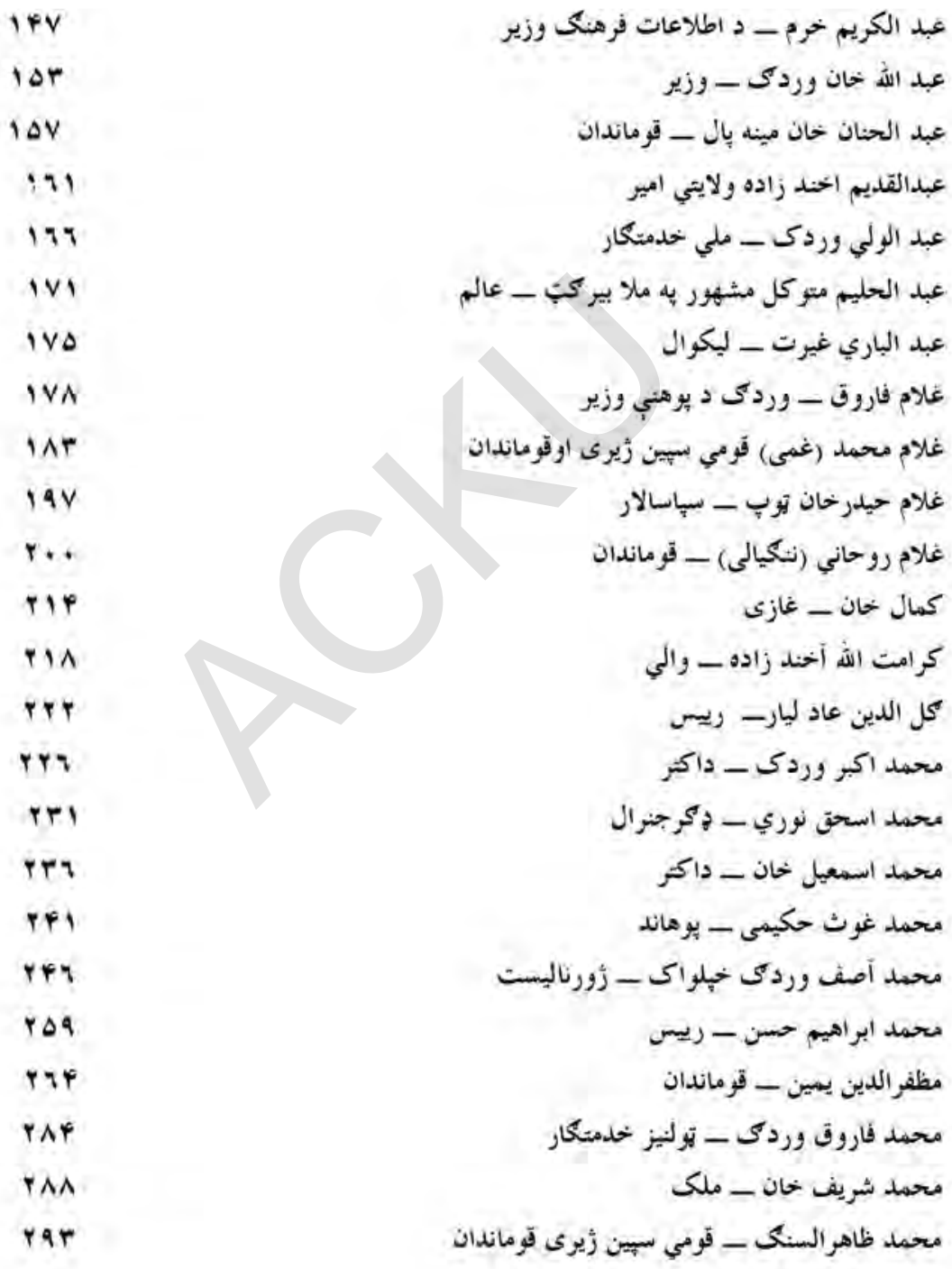


रav

$r .1$

$r+9$

$+, 4$

rir

riv

TT.

pry

rw.

PrT
محمد حيدرخان (باباحيدر) - قومي سيس زيرى

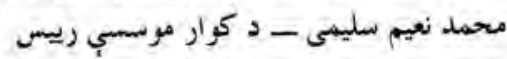
محمد دين - غازي محمد يحيى وردوكى ـ داكتر محسن خان طاهري - وكيل محهد كريم مولوي - دحركت قوماندان نصر اللة - ( نقشبند ) شيــيح الحديث مولنا تور محتد مسجدي _ قو ماندان هميشه كل خحان - - جهادي قوماندان همت بابا - سجياه سالار 


\section{سريزه :}

دوردكو دمشاهيرو لومرى ثوكى جي له جحاب نه را ووت نوله هولوري د غشيو

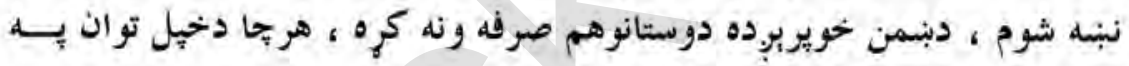

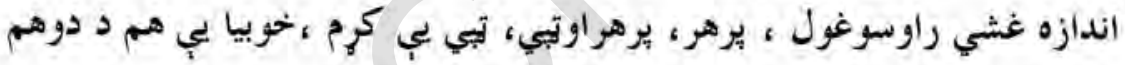

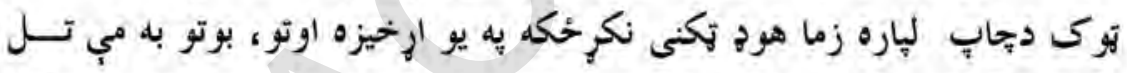

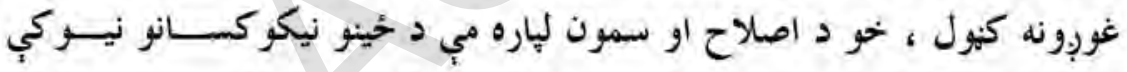

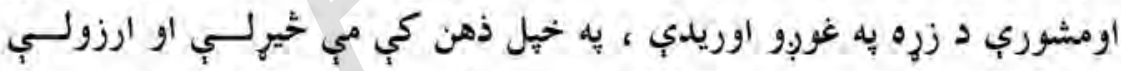

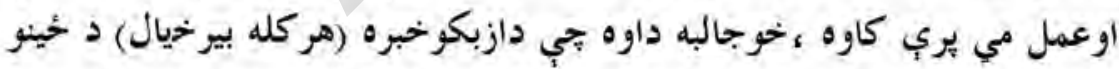

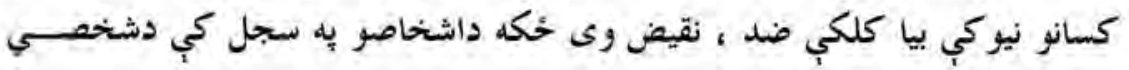

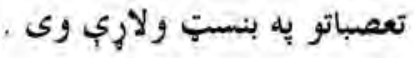

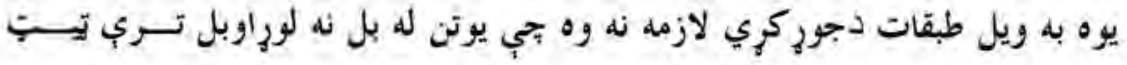
وبنيي بل به ويل هرخه د له خيل خحانه ليكلي (راوي) نلري. 


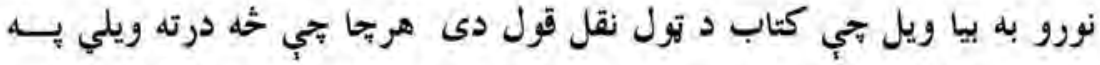

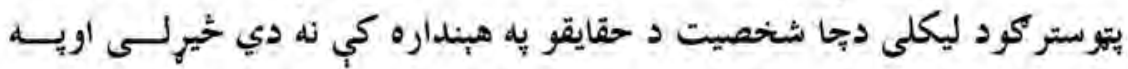

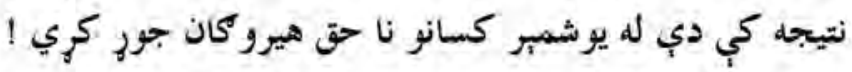

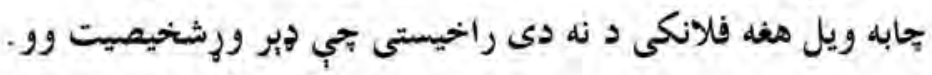

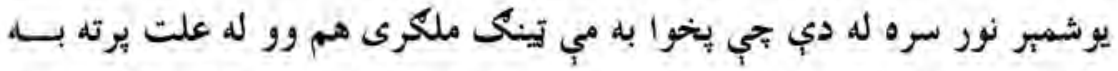

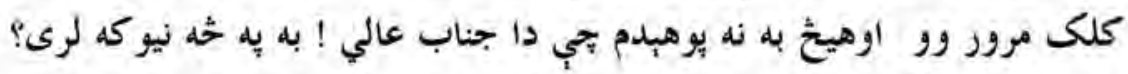

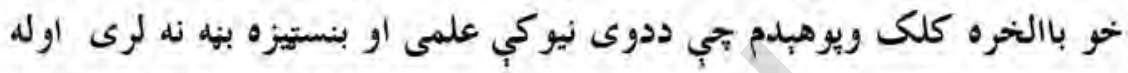

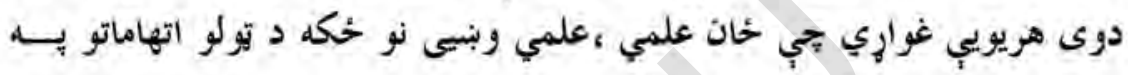

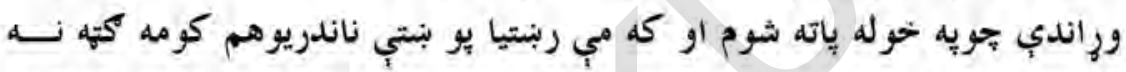

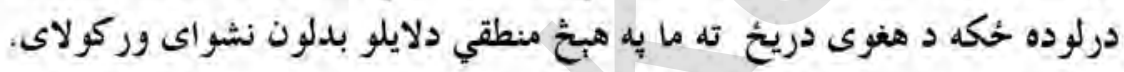

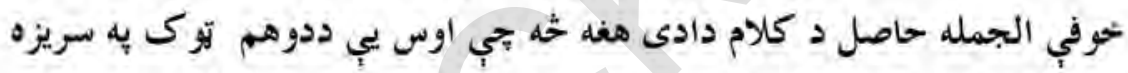

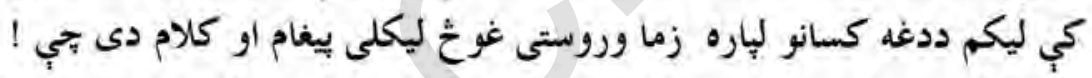

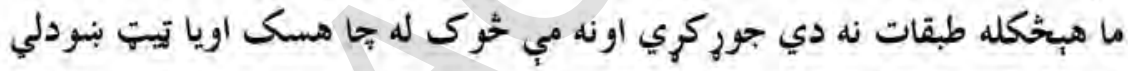

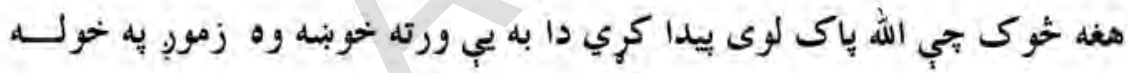

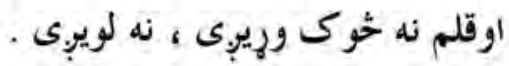

$$
\begin{aligned}
& \text { د ستر شاعر عبدالرحمن بابا به وينا : }
\end{aligned}
$$

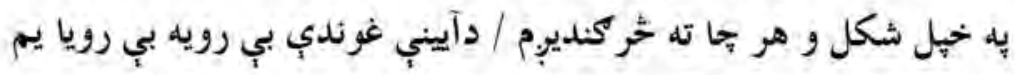

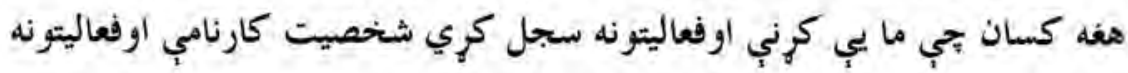

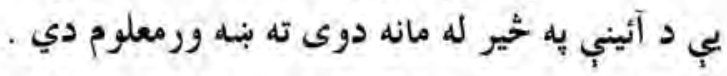

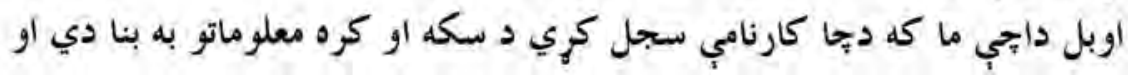

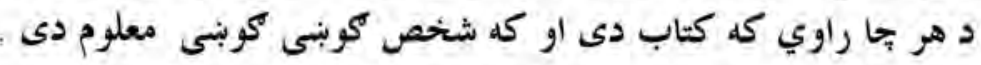




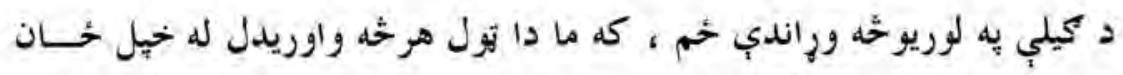

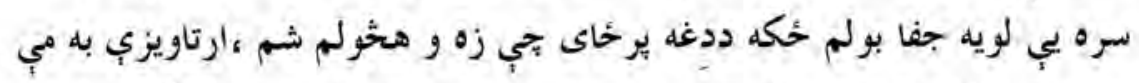

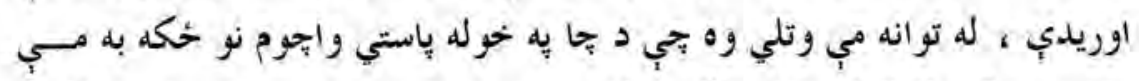

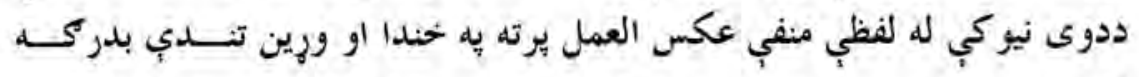

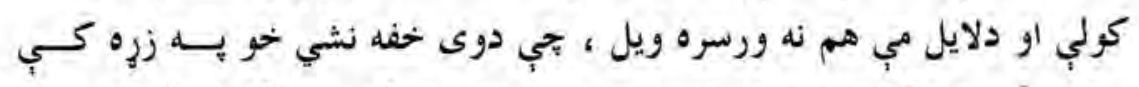

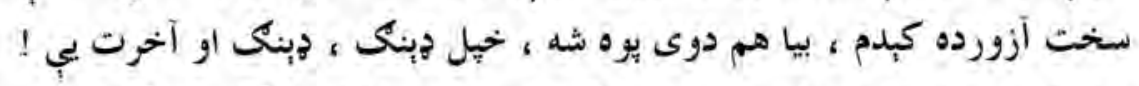

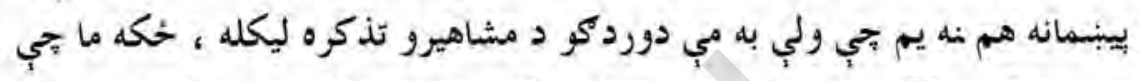

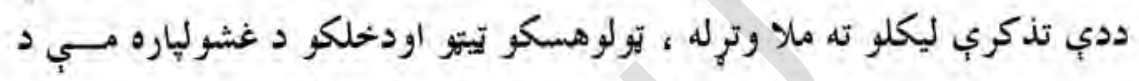

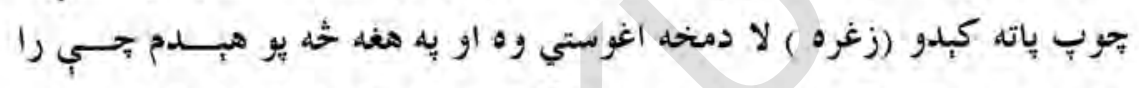

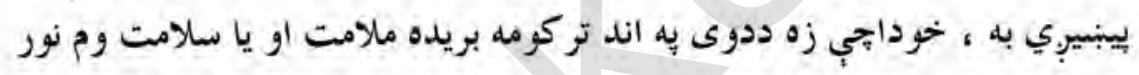

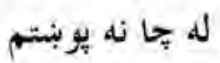

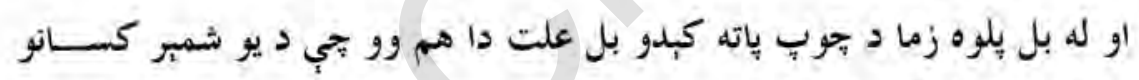

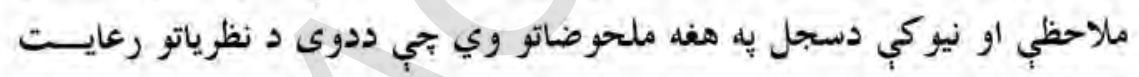

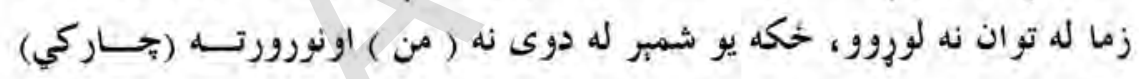

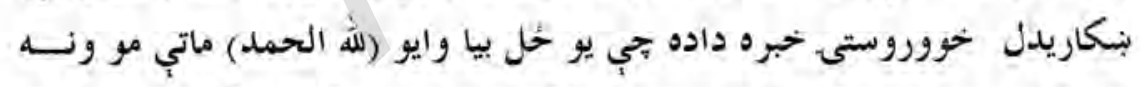

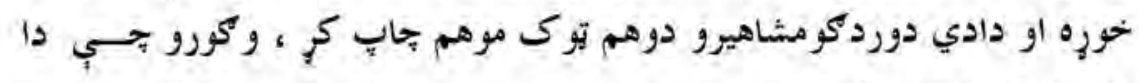

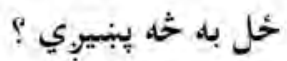

نيك يببن كري ، لويه خدايه ! ( حيات الله حليم ) 



\section{احسان الله - مايار}

احسان الله (مايار) د ورديكود فرهنكي خيرويــ

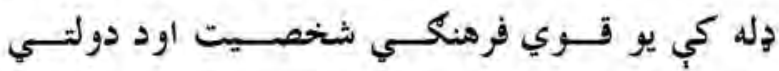

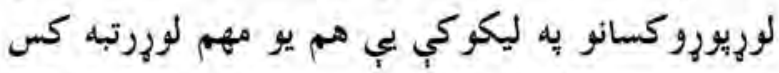

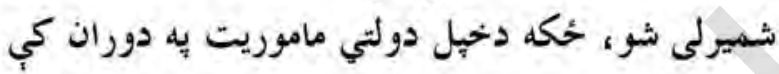

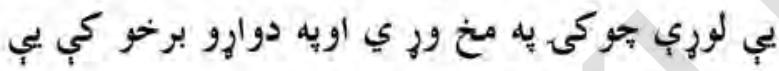

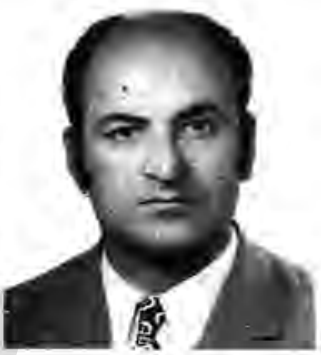

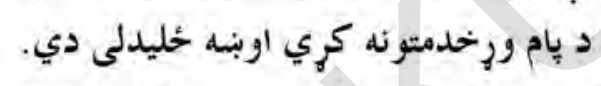

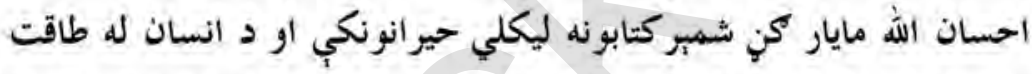

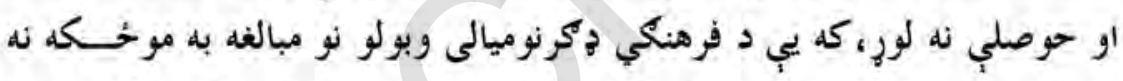

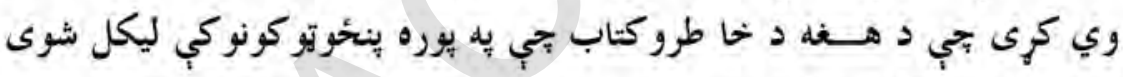

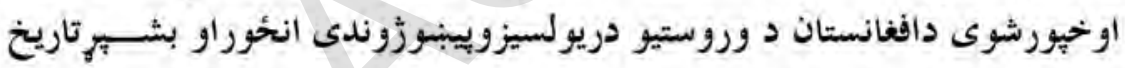

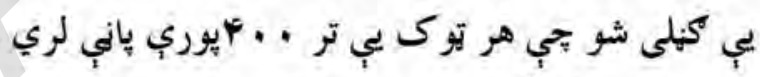

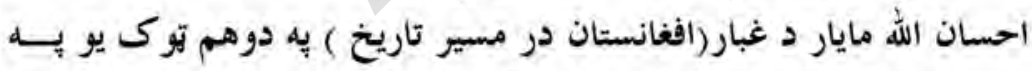

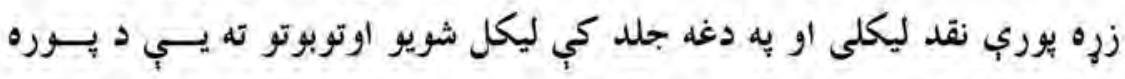

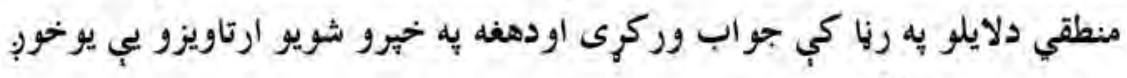
او تاريخي نقد ليكلى دي.

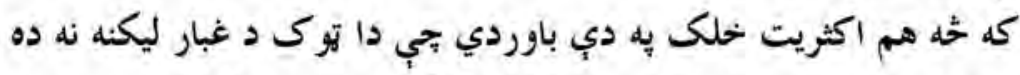

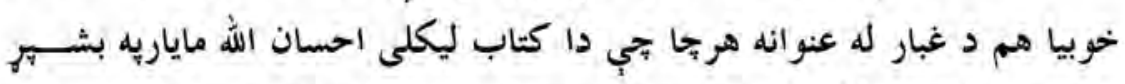

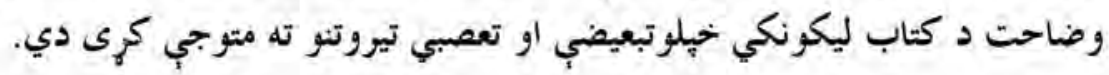


r دوركى مشاهير دوهم توكى

غبارددغه يه خاي جي يبنبي دو وا قيعتونو يه رنبا كي وخيري او يه تـاريخ

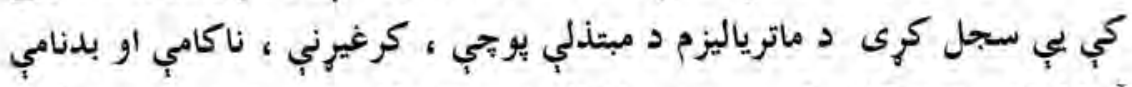

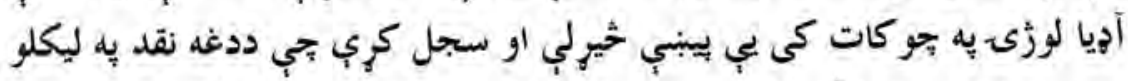

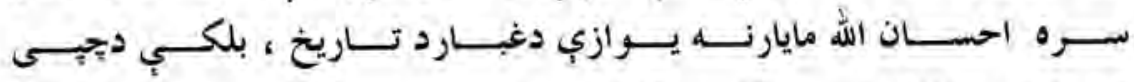
تاريخونويو بيداراوريبنتني نقاد وبولو.

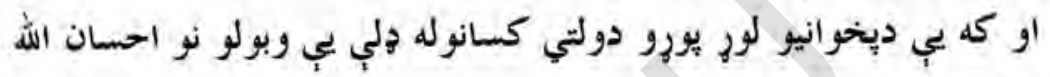

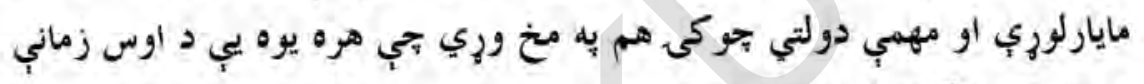

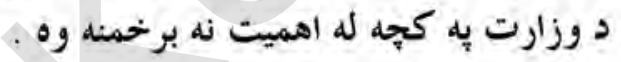

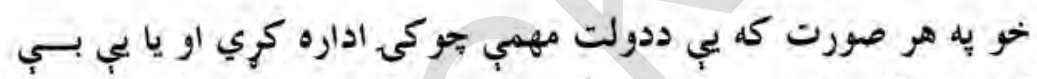

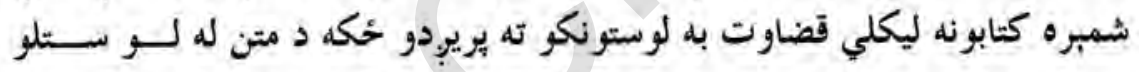

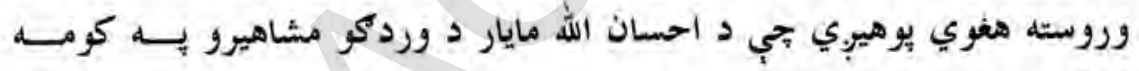
كتيكورى كي حسابيداى شي

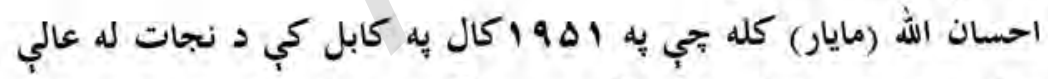

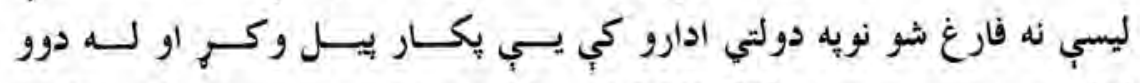

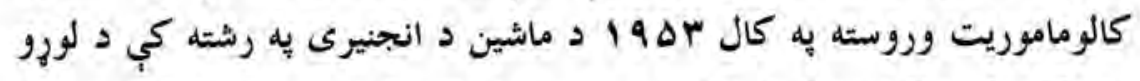

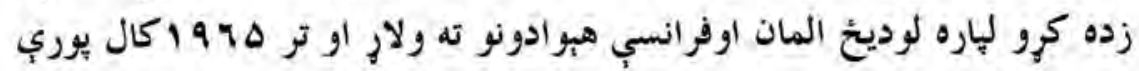

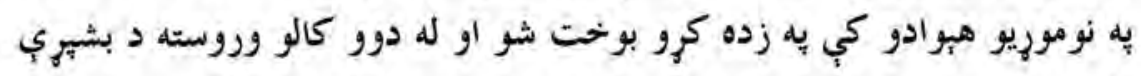

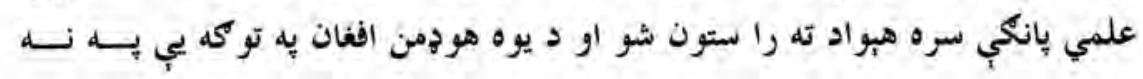

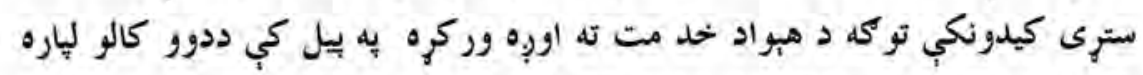

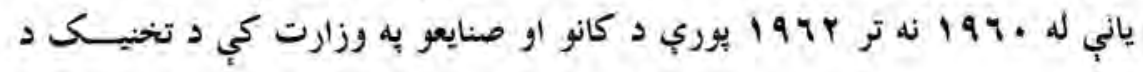




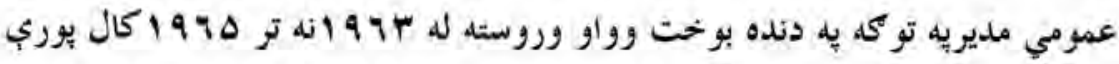

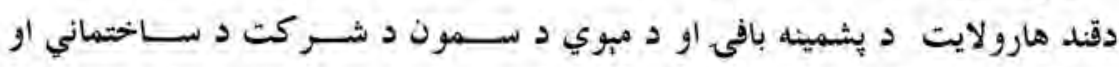

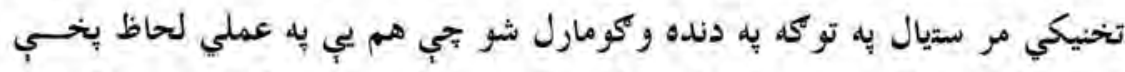

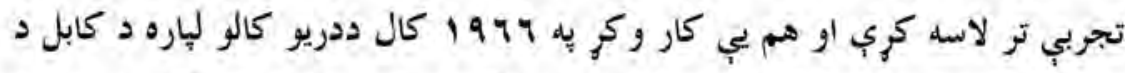

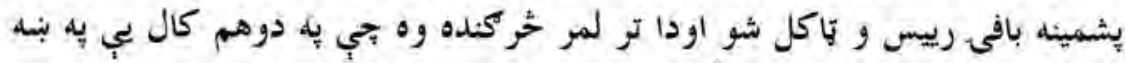
او اعلى كيفيت ددي فافريكي د توليد كجهه دوه برابره كره .

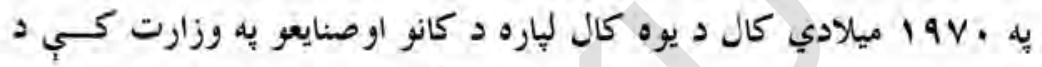

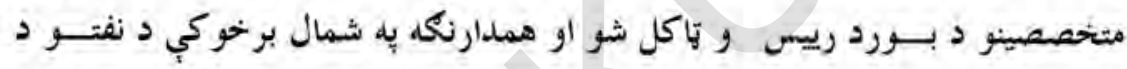
تفحصاتو د مزار شريف د كود برق د همدغه ولايت د نساجى فافريكي ، د غورى د سمنتو يه يروزو كي د ددولت با صلاحيته استازي يه توكه دنده تر سره كره بجي دا وخت د بكر اميود نساجى اود قندهارد ميوي د سمون شركت دو لتي اســتازى هم وو .

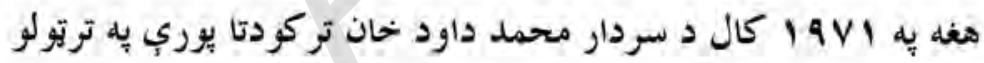

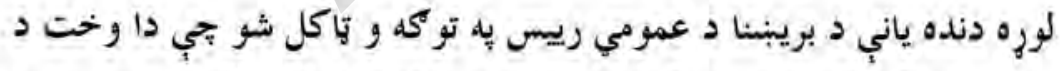

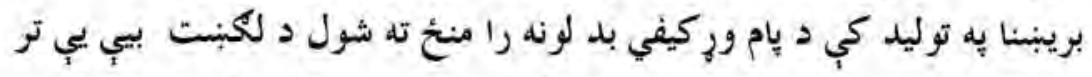
منصفانه كنترول لاند ي راغلي او دجا كور د شيب يه تور تم كي ثياره توي ياته نشو او نه هم د نن حيه شان د بيلونو له خدبروالى كومه كيله اوشكايت لله جا نه

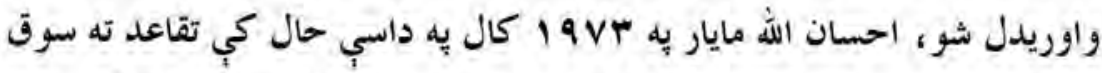

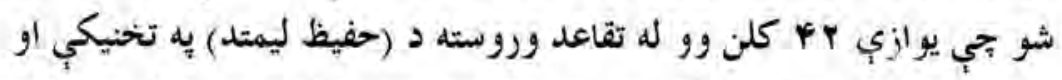
سودا كريز شركت كي د كمونستائوتركودتا يورب يه كار مصروف وو، كله 


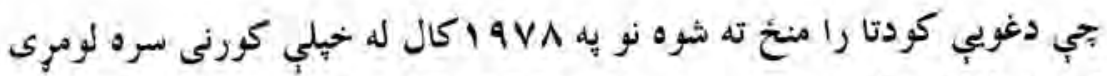

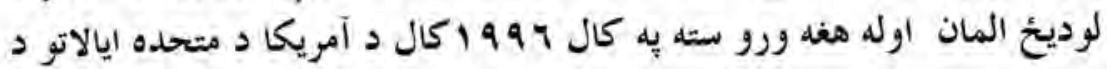

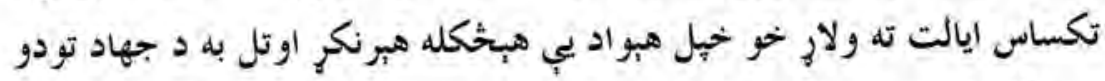

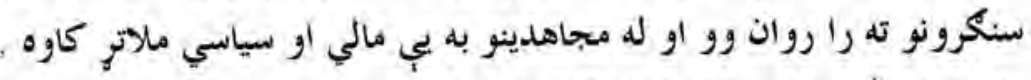

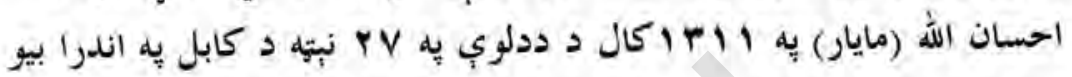

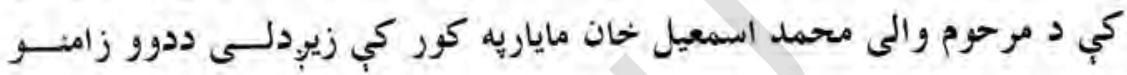
اويوب لور يلار دي. 


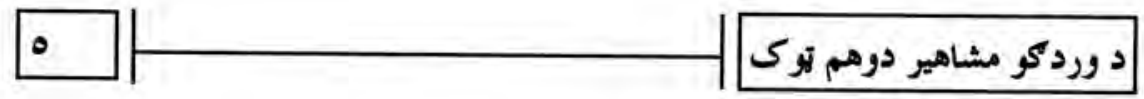

\section{احسان الله (آرينزى)}

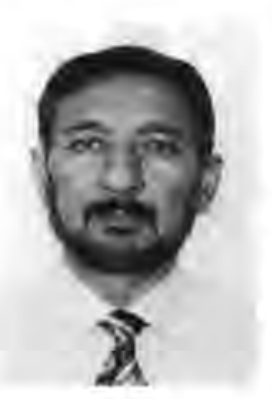

احسان الله آرينزى د افغانستان يو ييرّندل شوى ادبي او

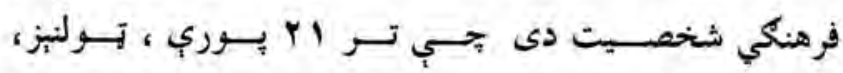

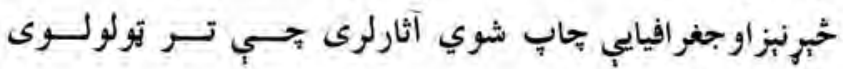

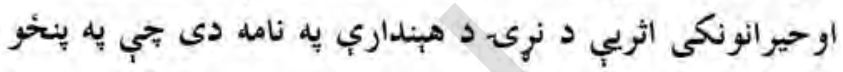

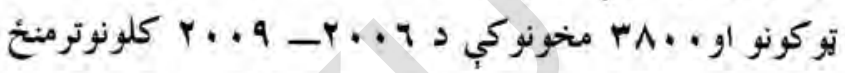

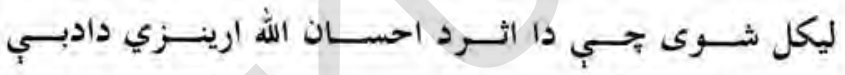
فعاليتونويوترتولولوى حير انونكى اومهم شاهكار كنيلى شو.

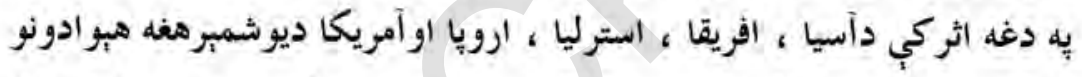

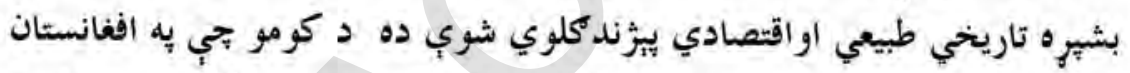

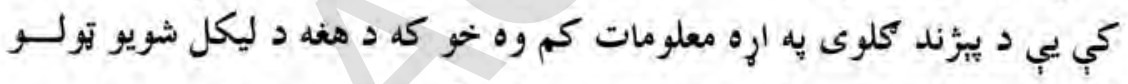

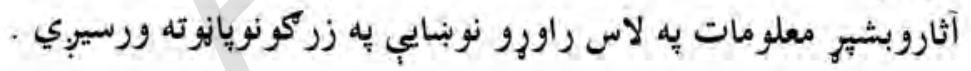

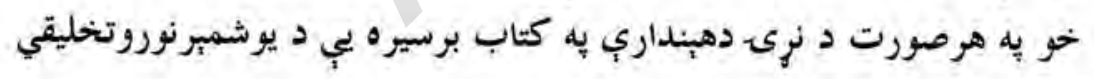
اوخيرنيزو آثارونومونه هم اخلو:

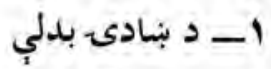

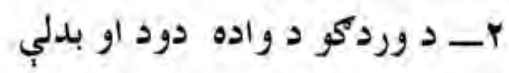

$$
\begin{aligned}
& \text { r- r- شلبدلي تارونه }
\end{aligned}
$$

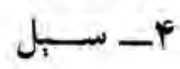

$$
\begin{aligned}
& \text { هـ تند ر } \\
& \text { ل- سري جامي }
\end{aligned}
$$


7

د وردكو مشاهير دوهم تبوكى

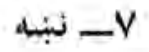

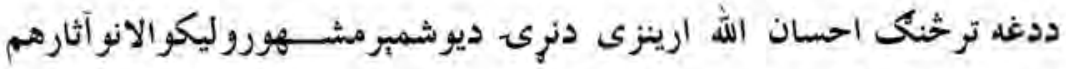

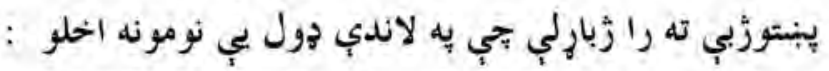

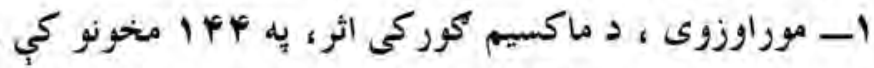

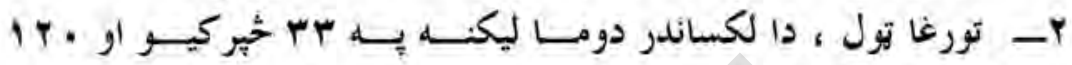

مخمونوكي.

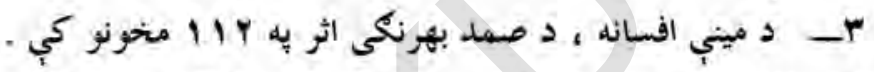

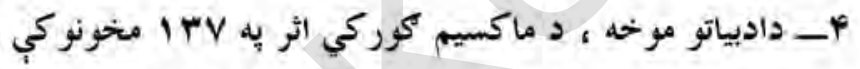

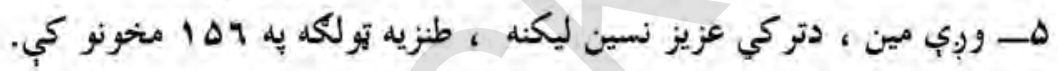

ج- زوندي د وي خلكى ، د مختلفو ليكوالو اثرونه.

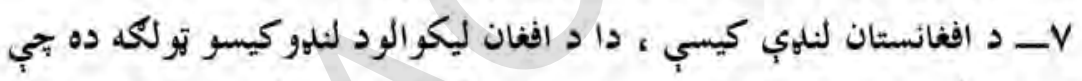

د احسان الله ارينزى لخوا د بنبتر اودرى نه انكليسى ثله ارول شوي ده .

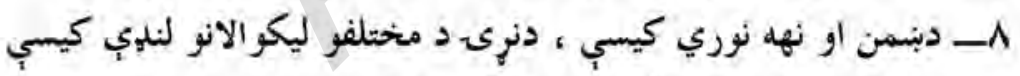

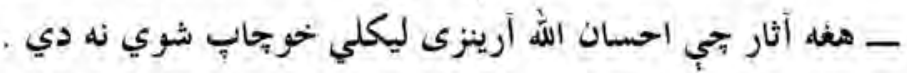

اــ نريو الى تو لني( دنري د لويواوكوجنيوسياسي يوخي اقتصادي اوفرهنكي

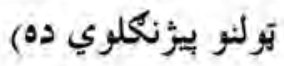

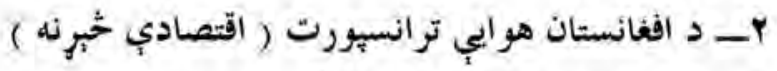

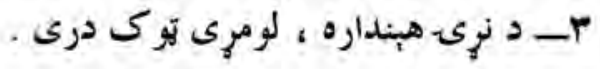

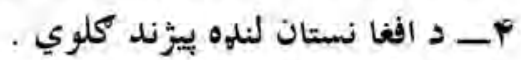

هـ د اسلامي هبو ادونو لنهه يبزّند كلوي . 


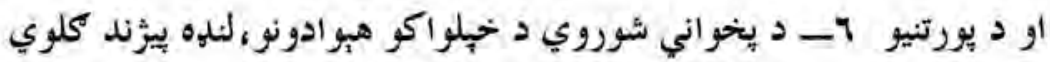

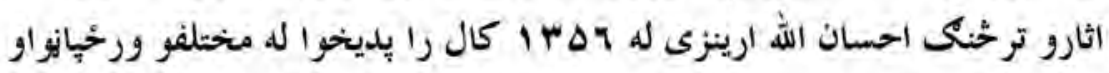

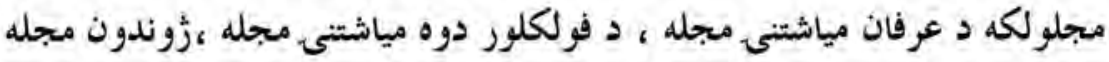

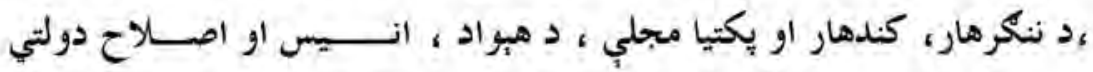

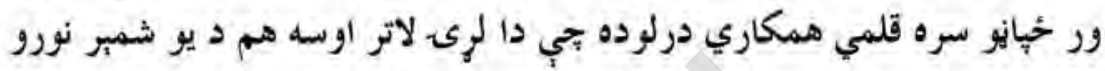

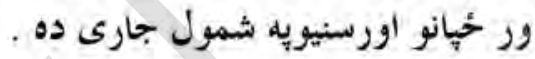

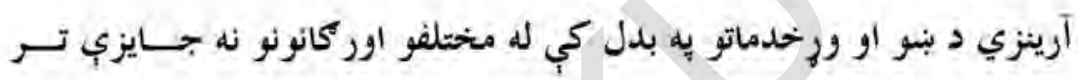

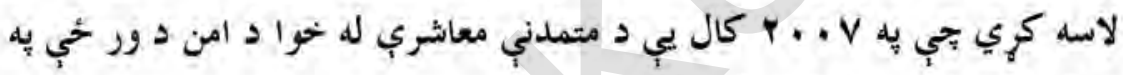

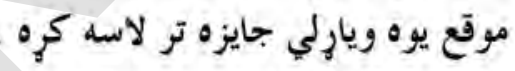

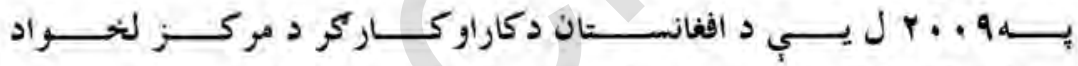

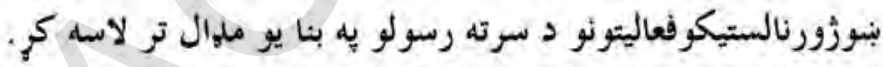

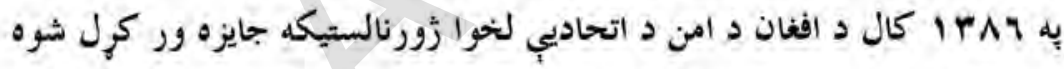

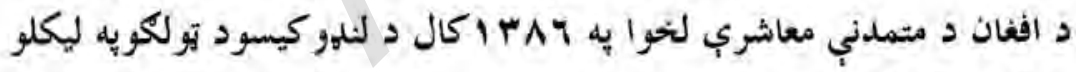
ستاينليك وركرل شو.

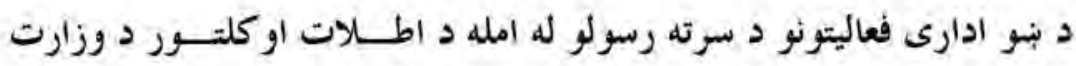

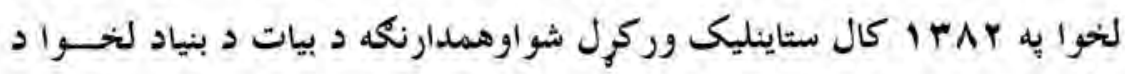

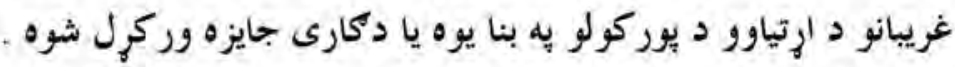

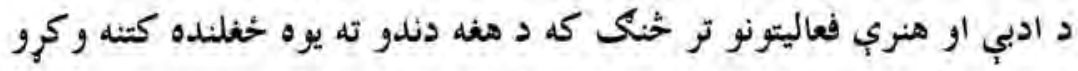

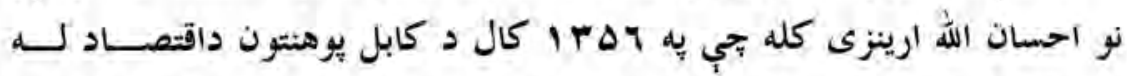

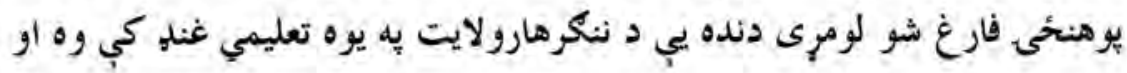




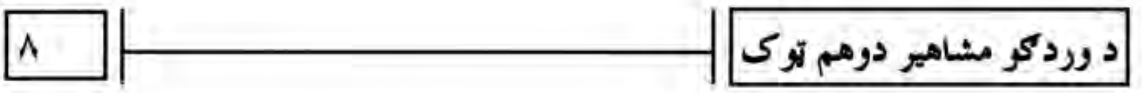

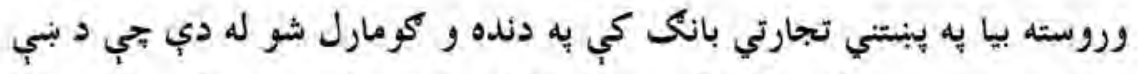

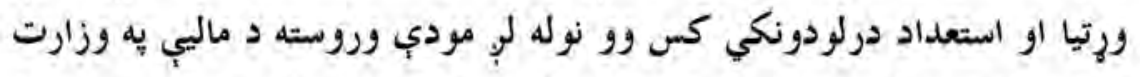

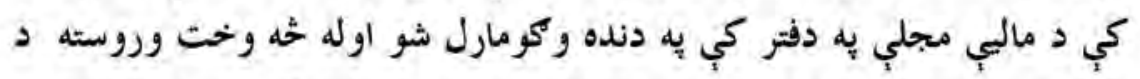

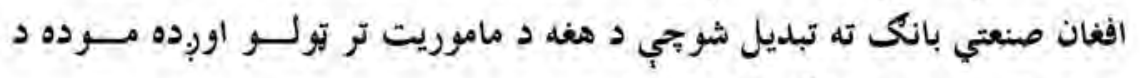

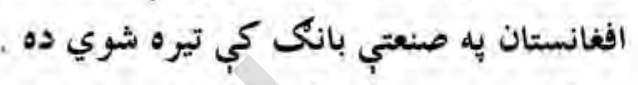

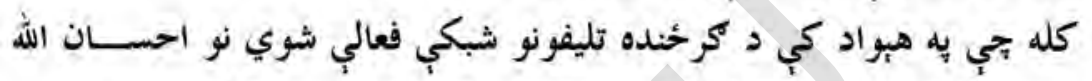

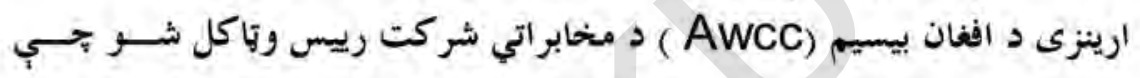

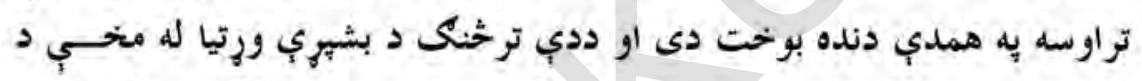

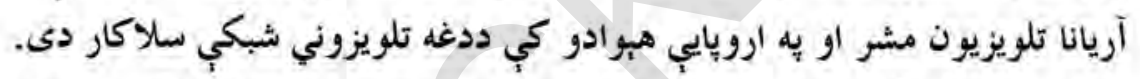

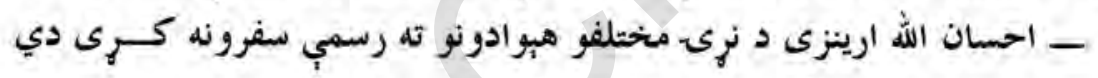

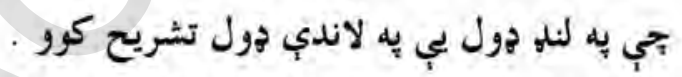

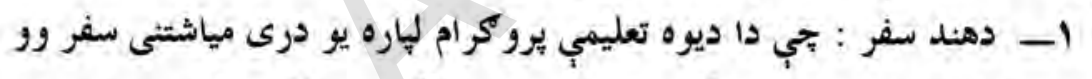

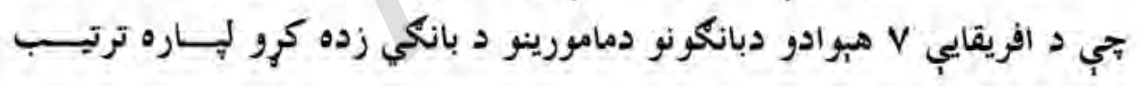
شوى وو .

r- دشوروي سفر : د ليكوالانو د اتحاديب به مالّي لكبنـت برابر شوي ور خلوينست ورخي يب دوام وركر

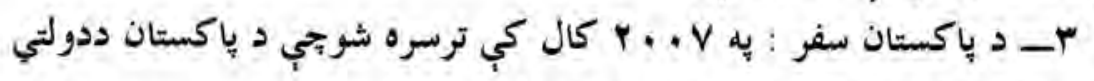

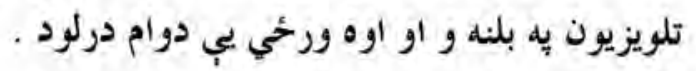




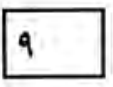

دوردكى مشاهير دوهم توكى

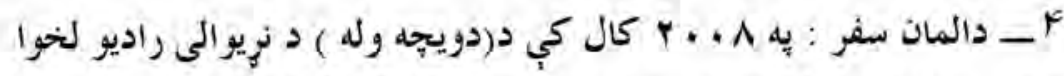

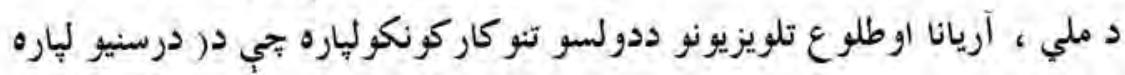

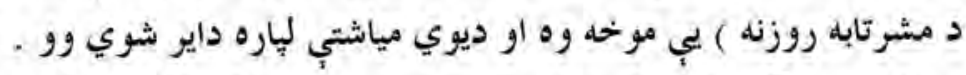

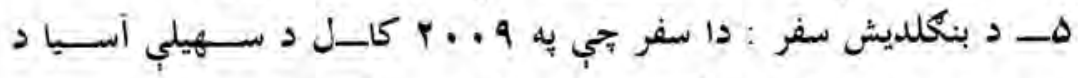

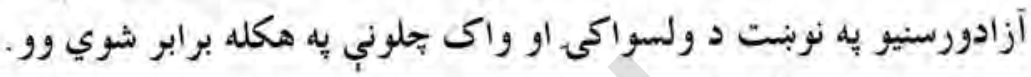

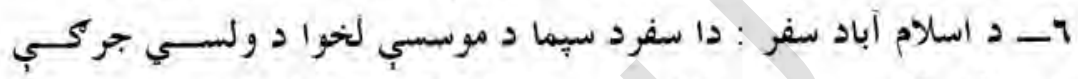

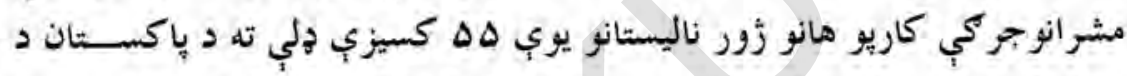

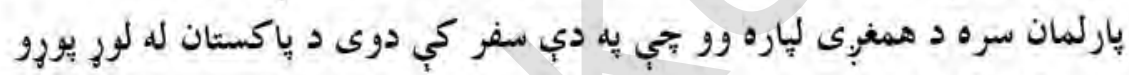

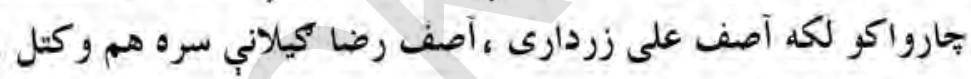

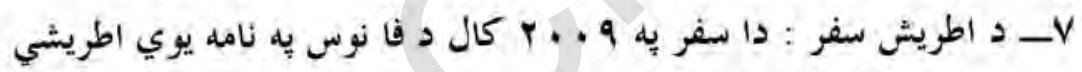

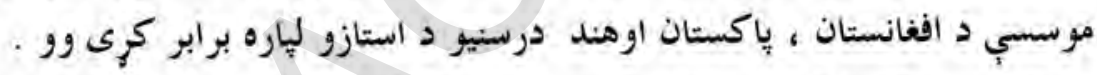

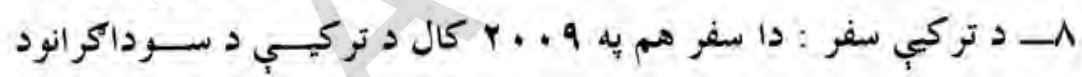

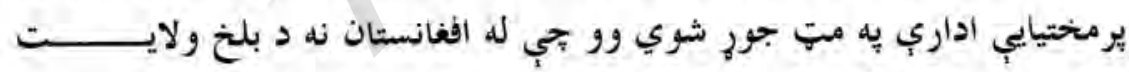

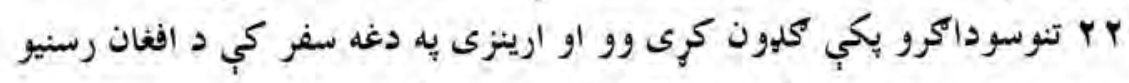

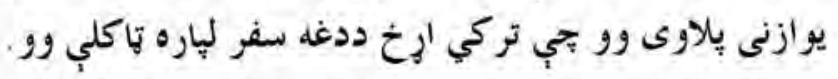

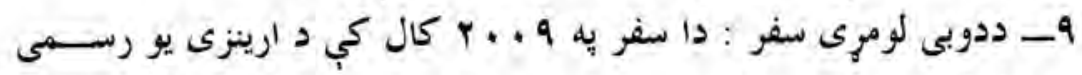

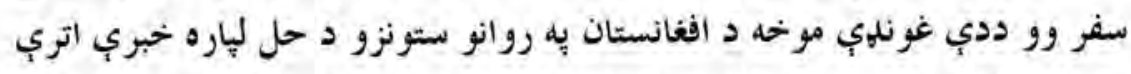

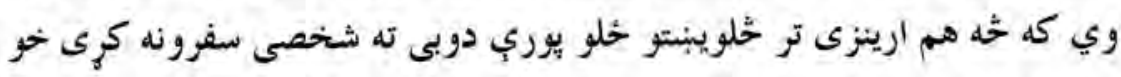

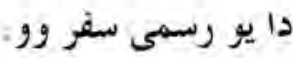


1.

د وردكو مشاهير دوهم توكى

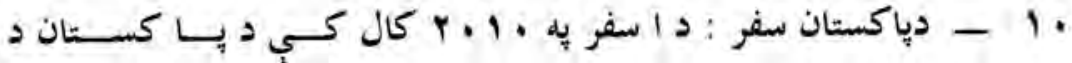

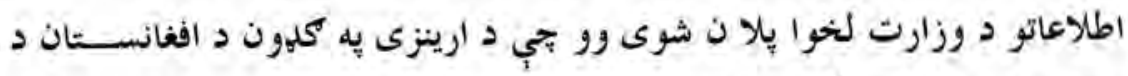
رسنيو لمو استازيو يكي برخه درلوده .

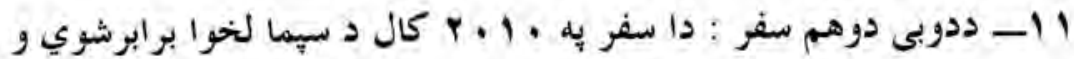
جي يه دغه سفر كي ارينزى او داكتر اكبر (اكبر) د سارك يله سرمشريزه غونليه

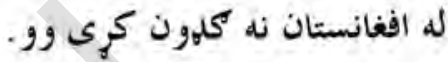

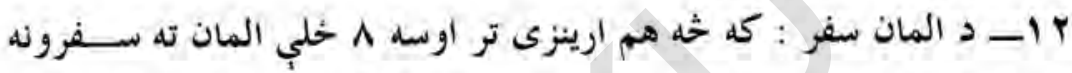
كري دي خو دا يورنسمي سفروو تحي د هنر مندانود كلنى غونلمي يه يوه جشن

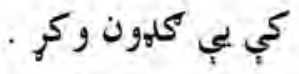

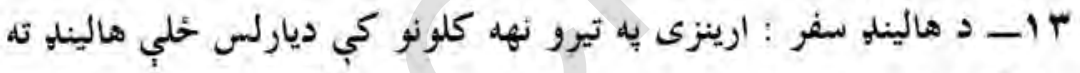
سفرونه كريى خودا د هغه رسمي سفر وو تجي يه 11 1 . بكال د افغان هنرمندانو يه يوه جشن كي د كلدون لياره هغله هبر اد ته تللى وو .

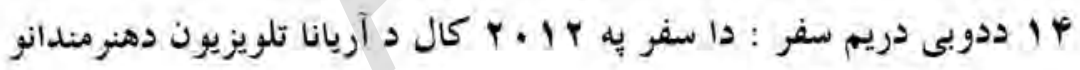

$$
\text { يه شتبرج جشن كي د كلمون لياره وو . }
$$

هغه حينو هبر ادو ته غير رسمي سيا حتى او سوداكريزسفرونه هم كــري دي تي كولاى شو د ياكستان ، هندستان ، بنكله ديش ، بوتان ، ايران ، عربستان ، تو كيي ، روسيبي ، كرجستان ، آذربايجان ،ارمنستان ، تر كمنستان ، تاجكستان ،دوبى ،بلغاريا ، هالينلي ، فرانسه ، بلجيم ، المان ، جِنماركى ، سويليون ، ناروي او فنلينده ، نومونه واحلو. 


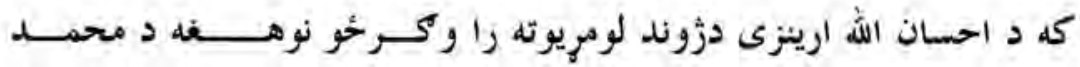

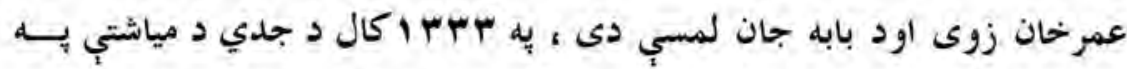

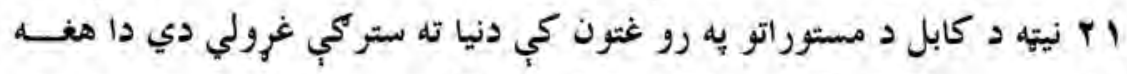

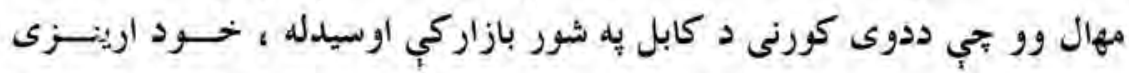

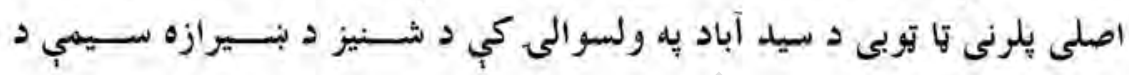
جاردهي كلى دي . جإنى

ارينزى له كوجينوالي نه د كتاب او قلم سره زئبه مينه درلــوده اود غـــازي محمد ايوب خان يه بنسونخي كي شامل شو او تو دولسم تولكي يوري اول نمره

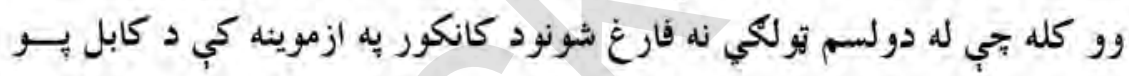

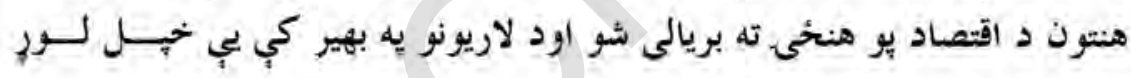
تحصيلات تر سره كرل 


\section{Ir}

دوركو مشاهير دوهم توكى

\section{الله خان - جهادي قوماندان}

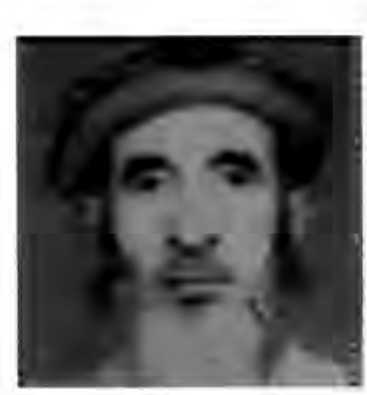

كله جي د غويب خونزي كودتا را منح ته شوه نو

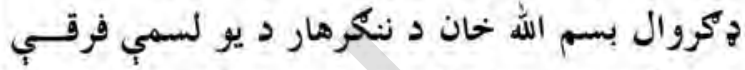

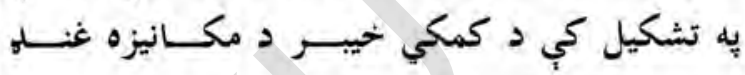

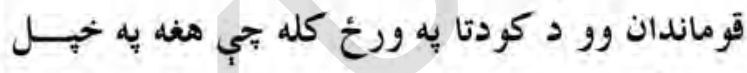

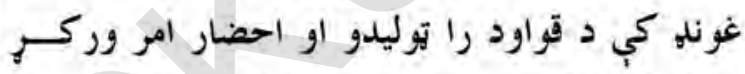

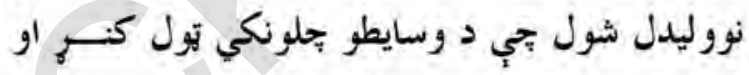

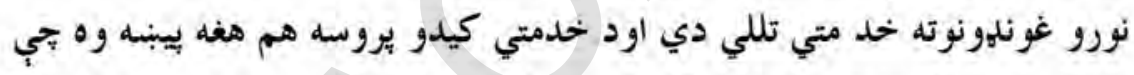

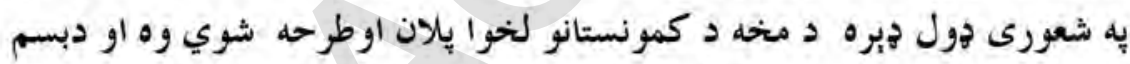

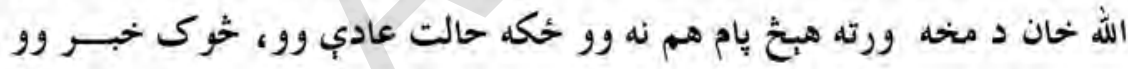

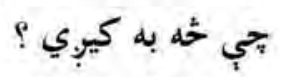

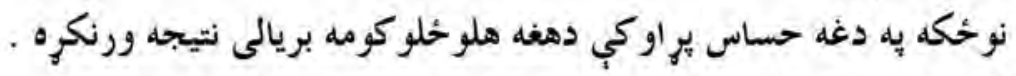

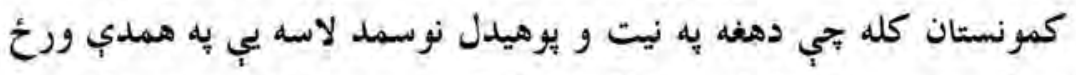

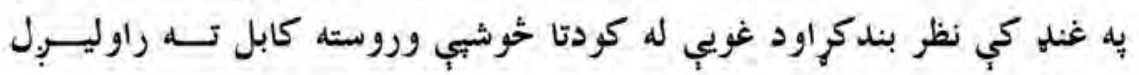

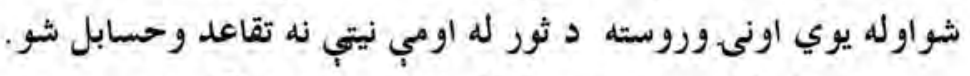

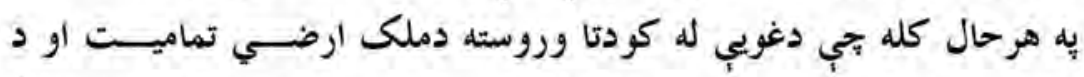

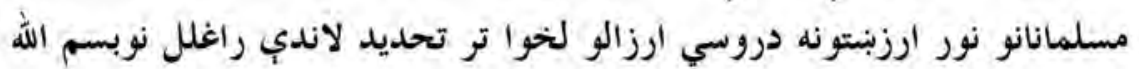




\section{ir}

د وردكو مثاهير دوهم توكى

خان له خحند يوته لاس يكار شو او د يولرملي اونجات بنسونكو سري تحركــاتو

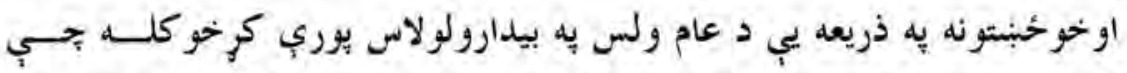

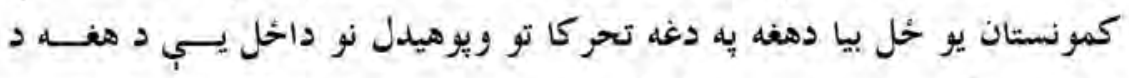

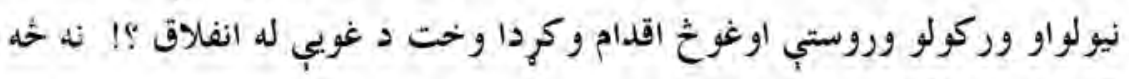

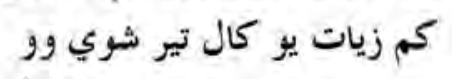

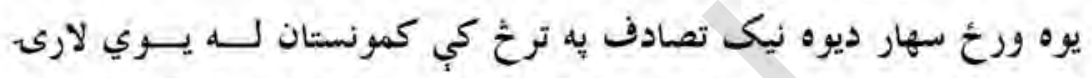

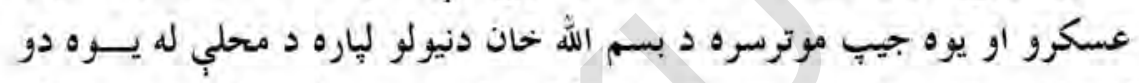

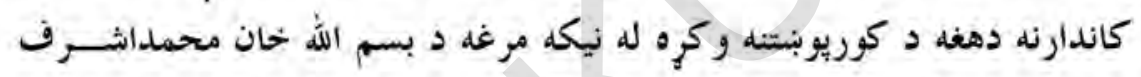

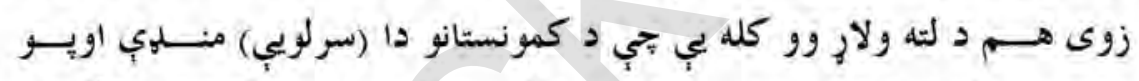

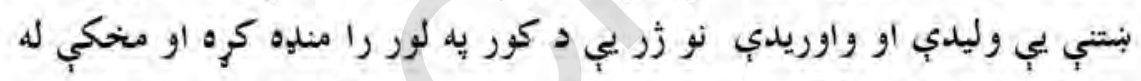

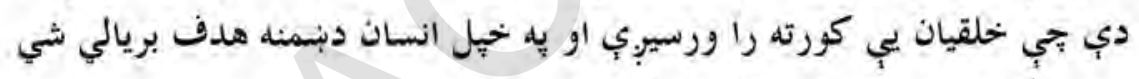

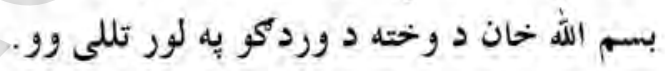

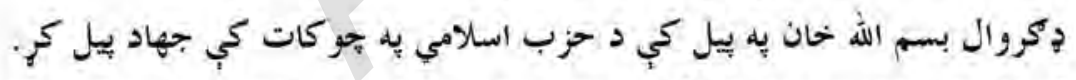
له دي بي هغه يو ماهرعسكري منصب دار وو نويه ديرخاص تلدبير اوهنربي د

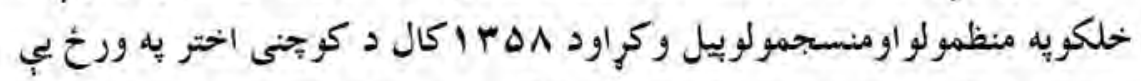
ديوه سميزملي اوجهادي خوحبنت يه ترخ كي د شنيزد ســيمي د رورحسانيونود

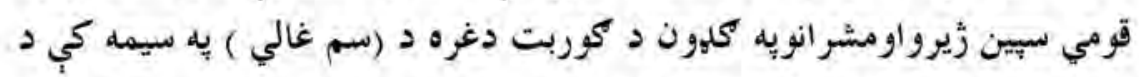
اسلامي ولولويه درشل كي يه اتفاق او ورورولى ملي اسلامي بيرغ ورياوه او يه

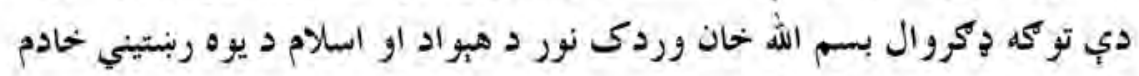

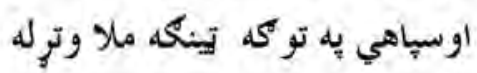




\section{$1 \leqslant$}

د وردكو مشاهير دوهم توكى

دوخت يه تيريدو د همدي كال د زمرى يه مياشت كي د كوربث يه تاريخي

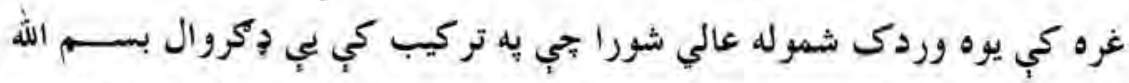

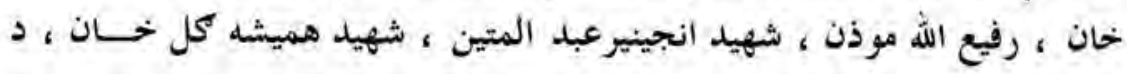

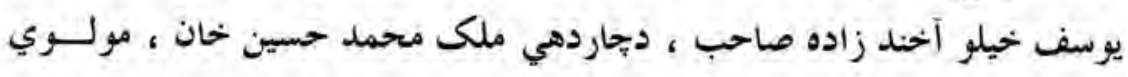
عبد المحمود آخند زاده ، مولوي محمد حسن آختدزاده ، مولوي عبد الرحمن آخند زاده ، مدير غلام محمد (غمي) ملك محمد ها شم خحان ،مامورسردارخحان ، مولوي فضل قديم آخند زاده ،محمد كبيرخان ، قاضي كملاب الدين ، موجود وو ، جوره كره ترخث د نظرونو به اتفاق او يوالي جهادي او سيميزي جارب يه مخ يوسي · مدر

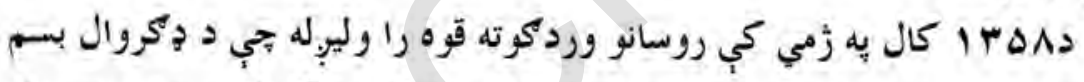

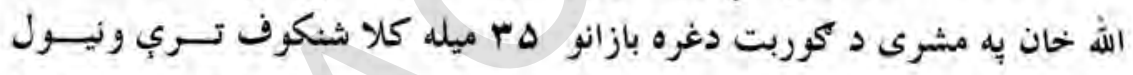

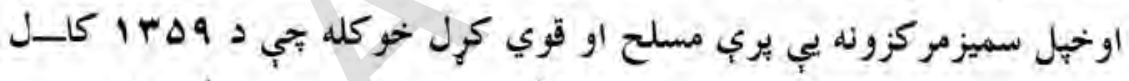

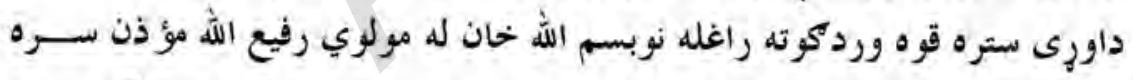
سلا وركره بحي قوه درنده ده او غازيان دا وس نلري تجي ور سره ورجنكيري بنه داده جي له نظاهي ثا كتيك نه يكار اخيستلو سره بشرى زخيري ثله زيان وانروو خو مؤذن صيب يه غو خثه ورته وويل : تجي يه اسلام كي تيبنته نشته خورا فحورا

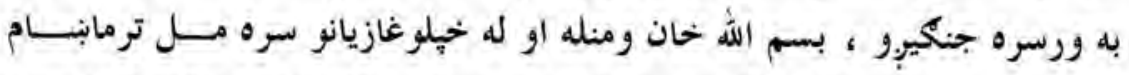

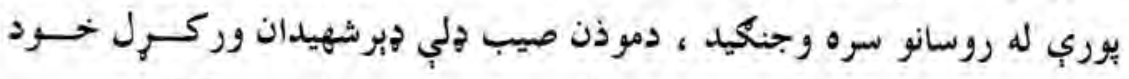

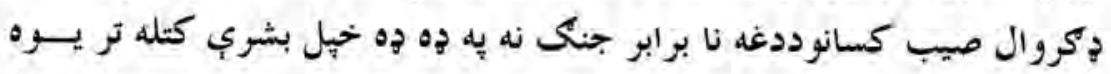
بريده صرفه جوبي كره مرون. 
10

د وردكو مشاهير دوهم توك

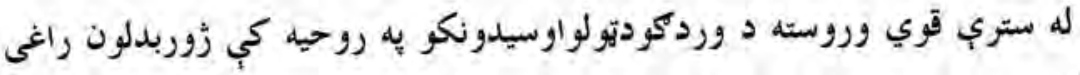
جيوكورنى د هجرت وطن ته ولاري خود غازيانوصفونه لا بسي تينك شول. وكروال بسم الله خان دا وخت د انجينير كمل البدين حكمتيار لخوا به سيمل

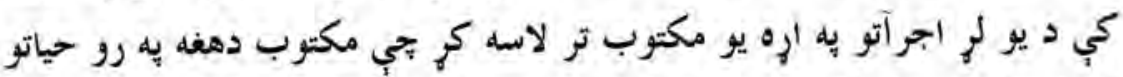

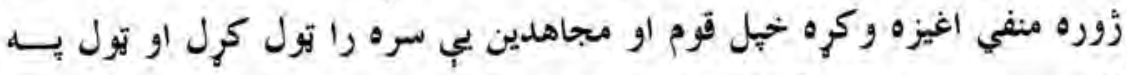

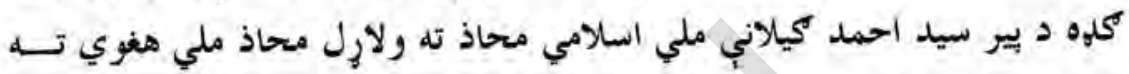
خداي وس يوازي لس ميله وسله وركره اووطن ته 2 راتكى يه مهال يه لاري كي هغوي ته د پاكستاني مليشمو يه لباس كي يو شميرنا خر كندو وسلو الوكسانولاره

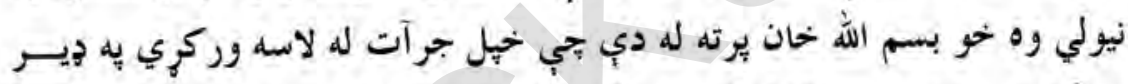

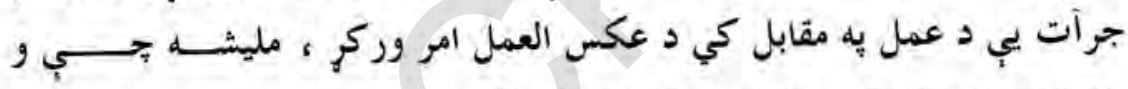
يوهيده ويني بهيربى نو زُر يب ميدان خوشى كي

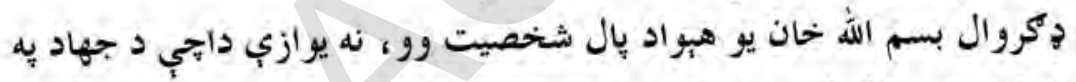
دوران كي يه وردكوكي د جهادي قوماندانانويه قطاركي يوتكره ، يبزندل شوي

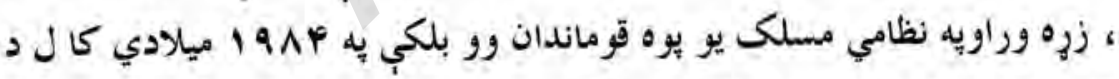

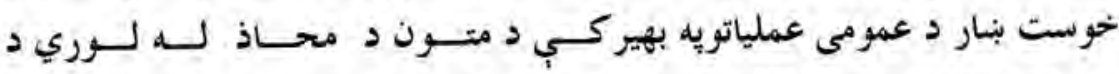
عملياتوقوماندان هم و تياكل شو تجي له هغه سره ددغه محا ذ يه عملياتوكي و كيل

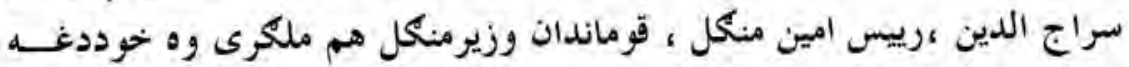
محاذعمومي قومانده درّكروال صيب يه غاره وه دغه عمليات ددريو مياشتو لِاره د خوست يه توره غاره ،نادرشا كوتّ، غلنك او سنكيو كي دوام درلود جي د 


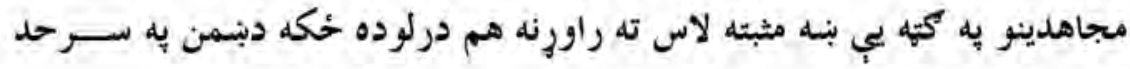
كي د نظامي تحر كاتود بهير نه زره تورى او يه شا تكى ته ارج شو .

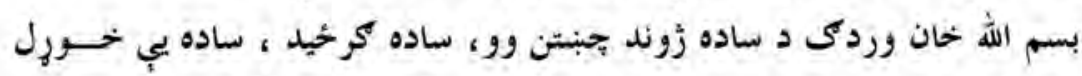
او اغوستل ، تجملات يب نه خو بنول د هيواد ، ولس اوله خلكو سره يب هيـــره مينه دولوده د هو جا خبري ته يب غورِ نيوه او تل د هغوي مثبتوغوبنتنو ته زمن ورو.

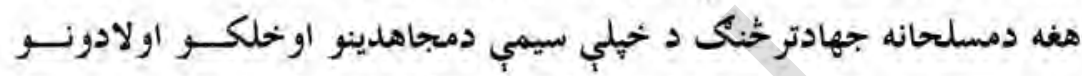

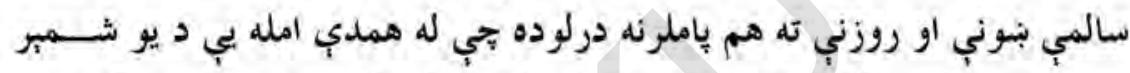
مرستندويه مونسولكه (لجنته الدوعته الاسلاميه ، آى آرسبي اود سويدن كميتي ) ياملرنه هم سيمي ته راجلب كره او له خجل ولس سره يتي دا موسسبي همكارى ته وهحولي ، ديني مدرسي ،دارلحفا ظونه او مبايل رو غتيايب كلينكونه د شنيز يه بيلا بيلو برخو كي د هغه يه هاند او هخو فعال شول .

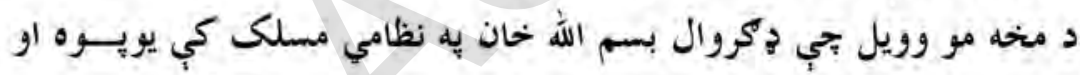

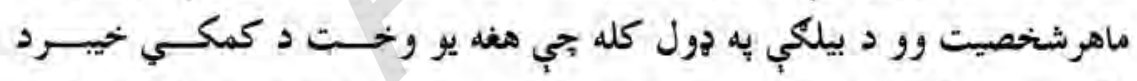
مكانيزه غنله قوماندان وو نونوي جمهوروييس سردار محمد داود خحان يه ناخايب

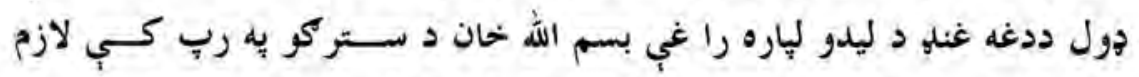

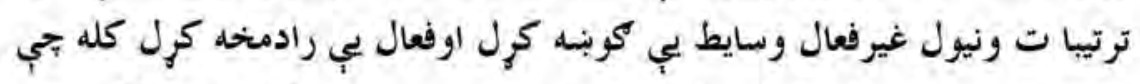
محمد داود خحان راغي د غند له معايني وروسته يبي وويل : كه بجيري ياكستــان حمله وكرى إ ستا عكس العمل بله خده وي ؟ دكروال بسم الله خان سمد لاسه قطعاتو ته د عملياتو امر وركي د توبيونو دوز

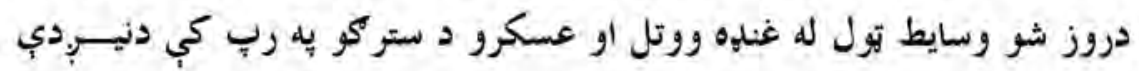


$1 \mathrm{~V}$

د وردكو مشاهير دوهم توكى

غونلهيو يه سربيرغونه وريول دافع هوا داسي هوايي شولى جور كر لكه ددبنسن جنكي الو تكي تب في الحاله بمبارد كوي سردار محمد داود خحان ورته وويل

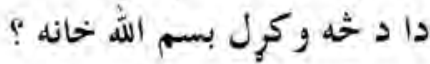

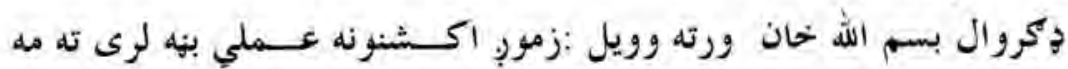
وارخطا كيره إ يه كفتار كي درواغ را خي خو عملي اكشن هيخكله درواغ نه

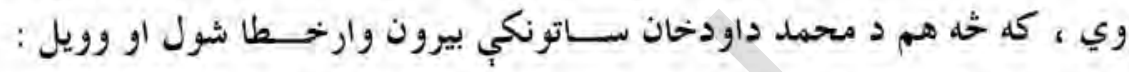
(داود خانه تروركرد ) خوخبرنه وه تجي دا تول يو حربى مانور دى ، لــه هغسله

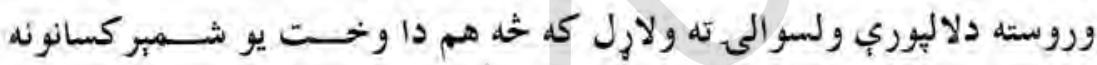

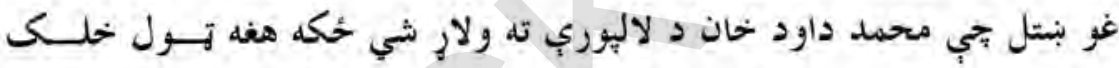

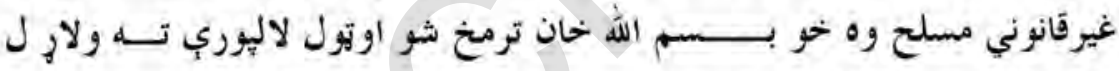

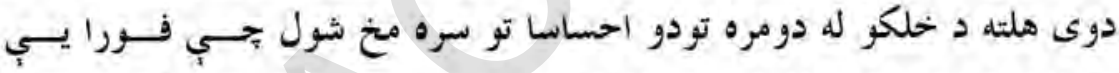
(زوندي د وي محمد داودخان ، تل د وي جمهوريت ) شعارونه وركرل دا سي ثيبه هم راوربسيده بحي عسكر او خلك سره مكلشول او محمد داود خحان يـي ني تومنح وركى شور خو بيا هم يه نيكو احساساتو يب بدركمه كر.

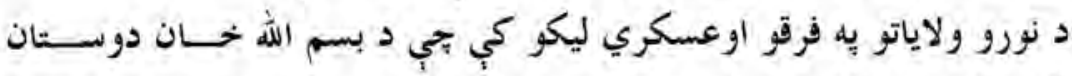
اوملكرى له دغه فعاليت نه خبرشول نود مــخابرواوتليفونوله لاري يـي هغه ته يه

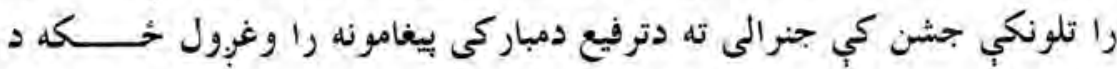

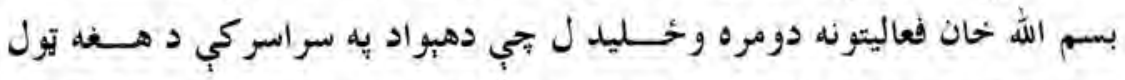

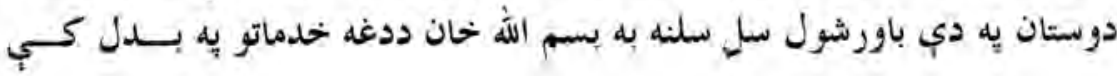


$1 \wedge$

دو وركو مشاهير دوهم ليوك

دجنرالى رتبي ته ترفيع كوي، دهغوي دا باوراوهاند سم وو خكه جي د محمداود خان له دفتر نه هم به راتلونكي جشن كي د هغه د جنر الى تينكه زمنه وششوه

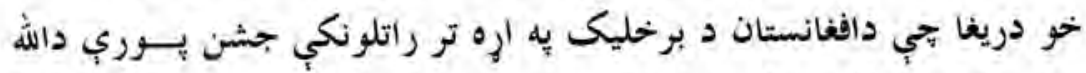

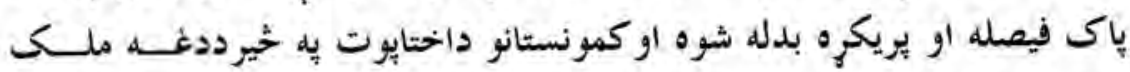
سياسي فضا به خيلو منكلوكي ونيوه. شهيد سردارمحمد داود خحان جي د سيا ست له صحني نه ليري شو ، نوكريو زَمنو يي د عمل جامه و اته غو ستله . كلونه تير شول سياسي نظامونه بدل را بلدل شول تر هغسلـه جـــي د طالبــانو

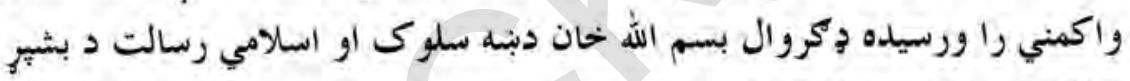
دركى يه رنا كي خيله جهادي دنده ختمه وبلله او . . آميله خفيفه وسله طالبانو

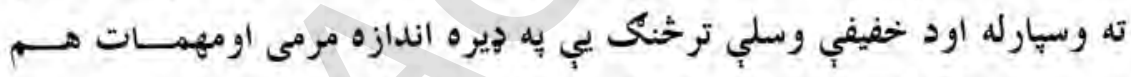
هغوى ته وركرل ، لنلهه داجي د شلو ده سلندر (لس لنده) موتروية شا وخوا كي وسلي او نور مهمات طالبانو تري يورل .

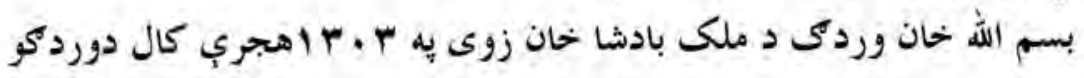

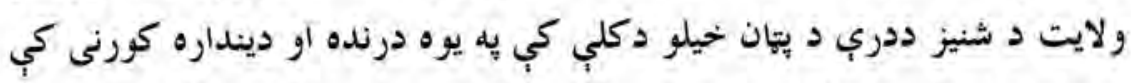

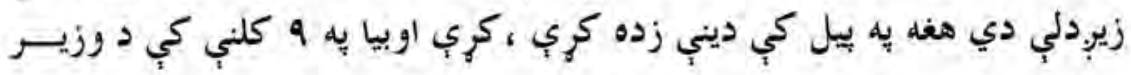
غلام محمد خان له زوى معين شيردل خحان سره كابل ته راغى او ريه احضــــيه

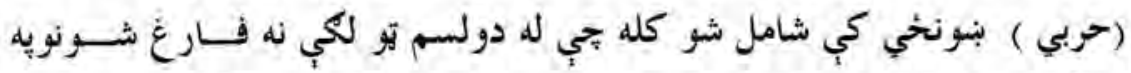

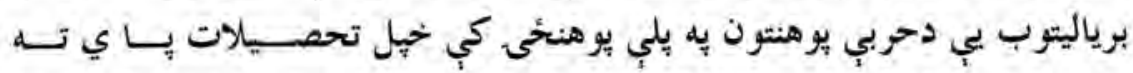

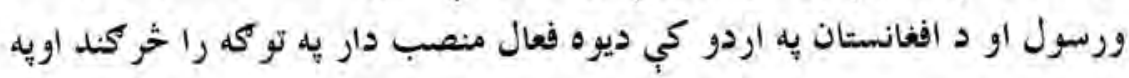




\section{9}

د وردكو مشاهير دوهم توكى

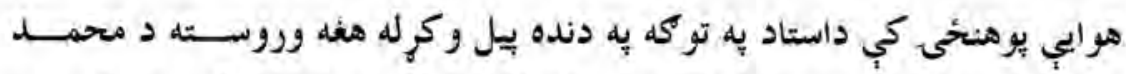

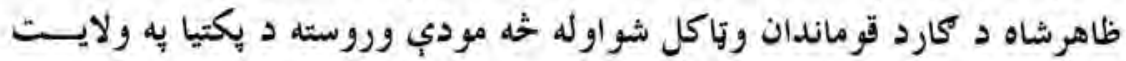
كي د ضبط احوالاتورييس شو اووروسته بيا د افغانستان دنظامي تشكليلاتو يــــ ليكو كي دخيبر، اسمارد مكانيزه غونلوونو قوماندان وو.

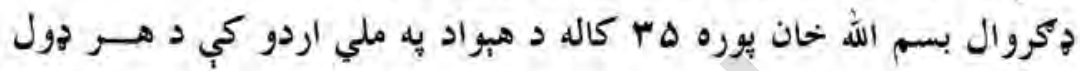
ستونزمنو شرايطو يه منلو او قبلوو سره دندي تر سره كري او نه يوازي داجهي

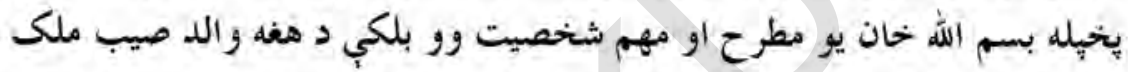
با دشاخان هم قومي اوسيميز سيين زيرى او مشروو او د خيل زوند يه زمانه كي

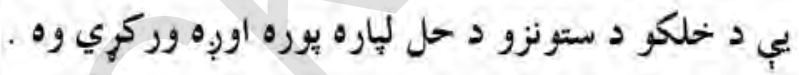
بادشاخحان دسقاو د زوى ستردبنمن وو او د سقاوى به كال كله جي سقاويان

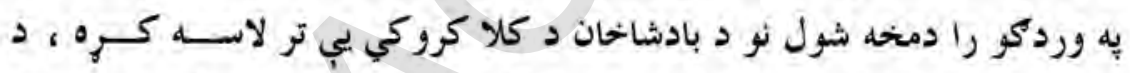
سقاوزوى (ظفرخان تو يجهي ته بحي د ششكاو اوسيدونكى وو او له باد شا خان سره يب خهلوي درلوده) امر وكيحي د با دشاخحان كلا به تويونو ورله ، ظفرخان

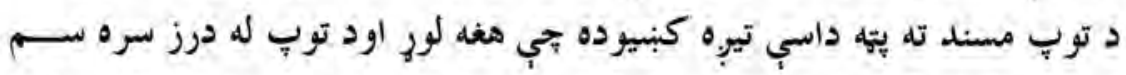
مرمى هو ابي دكوربت دغرو لمنوته ورسيده ، ظفرخان د سقاو زوى ته و وريل :

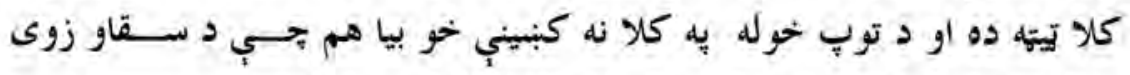
هوخومره اسراروكر زفر ظحان د باد شا خحان كلا ونه ويشتله .

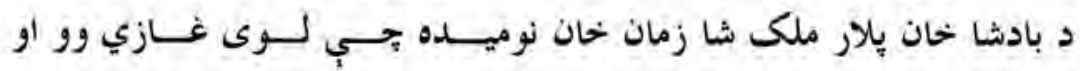
دسترغازي محمد جان خان يه زمانه كي يوتكره قوماندان ور. 
r.

دوركى مشاهير دوهم توكى

شا زمان خان نه يوازي دغازي محمد جان خان د ســـروغازيائو مشـــر وور

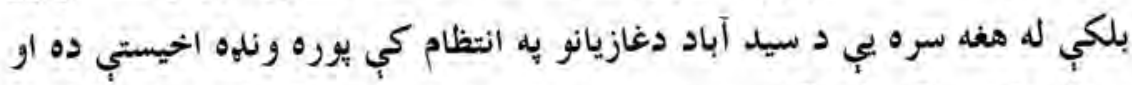
يه قلعه قاضي كي له انكليسانو سره به يوه مخامخ جكره كي شهيد شود هفه يه

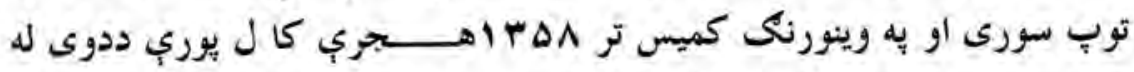

$$
\text { كـــورنى ســره دو تبركى يه رول ساتل كيده . }
$$

بسم الله خان جمكروال به خهلو اولادونواومجاهدينو به متحد المال خوول (بابه)

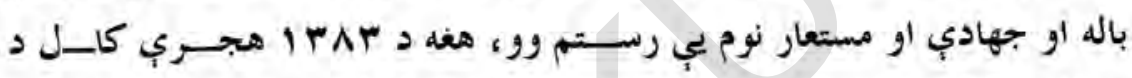

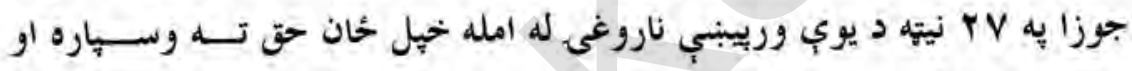

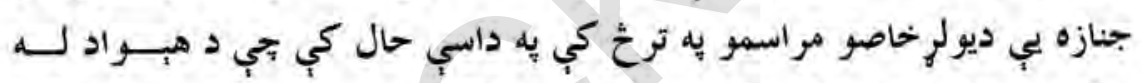
مركزاو ولاياتونه يه زركونو كسانو تكي كلهون كرى ور ، بخهيله يلرنى هديره كي

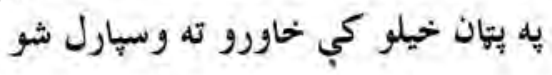




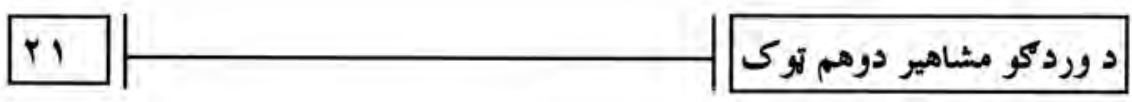

\section{الله خحان - ملك}

تر هرخه لومرى : د ملك بسم الله خحان كورنى د 2

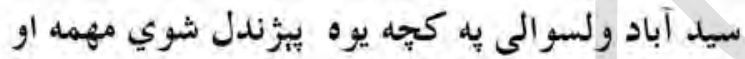

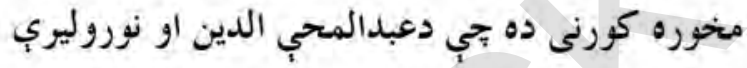

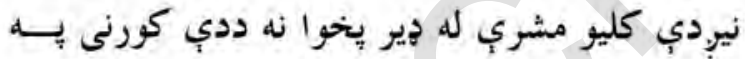
غاره وه هوب. د بسم الله خان ترخيكى ، دغه كورنى يو شمير وروستي او ورومبي مهــــ

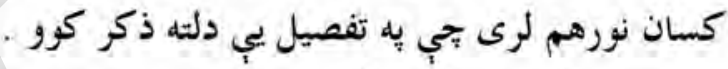

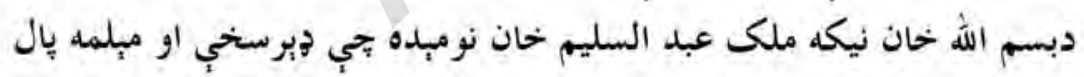

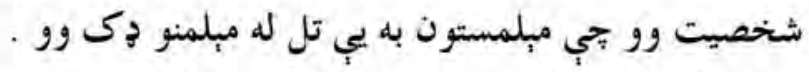

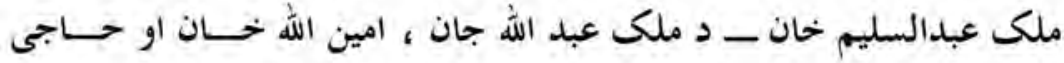

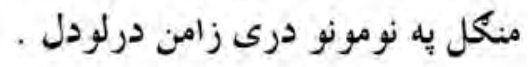

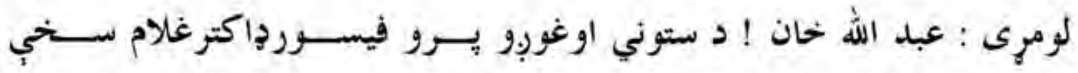

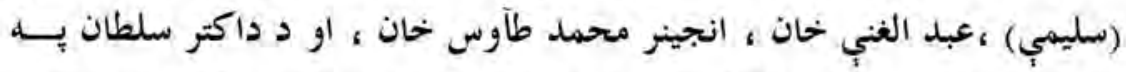

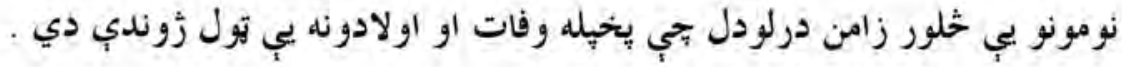




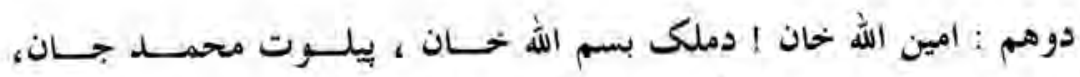

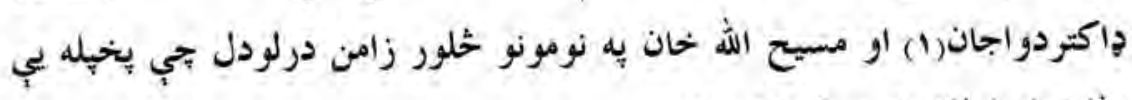

$$
\text { وفات او اولادونه يب زوندي دي . }
$$

دريم : حاجي منكل ! د انجينرمحمد نعيم سليمي (†) اسلدالله خحان، محسبـ الله

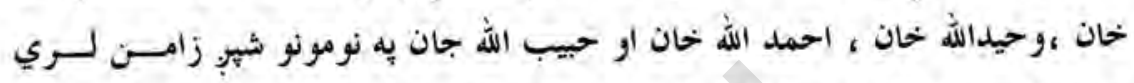
تي تول يب زُوندي او يه خهيله حاجي صيب هم زوندى دي .

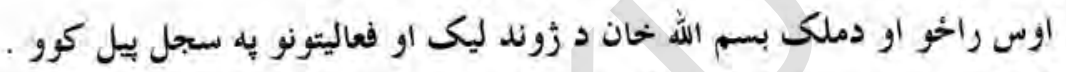

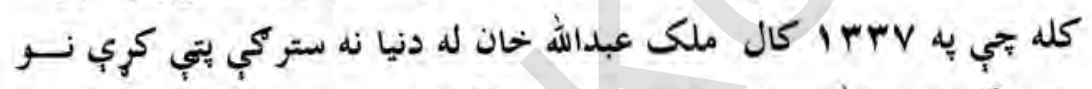
وراره ملك بسم الله خان بي دا وخت اتلس كلن وو دهغه د تكفين يه مراسمو

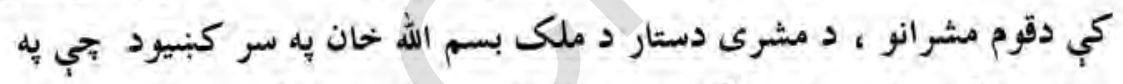

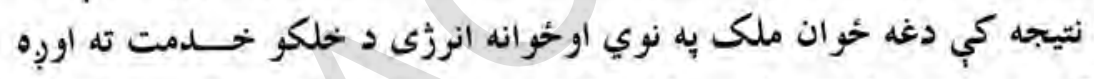

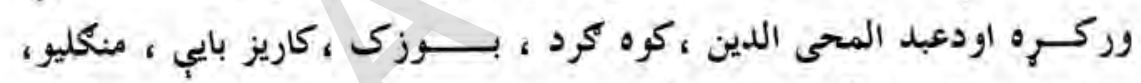

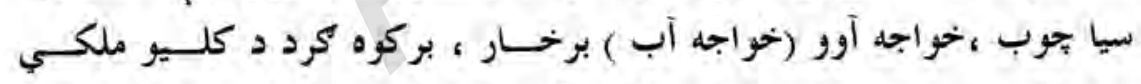

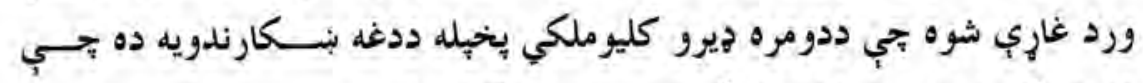

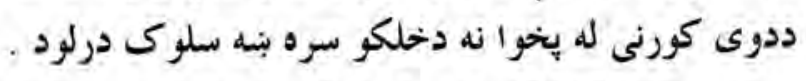

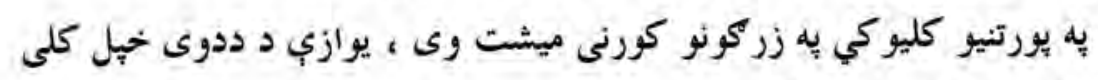
عبد المحي الدين . . ه كوره دى . . 
ملكى بسم الله خحان له هماغه يِل نه د خبلوخلكود ستونزو حل ته مسؤ لانه يام

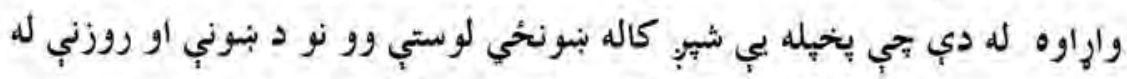

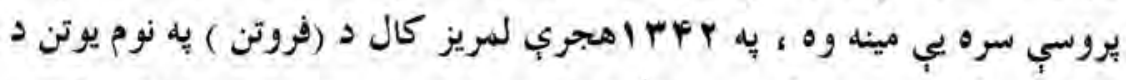

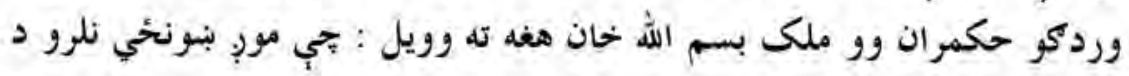

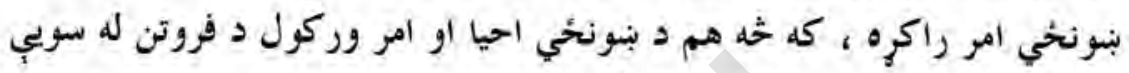

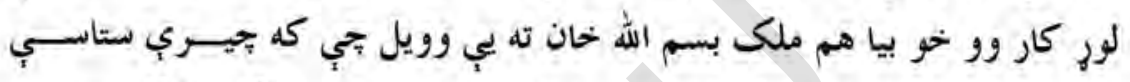

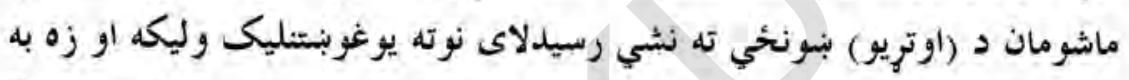

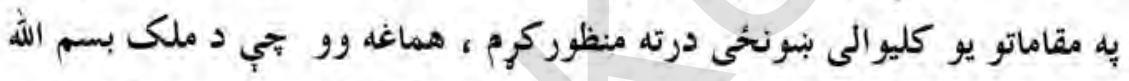

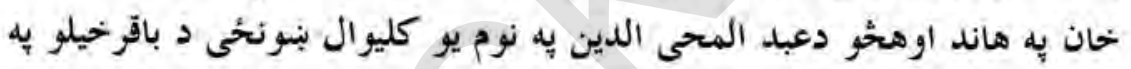

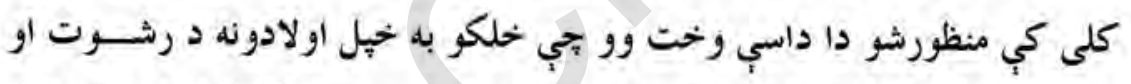

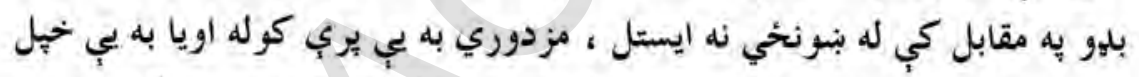

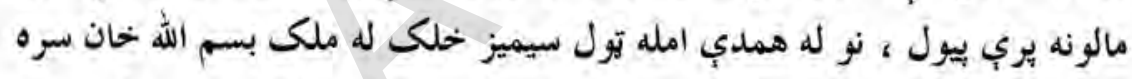

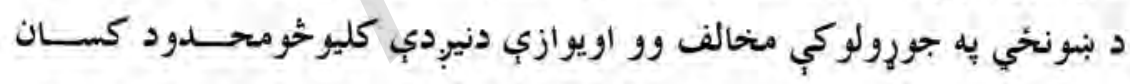

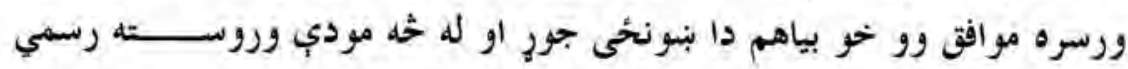

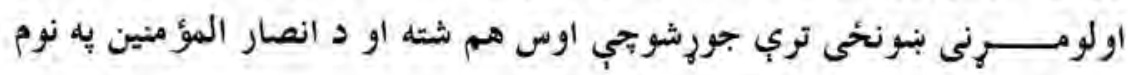

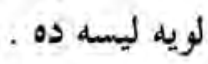

ملكى بسم الله خان نه يوازي له يوهنب سره مينه درلوده بلكي د خجلو خحلكو

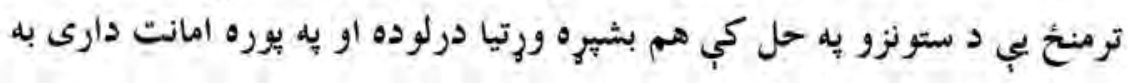

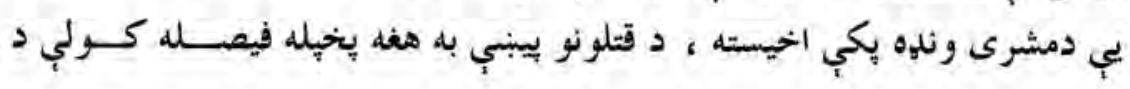


YE

دوركو مشاهير دوهم توكى

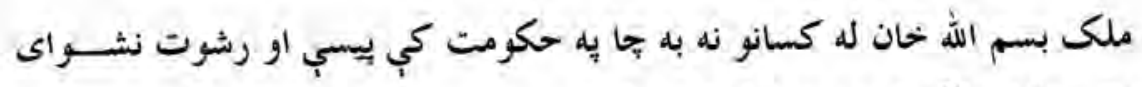
اخيستالاى خيكه د بلهو موارد بله نه وه.

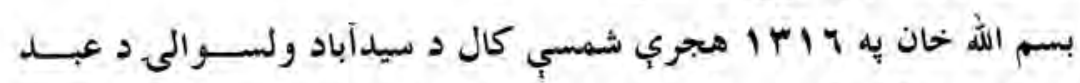

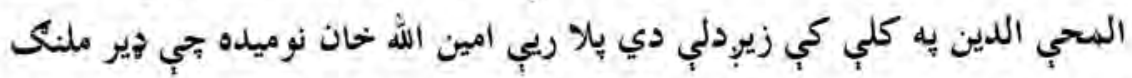

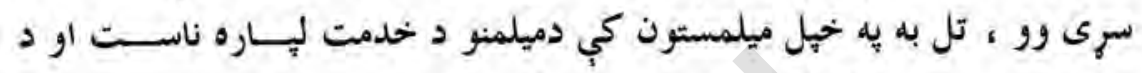
هغوى خدمت او د قر انكريم تلاوت بله بي كاوه . ملك بسم الله خان يه سختو او محرومو شرايطو كي د سيد آباد يه بئسونحي

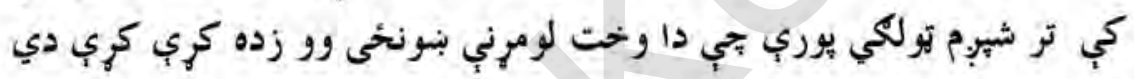
او له هغه وروسته بي د خيل قرم خدمت تله اوربه وركره .

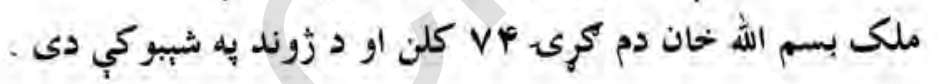




\section{Po}

د وردكو مشاهير دوهم توك

\section{تاج محمد خان وردك - وزير}

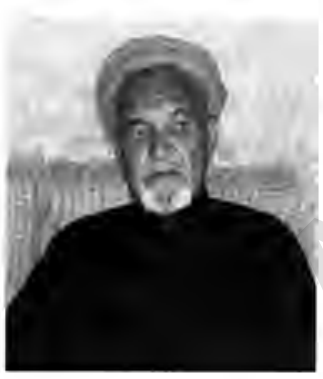

تاج محمد خحان ورد كى د خيلو تولو ماموريتونويــه

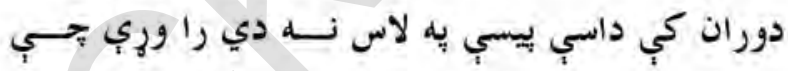
دهبواد د نورو ابن الوقت قدرتمندانو به خيرد يه درجنو كورونه اويا نور املاكى ورباندي واخلي او نه يي هم د قدرت يه مها ل د حرامو بيسو بي شمبره بنلهلونه يودبل

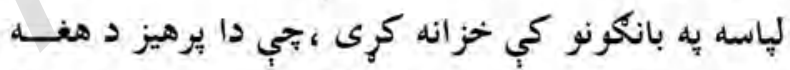

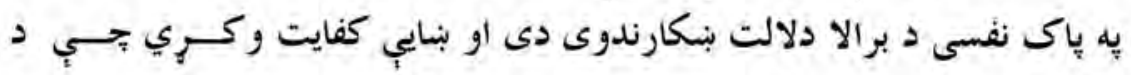
سياست يه دُكر دهغه داقتصادي تقوا بخخلى يرب وشي .

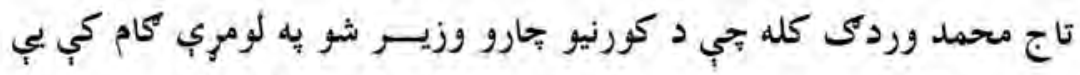

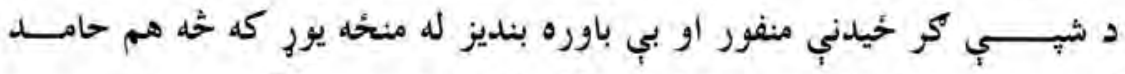

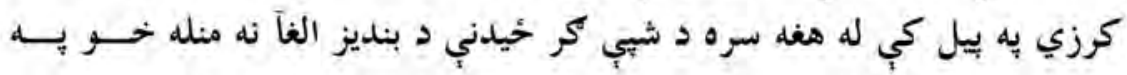

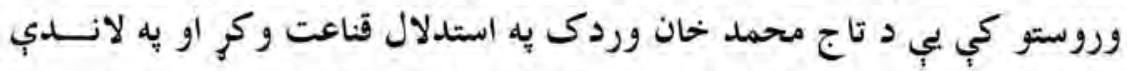

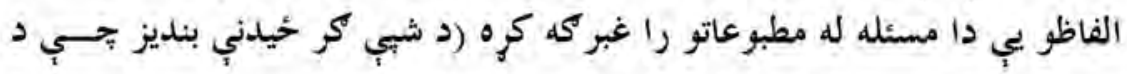


شبي له نهو بجو نه د سهارتر درى نيمو يوري نافذ ور د كورنيو بحارو دوزير تاج

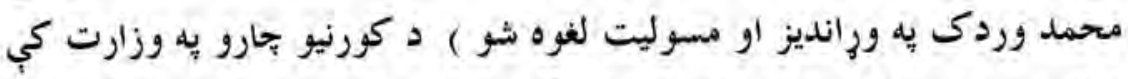

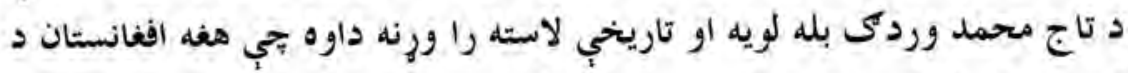

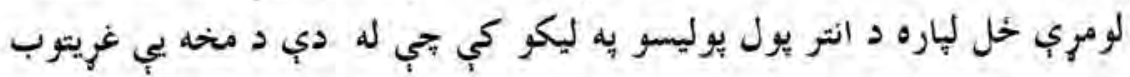

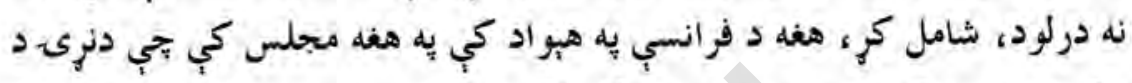

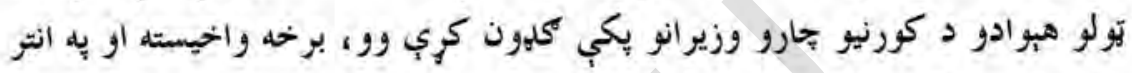

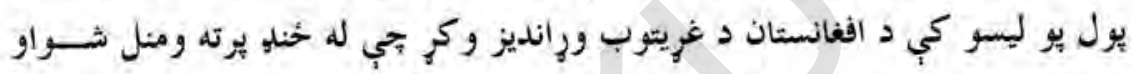
دا داسي غريتوب وو تي هيخكله او به هيخ سياسي نظام كي نشي فسخه كيداى.

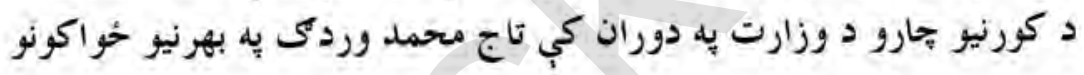

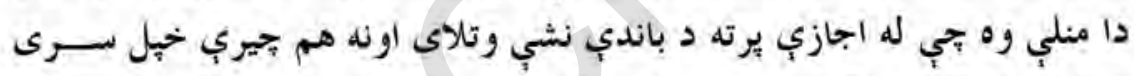

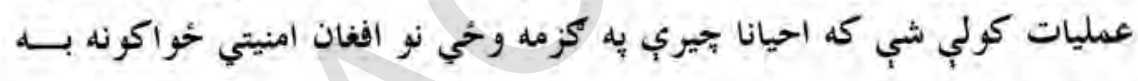
ورسره وي .

د كورنيو جارو له وزارت دمخه كله بجي د بكتيا والى ورو هلته هم د بهرنيانو

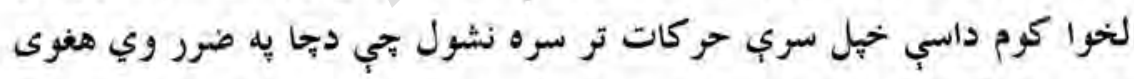

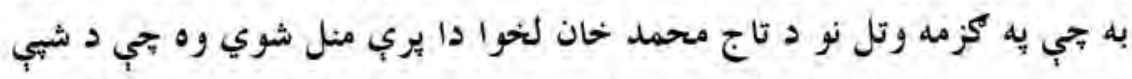

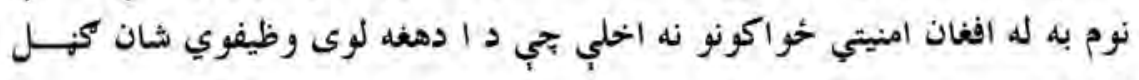
كيداى شى :

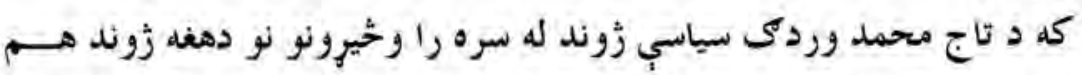
دوي مختلفي كارى مر حلي لرى جي يوه يجي د افغانستان له ديرش كلي كلني غميزي

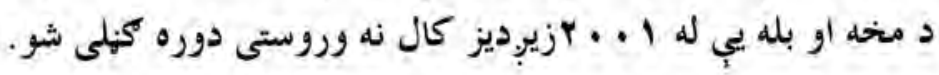


دهغه د لومري دوري ماموريتونه له عظمي صدارت نه را بيليوبي او دا جــي خنكه د شخصيت به لحاظ هغه مطرح كيبوي داستان يب داسي وو. د سردار محمد هاشم خحان د صدارت دوران ور ناخايه دوهمه نريواله جكيه

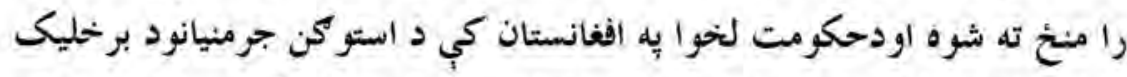
يه ارهه د ملت له استازو نه لويه جركنه راوغو بنتل شوه لله نيكه مـــرغه بجي ثاج

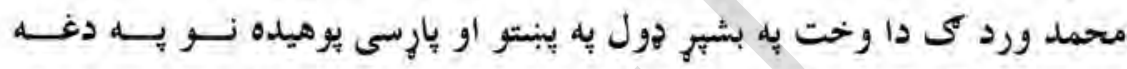

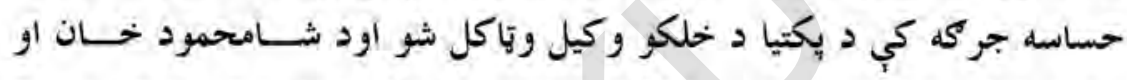

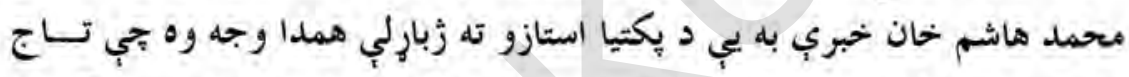

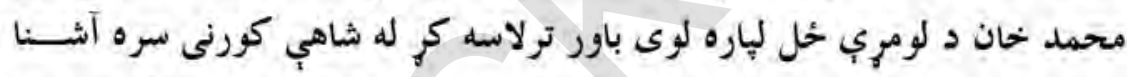

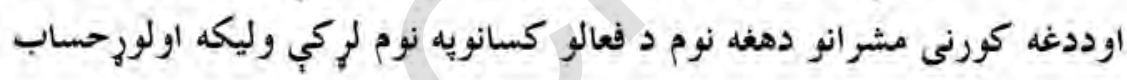

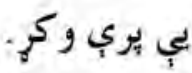

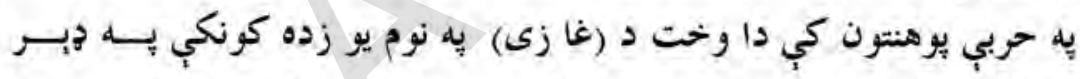

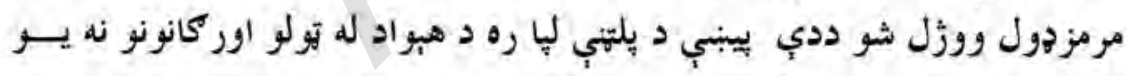

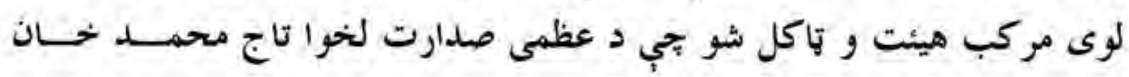

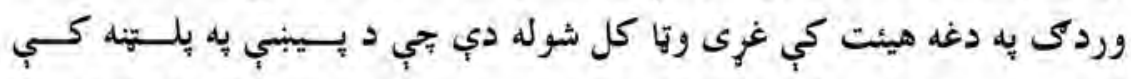

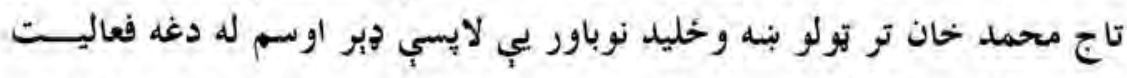
سره به قواي مركز كي د يوي داسي شعبي مشر شو جي ددوسيو ارزونه اويلتنه

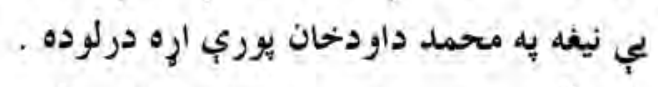

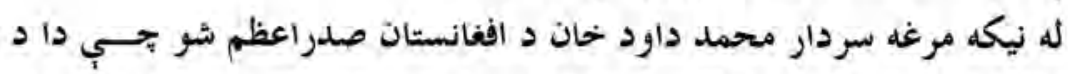
تاج محمد خان لياره يوبل نيك تصادف اوبنه جانس شوخيكه د صدارت تربـول 
i^

دوركو مشاهير دوهم توكى

ادارى كارونه تاج محمد خحان ته اريوند شول او د صدارت له دوو مربسـيـيالانو وروسته تول صلاحيت د تاج محمد خحان شو . كله بحي ميرزا علي خحان به ياكستان كي وفات شو نو تاج محمد خحان وردكى

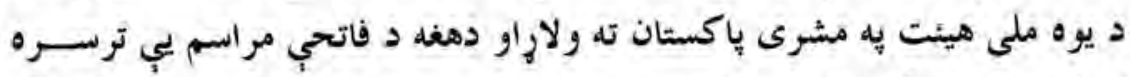

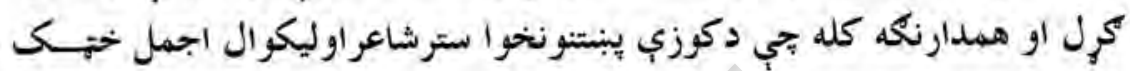
افغانستان ته راغى نو تاج محمد وردك د هغه مشر ميلمه يال ور ، دوردكى د

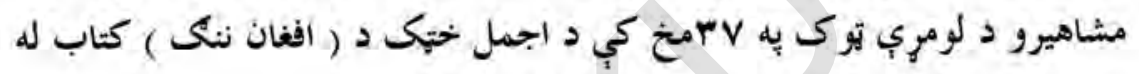
روايت نه يه دغه موضوع داسي رنها ابهول شوي ده .

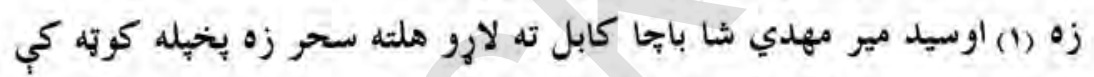
نانست وم بجي زما ميلمه يال مهماندار تاج محمد وردكى راغي او ورسره يــو

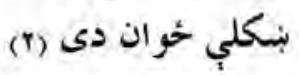
هيره مزيداره دريشي (وردي ) يب اجولي ده . يقين اوكري يه كابل كبنب دومره

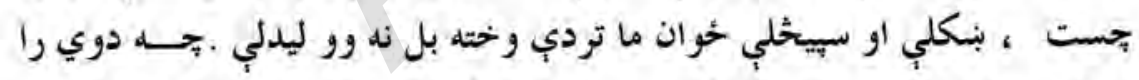

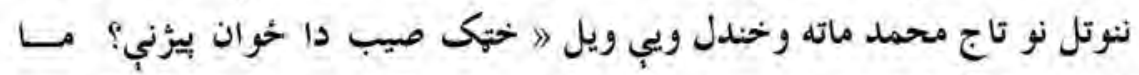
حُوان ته او كثل او به خُير شوم ورته . تاج محمد خان وويل بنه ورته وركوره ، دى يه تا رير مين دى او خا ص ستا ليدو ته را غلى دى 《) ما بيا هغله حوان تسله

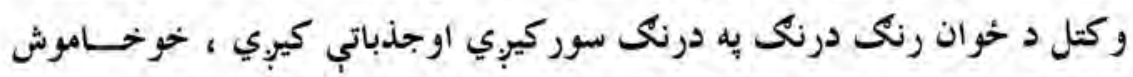
ولاردى ، كله ماته كوري او كله كوز كوري ، لكه جي خه ورته ياد ياديربي . 


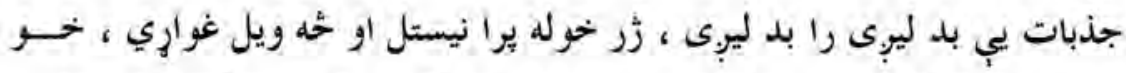

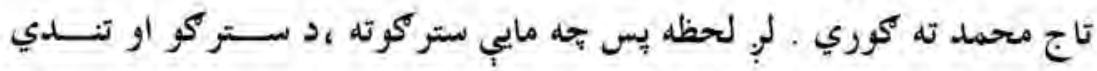

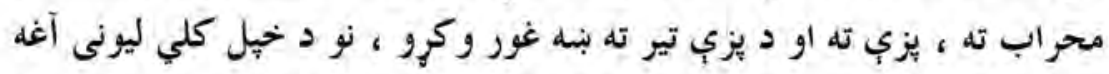

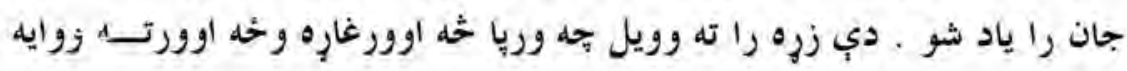

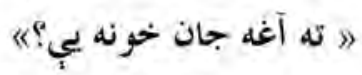

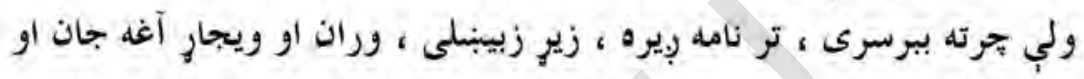

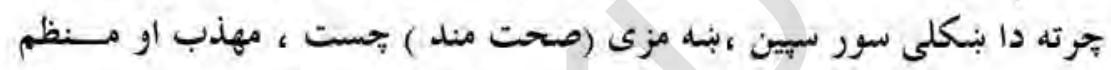

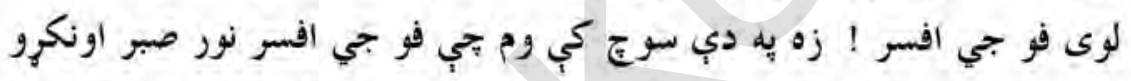

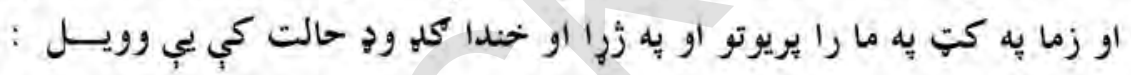

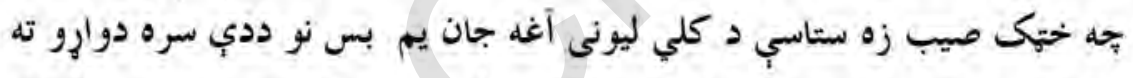

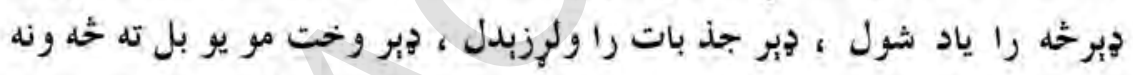

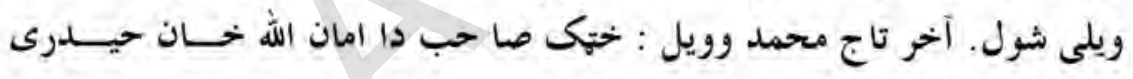

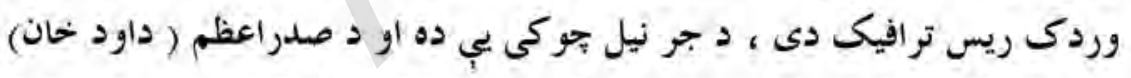

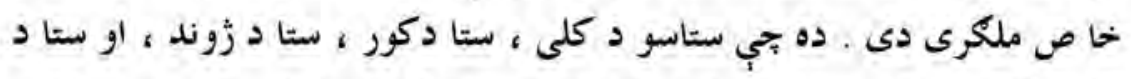

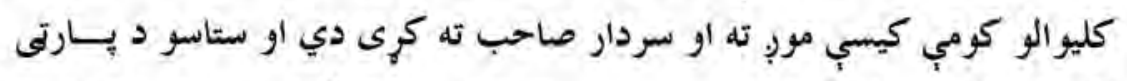

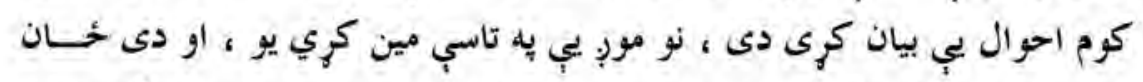

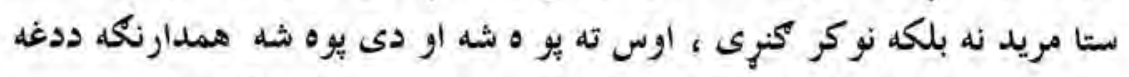

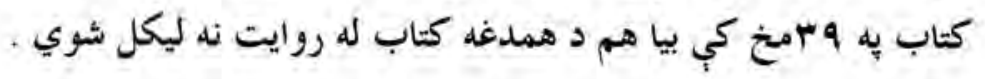

(1) (1) 
r. دوركي مشاهير دوهم توكى

د خداى كارو ته كوري خو كاله وروسته زه (1) بيا افغانستان ته ولارجم كابل هو تل كي ديره شوم هفته تيره شوه او امان الله خحان ما ونه ليده ،ماته را نغى نو

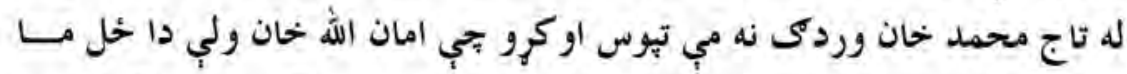
وئه اوليدو هغه زما يه خبرو حيران شو او بيا بي او سيلى اوكرو يه ستركو كي 12

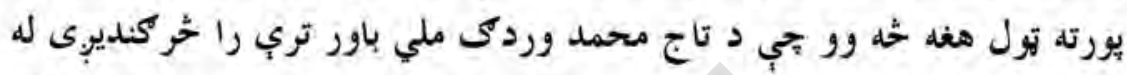
بل يلوه هغه كله جي د عظمى صدارت د ادارى برخي مسوروليت يه غاره درلود

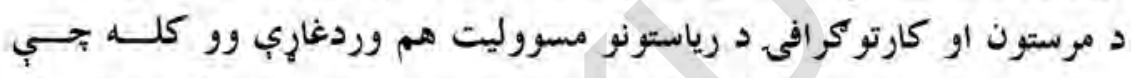
سردار محمد داود خان استعفا وكره نوتاج محمد خحان دهرات ولايت د غوريانو

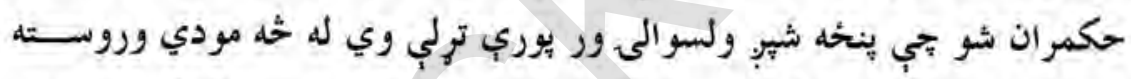

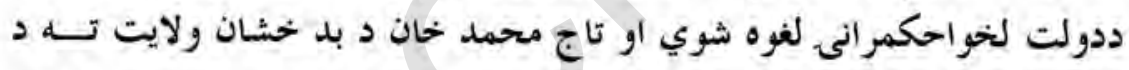
و الى د موستيال يه تو كه را بلدل شو ، كله جي ميوندوال صدراعظم شونو له دي

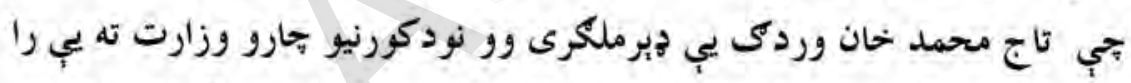

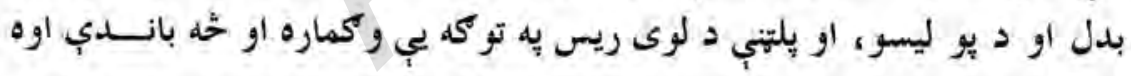
كاله يه دغه دنده بوخت وو هغه ته دا وخت د قو انينو تفسير هم ورد غاري شو

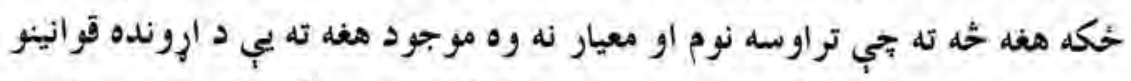

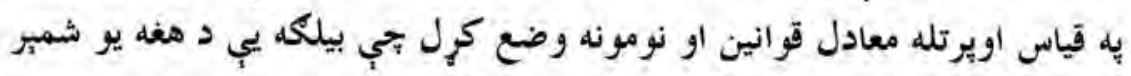

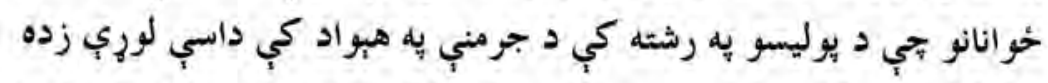

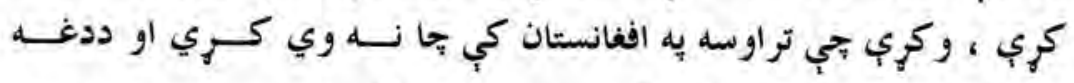
كسانودعلمي درجي د تثبيت لياره كوم داسي رسمى لقب نه وو تي دوى د ديري 
ونومول شى ، داسي لقب لكه به ملكى مسلكى كي يرو فيسور به نظامى كـي

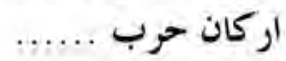

نوتاج محمد خان دقانون د تقسيريه تناسب دغه تحصيلكرووته نومونه وتياكل تردغه منُخ د لفمان به ولايت كي د حكومت به مخحالفت د محمد قاسم صــافي يه مشرى يولي إردوريز مظاهري او لاريونونه را يبل شول تاج محمــــ ورد كى ددغه مخالفتونو او لاريونونو د خنثى كولو لياره ديوه باصالاحيته هيئت يه مشرى لئ

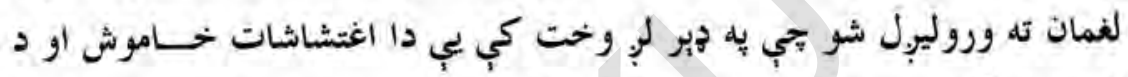

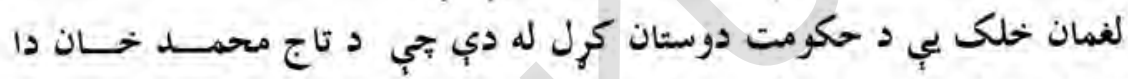

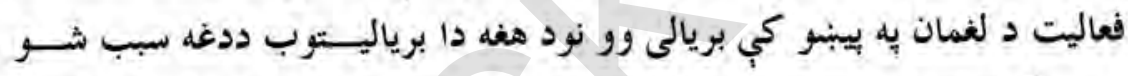

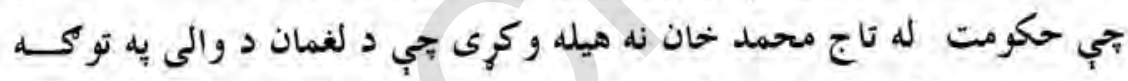

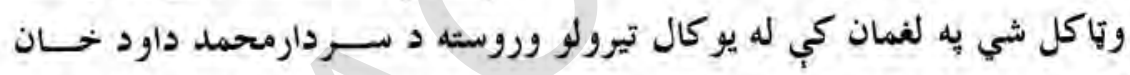
كودتا رامنتخ ته شوه اوتاج محمد خان كابل ته راوغوبنتل شو خو له رارمسـيدو سره سم يو شمبرمغرضوكريو محمد داود خحان ته د هغه يه ارهه شيطانى وكــري

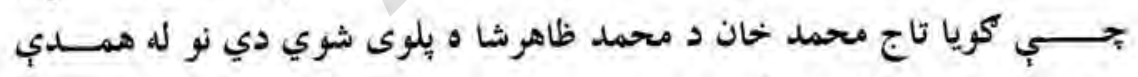
امله ددريو مياشتو خلاره ببكاره وو، بيا وروسته د سردار محمل داود خحان د بشير باور به رنا كي د بلد خشان د والى يه توكه وتياكل شو تاج محمد وردكى د هيو اد يه دغه ليرى ير اته ولايت كي يه ديرويبنتينولى او صلداقت سره د هيواد د نوى جمهور ريس د يوه باورى استازى به تو مكه يه كار

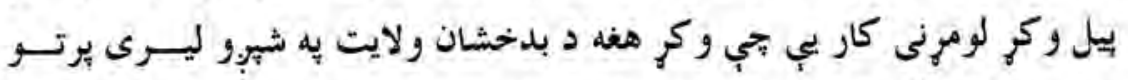
ولسواليوكي لكه شغنان ، كران منجان ، درواز ، خو اهان ، واخحان او يــاميركي 
هو ايب زكرونه جور كرل او يه مركزي حكومت يب داسى الوتكي ومنلي بجي حيه

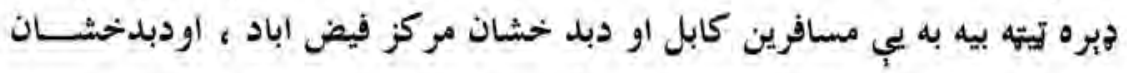

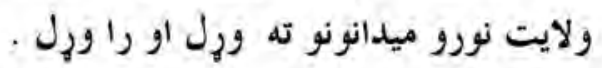

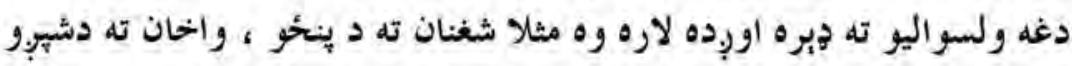
، خو اهان ته د دولسو او درواز ته هم د دولسو ، كران او منجان ته د شـــبورو ورخو لاري وي دغوالوتكو د شلو تنو ظرفيت درلود كله نا كلــه بــهـ تـــاج محمدلحان يه دغه الوتكو كى سفر كاوه او كله به تجي الو تكه هوا ته بورته شور نو تاج محمد به له خوشحالى دهغه د ادارى دستكا ته كبنيناست او ترديره به يب

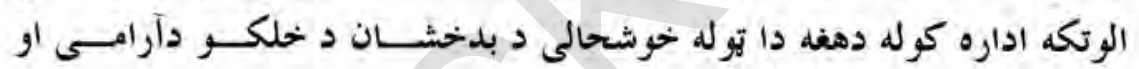

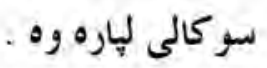

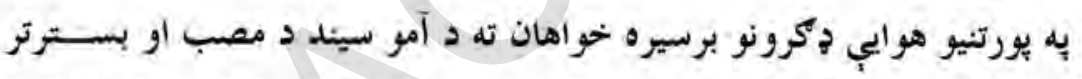

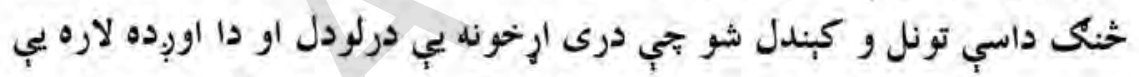
له دولس ورخو نه دوونيمو ورخو ته را لنده كره او ددغد ترخنك يب دكو كجي

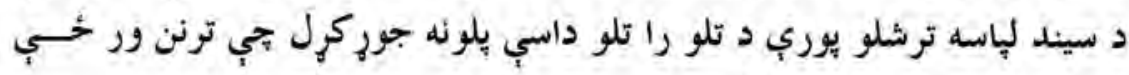
بوري دا يلونه بِ خحاى ولاردي تاج محمد خحان وردى دبد خشان يه ماموريت كي له سياسي سر خوبِيو سره هم مخ شوي دى د بهر الدين (باعث ) به نوم يو ستمي مزاجه د نظام به ور انلدي يرته له دي جي سياسي مجوزاوياكوم منطقي دليل ولرى له يوشمبر ڤيلويانو سره

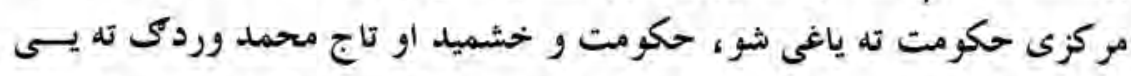
فرمان وركر تجي مورِ هليكو يتراو نورامكانات درليورو ته دغه ياغيانو ته غــابثى 


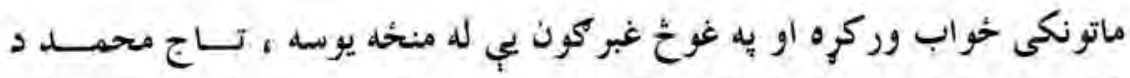

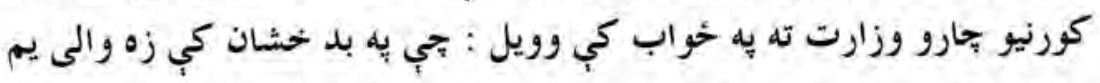

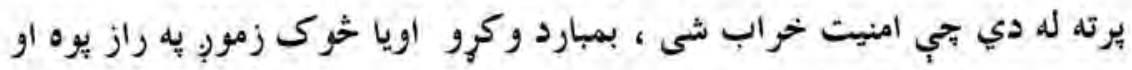

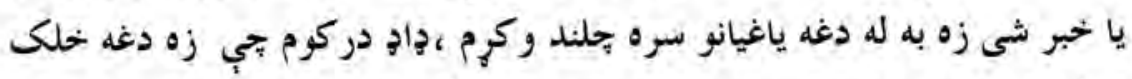
نيولى شم تاسي بيغه اوسى ، هغه وه بحي لاس بكار شو اودياغيانوتولي لاري بي

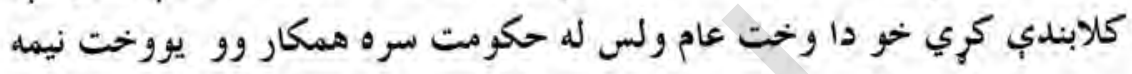

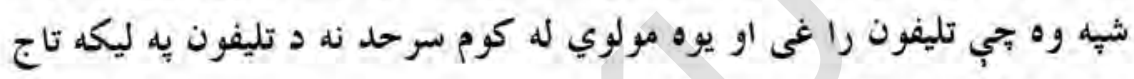

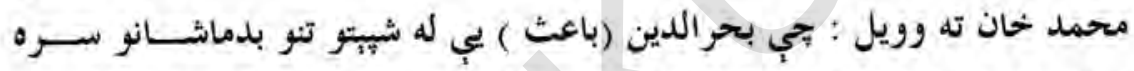

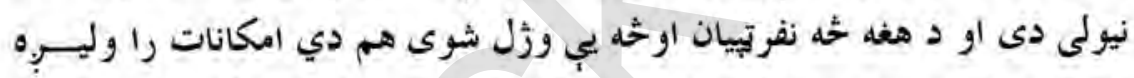

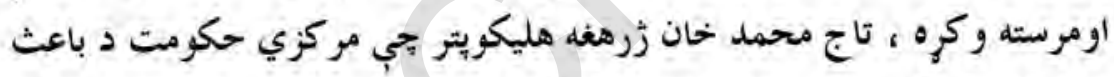

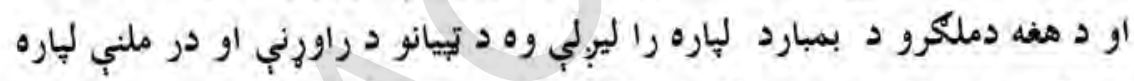

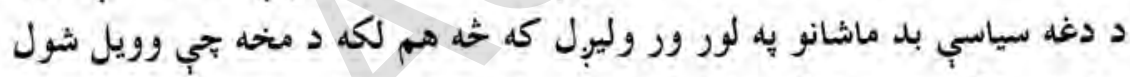

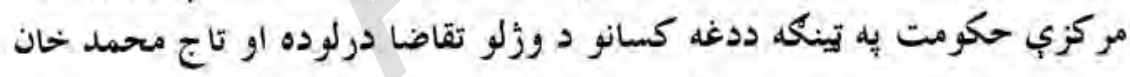

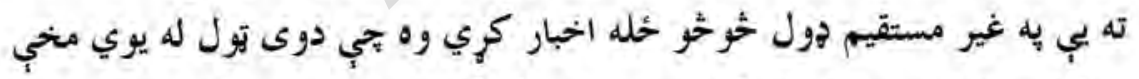

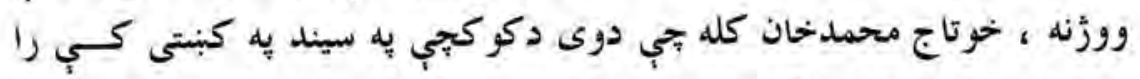

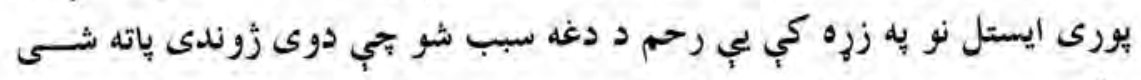

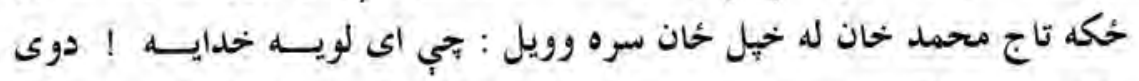

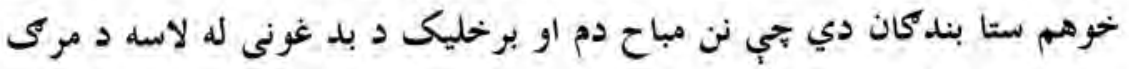
تو بولي رسيدلي دى . 
عجالتا يبي هغوى ونه وزّل ،خوخبره بيرته به بحر الدين با عث را تكيه كور

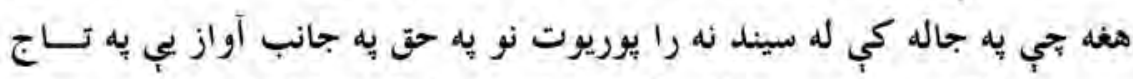

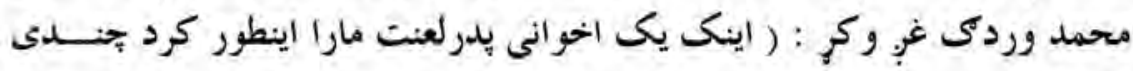
مارا كثت و جندى مارا زخمى ساخت ) دغه بد ماشي او منكر دِلي د افغانستان د تجزيب بالان هم درلود خو بيــاهم دوى د درملني لهاره فيض آباد ته را وستل شــول اولاس يبني يب اولحكى به رور غترن كي واجول شول بله ورخخ يبي تاج محمد خان روغتون ته د يو بنستب ليارث ورغى او له د وى سره يب ديره مهر باني وكره ، بحر الدين (باعث) د عيادت يه شيبه كي تاج محمدخان ته وويل : جي دومره انسانيت راسره كوى ،درملنـــ موكوى، جووزي هم را كوى ، خو دا يبني او لاس مو ولي وا زولني كـري دي

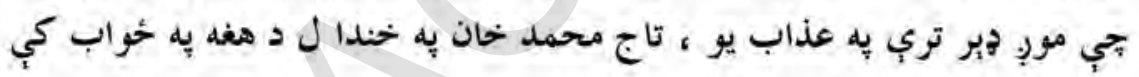

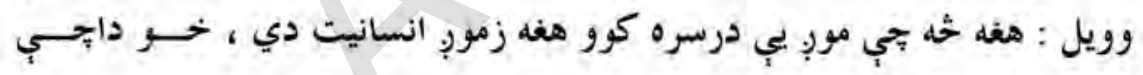
ينبي او لاس مو ولي زولني دي دا ستاسو خيل اخحلاق دي.

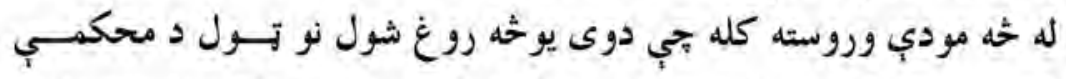
لياره كابل ته را وليول شول ، خودلته به كابل كي يب بيا ستركي وغريدي او د و زوند تمه ورته يبدا شوه او يه تحقيقاتو كي يب يه تاج محمد خحان تورونه ولكول كله جي تاج محمد خان د بيبنو د وضاحت لياره كابل ته وغو بنتل شو نو هغه بي له خحنده تيول وارد شوي اتهامات يه خحان ومنل او وويل : جي بحر الدين باعث

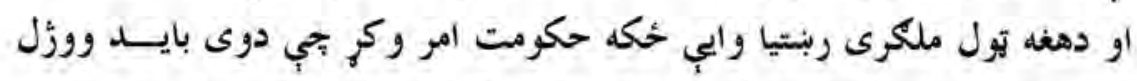
شي ، خوما دوى زونلدي يرينسودل خو جي تر كابل يورب را وربسيدل. 


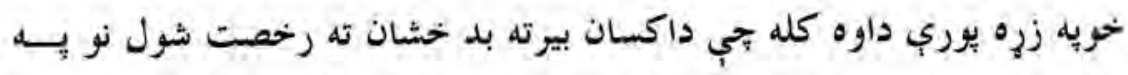

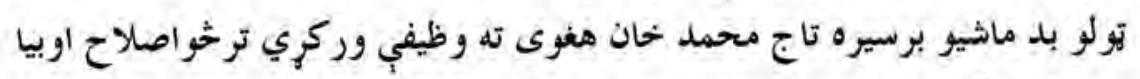

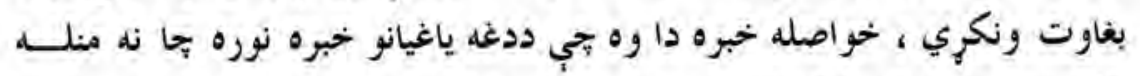

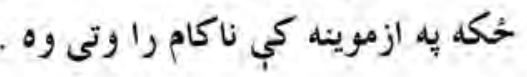

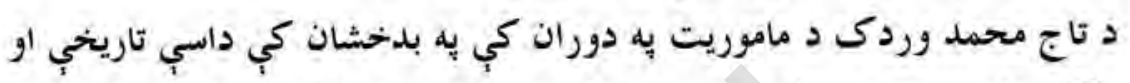

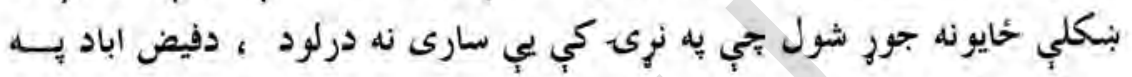

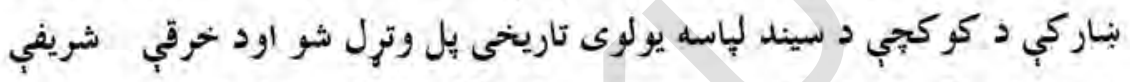

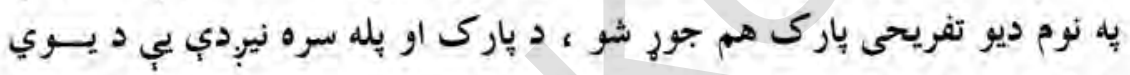

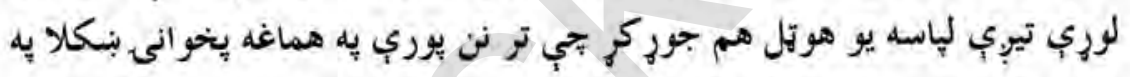

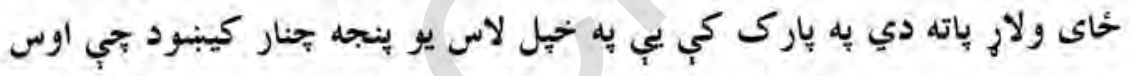

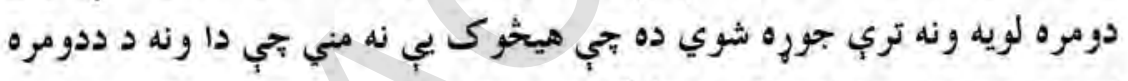

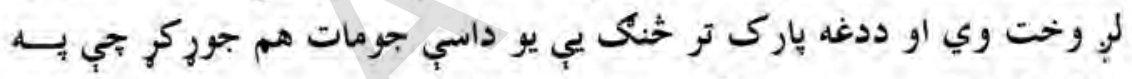

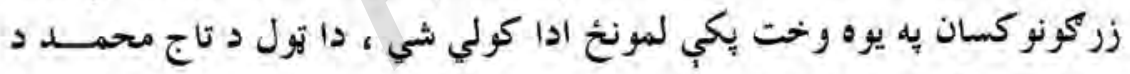

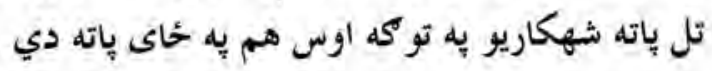

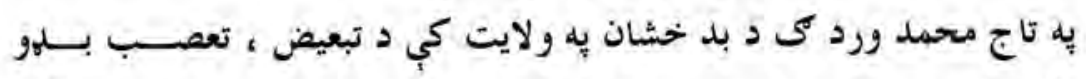

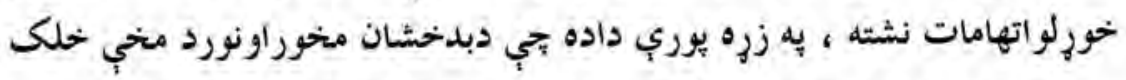

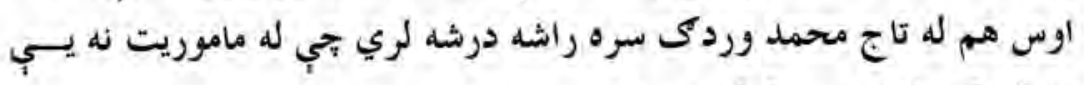

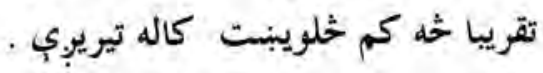

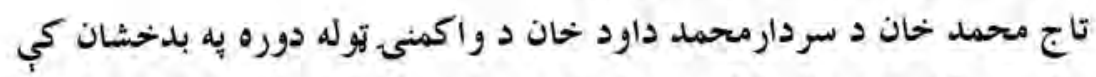
والى وو كله بجي دغويب كودتا را منح ته شوه او كمونستان را غلل نو يه هماغه 
ورخ اسلم وطنجار هغه ته ثليفون وكر او له بل خشان نه يي را وغوبتت او حفيظ

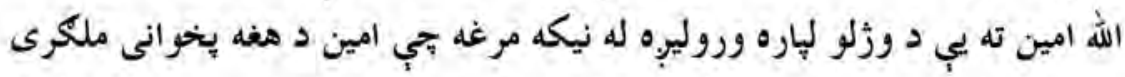
وو نو عجالتا له بندي كيدو وزغورل ثُو خو كله بجي له يوي اونى وروسته حفيظ

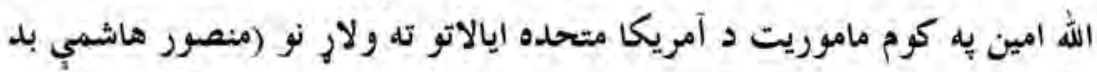

خشب) له تركي نه د مغه د بندي كيدو امر واخيست (1)

تاج محمد وروكى دخه باندي يوه كال لهاره بندي وو كله تي د بنديخاني را ووت نو يه وردكو كي له يو خه مودي ياته كيدو او جهاد وروسته بيبنور ته ولار او هلته د بيرسيد احمد كيلاني يه تنظيم كي د هغه سلاكاراو د خهه وخت لهاره محاذ به دارلانشا كي وو داوخت يبي له افغان برحاله بيلو تانو سره أريكي ونيوى جي شخص ببركى كارمل به بمبارد كوى خو دريغا بحي د هغوى دا يلان نا كام

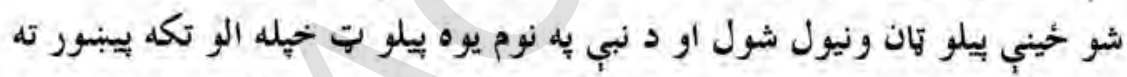
وتبنتوله .تاج محمد وردكى يه يبينبور كي له يو خه مودي تيرولو وروسته له خيل

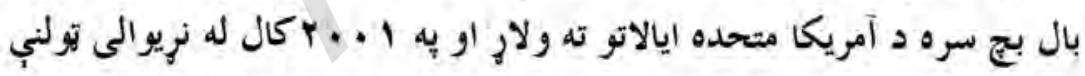
سره بيرته افغانستان ته راغي او دوهمه مرحله ماموريت يب ييل كر . تاج محمد وردى د زوند به شيبوكي دى يه كارته مامورين كي د غره يه لهن كي بيه يودريمه درجه كوركي اوسيوبي .

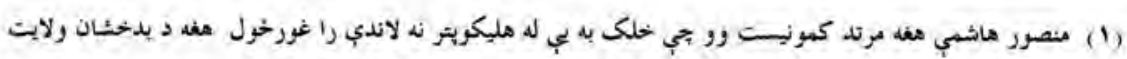

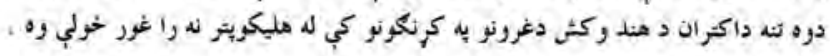




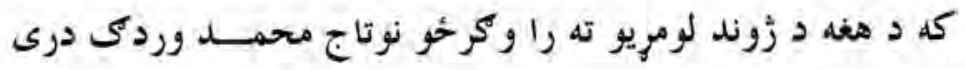

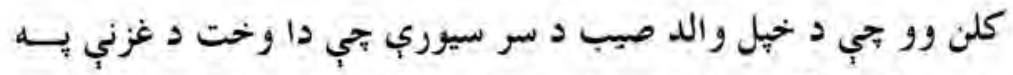

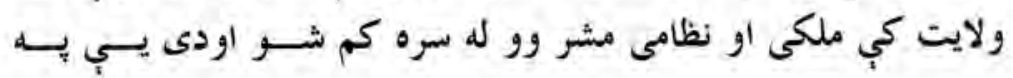

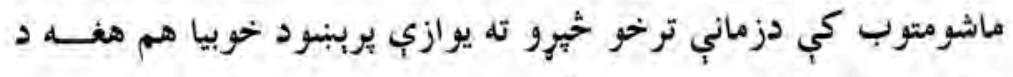

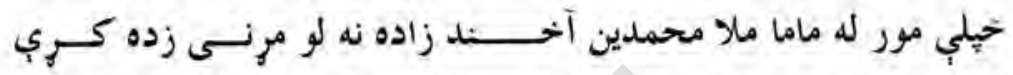
وكري دا وخت به وطن كي بنونحئ نه وو د هغه يه ماشوتوب كي دئه

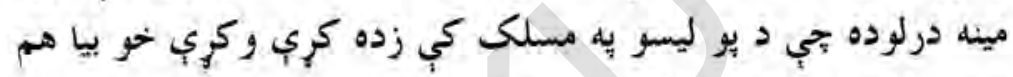

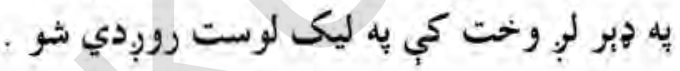




\section{$r \wedge$}

د وردكو مشاهير دوهم تركى

\section{جمال الدين خان وردك ـ د كارد قواوو قوماندان}

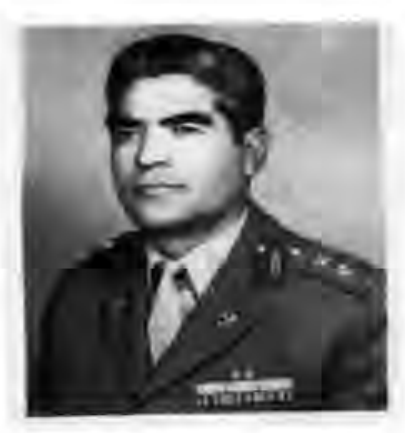

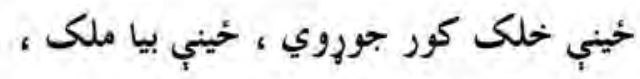

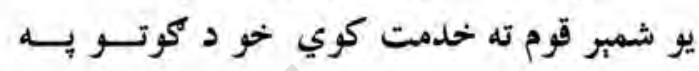

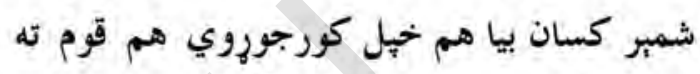

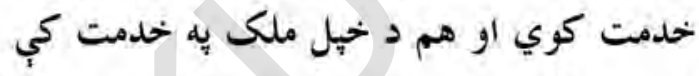

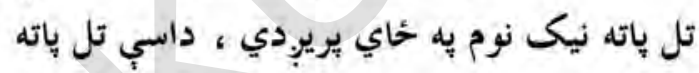

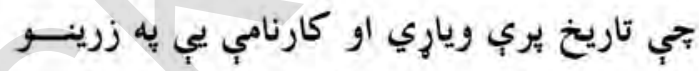

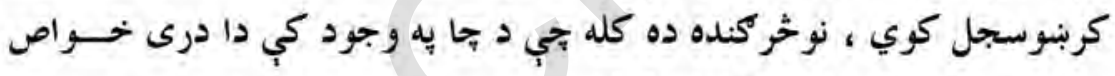

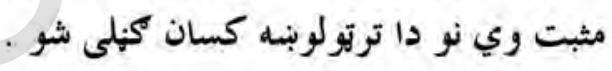

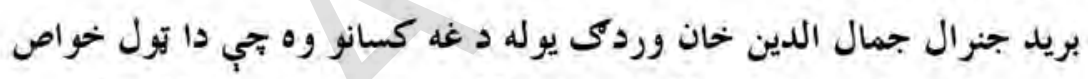

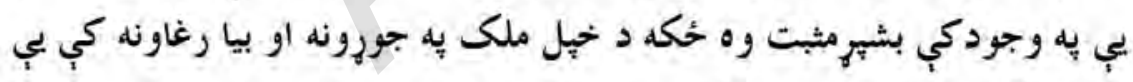

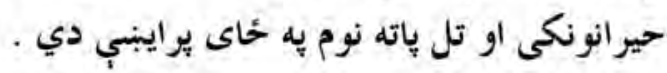

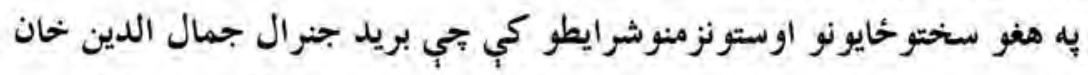

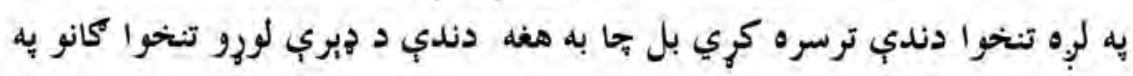

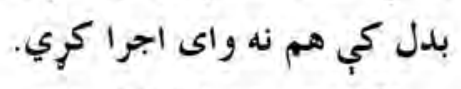

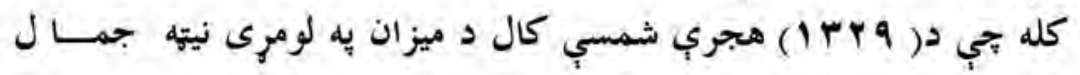

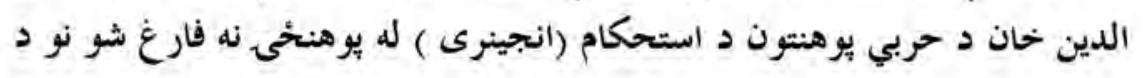




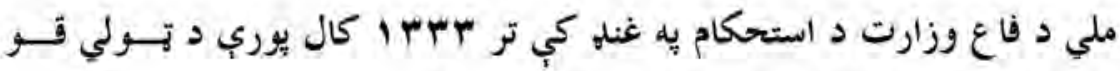

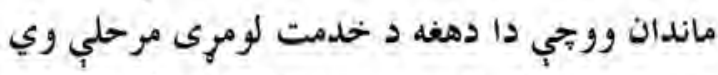

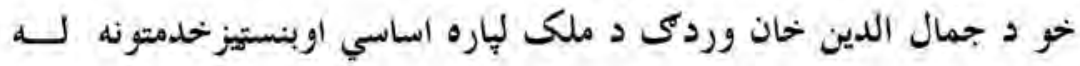

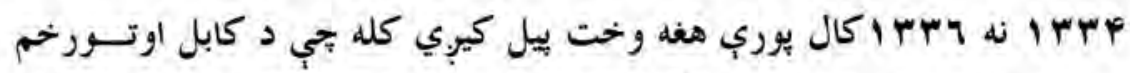

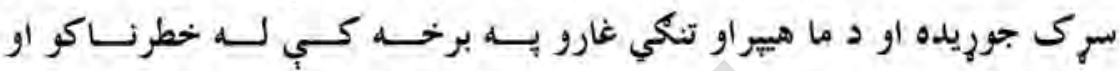

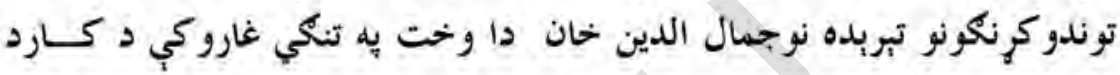

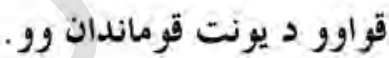

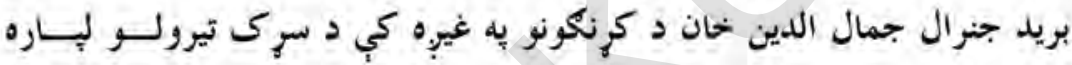

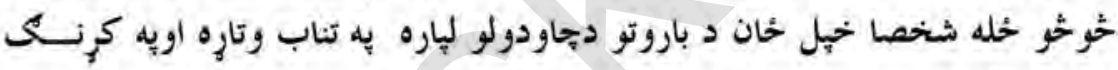

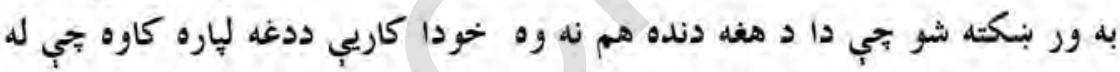

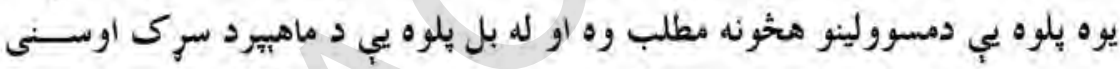

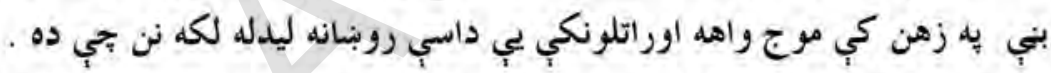

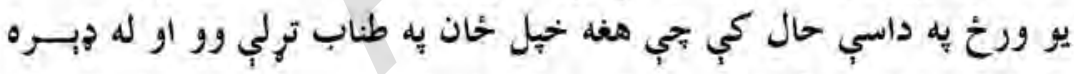

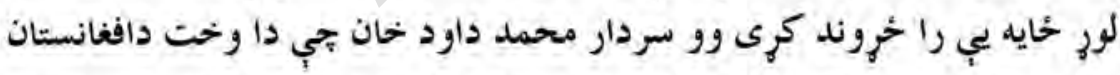

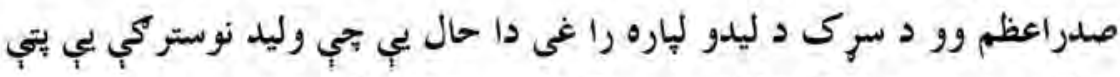

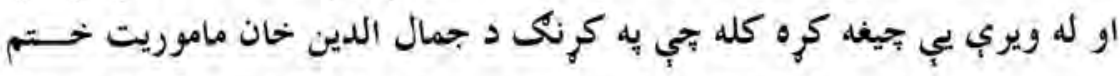

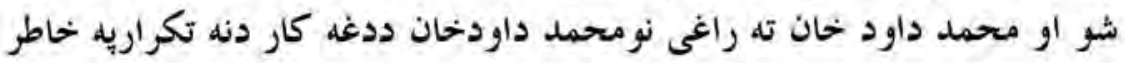

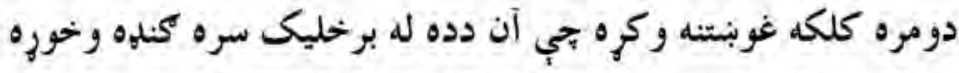

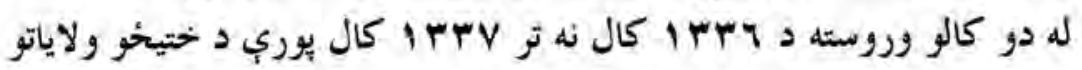

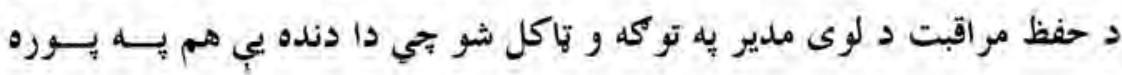


\&.

د وردكو مشاهير دوهم توكى

صداقت او امائت دارى بره تر سره كره خحو ويلاى شو تجي يه دنده كي دهغه

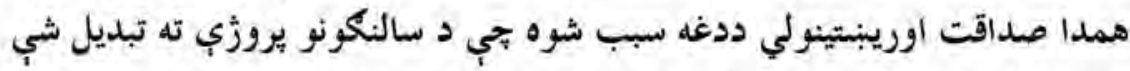

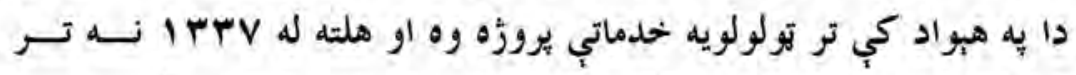

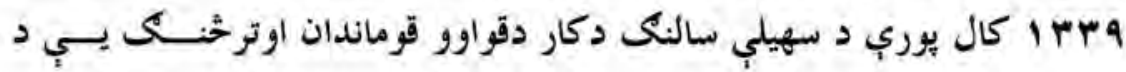

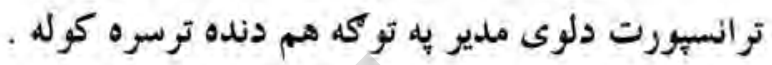

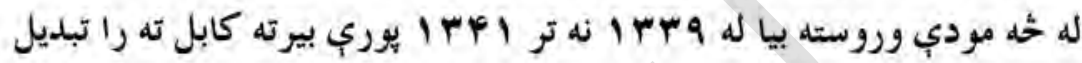

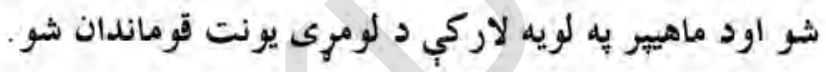

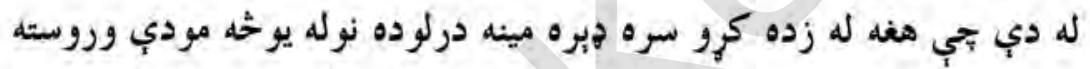

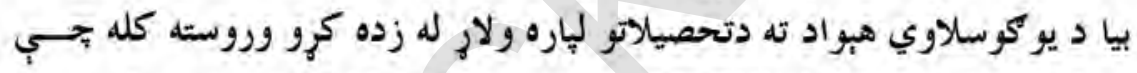

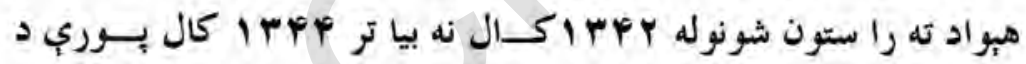

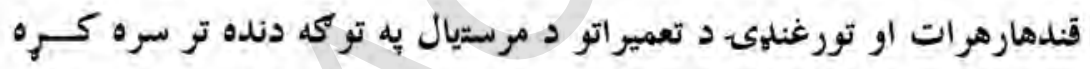

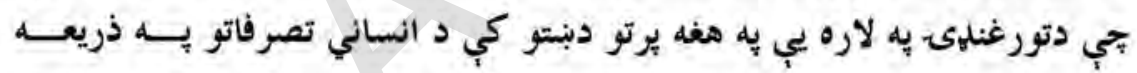

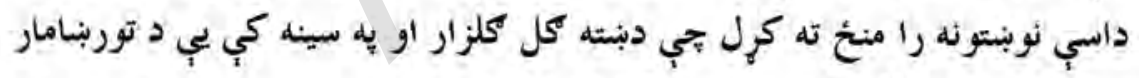

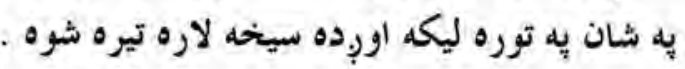

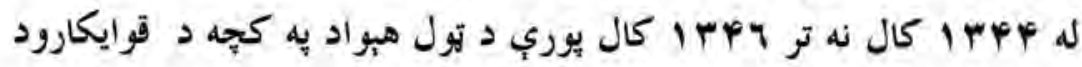

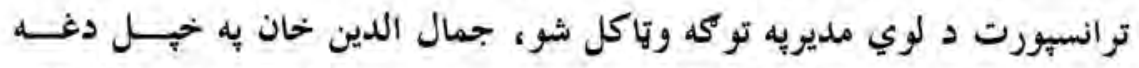

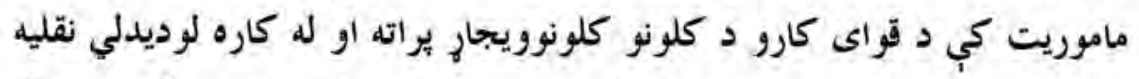

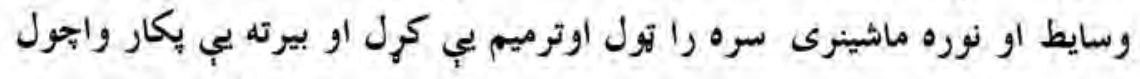

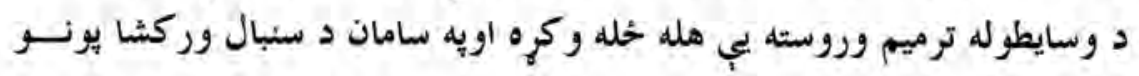
تابيا بي ونيوه. 


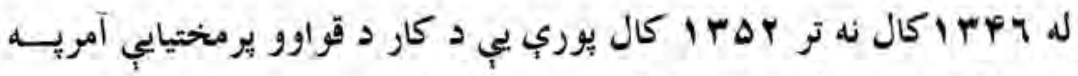

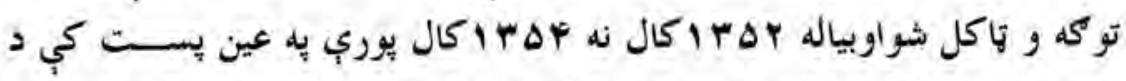

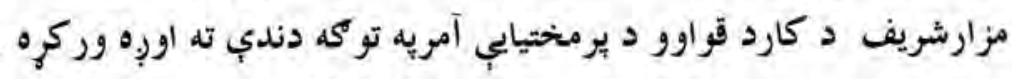

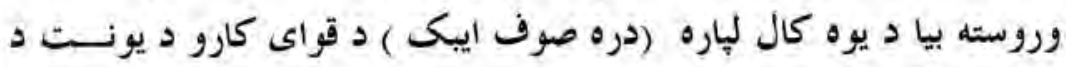

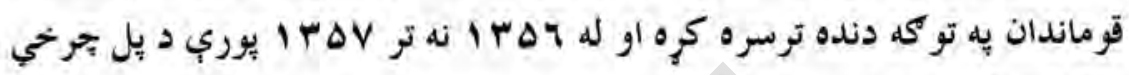

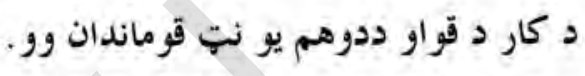

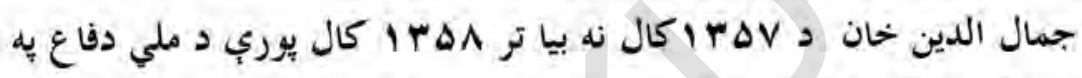

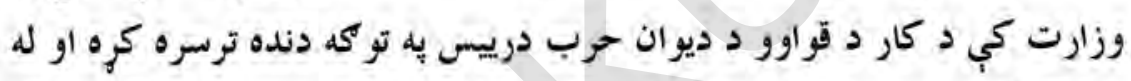

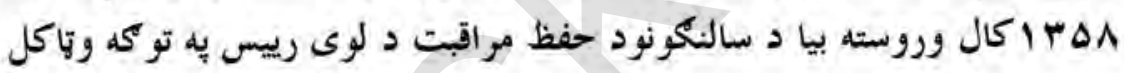

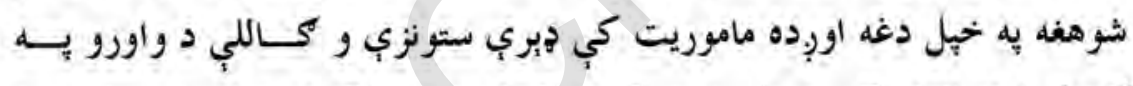

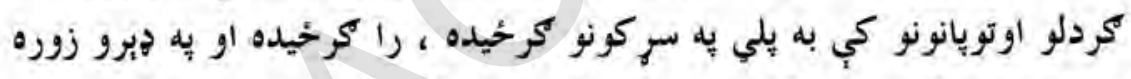

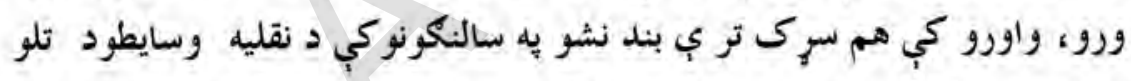

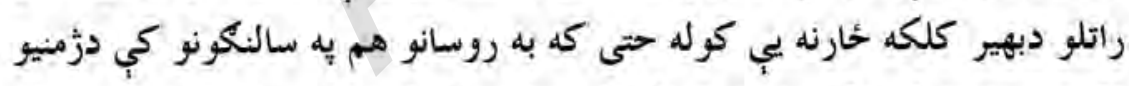

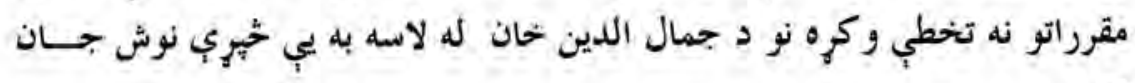

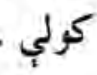

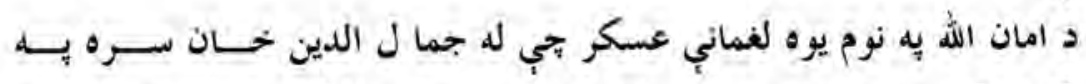

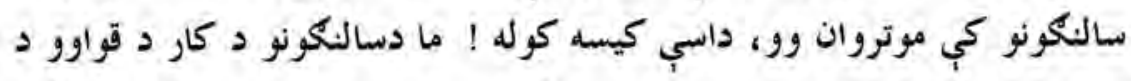

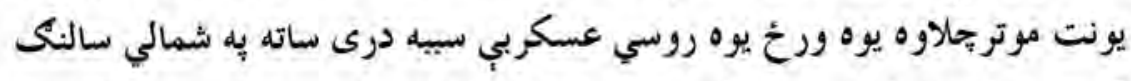

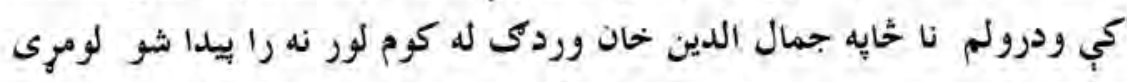

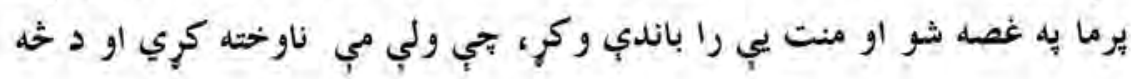


للاره د سرك يه سرولار يم ، خو كله جي بِه مطلب يوه شو نو له روسي عسكر

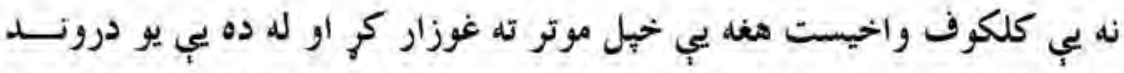

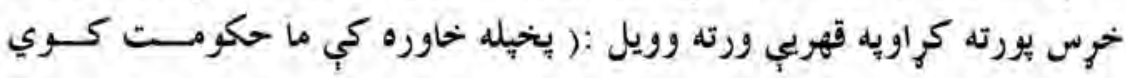

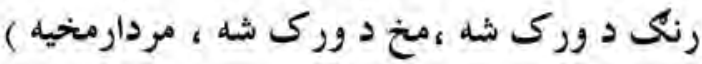

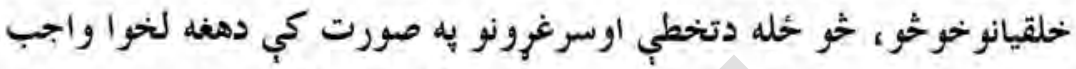

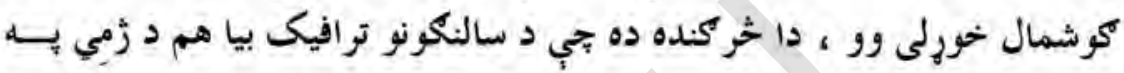

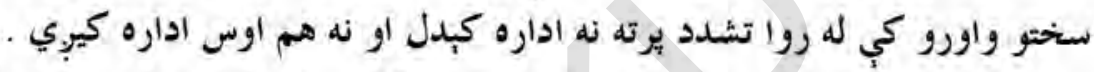

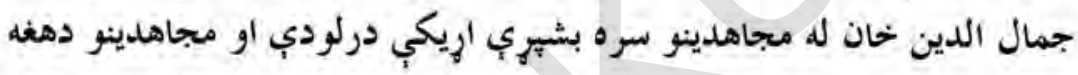

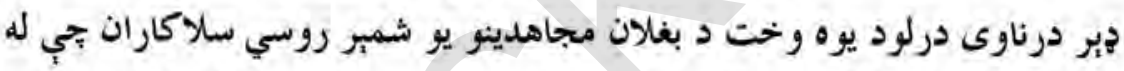

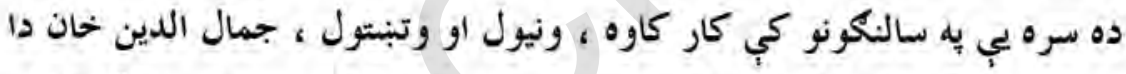

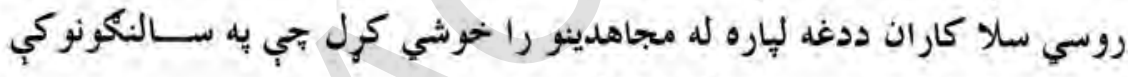
بي ديوي ابزارى وسيلي يه تو كهد توي كار اخيست.

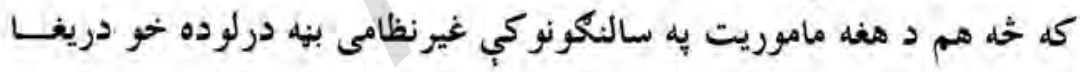

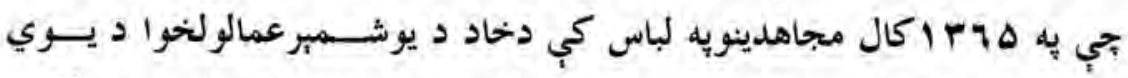

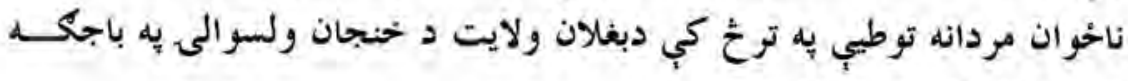
نومي خاي كي شهيد كرائ شو.

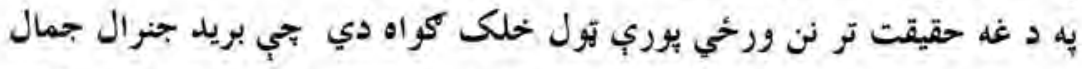

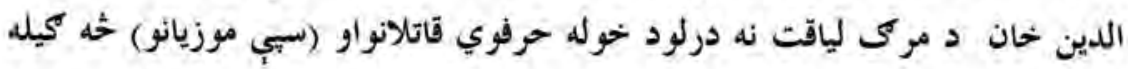

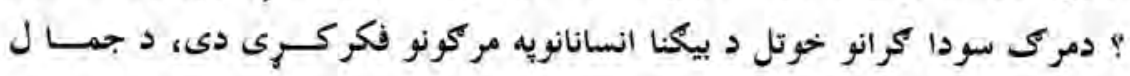

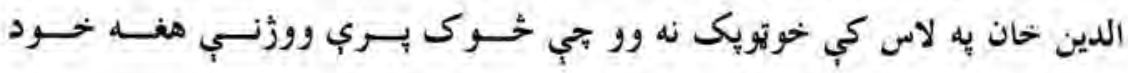




\section{$\leqslant$} د وردكو مشاهير دوهم توكى

سالنكونويه قهرجنو واورينو ثميوكي يه دغه لاره تيريدونكو مســافروته د نجسات

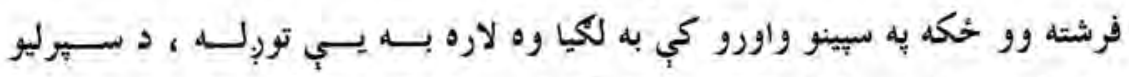

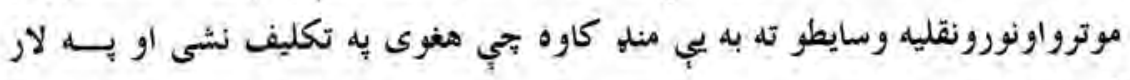

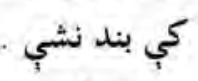
جمال الدين خان خويه سالنكونوكي د جورونكي اونجات بنبونكي ماشيننري

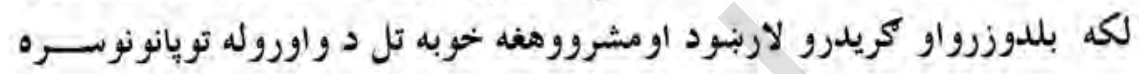

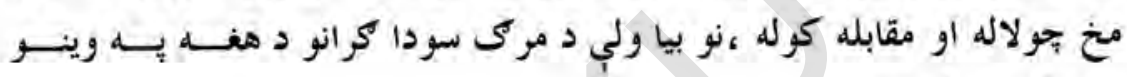

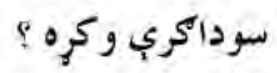
به جمال الدين خان خو شمالي أوسهيلي دواره يلوه سالنكونه خوار شول او

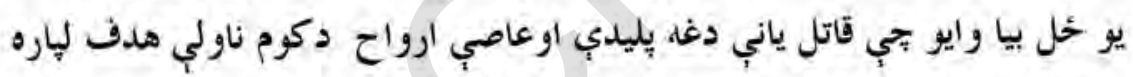

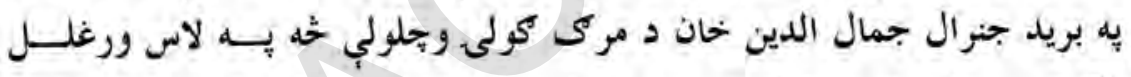

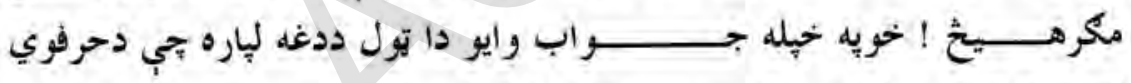

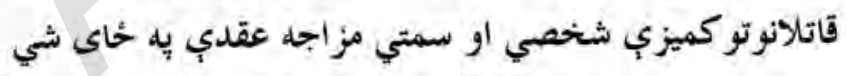

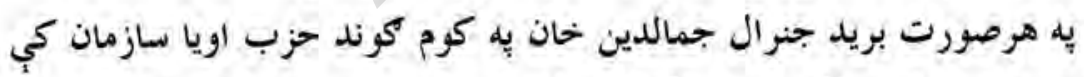

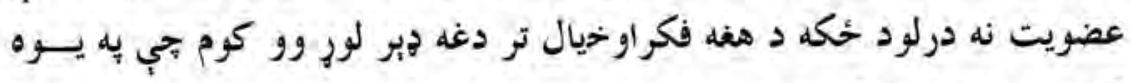

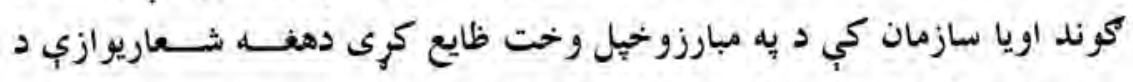

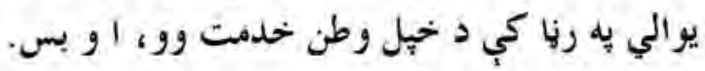

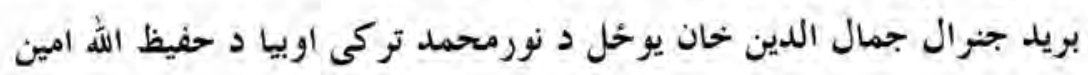

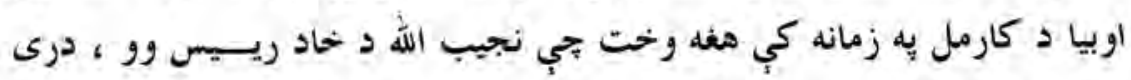

$$
\text { واره بندي شو او بيرته به را خوشى شو. }
$$




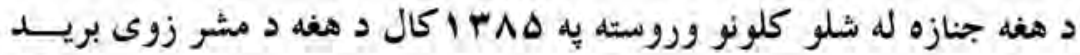

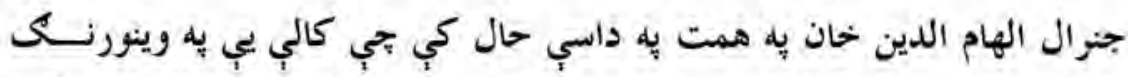
اوهلهوكي يب سره كلهوج شوي وو ، وردكو ته را ورل شوه اوداونخي د حكيم

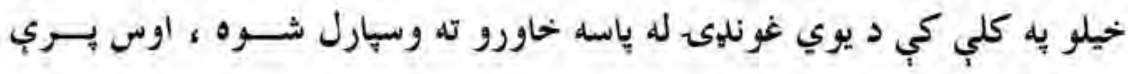
كنبده جوري ده نده

د وردكو يه خلكو كي اوس دا عامه اصتلاح ده بحي د هر جا د داسي زامن

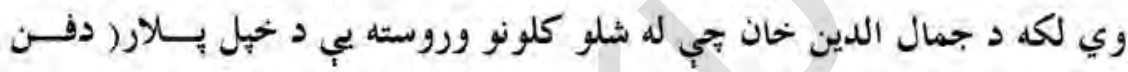
اوكفن له سره وكرل ) هفه تجي له شلو كلونو را يديخوا بي دعا او بي كفنــه د

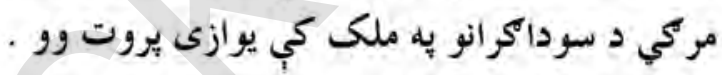

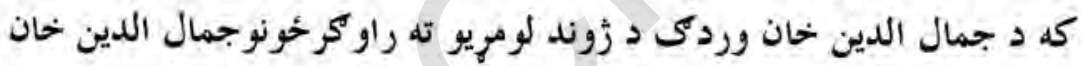
وروى د غوث الدين خان زوى اويه V.r. ا كال د وردكود سيد آباد ولسوالى.

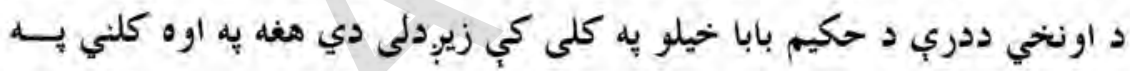

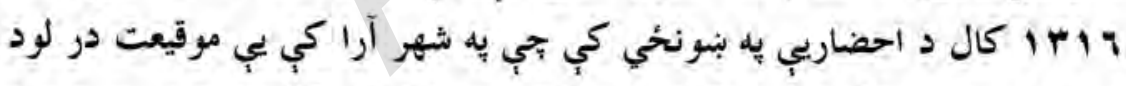
خيلي لومرنى زده كري يبل كري او بالاخره يه ه بما بال كال له حربي يو هنتون نه فارغ ش

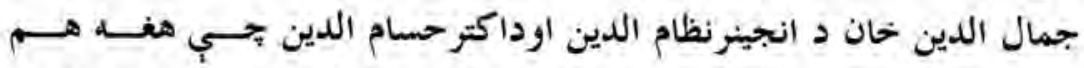
ددكروال يه رتبه نظامى منصب دار وو دوه ورونه نورهم درلودل جي نظام الدين

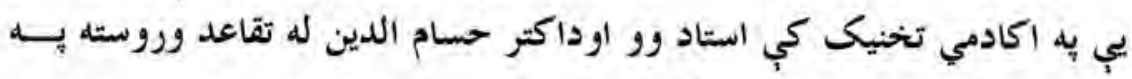
حكيم خيلو كي ددوى يه كلينيك كي كار كاوه . 
ددغه ترخنك جمالدين خان يشخه داسي زامن درلودل جي هر يو يب د ملكى

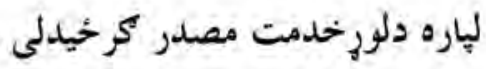

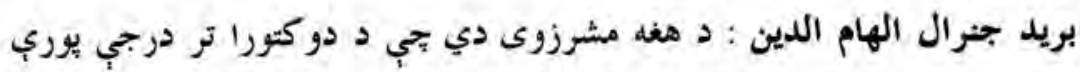

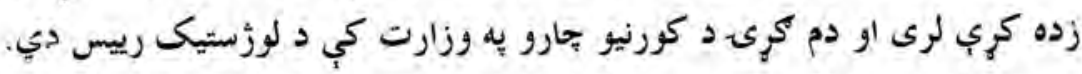

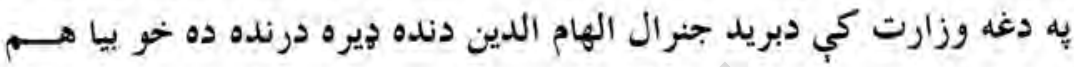

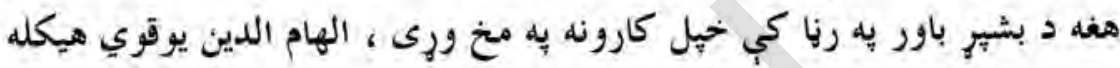

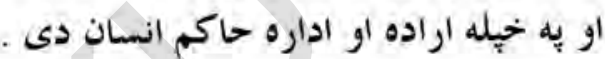

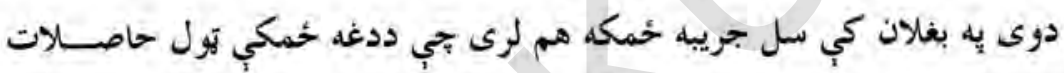

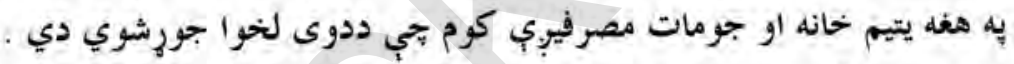

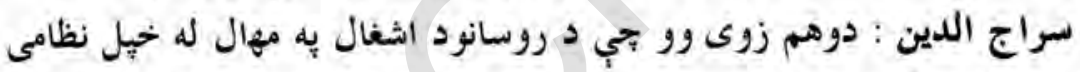

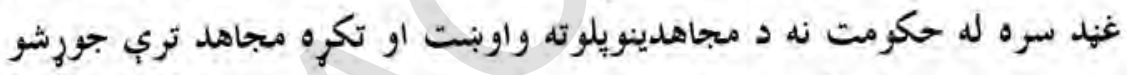

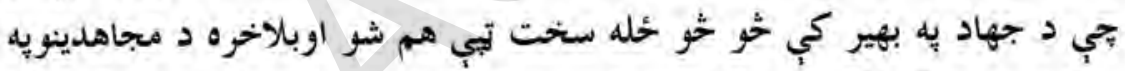

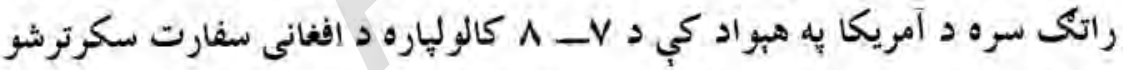

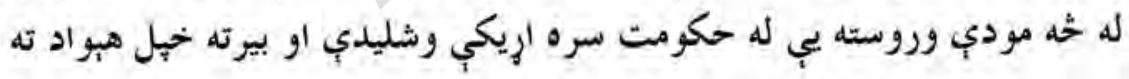

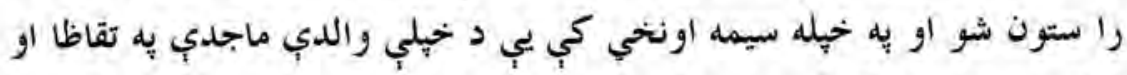

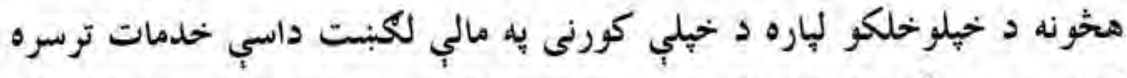

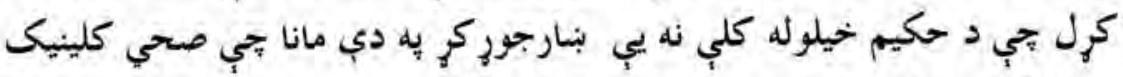

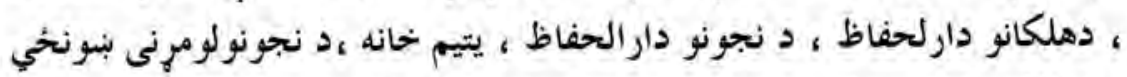

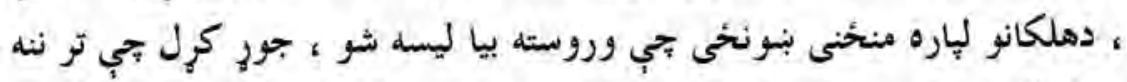

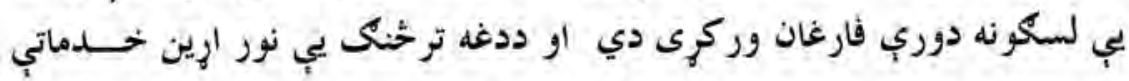




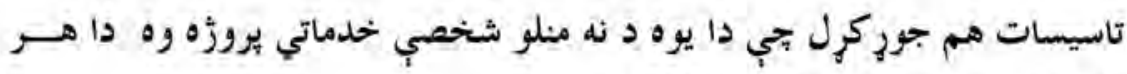

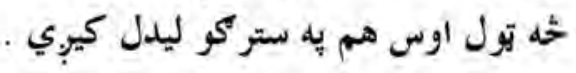

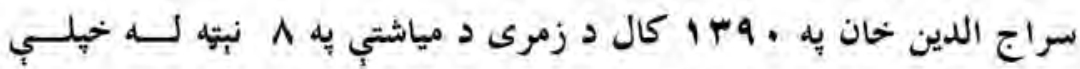

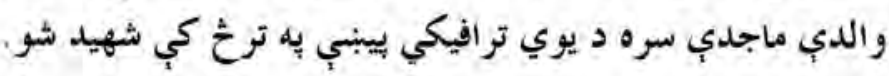

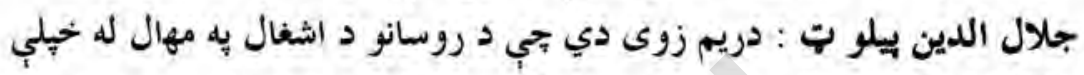

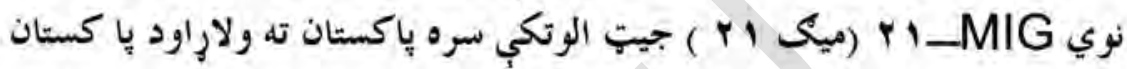

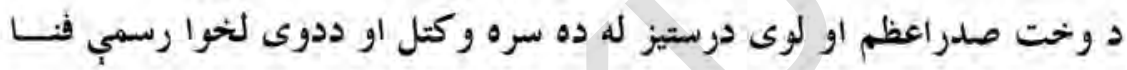

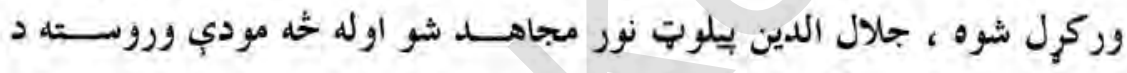

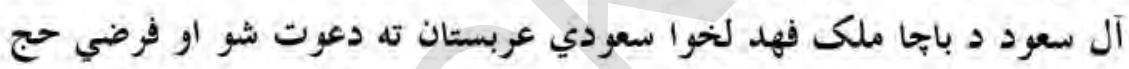

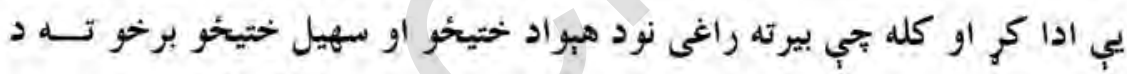

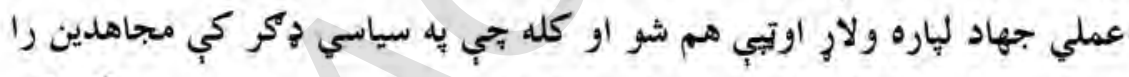

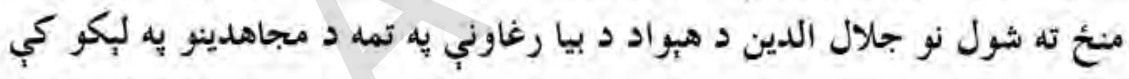

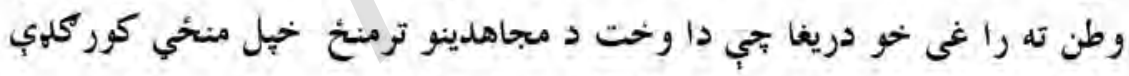

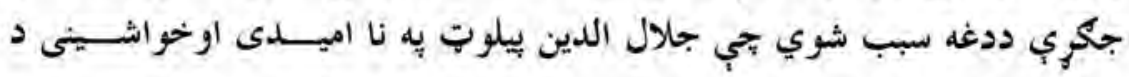

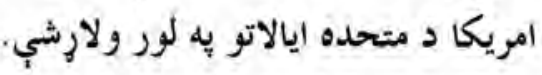

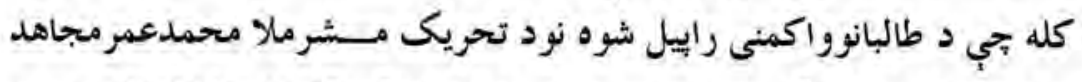

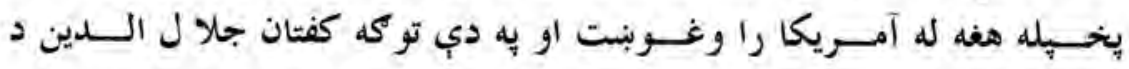

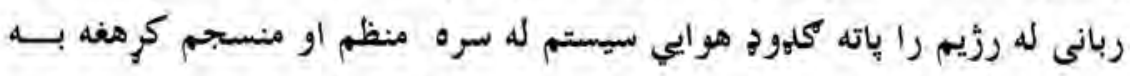

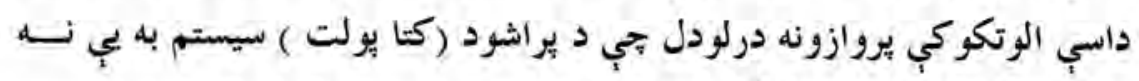

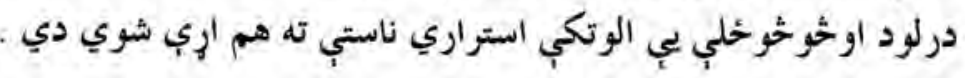




\section{$\varepsilon V$}

دوركى مشاهير دوهم توكى

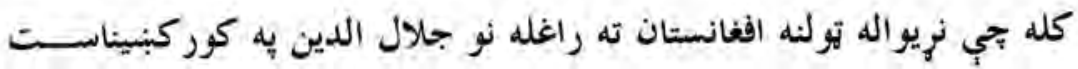

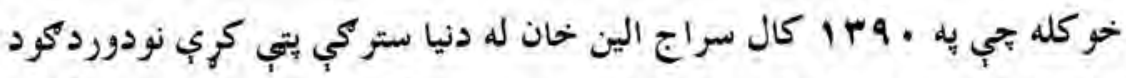
تولوولسو اليونه را تولو شويو سيين زيرو او مشرانو لخوا د هغه د تدفين او تكفين

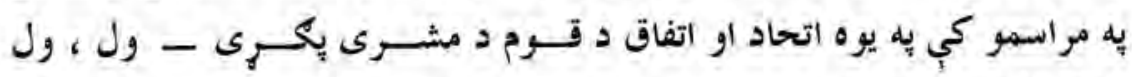
جلال الدين ته ورتيرل شره . خالدين خلورم زوى دى جي له اكادمي يوليس نه فارغ شوى وو او جنايب منصب دار تري جور شو اووروسته بيا د مجاهدينو ليكو ثه ولار .

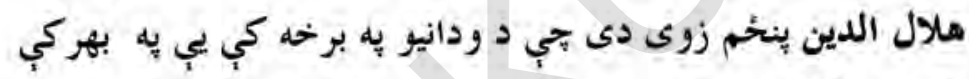
زمه كري ، كري دي . 


\section{$\varepsilon \wedge$}

د وردكو مشاهير دوهم يوك

\section{جمعه خان (همد رد ) - - والى}

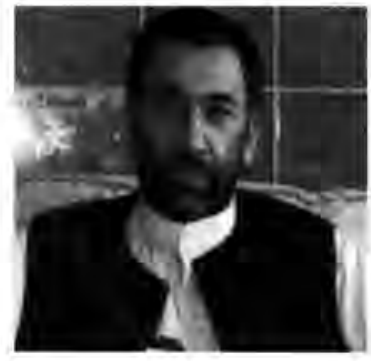

جمعه خان همدرد د جهاد يه مهال يخهله سيمه

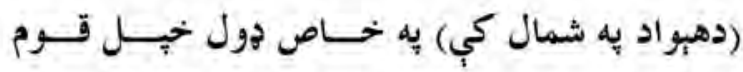
وردكى ، يه عام جول تول بينتانه د توكميز إردورله غليم توب نه يه زوكو دوروكي له هر زول تيرى اوغتج اخيستونكو بريدونونه بج اوسرلوري وساتل نوخيكه به د هغه نوميالي نوم د كيقباد ، كيخسرو خيه حخيــرد

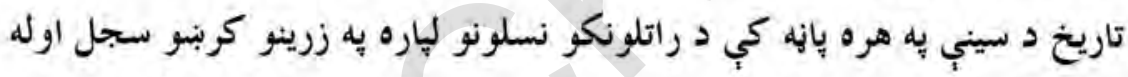
وياره ذوكي كار نامي او فعاليتونه به يب د غيرت د مشالونو تل ياته بيلكي وي.

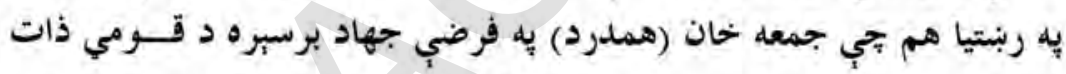

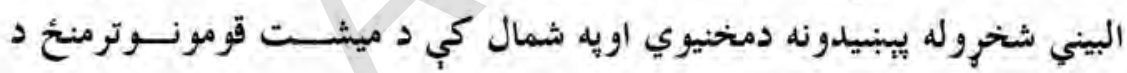
نيكواريكو يه احيا اوزوندي كولوكي هخاند وو.

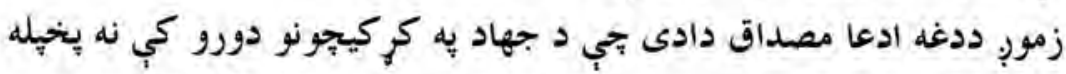

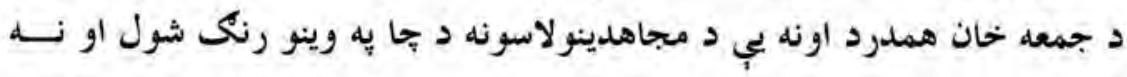
هم د بل حا لاسونه ، دهغه د (مجاهدينو او يا نورو متعهدينو) يه وينو سره شول دا يه دي مانا نه وو بحي جمعه خان (همدرد) كمزوري وو، نه ! دهغه له شخصي خصوصياتو نه يو دا وه هي اصلا له هبجا او هيخ قوم سره تضاد نه درلود يـــو

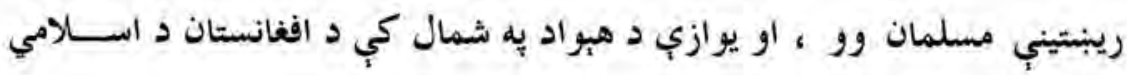


حزب يو تكره ، متعهد او وفادار قوماندا ن وو بجي د مقابلي لوري يب يوازي او

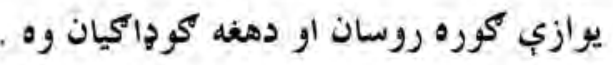

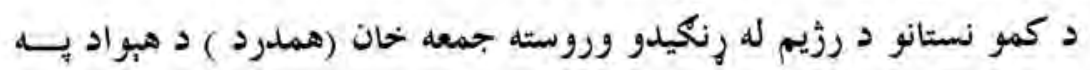

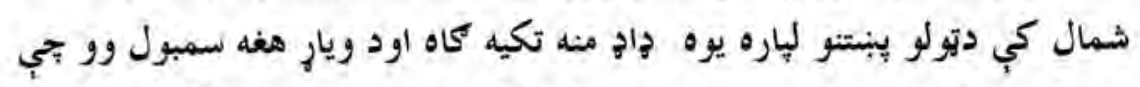

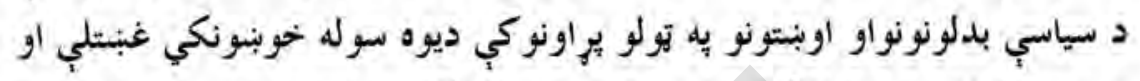

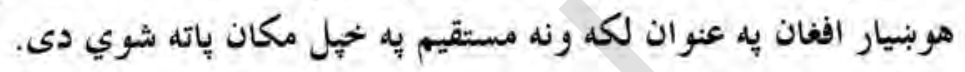

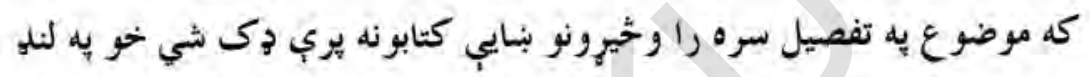

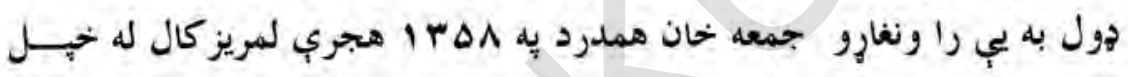

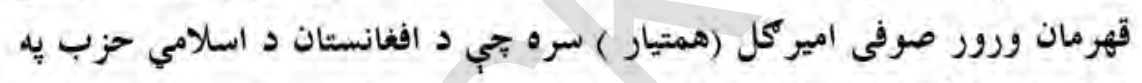

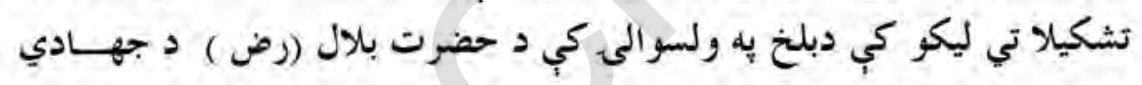

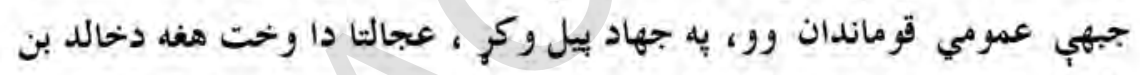

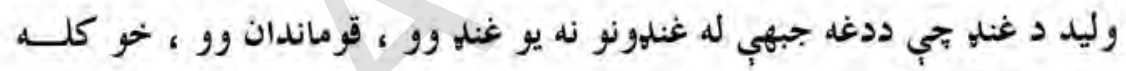

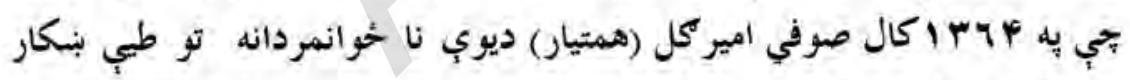

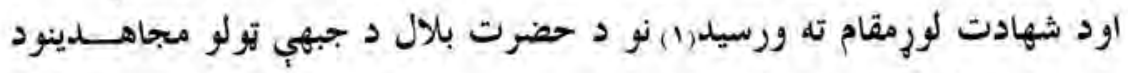

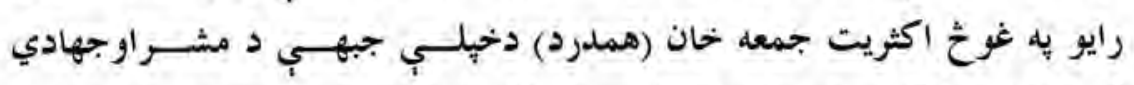

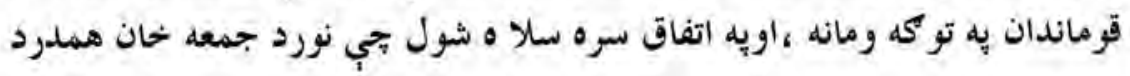

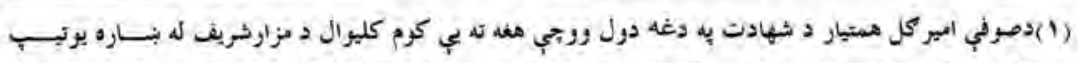

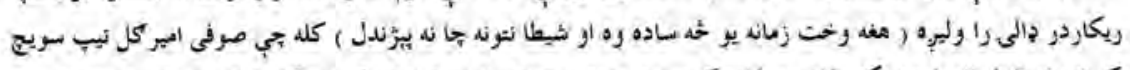

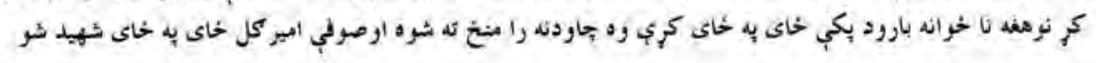


•.

دوردكو مشاهير دوهم توكى

تو قيادت اوقو ماندي لاندي يه دغه جبهه كي د يخوا يه خير خيل سـيبخلى جهاد ته ادامه وركري .

ياته دي نه وى تجي دا وخت د حضرت بلال جبهي دبلخ ولايت يــه مختلفــو ولسواليو كي به لاندي تفصيل خملورغت غندونه د فعاليت يه جو كات كي درلودل .

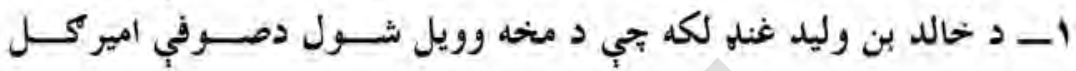

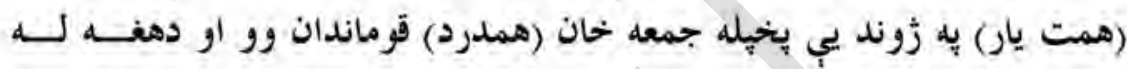
شهادت وروسته كله بي جمعل خان همدرد د حضرت بلال د جبهي عمـــومي اميرشو نو ددغه غنده قوماندان مامورمحمد نسيم ووتاكل شو

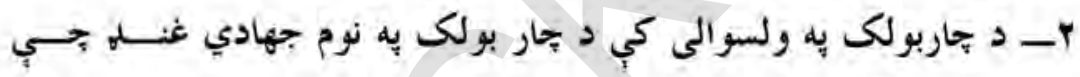

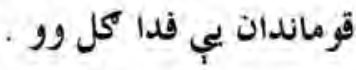

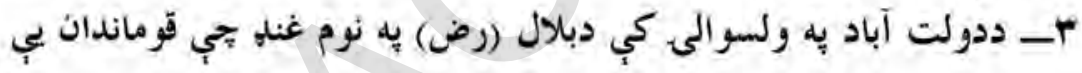

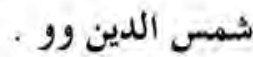
†- د بلخ به ولسوالى كي د شهيد (همتيار) يه نوم غنده تجي قو ماندان يــي جمعه الدين وو او دهمتيار له شهادت وروسته دا نوم ورباندي كبنيودل شو . .

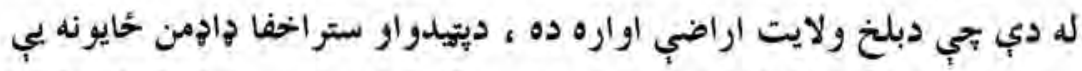

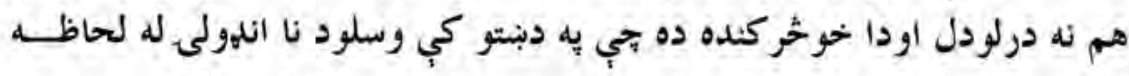

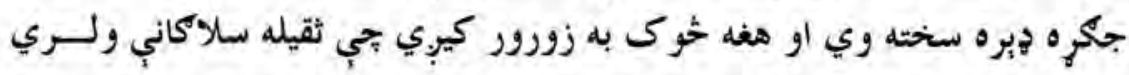
خو بيا هم كله به بحي جكره ونبنته نو(نره) جكره به وه او مجاهدينو به خيـل سنكرونه نه خوشي كول كه خه هم 2 جبهي عمومي مركز 2 شولكري ولسوالى لى 


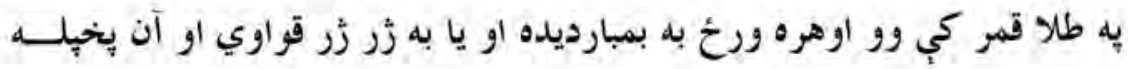

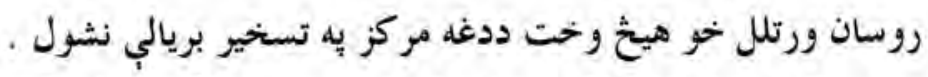

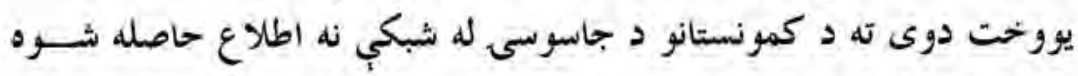

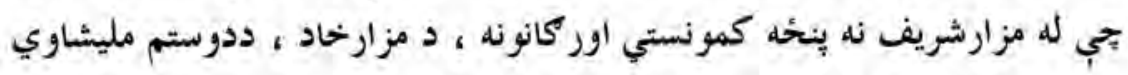

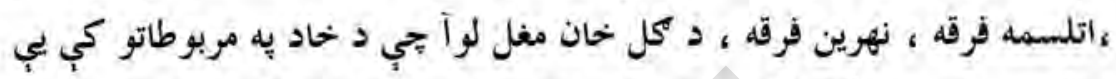

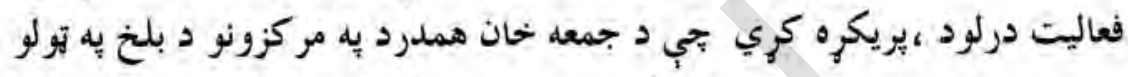

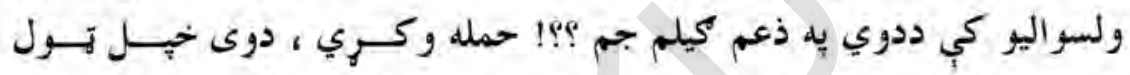

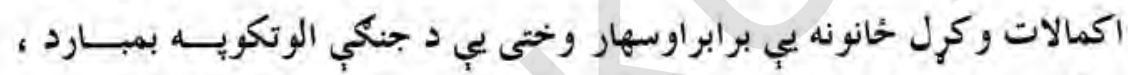

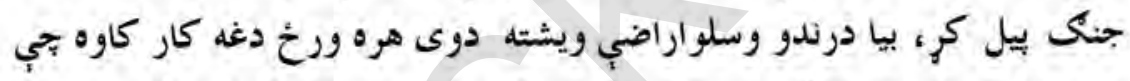

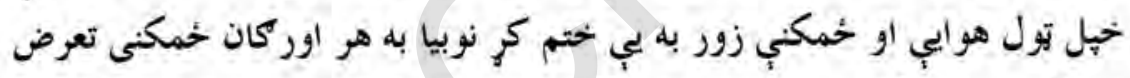

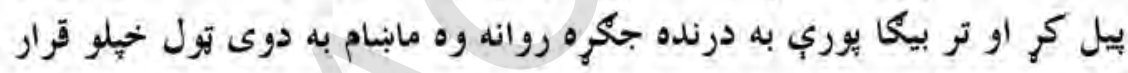

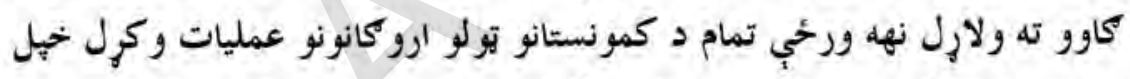

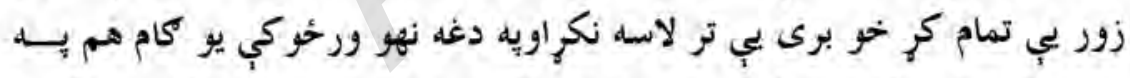

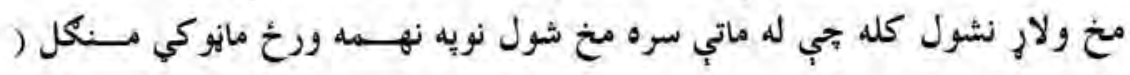

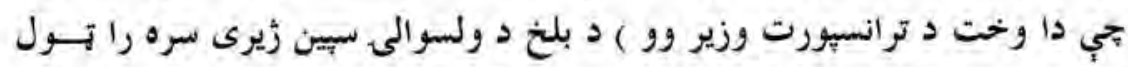

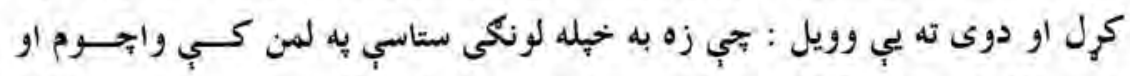

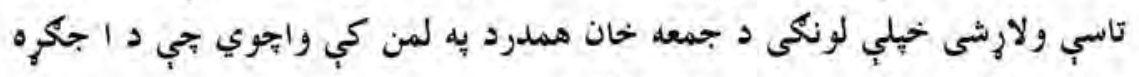

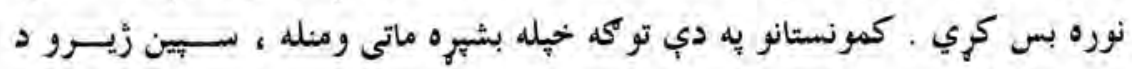

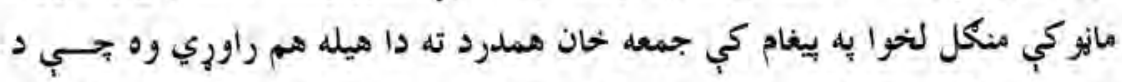

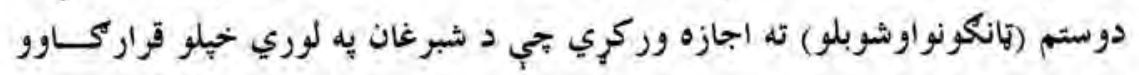




\section{or}

دودكو مشاهير دومم توكى

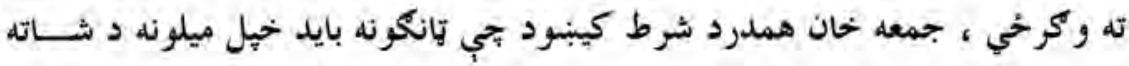
لور ته واروري او بيا به سركى تير شي خو جالبه دا وه جي دو ستم بيا هم له همدغه

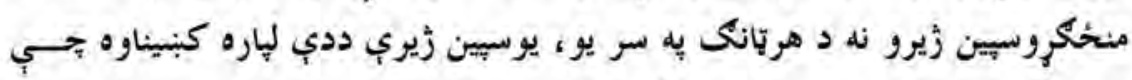
جمعه خان همدرد يوي عمليات ونكري .

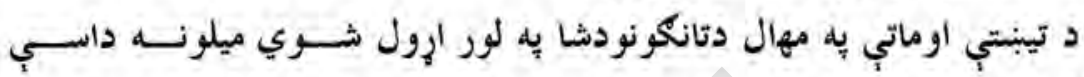

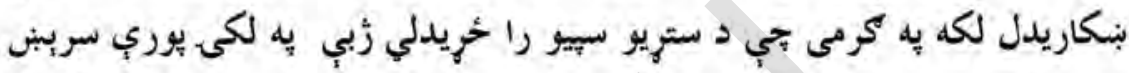

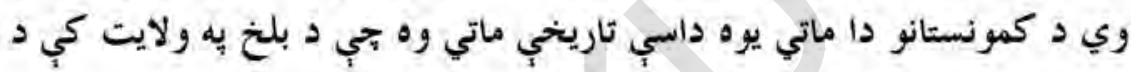
مجاهدينواو نورعام ولس تومنح يه (يرتكونو) بلدركه شوه . د وخت به تيريدوسره د جهاد يه ليكو كي دجمعه خحان همدرد بنه ورتيا او زرورتيا ددغه سبب شوه جي د بلخ ولسوالىه دغه جهادي مركز (د حضرت بلال " رض " جهادي جبهه ) د افغانستان د اسلامي حزب د ه شـــالى ولايــاتو د

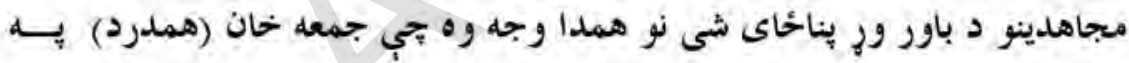

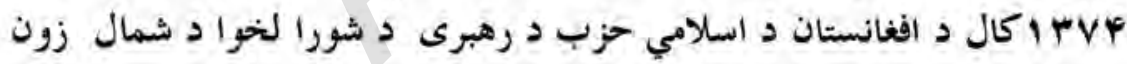
د تنظيمه ريس نه توكه، وتياكل شي . د جهاد يه مهال جمعه خان همدرد د بِاكستان له تك او راتك سره جيندان مينه نه درلوده دو سلو اكمالات بي مجاهدينوكول او يوازي به بنسائي دوه حله ياكستان ته تللى وي . جمعه خان همدرد له هيخ بهرنى هبو اد سره د نورو؟؟ يه شان كوم سياسـي تعلقات ثله درلودل ، كه نه د هغه لِاره ددي بنه زمينه برابره وه جي د كاونلريو او يا نوري نرى له كوم هبو اد سره سياسي اريكي ولري او خهيل حان د نورو يه 
or د وردكو مشاهير دوهم تركى

شان مجازي شهرت او قدرت تل ورسوي دداسب كرنو بيلكه د هغه يه وجود او شخصيت هيخ نشته . كله بجي د كمونستانوخوترى ، ظالمانه واكمني او دوروه يه افغانستان كي ياى

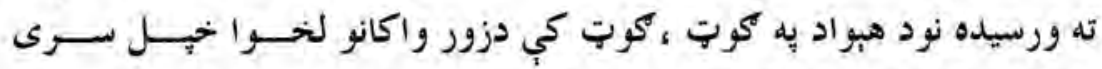

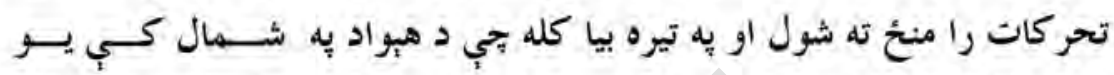
شمبرملو ك الطوايفي ته ورته جوربنتونه را بيدا شول او به رآس كي يج يخو انى بي رحمه زور واكان وه نو د خلكويه بيخايه حخورولواو وبرولوبي بيل را وركر سره له دي تجي دا وخت ددوى د تاوتريخو اليو او منفى نفوذ د اعمال له امله يو شمبر كو بنى جهادي حوزي او لو بِ جبهي ته دو تسليميدو يه حال كي شوي

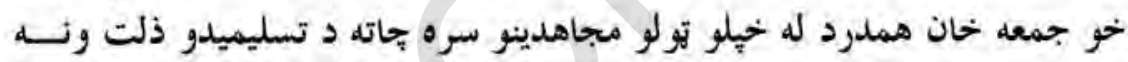

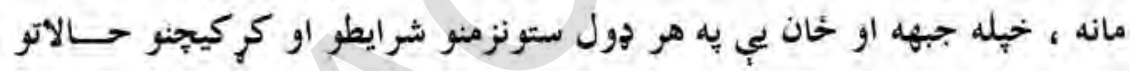
كي حسحي سلامت وساتل .

كله تجي طالبانود ميمني له لوري شبر غان ته را وربيدل او دا بنار يب ونيو

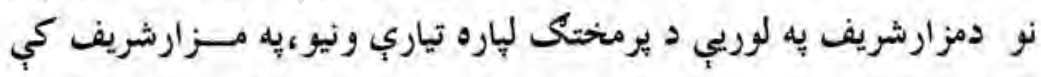
حاجي محمل محقق ،دوستم ، درباني وله تبله سره را تول او به اصتلاح يوه مشورتي شورا لي جوره كره يه دغه شورا كي له جمعه خان همدرد نه هيله وشوه جي طالبانو دمخنيوي لِاره بايد يه خيل قلمرو (بلخ ولسوالىه ) كي دفاعي خطونه وابول شي خو جمعه خان (همدرد) بحي بشير سياسي او نظامي بلوغ غيب درولو، هغوى ته يب وويل : بجي زه له طالبانو سره جكره نشم كولاى تاسي تي د خط اجولو مينه وال واست نو ددغه خط تر تولو بنه حخاى شبرغان ورو جي 
هلته بايل اجول شوي واى ، او يه كنايوى جول يبي دوى تله وويل : ساده يه

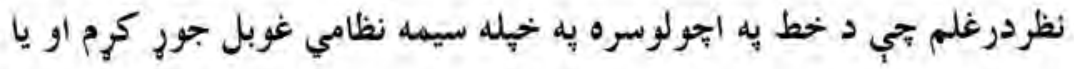

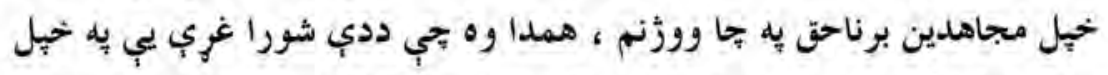
دغه خطرناك سياست او موضوع كيرى كي ناكام كري لئ او يخيله هم ددي لِاره بحي د كومي توطيب بنكار نشي او يا بي لاسونه د بيكنا مسلمانانو به وينو

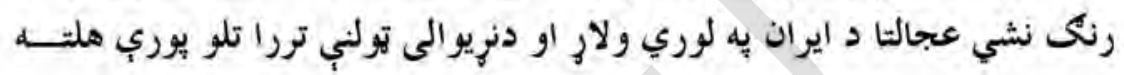

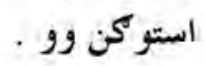
كله بتي د طالبانو واكمني ياى ته ورسيده نو جمعه خحان همدرد بيرته بلخ ته

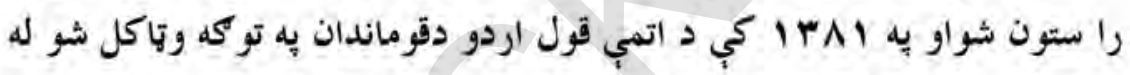

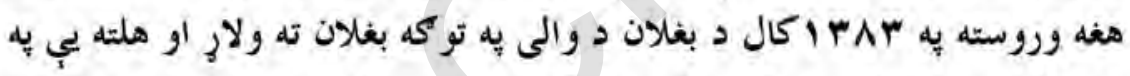
ييل كي دبغلان ولايت تول دو لتي املاكى د غاصبينو له لاسه واخيستل او ددغه ولايت بيا رغاوني ته بي مسورولانه ياملرنه وكره له دي بحي د بغلان ولايت مركز د خلقيانو د واكمنى ية مهال د يلخمري بنسار ته را غلى وو او دا داسي بنسار دي جي د بناري يرا ختيا لياره خاى نلري نو جمعه خان همدرد د خيل ماموريت له

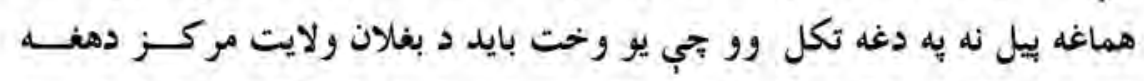

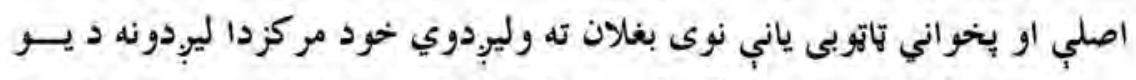

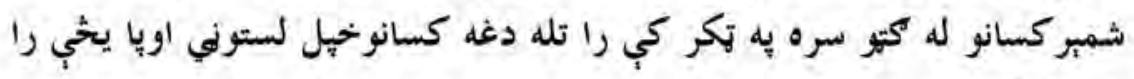
بلهوهل كابل ته به را غلل او د جمهور ريس لومري مرستيال ضيا مسعود ته به بي

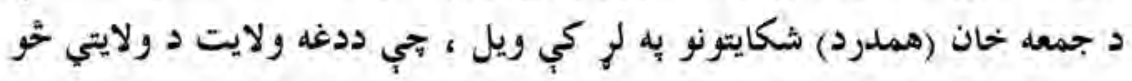

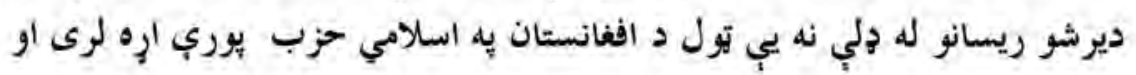




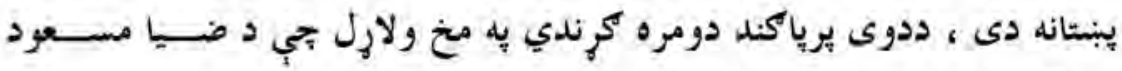

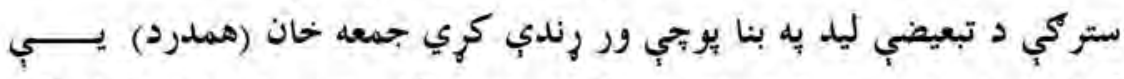

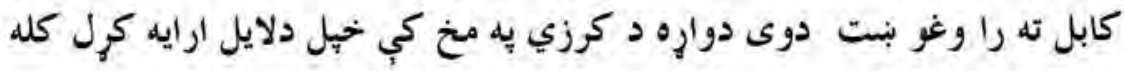

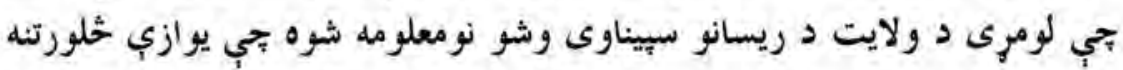

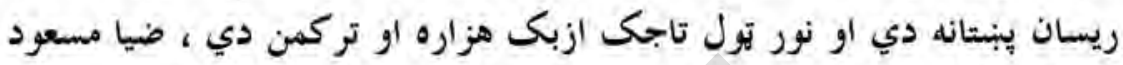

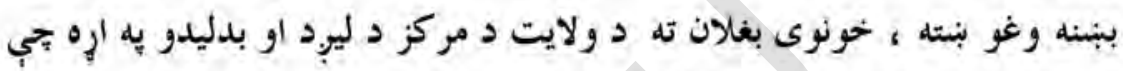

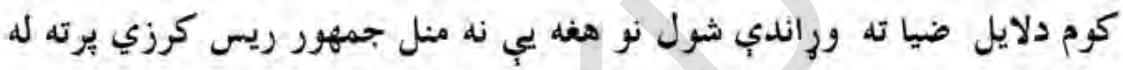

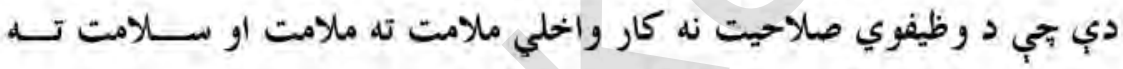

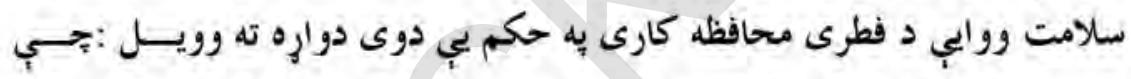

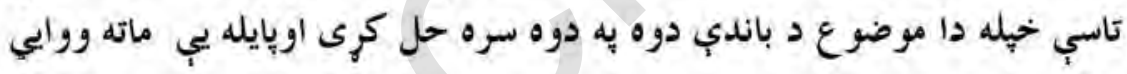

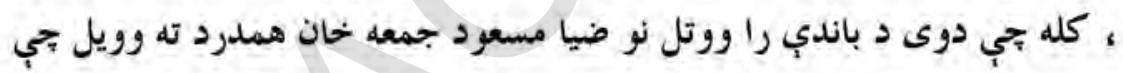

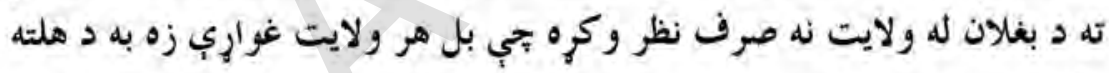

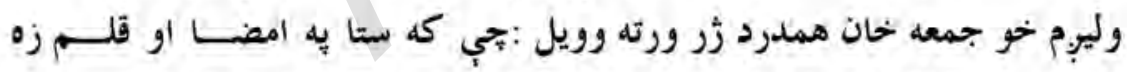

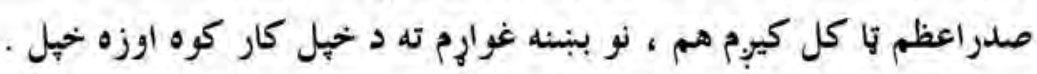

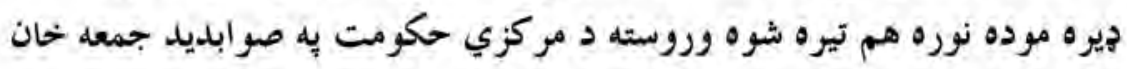

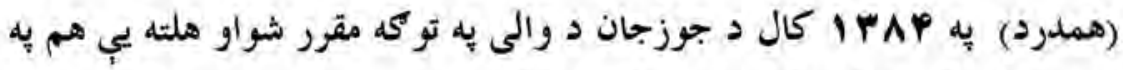

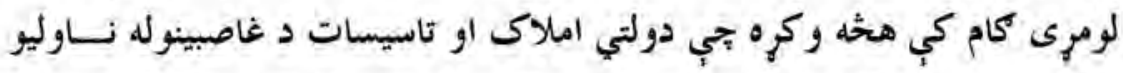

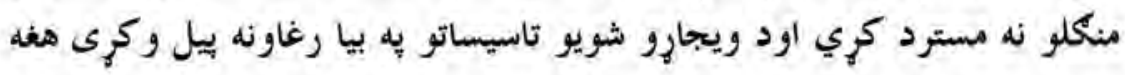

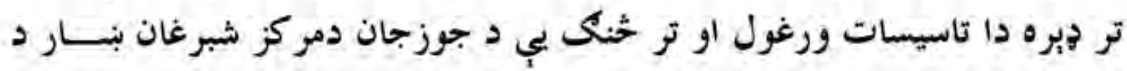

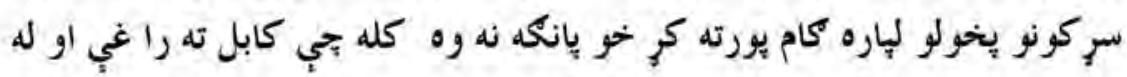


07

د وردكو مشاهير دوهم توكى

جمهور ريس نه يب د بودجي غو بنتنه وكره يه هر دليل به بحي كرزي د بودجي كي

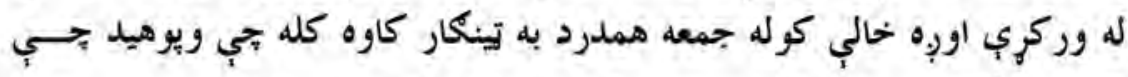
كرزى بإنكه نه منظوروي او سرخورجي جوروي نوله مجبوريت نه يــي اســتعفا وليكله كرزي ته يب وراندي كره او ورته وويل: جي دا به دي مانا ده بحي زمهـ

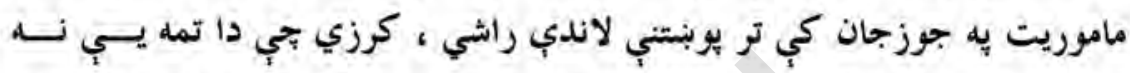
درلوده زر يجي د سركونو يخولو لياره بوديجه ورته منظوركيره اود شبرغان بنسارد سركى يخولو كار يه درز روان شو ، خو دا بحي وائي د هبجا كرني د ويبنو ملتر

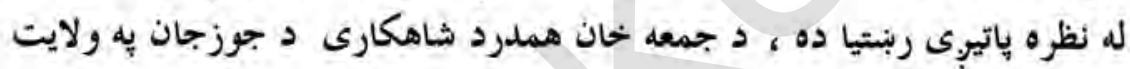
كي له لهر نه هم روبنانه دى او دا يو بنكاره حقيقت دى دي نه نه تنها جمعه خحان همدرد بلكي هو وردى والى يه جوزجان كي تل باته خدمتونه كرى خو افسوس

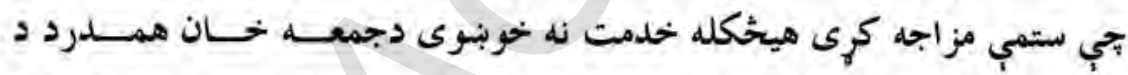
جوزجان يه ماموريت كي هم يوشمبرخودغرضه اوستمي مزاجه كريو بجي به راس

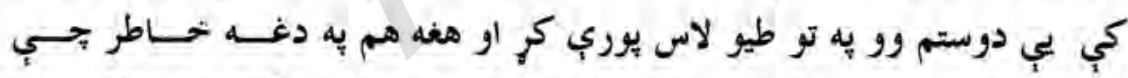

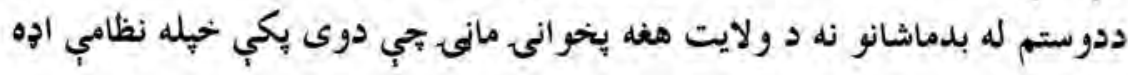
جوره كري وه ، واخيستل شو ه دوستميانوله تخار ، بغلان او ميمني نه سياسي بل ماشان سره را غونله كرل او دلاريونونويه جورولو يب داسي بد ماشيو ته بلمبي

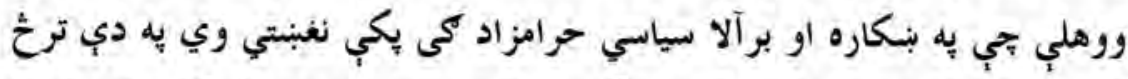
كي جمعه خحان همدرد له مركزي حكومت نه مرسته و غو بنته له كابل نه اتيـ كسيه داسي تركى تباره عسكر شبرغان ته را وليرل شول جي له را رسيدو سره سم له لاريون كونكو سره يوخاى شول دا وخت بذ ماشانود ولايت تولي اداري 
لاندي كري او دولايت د ودانى يه لور را وان شول مركزي حكرمت دا هرخهد د

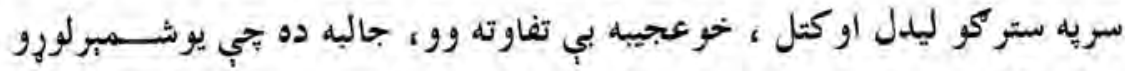
دولتي كريوهم دا بهير يه مزه مزه خخاره خوند يب وركاوه اود قهر مان جمعه خان

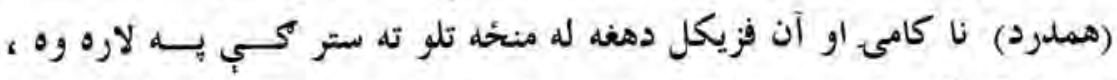

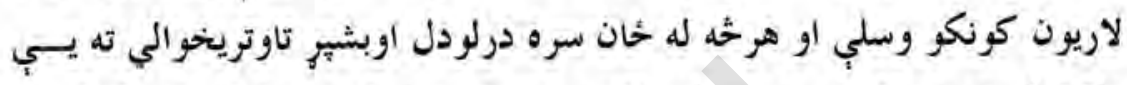
ملا ترلي وه د ولايت د مقريه لور لايسب را دمخه شول او د توكميزي كركـي ناروا جيغي يب وهلي نا خايه د لاريون كونكو له لورى كولى وجليدي او ناجحارلد

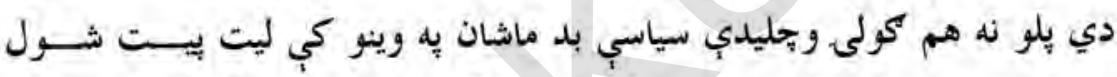
دوستم بتي ربنتيا ميدان وليد نو وتكيد او ( آنكى ) يب وواهد حيكم قهرمان جمعه خان همدرد د بسياسب خشونث جواب به خشونت وركر نو حخكه دوستم دا عمل له خحان او ملكرو سره لوى ظلم وباله اويه مركزي حكومت بي بحيغه كلره كره. مورجدلته به كلكه مدعى كيرو او وايو تجي مورج ولبي نورو قومونو ته منسوب

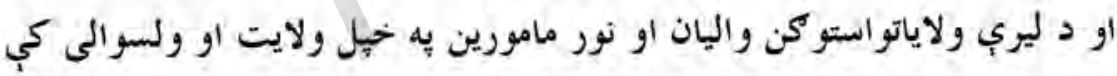

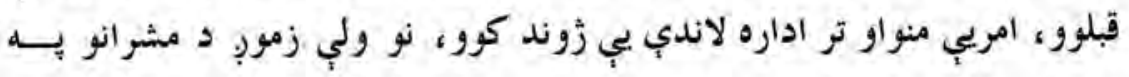

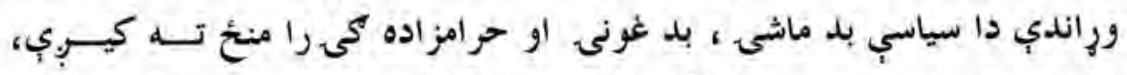
وحدت ملي همداسي وى ؟؟ لكه يه جوزجان كي جي دوستم او د هغه ناروا جذلي

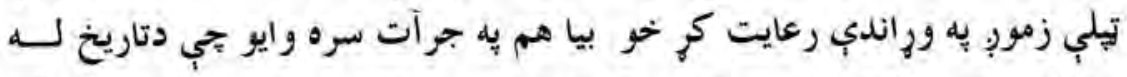
حافظي دهيجا كرني يتب نه ياتيربي هغه دوستم جي لاس يب د سلكونوزرون بيكنا مسلمانانويه وينو ربك دى او لم كمونستانو سره بلهي دي ديكنا انسانانو به وينو 


\section{$\bullet \wedge$}

د وردكو مشاهير دوهم توكى

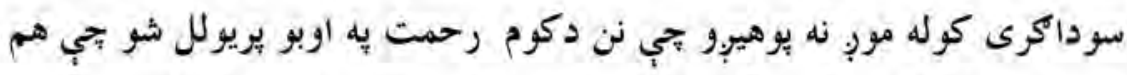

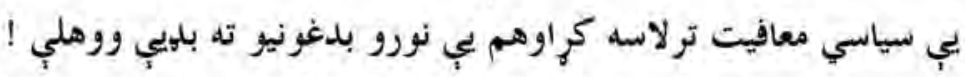

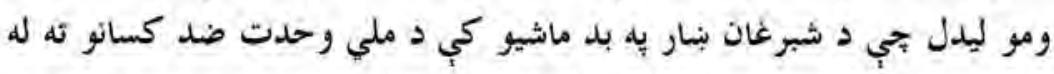

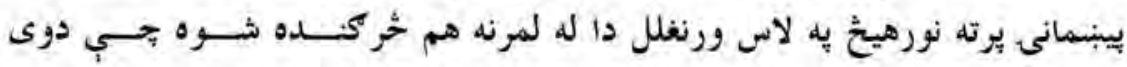

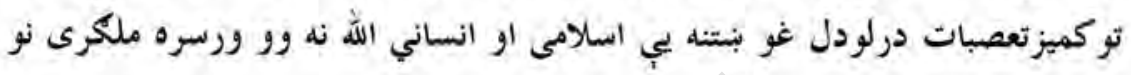

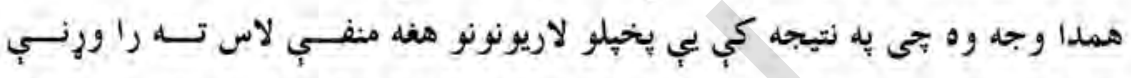

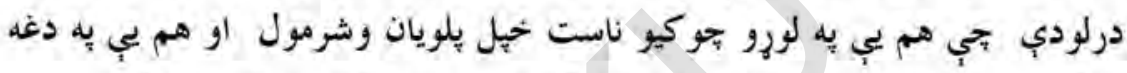

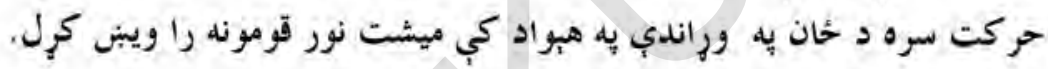

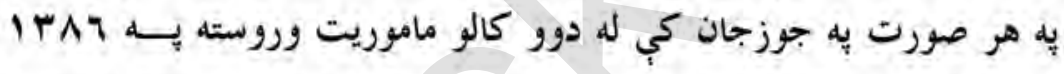

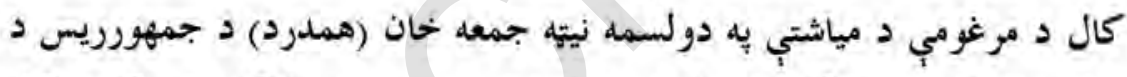

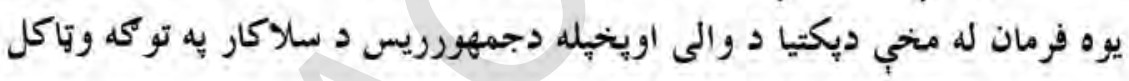

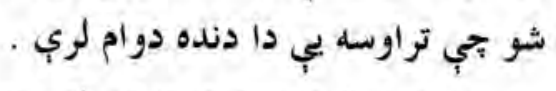

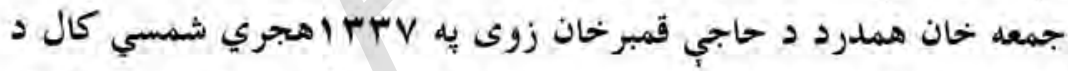

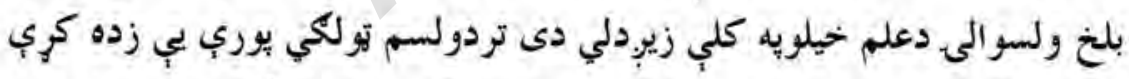

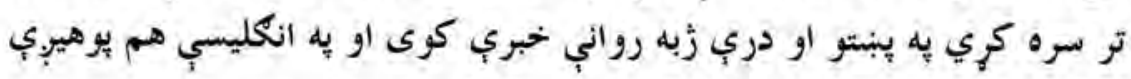

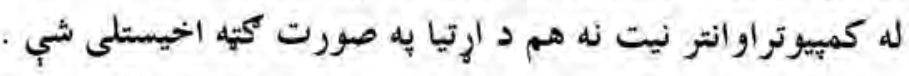

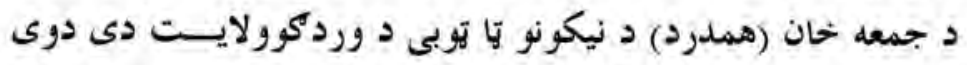

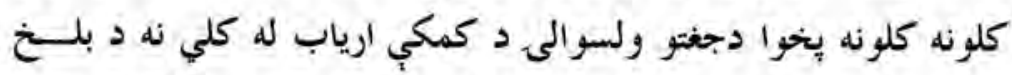

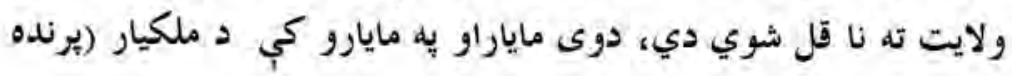

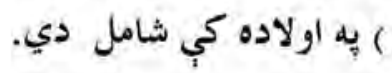




\section{حبي الله - مايار خدايب خدمتكار}

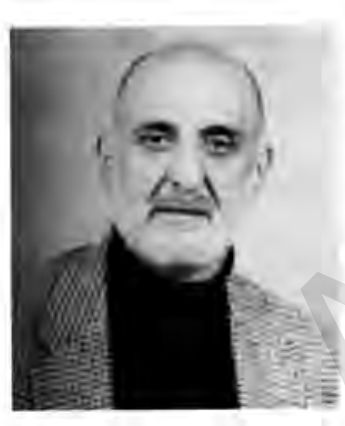

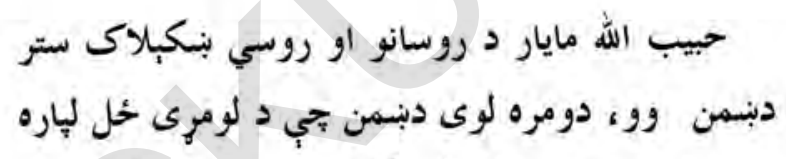

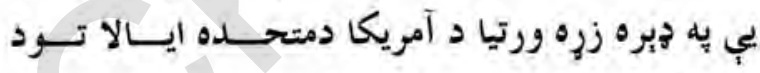

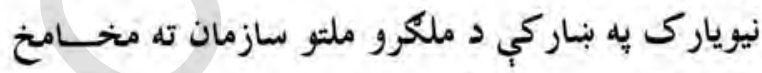

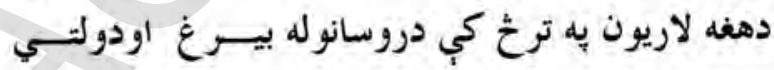

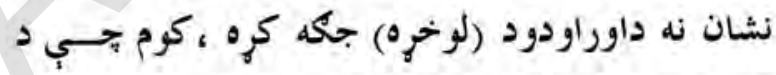

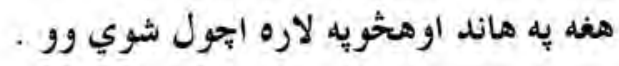

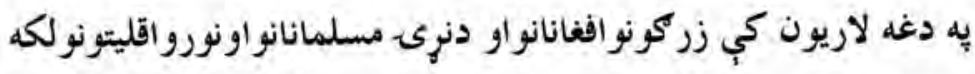

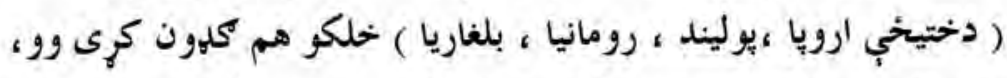

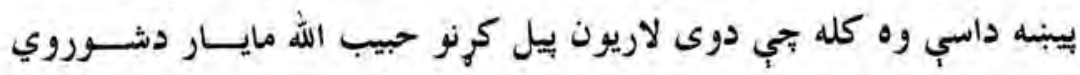

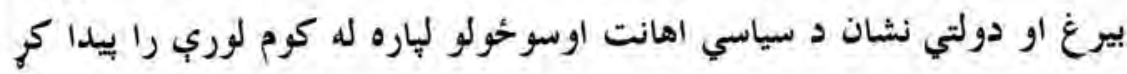

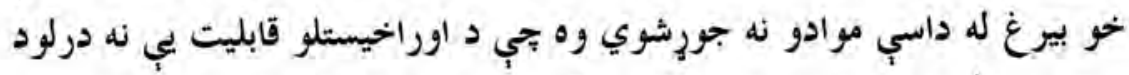

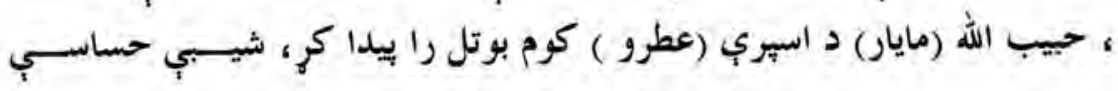


7.

د وردكو مشاهير دوهم تئوكى

وي ، يردى وطـن وو، د شوروي د يراختيا غوبنتئي دسياست او به الفغانستان

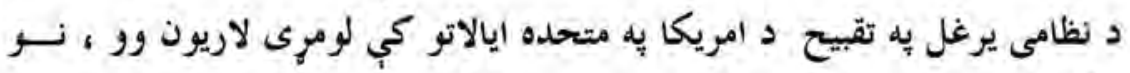

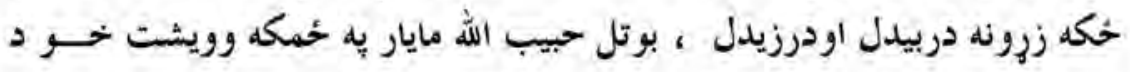

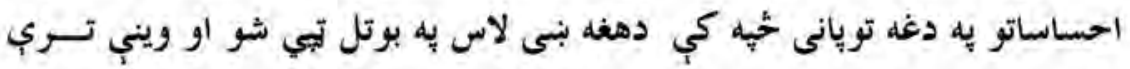

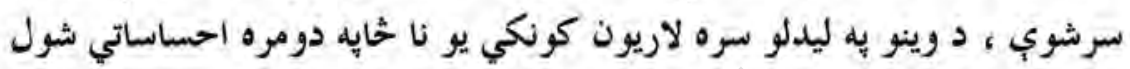
بي د داكتر(جوهان) يه نوم يوه ينجابى جي له لندن دهمدغه لاريون لهاره راغلى

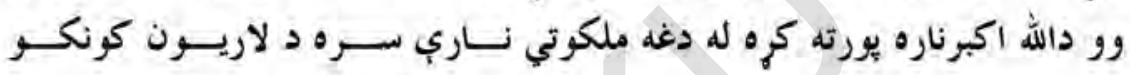

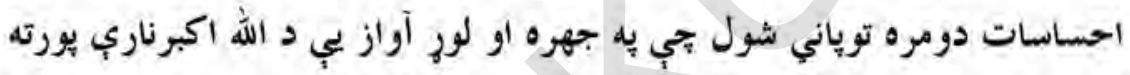
كري داد نيوياركى يه بنار كي دالله اكبر لومرى ملكوتي غو. وو بحي دنيوريارك كوخي يب ولرزولي ، احساسات توياني شول اود مركى يـهـ شـــوروى نـارو د

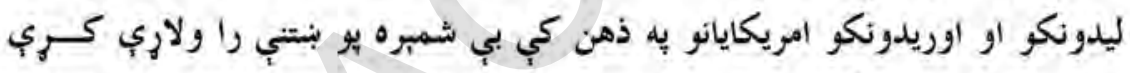

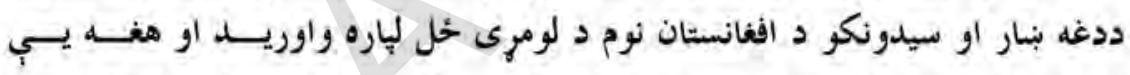

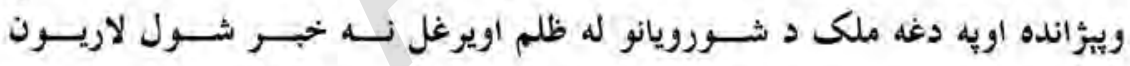

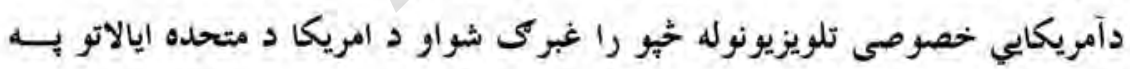
تولو بنارونوكي دشورويانو د مظالمو ديندوره و رونكيدله .

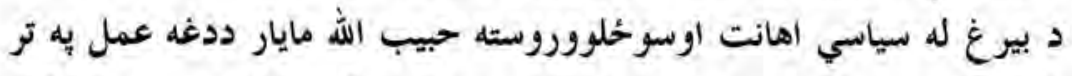

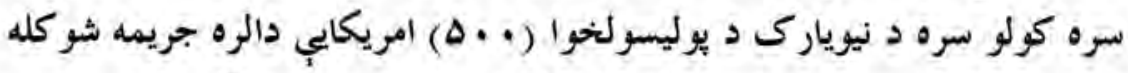
تحي دهغه كورته د جـــيمي تعرفه راوليول شوه او خبره تر محكمي ورسبده نو

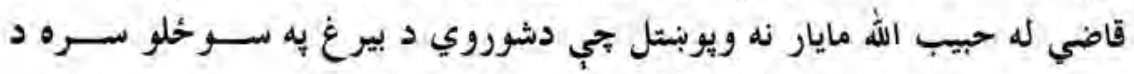
امريكا بهرنى سياست تريوبنتي لاندي را ووست ، دا ولي ؟ 


$$
\begin{aligned}
& \text { ـ تهد كرم هيراد يبي" } \\
& \text { - ستوئزه خهه وه } \\
& \text { - ولي د دا كار وركز ؟ }
\end{aligned}
$$

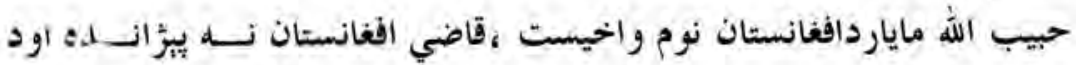
موضوع يه إره يب وضاحت وغو بنست خو كله تجي حبيب الله مايار دشـــورويانوله بربنه تيرى ، بمباريو اونورومظالمونه يادونه وكره نوقاضي سربنكته واجوه لكه

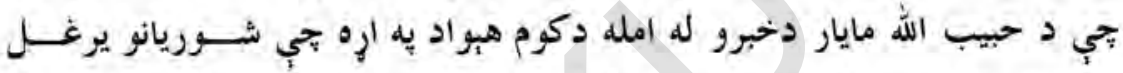
ورباندي كري وو خهه ور يه زره شول له سوج وروسته د جريمب له حصول نــه تيرشو اوله حبيب الله مايار نه يبي كلكه ببنسه وغوبنسته .

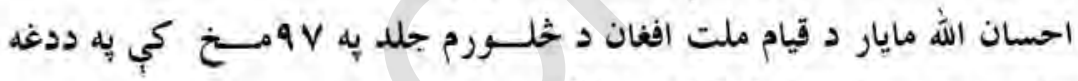

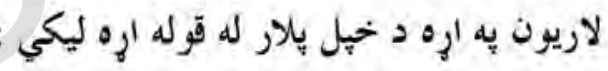

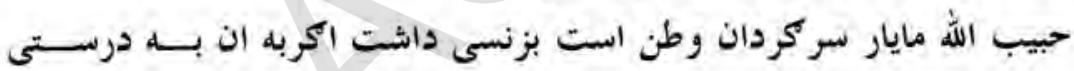
رسيدكى ميكرد كارش بسيار خوبى ميبود اما حالا محدود ابست : درين اواخسـر مظاهره روى دست قرار داشت كه موفقانه خحاتمه يافت . ددغه توخنكى حبيب الله مايارلومرنى اففان مسلمان وو جي د امريكا د متحده

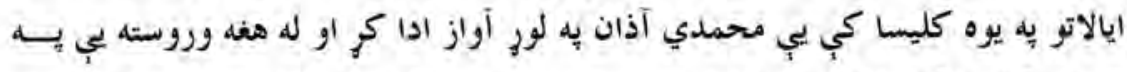

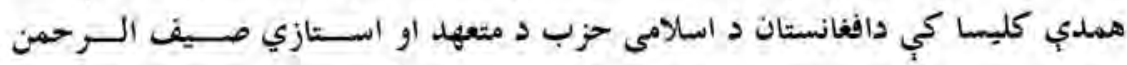

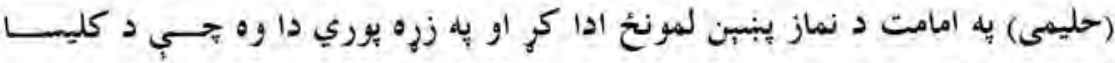

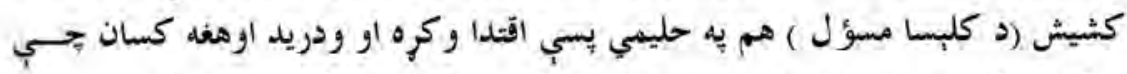
يه كلبسا كي وه او دا حال يب وليد نوله ستر كو يب نومب اوبنكي راو بهيدلي. 


\section{ir}

د وردكو مشاهير دوهم توكى

د مايار خيه دغه همت او جرآت امريكا ميشتو مسلمانا نو أفـــين وورايـــهـ او دافغانستان او نرى جهيور رسنيويه دغه يبنسه تبصري هم وركري .

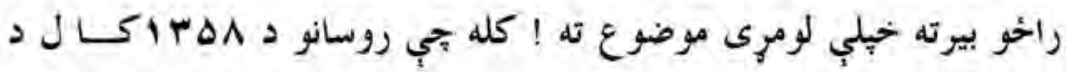

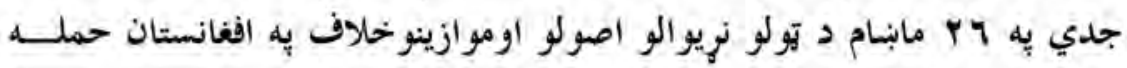
وكره او دا ملك يب تو خيل استعماري تسلط لاندي را ووست نو يه حبيب الله

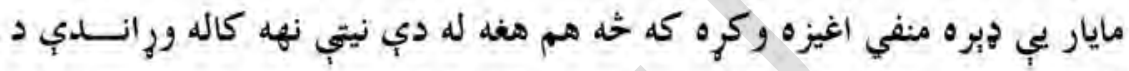
آمريكا متحده ايالاتو ته راغلى وو خويه يلرنى هبو ادي يب د بِيرديو تاخت تاز د هغه

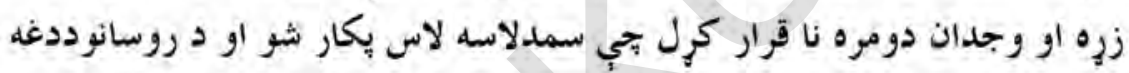

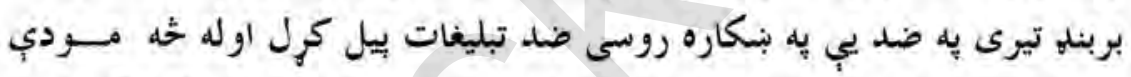

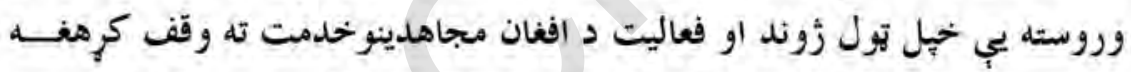
تبيان جي له افغانستان نه به د آمريكا متحده ايالاتو ته راتلل لحبيب الله مايار به دو هغوى درملنه كوله اونوره لازمه مرسته به يب هم ورسره كوله آن تردي جي خي

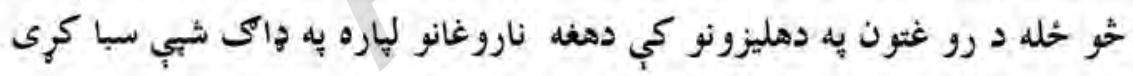

\section{كوم تجب له لاس يبنسوبه لويدلي له افغانستان نه را غلي وو}

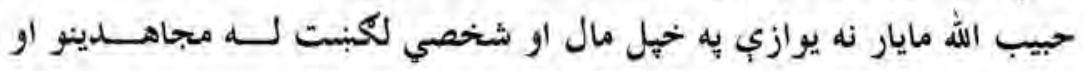

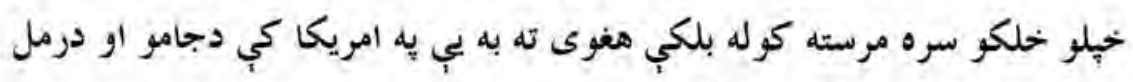

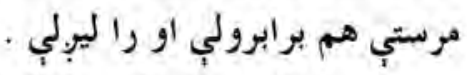

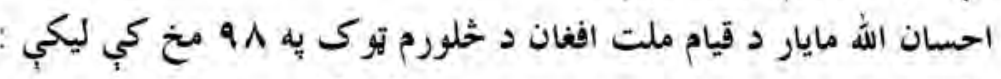
مكتوب كه از يدرم داشتم خلاصه ائرا از نكا يكى مهاجر دربـاره جهـيـاد و زندكى در هجرت مطالبى دارد درين جا ميكزارم اودر نامه خود نوشــته بــود 


\section{ar}

د ورديو مشاهير دومه توكى

زندكى كه ميخو استم در دره خوات وردكى ويا استالف بهشت آسا زيرجتــر آسمان لاجوردين افغانستان خحاتمه يابد ليكن تعدادى اولاد نا صالح كثور ما اين آرزويم را به يغما برده ومرا در آخر عمر سركردان آمريكا كردانيل .

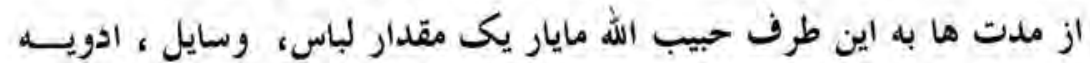

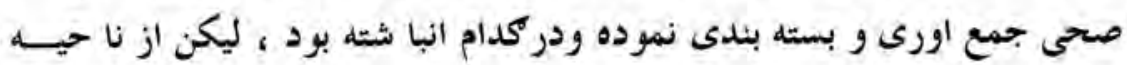

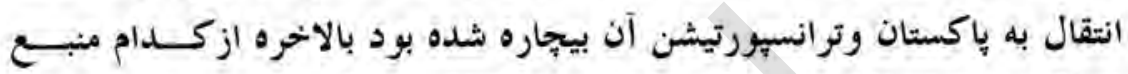
عسكرى برايش تليفون شد كه ما شنيده ام كالا به يا كستان روانه ميداريد وما

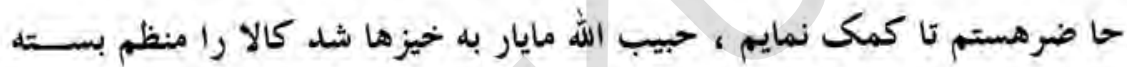

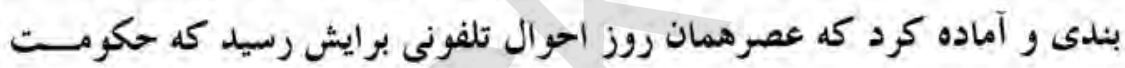
ياكستان اجازه نميدهد كه اموال را برسانم كه در نتيجه حبيب الله مايار متــاثر شد ولى جند هفته بعل خبر خوشى رسيد كه مال ها را به (مارى لند ) رواثه دارد تا ازانجا توسط طياره به بإكستان نقل داده شود ، ليكن شرط اساسى اينست كه روزنامه نكار ها خبر نشود وهمه عمليه محرمانه إنجام يابد تا اينكه تيلرها رسيد

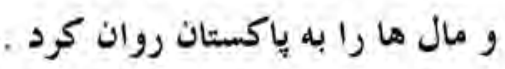

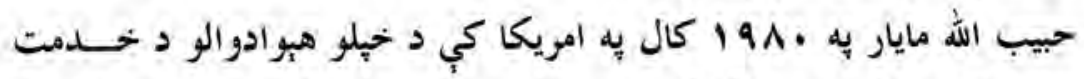

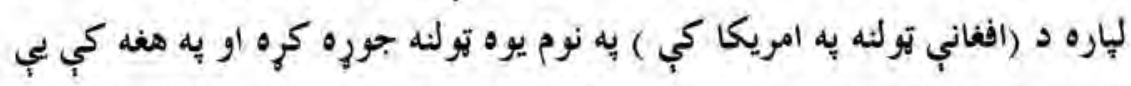

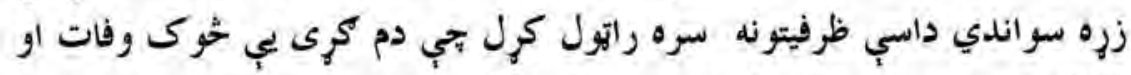

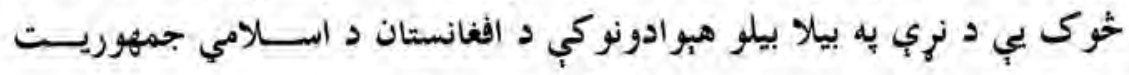
سفيران دي لكه مرحوم صديق سلجوقي د مصريخوانى سفير ، زلمى عزيــز د د

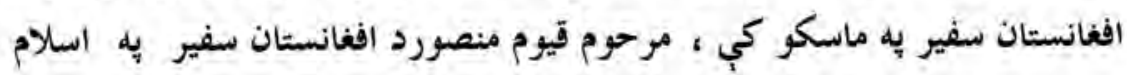


آباد كي ، محمدانور د افغانستان سفير به عراق كي ، د يروان بخواني والــى

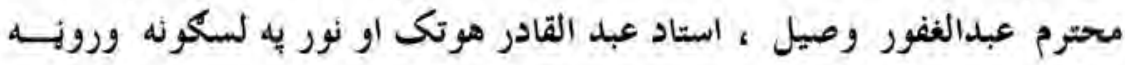

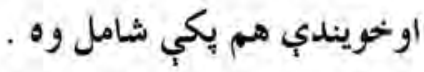

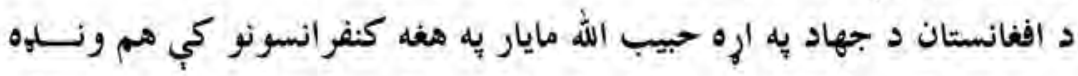

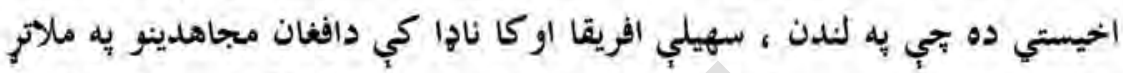

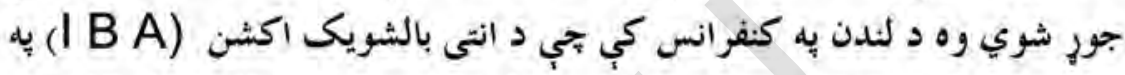
نوم جورشو د نظامي انجمن مسوول وو او لنهه داجي دهغه فعاليتونو له امله بحي لهي

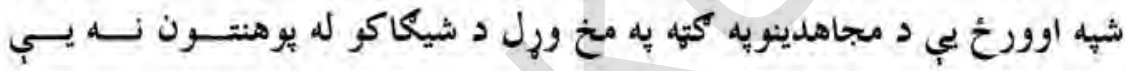
افتخارى دو كتورا هم تر لاسه كري دهن

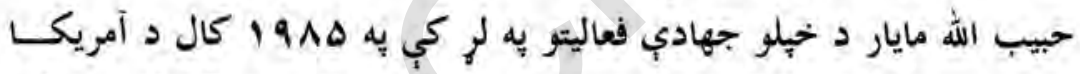

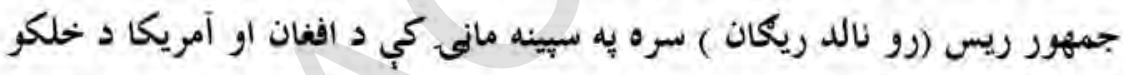

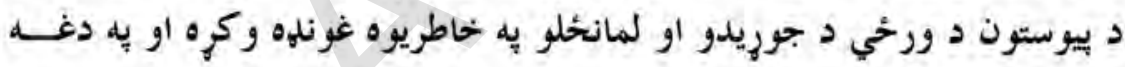

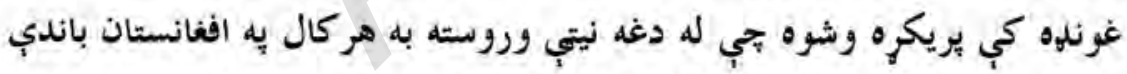

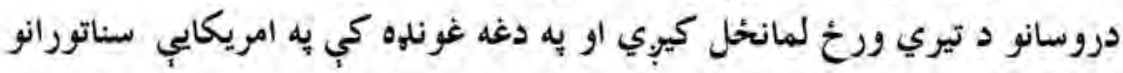

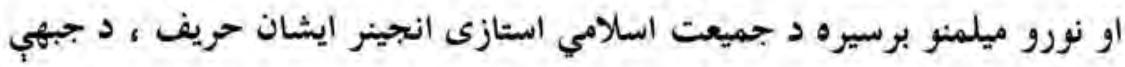

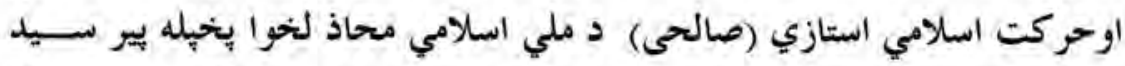

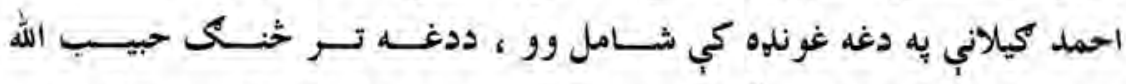

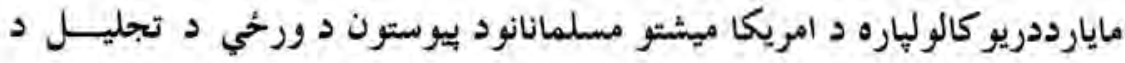

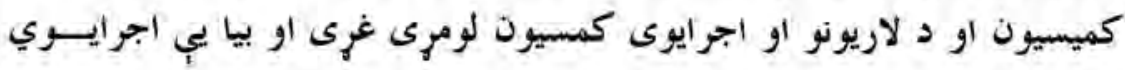


او يه دي توكهة يب دآمريكا د وخت جمهور ريس رونالد ريككـان ، ثنــا او

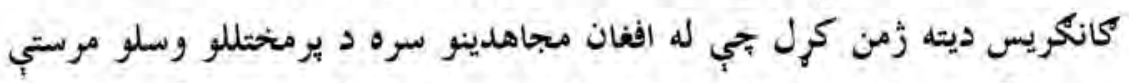

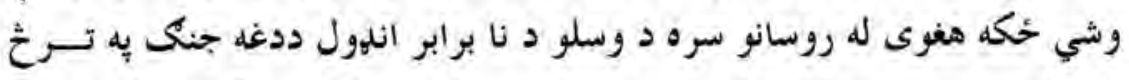

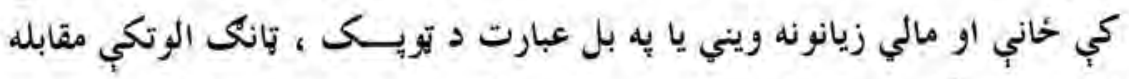

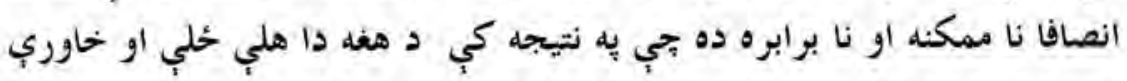

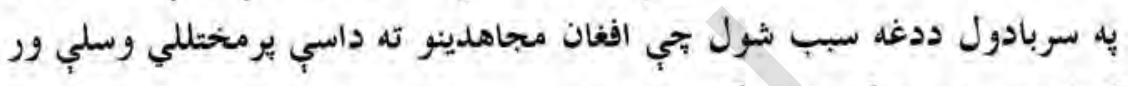

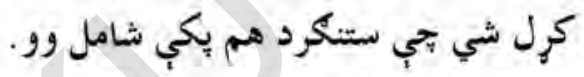

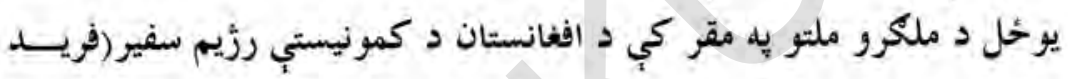

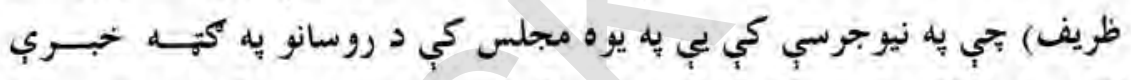

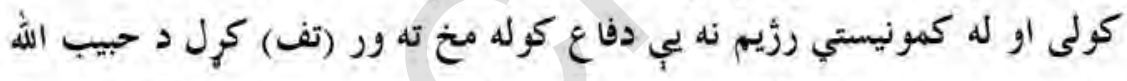

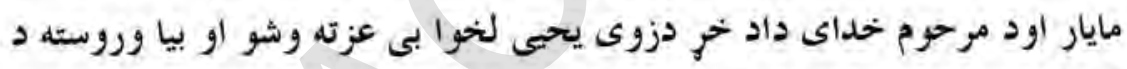

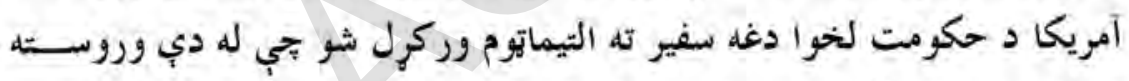

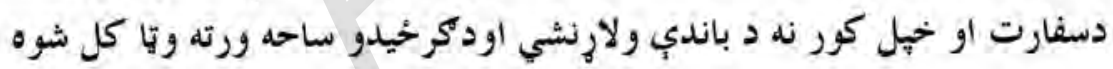

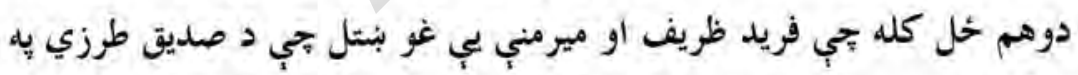

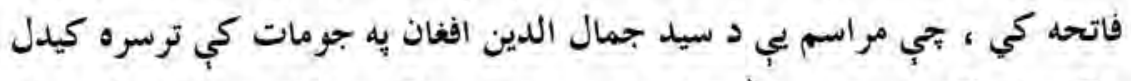

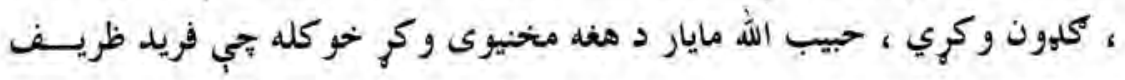

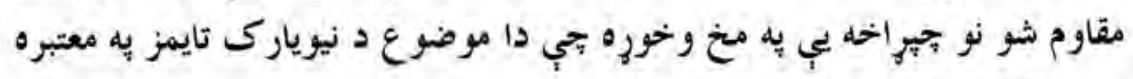

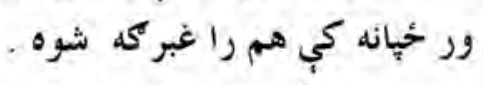

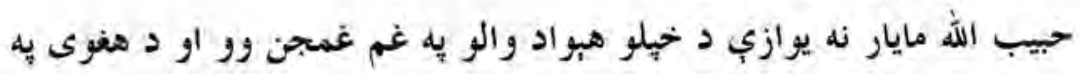

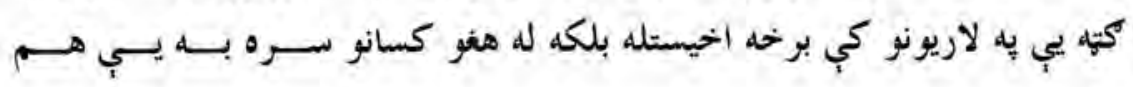




\section{7}

دوركو مشاهير دوهم توكى

دلاريونويه جورولو كي مرنسـته كوله د كومو تي هبرادونه يب د كوره روسانو لخوا اشغال شوي ور .

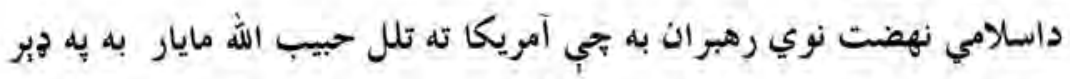
ورين تندي هغوى ته بنسه راغلاست ويل له هغوى سره به يب منله توره كوله او له هغوى ته به يب لازمه لار بنسونه كوله

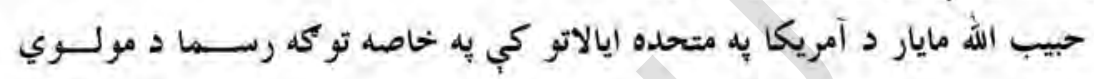

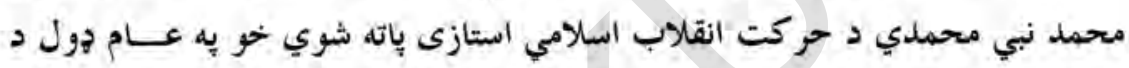

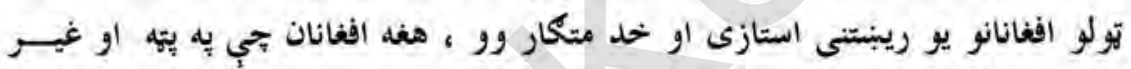
قانوني هول به آمريكا ته راتلل او هلثه به بندي كيدل نو حبيب الله مايار به هغوي له

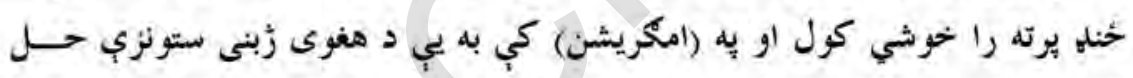
كولي ، قانوني اسناد به يب ورته جورول او كارونه به يب ور ته يبدا كول.

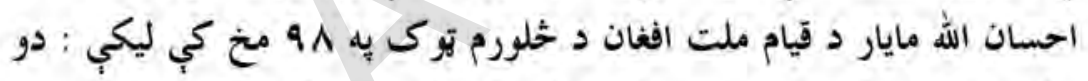
سال قبل هم نفر مرد وزن جوان افغان طور قاجحاق به امريكا امده بودنـلـد و در

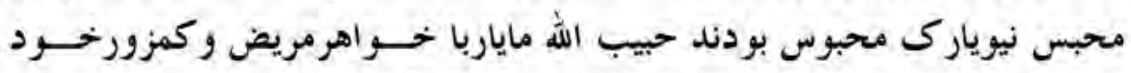
و سيمه جان ، ومصطفى يسرش و دو نفر سناتور مظاهور كردند و بعد از جنجال محبوسين رها شدند و روى صفحه تلويزيون صحنه رهايع انها نيز يخش شلد .

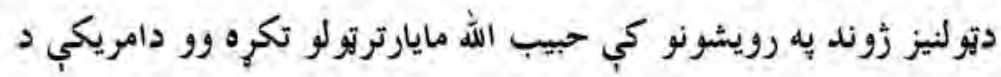
متحده ايالاتو د نيو ياركى يله بنار كي دا معموله خبره وه بجي مركى حق دي تبول

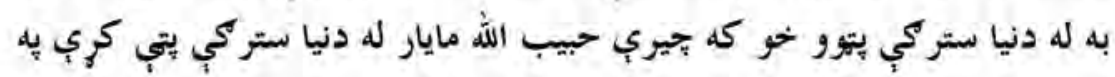

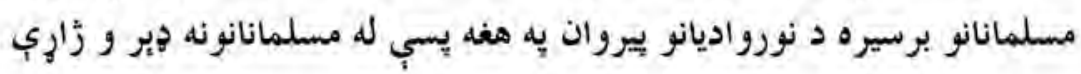


جي دا يه ظاهره توكي ته ورته كلام دى خو يه حقيقت كي له دغه كلام نه دحبيب الله مايار د شخصيت هينداره د يوه مسلهان له عنوانه نجي نه تنها له مسلمانانوسره بلكي د نرى د نورو اديانو له يُورانو او يلويانوسره نيكي او بنبي

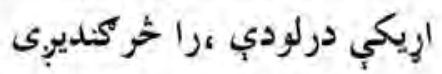

د افغانانولهاره دبنواو تولنيزو حدماتو يه ترسره كولو نسره حبيب الله مايار به نيو يارك كي دوروكي افغانستان) دبنساروال لقب هم كتلى وو بجي دهغه دا لقب يه اخبارو او نورو رسنيو كي هم را غبركى شوي وو. د امريكا د متحده ايالاتو د جورج دِبليو بوش يه نوم يوه ريس جمهور ديوه

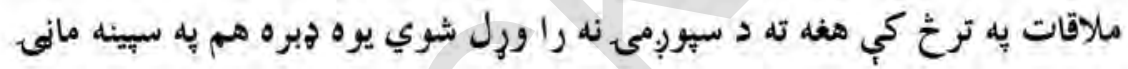
كي وركر.

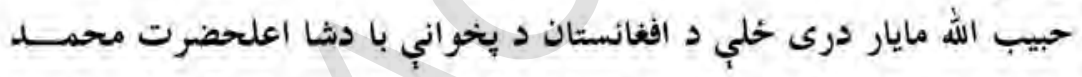
ظاهرشا سره د افغانستان د لانجب د حل به خاطر ايتاليا ته سفر كرى او هغلي بي بي

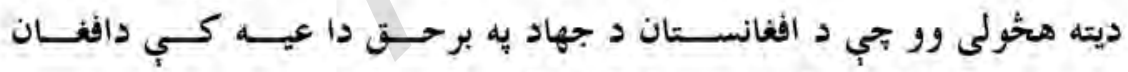

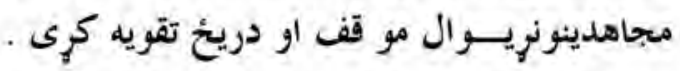

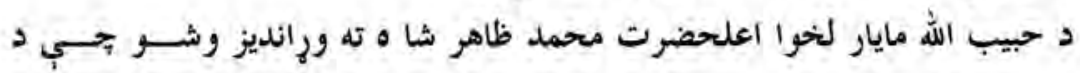

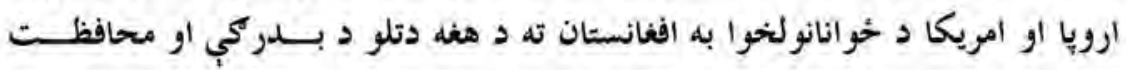
لباره يو زركسيزتشريفاتي تولى (كارد ) جورشي اوتول به غبركى افغانستان ته ولاري

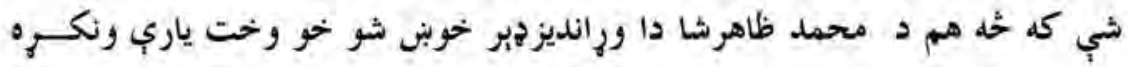
دوى تول مخكي له دي جي دا تولى جور شي افغانستان ته را غلل . 
iN

د وردك مشاهير دوهم توكى

رِه وروستي سفر كي حبيب الله مايار ته د اعلى محمد ظاهرشا لخوا دافغان لانجي

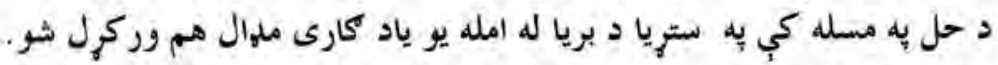

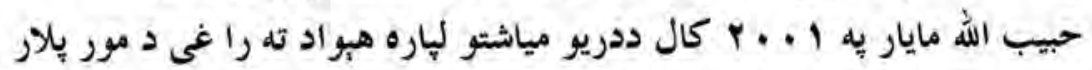
خهلوخيلو انو، شهيدانو اونورومتوفى كسائوعمومى فاتحه يب يه شيخ ياسين جغتو تنكي او نوروكليو او بانلهوكي د اتو غوايانويه حلالولو سره واخيسته او به خيه خيل

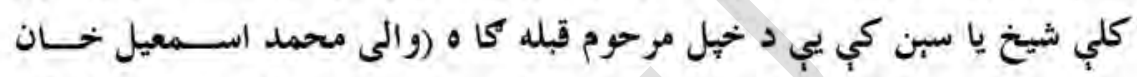
مايار) به نوم د يوه بنّو نحُي د ودانى جورولو ته هم خُاى وركر اوددغه ترخيكى

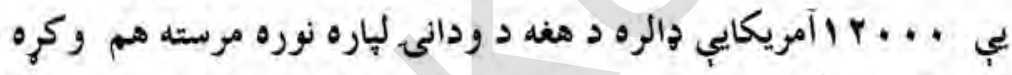

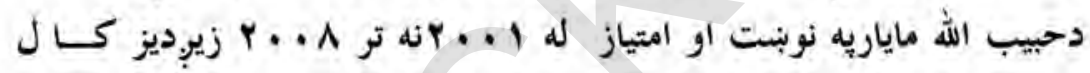
يوري د(افغاني تولنه يه امريكا كي ) به نوم يوه (مياشتنى) خحيرونه دقاضي سلطان

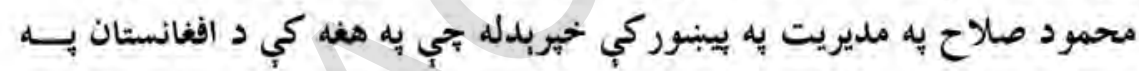
اره سياسي ، فرهنكي ، اقتصادي او انتقادي يه زهرهيوري مطالب خهربدل او د افغانستان او دنرى هر كوت ته ليرِل كيدل .

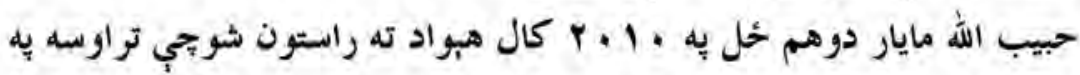

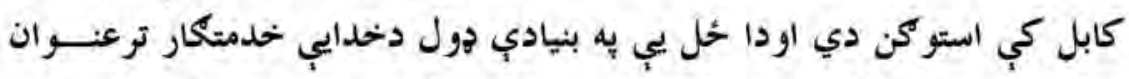

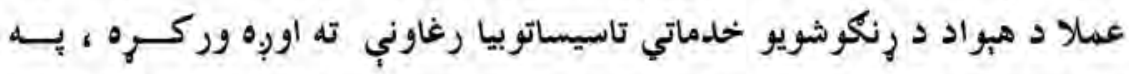

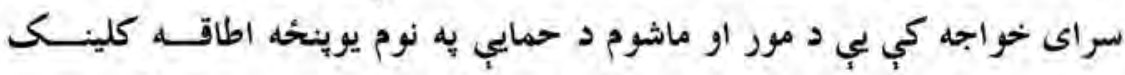
جورير، دهيواد يه مختلفو ولاياتوكي يب له خلكو سره د شبدو وركونكو(وزو ) مرستي وكري د بنسونتيو لهاره يب كتابجي قلمونه واخيستل او يه زده كونكو يب ني وويشل له بيوزلو سره يب نقدي مرستي وكري اودذغه تولو مرستو تر خيكى يب ني 


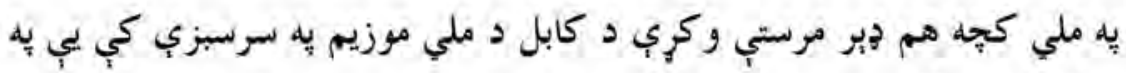

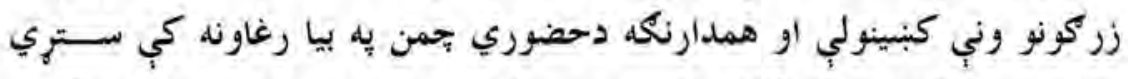

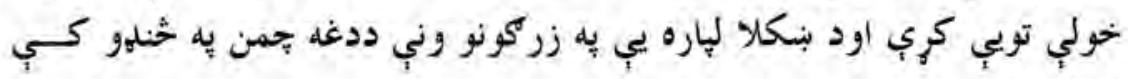
كبنينولي

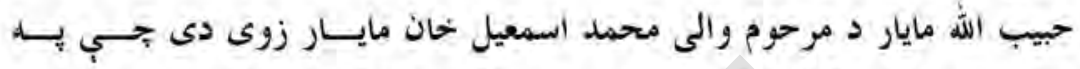

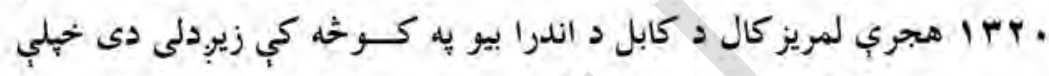

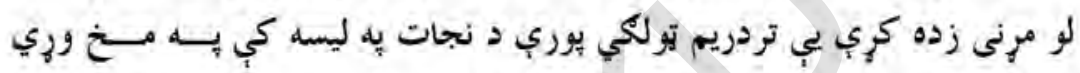

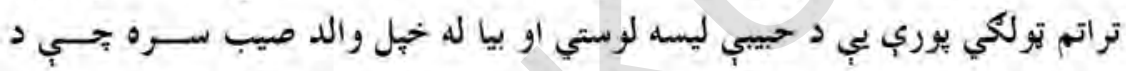

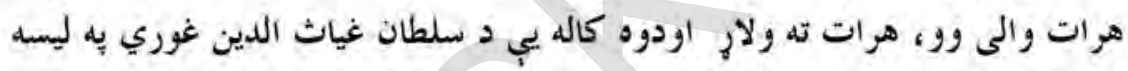

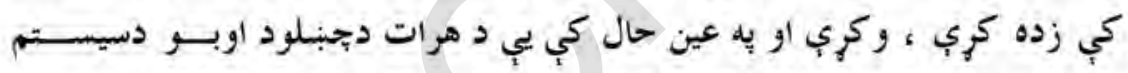

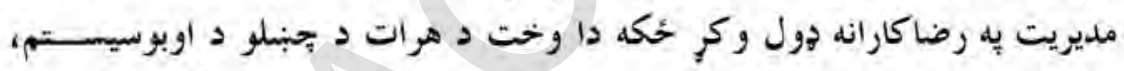

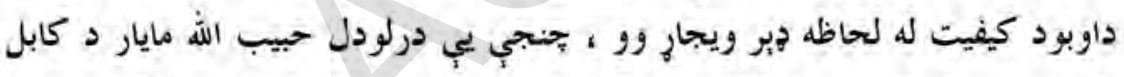

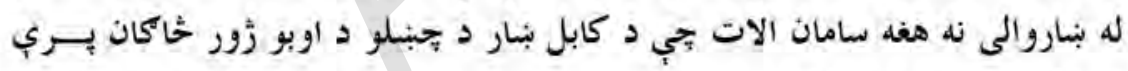

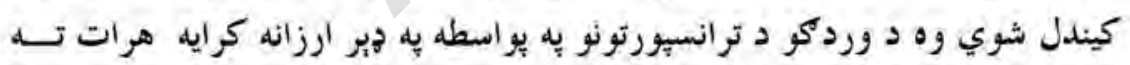

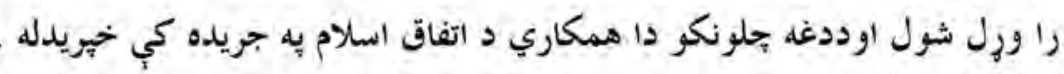

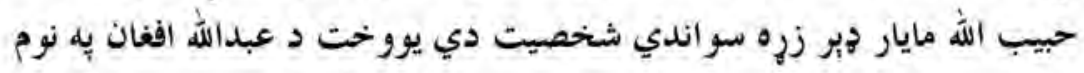

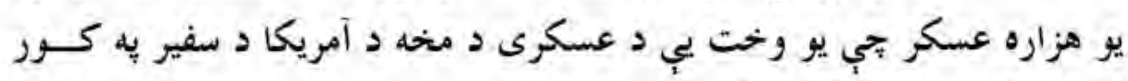

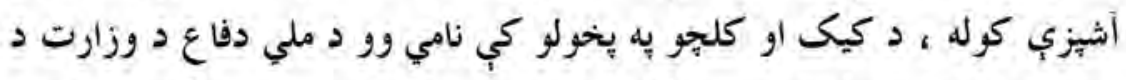

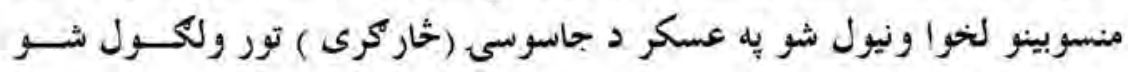

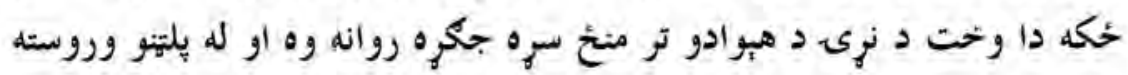


V. دوركي مشاهير دوهم توكى

يه عسكر د اعدام حكم حادر شو حبيب الله مايار د دغله له ورثي نه د بادشا يـــا عنوان د نجات غو بنست ليك واخيست او د شاهى اركى يه لور روان شوغو بنتن

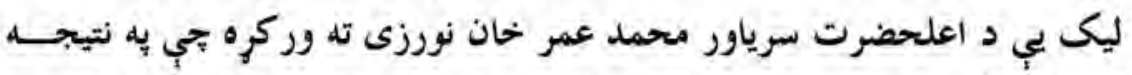
كي عبدالله هزاره له اعدام نه بع خو تل ياته بندى شو اصلا محمد ظاهرشا ته دا

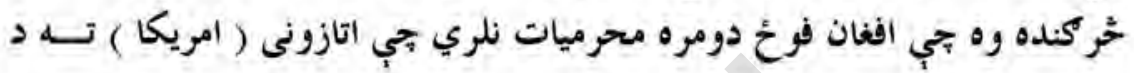

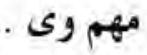

دغه عسكر بيا د خونريو كمونستانو د واكمنى جيه مهال دهغوى لخوا له خهيلو دريو نورو ورونو سره يو خاى شهيد شو

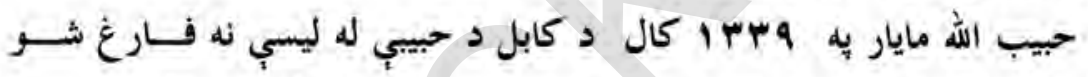

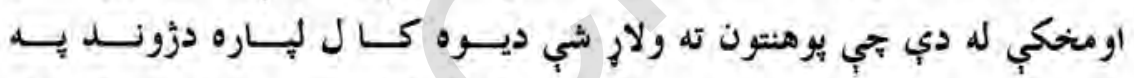

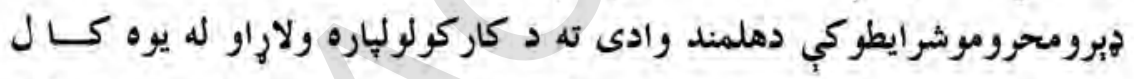
وروسته بيرته كابل ته راغى او خهله د مكلفيت دورو يجي د احتياط يه بنسونحي كي

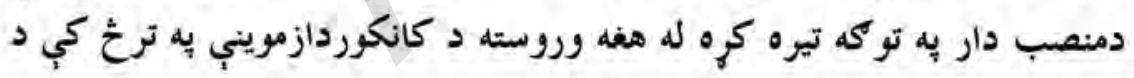

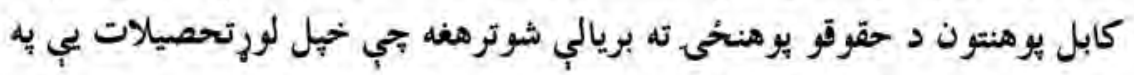
نومورى يو هنخى كي ختم كرل.

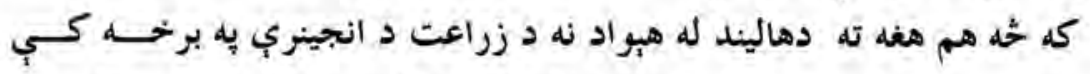
يوتحميلي بورس هم راغلى ور هغه ددغه لياره هاليند ته ولار نشو تجي له يوي له هي

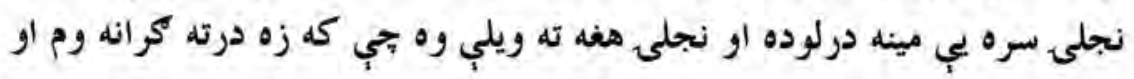

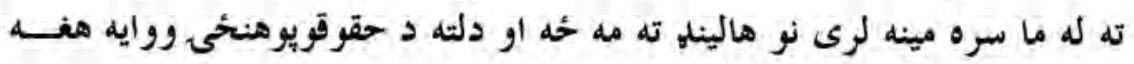

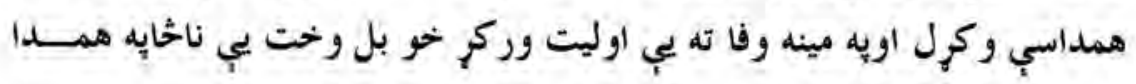




\section{VI}

\section{دوركى مشاهير دوهم تيرك}

نجلي ، له بلار سره يه خيبرهوتل كي د هيواد د يوه مشهروبدماث ومخ ته ناسته

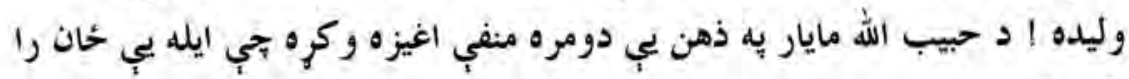

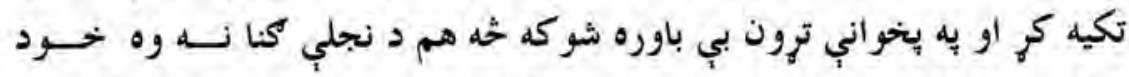

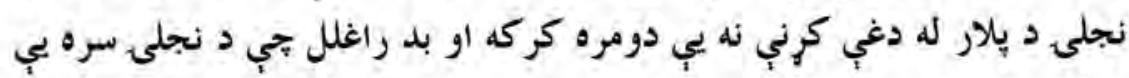

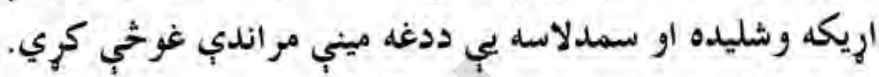

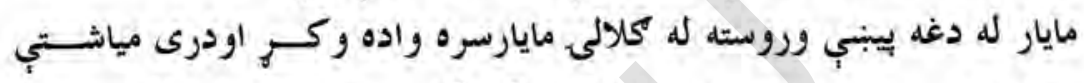
وروسته د (توريست) بيه عنوان يه I I اد آمريكا متحده ايالاتو ته ولاه

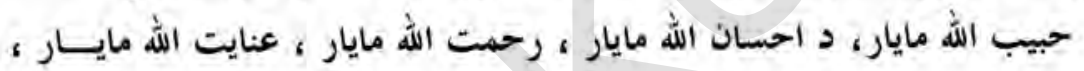

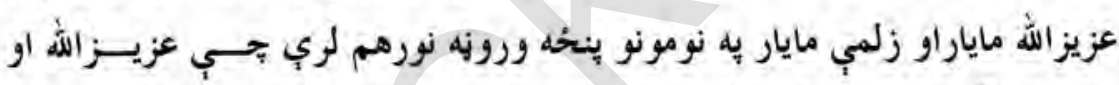
رحمث الله مايار يب وفات او نور بب زونلدي دي او همدارنكه د مصطفى فايار، زليخا مايار او على جان مايار به نومونو درى زوندي اولادونه هم لرى. 


\section{رحمت الله خان (رؤوفى )

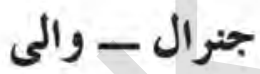

كله جي د جنر ال رحمت الله رؤوفى زوند ليك او كارنامي د هغله د تاريسـيخ

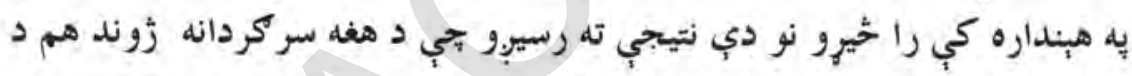

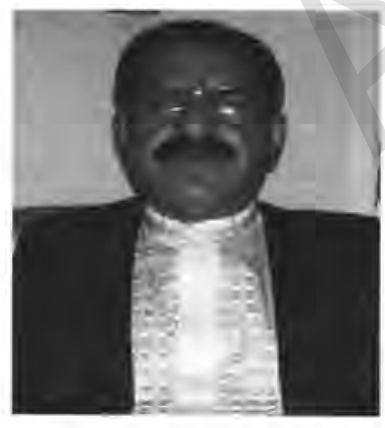

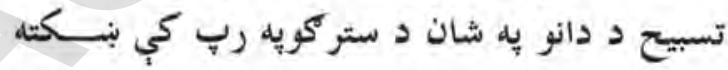

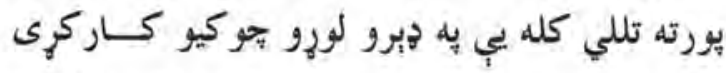

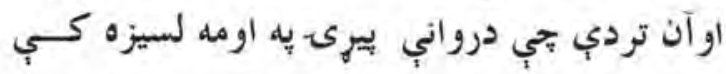

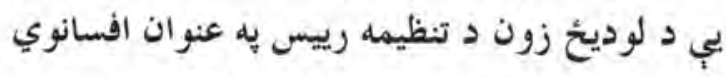

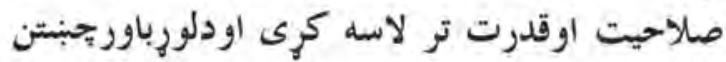

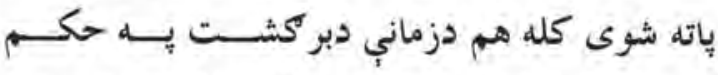

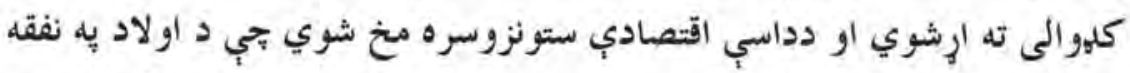

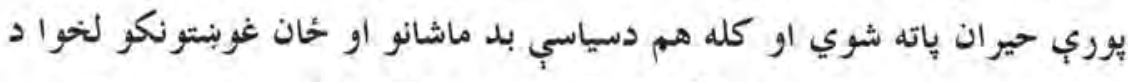

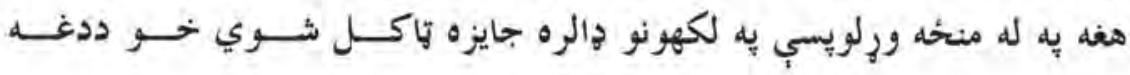




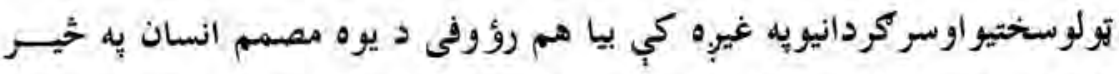
روندى اوثابت قدم به حأى ياته شوى او د زماني ترخو نا خو الويب هم به رو روحيه داسي منفي اغيزه نه ده كري بجي هغه د له يبّنو ورغورخوي أويا د هغه به اراده كي كوم منفي بلدلون راولي .

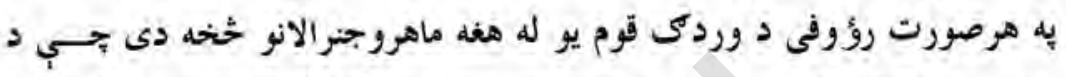

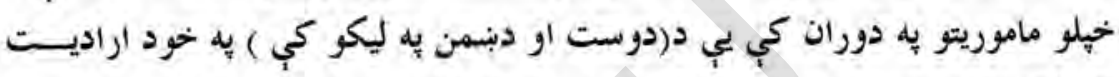
كار كرى او داسي كمزوري نقطه نه ده تري ليدل شوي جي نيغه كوتسهـ د ورتسه.

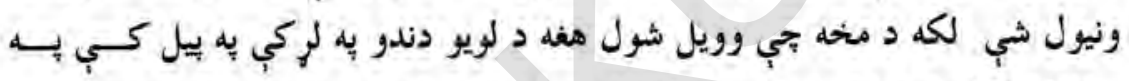
ه . . .

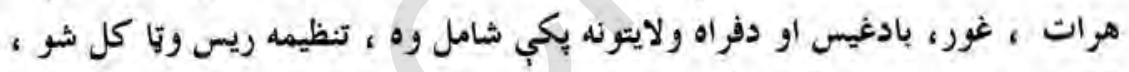

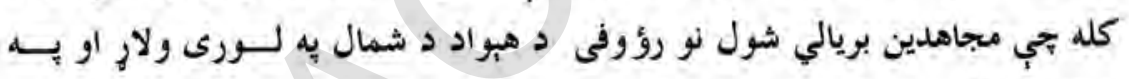

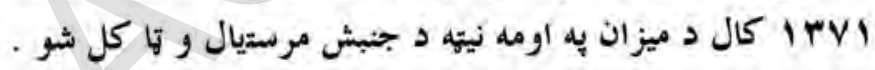

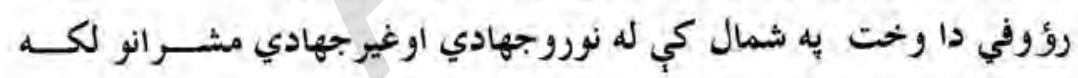
جمعه خان (همدرد ) عطا محمد (نور) ، محمد (محقق )، سيد منصور ( نادرى ) ، جنرال مومن ، رسول يهلوان ،غفار يهلوان سره هم ييثزند كلوي اواريكي ييدا

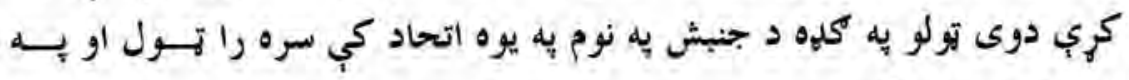
فعاليت يب يبل وركي. رؤوفى وو، تجي هغو كسنانو ته يجي يجي د الفغانستان د تجزي يلويسـان وه او

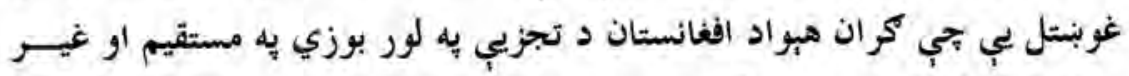

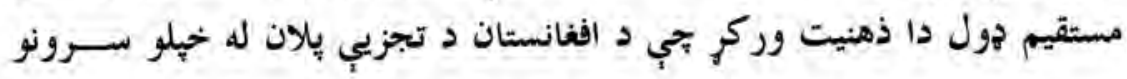




\section{V\&}

دوردى مشاهير دوهم توكى

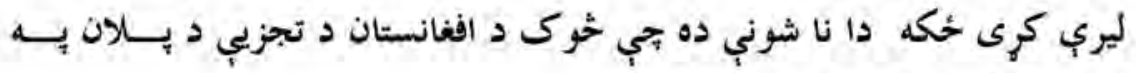
عملي كولو وتوانيوبٍ اويا د بريالي شي.

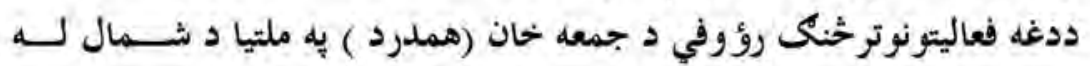

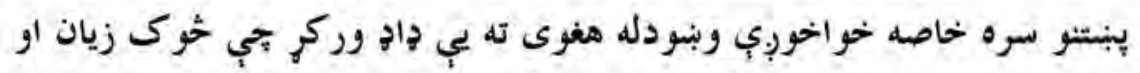
نقصان نشي ورارولى او له نوروقومونوسره يجي دهغوى د قومي ستونزو د حسلـل لياره هم درنده اوبِه وركره .

يبنبي لإيسي درندي شوي د طالبانو دتحريك سياهيان دهيواد شمالي ولاياتو ته راوربسيدل او سرأنجام يه IrVV كال جنرال رحمت الله رؤوفى د دي لياره بي لاس يب يه وينو رنك نشي يه سهين لاس له خبل كهول سره دماوراى النهر

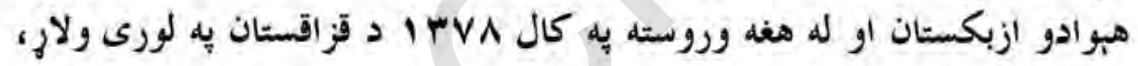
دا هيوادونه تازه د روســيي له استعماري ولكي نه خحلاص شوى وو نواقتصاد يب هبر كمزورى او ددي جو كمه نه وه جي له قزاقى اوسيدونكو يرته د نوروكتلوي كلهو الو اعاشي ته لتئكى شى نو حُكه لكه دمخه تجي وويل شول رؤوفى دا وخت له له له

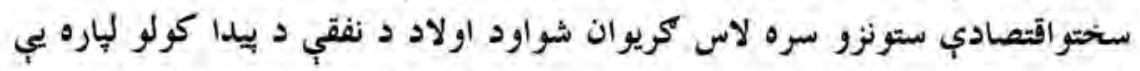

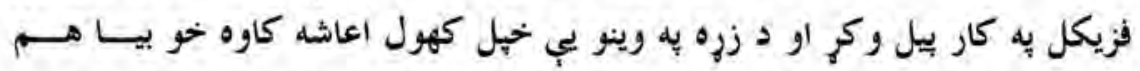

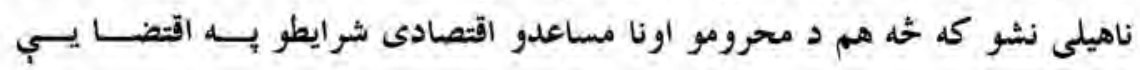

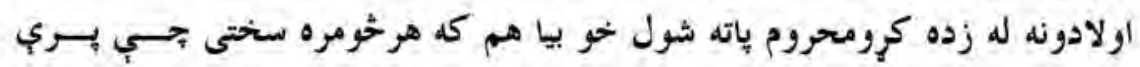
راغلي ثا بت قدم ياته شور . 
Vo د وردكو مشاهير دوهم تبرك

د كاناها د مهاجرت جانس ورته بيدا شو خو ولارج نشو اوهر لحظه يه دغــــ فكر كي وو بحي خه وخحت به يب د خيل هيواد به لور دروازه بو انستل شي جي له و اولادونو سره يو خاى ولاه شيى .

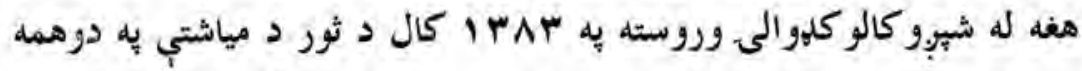
نيته بويالي شو تي بيرته خيل هيواد ته را شى او لله نوي حكومت سره عمــال

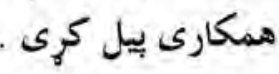

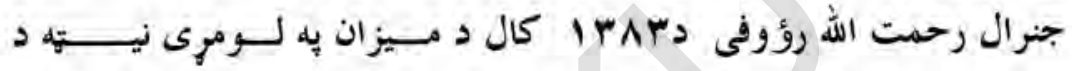
يكتــيا د كل اردو قوماندان وتاكل شو او بله جير صداقت بي بيرته د خيل كر ان

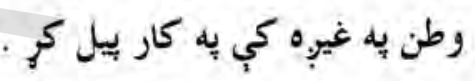

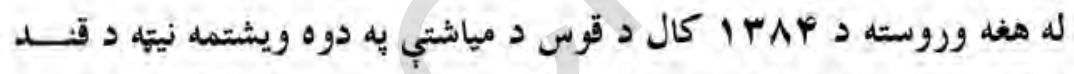

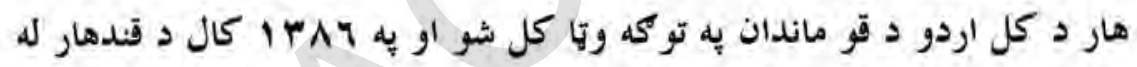
ولايت نه د ملي د فاع وزارت ته را تبديل شو خو د حئو ملحورضاتو بله بنا يسي

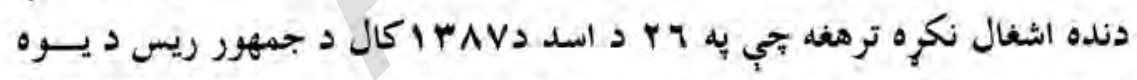

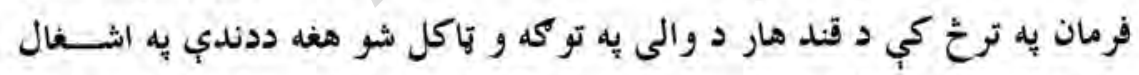

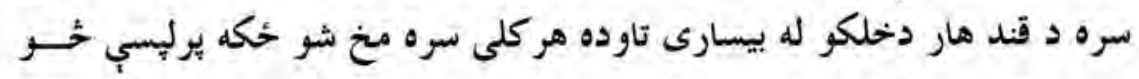
ورحي هغه ته د قندهار بنار او ولسواليو نه د استقبال اوهر كلي لهاره خلك راتلل

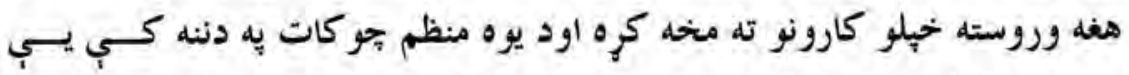

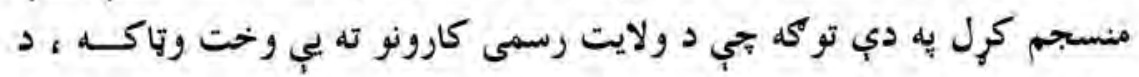

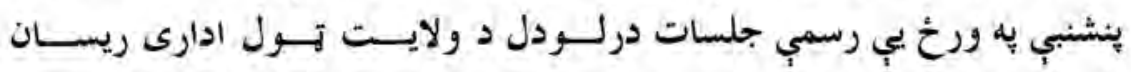
خارنوالان د بناروالى او امنيت ملي منسوبين امنيه قوماندان ترافيك او د كــلـ 


\section{Vy}

د وردكر مشامير دوهم ترك

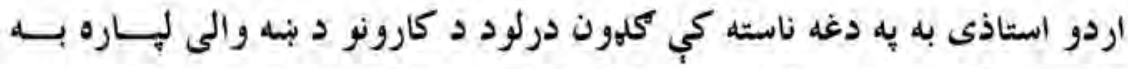
لازمي يويكري صادريدلى ، ددغه تولو فعاليتونوترخنكى رؤوفى له طالبانود نيمه

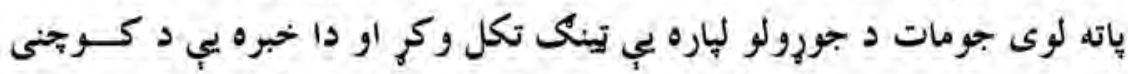

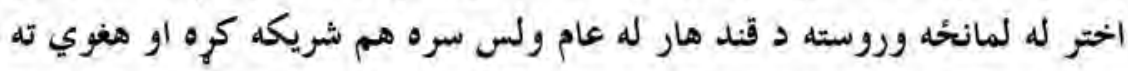
يب جار وركره بحي دا جومات به كه خداى كول جوروي ، رحمت الله رؤوفى يه قندهار د خلكو نوروستونزو ته هم بشيره رسيد كــى كوله د خلكو له ستونزو به يب وخت يه وخت خ خان خبراوه يه فــاتحواودنورو تاريخي ور حؤ يه لمانحنه كي به يب يخهله كلهون كاوه . هغه د قند هار د ولايت يه كجهه د ملي يخلاينب د يوي سراسرى شئس شورا د جورولو يّان هم جوراو دغه يورسه يب بشيره كره جي د ولايتى شورا ريسيس احمل ولى كرزى يه غريتوب برسبره يه ملي شورا كي د قندهار ولايت د ولسي

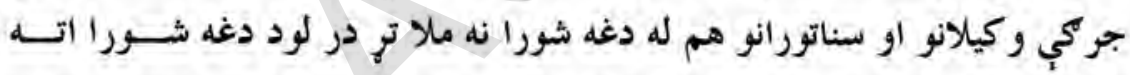
غونلمي وكرى ، دا شورا بحي د غرو شمبره يب تردور سور تنو يورى ربسـيده د

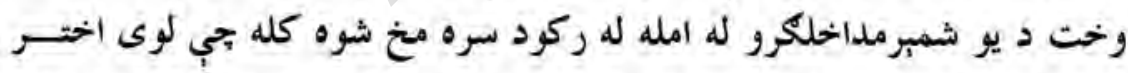
رانيردي او د شورا يو شمبر غري دا وخت د حج د فريضي د ادا كولو لِيـاره

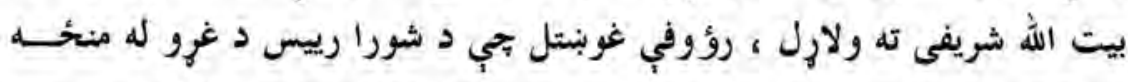

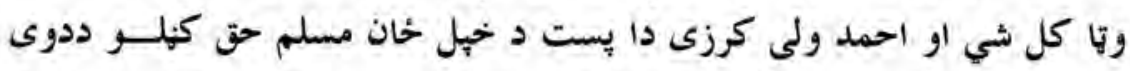
ترمنحُ لومرى لفظى اختلاف رامنح ته شو او ورو ورو دا الختلاف د احمل ولـي لـي كرزي د يلويانو يه لمسيون لايسي هربده او له بل يلوه نوموري له بهرنيانو ســـره هم تينكي اريكي در لودي ، روانه انكليسي زبله يب زده وه . 


\section{VV}

دوركو مشاهير دوهم توكى

خو هغه حثه بحي د جنرال رحمت الله رؤوقى دكندهار يه ولايت كي ددندي د اجرا يه مهال نه خوبنيده ، د هغه يه كارونو كي د نورو بيخايه مداخله وه او دا

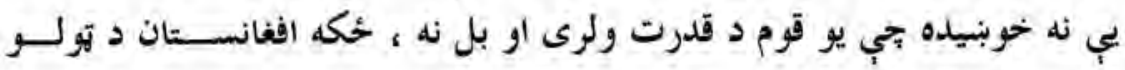

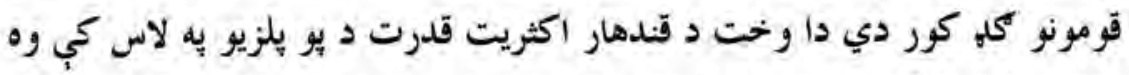
ددي تولوترخنك داوخت يه قندهار كي د افغانستان د ملي دفاع وزارت يو له املاكى د احمد ولي كرزي اومحمود كرزي لخوا لاندي شوي وه اود استوكني شهركوئه يكي جور شوي وه جي دغه كار يه هيخ وجه رؤوفى ته د منلو ورئه وه

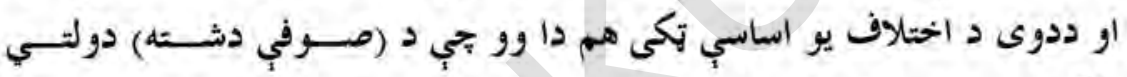
ملكيت وو تحب غصب شوي وه، عينو مينه به زور نيول شوي وه او بيا يرعـام

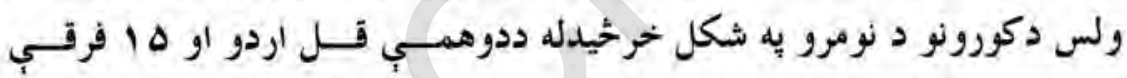

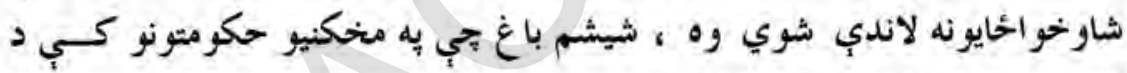

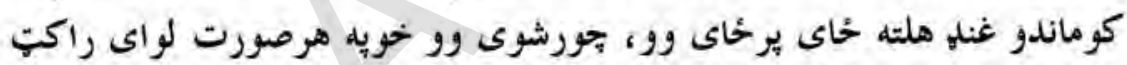
، دا فع هواد ينجوايب حمكي ، د ميدان هوابي شا وخوا خمكي دا تول حخايونه د احمد ولي اودهغه د انلهيوالانو لخوا تخم تبكار شوي وه تجي دا هرتول د احمد ولي او رؤوفى تر منحُ د زّور او نه يخلا كيدو نكي اختالافاتو سيب شول .

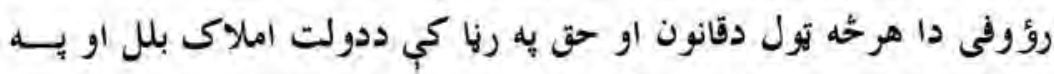
اموراتو كي د هبها تو اغيز لاندي كار نه خوبنيده مدا خله او لاس وهنه يب د سنتى كركي سبب كيده اود ملي شتمنى غصب او يه زور اوجبر لاندي كول د

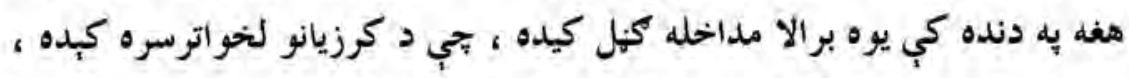
اوسر انجام يه دوه سركه كي د موتر يلورولو يه خاى دهغه او د احمد ولى كرزي 


\section{VA}

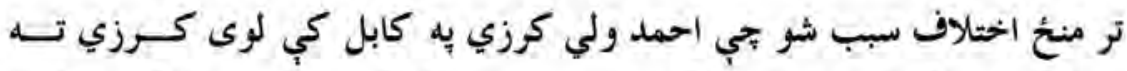

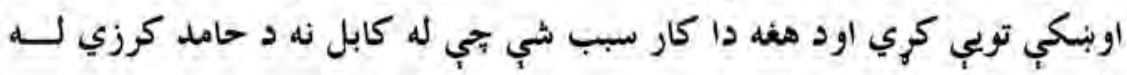

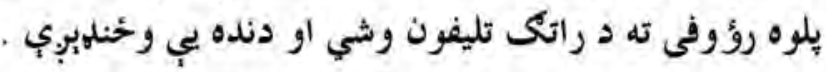

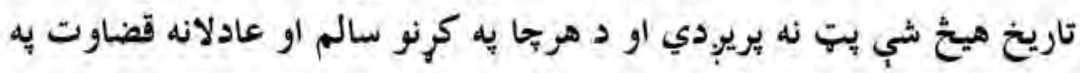

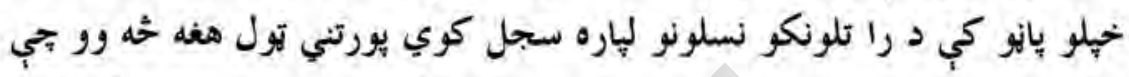

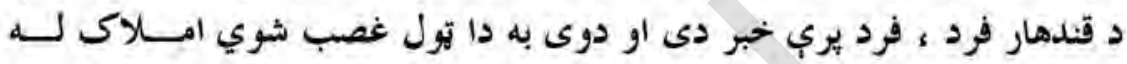

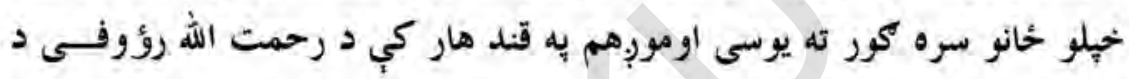

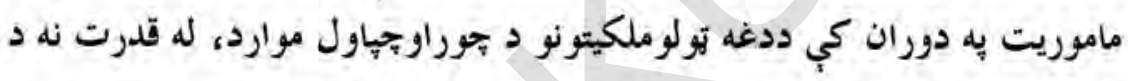

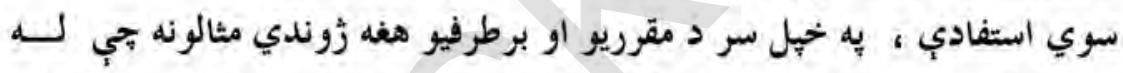

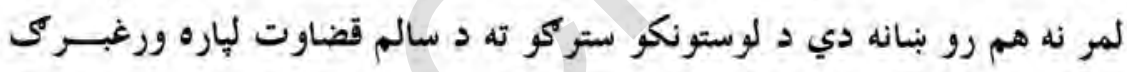

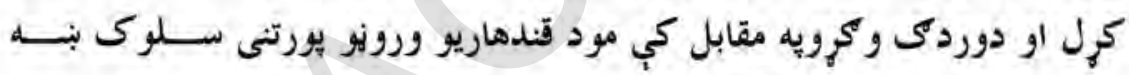

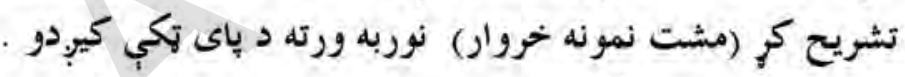

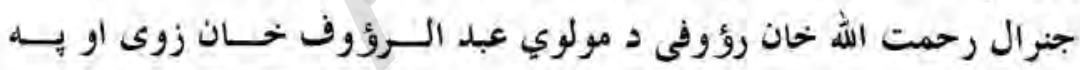

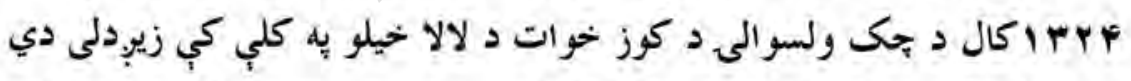

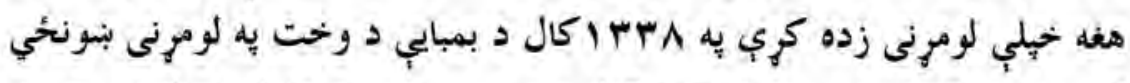

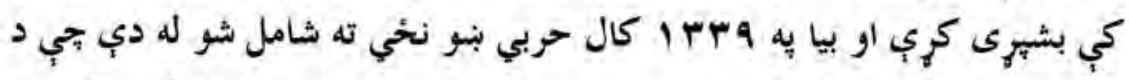

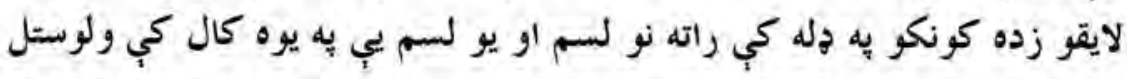

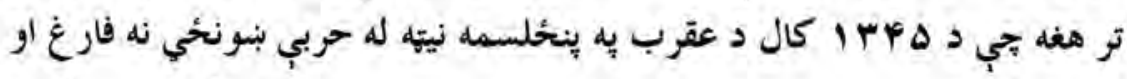

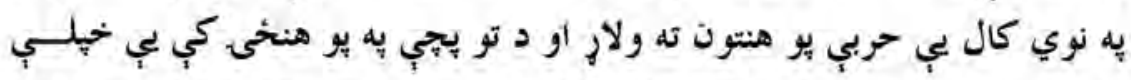

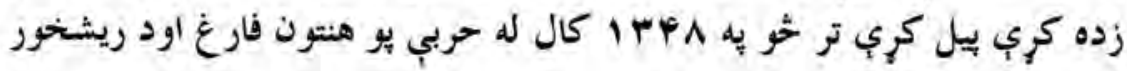




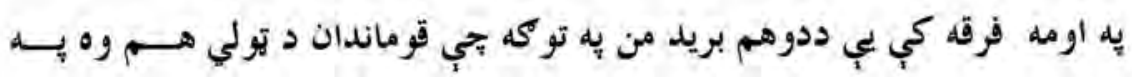

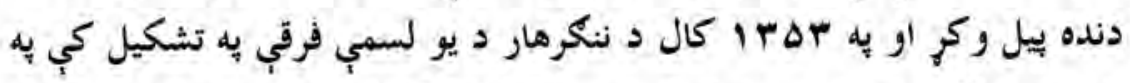

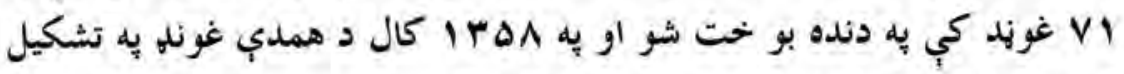

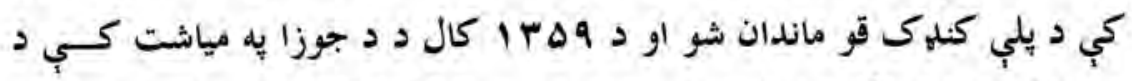

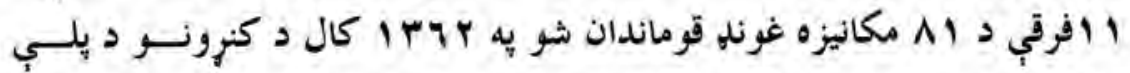

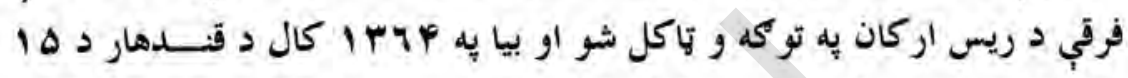

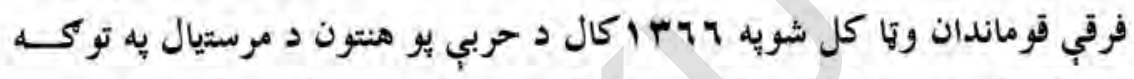

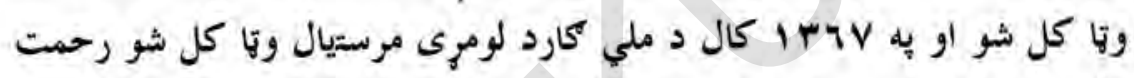

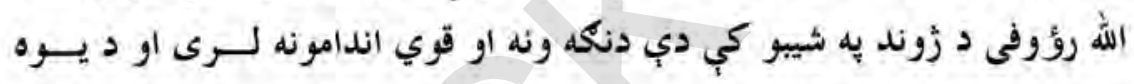

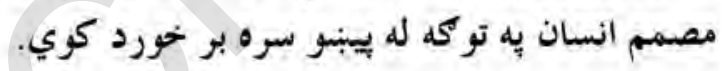


رسول داد خان( وصيل ) مستو في

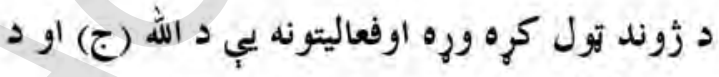

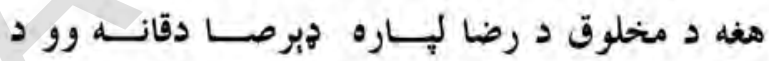

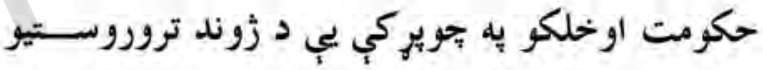

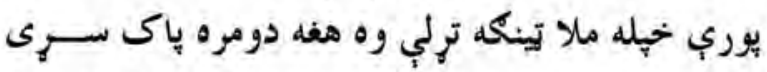

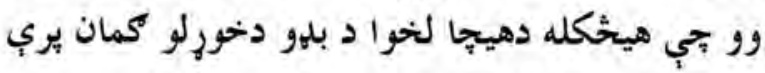

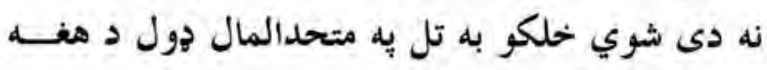

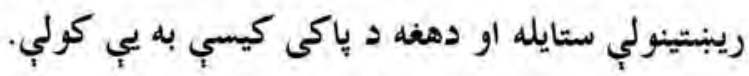

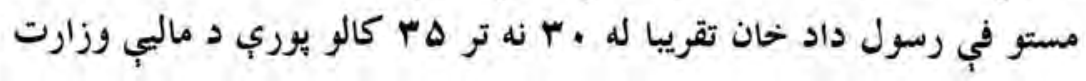

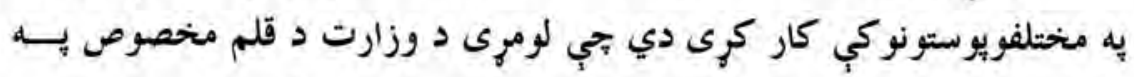

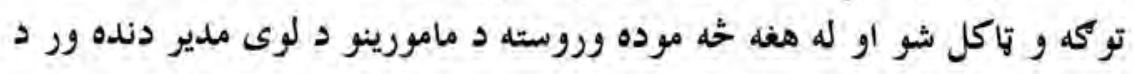


$\wedge 1$ دوركو مشاهير دوهم توك

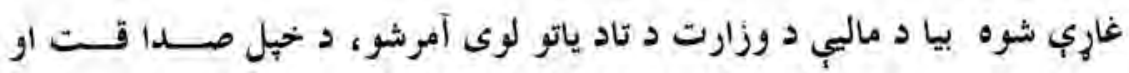

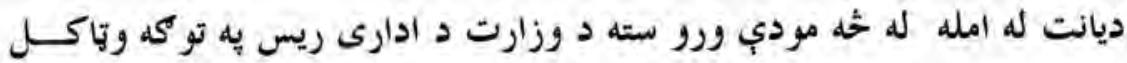
شواوله خحه مودي ورو سته د وزارت ماليي د تفتيش د ريس يه تو كه ورتّا كل شو

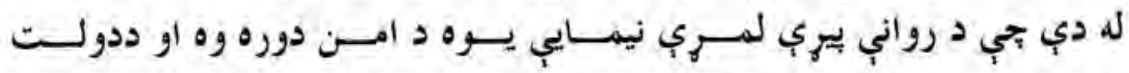

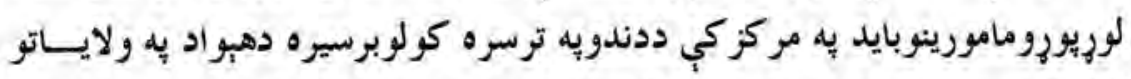

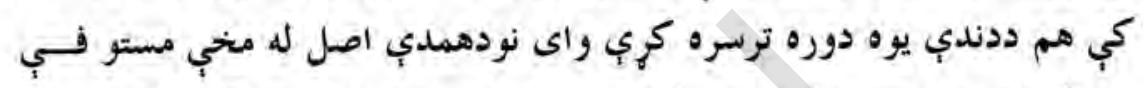
رسول داد خان هم د خه وخت لياره د هرات د مستو في يه توكه و كمارل شو

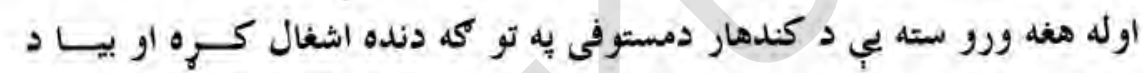
هير اد يه ختيخو ولاياتوكي د ننكر هاردمستوفى يه توكه وتباكل شو له هغه وروسته

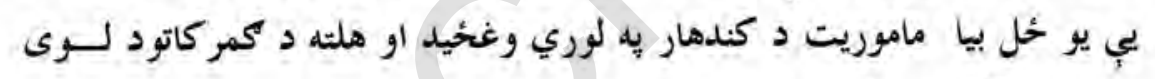
ريس به توكه مقررشو :

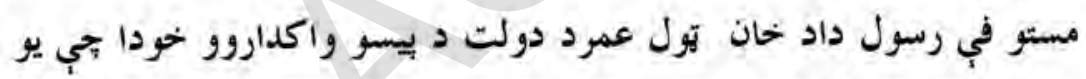
ياكى نفس اوهبواد يال شخصبت وو اويه هغه زمورج د ياكى نفسي د ادعا غوره او كره ثبوت دادي جي دهير اد يه مركز برسيره يه هفه بئارونو كي تجي ده بكيكي دندي يه متخ وري دي هيخ داسي شخصي املاكى نلري بجي اوس را بنشكاره شي جي دا يخهله ددي بنكا رندويه ده جي مستو في رسول داد خحان تول عمرله خيل

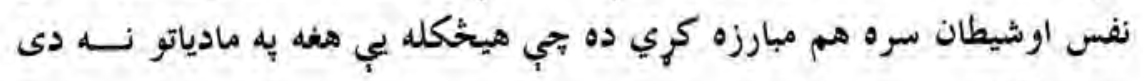

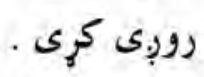

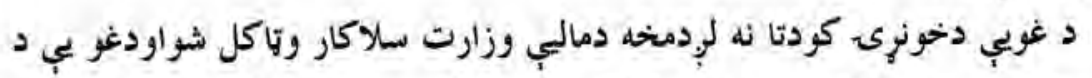
كودتا يه را منغ ته كيدو سره يب له كمونستى حكومت سره اريكي وشليدي حخكه 


\section{AT}

\section{د وردكو مشاهير دوهم توك}

دا وخت د ملك يه سياسي اوتولنيزه فضا د بي باورى ، او اختناق توري وريخي را

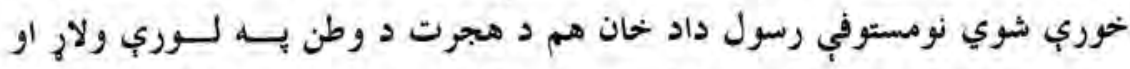

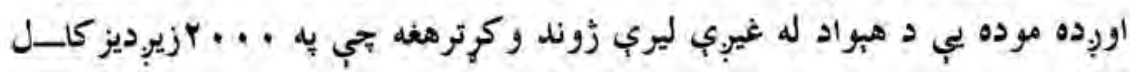
كاناديا ته مهاجرشواود زورند ترورو ستي سلكي يوري هماليه وو. مستوفي رسول داد خحان د الحاج محمد وصيل خان زوى د وردكودجيفتئ

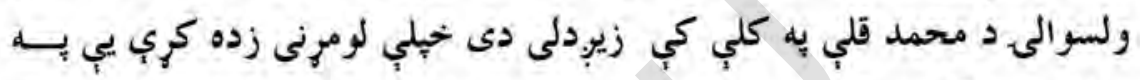

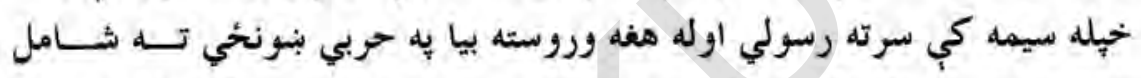
شواويه دي بنونحي كي دتعليماتوترختميدو وروسته د لوروزيده كرو لياره حربي يوهنترن ته ولار خو د ناروغى له امله يب ونشواي كراى بحي حربي تحصــيلات

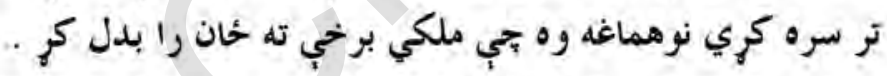

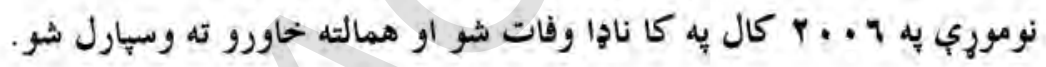




\section{$\Lambda$}

د وردكو مشاهير دوهم توكى

\section{زر جان بها - انجينر}

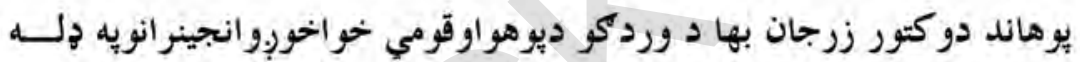

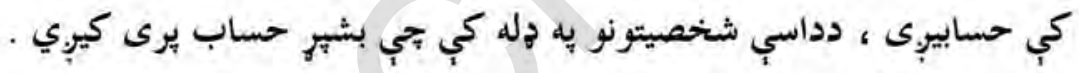

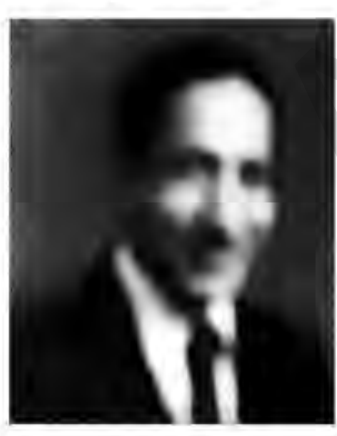

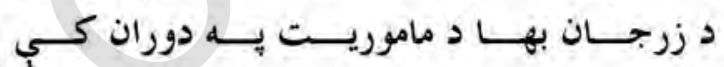

لوروجو كيوته رسيدل اويه هغه نصب كيدل اكثـرا د روا بطو(اريكو) بيه بنا وه خو زرجان بها د خهيلي يوهي لياقت او كفايت له مخب د بوهنتون د علمــي بـــورد لخوا د انجينيرى د بوهنحخى هي د مخه يكي اســاد

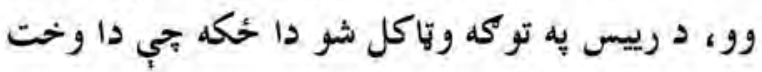

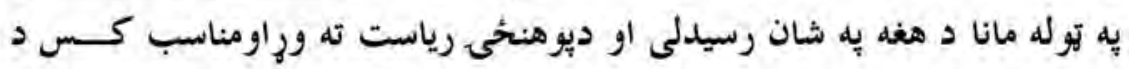
انجينيري يه يوهنحى كي نه ورو. يوهاند بها د خيل ماموريت به دوران كي يه خاصه توكمه د انجينرى بوهنحئ.

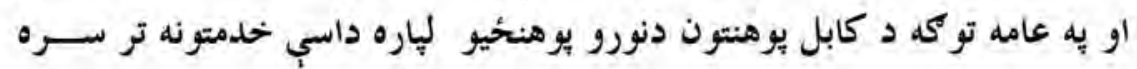




\section{$\Lambda \varepsilon$}

دوركى مشاهير دوهم توكى

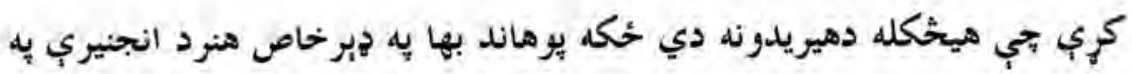

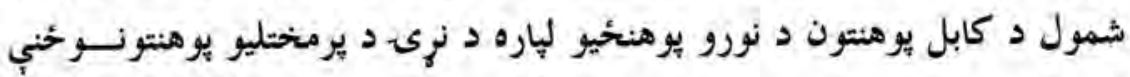

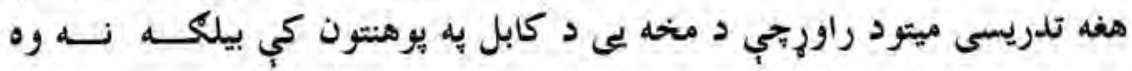

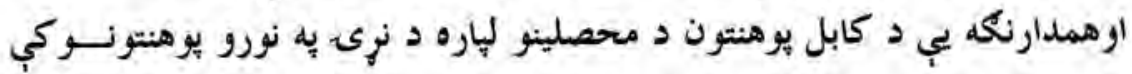

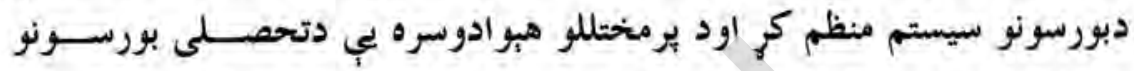

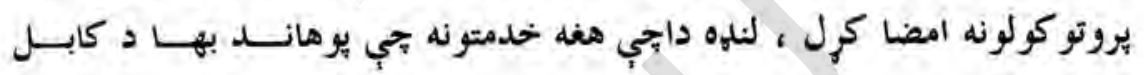

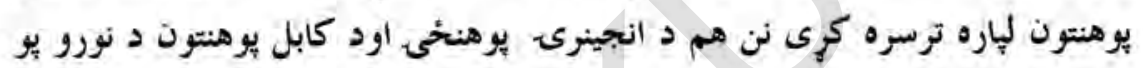

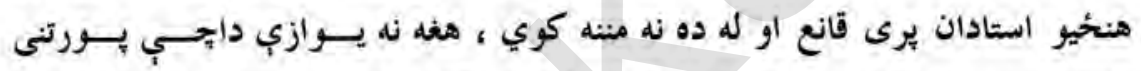

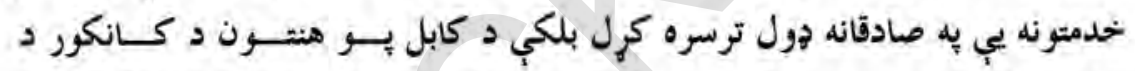

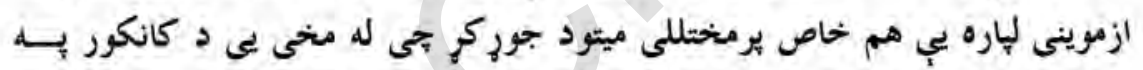

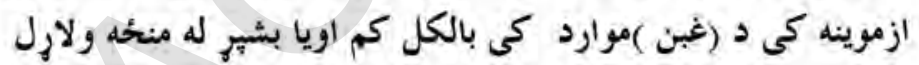

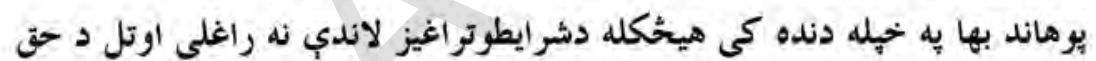
اوحقيقت ملكرى او يلوى ووحي يه دي ارهه د هغه د فعاليتو يوه بيلكه دلته را ورو. يووخت دده دماموريت يه دوران كي بجي دجمهورويس محمد داود خـــان واكمني وه او دهفه لور دده دزده كونكى وه ، يه كلنى ازموينه كي د يوبنتنود نه جواب له امله ترى نا كامه شوه ، د بوهنحي استادانواو د كابل بوهنتون ريس دا نه منله جحي د سردار محمد داود خحان لور دى ناكامه شي نو يبي له يوهاند بها نه هيله وكره جحى نجلى د محمد داود خان لور ده او هغه د ملك برحاله جمهور

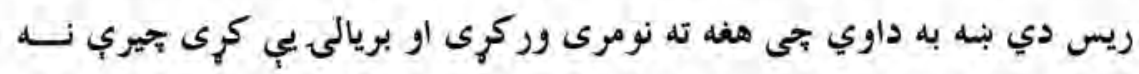

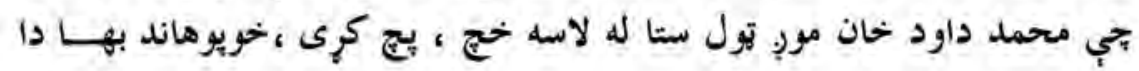


No

دوركي مشاهير دومم تيوك

خبره ونه منله او يخهله يب د هر خحه مسؤ ليت واخيست ، خبره د وزير انو ترشورا ورسيده خو بيا هم د يوهاند بها به اراده كى كوم داسي بلدلون را نغى جـيـي نجلي يه برياليتوب كي د له شنه براغ نه استازيتوب وركرى ترهغه تحى موضوع تر محمد داود خان يورى وربسده اوهغه يوهاند بها خيل حضورته ور وغو بنبت ، د بوهنتون استادانو او ريسانو انكيرله بجي بنايي بها ته به محمد داود خان له له خوا سخت زيان وارول شي خو كله تحى بها د محمد داود خحان حضـــور تــــ ورغى قخحكى له دي تحى جمهور ريس له هغه سره رو غبروكرى ، بها وليــل بحى محمد داود خحان درى حملى خيل لاس كريوان او مخ بي آسمان ته كر او د الله شكر ينى ادا كر بحي يه ملك كي بي بيه حق داسي تينك كسان شته بحي آن له

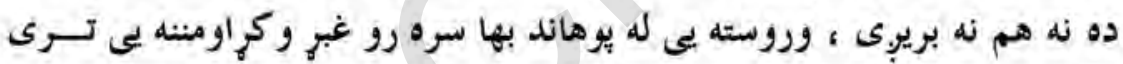
وكره هـى حق دي اداكرى هيخثكه مه بريوبه زه درته هيخ نه وايم . يوهاند زرجان بها سربيره ير دى بجي يو ماهر انجينيروو بلكي به حق يو زره سواندى قومي شخيصت هم وو كله بحي د انجينرى د يوهنحي ريبس وو نولس تنه هغه وردك استادان بتي د استادى د توظيف لياره يب تول معيارونه يوره وه او بشيرظرفيت يب درلود ، خو د حينو ملحوضاتو يه بنا يخهيلــه آرزو نشـــواى بريالي كيداى يوهاند بها غيرت وكر او هغه يبي له خيل خان سره استادان وتاكل داوخت يه ده د نورو قومونو لخوا د قوم يالني تور ولكيـــد او يـــه دي ارهـ د حينو كريو تو منئ داسي جوكى جوكي را يبدا شوي جي كويا (بها ) تر خيل حخان تول وردك راو خرخول خوبها دي تبليفاتو ته تينك غورج نيولى اويـــه انتظــار

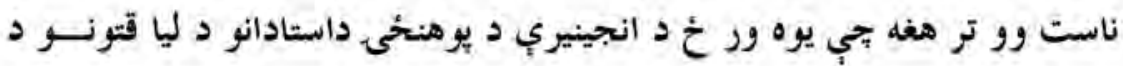


A

د وردكو مشاهير دوهم توكى

كلكي ارزوني خبره را منئ ته شوه دا خبره جي كله د يقيني كيدو يه لــور ور ور

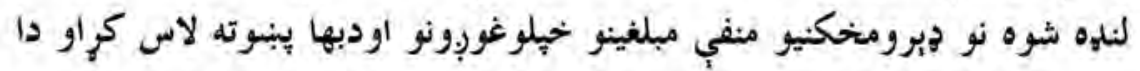
يب ومنله جي بيحايه تبليغات او ارتاويزي بي باد كري دي . د نوروتولنيزوخد متونويه لركي زرجان بها د Vيليونو دالرو خه توليزارزبنت

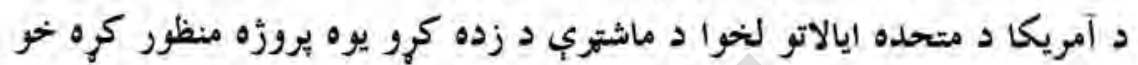

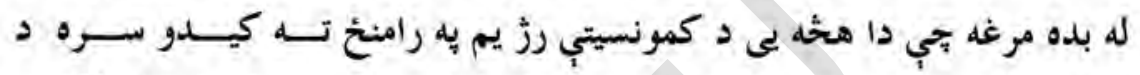
روسانو او د هغه د جانى يلويانو لخورا سبوتاز شوى خو بيا بي هم د ينحه لكه او شل زره دالرو يه مجموعي لكبنت د كابل يو هنتون د علمي ارتيــاوو د ديــوره كولو لياره علمي كتا بونه وا خيستل اودا ستونزه يع تر يوه بريده حل كره .

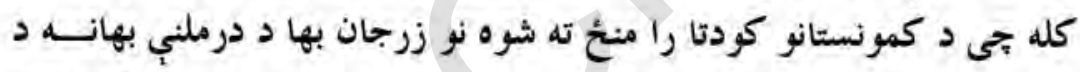
هند يه لورى ولاجر اجى هماغه يع تك شو اوحمان بيى د امين دجلادانو له منكلو

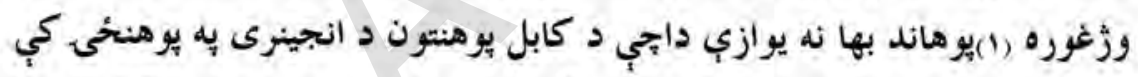

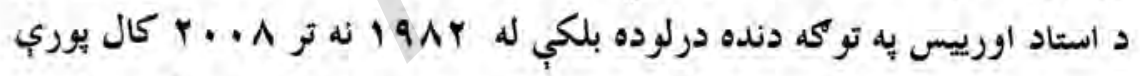
كله بحي د آمريكا يه متحده ايالاتوكي وو هلته هم د بيرويه يوهنتون كي د استاد

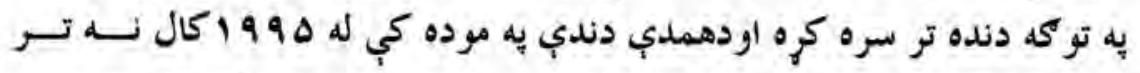

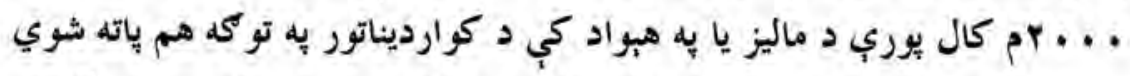

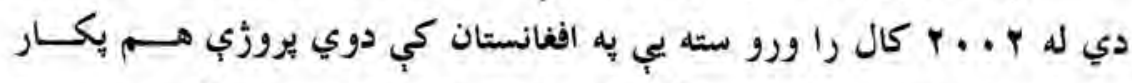
واجولي جي يوه يب دتولنيزيرمختك او دخوانانو لهاره د لورو زده كرو يروسه وه

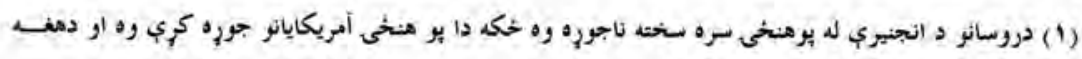
درسي ميتود يكي به مخ ورال كيده. 


\section{$\Lambda \mathrm{V}$}

دوركو مشاهير دومهم تركى

جي د بي وسه كسانو لهاره يكي د تحصيل زمينه برابريلدله اوبله يب د تخنيكي او

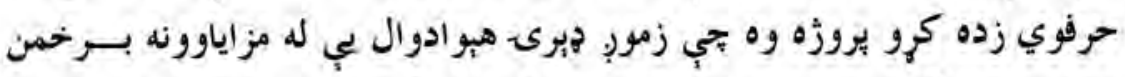
شول همدارنكه هغه د خخيلي سيمب د بنونحئي بنو نكو ته هغه وخت د مالي منابعو اونورو امكاناتو تابيا ونيوه جي دولت هيخ امكانات نه درلودل . يوهاند بها د انجينرى او ديزاين يه برخه كي هير كتابونه ليكلي دي يه يه عربى يبنتو، انكليسى ، جرمنى زبو رواني خبري كولي شي او همدارنكه د ياكســان

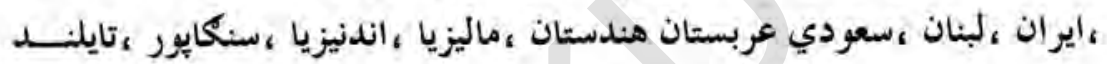
، جايان او كاناها هيوادونو ته يب سفرونه هم كري دي.

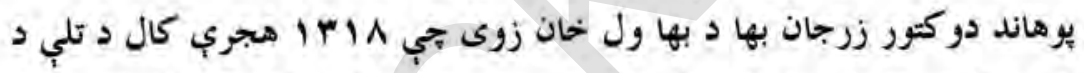

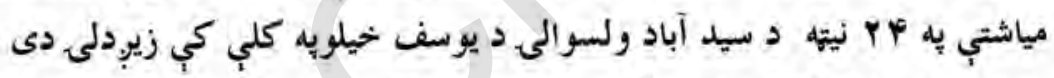

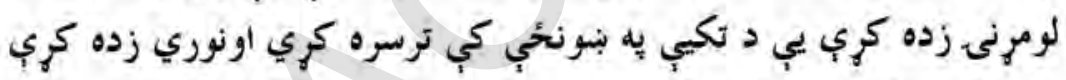
بي د كابل يه عالي دار المعلمين كي بشيري كري دي دي . زرجان بها زوندى دى او د آمريكا يه متحده ايالاتو كي زوند كوي .

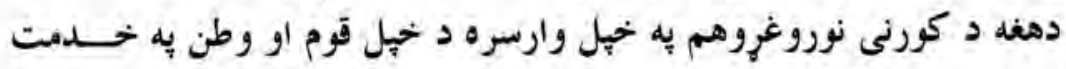
كي خولي توبي كر ي دي دي . اسدالله (بها) دهغه بل وروردى تحي دغويبي كودتا د را منحُ ته كيدو يه مهال د اطريش يه مركز دويانا يه يوهنتون كي يه زده كرو بوخت وود كودتا ل خبريدو او اوريلدو يب وطن ته له راتلو نه ده ده وركره خيكه توكي هيلي يبي نا هيلي او نيمكري ياته شوي . 
$\wedge \wedge$

دوركى مشاهير دوهم توكى

اسدالله بها دنوروهيواد والو يه خيردهجرت يه وطن كي د يوي داسي تولني سلاكار شوتي ماشومان يب دادبي سياليو لياره د نيى بيلا بيلو هبوادو ته استول

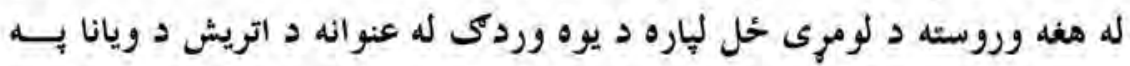
يوهنتون كي د اسلامياتوتلدريس يبل كر(1) اود زوند تر وروستي سلكي يوري يب تلريس كاوه ، ددغه تر خنكى يب به اتريش كي دي اففانستان د بيا رغاوني لِاره د مرستو تو لنه را منئ ته كره بحي ددي تولني رياست يب هم د زورند تر وروستيو يوري دهغه يه غاره وو، ددي تولني فعاليت تنها ادبي نه ووبلكي دهبواد يه دننه كي يب ديوهني ودي ته هم يه ياملرني سره د وردكو دشنيزاوهمدا رازدهبواد يه

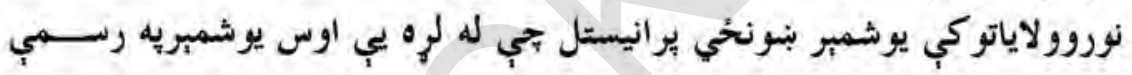

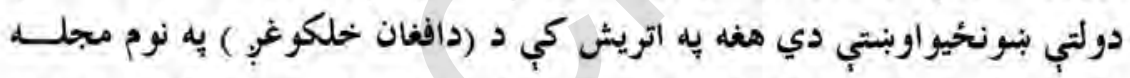

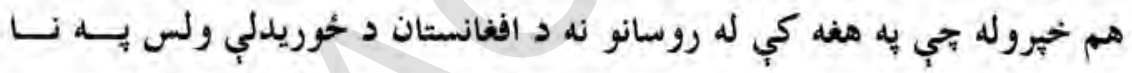
خو الوخيروني كيلدي ، دي مجلي يه هيواد كي دوننه هم خانكي درلودي جـي دكو درمجله يجي بنه بيلكه كنيلى شو.

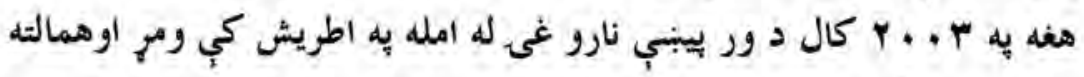
خاورو ته وسيارل شو.

محمدامين عمر دوغه كورنى بل خدمتكارغرى دى خي دزرجان بها دو تره زوى دى ديري خدمتونه يب دجهاد اوله جهاد نه را وروسته د كليوالى بنستونو

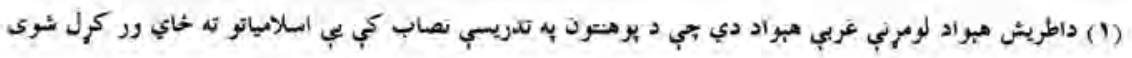


19 دو وركى مشاهير دوهم توكى

يه ودي اويراختيا كي ترسره كري اوهغل بهرني موستندويه امكانات تحب د هغل يه واكى وو يه زير صادقائه رول يبي د ملك يه بيا رغاوني لكولي دي هغه د خهيلو فعاليتونويه يبل كي د هجرت يه وطن كي د مهاجريثو لياره د شمشتويه كم

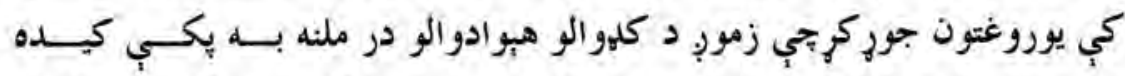

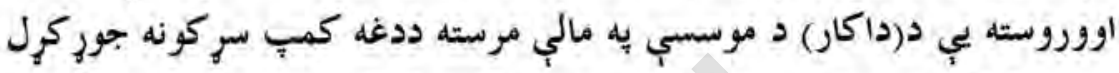
يِه • 99 19 كال بي د سويلهن له كوميتي سره كار يبل كري اود هغه يه مالي امكاناتو

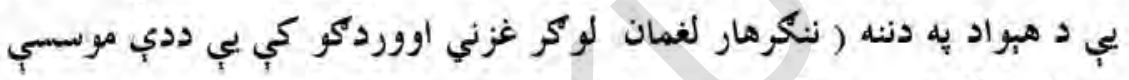
يه مالي امكاناتو يه لسكونو صحي كلينكونه ، بندونه ،دويسـالو ســــر بندونــهـ ، كاريزونه ، سركونه ، استنادي ديوالونه،د بنسونحيو ودانى جوري كري دي دي د هغه

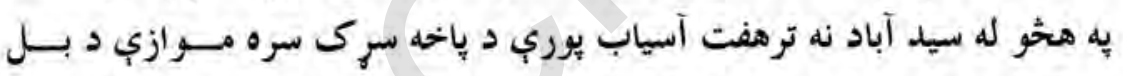
سرك جورول ، دآبدري د سركى رغاونه به وردكو كي د سلكونو خاكَانو لِاره

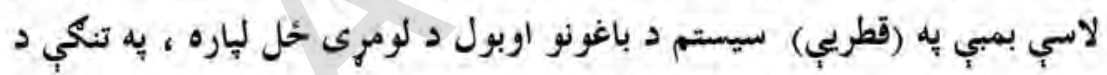

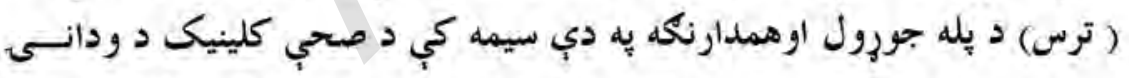
جورول ، د سيد آباد او (عمر ولي ) د ليسود ودانيو يه جغتو كي دغازي محمد جان خان او خداى نظرخان دليسو دودانيو ، دنيك يايقول د نور المدارس اوعمر

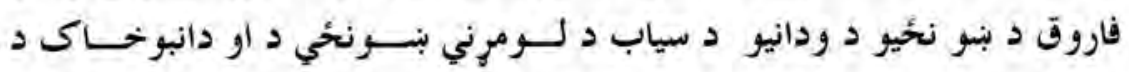
بنسونحي د ودانيو جورول شامل وو . هغه د يوسف خيلو يه كلي كي د جرمن انترنيشنل فاونديشن يه مالي مر سته له

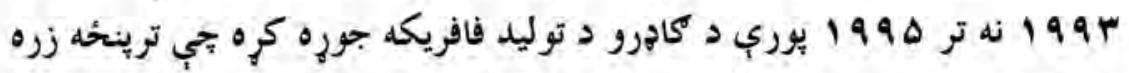

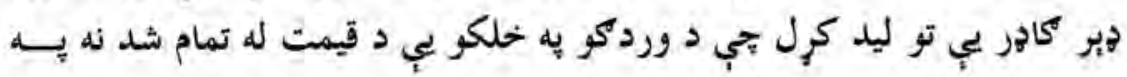


9. دوردك مشاهير دوهم توكى

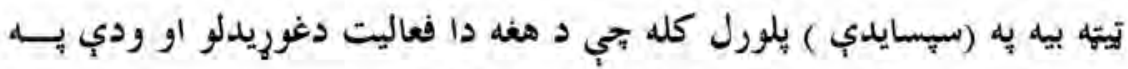

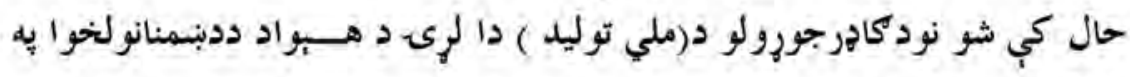

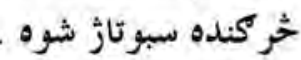

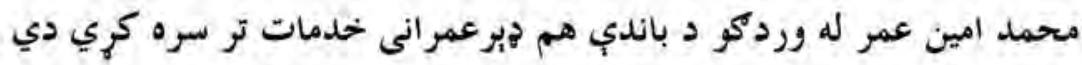

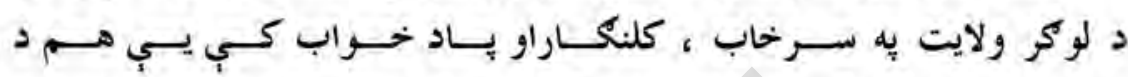

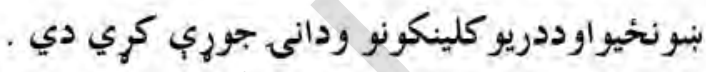

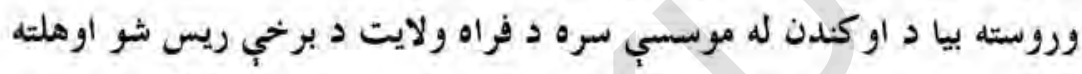

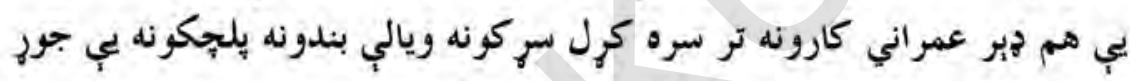

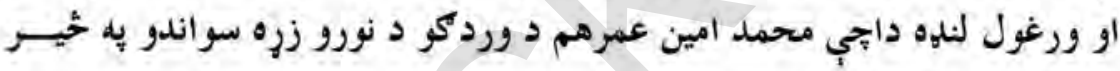

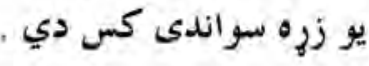




\section{زمركى - ياسر(استاد ياسر)}

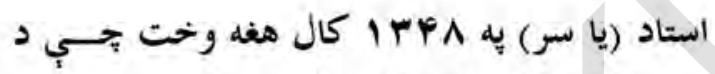

حبيبي يه ليسه كي زده كـــونكى وو لـــه اســلامي

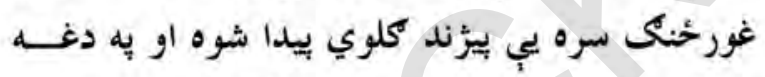
جو كات كي يجي رسماً مبارزه يبل كره او يه زره يوري يوري

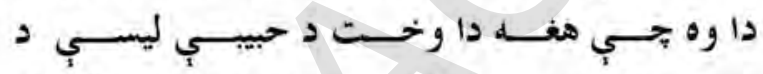
ممتازوشاتكردانويه جِله كي د يوه كال لياره د آمريكا متحده ايالاتو ته د زده كرو لياره ولارله دي تي مبارزشخصيت وونو د آمريكا جاييريال دهغه به روحيه كومه منفي اغيزه ونكره اوبيرته به سالمه اسلامي آيــد يالوزىى هيواد ته را وكرخيد او د خهلو مبارزو ورونو ترخنى يب اسلامي مبارزه لإيسي كرندى كره د محمد داود خان د واكمنى يه مهال استاد ياسرد هغه لِّ شمبر مبارزينويه جِله كي تي دسردارمحمد داود خحان د رزيم مخالفين وو ، يبنسور ته ولاراوهلته د اسلامي تحريك له مبارزينو سره يوخاى مبارزه بيل كره اوعجالثا ددغه نهضت يه تشكيل كي دمالي كمسيون مسوول وتاكل شو. 
له يوخه هسكوتيتووروسته به بيبنور كي زره تنكى شو اود زده د بشيرولوليّاره

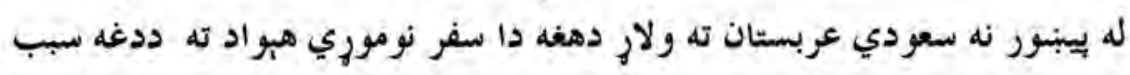

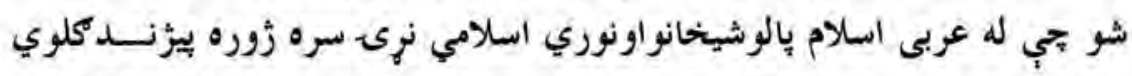

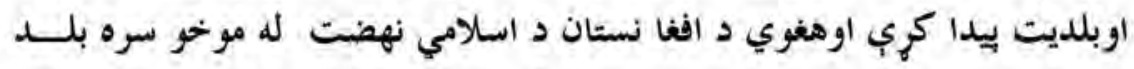

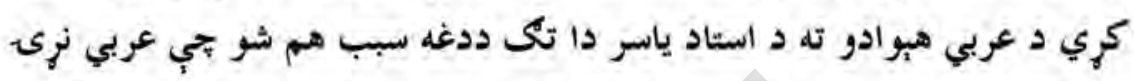

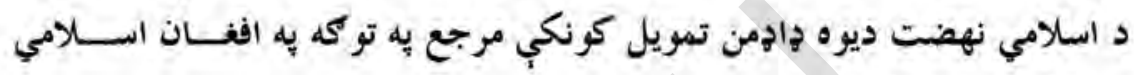

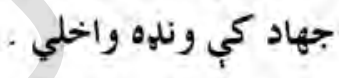

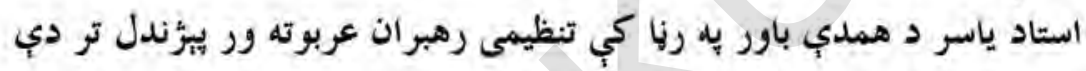

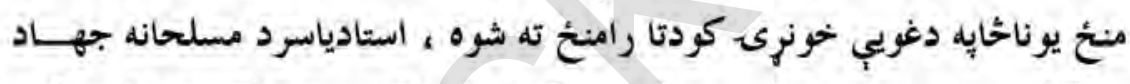

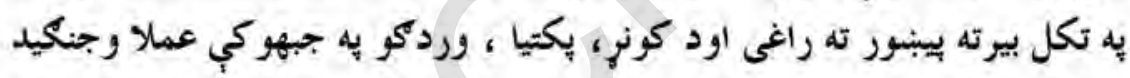

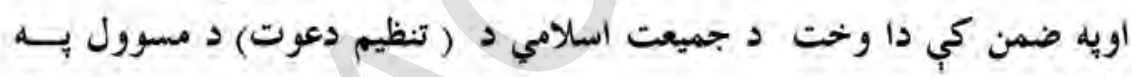

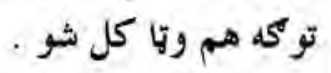

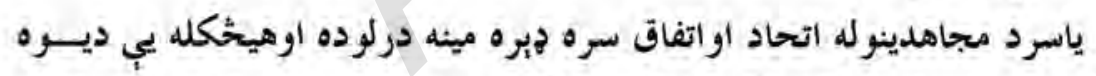

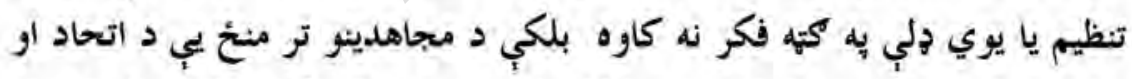

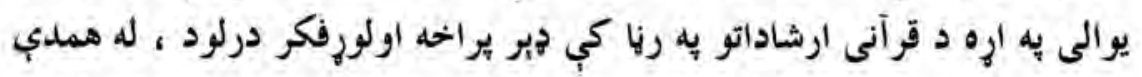

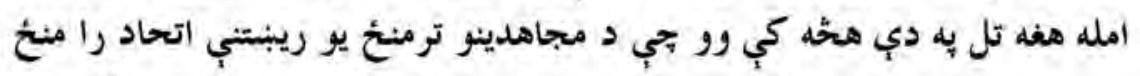

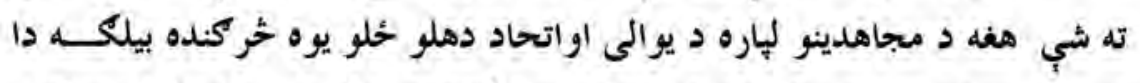

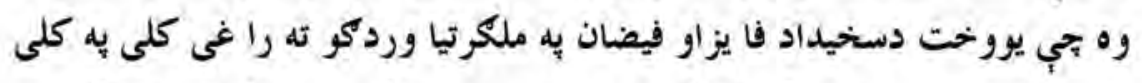

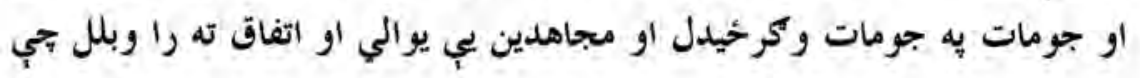


$9+$

د وردكو مشاهير دوهم توكى

دا سفرتوزيبره بريده بريالى هم وو حيكه دمجاهدينو يه روحيه كي يب د اتفاق يه

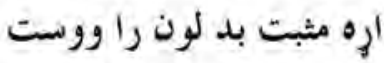

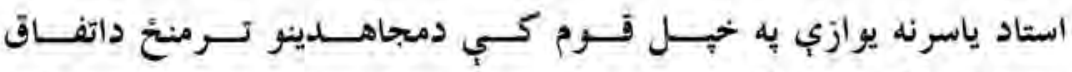

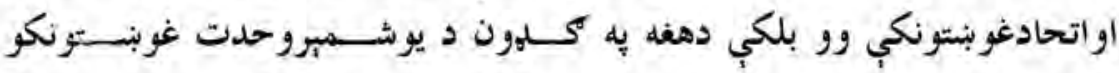

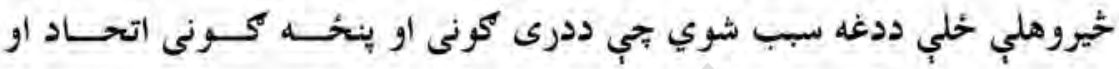
وروسته بيا اوه كوني اتحاد را منحُ ته شى يه دغه اتحاد كمى استاد يا سر تـله د

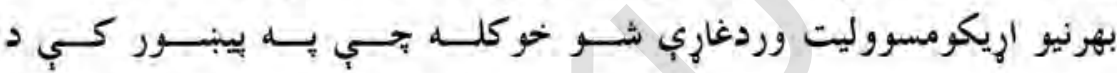
مجاهدينو(جلاى وطن) موقت حكومت را منئ ته شو او حضــرت حسبغته الله

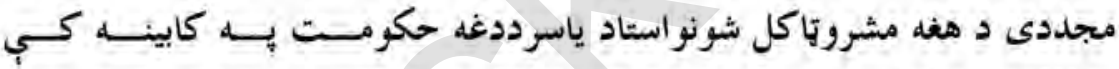

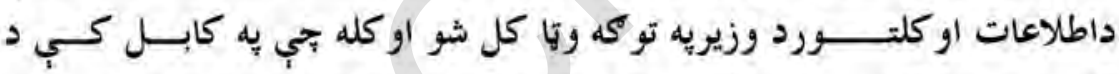
كمونستانو حكومت را نسكور شو نو دا حكومت د مجددي ترمشرى لانسلـي

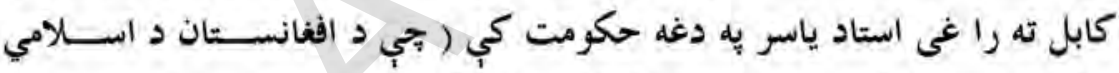
دولت تر عنوان لاندي يجي نوى به فعاليت بيل وكر ) د سا ختماني جارو د وزيريه توكه جي اوس دا وزارت د(تول كتهو) يا فوايد عامي د وزارت يه نوم يا ديوبي ،

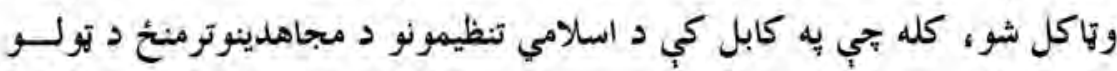

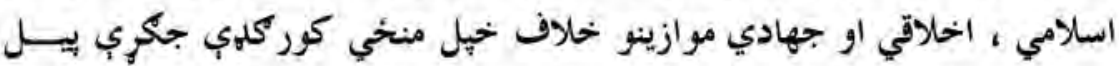

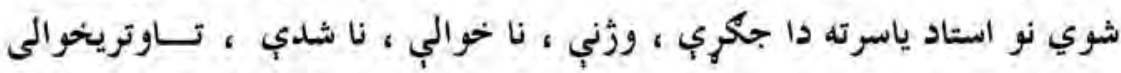
اونوري نادودي د زغم ورنه وي نوسمد لاسه يب به غو خه بريكره د وزارت له دندي استعفا وركره او ديوه آزاد خحياله او له كنا نه د خحلاص زورند يه لــوريبي

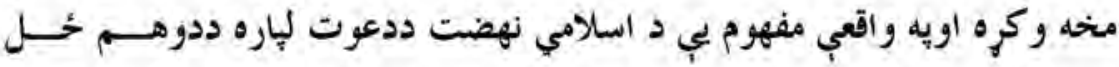


$4 \varepsilon$ دوركى مشاهير دوهم توكى

لياره له سره هلب خلي بيل كري كله تبي دطالبانوتحريك دهبو اد به سهيلي برخو

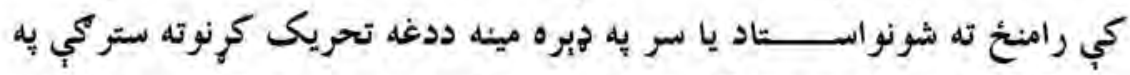

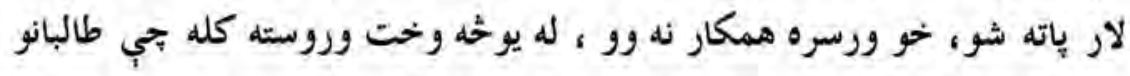

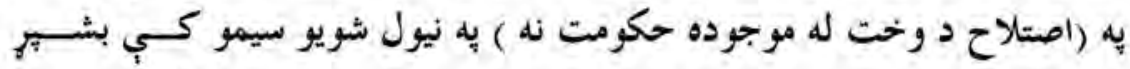

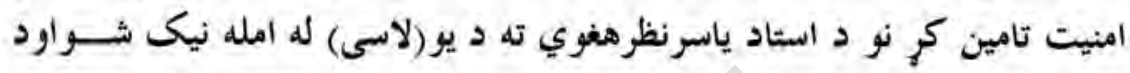

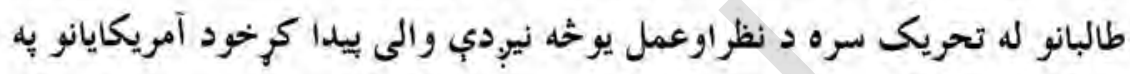

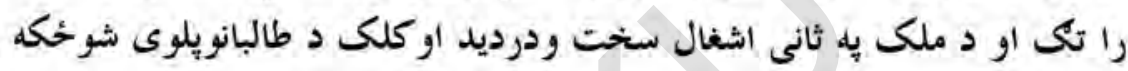
د اسلامي نهضت دمبارزي اصيلب موخي دا وخت د طالبانود تحريكى له موخو

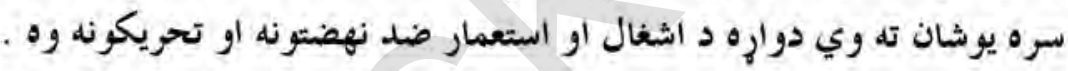

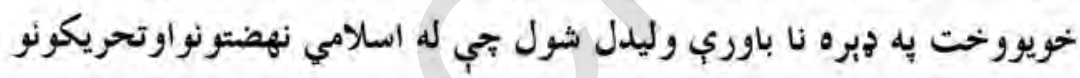

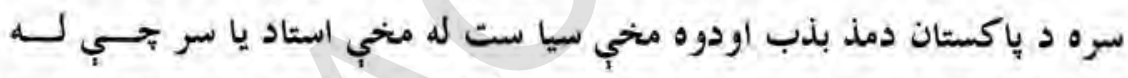

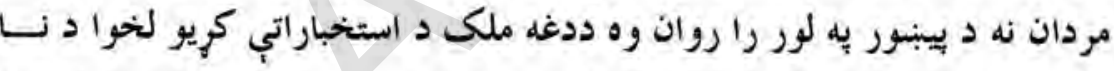

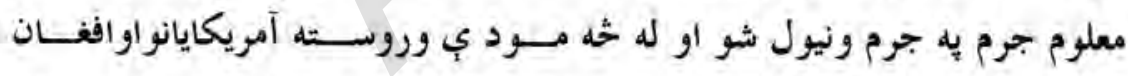

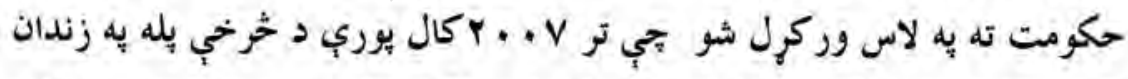

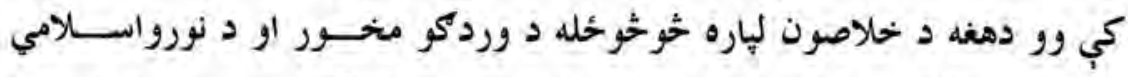

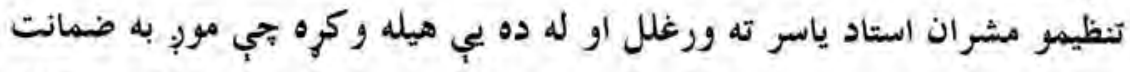

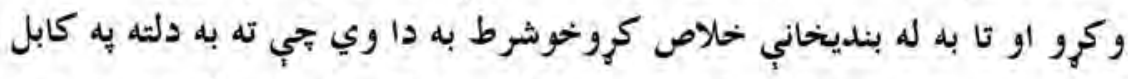

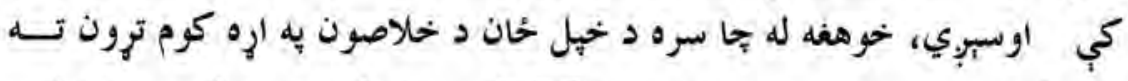

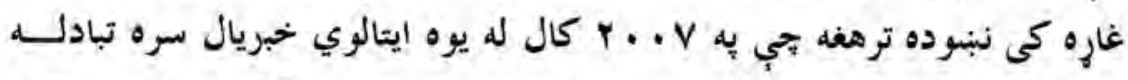

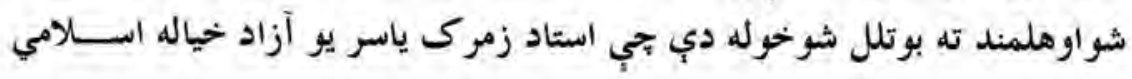


9० دوركو مشاهير دومم توكى

مبارز وو او يه واقعي مفهوم مبارزه بي خوبنوله نو له هلمند نه بيرته بيبنور تــه ولار خود هغه دا تول حركات اوسكنات د ســيمي د مغرضـــو او دوه منخيــو

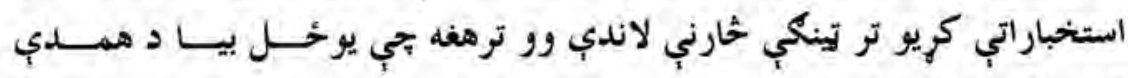
كريو،له خوا ونيول شواو بندي شو ، خو هيخوك نه وه بحي يو بنتيه وكري جي دا تول ولي ؟ او ولي د هغه به بر خليك دومره ملنلهي وهل كيبري .

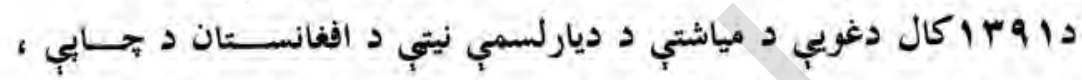

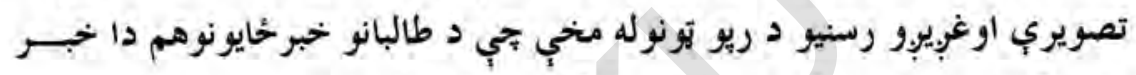
تائيد كره د استاد زمرك ياسر د برخليك يه اره يه لاندي متن خبررا غلي وو .

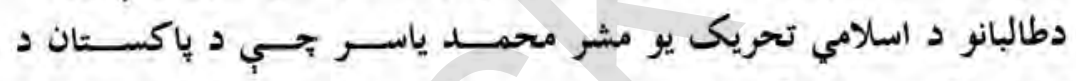
الستخباراتي كريو يه بند كي وو يه دي وروستيو كي يه مرموز ذول له منحُه تللي

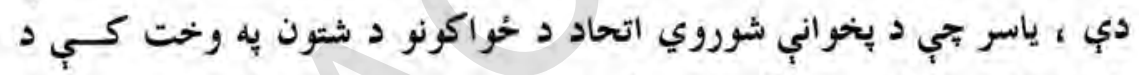
افغائستان د اسلامي تحويك مرستيال وواود مجاهدينو لخو ا د كابل لــه نيــول كيلدو وروسته يه ثر لورو دولتي يوستونو وتا كل شواويه باي كي له طالبانو سره

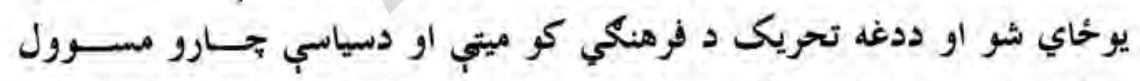

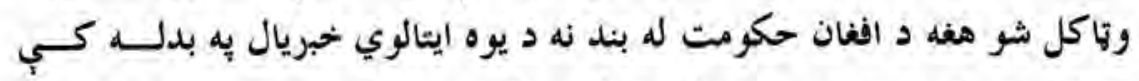

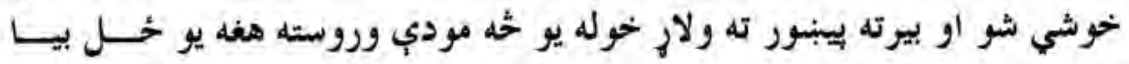
ددغه هيو اد استخباراتي كريو ونيو او يه مرموز مول بي له منحئه يورج . 


\section{7}

دوركو مشاهير دوهم توكى

\section{سخيداد فا ثز-د حج او اوقافو وزير}

سخيداد فائز دروسانود استيلا يه مهال يوتكره

اوفرهنكي شخصيت وو او د اطلاعات او كلت

$$
\text { ور يه وزارت كي يه دنده بوخت و . }
$$

كله جي د جهاد يه لوميو كي يبنبور ته ولار نو وليدل جي اسلامي نهفت يه دووبرخو يــاني حزب اسلامي حكمتياراو جميعت اسلامي رباني

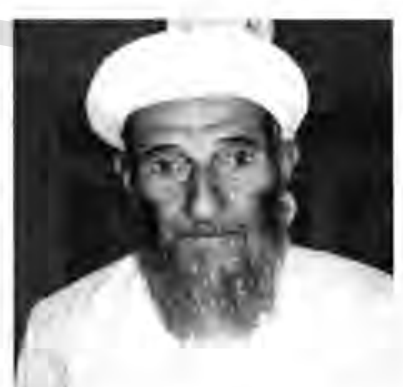

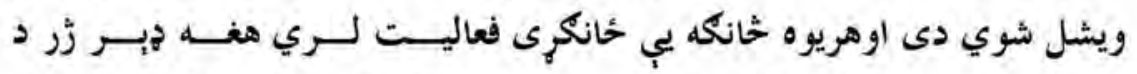

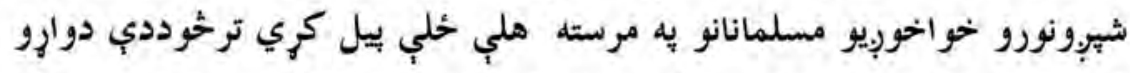

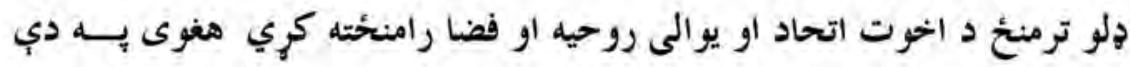

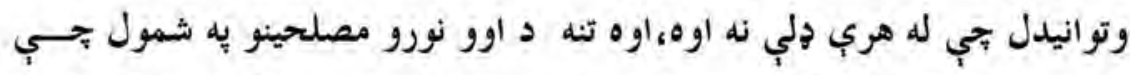
تول يب يويشت كسه كيدل د حل او تفا هم يوه شورا جوره كري يه دي شورا

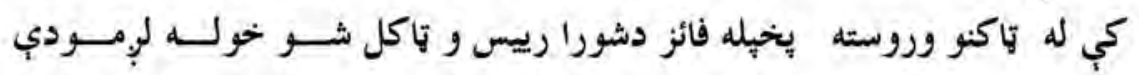


$9 \mathrm{~V}$ دورديو مشاهير دوهم توكى

وروسته د حيان غو بنتئر له امله دا شوراهم منحل شوه اوهر تنظيم يه خيل سرشو

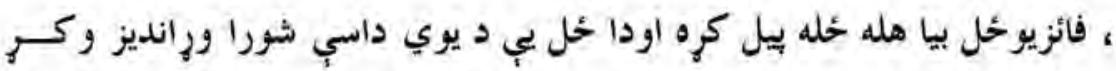

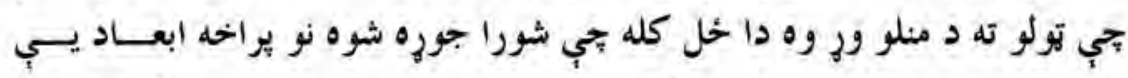

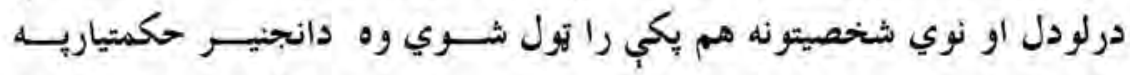
ورجانديزمولوي محمد نبي دنوي اتحاد د رياست لياره ونومول شو نوى اتحاد د حركت انقلاب اسلامي يه نوم ونومول شو ( حو دا حلّ دمولوي خالص حسزب اسلامي ، دنجات ملي جبهه او محاذ ملي هم را منح ته شوى وو ) او لنده داتي دا وخت د اسلامي تنظيمو شميره بنحئو ته رسيدلي وه او فا ئز پيه دغه اتحاد كي

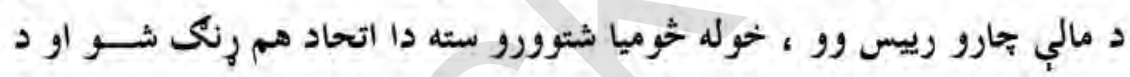
جهادي جولو يه شمبره كي هم د حركت انقلاب اسلامي تنظيم وروثير شو ، فائز دا وخت با يد د يوه تنظيم يه دننه كي خيل جهادي فعاليتونه يه مخ وري واي نو له همدي امله هغه د خينو ملحوظاتو يه بنا له جميعت اسلافي سره د مالي بحارو

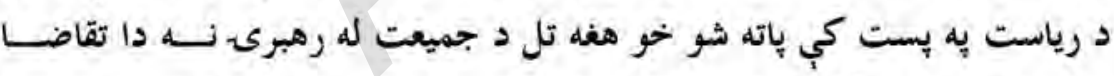

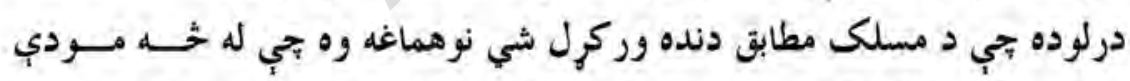

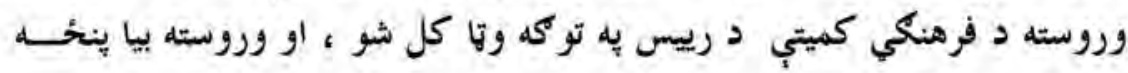
كونى اتحاد را منح ته شو حي د (افغانستان د آزادى لياره اسلامي اتحاد ) گه نوم ونومول شو اوفائز يه دغه اتحاد كي هم د فرهنكي رييس يه توكه باته شو خو كله جي يوه كال وروسته دا اتحاد هم وشريد او استاد سياف را منخته شو خو فائز

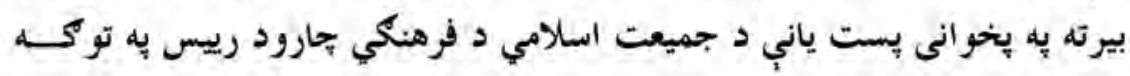

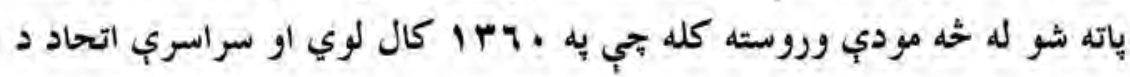




\section{1}

دوركى مشاهير دوهم توكى

( اتحاد السالامي مجاهدين افغانستان ) يه نوم را منحُ ته شو نوفائز يه دغه اتحاد كي دعالي شورا غوى اود فرهنكي كوميتي د مرستيال يه توكه وتئاكل شـــواويه

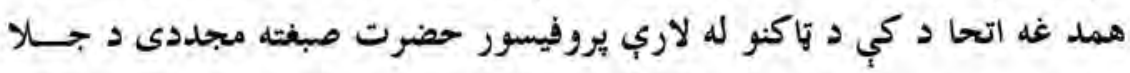

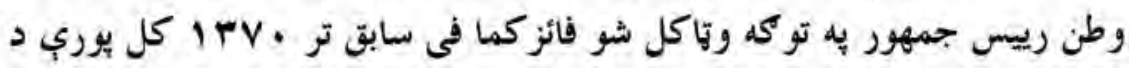

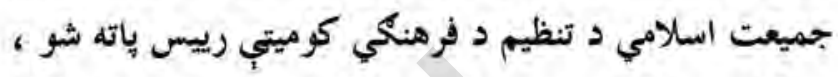

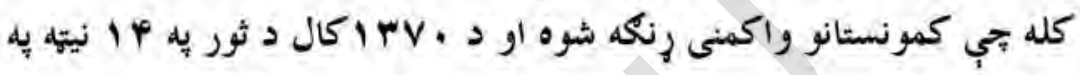

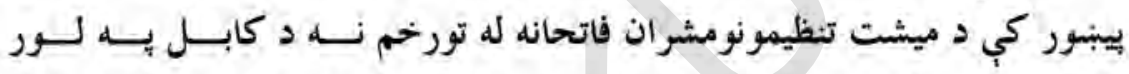

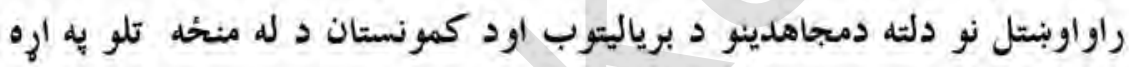

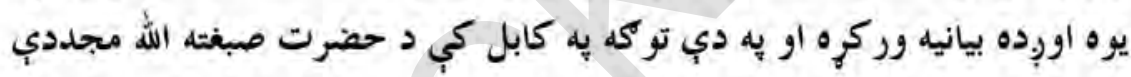
واكمني بيل شوه فائز د همدي مياشتي حيه دوريشتهل نيته د دافغاني سري مياشتي)

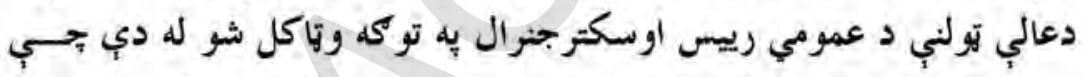
سخيداد فائزيو صادق او ريبنتنى انسان وو نو د I VVP كال د سرطان د مياشتي

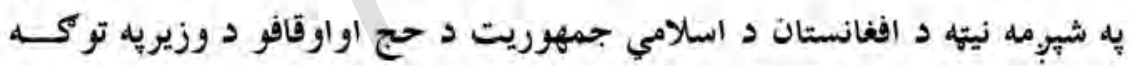

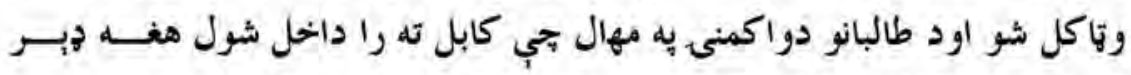

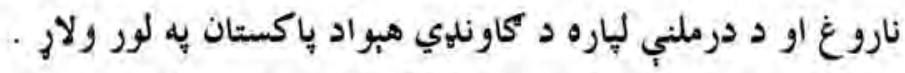
كه د هغه د زوند لومريوته را وكرئونوسخيداد فائز دغلام سرور زوى او به

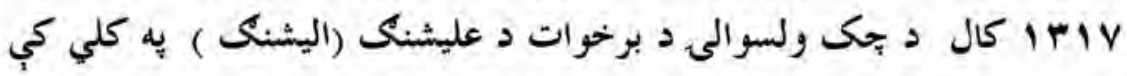

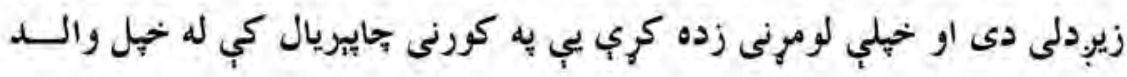
صيب نه بيل كرى او له هغه وروسته يبي فقه ، صرف نحوه (لغت )منطبـق او د نظم نور كتابونه د طالبانو په درسونو كي ولوستل، له خلورم تولكي نه ترى تولكي لهي 


\section{9}

دو وركو مشاهير دوهم توكى

يوري زده كري يب د غزني ولايت د نور المدارس يه نيمه رسمي ملرسه كي تر

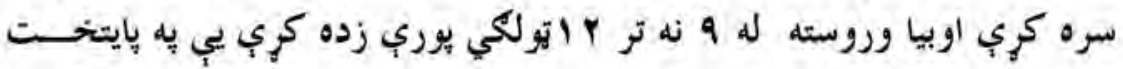
ياني د كابل به عربي دارلعلوم كي بشيري كري دي دى جي د زده كرو له بشبريدو

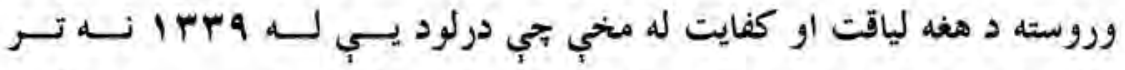
ب ب إيور ي يه نوموري مدرسه كي د ادارى مسوول او د تلدريسى مرستيال به

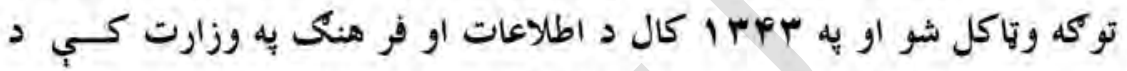
ليكوال او د تبليغاتود عمومي مديريت د غرى به توكه وتاكل شو او به كــــل ل r r r T بي ديبا م حق د مجلي مسووليت يه غاره واخيست اود همدي كا ل د سنبلي او عقرب يه مياشتوكي هيه نوموري مجله كي د مجلي د دو حيب او هاليسى

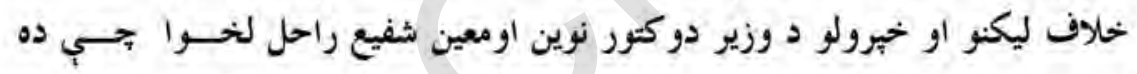

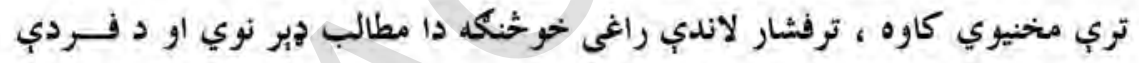

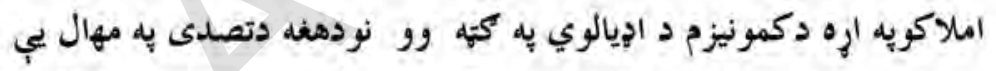

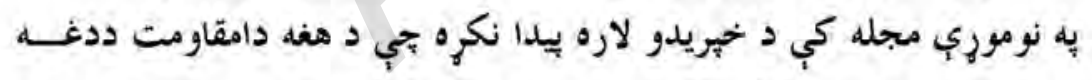

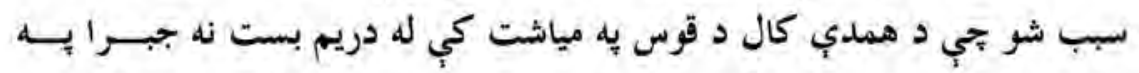

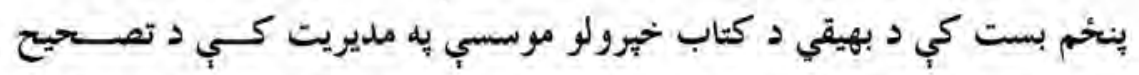

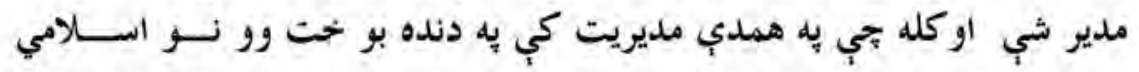

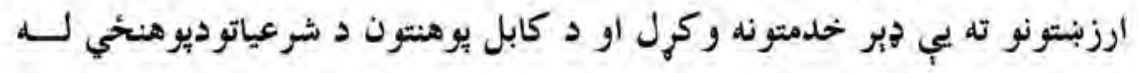

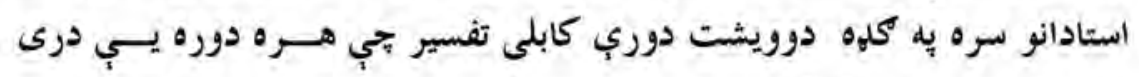
جلده وه ، جاب كرل او يه همدي وخت كي يب نورومجلو او ور خيانو ته هم يه ليكنو ييل وكراو سربيره يردي يب دوه مـستيقل كتابونه (داسلام رول يه تولنه 
$1, \ldots$

د وردكو مشاهير دوهم لوكى

كي) او بل (قرآن او نوين ير مختكونه ) ترعنوان لاندي بحي به ورو ستب كتاب يب د (و اعدولهم ما استطعتم من قرة ومن رباط الخيل ترهبون ) ترعنوان لاندي

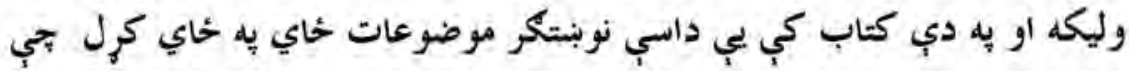
داسلام حربى اوتخنيكى ابديت يكي را نغنبتي وو اوهمدارنكه د روزي يه نوم يوه بله رنساله له عربي زبي نه را وزبا رله او د مينه والو يه واكى كي يي وركره

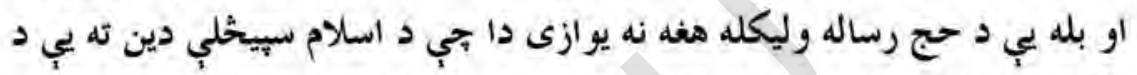
ليكنو له لاري خدمات ترسره كرل بلكي يه هر وخت كي يب د كمونيزم به ضد د حوانانو داذهانو د تنوير ، روبنانولو اوجورولو ته خحاصه باملرنه كري ده . .

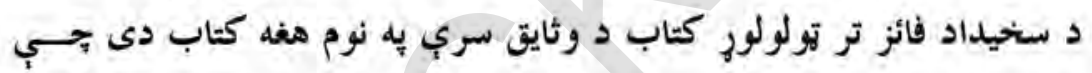
ينخه زره جلده بحاب شوي وو د ماسونيانود رسوا كولو او افشا كولو لياره را تول او منسجم كري دى دي.

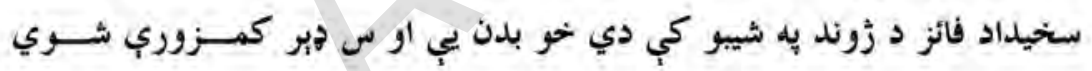




\section{سيد عبدالفني خان - فرقه مشر}

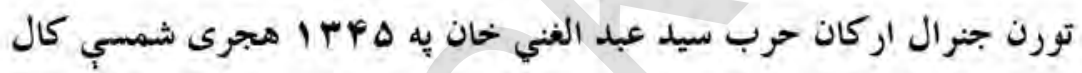
د جنر الى رتبي ته تو فيع وكره بي به دي تو كه هغه د افغانستان د معاصر اردور

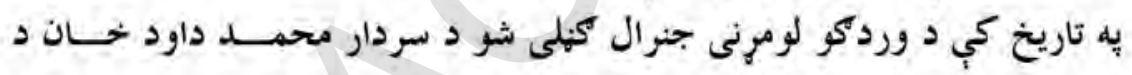

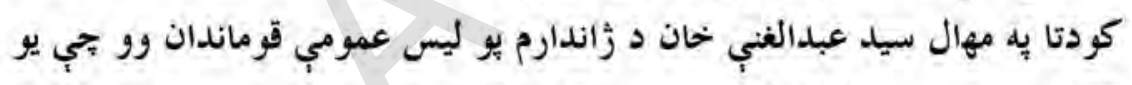

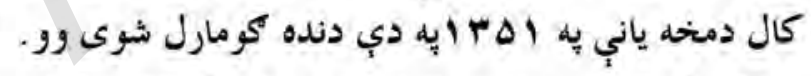

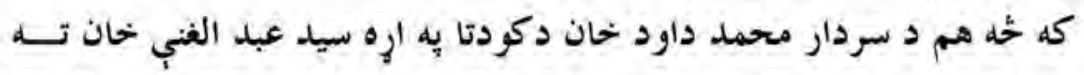
بشير معلومات وه او ددندي يه مقتضا يب محمد ظلاهرشا ه ته د كيدونكي كودتا

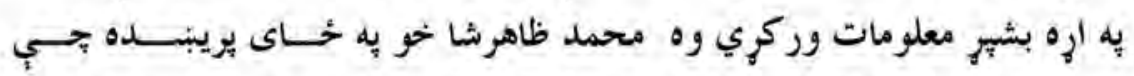

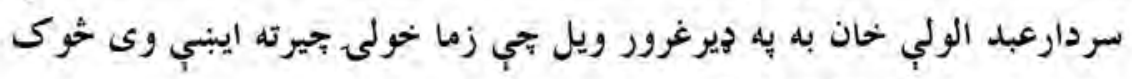
توان نلري عي كودتا د وركري .

سردار محمد داود خحان ته دكودتا يه إره د جنرال سيد عبد الغني خان لـه نيت نه بشهير معلومات حاصل ور نوخكه كله بتي كودتا بريالى شوه نـــوجنرا ل 
$1 . r$

د وردكر مشاهير دوهم ترك

سيد عيد الغني خحان يبي له خيل ورور سيد محمد نعيم سره لومري ددهمزنخ يه بنديخانه كي بندي او وروسته يب دواره شهيدان كرل .

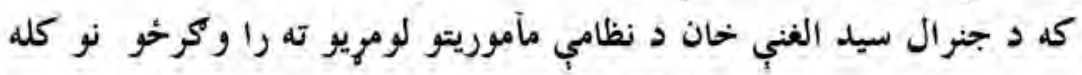

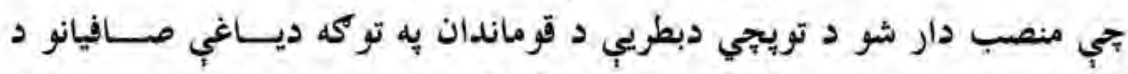

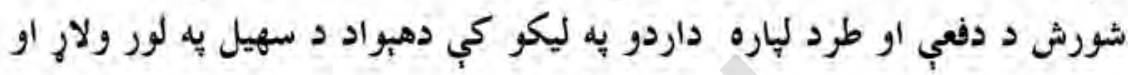

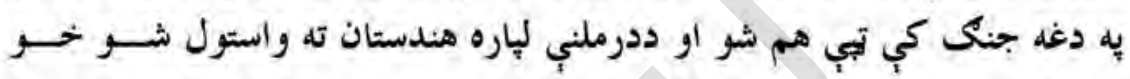

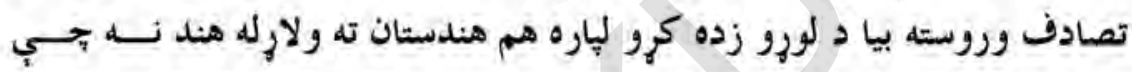

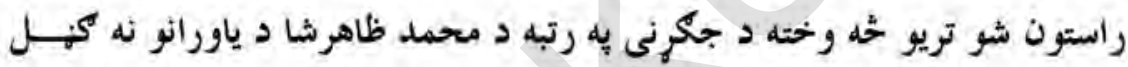

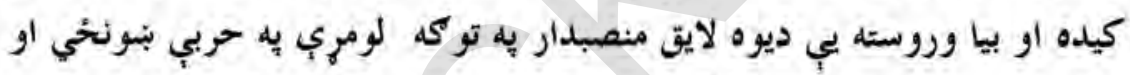
بيا به حوبي يو هنتون كي د انكليسي او نظامى احولو تدريس كاوه .

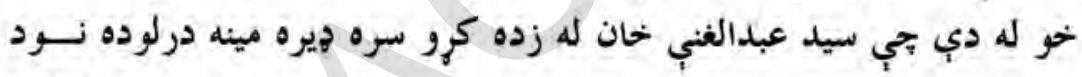

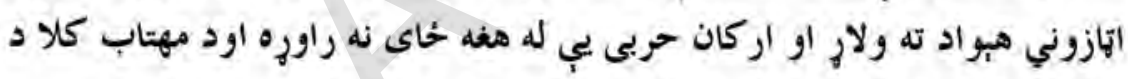

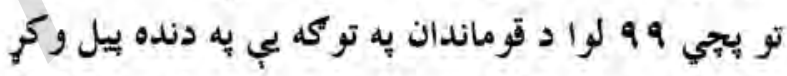
وروسته بيا به نثكرهار ولايت كي د يو لسمي فرقي قو ماندان شو .

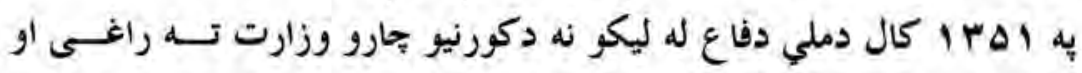

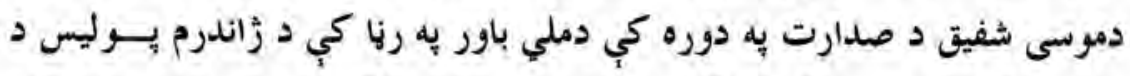

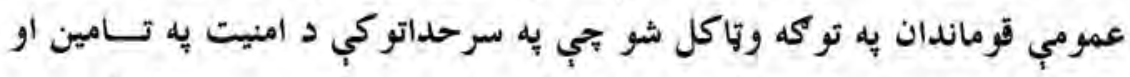

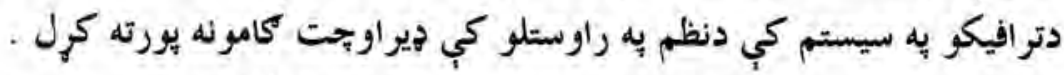

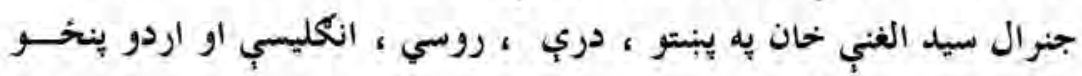
زيو يوره يوهيده او ليك او لوست يب ورباندي كاوه . 
$1 \cdot r$

د وردكو مشاهير دوهم تيرك

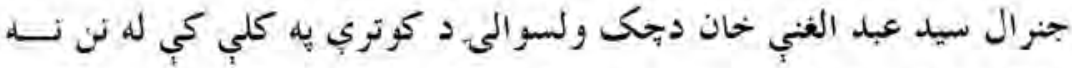

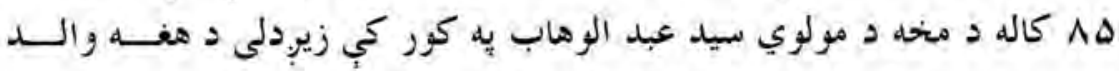

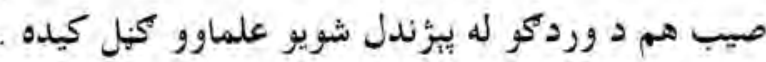

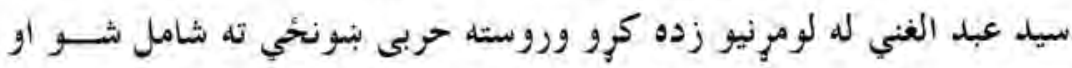
وروسته حربى يو هنتون ته ولارجاو يه لوميرى درجه بريالى او د اففغانستان د اردو

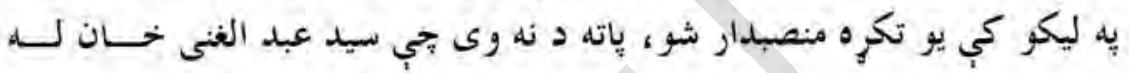
حوبي بنونتحي بيا توحربي يوهنتون بوري يه دوارو خايو كي اول نمره ور . جنرال سيد عبد الغني خحان يو زره سو ائدى ، هيو اد يالونكي او بشتير مسلمان شخصيت وو او ينخه وخته لمونج به بي يه جماعت ادا كاوه د خلقيانو له كودتا وروسته د كودتا كونكو يه تور بجي يه دِله كي بي هاشم خان آتشه ، دهفه ورورد سيد محمد نعيم ، د اكادمي يوليس قو ماندان نور محمد مسجدي او خوكرو ألـل ملا سيد موجود وه ، ونيول شول او شهيدان شول . دتورن جنرال اركان حرب سيد عبد الغني خحان ية كورنى كي بي شميره لوزر رتبه مامورين بتي شميره يب لسكونو ته رسيربي موجود وره م. 


\section{سميع جان شير زاده - سناتور}

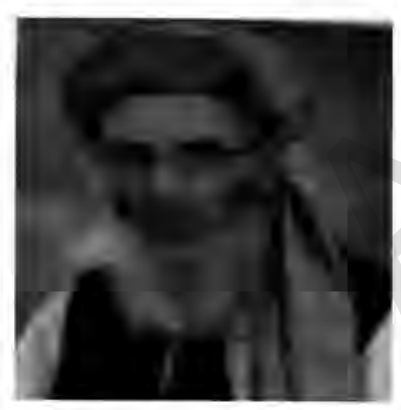

$$
\begin{aligned}
& \text { سمع جان شيرزاده د ملي شورا يـهـ ها دوره }
\end{aligned}
$$

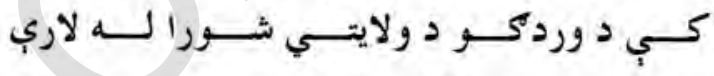

$$
\begin{aligned}
& \text { دوردكوسناتور وتاكل شو، خوديوه داسي ويبن او }
\end{aligned}
$$

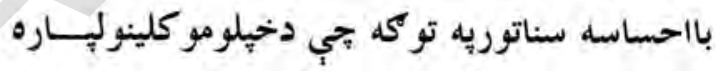

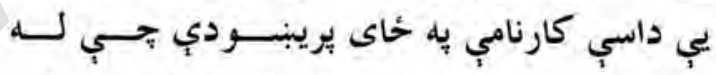

$$
\begin{aligned}
& \text { وروستيو او ورومبيو تولوسناتورانواودولسي جركي }
\end{aligned}
$$

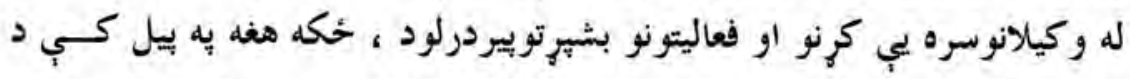
خهلو مو كلينود ستونزود حل لياره يه خوشحال مينه كي داسي دفتريوانيست تي دسناتورسمع جان شير زاده يه نا مه نه ، بلكي له هماغه يبل نه دوردكو د كور،

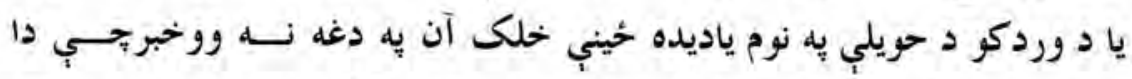
حويلى د جا ده ؟ خو د يوه خداى وركري نعمت يه توكه به يب دلته درى وخته هو هى نوش جان كوله او خينو خو لا دا هم انكيرله بجي سمع جان شير زاده هم 


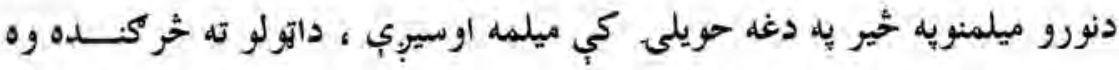

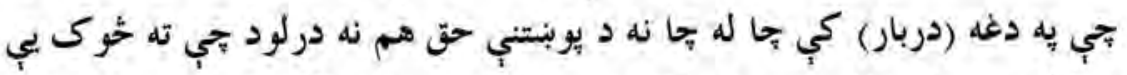

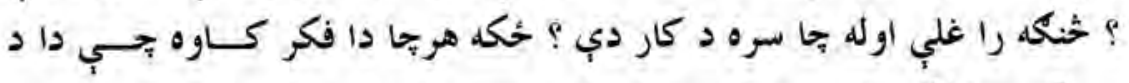

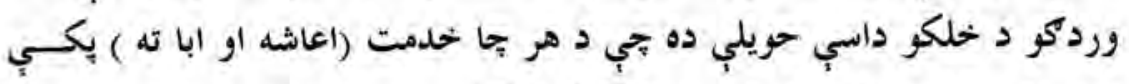

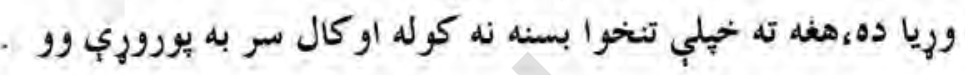

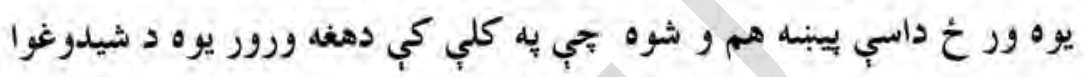

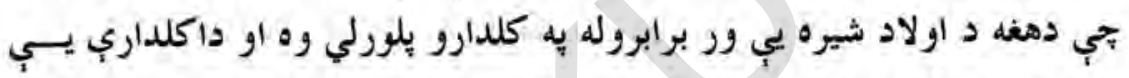

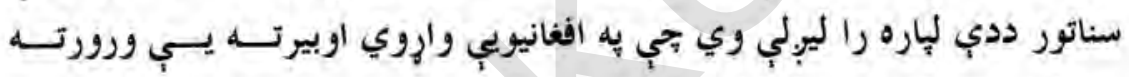

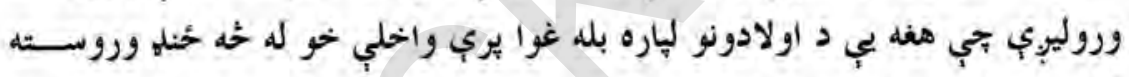

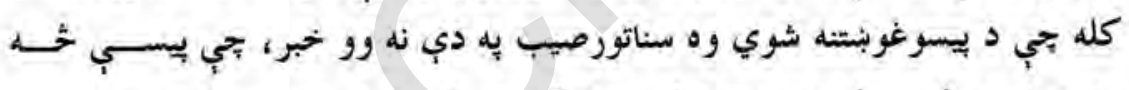

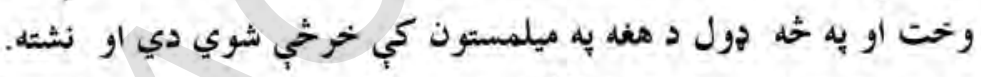

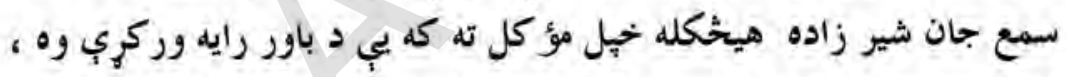

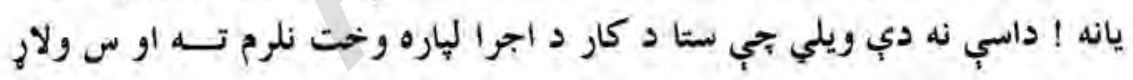
شه ، سبا راشه.

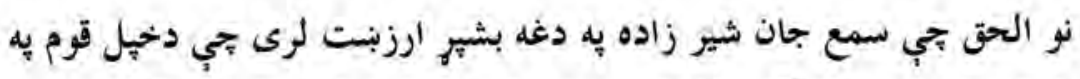

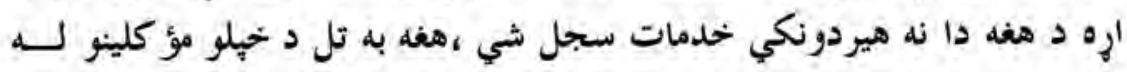

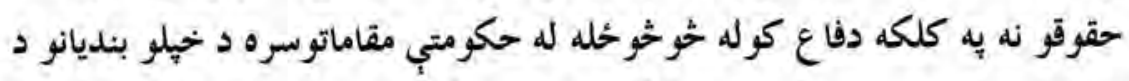

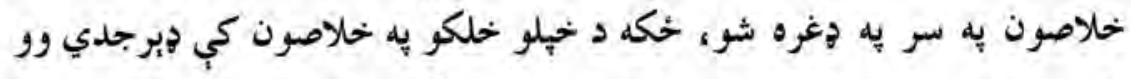

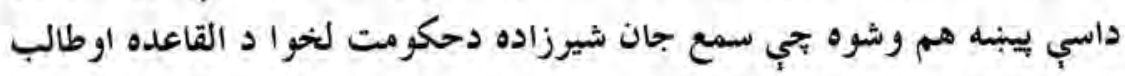

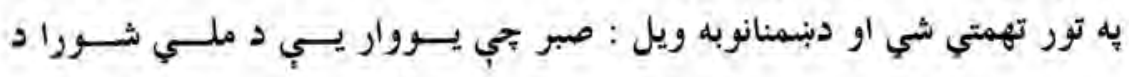


مصنونيت دوره ختمه شي او د سناتوري امثياز تري واخيستل شــي نوبيــا بــــ حكومت ورنسره كورى ، زر به محكمه كيري د حكومت خودا تول هرخه ورته يه زيره دي؟؟

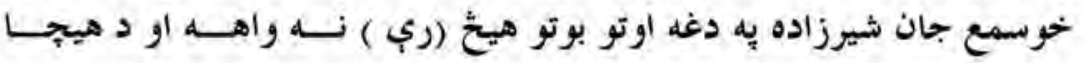
مجبوريت ته يب يه سياسي كر كه نه كتل .

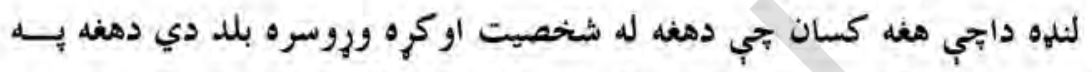

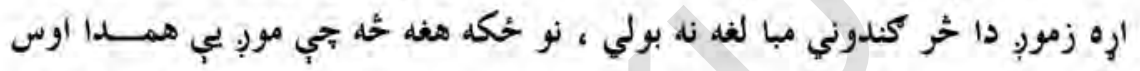

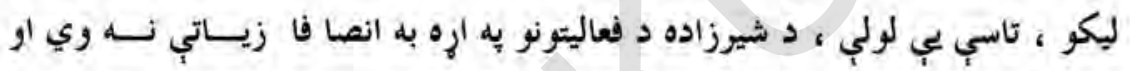

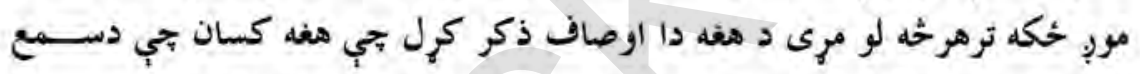

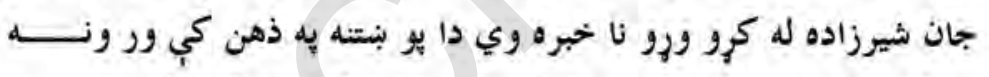

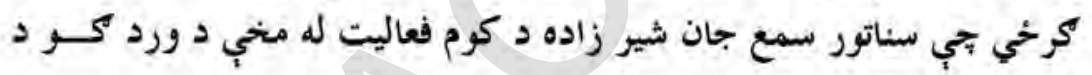

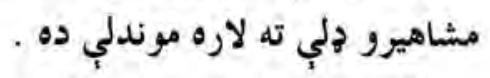
لكه د مخهه بحي وويل شول د وردكو د يخو انيو ملي شورا كانو يـــه ددوارو

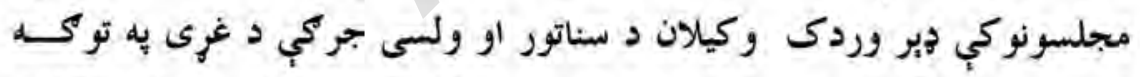
دندي تر سره كري خر يوه يب هم د سمع جان شيرزاده يه خيرد خهيلو مؤ كلينو به خدمت كي داسي سترياوي نه دي تيري كري بجي د سمع جان شير زاده يه

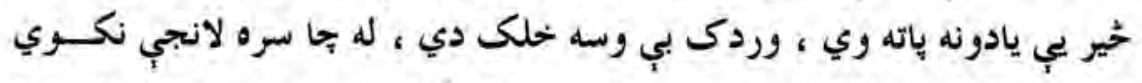

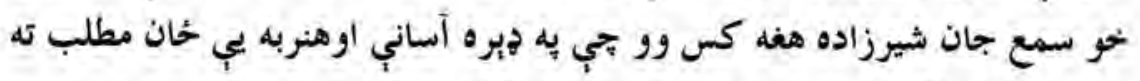
رساوه د وردكو حق به يب د زورورو له خولي را وكيبي. 


\section{$1 \cdot \mathrm{V}$}

د وردكو مشاهير دوهم توكى

د هغه يه خو مجلسونو كي زه ناست وم تجي خلك به راغلل او داسب ستونزه

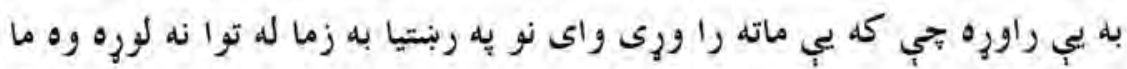

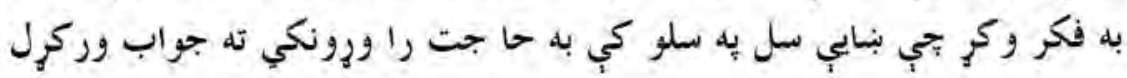

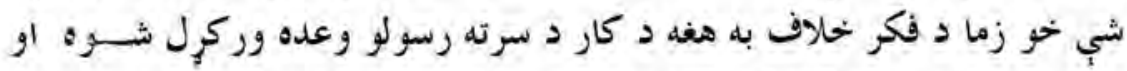

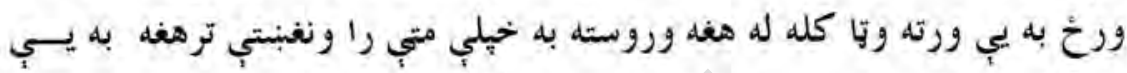
جي كا ر سرته نه وو رسولي تري لاس به سركيده به نه .

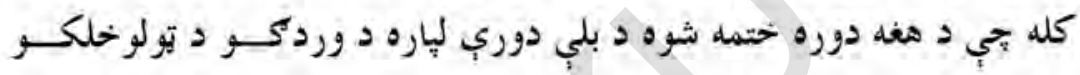

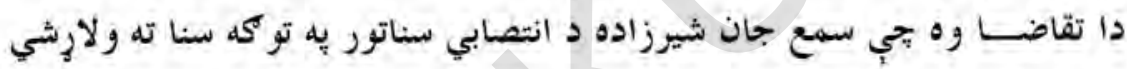
يه دغه إره هغه ته د وروكو د تورو مشر انو لخوا تائيد ليكونه هم جورشول خو د

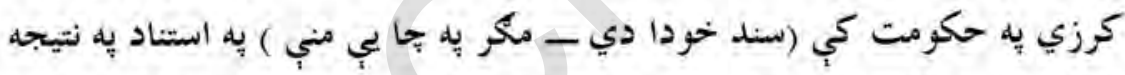
كي كرزي د ملت يالني اود قومونو تر منح د انلهول ساتني د تولو اصولو موازينو يّه بنكاره خالاف له يوه ولايت نه بخي دري سناتوران بي حق وو (دوه انتخابي يو

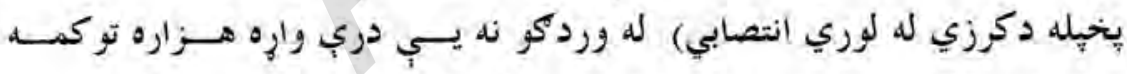

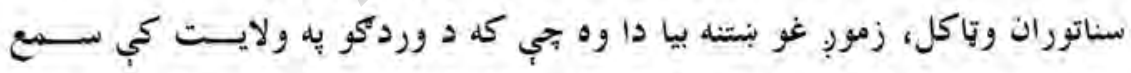

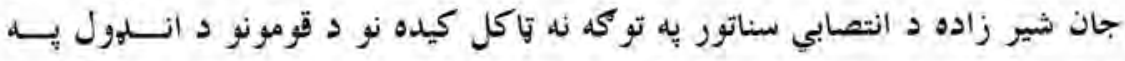

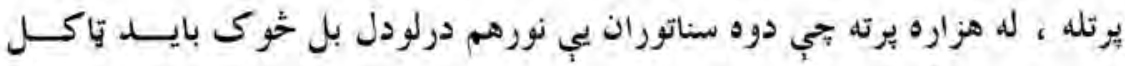
ثوي واى خيكه د ورودكو ولايت خوله وردكويرته د خيرونورو قومونو كــورهم دي دا يب د تاريخ به يانهله كي ستا يوه ملي تيزوتهه ملي ............ سناتور سميع جان شير زاده د ملك شير دل خان زوى او د ملك يسـردل

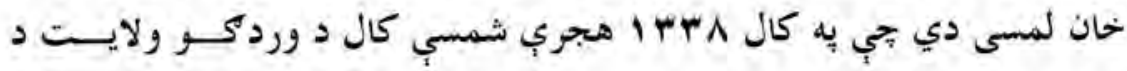


$1 \cdot 1$

د وردكو مشاهير دوهم توكى

جكى ولسوالى د كرددن مسجد ددري د مغل كوت (مهمدو ) يه كلي كي زيودلي

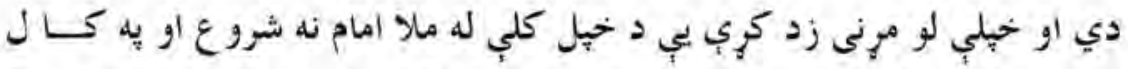

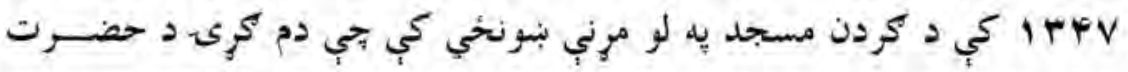

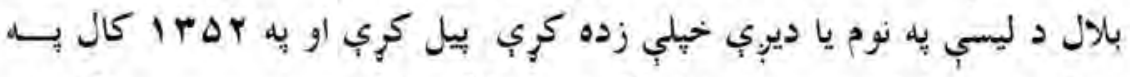

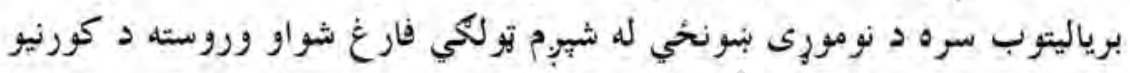

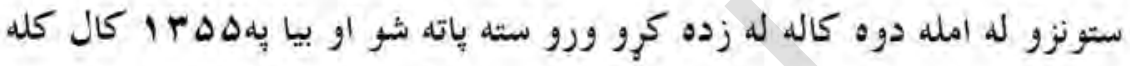

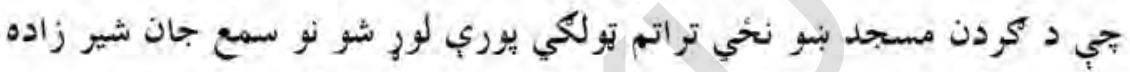

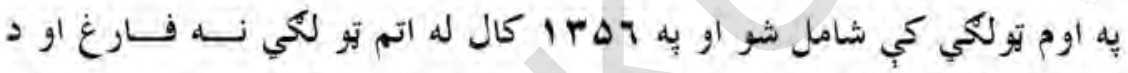

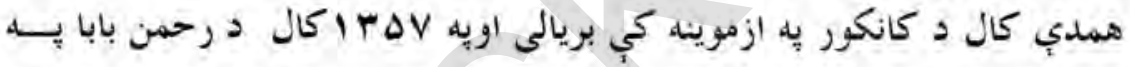

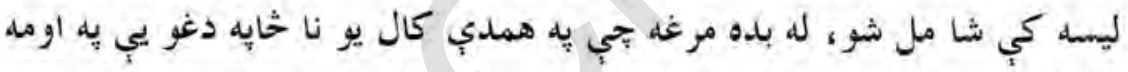

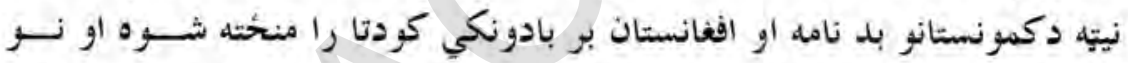

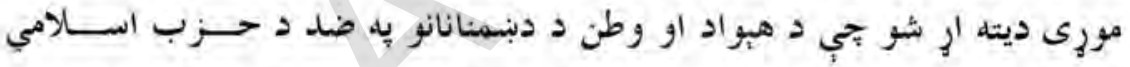

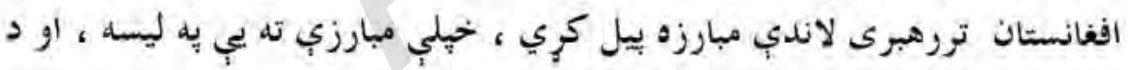

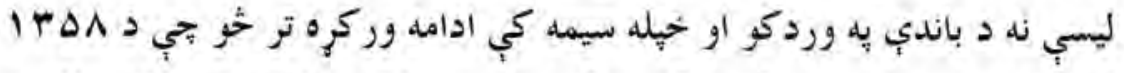

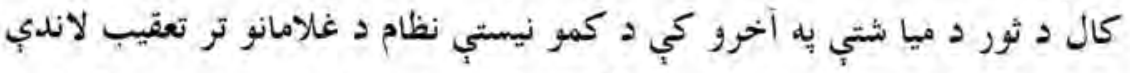

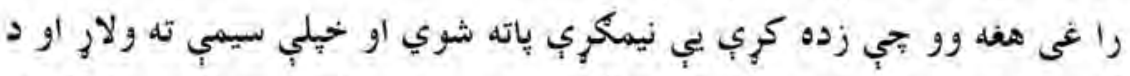

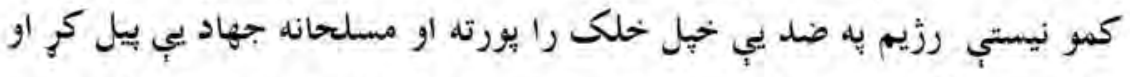

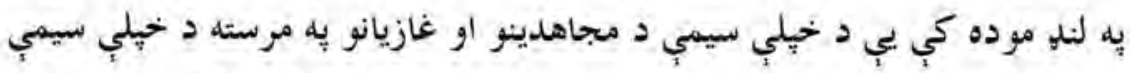

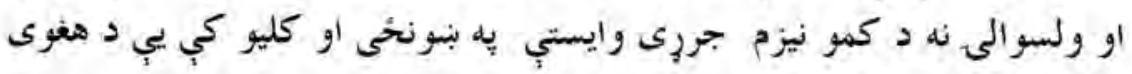

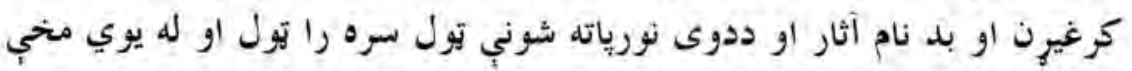




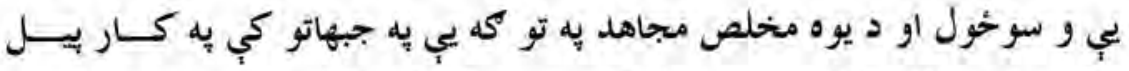

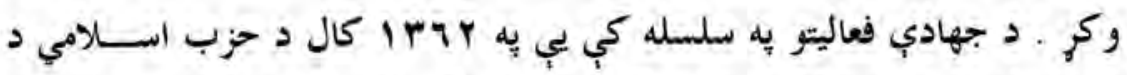

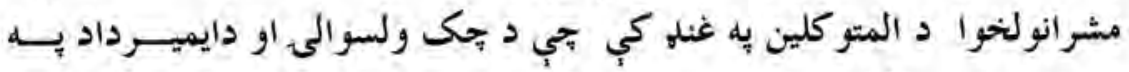

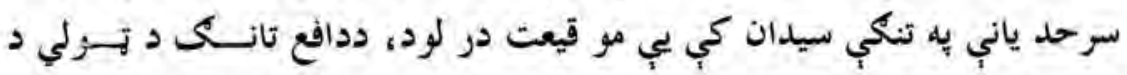

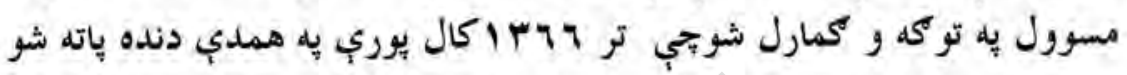

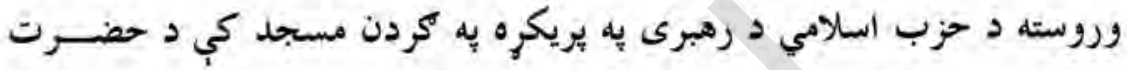

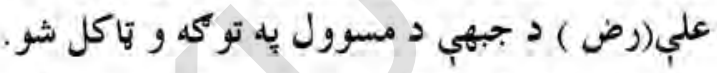

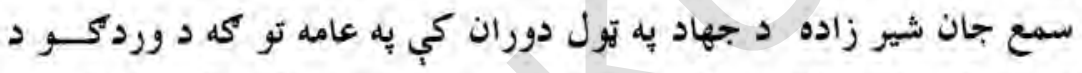

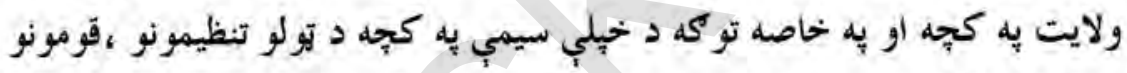

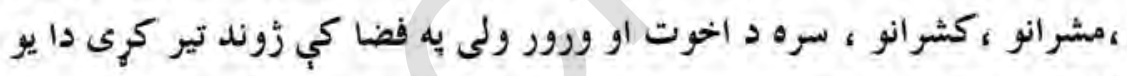

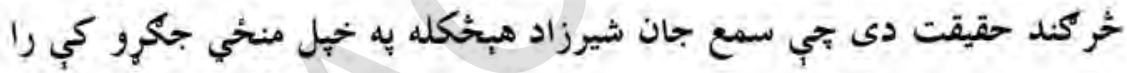

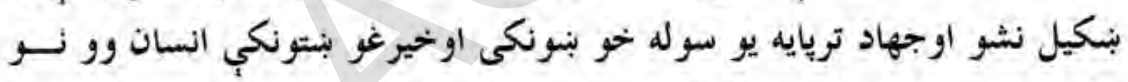

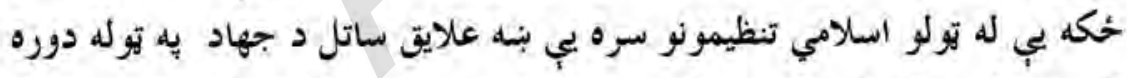

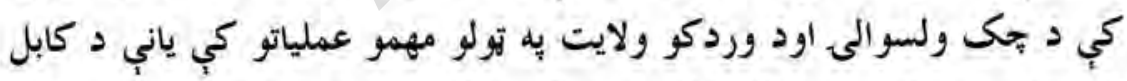

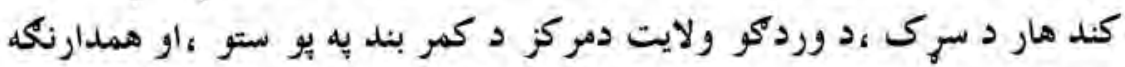

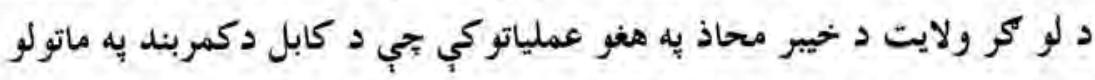

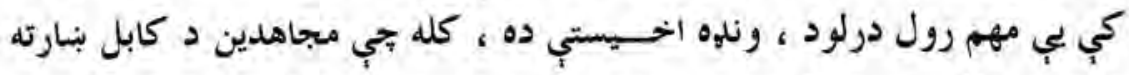

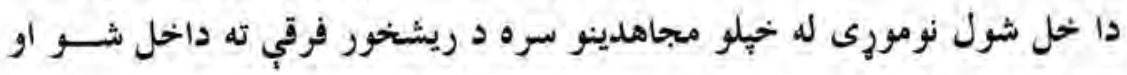

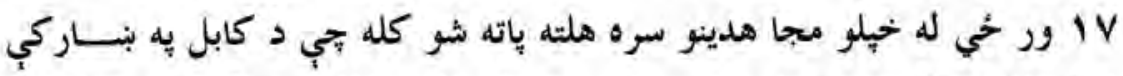

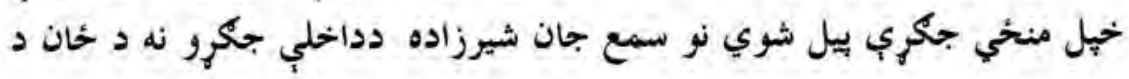




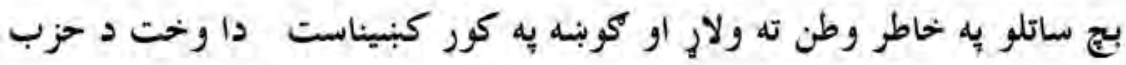

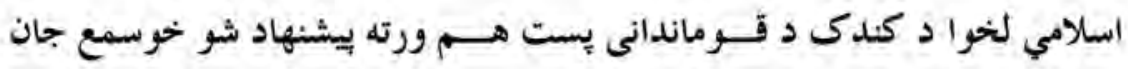

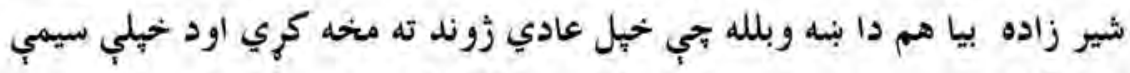

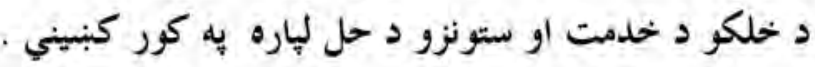

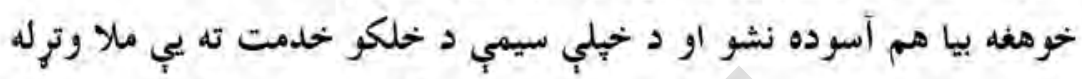

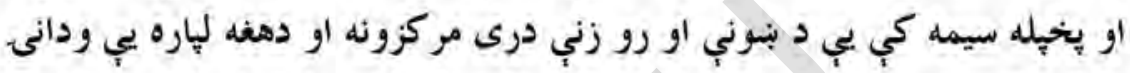

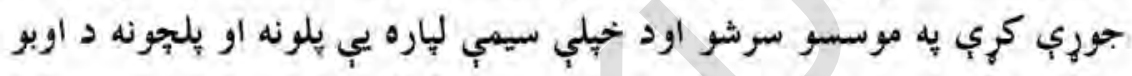

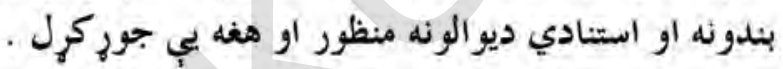

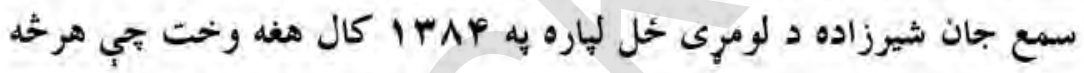

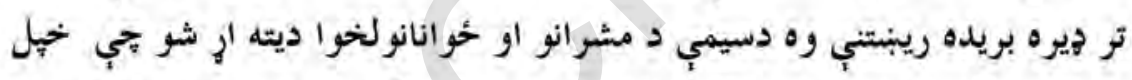

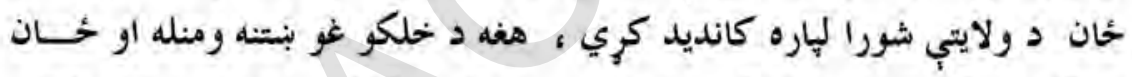

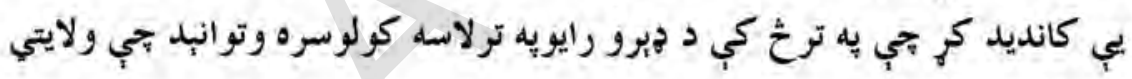
شورا ته بريالى شي .

د شور اككانو له اصولو سره سم د ورديكو د ولايتي شورا لومرنى خيل منحي

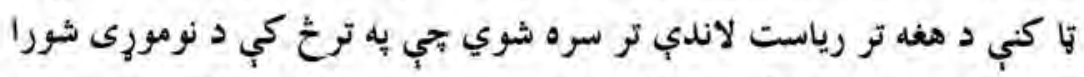

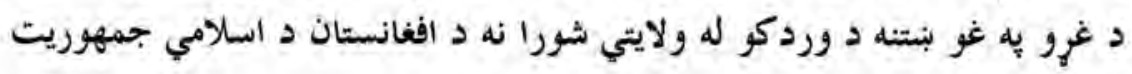

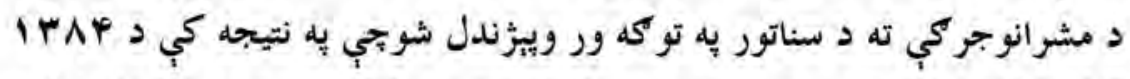

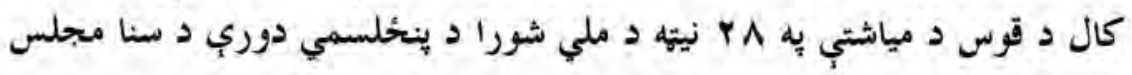

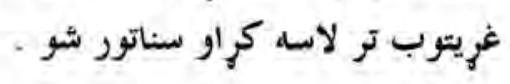




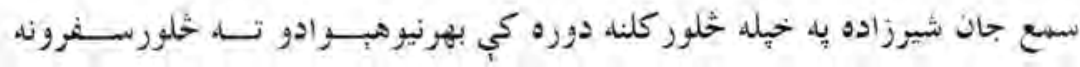

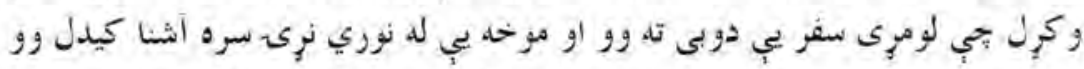

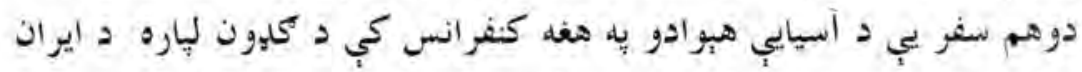

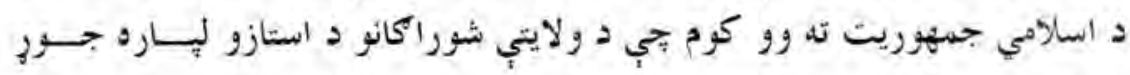
شوى ورن

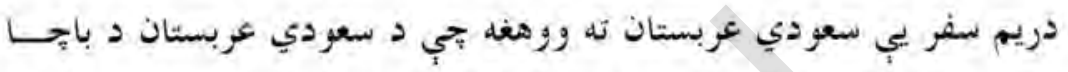

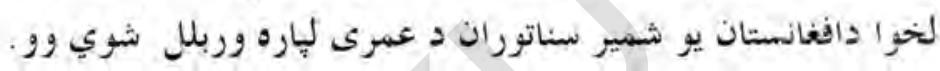

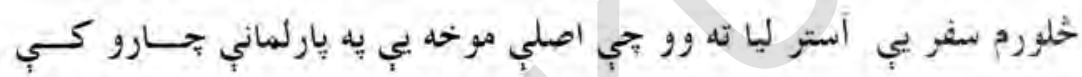

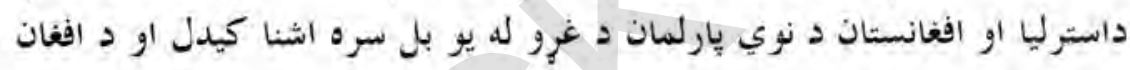

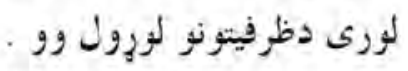

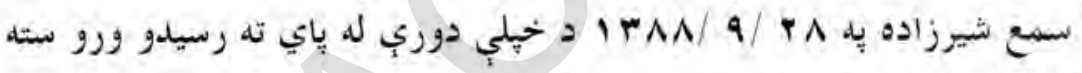

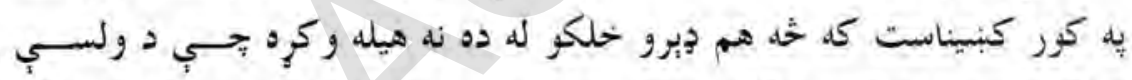

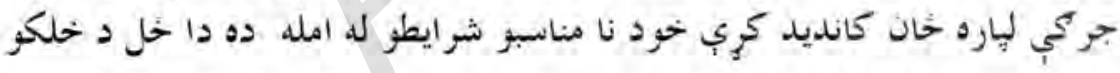

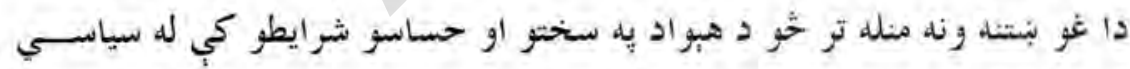
مسوروليت يرته زوند ولرى . 


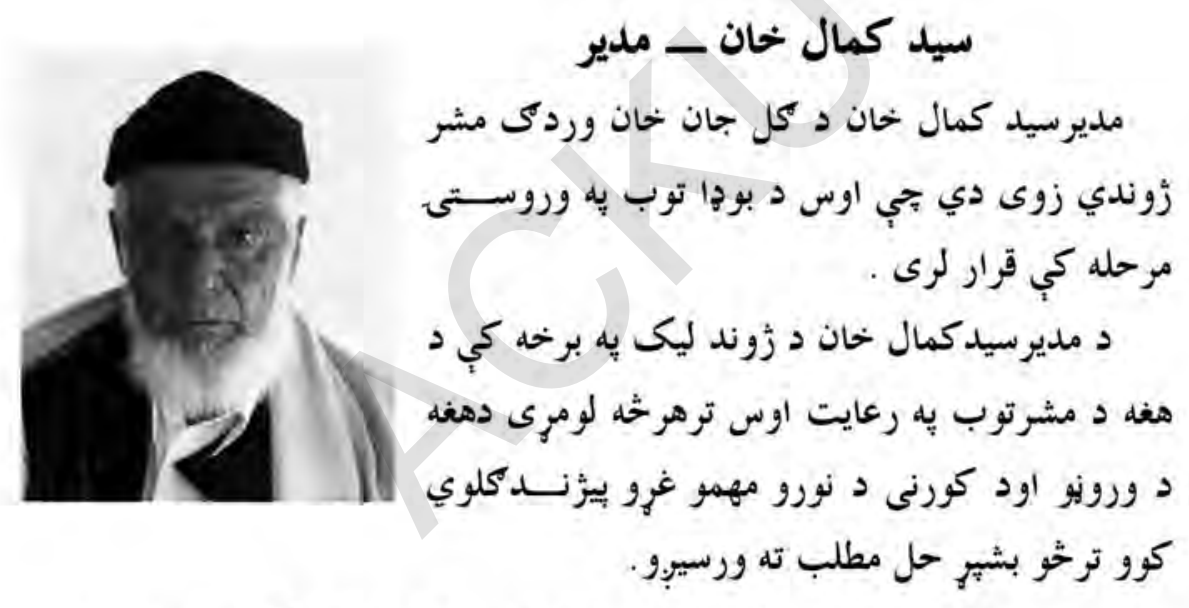

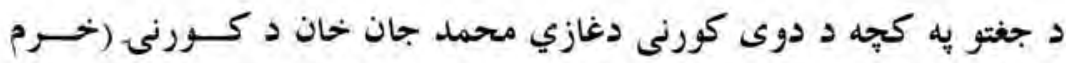

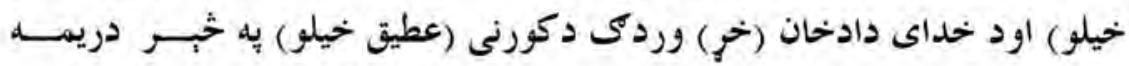

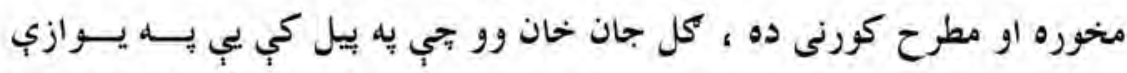

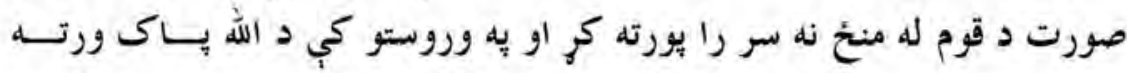
خوبنه شوه، نه يوازي داجي قوم ته، بلكي يو خل يب د يوي كودتايي توطيب بِ يه 


\section{$11 \%$}

مخنيوي، دفع او طرد كي د ملك برخليك ته ملي نجات هم وركرى او تل باتي تاريخي اونوميالى نوم يب پِه حُاى ير ايبنى دي. كل جان خان له يوازيتوب نه ووت ، اولادونه يبي وينخيدل ، كله حثلـــورو

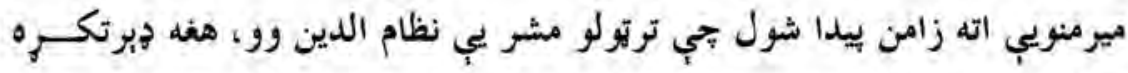
تورخن او نوميالى سرى تيرشوى، دوهم يب جمال خان نومبده ، نظام الدين او

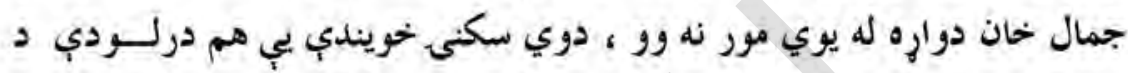
دوى مور د كالاندي وه.

ملير سيد كمال خحان ، حاجي سيد الرحمن خان ، حاجي سيد حســن خــان ، حاجي سيد عمر خان ، او سيد انور خان جي (به حو انب كي زوند له لاسه وركز) له بلي مور نه وو، د دوى مورهم د كلاندي وه او يوه سكنى خور يبي درلوده. سردارخحان بيا له بلي مورنه وه، نوموريى يه حو انه حو انى دو كمونستانو لخوا ونيول شو او تو نن يوري بيا جا ونه ليده. دوي خويندي يب له بلي مورنه وي تجي يوه زوندى او بله يب مره ده، د دوى مور د زابل ولايت د مركز (كاتلات) وه.

هبواد ته د كل جان خحان د خحمتونو يه بدل كي د و اكمثو نظامونو له خوا هيواد يه ببلابلو سيمو كي حمكي وركرل شوي بحي دغه خمكي يجي اوس تولي داولادونو يه لاس كي دي .

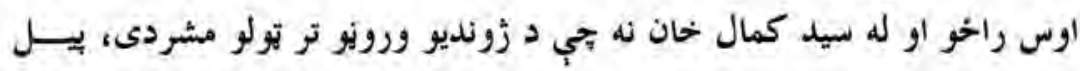
كوو! كه خحه هم سيد كمال خان دلثه د مدير به عنوان سجل شوى خو فعاليتونه او

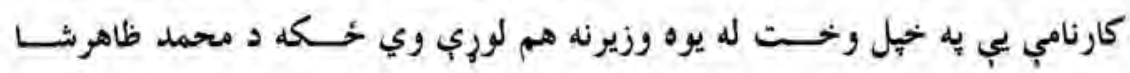




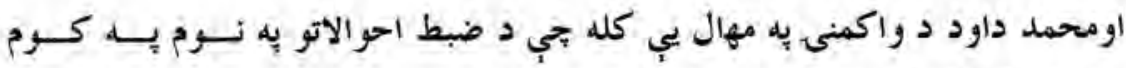

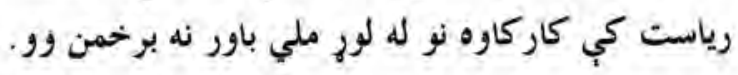
د هغه د ماموريت يه دوران كي ضبط احوالات دكمونستانو د زماني يه شان يو خونرى، حُوروونكي او وزونكي اداره نه ! بلكي يوه خدمتكاره، خواخورجي

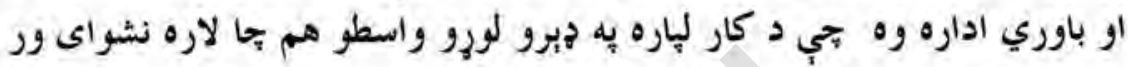

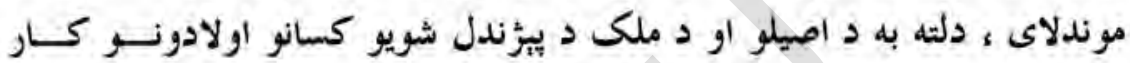

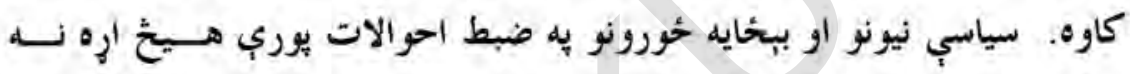
دولو

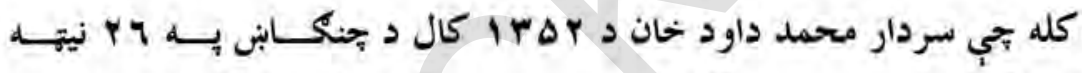

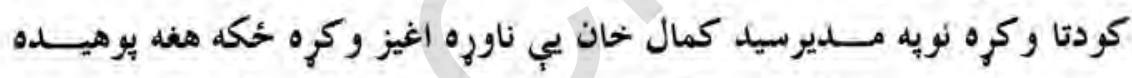
جي افغانستان د منتلفو قومونوكلمكوردي اوكودتا د جوارو غله شوه جي هـ هـر سياسي بلد ماش ته وروبنسول شوه.

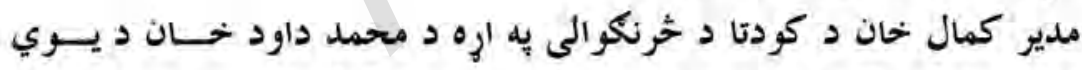
يوبنتي يه خواب كي وويل: خيل مبت او بازودغوخ كرل ، سردار صـيب ؛ افغانستان خلك تر اوسه سياسي بلوغ ته نه دي رسبدلي تجي دجمهوري نظــام اصول ويبرُني اوهغه رعايت كرى ، زه بيريجِج بجي زموبر ولس د شاهي كورنى د

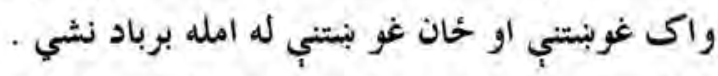

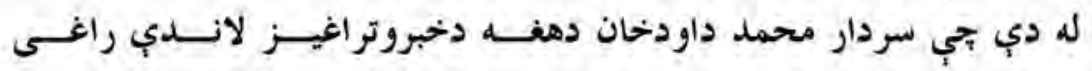
نوسمدلاسه يب ورته وويل : زه تا د ضبط احوالاتو رييس مقرووم نورخه وايي؟ 


\section{0}

دو وركو مشاهير دوهم تركى

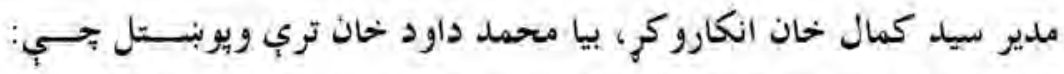
اخو كى لازم كني بتي د ضبط احو الات رييس وتّاكل شى مدير سيد كمال خان

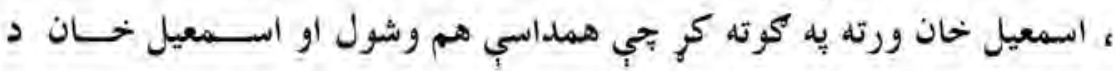
ضبط احورالاتو رييس شوه. خو جالبه دا وه بجي له يو خهة وخحت وروستله سيد كمال خحان يرته له دي بجي يَه حُان خبر وي، د محمد ظاهرشاه يه يلوى د همدغه اداري ترتعقيب لانـــدي راغى او سيل كمال خحان داسي وخت خبر شو بي ستونزه حل شوي وه. كله وحي د غويبي فاجعه را منحتيه شوه نو سيد كمال خحان د كارمل تو وخت يوري د خوارلسو مياشتو لباره بندي شو او كله بجي را خوشى شو نونيغ د خيل

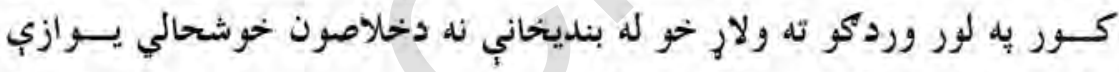
تركوره ورسره ملكري وه كله بجي كورته وربيد نو د خيل ورور سردارجان له نيول كيدو نه خبرشو، له يوي اونى وروسته بيرته كابل ته را غى او داكترنجيــبـ الله، جي دا وخت د خاد د دوزخي شبكي ريس وو، مديرسيد كمال خان ته وويل:

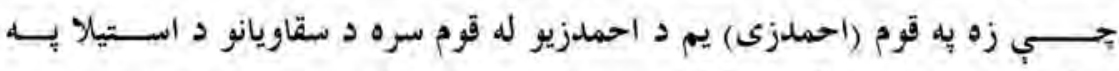

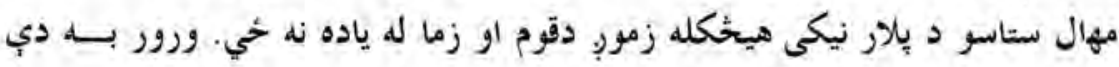
ييدا شي، زه به يب درته را خوشى كرم ، ته يوه عويضه وليكه ! كله بجي مـلدير كمال خحان عريضه وليكله د دي به خاى بحي سردارجان بيلدا شي، يخهيله مدير سيد

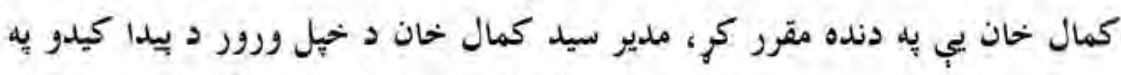

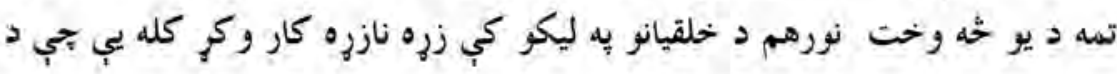




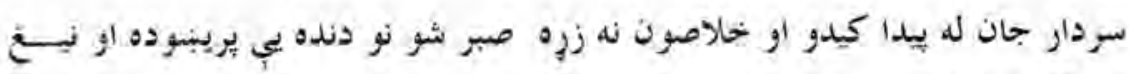
وردكتو ته ولاهز.

ـ الحاج سيدالرحمن خحان دوهم وروردي كله بحي مدير سيد كمال خان به دولت كي دنده درلوده نو حاجي سيد الرحمن خان او الحاج سيد حسبن خــان

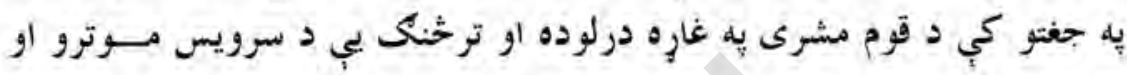
كرنيزوحمكو اداره هم ٍيه غاره درلوده دوى 12 ورخت ينخه شيرب عرادي سرويس موتو درلودل جي ددوى سرويس د كردن مسجد اوجغتو د خحلكو لياره يو الهبي نعت وو سهار به غزني ته تلل او بيكا به بيرته جغتو او بكى ولسوالى ته راتلل ددي تو خئك به يب د سيمه ايزوخلكو خيل منحخي لانجي هم فيصلة كولي

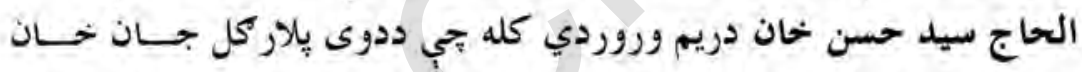
وفات شو نو د وردكو مشر انولخوا د قوم د مشرى يكري 2 هغله يه سركينبودل

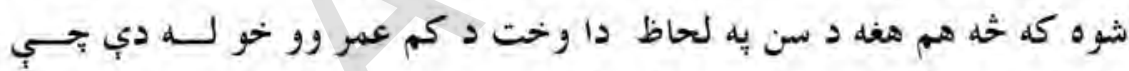

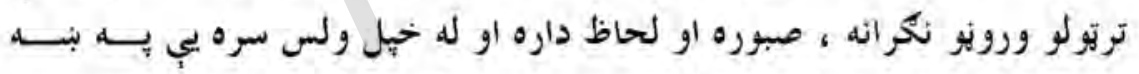
نلوكى راشه درشه درلوده نو يككرى دهغه يه سر كيبنودل شوه

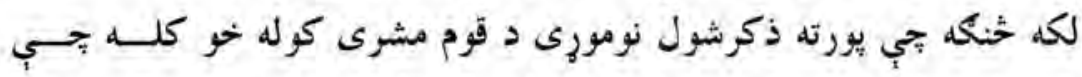

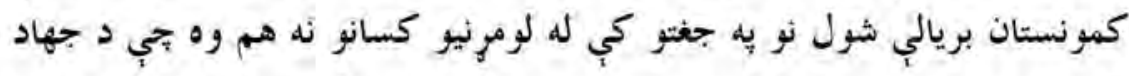

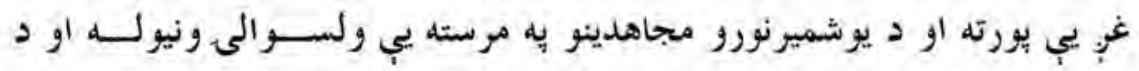

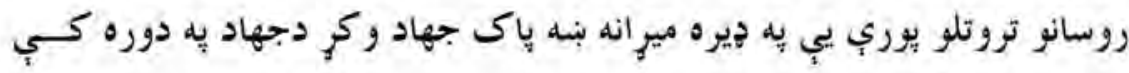

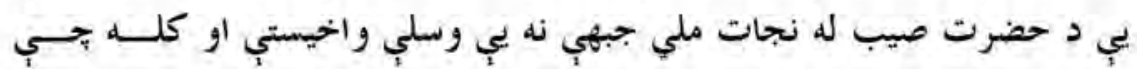
روسان ووتل نو بيايبي د وسلو له استعمال سره د زره له كومي مخه بنه وركره . 


\section{$11 \mathrm{~V}$}

دودكو مشاهير دوهم توكى

حاجي سيل عمرخحان خلورم وروردى هغه له جهاد نه دمخه د سردار محمد

داودخان د و واكمنى يه مهال د يوهني يه وزارت كي د قلم مخصوص مدير وو

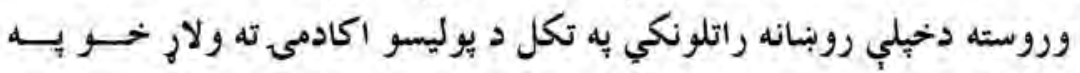
دوهم تولكي كي وو بحي د كمونستانو د مظالمو له امله يب له دي اكادمي سره د جهاد يه تكل مخه بنه وكره او د جهاد لياره د مجاهدينو ليكو ته ولار . د جهاد يه لوميو كي حاجي سيد حسن خان به بيبنور كي د حضرت صيب د ملي نجات له جبهي نه سلاح اخيستي وه خو كله بحي سيد عمر خان يبنبســور ته ولار نو دوردكواو ميدان دملي نجات د جبهي دمجاهدينو يه آرا اكثريت سره له

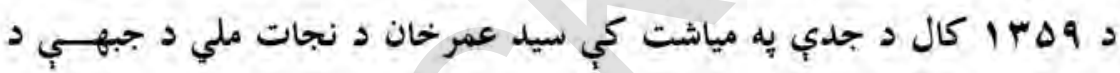
وردكو ولايتي اميرو تاكل شو هي هيه دي توكه يب سترى جهادي مسؤليت تـه

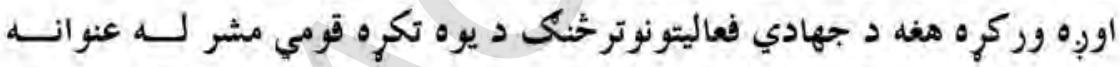

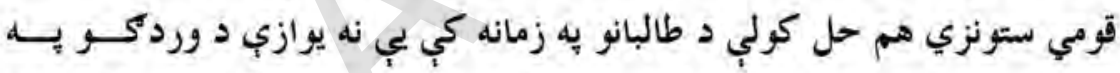
كجهه خيل منحي شخري حل كولي ، بلكي د غزني او نورو كاونلهيو ولايــاتود شخرو يه حل كي يب هم برخه اخيستله حاجي سيد عمرخان د شخرو بِ اوارولو كي خاص فطرى مهارت درلود حتى يه حيئو مواردو كي د قندهار او اوروز كان

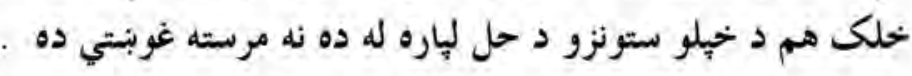
د كرزي د واكمني يه مهال كله بحي رسول امين د يوهني وزيو وو نو ســيد

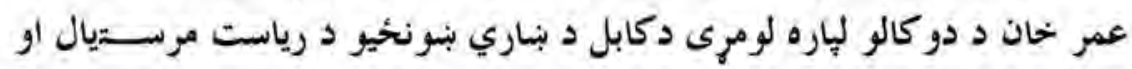

$$
\text { بيا وروبته يب ددو مياشتو لياره سريرست وو . }
$$




\section{1}

د وردكو مشاهير دوهم توكى

كله جي دافغانستان دجمهورريس دتاكلود لومرى دوري لهاره دك ديارتونود توزيع يروسه بيل شونوسيد عمر خان د وردكويه ولايــت كـي د تولتبـاكنو

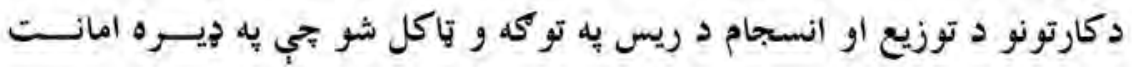
داري يب دا دنده به مخ يوره له هفه يوكال وروسته يب دملي شورا د يشحلسمي

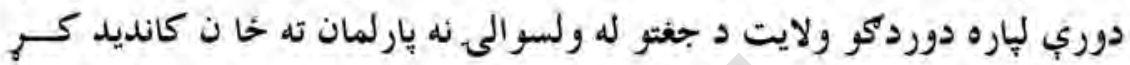
دغه دوري ته د وردكو نه جيرو كسانو حخان كانديد كري وو ، رايسي وويثــل شوي او يرته له يوي بنسخي د وروكي نه هيجا ذيكر ونه كاتجه . حاجي سيد عمر خان دم كرى د وردكو ولايت هيه مركز ميدان بنبــاركي د

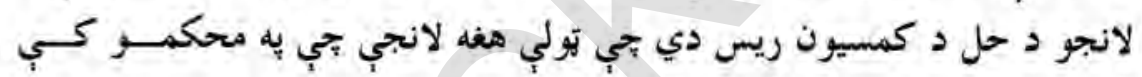

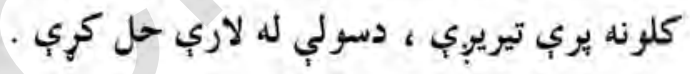
سردارجان ددوى تولو كشرى ورور وو جي جير مبارز او مسلمان شخصيت وو يو لمونح يب نه قضا كاوه د خيل مشر ورور سيد كمال خان تر خنك يجي يه عظمي صدارت كي د مامور يه تو كمه كار كاوه دكمونستانو ستحت دبنسمن وو او د جغتو يه ولموالى كي لومرثي كس وو بتي دو كمونستانو لخوا ونيول شو او بيا جا ونه ليد

سردار محمد خحان داسلامي تحريك دو لومرنيو ميّر انو لكه، ، انجينر حبيب الرحمن او صيف الرحمن نيازي تينك ملكري وو . لكه دمحه بجي وويل شول سردارجان د مور يــوازنى زوى وو جـــي دوي خويندي يي هم درلودي . 
د نادرجان يه نوم د سردارجان يو زوى د زو زنل يه شيبو كي دى بحي د خهلو

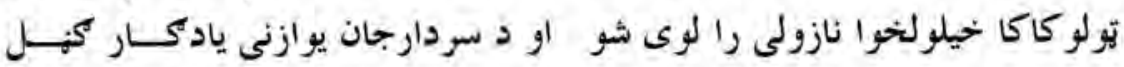

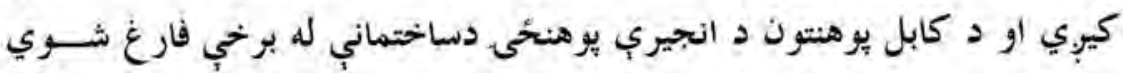
دي اود يوهنتون يه دوران كي د محصلينو استازي هم وو .

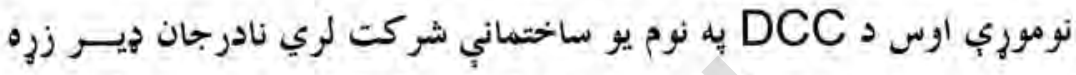
سواندي انسان دي او وردكو ته يب د خهيل توان يه اندازه جير خير رسيدلي دي

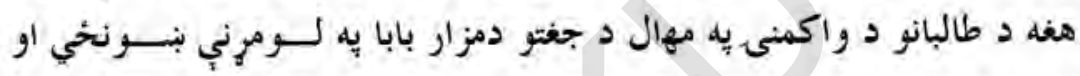
دغازي محمد جان به بنرونحى كي يه وريا جول د رياضياتو تدريس هم كري دي انجينر ميرويس وردكى : ددغــه كورنى بل تن دى بحي د اورجدو كلونو للاره CPAUد (كيو) به نوم د يوي غيردولتي موسي (NGO) لومرى مرستيال او بيا وروسته يب ريس شو.

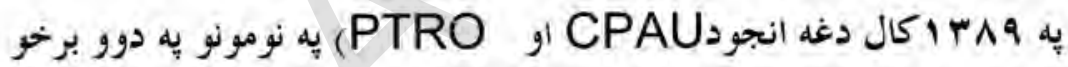
وويشل شوه =حي انجنير ميرويس د (PTRO) دبرخي رييس شو بجي دم كري دا موسسه به كابل برسيره د هيواد يه نورومهمو ولايتونو كي فعالي خانكي لرى انجينر ميرويس وردكى د براخه حو حسلي درلودونكى او قرار سرى دى .

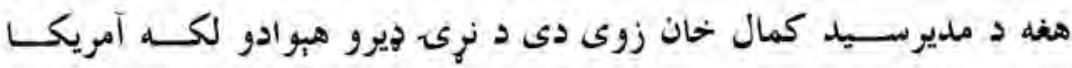

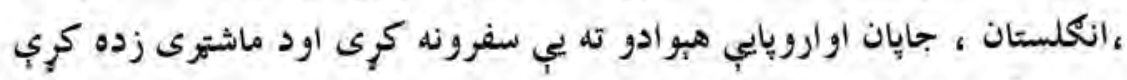
يب به انكليستان كي تر سره كري دي. محمد هارون جان : : دحاجي سيد حسن خان زوى او د كابل والى سلاكار 


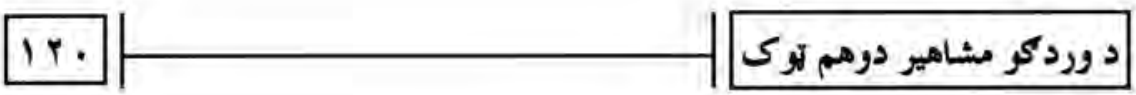

\section{شيرجان -حان- قومى مشر}

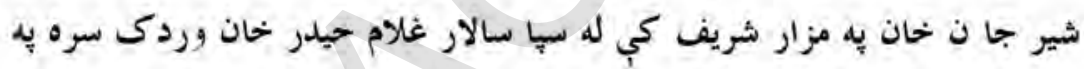

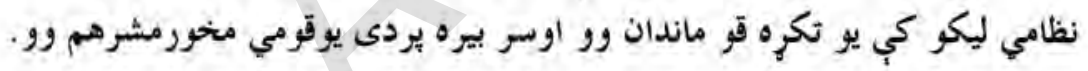

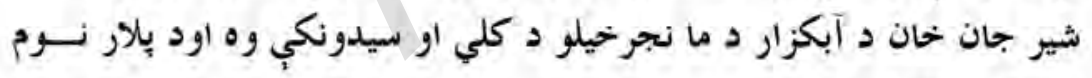

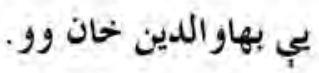

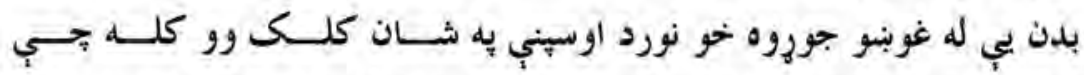

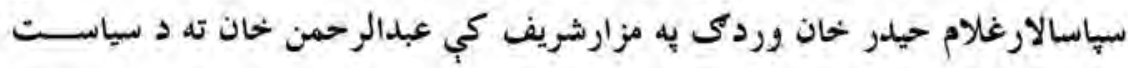

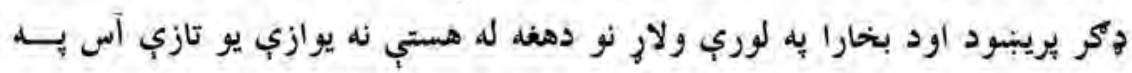

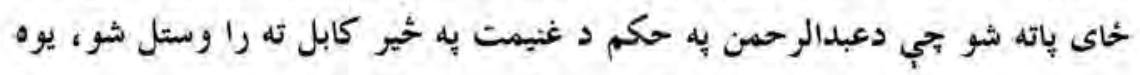

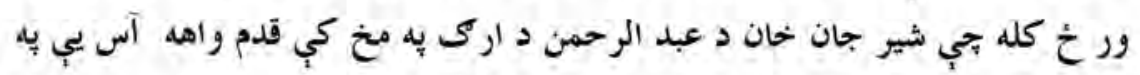

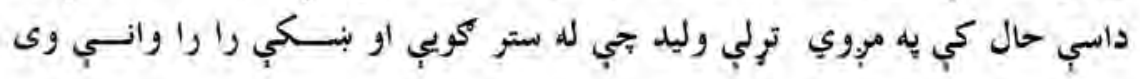




\section{$\mid+1$}

د وردكو مشاهير دوهم توكى

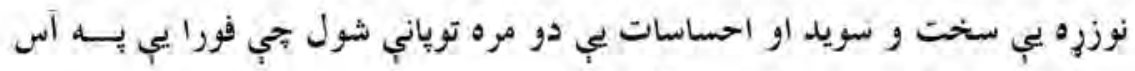

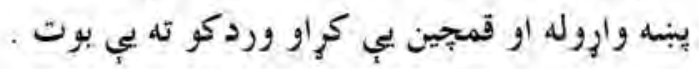

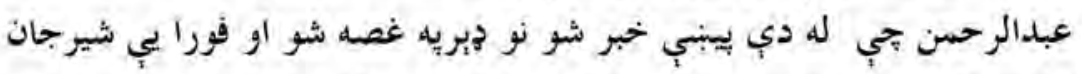

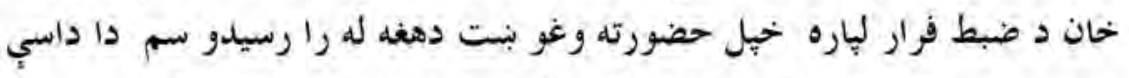
شيبه وه حي د عبد الرحمن دربار له خلكو او نورو درباريانو نه خكى وه عبــــ الرحمن ددي تولو ناستو كسانو به مخ كي شير جان خان ته د (ستا فلانه دمانه يه كلماتو بنكنحل وكرل ) او ورويل جي آس د ولي يه خيل سر بيولب دي ؟

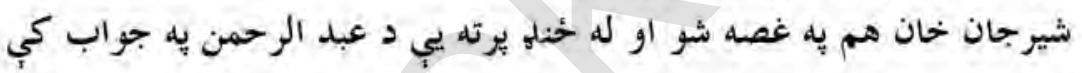

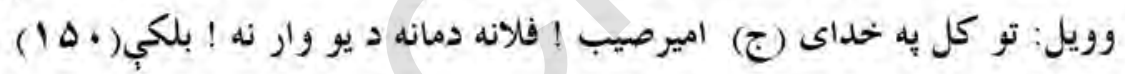
واره د (تربره ميراث د تربره وي) اوس يوه شوي او خواب بوره دروكرخيــــ ! كه نيمكري

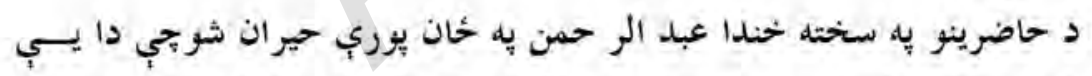
خه ! واوريدل ، له غصبي تور و ايشيد حخكه تر دي دمه هغه د خان يه ورواندي د

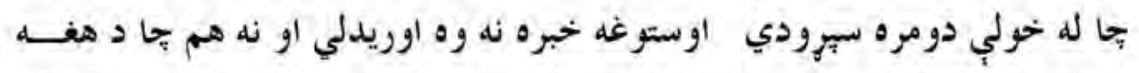
خبره ورغبر كه كري وه ، خو له دي اجي جرم يب يخهيله بيسب كري ورو له يوخده

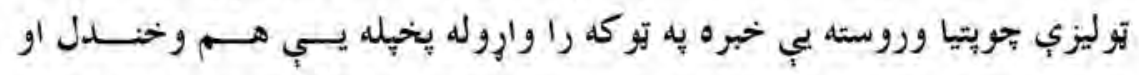
شيرجان خان ته بي وويل : يه داسي نوتربره د افرين ووى لكه ته جي د غلام 


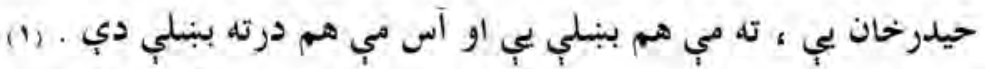

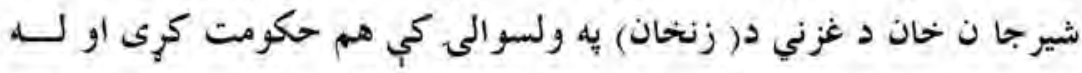
هغه ورونته 2 امير حبيب الله خان به زمانه كي بجي كله د جغتو علاقه دار وه نو دا وخت د سلطان بند ترميم كيده اوده هم ددغه بند يوه برخه قرارداد كرِ جيري غتب تاوان يب يكي وكر او له هغه ورو سته بيا يه ششكاو كي علاقدار شو.

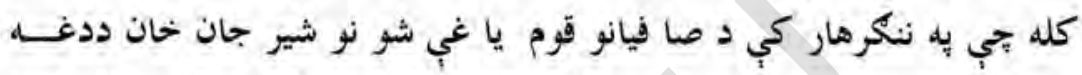

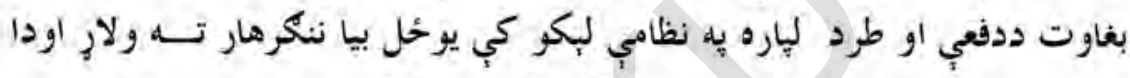

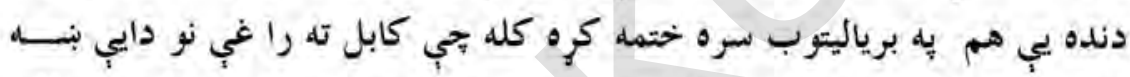

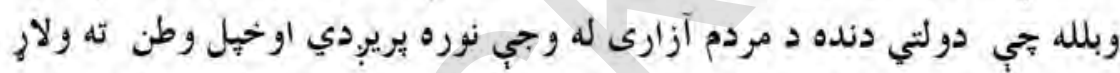

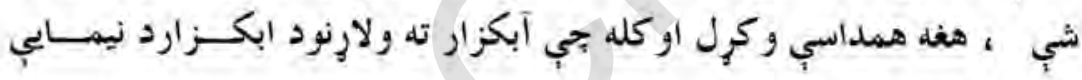

كليز ملك شتو

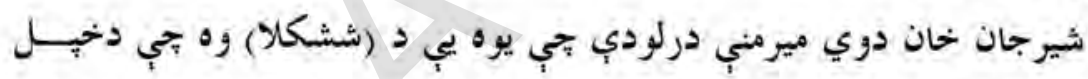
ماموريت به دوران كي يبي هلته كري وه اوبله د جغتو سعادت خحلودمحمد نبي خان عمه ور

هغه د جغتو د كفتان محمد حسن خان تينكى ملككري ووله هزاره كمانونه يبي د سوختي خمكي يه بيه و إخيستي . كله تجي يه هزارجاتوكي كاو سوار ياغي شو نو حكومث د وروكر او هزارجاتو

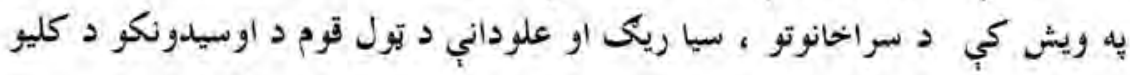
يه بولو يو ستي واجولى بجي ددغه تولو يوستومشرى شيرجان خان كوله 


\section{I r}

دوركى مشاهير دوهم توكى

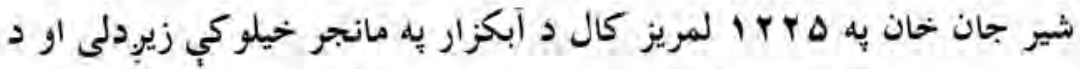

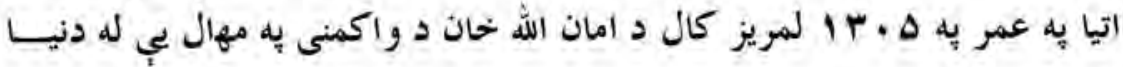

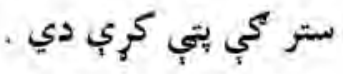

شيرجان خان د سعدالله خان ، محمد الله خان ، فتح الله خان ، محدي لـدنبى خحان او جليل خحان به نومونو ينخحه زامن درلودل بحي تولو يبي قـــوي هيكلونسه.

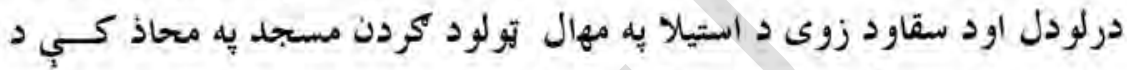
سقاو د زوى يه جكَّرو كي فعال كلمون درلود .

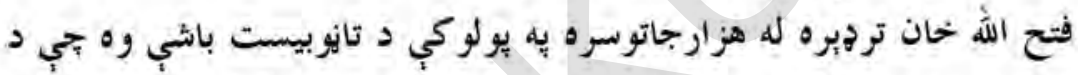
زوند تريايه يه(بيست باشى) مشهور وو، محمد الله خحان يه ابكزار كي مشرى او خاني كوله اويه خان كاكا مشهور وو، سعدالله خان وير يخحوا وفات شوي وو،او محمد نبى خان اوعبد الجليل خان يه انقلاب كي وفات شول شيرجان خان درى لونب درلودى جي يوه يب د (ميراكة ) د ملك ذكريا خان ميرمن وه ، دوهمه د كونده كول د ملك سرتورخان سره وه اووروستى يسي د دون شنيز د جاردهي د ملك كل وزير خان ميرمن وه بحي ددوو لومرنيو يب اولادونه

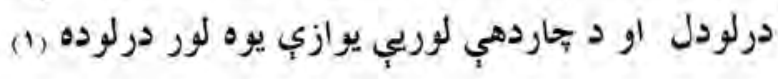




\section{ثرين ( شجاعت ) مولوي قوماندان}

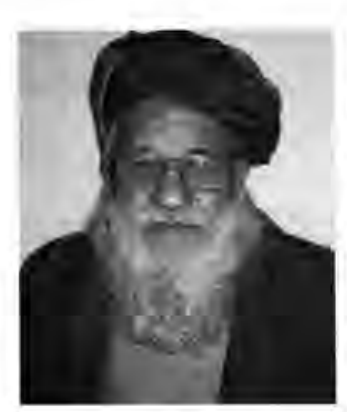

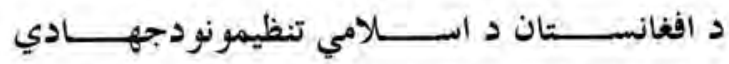

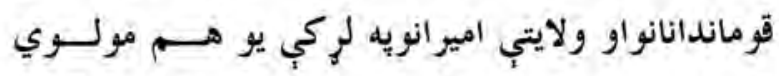
شرين (شجاغت) دى جي د جميعت اسلامي يه كوند

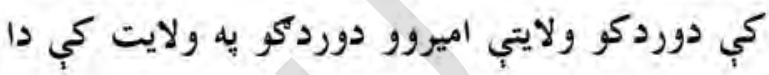

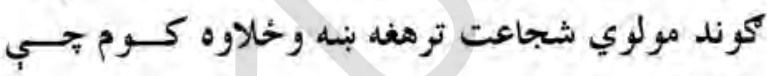

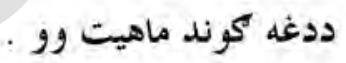

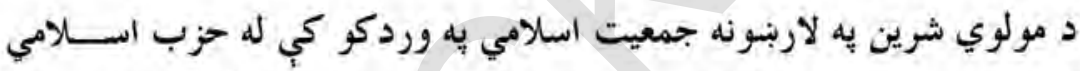

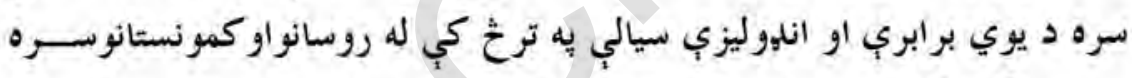

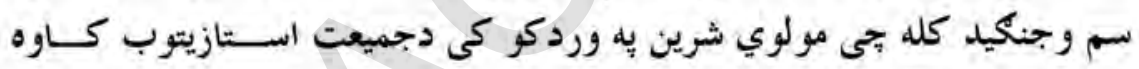

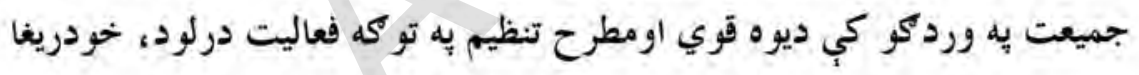

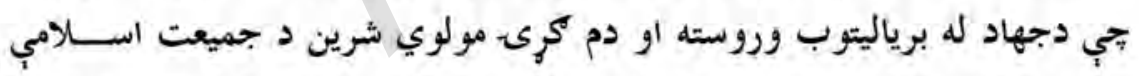

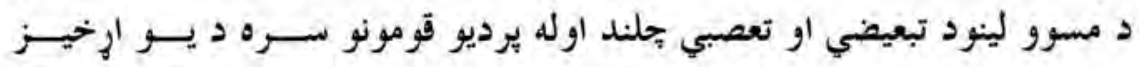

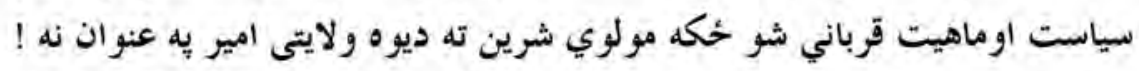

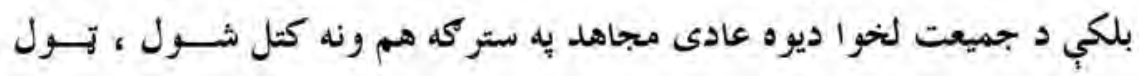

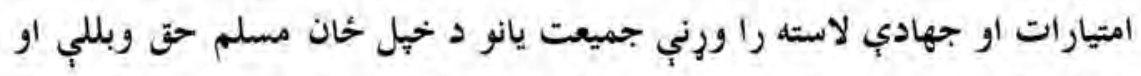

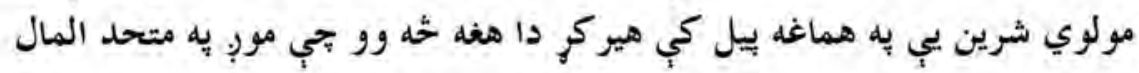

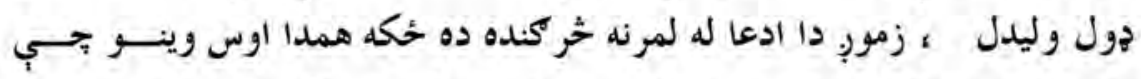

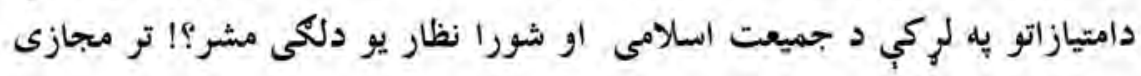


وزارت بورى ورسيد خو مولوي شرين د وردكو ولايت د جميعت اسـلامي د امير له عنوانه د نظار شورا او جميعت اسلامي د مسورلينو د سالم او عادلانـــ

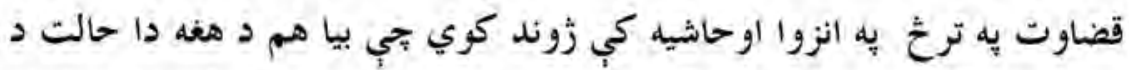
جميعت د كوندد تبعيضي سلوك يه باب د يو هيدو بشبر زيكنا ل را را كري هغه زيكنال كرم جيى ددوي يه فطرت كى د يُبتنو لِّاره نغبنتى دي 1

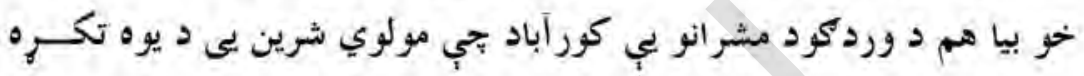
مجاهد يه عنوان بيرته يه خهيله خوايوري راونيو اودهغه حيثيت يحي د يوه يياوريى جهادي قو ماندان يه توكّه خوندي وساته . كه خه هم مولوي شرين جميعت تله جير وفاداروو اولا تو اوسه هـــم ورتــهـ وفادار دي خوجميعت اسلامي له ييل هغه ته نه وو وفادار ! او لله هغه نه يــي د جهاد يه مهال د يوي وسيلى يه تو كه كارا خيست ، مورج ددي شاهدان وو بحى

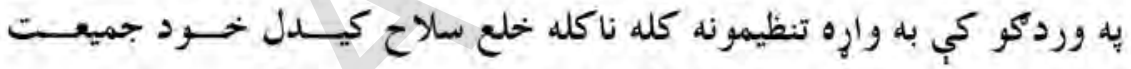
اسلامي وول او نفوس يه وردكو كى له حزب اسلامى او حركت اسلامى ثله هم يباوري ورواوهيجا د جميعت غرى ته كارِه نشواي كتلاى مولوي شرين به تـل كمونستانو عمليات كول له سترى قوى وروسته كله تجى كمو نستانو د بحك يه ولسو الىى كي د ولمسو اللى به عنوان كومي نظامي يوستي واجولي نومولوي شرين د

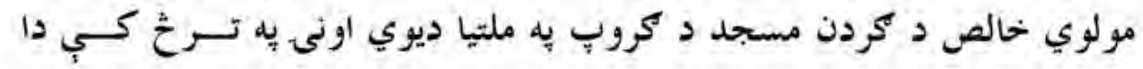

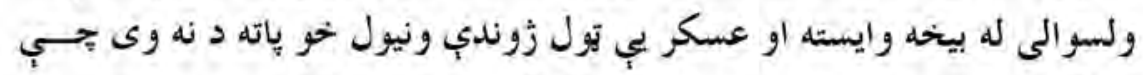
عسكر يب لل يوي مخي زوندي رخصت كرل . 
مولوي شرين د روند لله بيل نه مبارزه روحيه درلوده هغه له استاد رباني سره يه مكه معظمه كي ويبرّندل دا د سردار محمد داود خحان د و واكمنى زمانه وه او

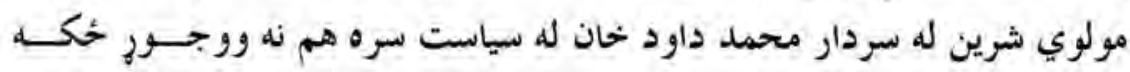
دهغه يه نظامي او اداري تشكيالتوكي كمونستانوخحاى درلود.

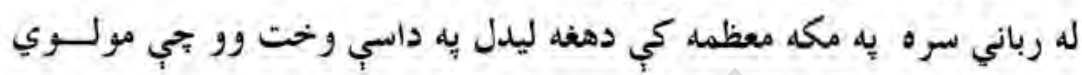
شرين بِه باب سلام كي افغان كاركرانو ته وعظ كاوه او رباني هم يو سات دهغه وعظ ته ولار وو وروسته بي مولوي شرين ته وويل :

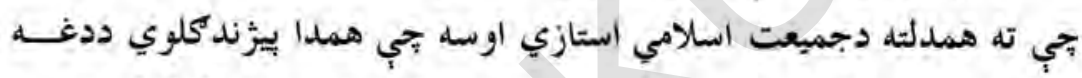

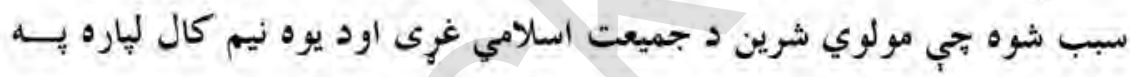
سعودي عربستان كي دجميعت اسلامي استازى واوسى . كله جي مولوي شرين اففانستان ته راغى نود كابل به ميرويس ميدان كـي يــي

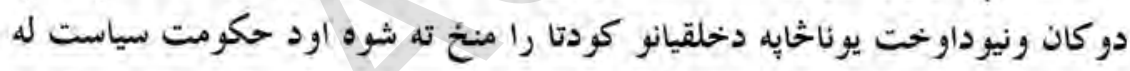

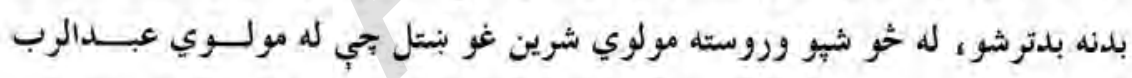

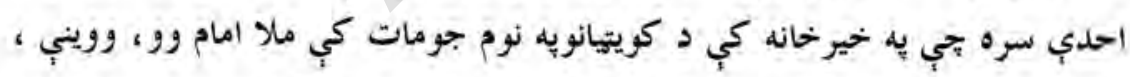

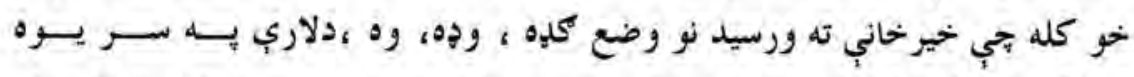

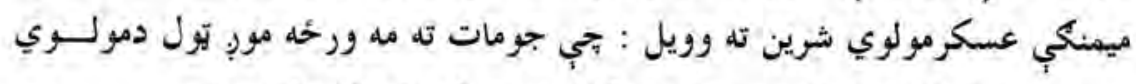
صيب د نيولو لياره را غلى يو جومات كابند دى له دعه خحايه ليري شها.

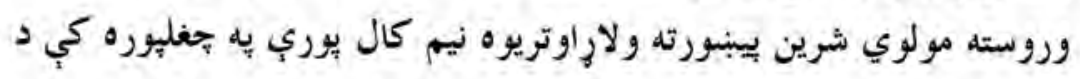

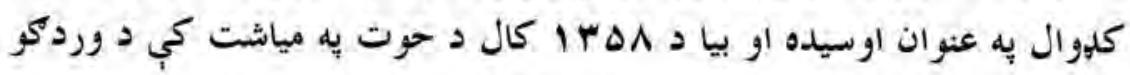

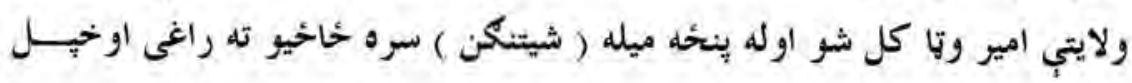


لومرنى مسلحانه جهاد بي بيل كر لله هغه وروسته وردكو ته راغى او خيل جهاد

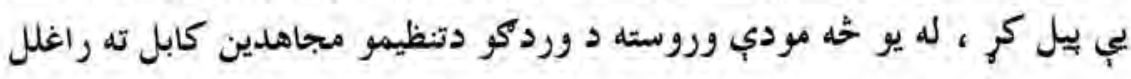

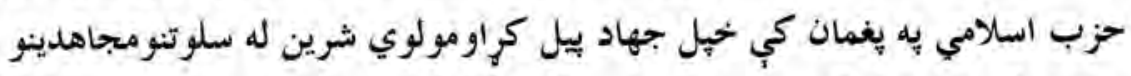

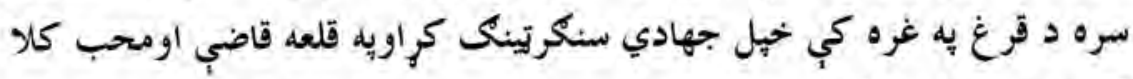

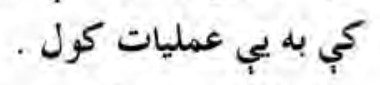

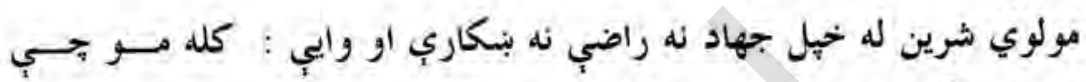

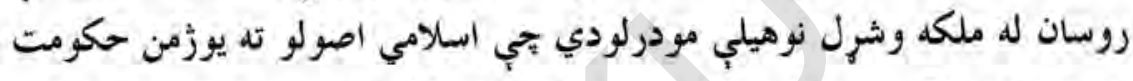

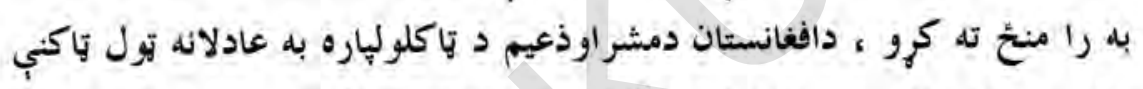

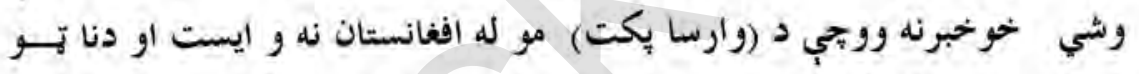

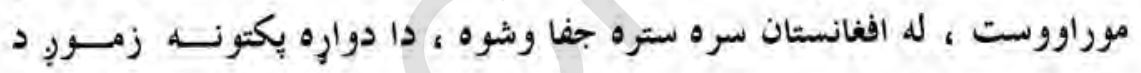

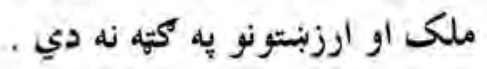

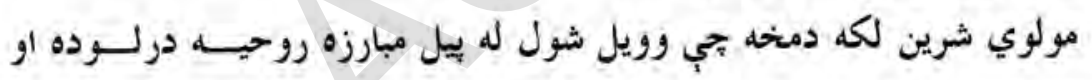

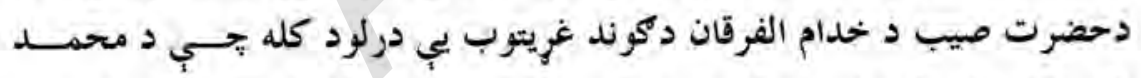

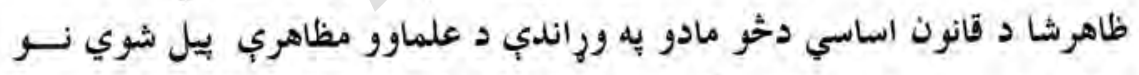

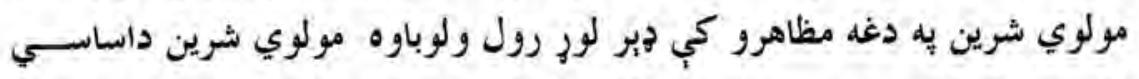

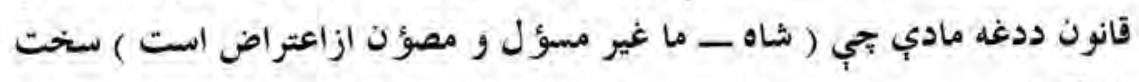

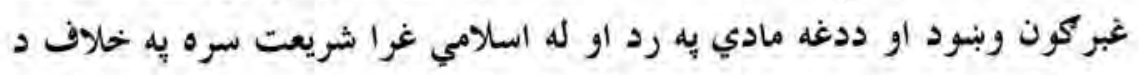

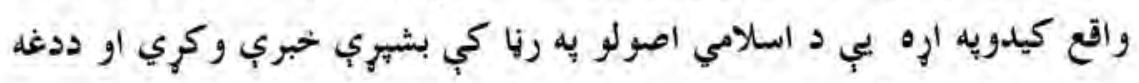

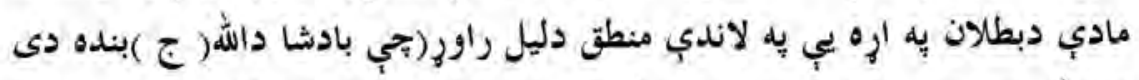

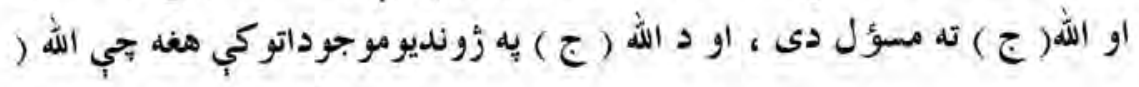


IrA دو وركو مشاهير دوهم توكى

ج ) ته به مسؤليت نه يو هيبِي جاريان اوحيوانات دي نودمحمد ظاهر شا اوس

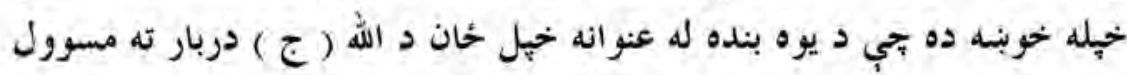

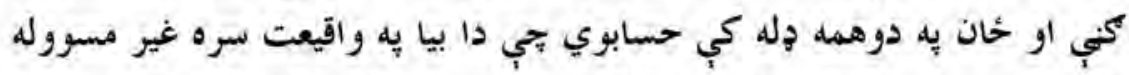

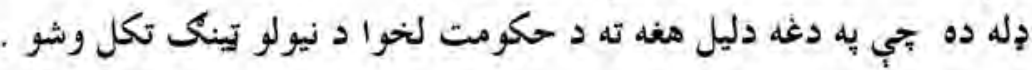

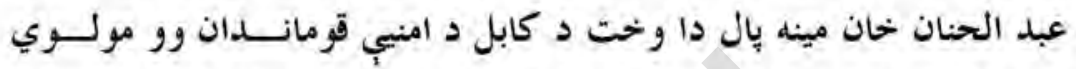

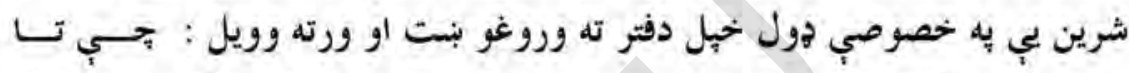

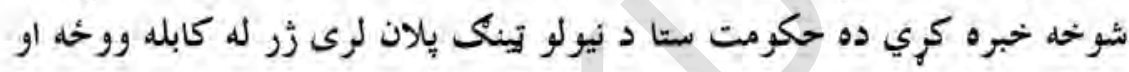

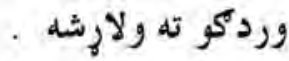

مولوي شرين وردكو ته ولار خو بيا هم كله تجي هلته ورسيد نو ديوي نيمي

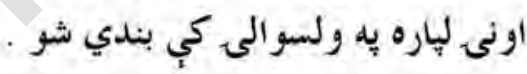

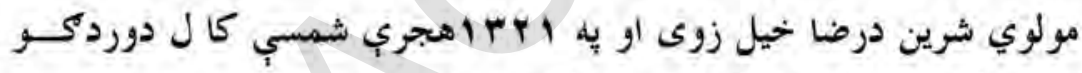

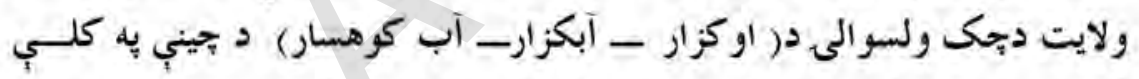

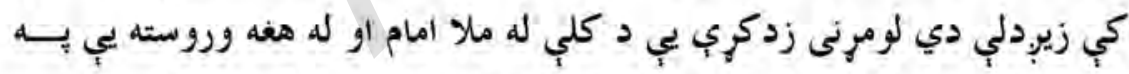

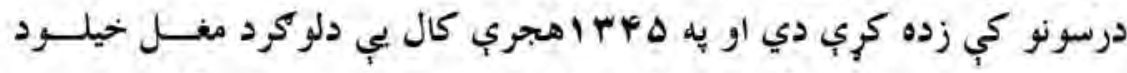

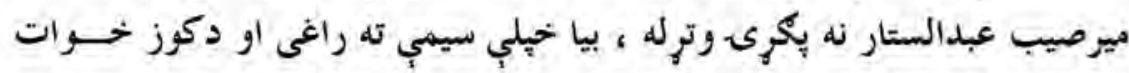

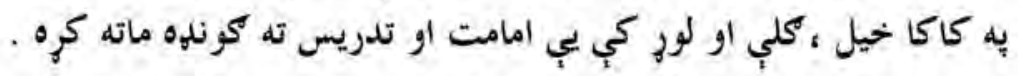

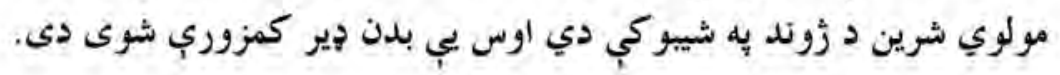




\section{شريندل خان - السنك}

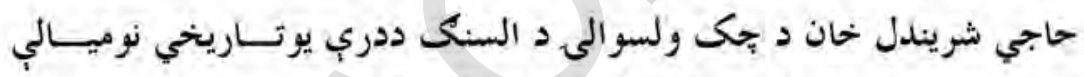

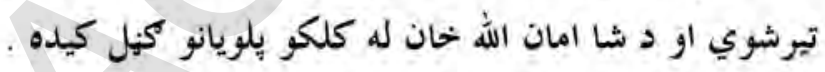

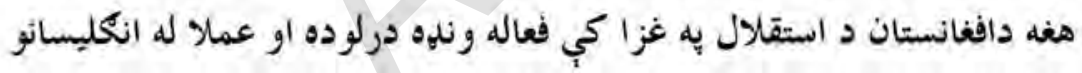

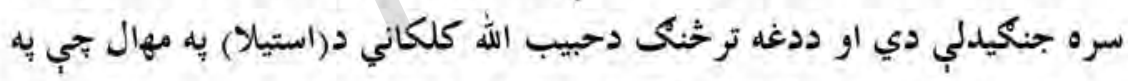

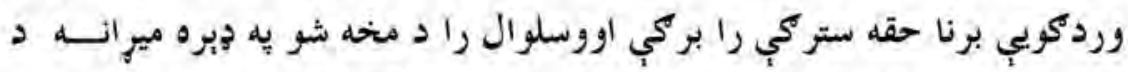

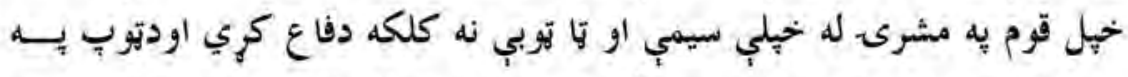

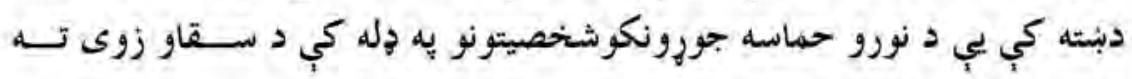

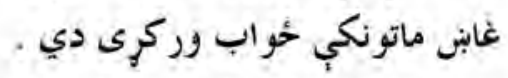

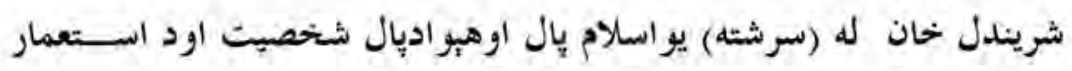

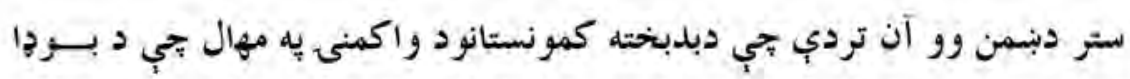

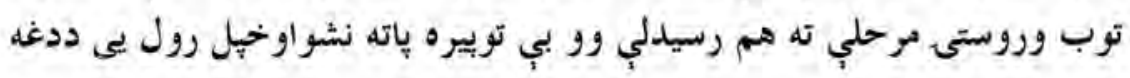


Ir.

د وردكو مشاهير دوهم توكى

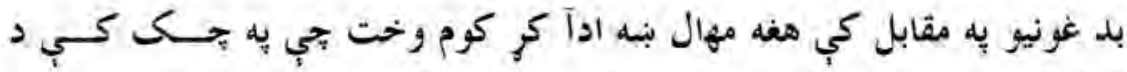

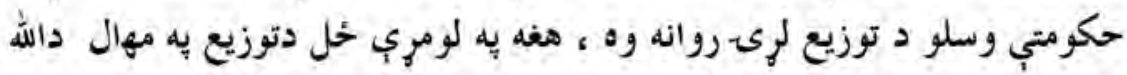
اكبر ملكوتي ( نعره ) يورته كره جي به توخ كي يب مجاهدينو روحيه واخيسته

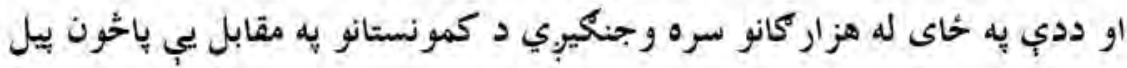
كر بيبنه داسي وه كله بجي كمونسمان تيروتل او له هزاركانو سره د ورودكــو د

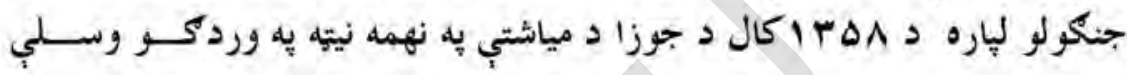
وويشلي ، نوشريندل خحان لو مرنى كس وو جيج دولسوال او دهغه د كمونستت

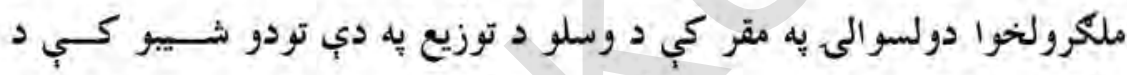

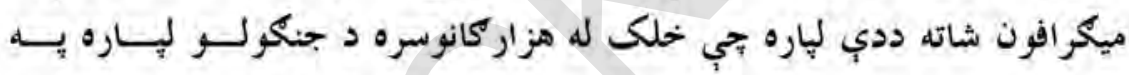

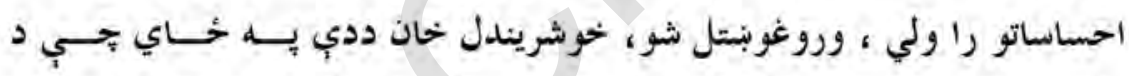

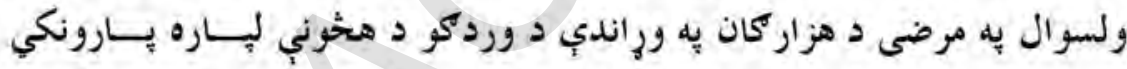
خبري وكري يونا خايه يب د ميكروفون له شا نه د الله اكبر ، يا جهاريار ملكوتي

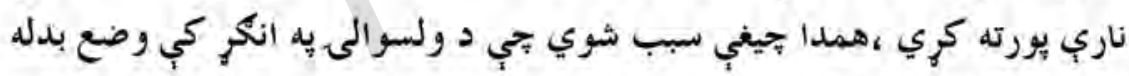
شي د (تكبير نارو) د ستر كمو يه رب كي د (هورا ) د يليدي او يـــردى جيغـي

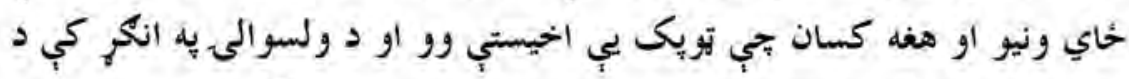
ولسوالى د عسكرو ، حزبي منشيانواو نورو كمونستانو ترتينك نظارت لانــلـي وو ، ستركي رني شوي اوجيرو كسانو يه دي حساسه شيبه كي له شريندل خان سره د الله اكبر ناري بدركه كري او وضع داسي شوه جي د خلقيانو قومانــــه بيخي رجنكه شي او راتول شوي شا و خوا كسان تيت يركى او به لاره او بتئو كي د خهلو كورونويه لورمخه كريى . 


\section{1}

دوركى مشاهير دوهم تبرك

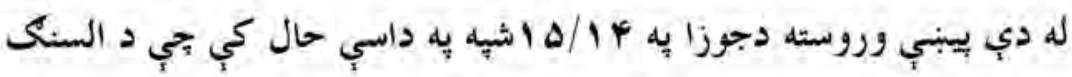

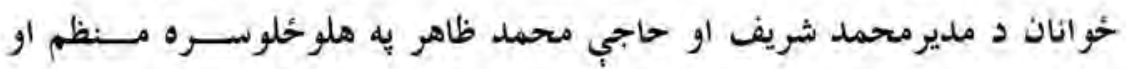
منسجم شول او د ثبي بِيه اتو بجود بازون خيلو يه جومات كي ســره راغونسله شول بِه داسي حال كي جي حاجي شريندل شحان قر آن عظيم الثان يه خِل لاس

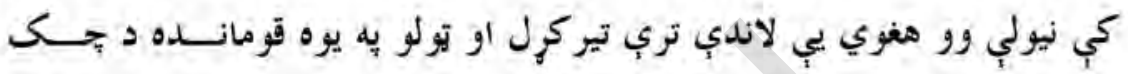

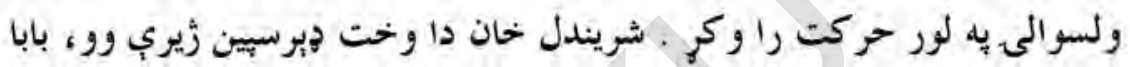
وو، خو د مجاهدينوهخوني اويه هفوي يسي دعا ثه بيا تكره حخوان وو ، هغه د

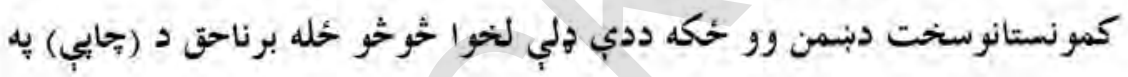
بنه كلا بند شو خو د الله يه فضل به تري وساتل شو. ددي تولو مبارزو تاريخونه اوداستانونه يب همدا اوس هم دخلكواوعام ولس به خوله اوذهن كي زوندي ياته دي

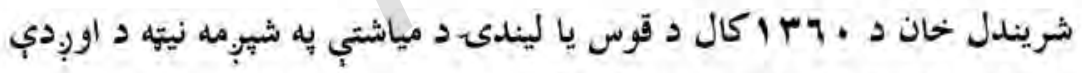
ثاروغى له امله خبل خحا ن حق ته تسليم كراووفات شو. 


\section{صديق الله (ويرا )}

هاكتر صديق الله (ويرا) د جهاد به تودو شيبو كي يه الهيه

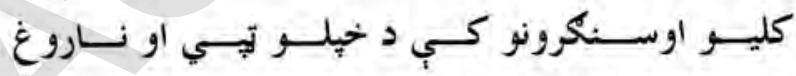

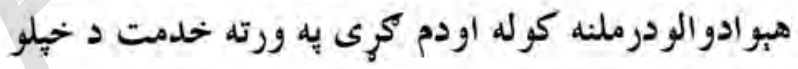

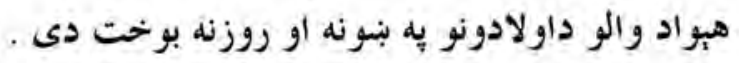

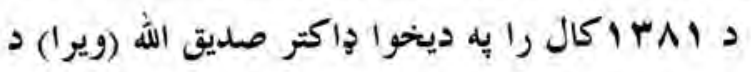

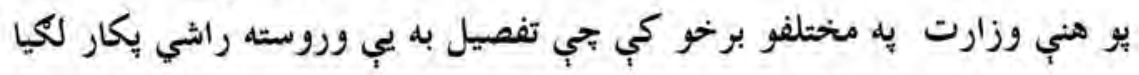

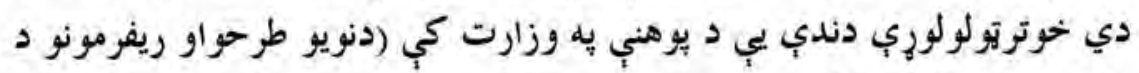

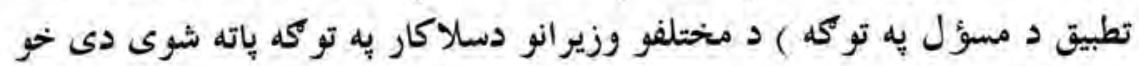

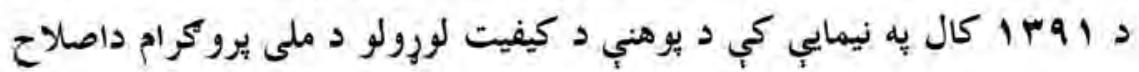

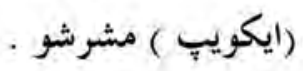




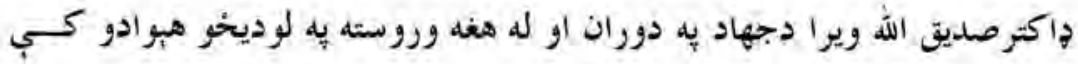

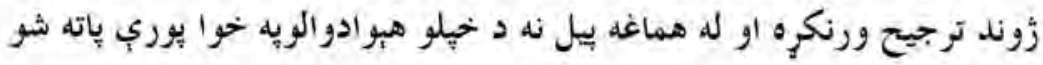

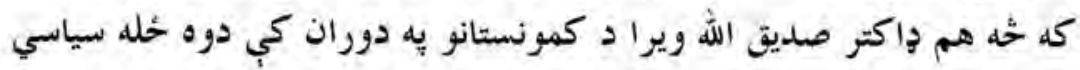

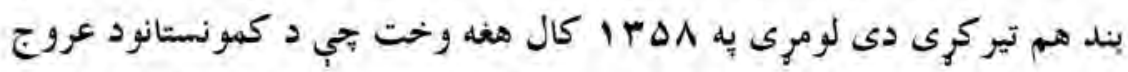

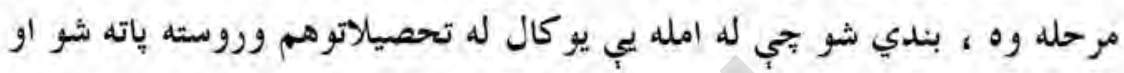

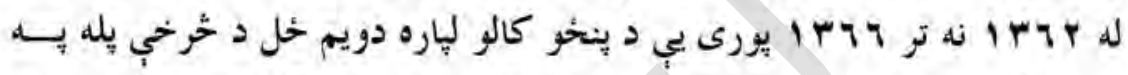

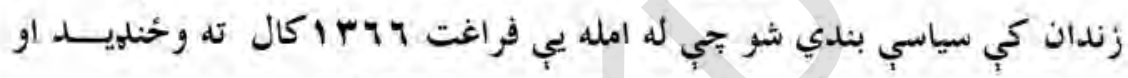

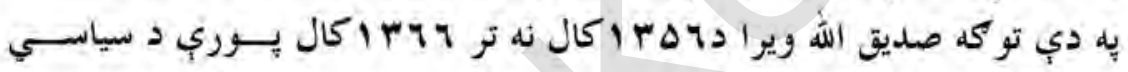

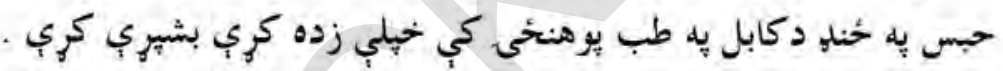

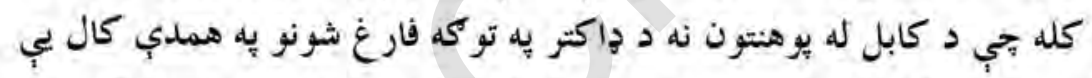

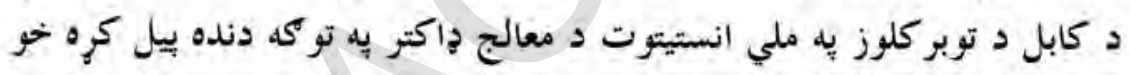

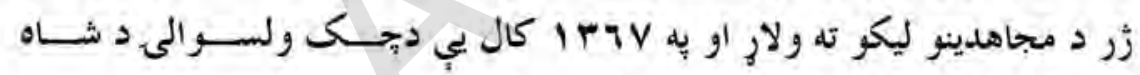

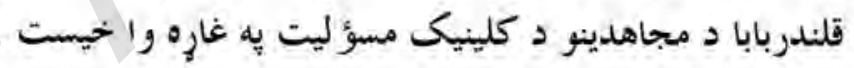

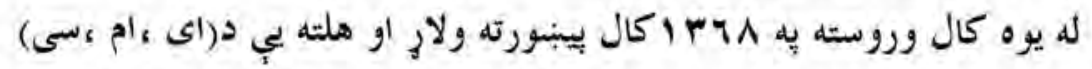

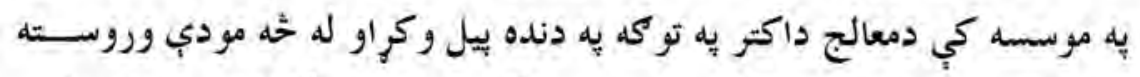

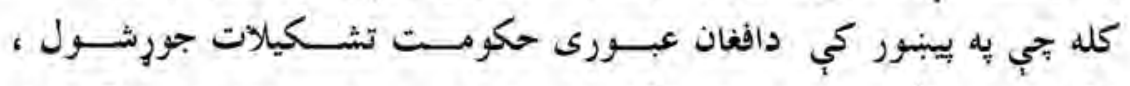

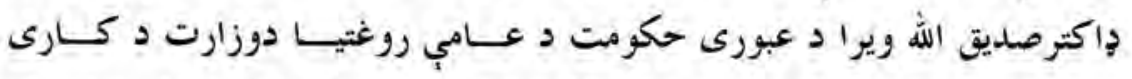

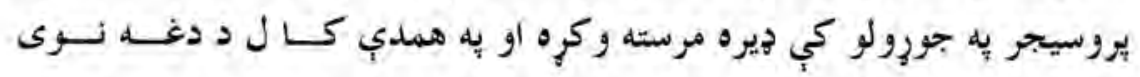

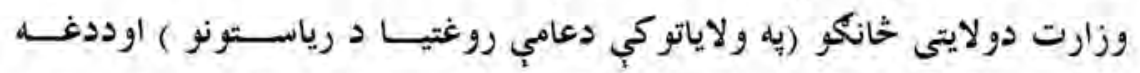

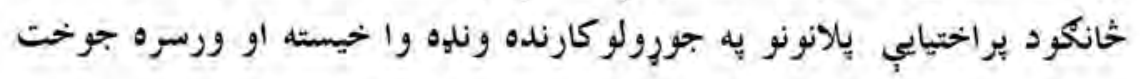




\section{Ir}

دوركو مشاهير دوهم توكى

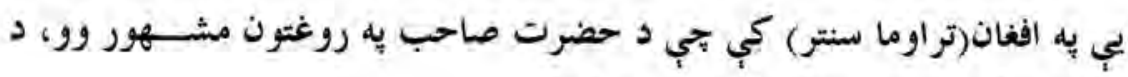
معالج هواكتر يه حيث هم دنده ترسره كوله. يه كال وq وب اصديق الله ويرا د ولايتى صحى مركزونو د ليدو او ســروىى

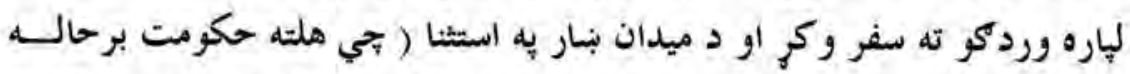
وو ) د وردكوولايت د تولو ولسواليو مهم كلينيكونه وليدل او معاينه بي كرل جي ددي سروى د يايلو خخه بي د ولايتى انكثافى(يراختيايب) هالانونويه نهايب كولو كي فيره كميه واخيستل شوه .

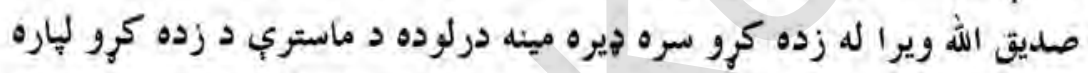

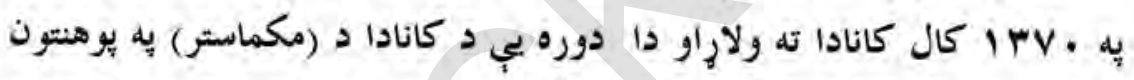

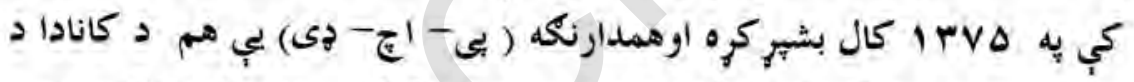

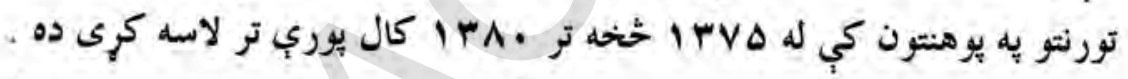

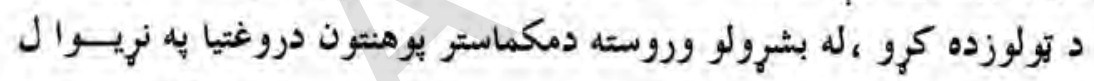

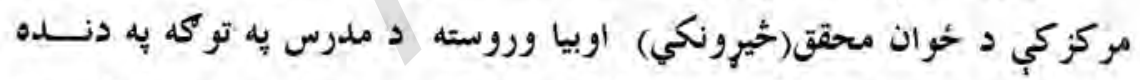

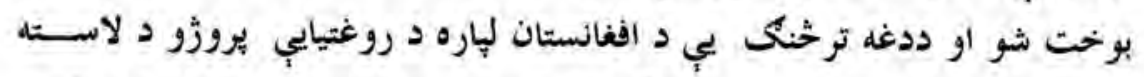

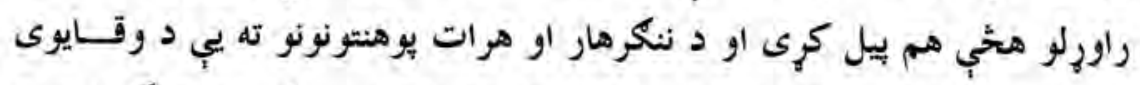

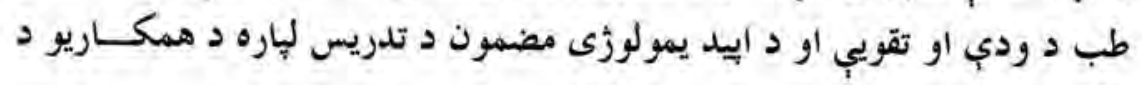
امكاناتو د خيرلو يه موخه سفروئه وكرل.

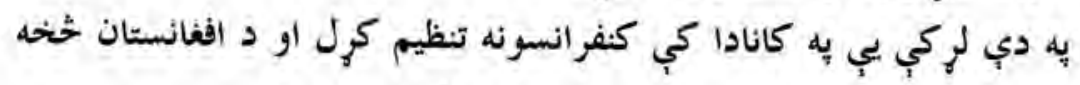
يب د عامى روغنيا وزير او د نويوالى روغنيا يب مركز (دبليو - أج- او) رييس هم 
رسمأ د (مكماستر) بوهيتون ته وروغوبنتل اوقيونوررسمى ملاقاتونه يبي يه دريو نورو ايالتونو كي هم ورته برابر كري .

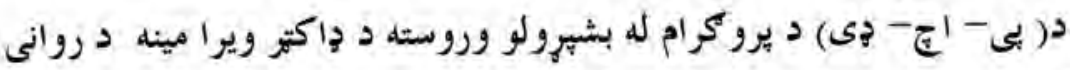

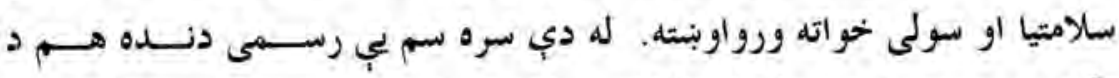

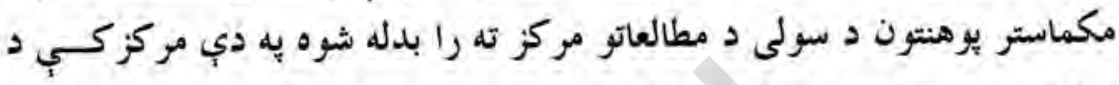
تحقيق او د سولي د نيوالو يروزو د مسووليت برسيره، هاكتر ويرا د ماسترى د

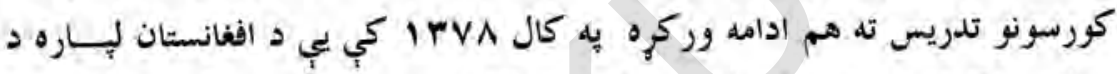

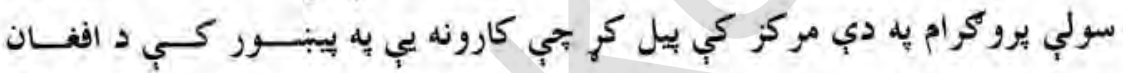
يوهنتون او د سولي د موسساتو سره تعليمى فعاليثونه جي به لر كي يب دي د بنســونكو

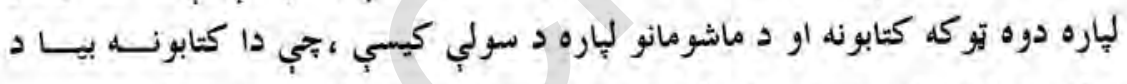
يوهني وزارت د يو نسيف به مالي مرسته جاب او به بنسونحئ بي وريشل

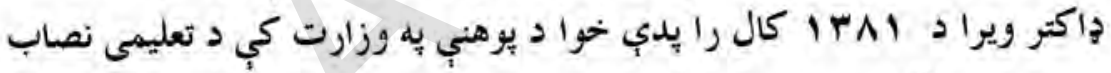
او بيا د بنوونكو د روزني د ريفورمونو د يرمخ بيولو مشرى هم كري ده يه دي دي لهي

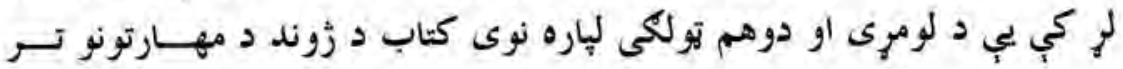
عنوان لاندي ليكلى دى تي اوس به تولو بنوو نخيو كي تلدريس كبرئي.

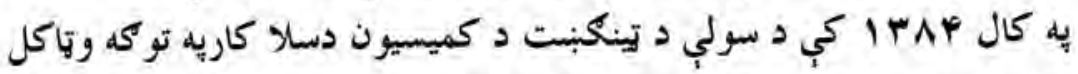

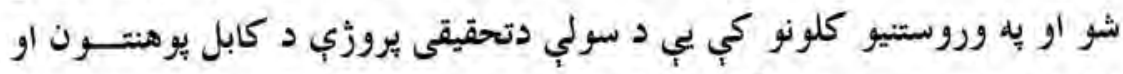

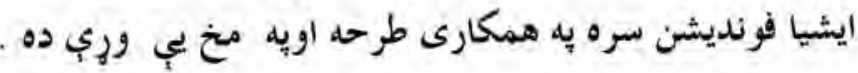




\section{$1 \% 9$}

دوركو مشاهير دوهم توك

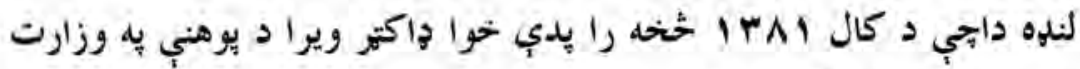
كي دنورو دندو ترخنك د تعليمى نصاب او بيا د بنوونكو د روزني د ريفورمونه د يرمخ بيولو مشرى هم يه غاره لرلي ده . او همدارنكه يب د لومرى او دوهم تولكى لياره د زوند د مهارتونو ترعنوان لاندي نوى كتابرنه ليكلي بجي اوس يه تولو بنوونتحيو كي تلريس كبري.

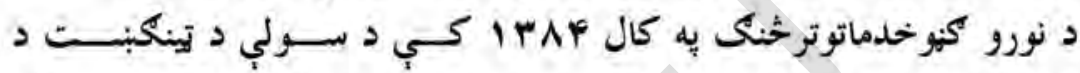
كميسيون د مشاور يه توكه هم وتاكل شو او يه وروستنيو كلونو كي د نبــولي

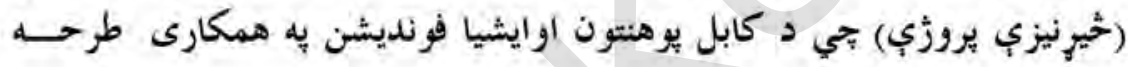

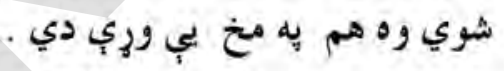
داكتر صلديق الله ويرا يه VIr

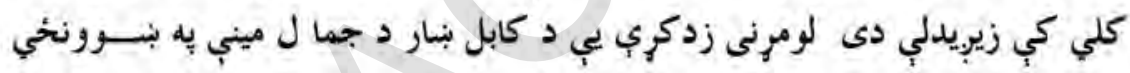

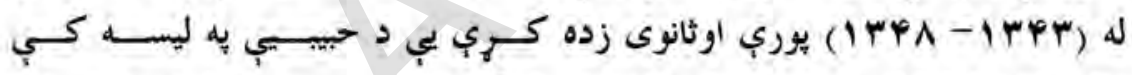

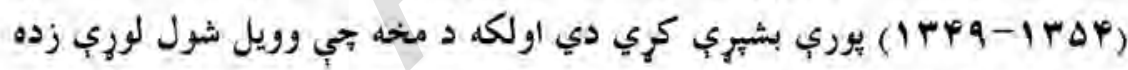
كري يـي د كابل يوهنتون د طب به بوهنحئ كي تر سره كري دي . 


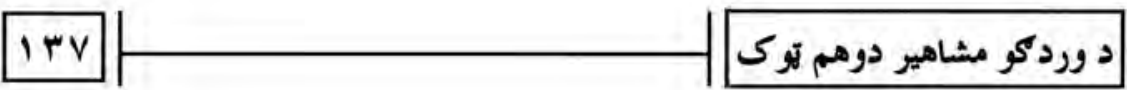

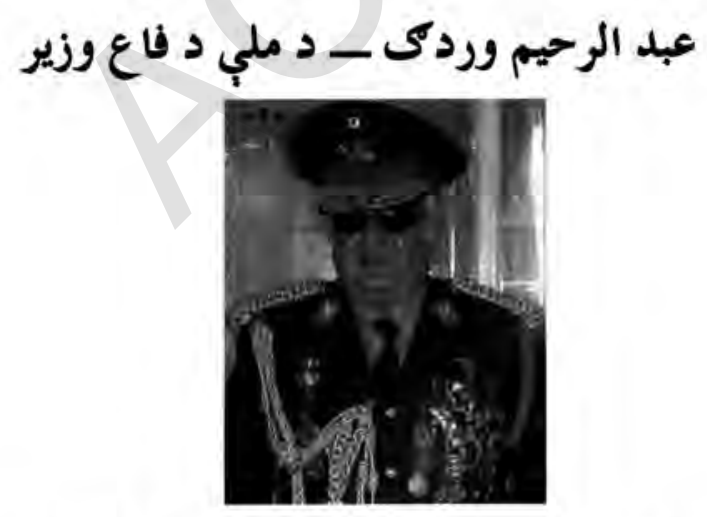

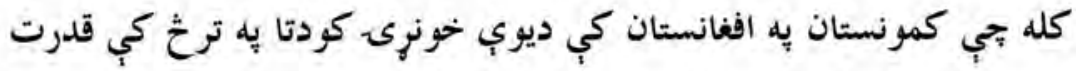

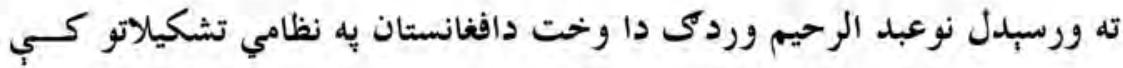

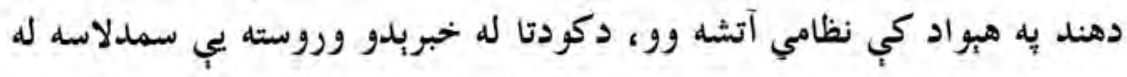


كمو نستانو سره خيل مخالفت اعلان اوخهله دنده يب د هند يه هيــواد كـي يرينسو ده.

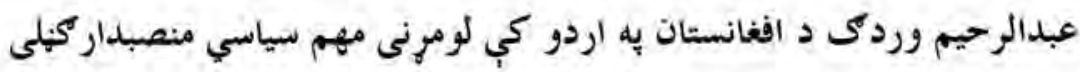

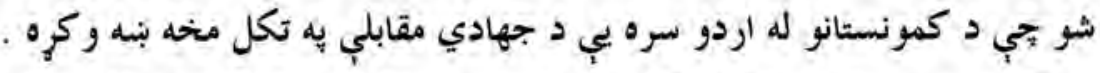

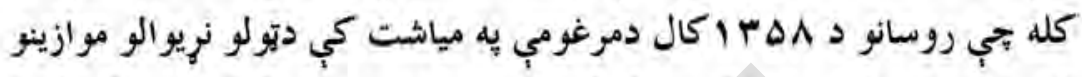

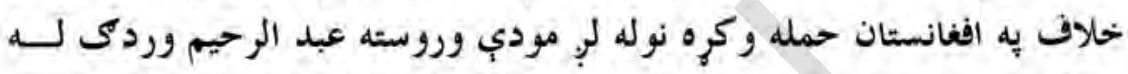

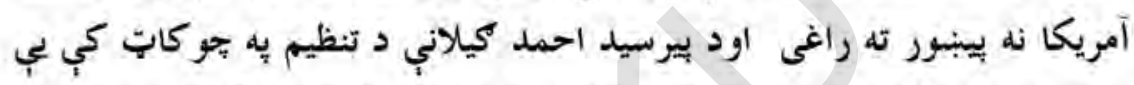

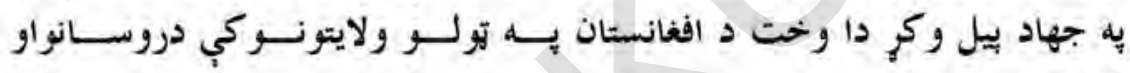

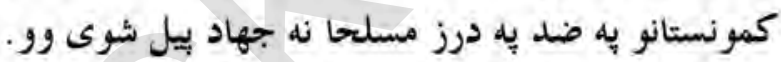

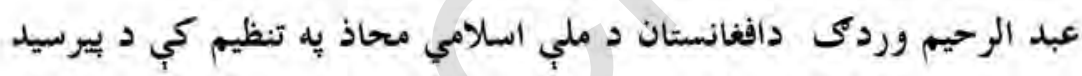

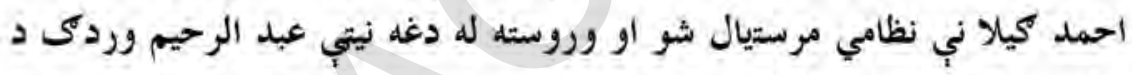

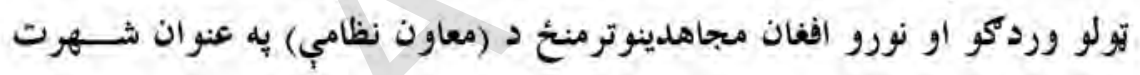
وموند .

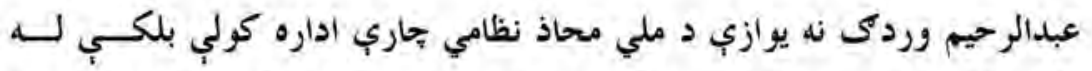

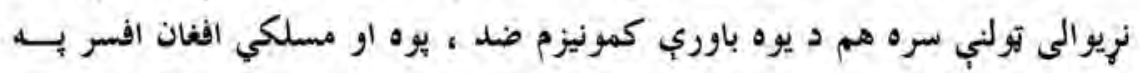

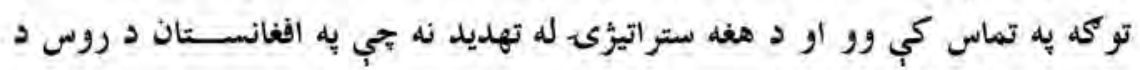

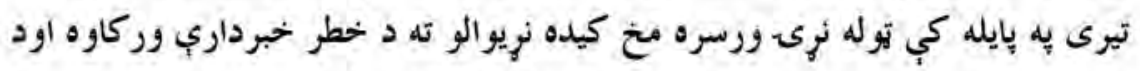

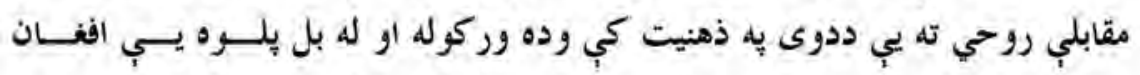

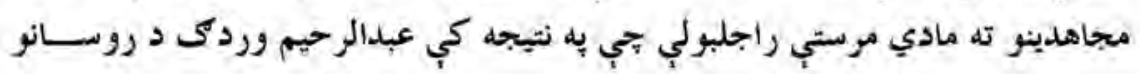


به مقابل كي راجلب شوي مـالي اولورُستيكي مرستي او نور امكانات له تبعسيض

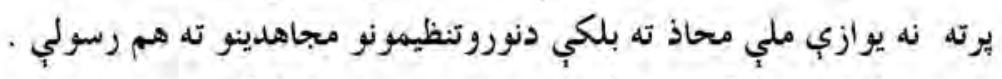

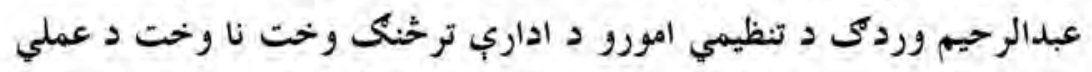

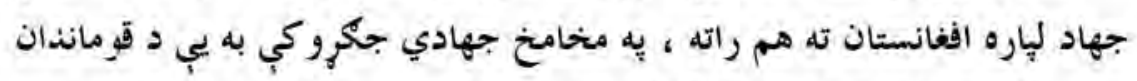
يه عنوان دجهادي حرب اداره كوله

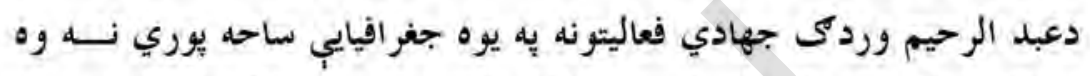

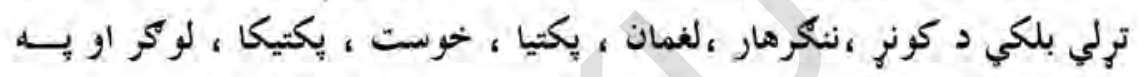

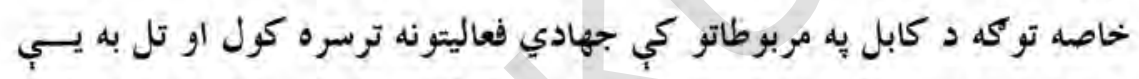

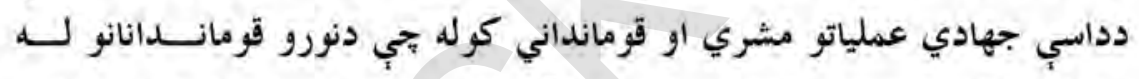

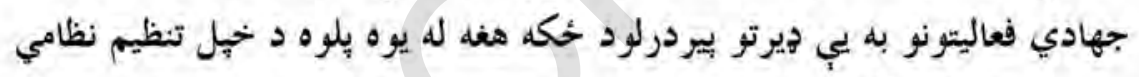

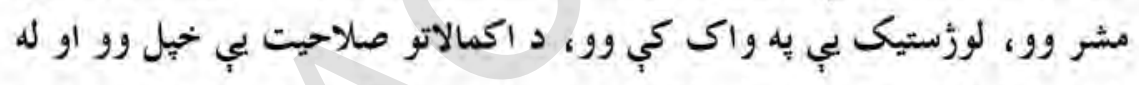

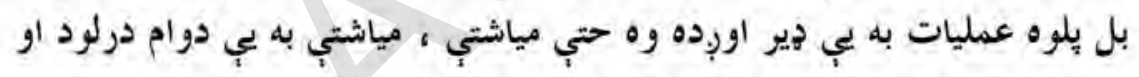

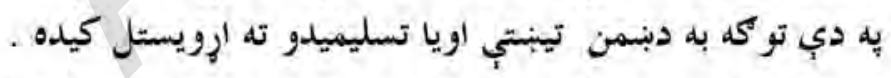

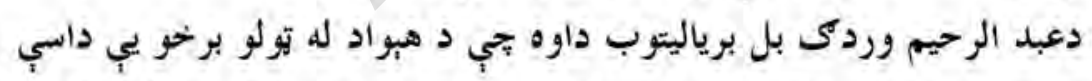

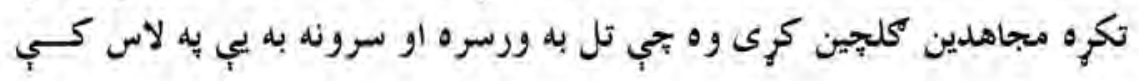

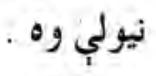

اودريم داجب يخخيله عبد الرحيم وردكى يو يوه او ماهر نظامي منصــبدار وو

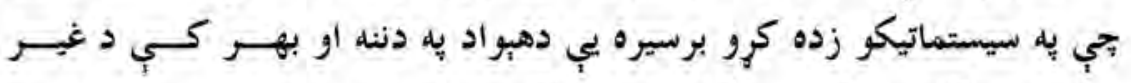

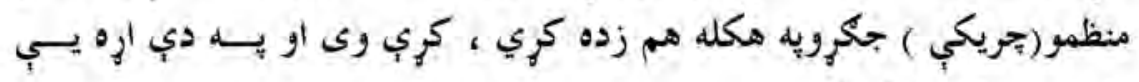

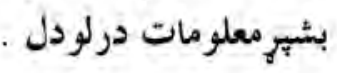




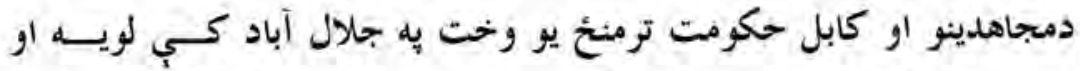

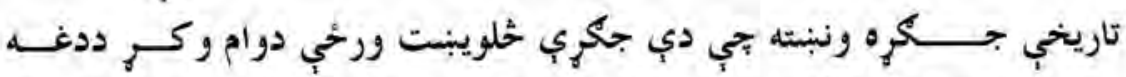

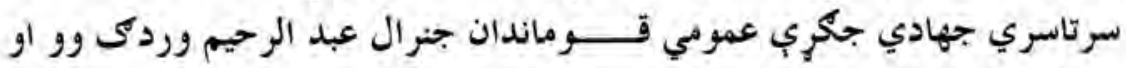

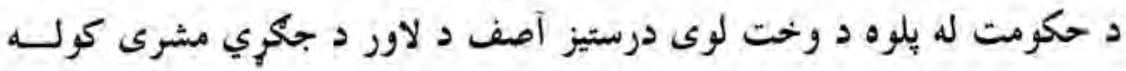

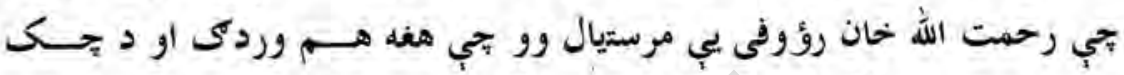

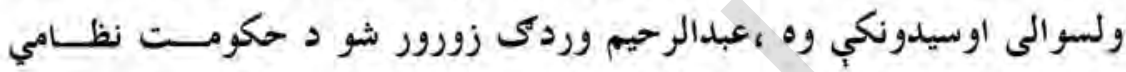

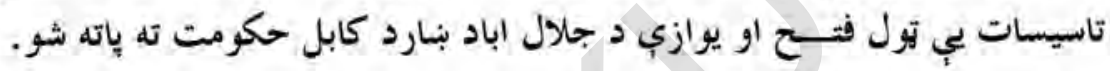

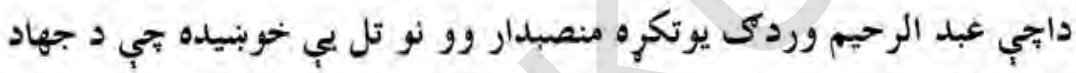

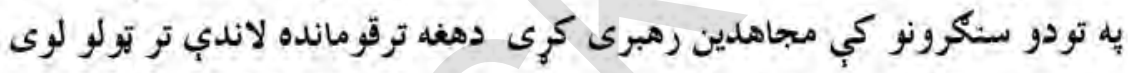

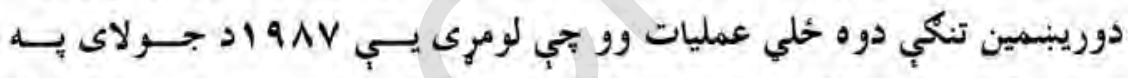

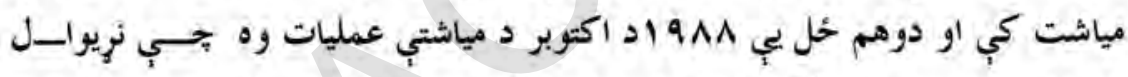

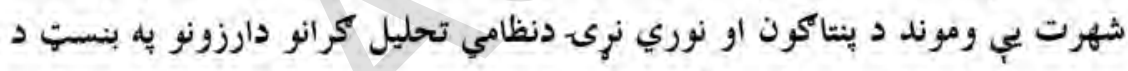

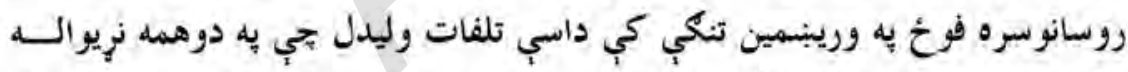

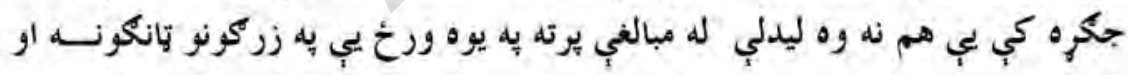

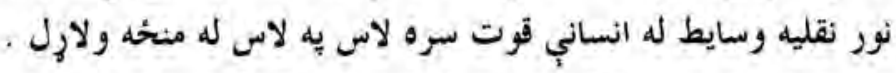

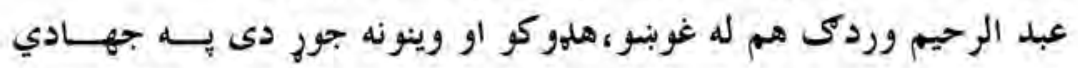

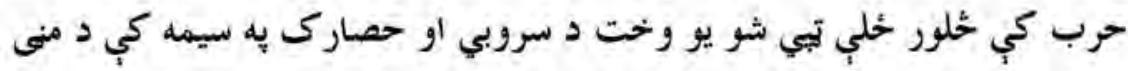

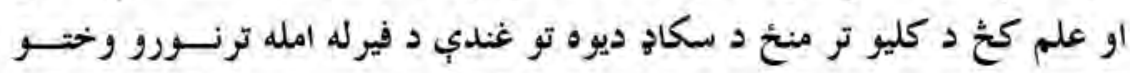

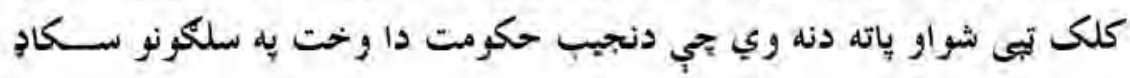


توغندى د بينتتو يه سيمو او كليو وسوغول او يوازي يو حخلي يو فير يب دكايسا

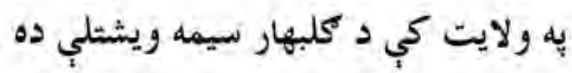

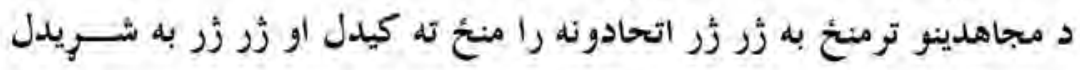

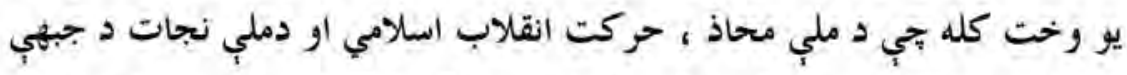

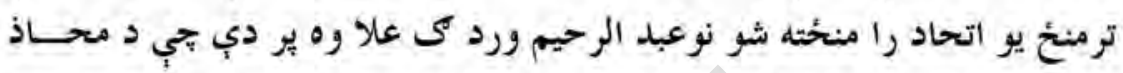

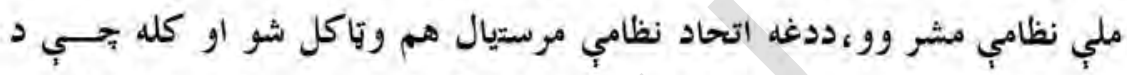

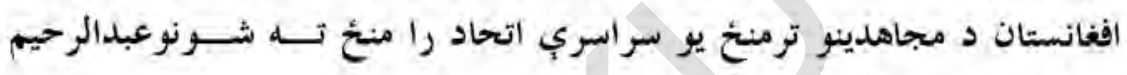

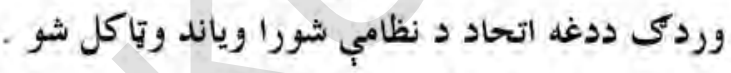

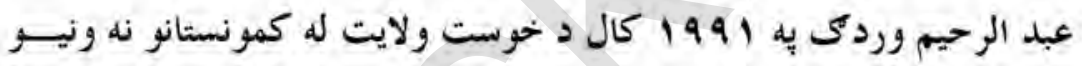

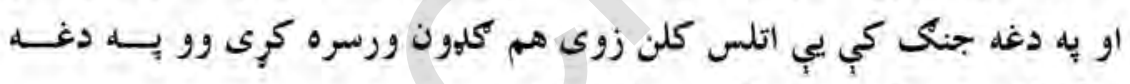

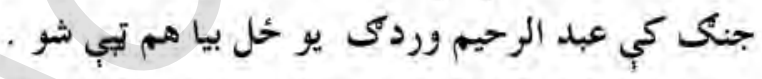

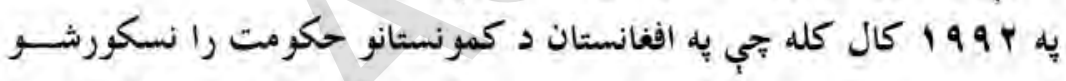

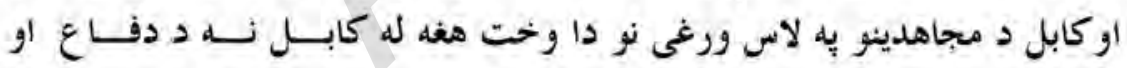

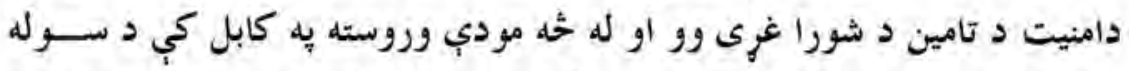

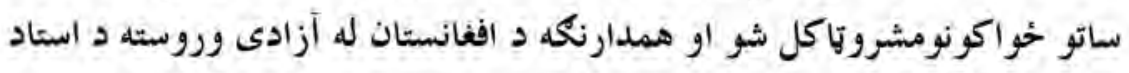

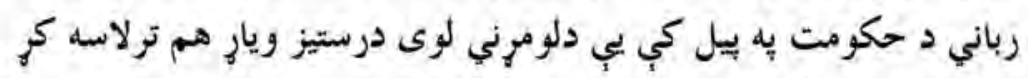

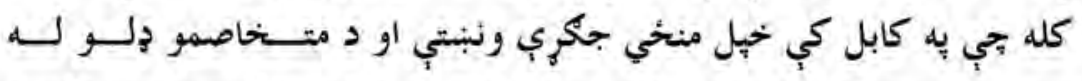

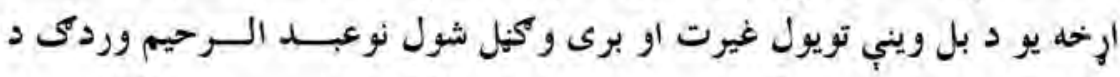

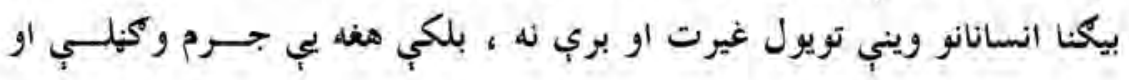




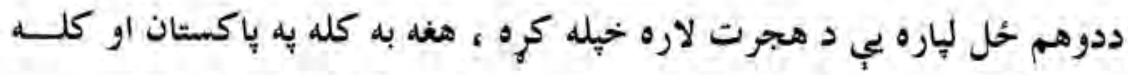
يه آمريكا كي وو خو د افغانستان يه روانو خونريو حالاتو به جير خوريده .

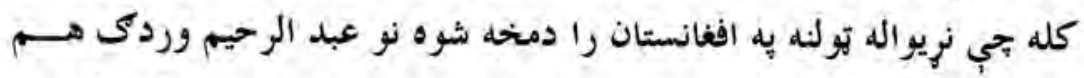
ددوى يه ليكو كي افغانستان ته راغى او د ملي دفاع وزارت په مربوطاتو كي يب

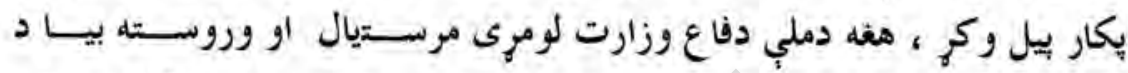

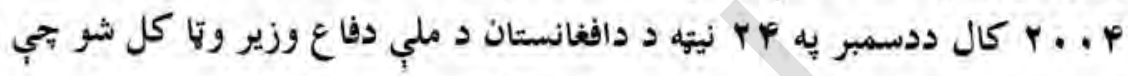
تر اله أيوري د افغانستان د ملي دفاع وزير وو. كله جي د ياكستان او نويوالى تولني (ناتو) د كلهو توطيو د يوه جور شوي

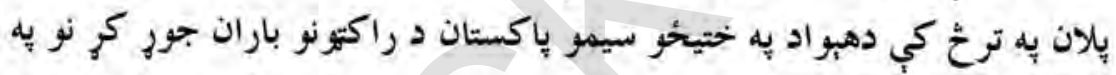

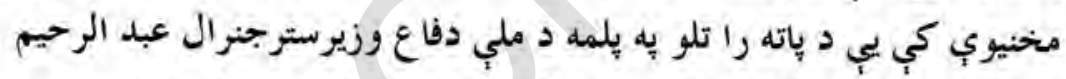
وردكى اودكورنيو جارو وزير بسم الله محمدي دم( ملي - ناملي ؟؟؟ ) شورا لخوا احضار، سلب باور ، اود خهلو وزارتونو سريرستان وتياكل شول .

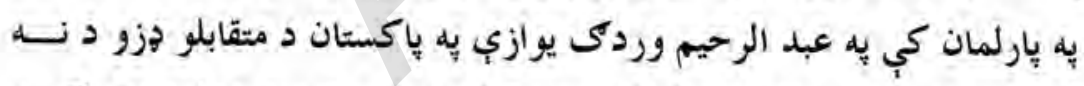

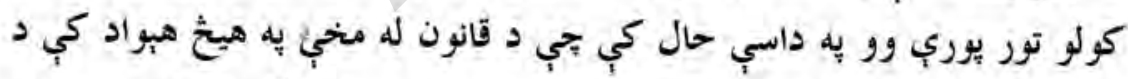

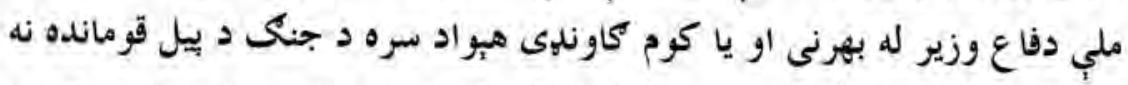

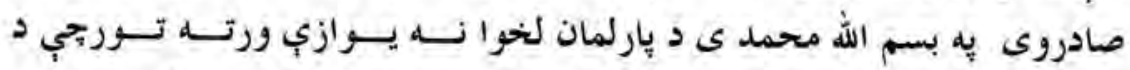
يوليسو سرحدى قواوى يب خيه لاس كي وى بلكي ينحه نور تورونه لكه د تبعيض

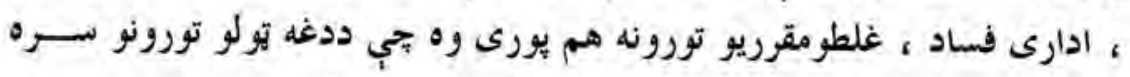

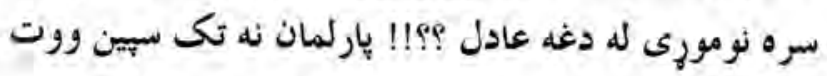


عبدالرحيم وردك يه خيل شهامت نورذلت ونه مانه سياســي ايمسـان يسي

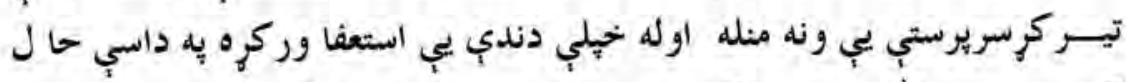

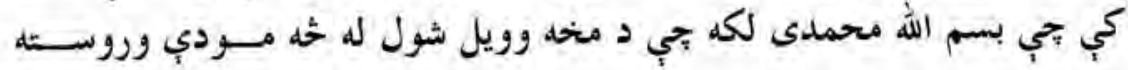
دداخلي او بهرنيو دروازو يه دربلو يه دي وتوانيد بجي دولسي جركي وكيلان د بلهو يواسطه تطميع اودعبدالرحيم وردك يه خاى د ملي دفاع وزيرشي يه داسي

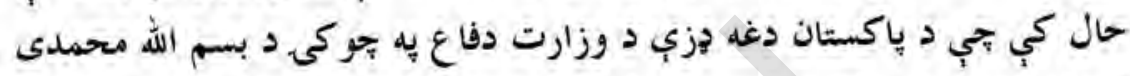

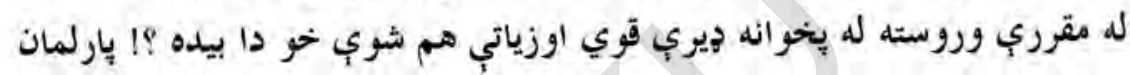

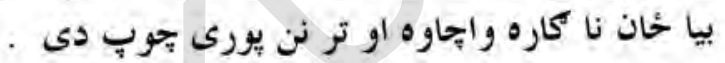

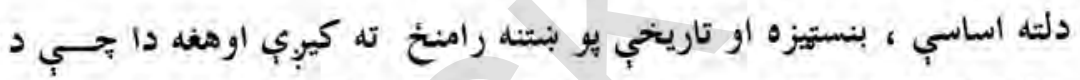
ملي دفاع او كورنيو جارو وزيران د يارلمان (ولسي جركي) لخوا د كوم جرم بيه تورتورن وو بتي سلب باور شول او بيا بسم الله محمد ي د كوم رحمت يه اوبو بريمنخل شواو د كوم هغه لياقت ارزونه يب وشوه تي د كورنيو جارو يه وزارت

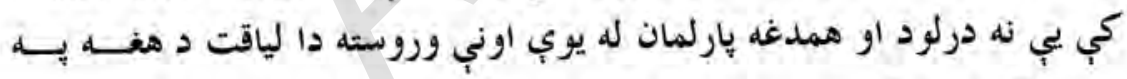
وجود كي بيدا كر جي يو خل بيا بي رايه وركره او يوه درجه لورج ياني دملـي

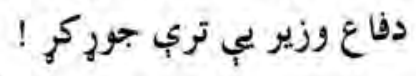

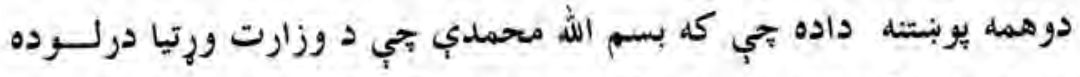
نودا ورتيا يب د كورنيو جارو د وزارت يه تصدى كي كوم ليوه خورلي وه ؟ جيحي د ملي دفاع وزارت ته يب بيرته راقيى كره .

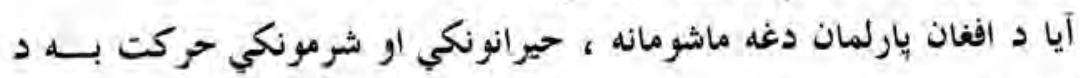
تاريخ له قضاوت نه يتّ ياته شي . 


\section{$1 \leq \leq$}

دوركى مشاهير دوهم توكى

او دريمه يو بنتينه مو داده بجي آيا دنرى يه بارلمانونوكي د ورته عمل بيلكي

$$
\begin{aligned}
& \text { يه كوم تاريخ كي جا ليدلي او يا اوريدلي ؟ }
\end{aligned}
$$

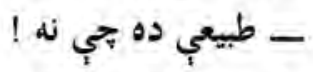

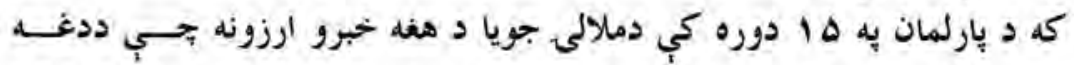

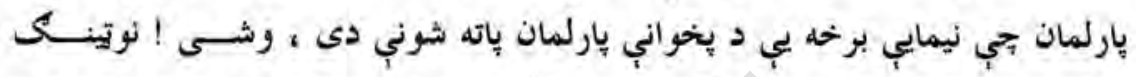

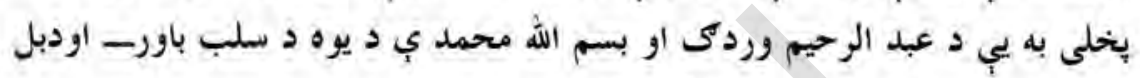
د انتصاب يه دغه وروبستي اقدام كي ونشي؟ لهي؟ -

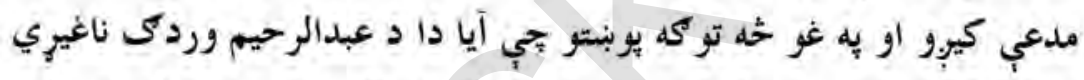

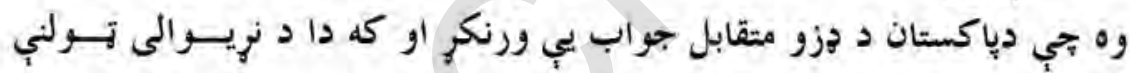
اوكرزي يوه جوره شوي منتكى سناريو وهن

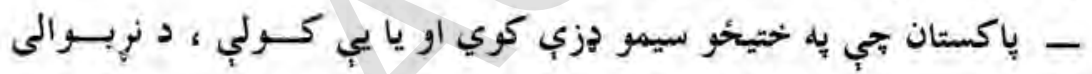
تولني نظامي ماموريت يه افغانستان كي خثه دي ؟ د نصر الدين خبره مكر دلته يب بنجاره راوري ، يا كروت خرخوى ؟ يه نورو وزارتونو كي ديته ورته داسي بينبي نه دي تكرأر شوي بي زئي زوندي

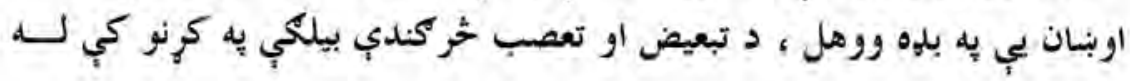
ورايه برينبي - كابل بانك جا جوركر ،هفه وخت دا بيده يارلمان بحيري وو ولي يسي غوح غبركون ونبنسروف 
د شيريوركورنه جي جور كيدل هغه وخت يارلمان به خه لكيا وو ،دكابــل

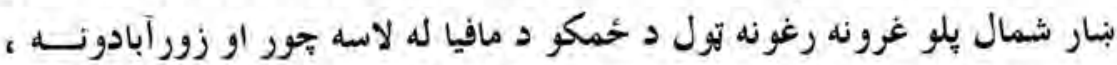

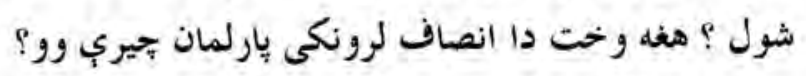

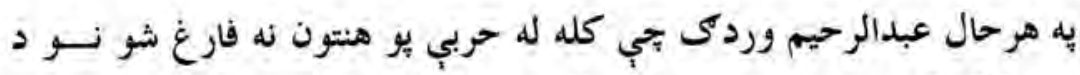

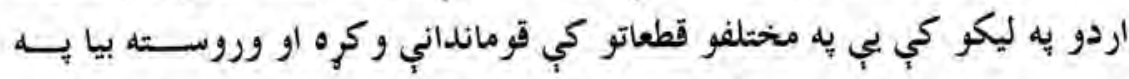

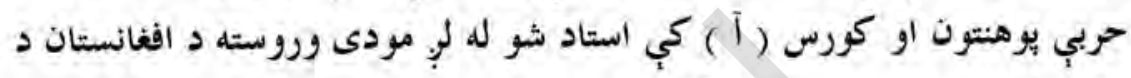

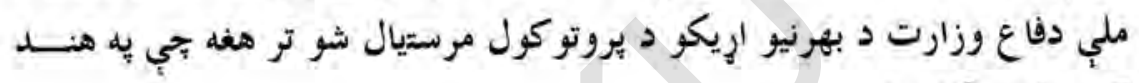

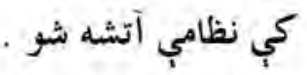

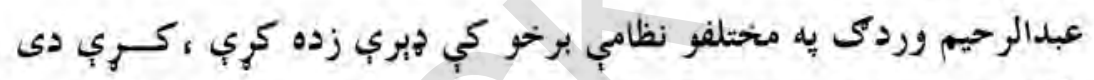

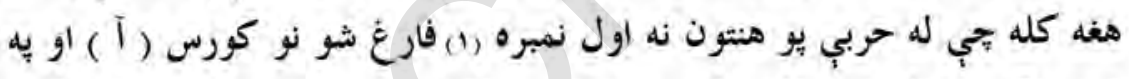

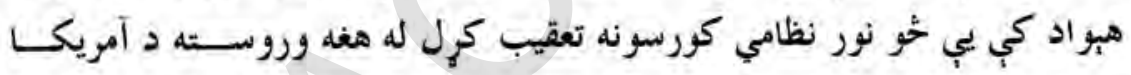

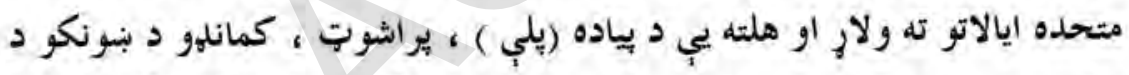

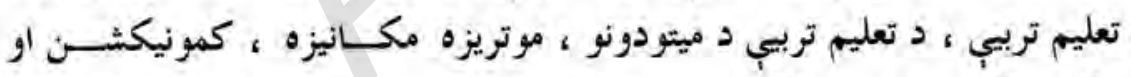

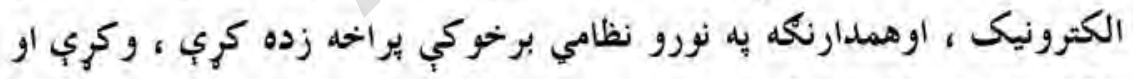

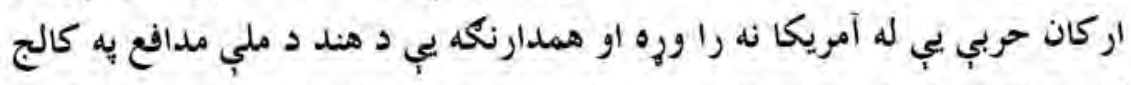

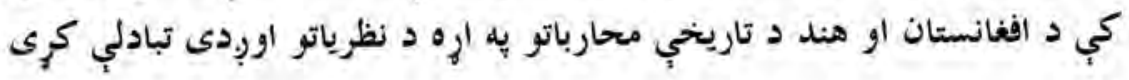
دي

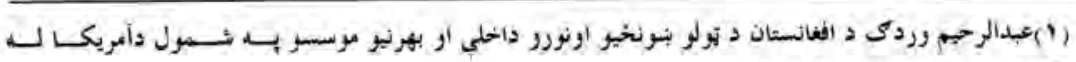
دريومكتونو نه أول نهره فارغ شري دي دي. 


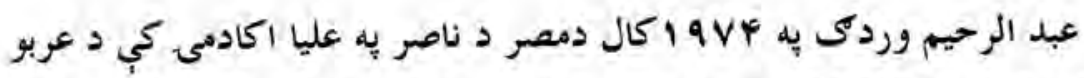

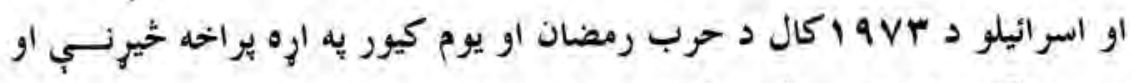
ارزوني كري دى او بريالى يايلي يجي به لاس را وري دي.

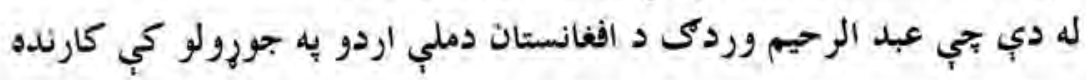

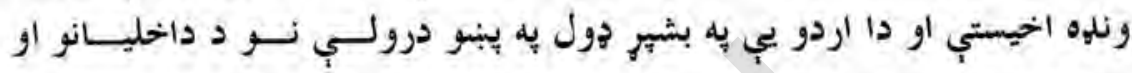
بهرنيانو تر منحُ بي د افغانستان د اردو د بلار لقب هم كتلى دى . عبد الرحيم وردكى يه يبنتو انكليسي او درى زبو زيرمفيد كتابونه ليكلي دى

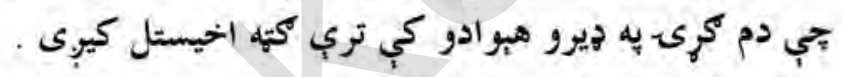

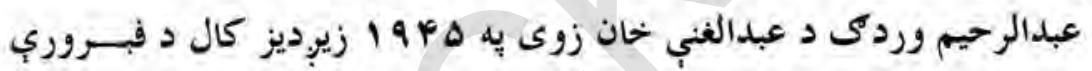

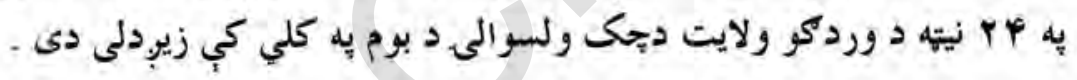




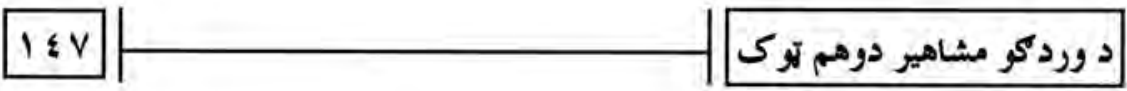

\section{عبد الكريم (خرم ) ــــد اطلاعات اوكلتور وزير}

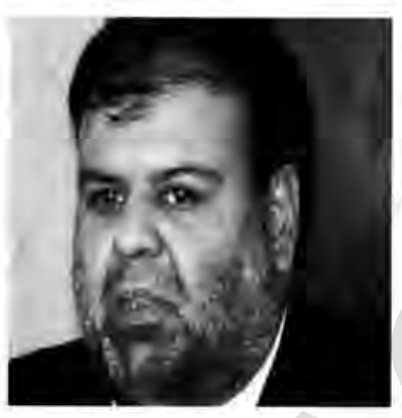

عبد الكريم (خرم) د هيراد د ادبي اوفرهنكي

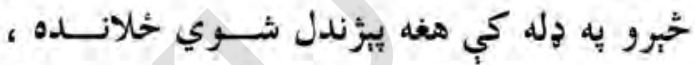
فرهكي اوادبي خيره ده تحي بشيرملي او نريوال حساب يري كبداى شي.

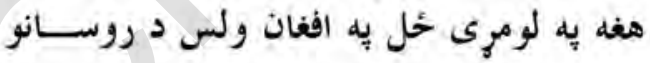
اوكمونستانو نا دودي اونورمظالم د يوه هنـــري فلم يه يرده د نريوالو دسالم اوعادلانه قضاوت لياره د هغوى ستركو ته ورغبركى كرل تجي كولاى شو ددغه هنري فلم جورول او ننداري ته وراندي كول د هفه د هنري شاهكاريواوادبي فعاليتونوترتولولوري شاخص وكنيو ددغه ترخنك خرم يه هفو ورخيانو كي جي د جهاد به إِه يب مطالب خجرول د مقالواونوروعلمي اوجهادي مطالبويه خيرولوهم بيل وكر .

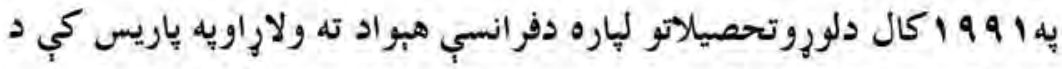
نريوالواريكو د مطالعاتو اوخيرنو به انسيتوت كي خه نريوالواريكو(دييلوماسـي)

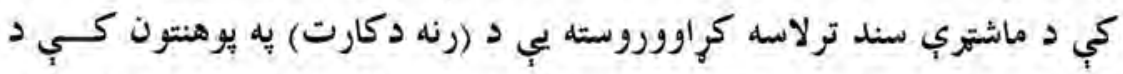
صادراتو، دحقوقو يه برخه كي دفوق ماشتري سند ترلاسه كر اوددغه ترخنـــ 


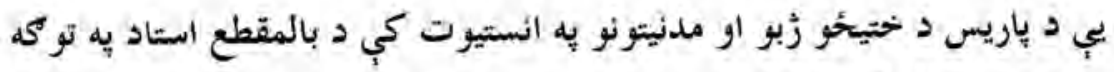

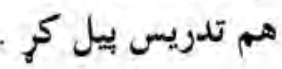

عبد الكريم خرم د هبواد به دننه اوبهركي هرخاى به بحي وو له مطبوعاتوسره

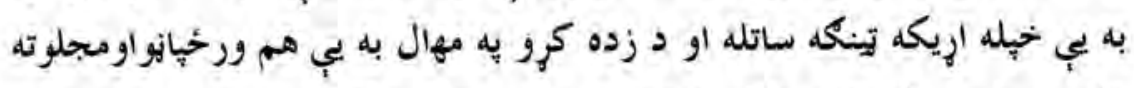

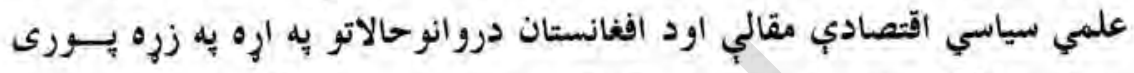
مضامين ليكل اوخيرول ، دوه توكه كتابونه جي يوبي د(شكست سياسب) اوبل ديل يب (قدرت هاى بزركى در تلاش بي قدرتى ) به نوم تجي (باسكال يونيياس) ليكلي

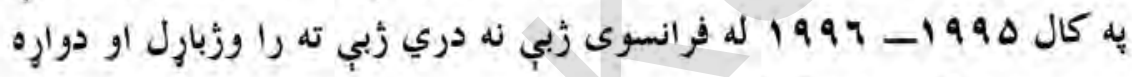

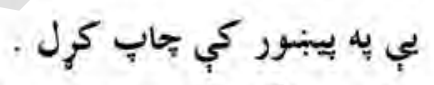

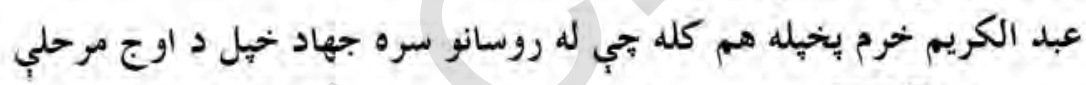

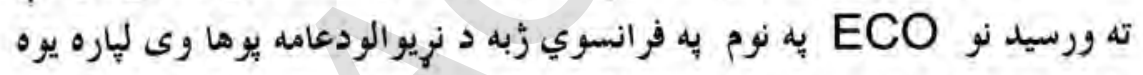

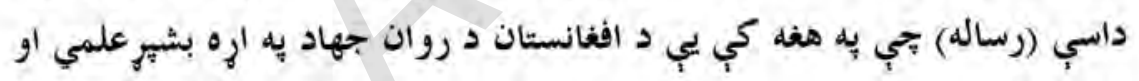

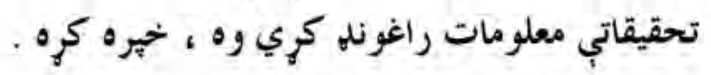

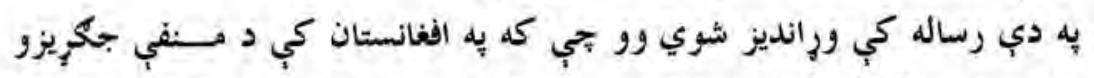

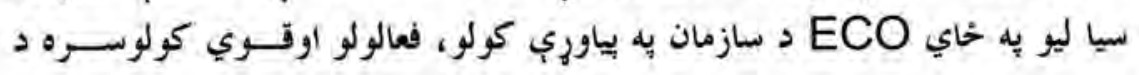

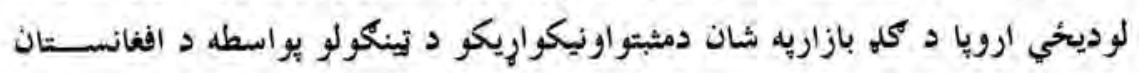

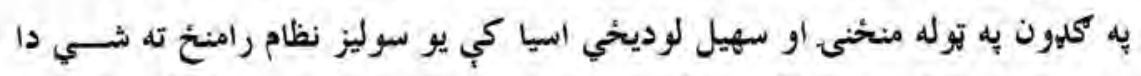

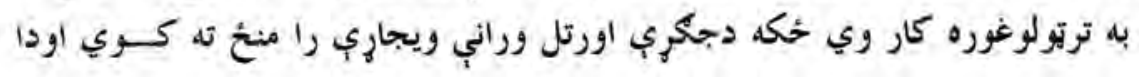

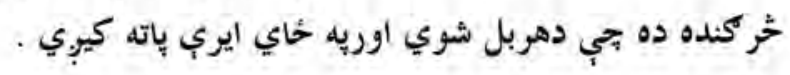




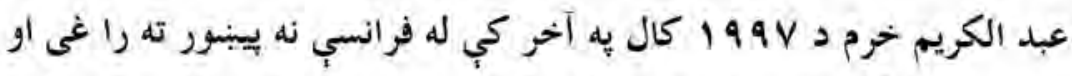

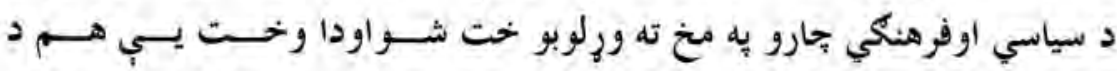

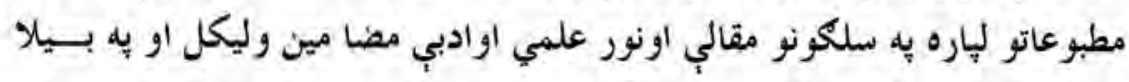

$$
\text { بيلو كنفر انسونو كي يب كلهون هم وركر . }
$$

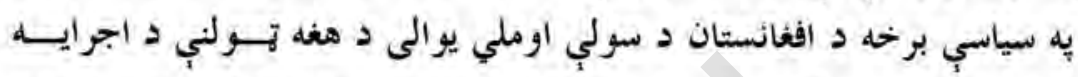

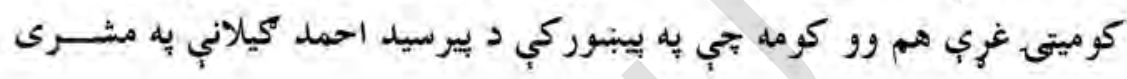
جوره شوي وه مان.

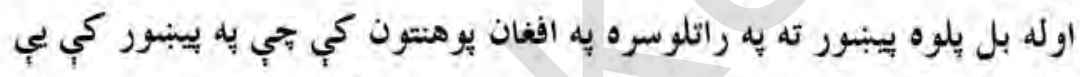

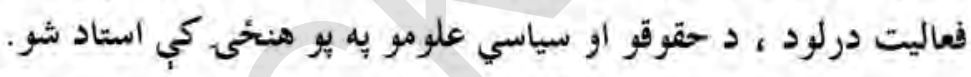

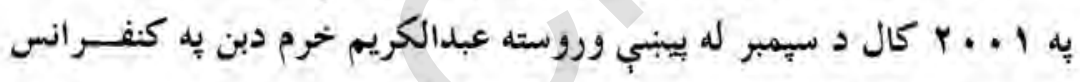

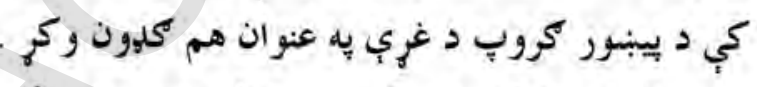

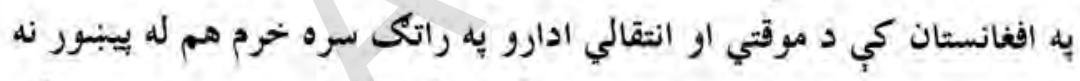

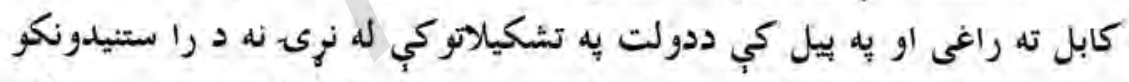

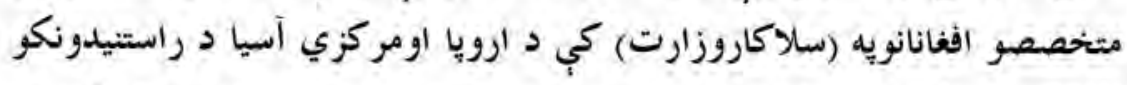

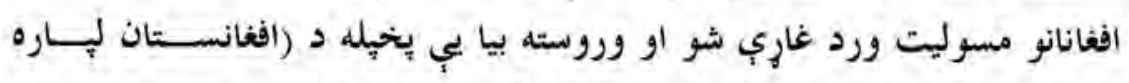

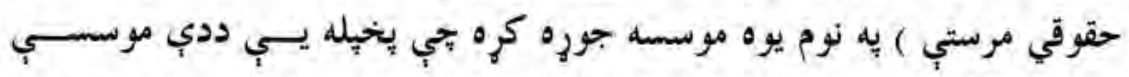

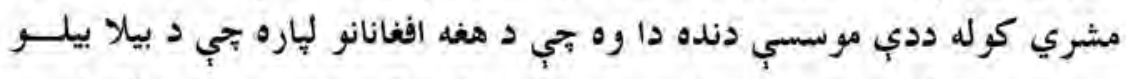

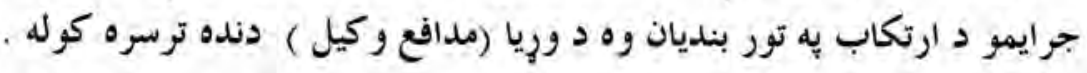

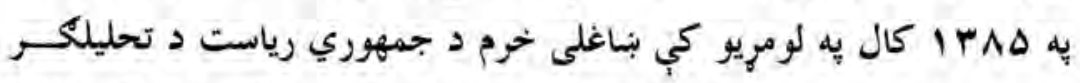
اوله كمي مودب وروسته د جمهوري رياست د مطبوعاتي سلاكار به توكمه و وتاكل 
10.

دو وركى مشاهير دوهم توكى

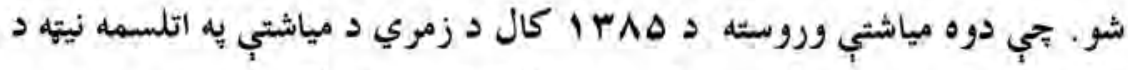
جمهور رئيس له خوا ولسي جركي ته د اطلاعاتو او فرهنك د وزيو به عنوان د باور درايب اخيستلو لياره ورويبرّندل شوجي هيه برياليتوب سره يب د باور رايــه ترلاسه كره او داطلاعاتو اوفرهنك وزير شو، اويردغه دنده دخلوركاله يه موده

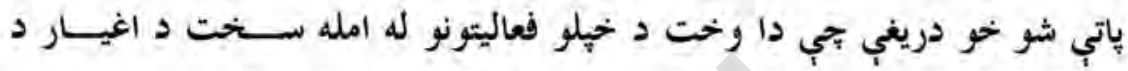
ستركو خار شو ، يووخت هغه د سنا مجلس ته ور وغوبنتل شواود (زلمى ) يٍ نوم يوه زابلي سناتور له ده سره كومه شخه شولانكه وركره ، كريم خحرم يه غصه شواودنوموري سناتور خوله يب د خحيل لاس د كوتو تو منتح د هغه ترستر كو لاندي

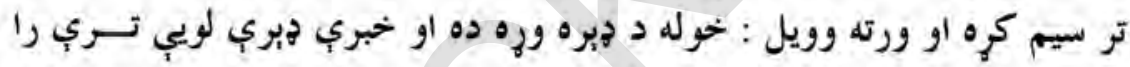
باسي، والله كه داسي راته بنبكاري لكه يو نخود ! سناتر خحواركى به حخان بوري

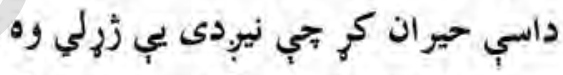
د اطلاعات او فرهنك به وزارت كي د عبدالكريم خرم نياكل رقييانو تل ديبر

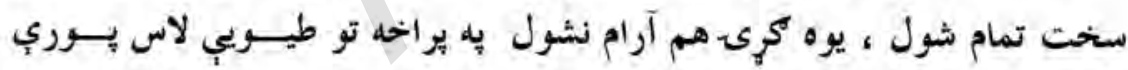

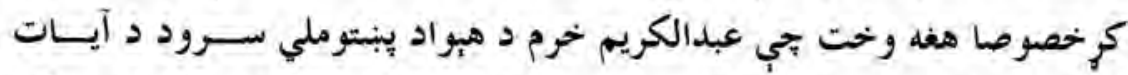

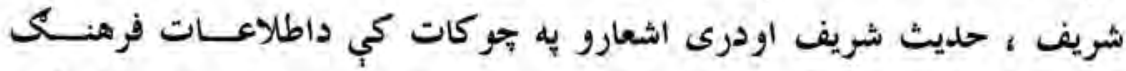
وزارت يه شهالي دبوال منقوش كر دهغه به دبنسمنانو يج دومره بده اغيزه وكره

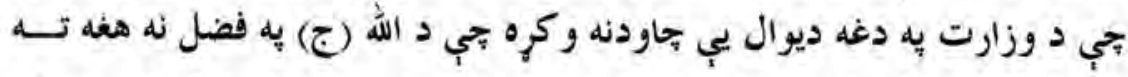
كوم زيان ورسيد او نه هم نقشونه را يريوتل ! اودوهمه جاودنه د قدندهار يه سفر

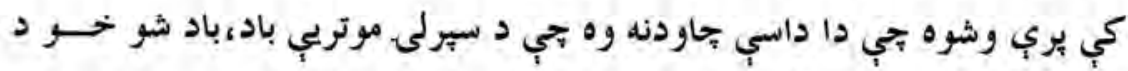
الله (ج) ساتنه وه عبد الكريم خرم ته بيا هم كوم زيان ونه رسيد .. 


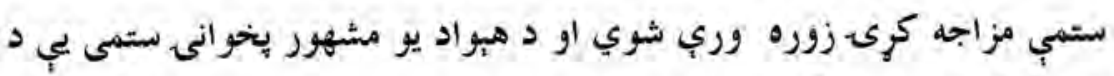

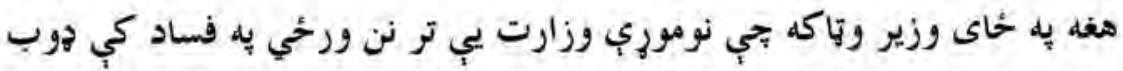

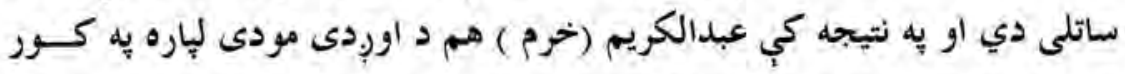

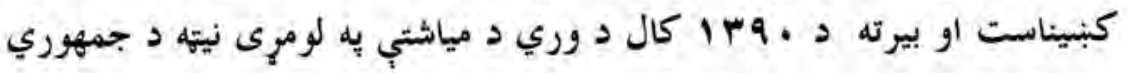
رياست ددفتر د رئيس يه تو كمه وتياكل شو او اوس هم نوموري دنده يو مـخ بيايجي كه د هغه دزوند لوميويو ته راومكرحونوعبد الكريم خرم هم دنورو كريدلو او

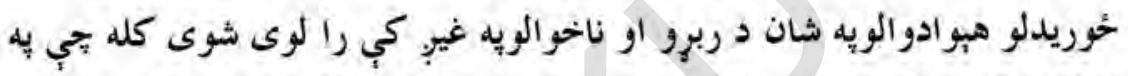
V V ا كال د كمونستانو كودتا را منئ ته شوه نوعبد الكريم خرم د استقلال د ليسي د نهم تولكي زده كورنكى وو له دي جي عبدالكريم خرم د كمونســانو سخت منحالف وو او له بيل نه د هغوى به ضد مبارزه روحيه درلوده نوله هماغي لومرى شيبي يب د كمونستانو دالحادي تيوري توري كندي ته د نويو حو انـانو دلوديدلونه د منخيوي او نجات لِاره هلي حخلي يبل كري هغه به دي لهّه كي شو جي دج حؤ انانو دسياسي نجات لهاره د نرى د سياسي مفكرينو د آثارو لوستل بيل كري عبدالكريم خرم دا وخت عملاً د مجاهدينوسره به كابل بنساركي د كمونستي نظام يو ضد فعاليت ييل كراود متعلمينو او محصلينو د ذهنيتونو د روبنسانولولياره

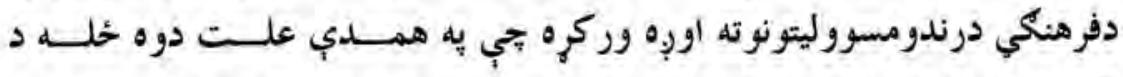

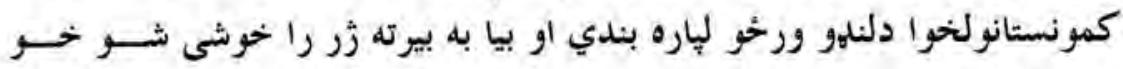

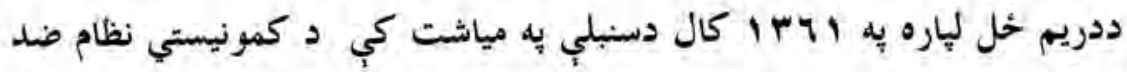

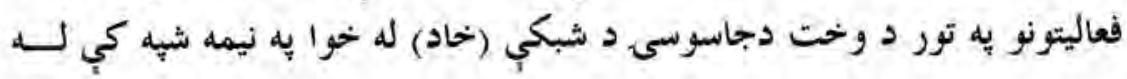


خيله كوره ونيول شواوبنديخاني ته وليوبدول شوله بنديخاني وروسته نجودي يسـو

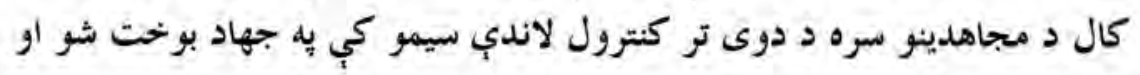

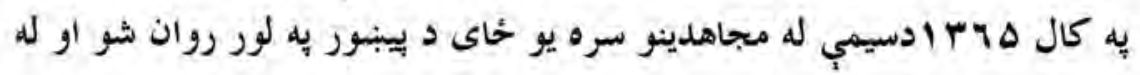

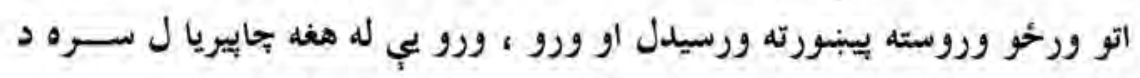

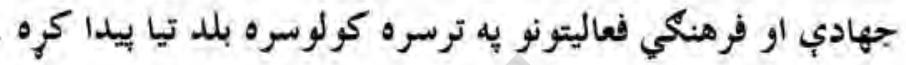

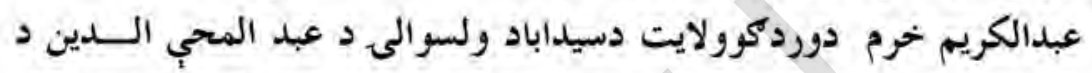

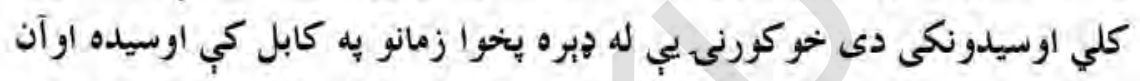

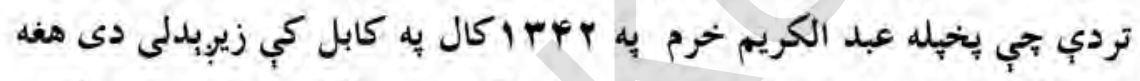

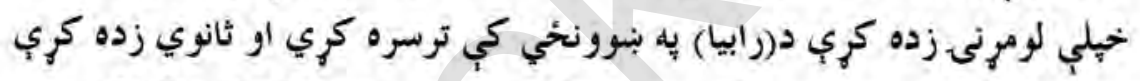

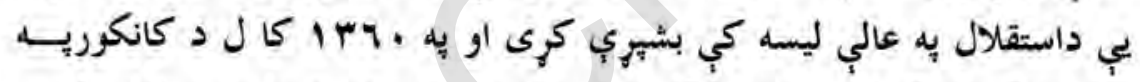

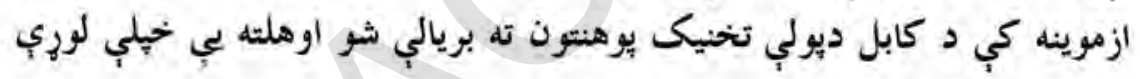
زده ترسره كري دي.

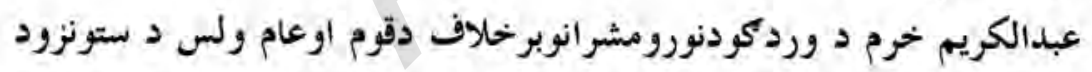

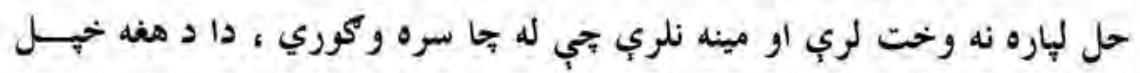

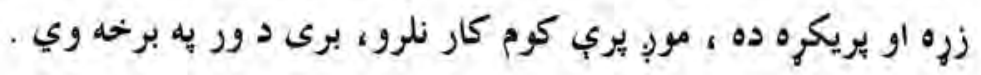




\section{عبدالله خان وردمى - وزير}

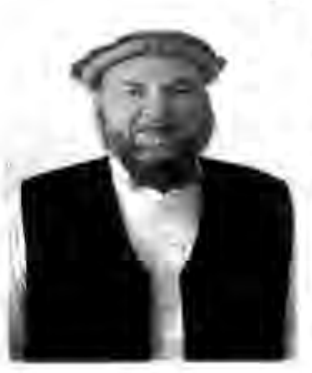

د عبد الله خان ورد كى اصل نوم (محمد جان) دي

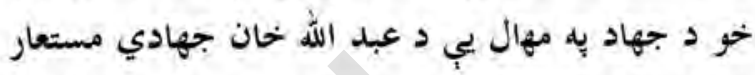

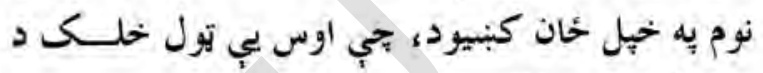
عبدالله خحان وردمى به نوم بيرني

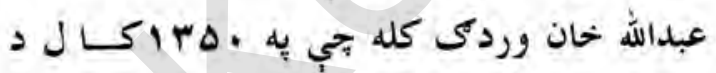

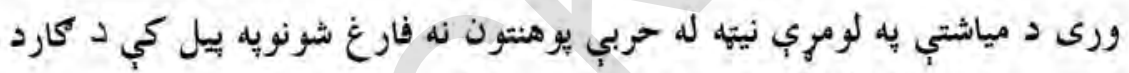

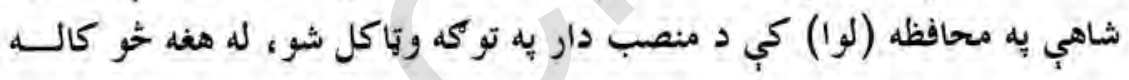

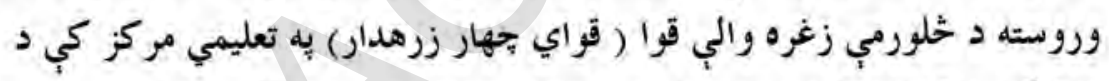

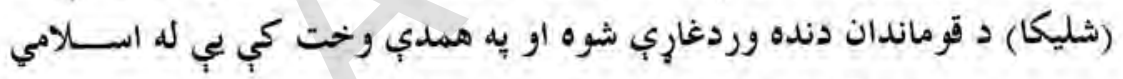

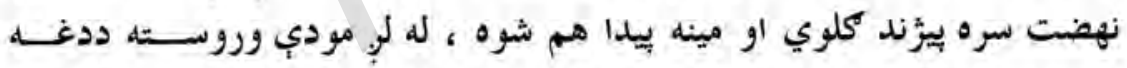

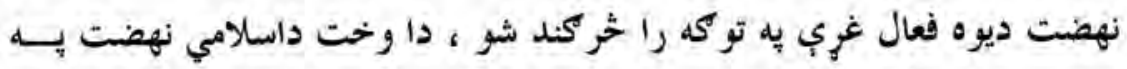

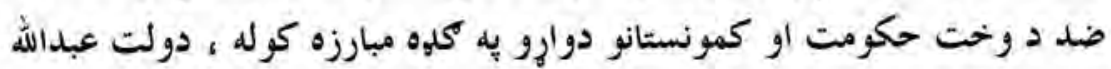

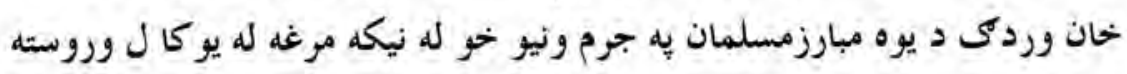

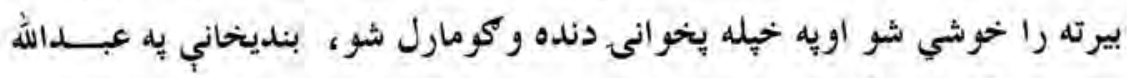

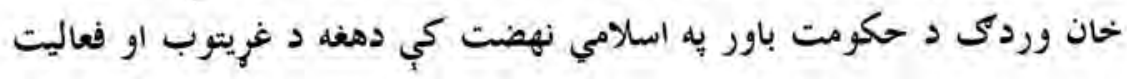

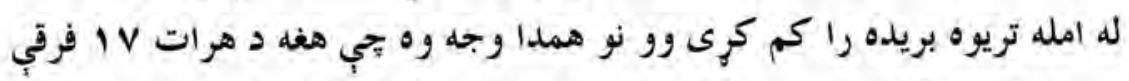

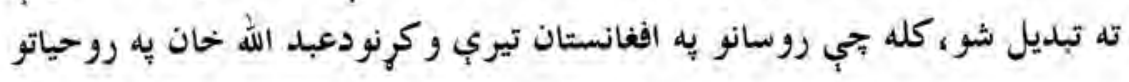




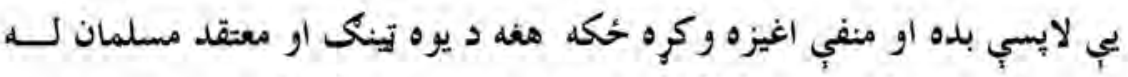

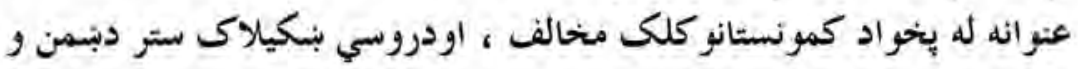

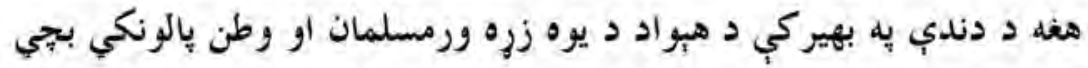

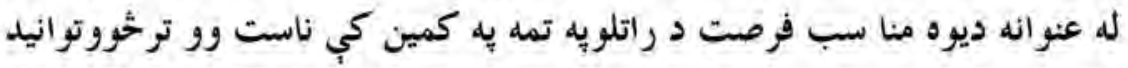

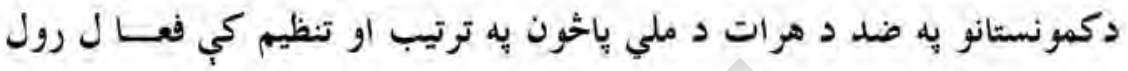
ولوبوي .

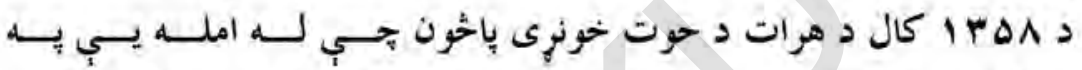

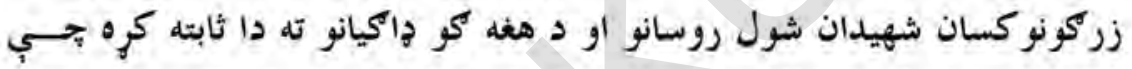

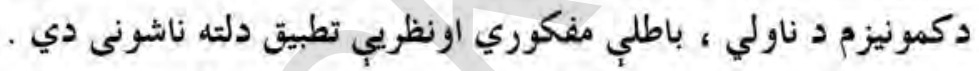

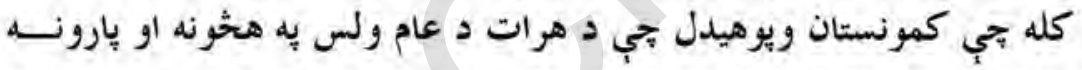

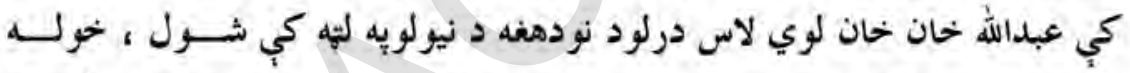

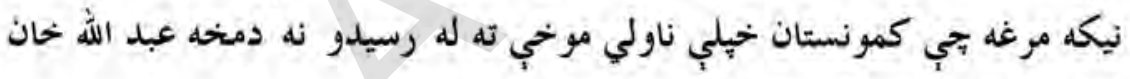

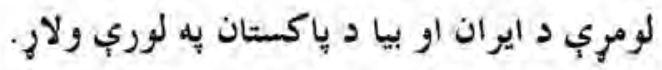

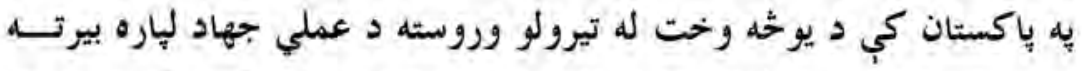

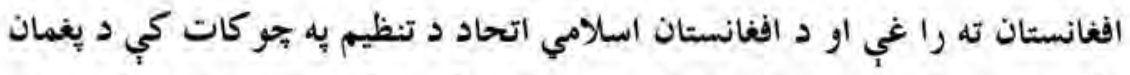

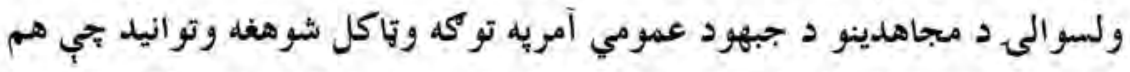
دا جبهي منظمي او اداره كري اوهم وخت به وخئ وخت يه كابل اغيزناكى عمليات

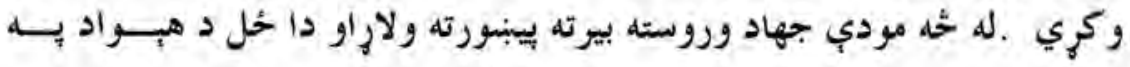

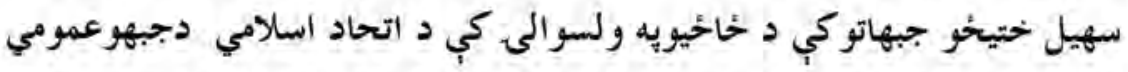

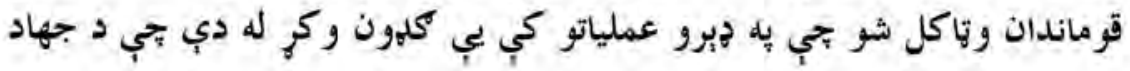




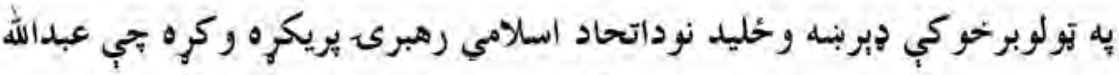

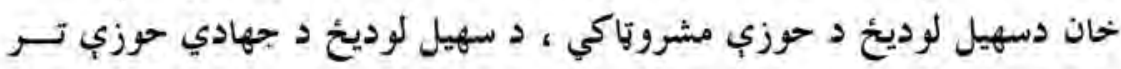
كنترول لاندي دا وخت دهيو اد(9) ولايتونوجهاد اداره كيده .

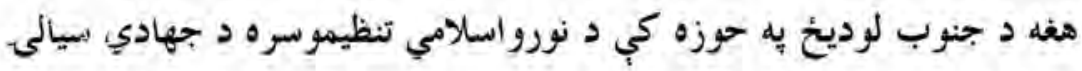

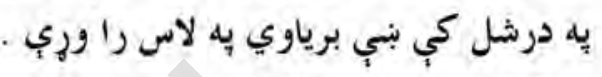

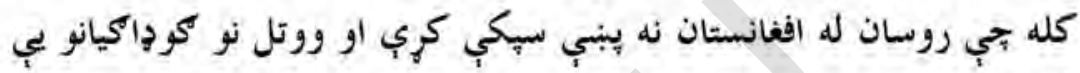

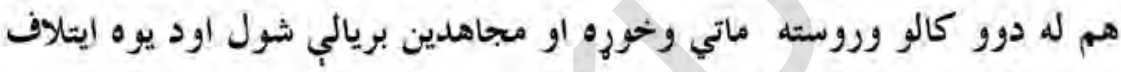

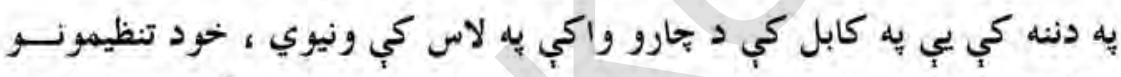

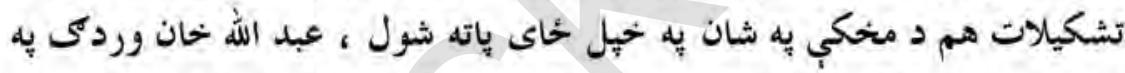

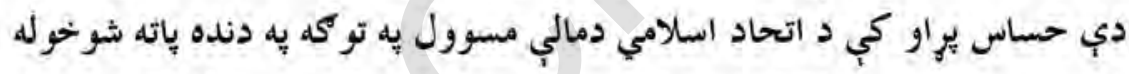

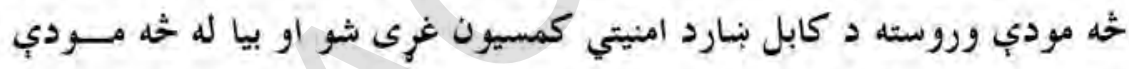

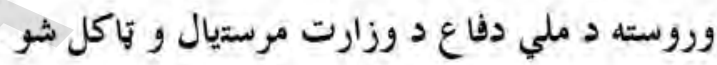

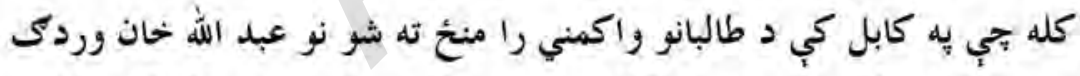

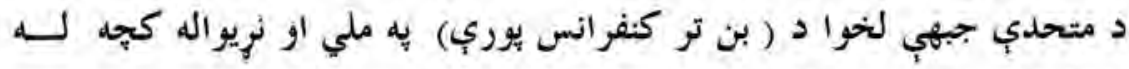

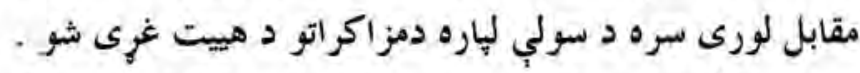

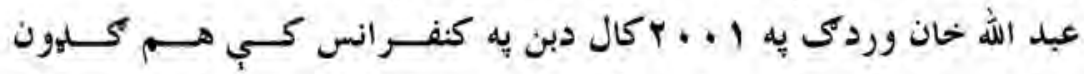

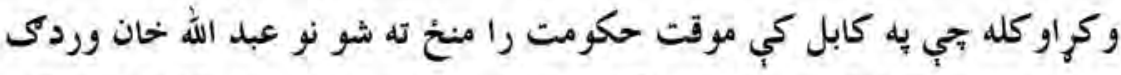
د شهيدانو او معلولينود وزيريه توكه وبّاكل شواوهمدارئل هم به دي جوكى ياته شو. 


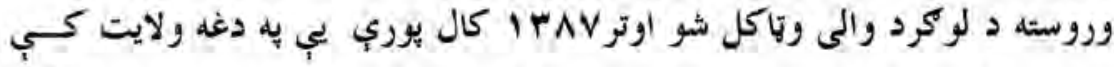

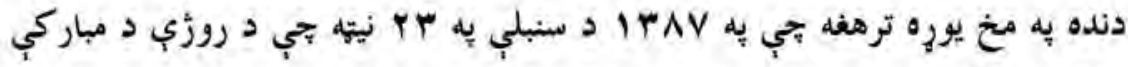

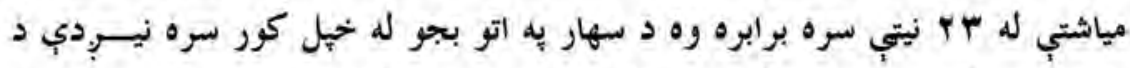
يغمان د يجك د تيب له خئك سره له خيلو دوو ساتونكو او يوه جحلونكي ســره يوه بنـخ شوي ماين د جاودني له امله جي ددين اورطن ددبنـــمنانولخوا ايبنـــودل

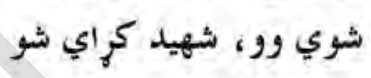

عبدالله خان وردكى يه ملك كي د سولي د تامين او د ملي يراختيا او يرمختيا لياره دنرى ذهبرشمبرهبر ادونوته لكه آمريكا ، انكلستان ، آلمان ، فوانسه ، سويس ، هالند ، ايتاليا ، اتريش، تركيه ، سعودي عربستان ، عمان ، عربى متحده

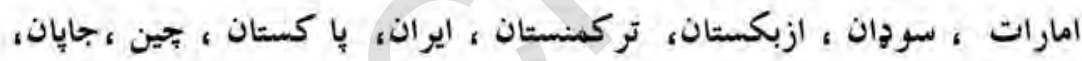

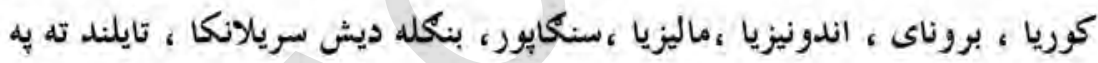
سيمنارونوخبرو اترواو كنفر انسونو كي د كلهون لِإره سفرونه كري دي هغه به به يبنتو، دري انكلسي اوعربي زبه رواني خبري كولي عبد الله خان ورد كى د بيت الله شريفي به زيارت مشرف شوي او حاجي هم وو اوتئي

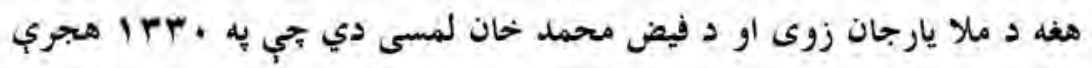
كال د سيد آباد ولسوالى د سبي سى به كلي كي به يوه دينداره او مسلمانه كورنى

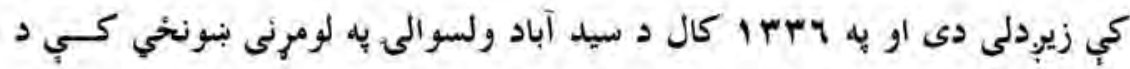
زده كرو لِياره شامل شو له هفه ورو سته به حربي بنسونخي كي شامل شو اود حربى

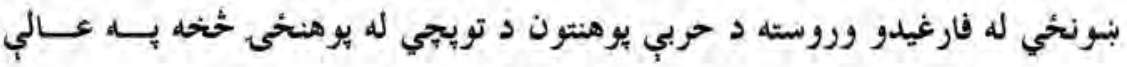

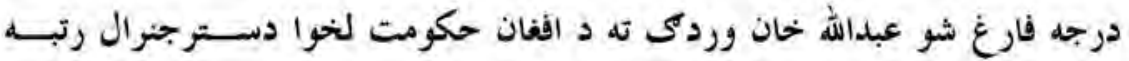




\section{عبد الحنان خان ، مينه بال - قوماندان}

عبد الحنان خان (مينه يال) د وردكو د يخوانيوعسكري منصب دار انويه جهله كي يو يثزندل شوي اونوميالى منصبدار وو جي له نامه سره يب نه يوازي وروكى بلكي تول افغانان بلد دي . عبد الحنان خحان مينه بال كله جي له حربي يوهنتون نه اول نمره فارغ شو نو يه جيروخايوكي ددندي د اجرا ورإنديز ورته وشو خوهغه يه خيله رضا اورغبت

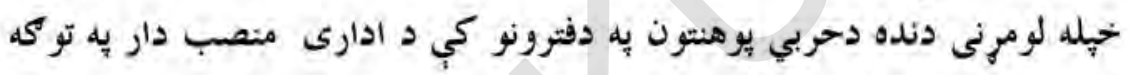

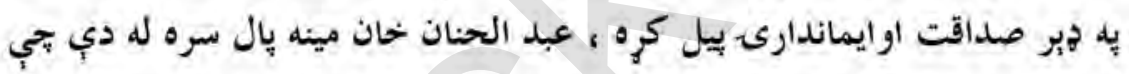
ورظظفيت او لياقت بي درلود ، قانوني سرى هم وو، احمد شاه د محمد ظاهرشا زوى تجي دا وحت د حوبي يوهنتون محصل وو يوه ورؤ يب د عبد الحنان خان

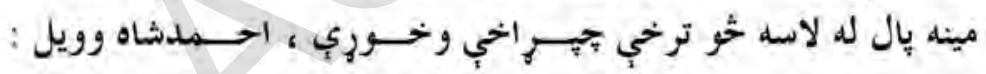

$$
\begin{aligned}
& \text { - ما يبزّني بجي زه خوكى يم ؟ } \\
& \text { - عبد الحنان -حان ورتة وريل = }
\end{aligned}
$$

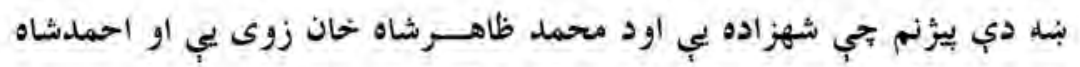

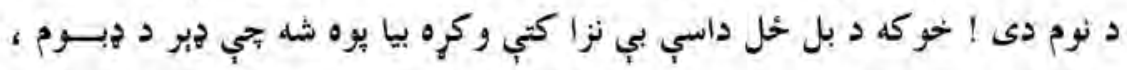

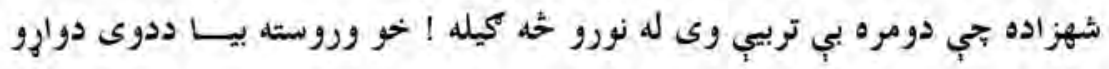

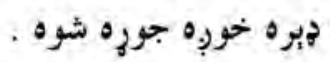

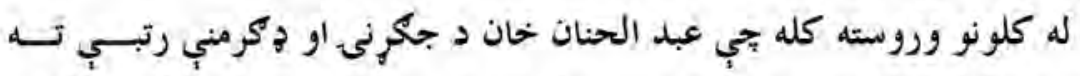
ورسيد نود ملي دفاع وزارت درستيز وال شو تي د هغه وخت يه نظامي ليكــــ 
كي دايوه ونبره لوره اوباصلاحيته جو كى. وه له هغه وروسته يب د كورنيو جارو 2

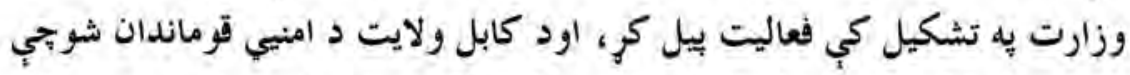

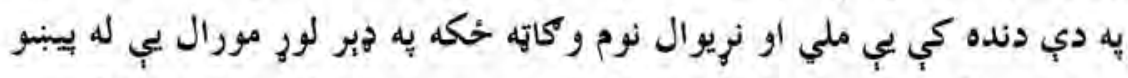

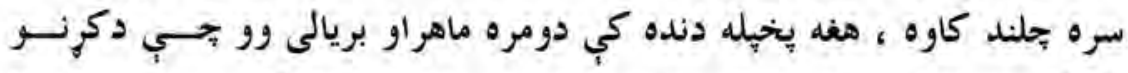

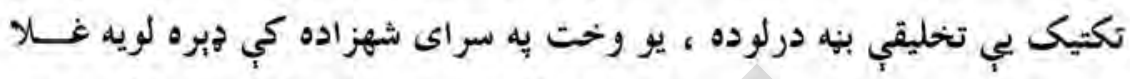

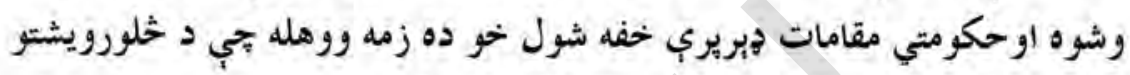

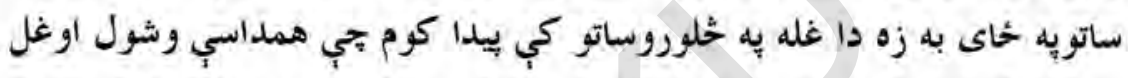

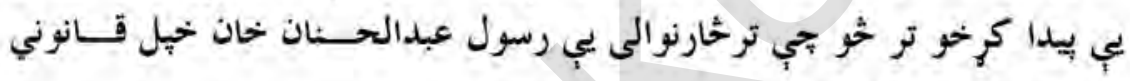

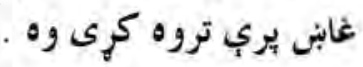

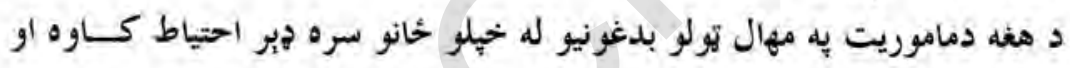

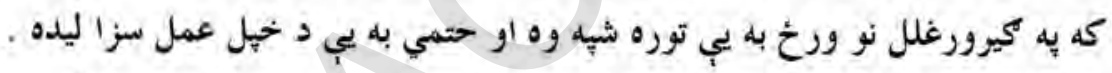

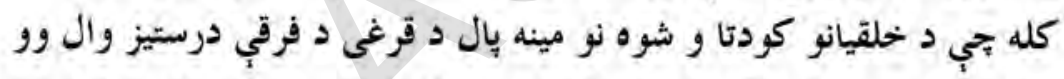

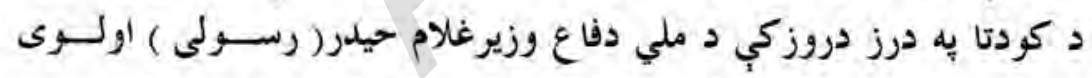

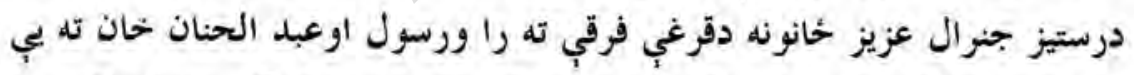

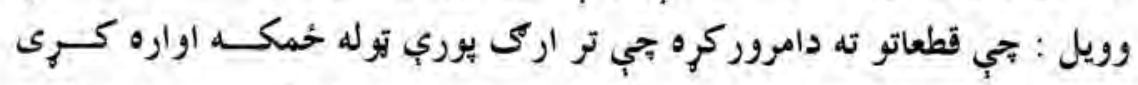

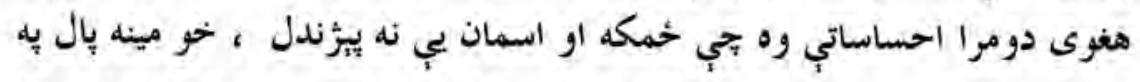

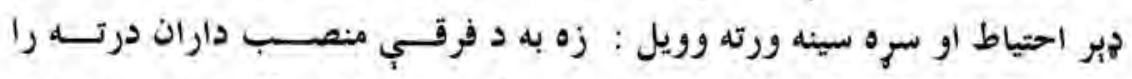

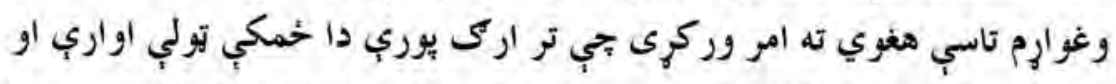

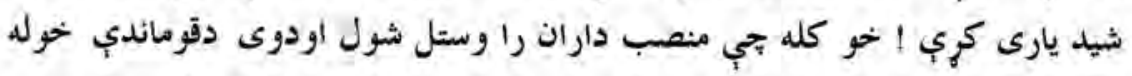

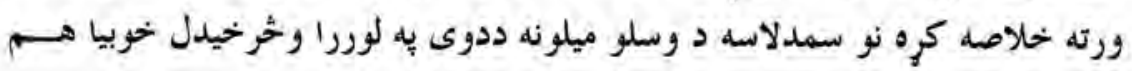




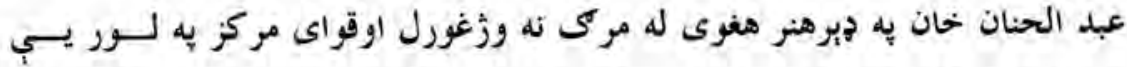

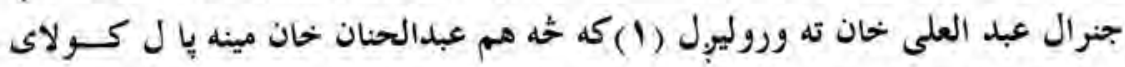
شول بتي كودتا له بشيري ناكامى سره مخ كري خو هغه يه دي برخه كي د محسد

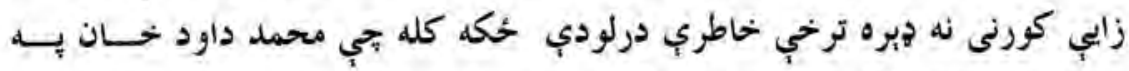

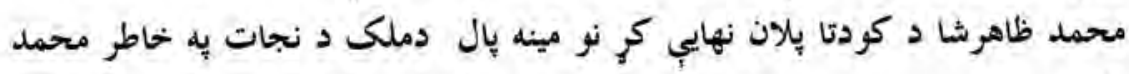

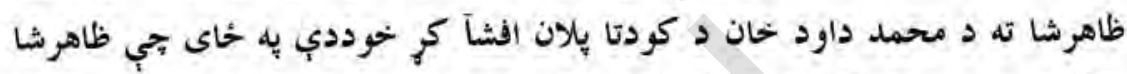
د كودتا به مخنيوي كي اقدام وكري عبد الحنان خان مينه بال ته يب وويل : اين موضوع بي خانكي ماست (دا زمورج كورنى مسله ده ) كله جي د دمحمد

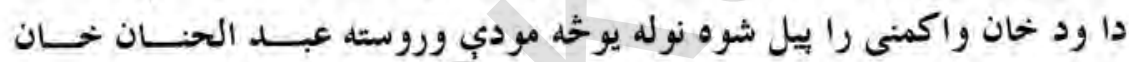

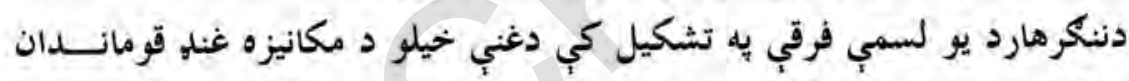

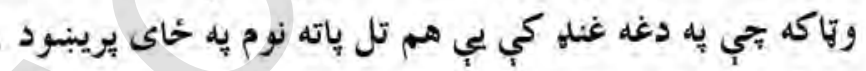

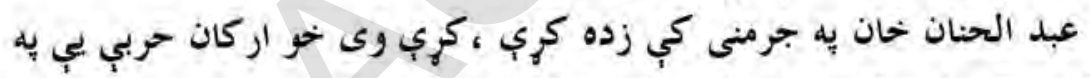
جكرنى كي له تركي نه راوري ده ، هغه د سياسي حالاتو يه تحليل او تفستسير

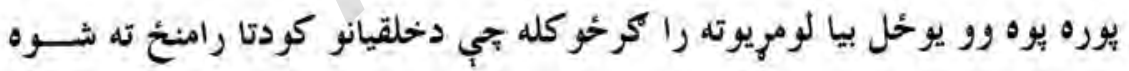
نويوه باورى شخص د روانو سياسي حالاتو به اره له هغd نه يو بنتثنه وكره ، هغه

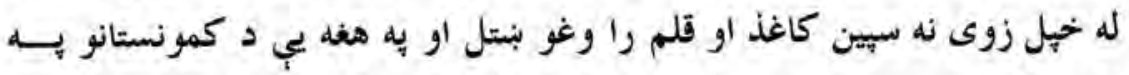

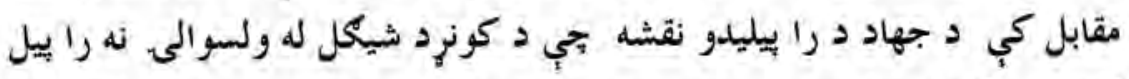
كيده ، وكبنله ! او ورو - ورو يب د جهاد دا يروسه هغه سيمو ته جي واقعا بيا

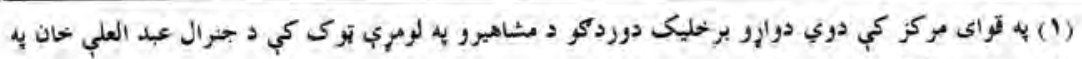

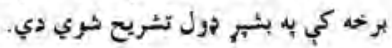


17.

دوركو مشاهير دوهم ترك

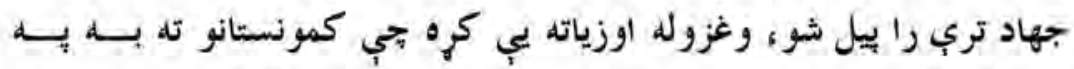
سياسي ذوكر كي سرخوربى جوريوي او روسان به رأ دعوت كوي خحو د روسانو

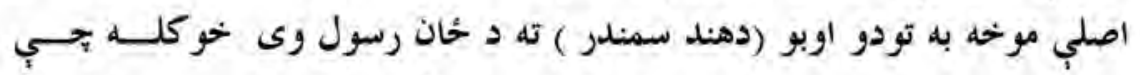

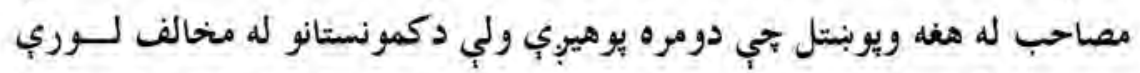

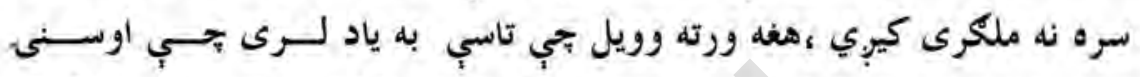
تنظيمونه به ديريوي دوي به يو به بل باور له لاسه وركوي ، خيل منحي جكي لهي

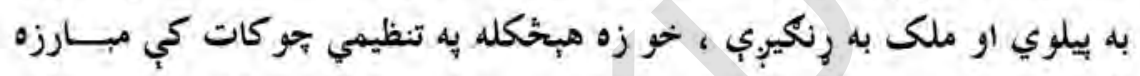

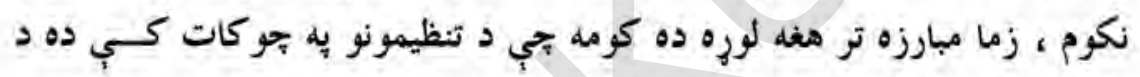
اضدادو يه بحو كات كي مبارزه دهبواد د تباهي او بربادى سبب كيوبي .

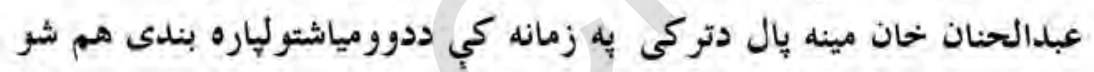
خو له نيكه مرغه بيرته زورندى شو .

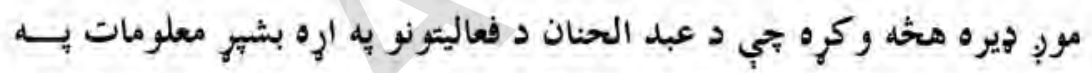
لاس را ورور خو هو خو هلي خلي تجي راخوشى مو وكره بريالي نشور او دا لند.

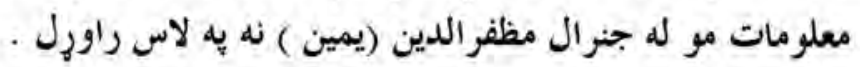

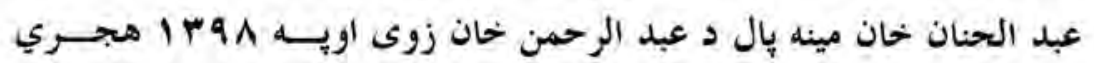

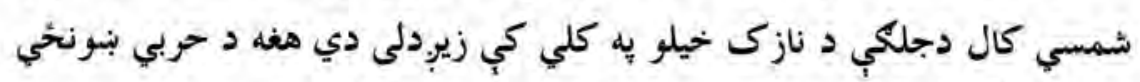
دوهم تولكي ته شامل شواو تر حربي يو هنتون يوري اول نمره وو . 


\section{عبد القديم آخند زاده - ولايتي امير}

مولوي عبد القديم آخند زاده له يِيل نــهـ مبــارز

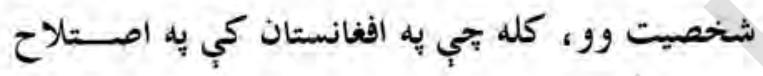

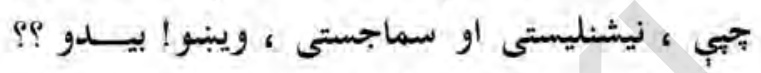

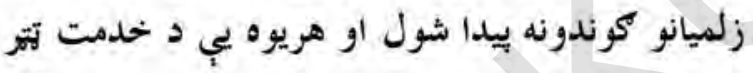

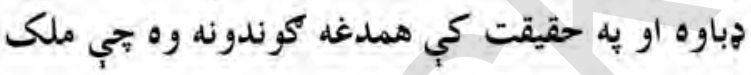

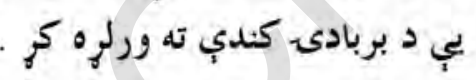

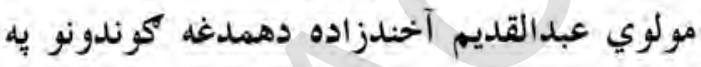

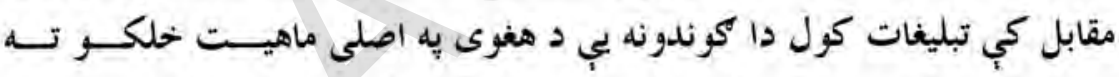

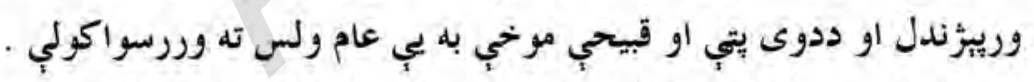

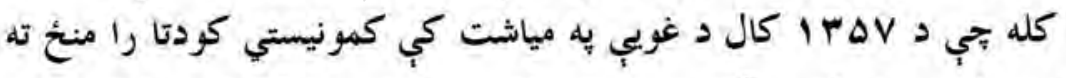

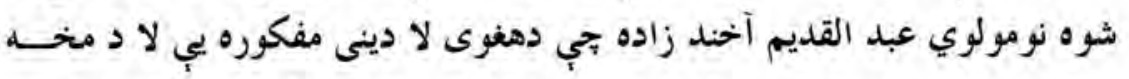

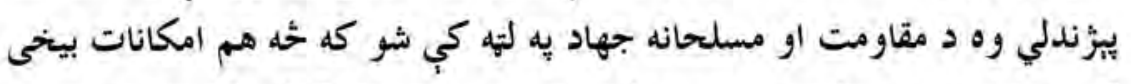

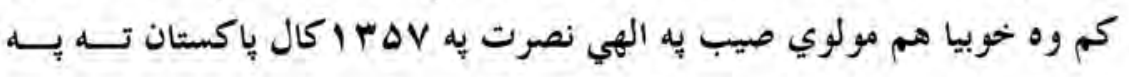

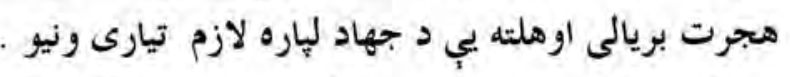

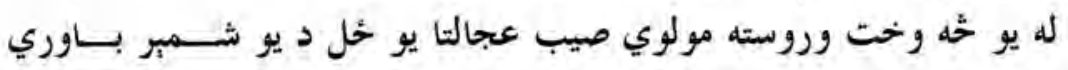

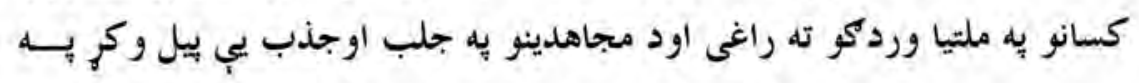


دوى دا وحت جيوي سختي شيبي را غلب خكه د شبي لخوا به دوى جلب او جذب

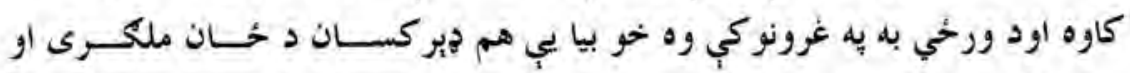

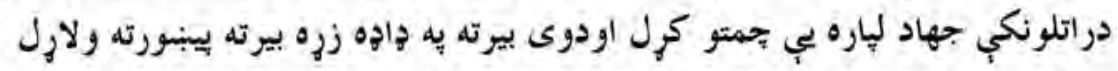

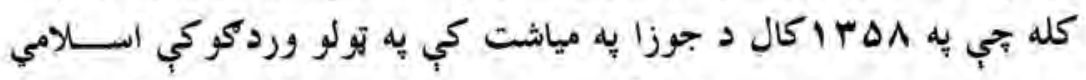

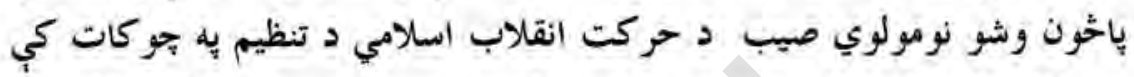

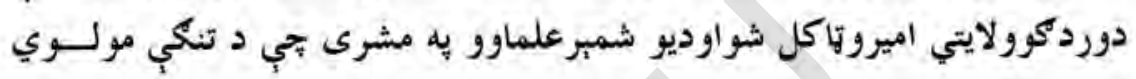

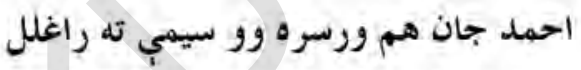

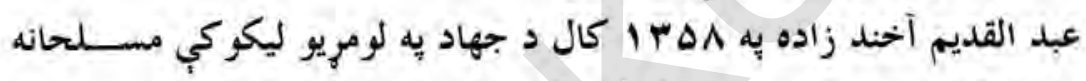

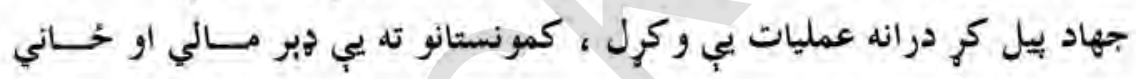
زيانونه وروارول دآخند زاده صيب جهاد يوازي د وردكيو يه سيمه كي نه وه محدود بلكي دهغه

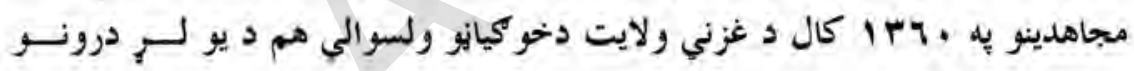

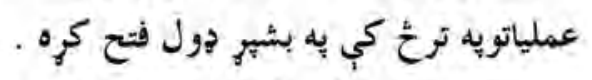

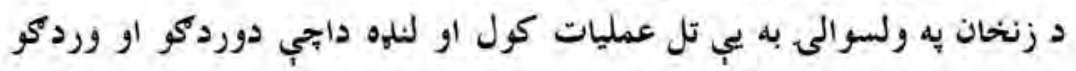

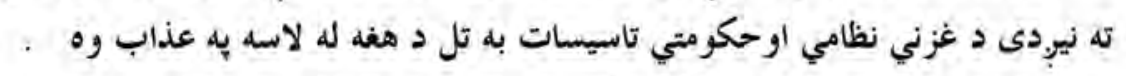

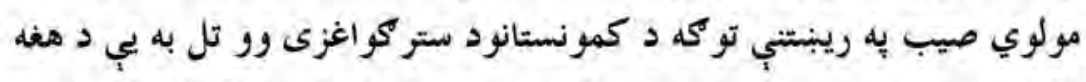

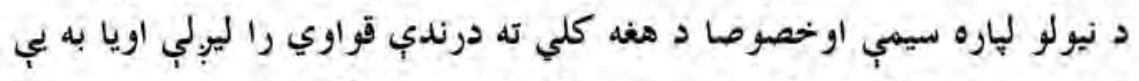

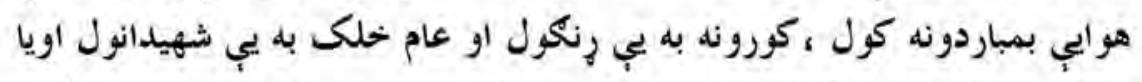

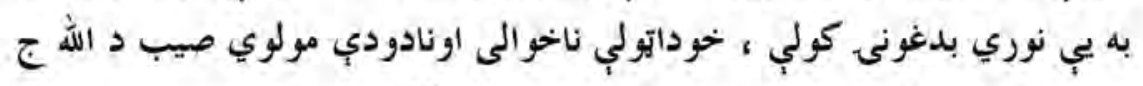

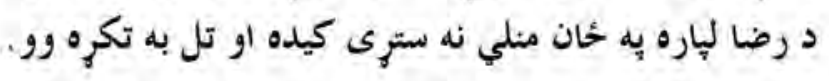


مولوي صيب هيخكله دهجرت يه مقصد د خيلي سيمب يريبنودو ته زره بئسه

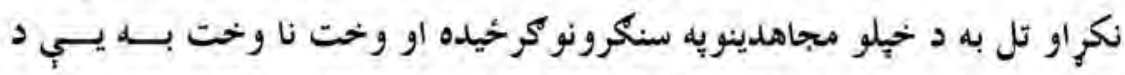
وردكوتولوولسو اليوته دجهادي سنكيرونو د ليدو لِاره سفرونه كول او يسـه دي توكه به يب د حركت انقلاب اسلامي د ولسو اليو له مسوولينو سره دجهاد د بنه

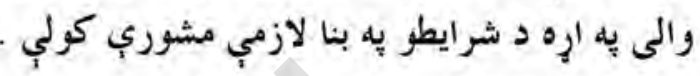

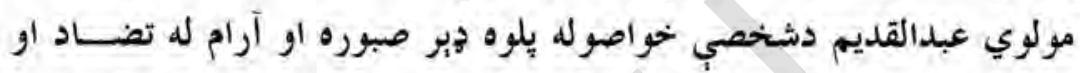

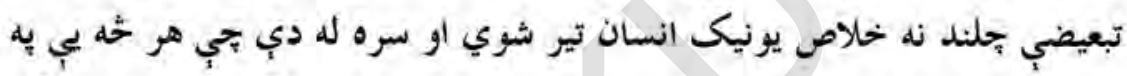

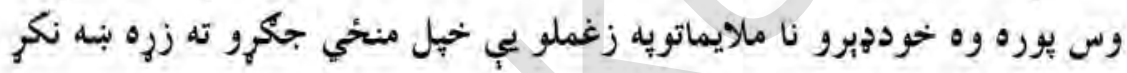
او نه هم دداسي بلد بختيو تاريخ لري

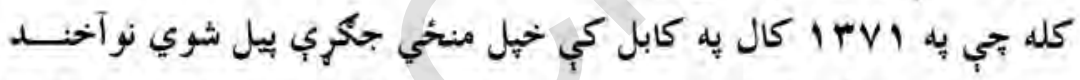

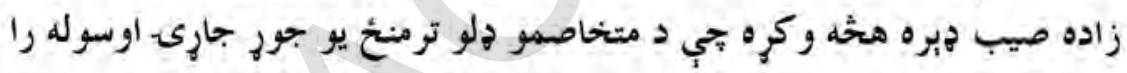

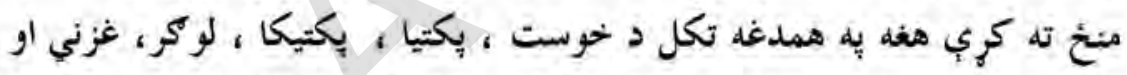
وردكو دمجاهدينو مشر ان سره راتول كرل اود ششكلا به كلي كي يب يوه لويه

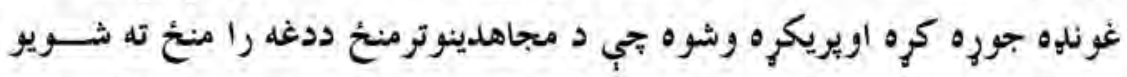

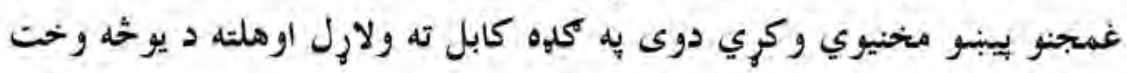
لهاره د متخاصمو ولوتومنحُ د حايل يله توكله واقع شول خو (بيا همو خركى همو

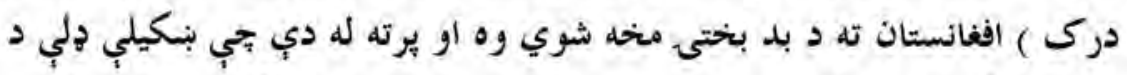
قر آني احكامويه رنا كي د اسلامي انقلاب د لاسته را ورنو شكر ان به خحاى كري

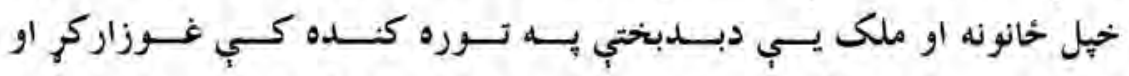
ددنسمنانو(روسانواو كمونستانو ) (سوخي) يب را سري كري ، ملامت بلهي نه 


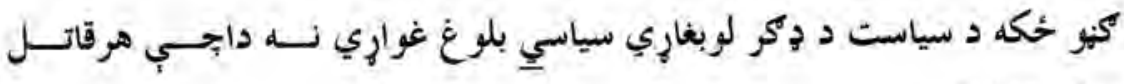

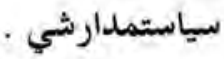

مولوي صيب عبد القديم آخند زاده د خحلكو د اولادونو له ليك او لوبسـت دهي

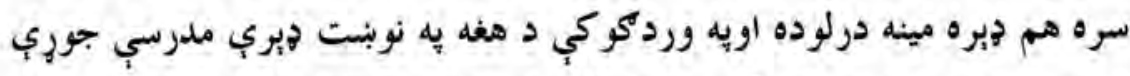

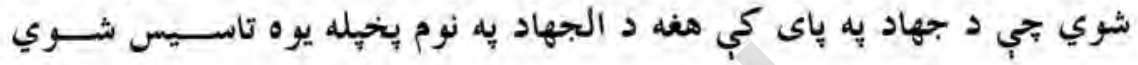

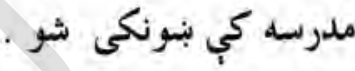

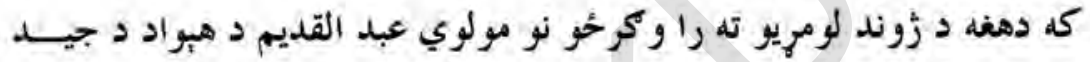

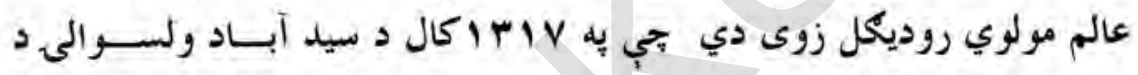

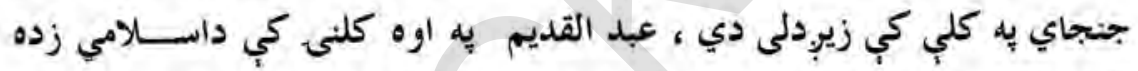

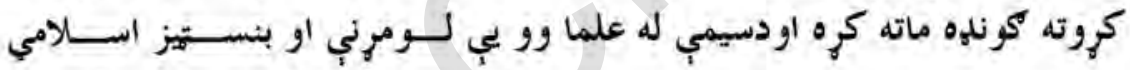

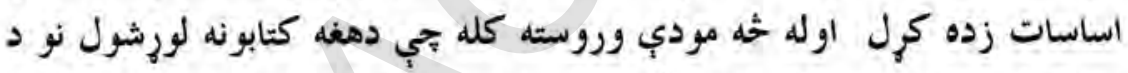

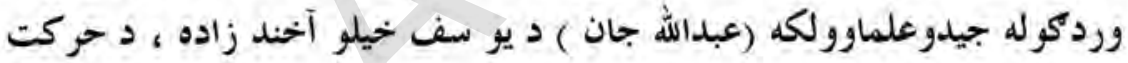

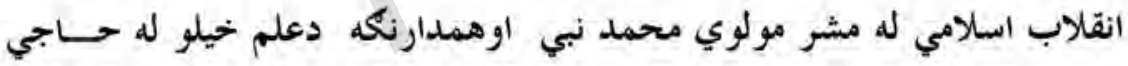

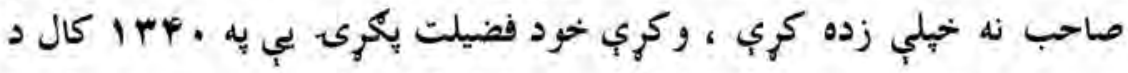

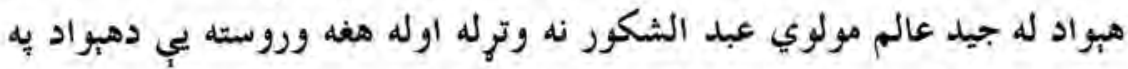

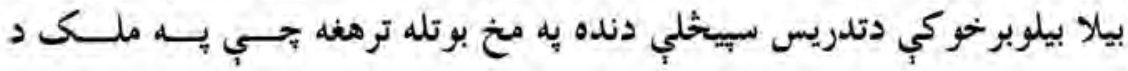

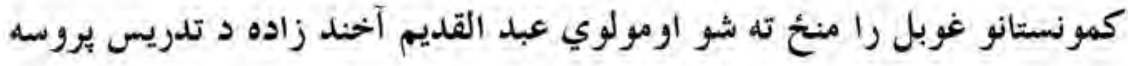

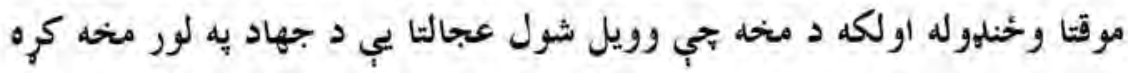

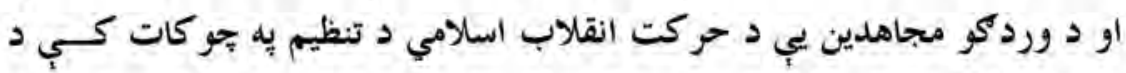

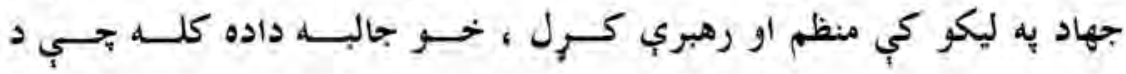




\section{0}

د وردك مشاهير دوهم توكى

يوغلكرواوطا غوتيانو واكى يه ملك كي ختم شو نو مولوي صاحب يرته له دب

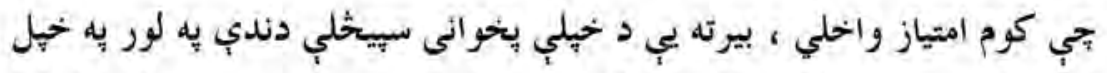

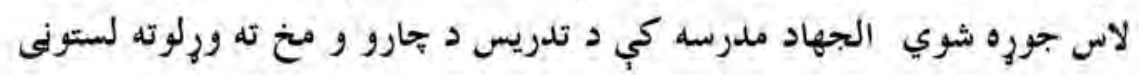

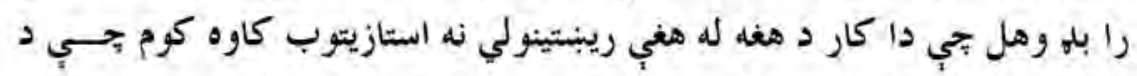

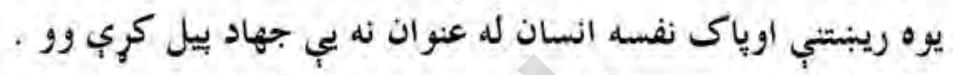

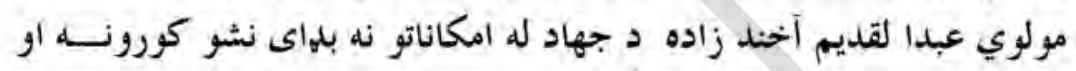

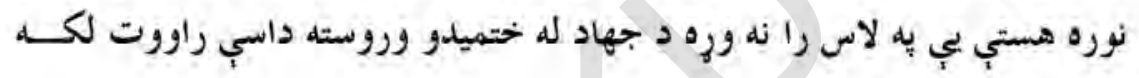

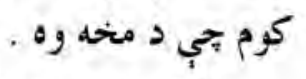

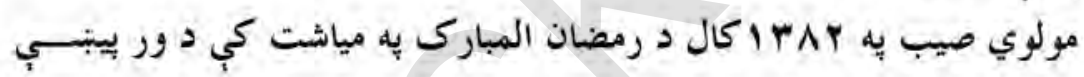

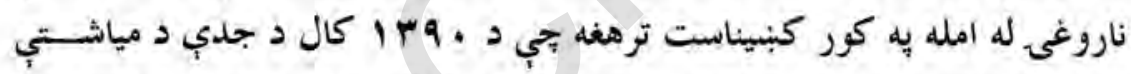

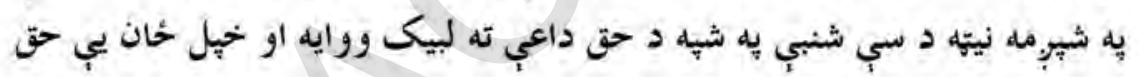
ته تسليم كر. 


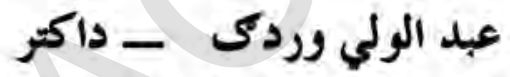

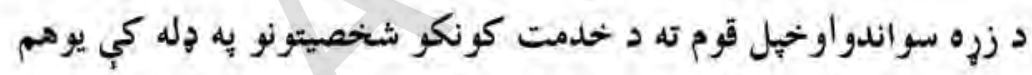

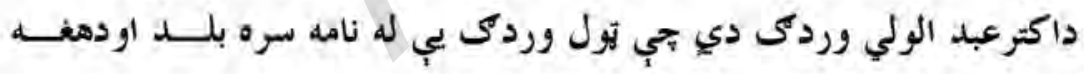

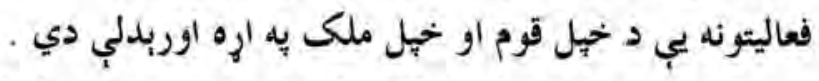

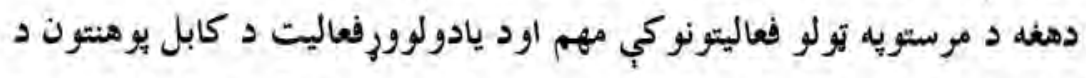

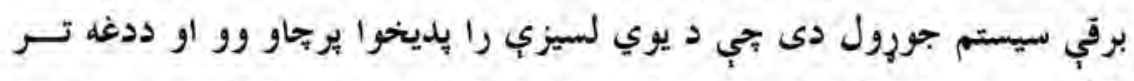

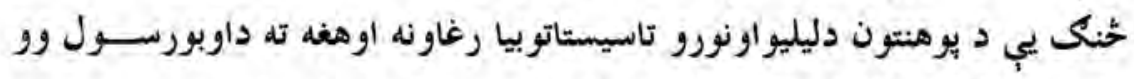

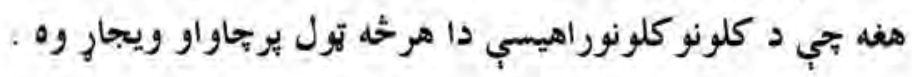

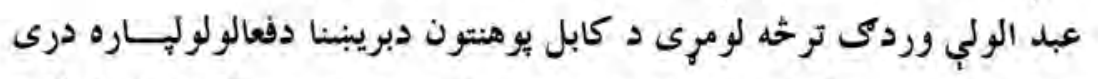

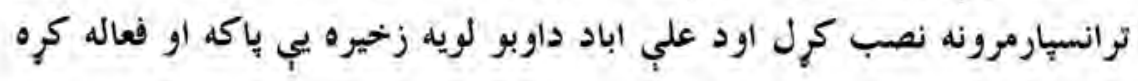


او يه دي توكه بِ د كابل يو هنتون د ليليو ينخم منزل ته اوبه وخيثولي اوكله

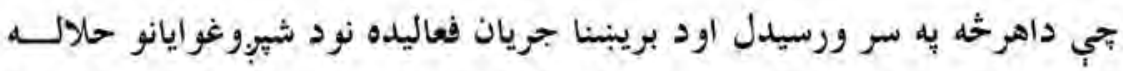

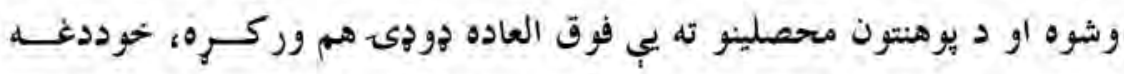

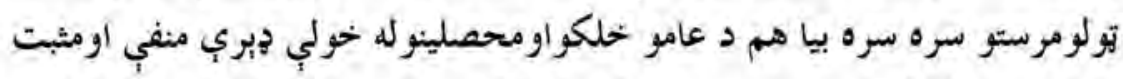

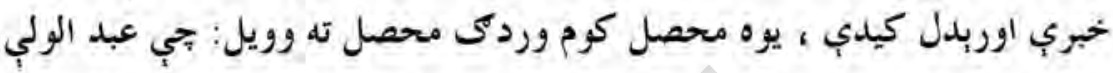

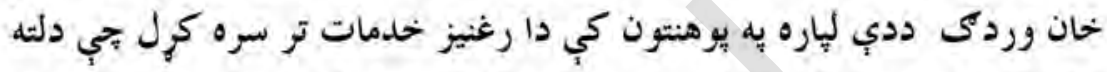

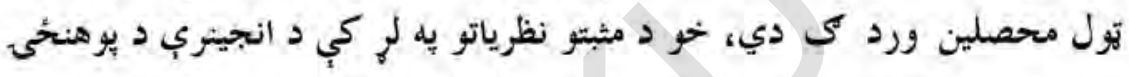

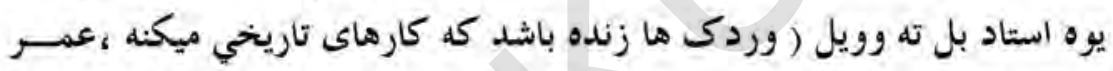

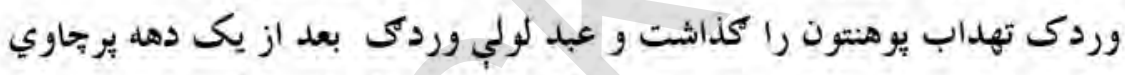

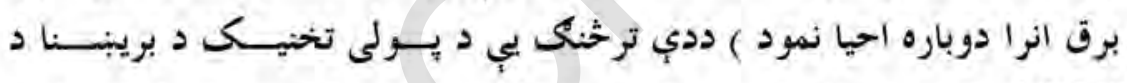

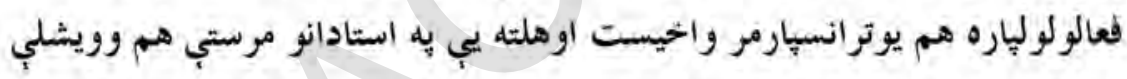

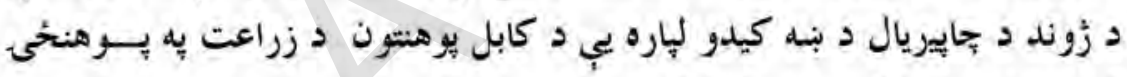

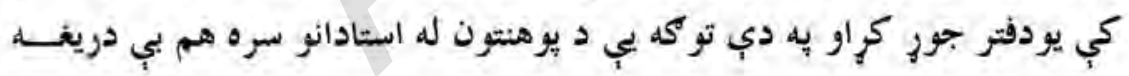

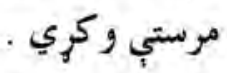

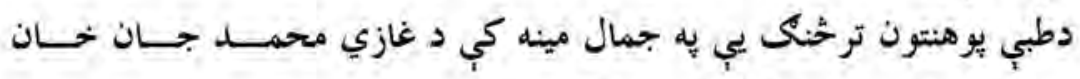

$$
\text { ترجومات يوري هم د سركى مرمت وكير توني }
$$

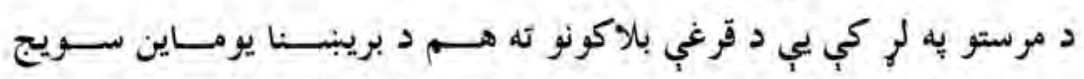

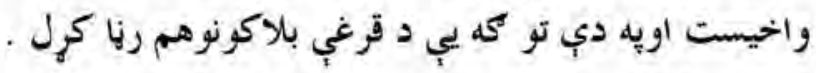

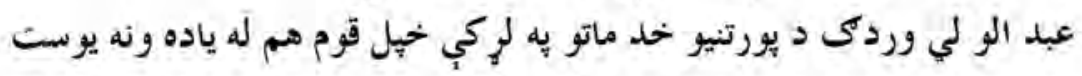

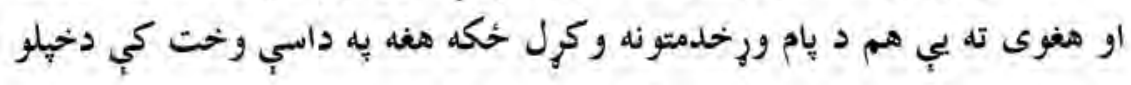




\section{1}

د وردكو مشاهير دوهم توك

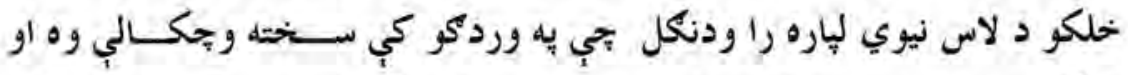

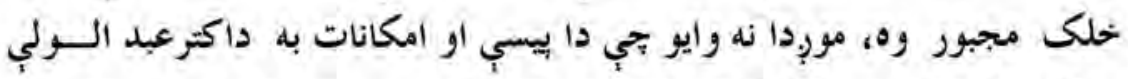

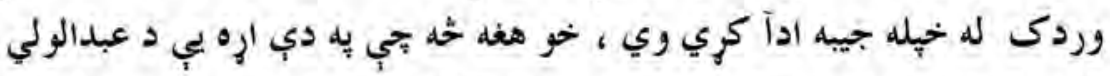

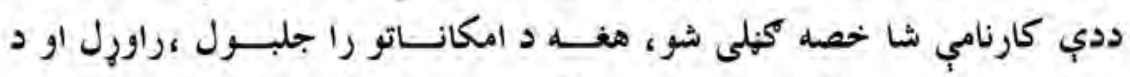

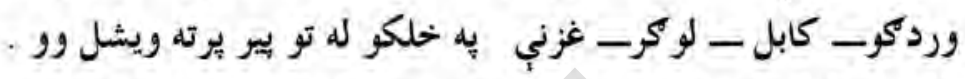

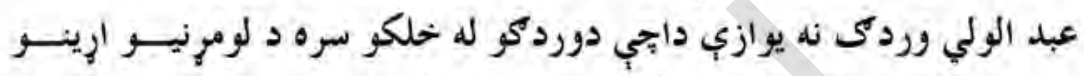

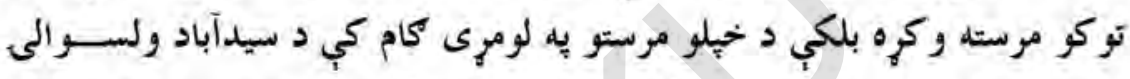

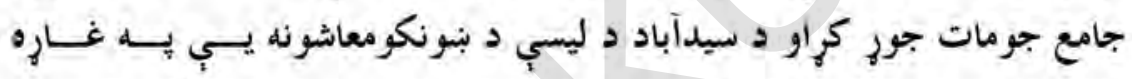

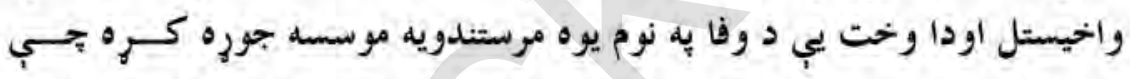

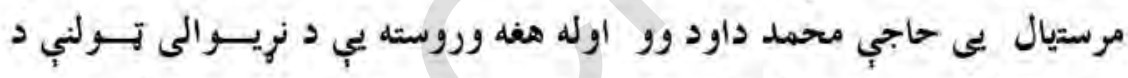

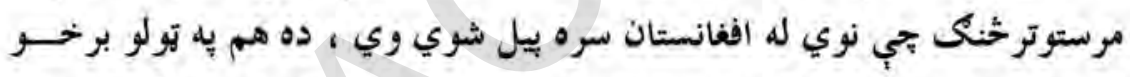

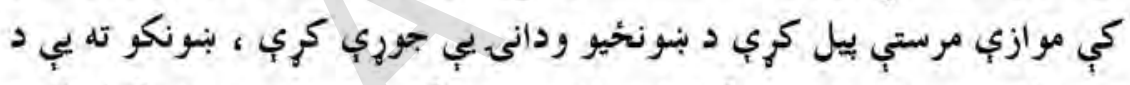

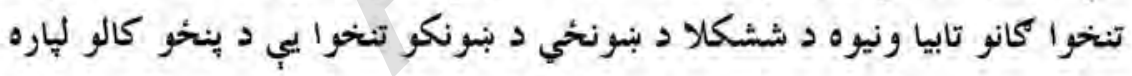

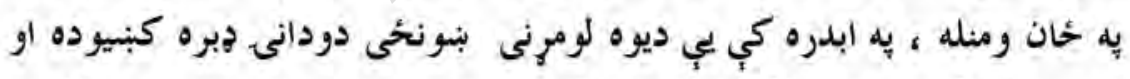

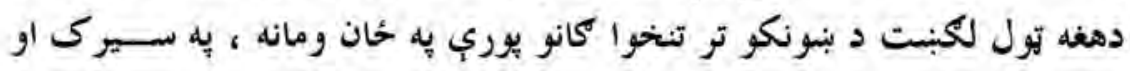

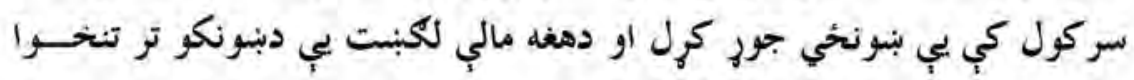

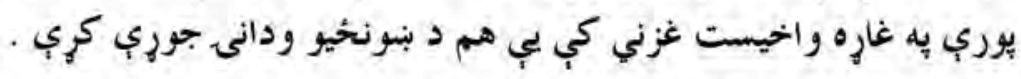

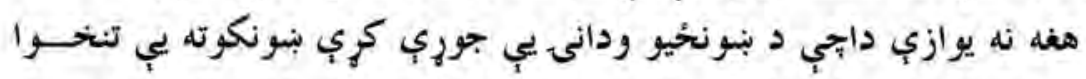

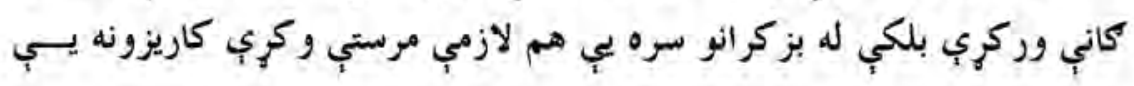


ورته يإى كرل د ميوه لرونكو ونو (منو ) نهالكي يري وويشل . ، كمكى آبدري

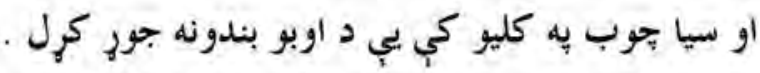

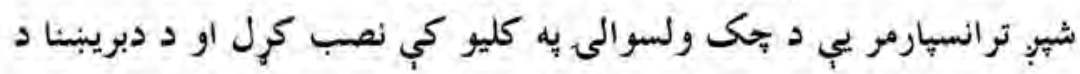

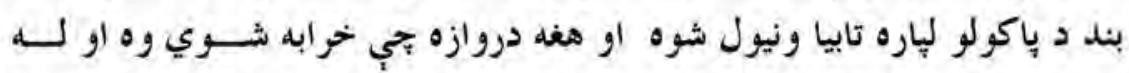

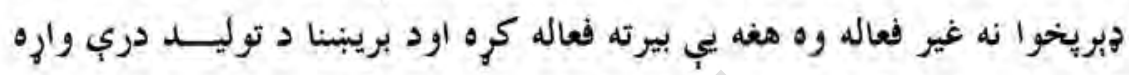

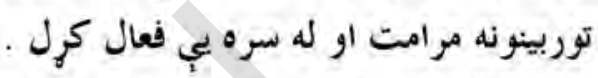

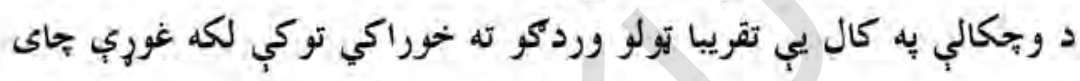

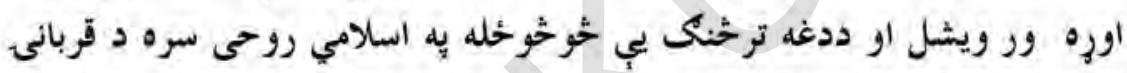

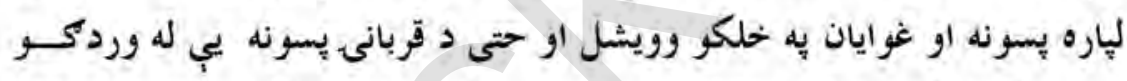

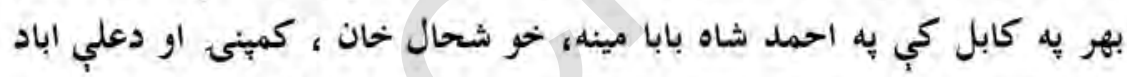

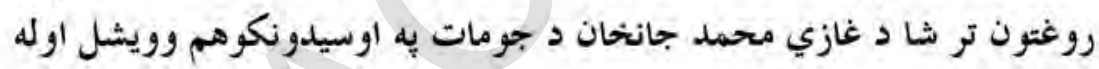

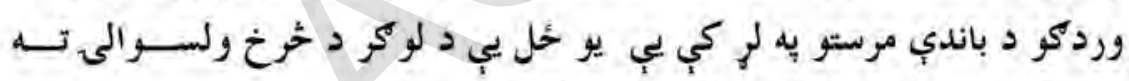

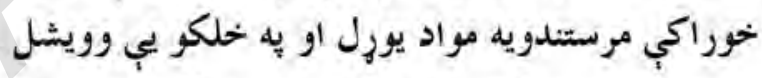

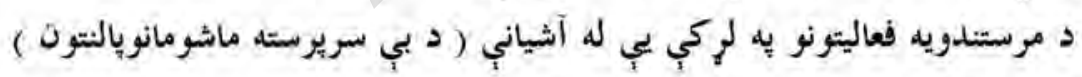
سره هم مرسته وكره .

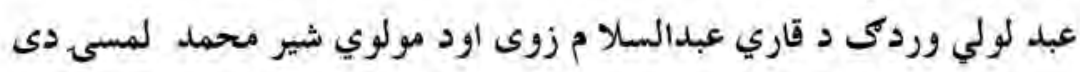

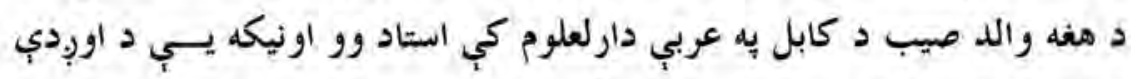

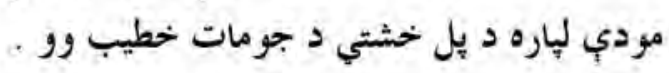

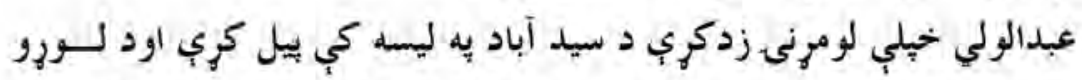

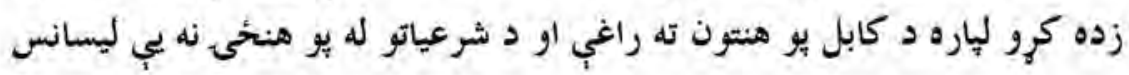


iv.

دوركو مشاهير دوهم هوكى

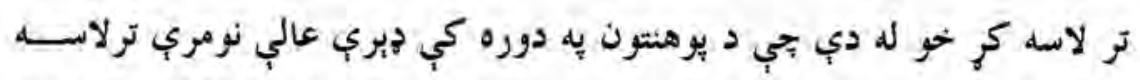

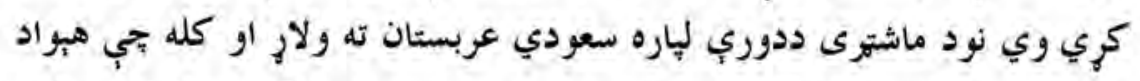

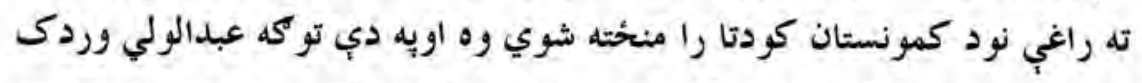

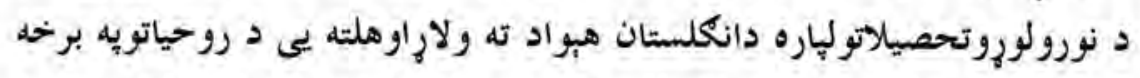

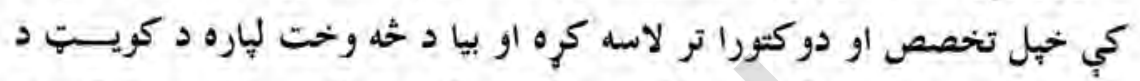

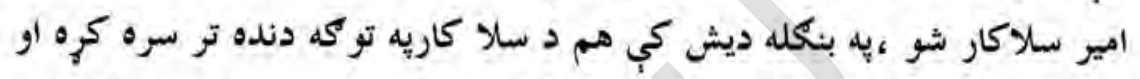

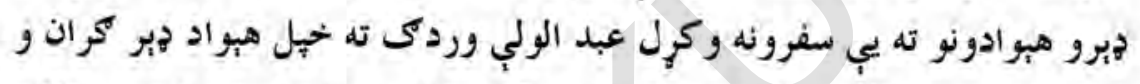

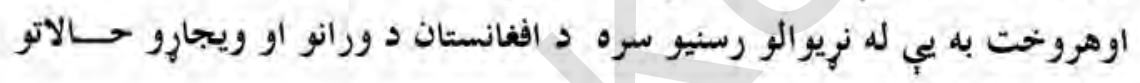

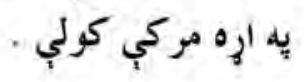




\section{عبد الحليم (متوكل) - مشهور به بيركت \\ مولوي قوماندان}

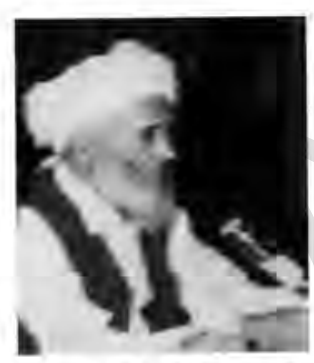

مولوي عبد الحليم بيركّب د وردكو يو له داسـي موني

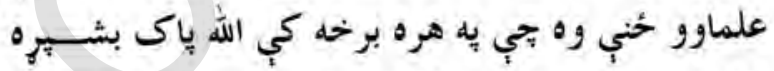

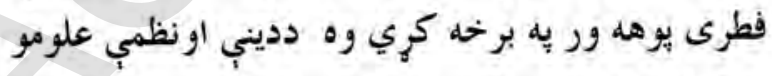

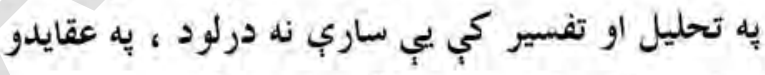

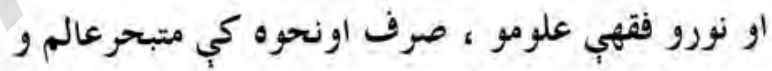

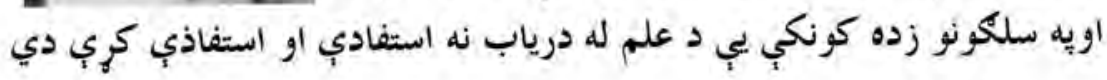

مولوي عبدالحليم (بيركتب) د مولنا ى روم پِه مثنوي د حال اوقال به رَبه يو هيده

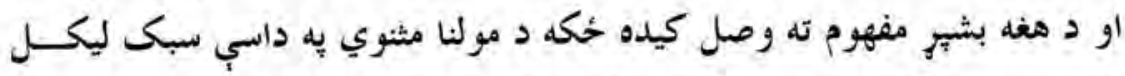

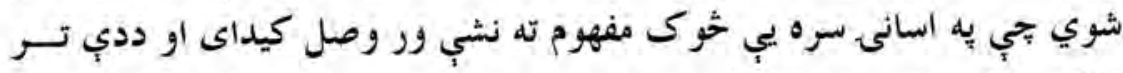

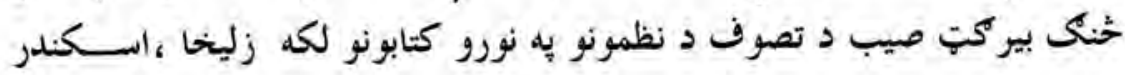




\section{IVr}

دوركو مشاهير دوهم توكى

نامه ، كملستان بوستان اود خواجه حافظ مفهوم ته بشّهرلاس رسى درلود اوددغه كتابونو تول بيتونه يب تقريبا يه ياد وه . مولوي بيركب د تصوف يه علم كي د خلافت تر درجي رسيدلي و اود كابل دحضرت صيب نور المشايخ د طريقي ييرو اومريد وو همدارنكه د خدام الفرقان د ويبنو علماور د تحريك له مهمو غريو نه هم شمبرل كيده .

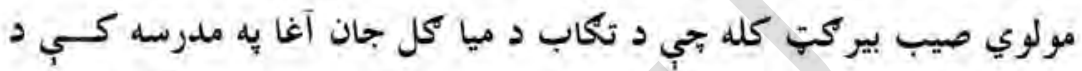

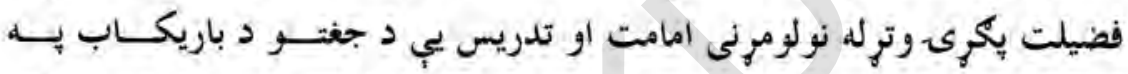
كليوكي لكه كول ييركى ،دوراني ، غوزبه، ، ملا حافظ او مراد خان كي بيل كر

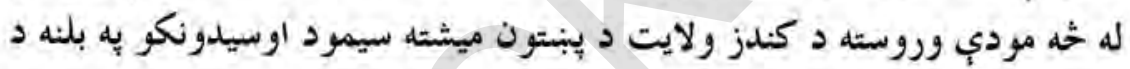

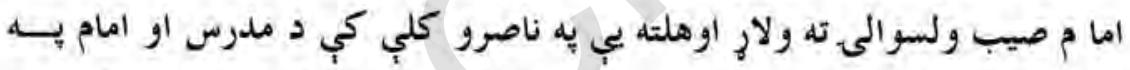

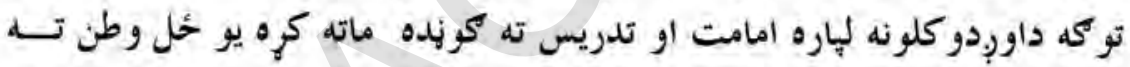
راغى او د يوه كال لياره د مردن مسجد د كرت مغل (مهمدو ) يه كلي كي هم

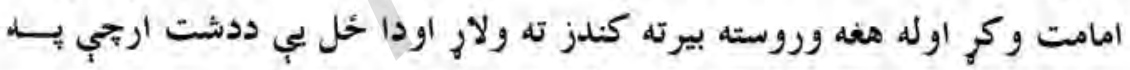
(شاه روان ) سيمه كي د وكيل عبد الله خان وردكى به كلي كي يوه لويه مدربسه جوره كره اوكي شمبر ديثي علما يب وروزل . د غويب له كودتا وروسته خجل كور اوكلي ته راغى اومقدس جهاد ته يب ملا

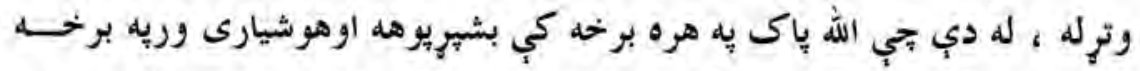

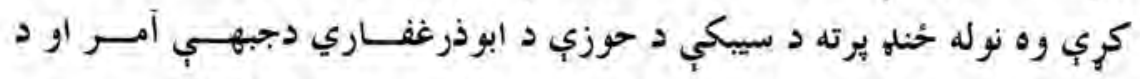

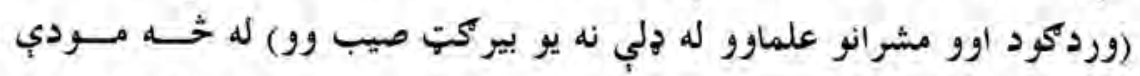

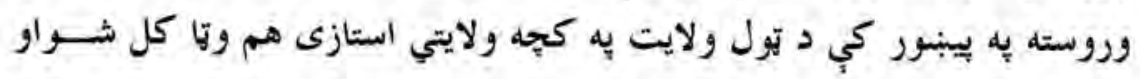


وروبتيه بيا د افغان ميشته الفغانانو يه بلنه د امريكي متحده اليالاتو ته ولار او هلته

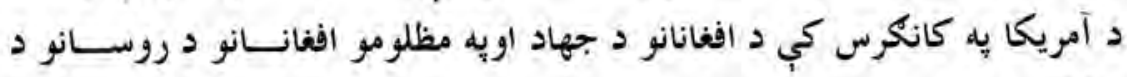

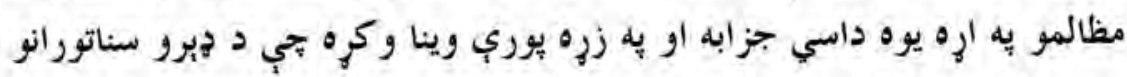

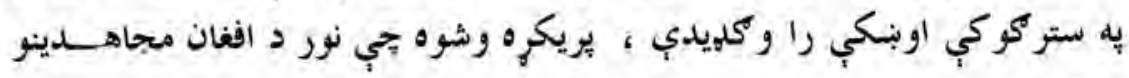

$$
\text { سره د ير مختللو وسلو مرستي هم وشي. }
$$

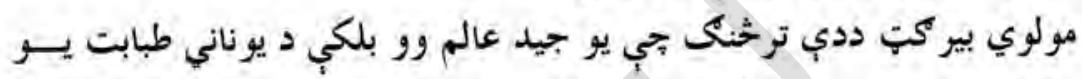

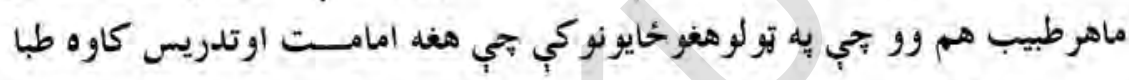

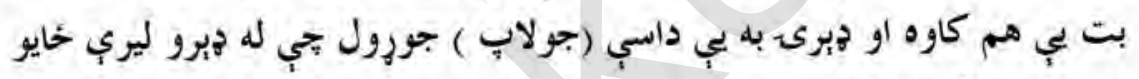
به ورته خلك را تلل ، هغه يه خبل طبابت كي دومره رسيدلى وو تجي يوه ورخ و كندزد دشت ارجي به ولسوالى كي دهغل له مقتديانو نه دوو شوخو تنويبي وغو

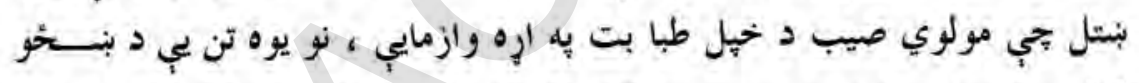
كالي واغستل يحادري يجي يه سر را كش كره او بل تن ترلاس نيولي جومات تـــ راغلل ، نارينه يب مولوي صيب ته يب وويل : ميرمن مي زيره ناروغه ده ! تاسي هغd معاينه كري او درمل وركرى او كه يب درملنه نه كيوي نو را ته ووابي بتي

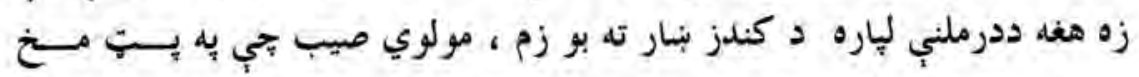

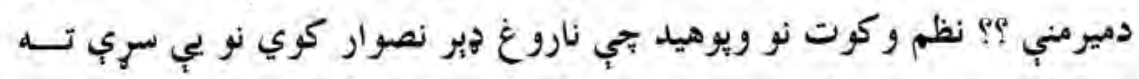

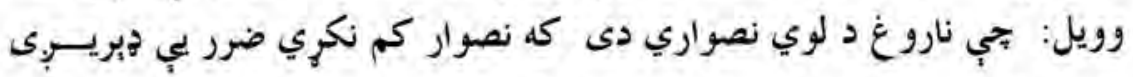

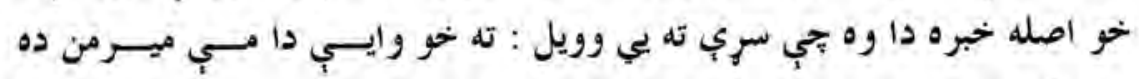

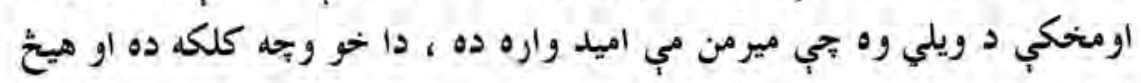
اولاد يه خيته نلري ! دا خمه كيسه ده ؛ نفر دوارِه حق حيران شول سري بحادري 


\section{IV $\varepsilon$}

\section{دوردكم مشاهير دوهم توكى}

له سره واروله او خه خندا يب مولوي صيب ته وويل: زموجٍ يه ازموينه كي بريالي شوي . - م

بيركّي صيب برسيره يردي تجي يو جيد عالم وو ، يو ماهر يوناني طبيب وو

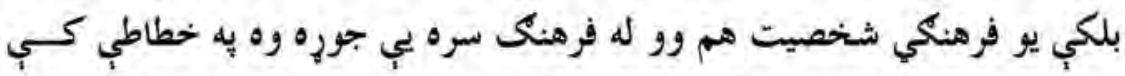

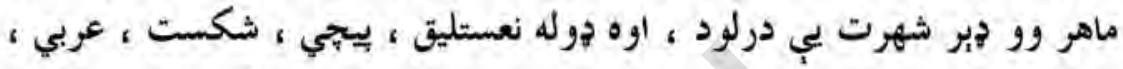

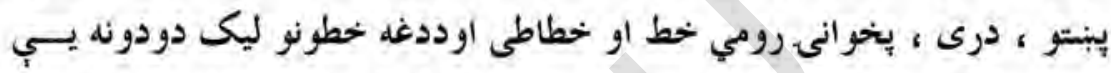

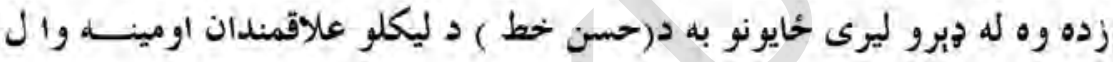

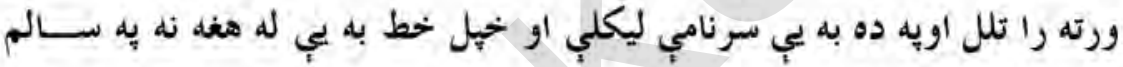
تقليد بنكلى كاوه .

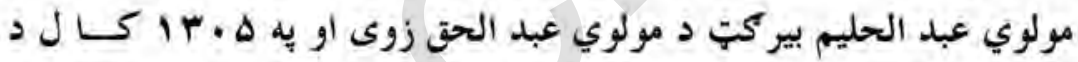

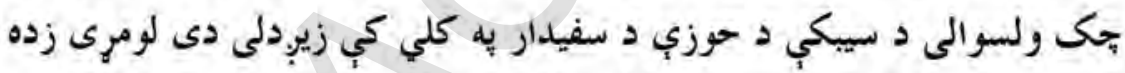

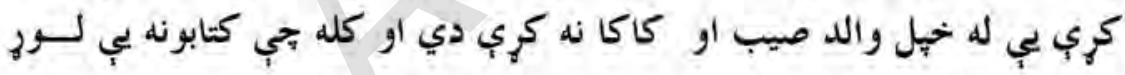

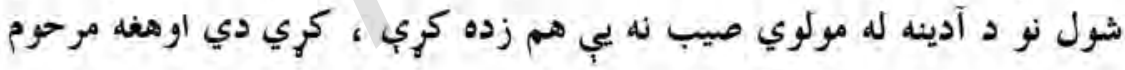

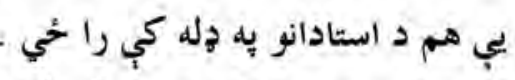

مولوي صيب كله بجي د آمريكا له متحده ايالاتو نه را ستون شو نونيغ وطن

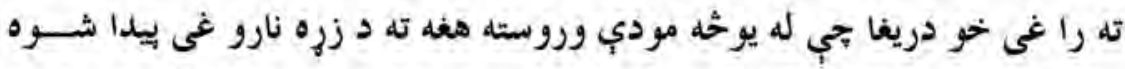

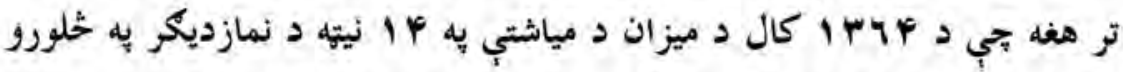

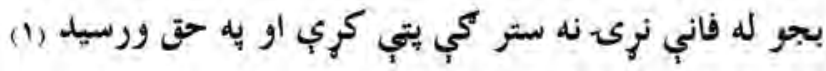




\section{عبد البارى (غيرت)}

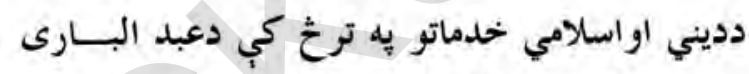

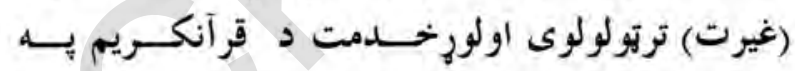

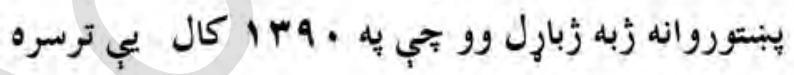

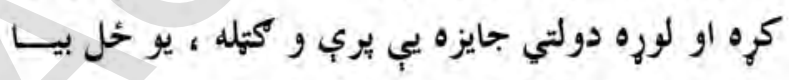

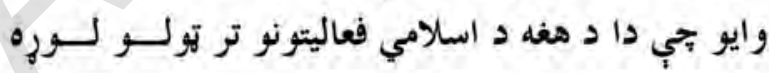

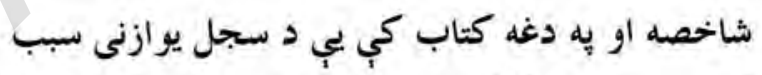

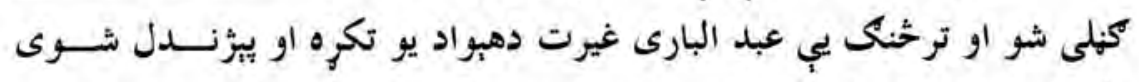

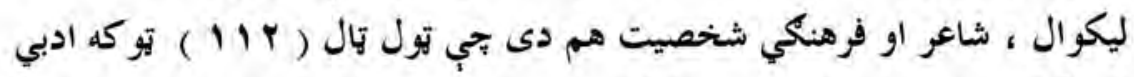

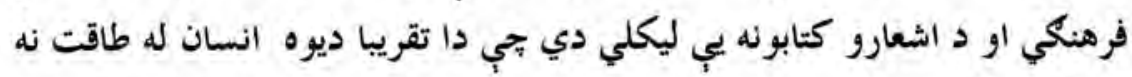
لوز كار بنكارى . - مئ. 


\section{7}

\section{د وردكى مشاهير دوهم توكى}

عبدالبارى غيرت به دغه نوبنت او زيار د اطلات او فرهنك د وزارت لخوا يه بنخو هغو ليكوالانو كي وحسابل شو جي ددغه وزارت لخوا يبي تر تولو لوره فرهنكي او ادبي جايزي تر لاسه كري .

دادبي جايزويه لر كي بي د مدنى تولنو، حج او اوقاف وزارت اود يوه كتاب د ليكلو له امله يبي د آمريكا د (هارد وا رد) د يوهنتون لخوا هم نقدى جايزي تر لاسه كري دي .

عبدالبارى غيرت يه سلكوتو دينى ، ادبي ، سياسي او اقتصسادي مقالي ليكلي تي يه دولثي او غيردولثي ربنيو كي جاب شوي هم دي . عبدالبارى غيرت د جهاد يه مهال يه يِبنور كي هم ادبي اوجهادي فعاليتونه كري دي اود هجرت يه وطن كي د اففانستان د ملي اسلامي محاذ د فرهنكـي رياست مرستيال او له هغه وروسته دهمدي تنظيم د بنوني او روزني د رياسـتـ . سماك

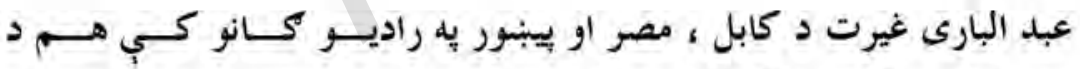

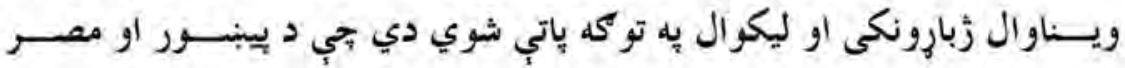
راديو كانو دروسانو يه ضد جهادي خجروني درلودي .

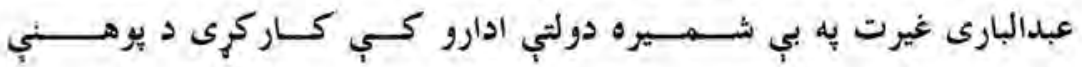
،اطلاعات فوهنك عد لي به وزارتونواوهمدارنكه يب يه ستر محكمه كي ربسـي لئي كارونه به مخ ورجى دي .

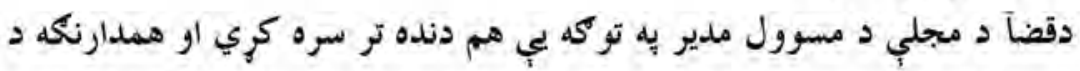

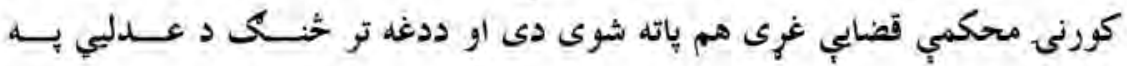


وزارت كي د) تنفيذ احكام ) د ريس به توكه هم دنده ير مخ وري ده اوري يه نوموري

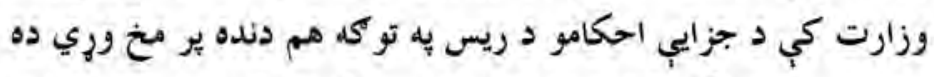
يه ستره محكمه كي يب دتدقيق او مطالعاتو د رياست د قضايب غري يه تو كهن. تر دُبره دنده ترسره كري او بِه ستره محكمه كي د يلتي رياست قضايب غرهم هم

عبد الباري غيرت د نرى ذهيري هبو ادو ته رسمي سفرونه هم كري دي جـي

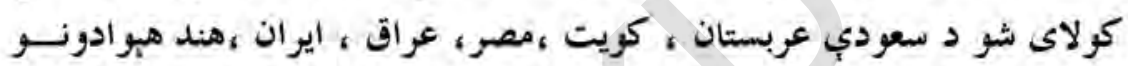
نومونه واخلو . مترو

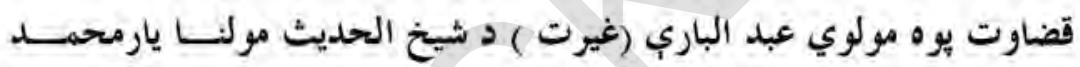

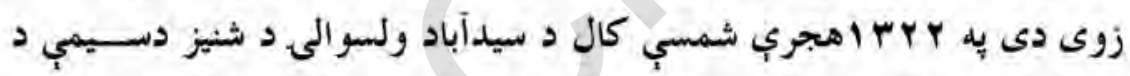
حسن خيلو يه كلي زيودلي دي . لومونى زده كري يجي د كابل يه عربي دارلملوم كي ترسره كري او وروسته يب د كابل يوهنتون د شرعياتوله يوهنتحي ليسانس يل لاس رأوري او د اسلامياتو خه رشته كي بي د ينجاب له يونيورسيتى نه ماثــتري يه لاس راوري ده. عبد البارى غيرت شاعر هم دى او يه بر أ كلنى كي يب شعري قريحه بيداره شوي ده او به 11 إ كلنب كي يجي يه نثر ليكنه هم يبل كري دي . 


\section{غلام فاروق وردكى - د بو هني وزير}

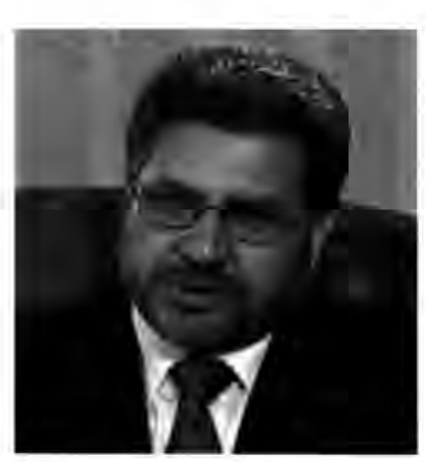

يه كابل كي د كمونستانو دخونرى كودتا د را

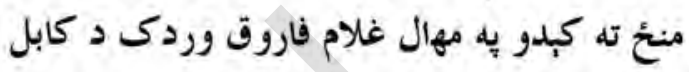

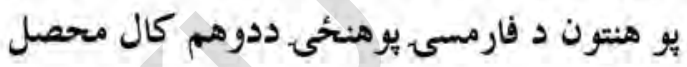

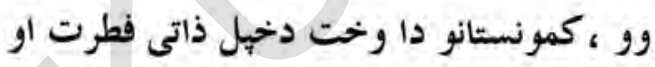

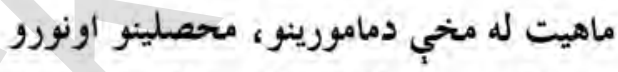

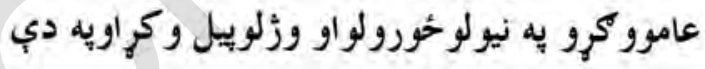

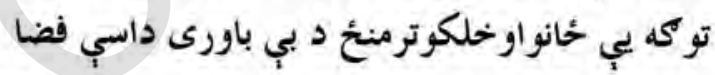

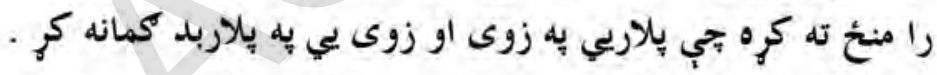

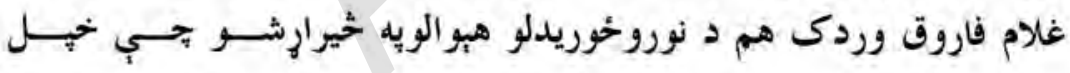

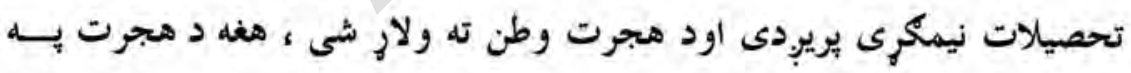

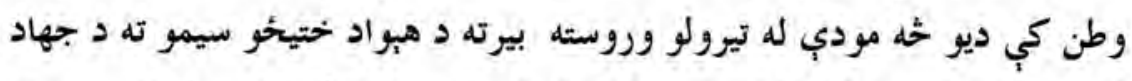

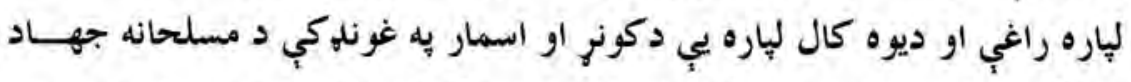

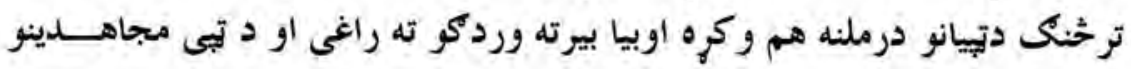

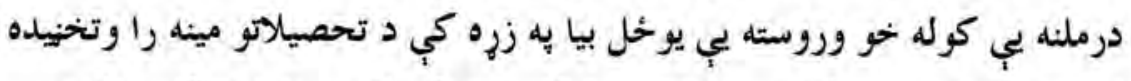

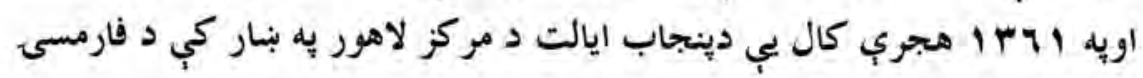

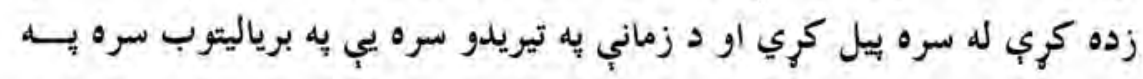




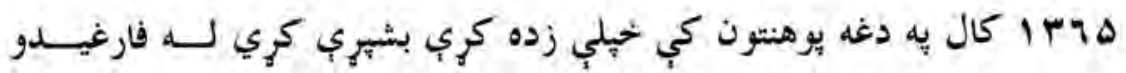

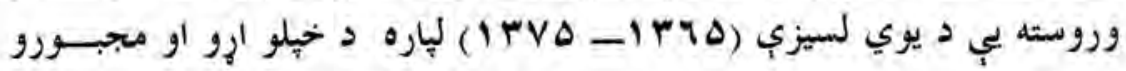

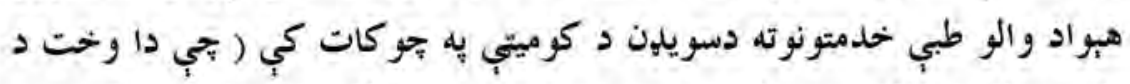

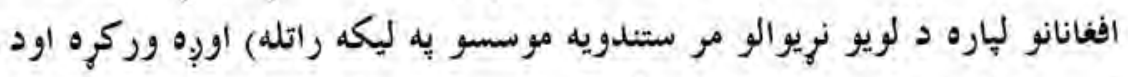

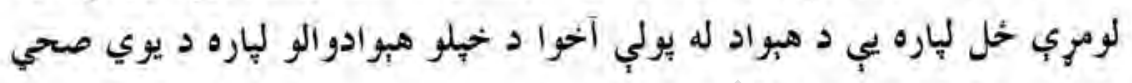

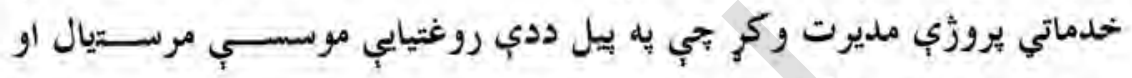
وروسته يب رييس وتاكل شو مان.

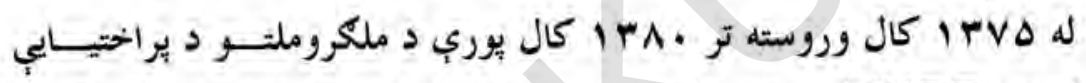

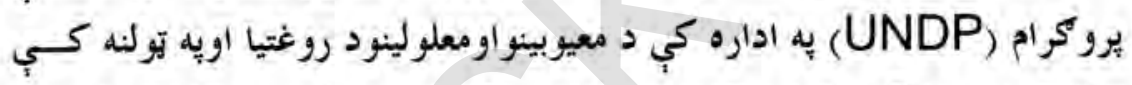

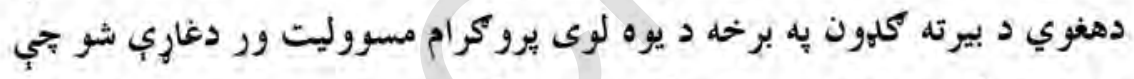

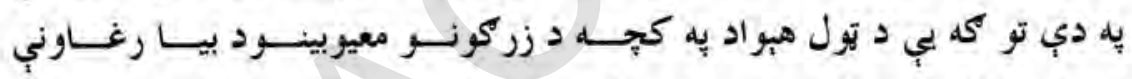

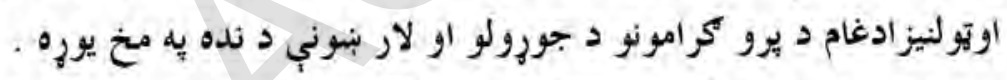

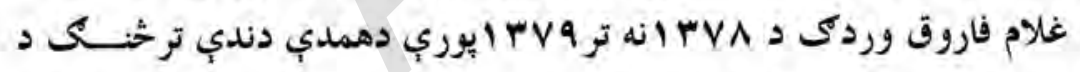

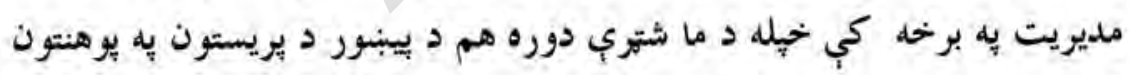

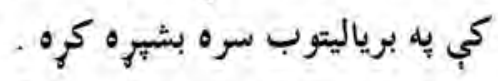

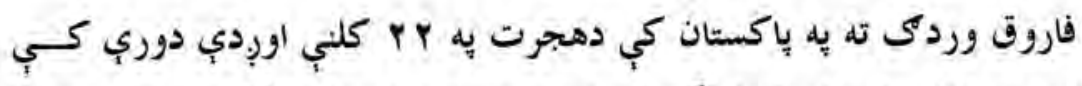

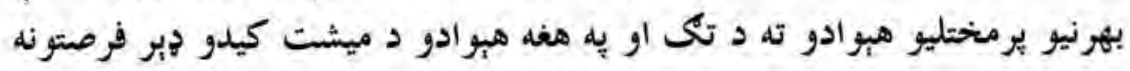

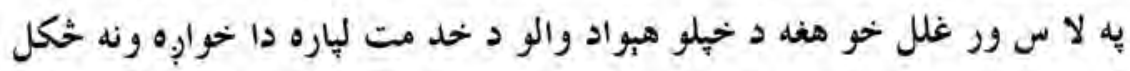

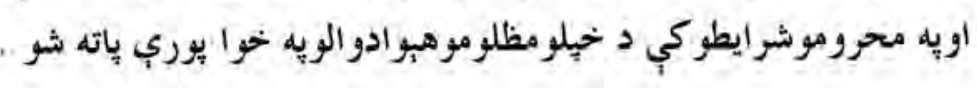


11.

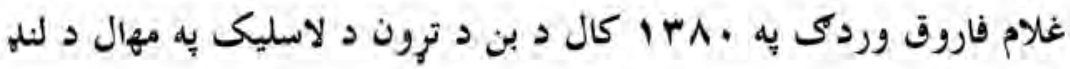

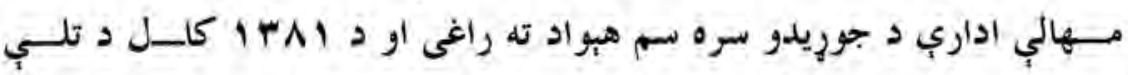

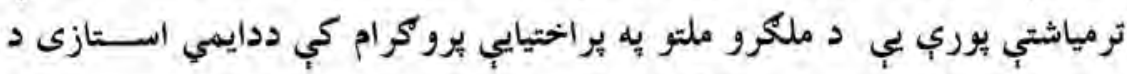

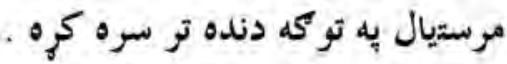

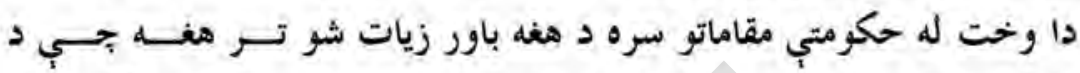

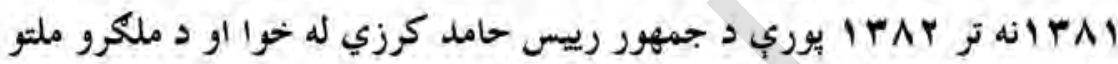

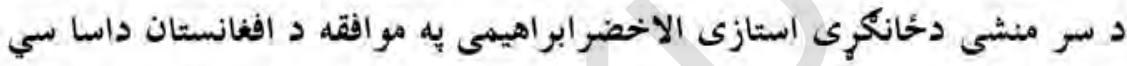

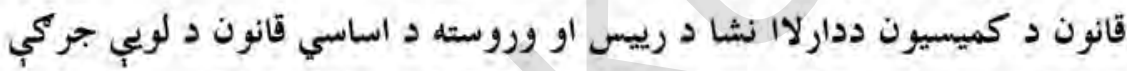

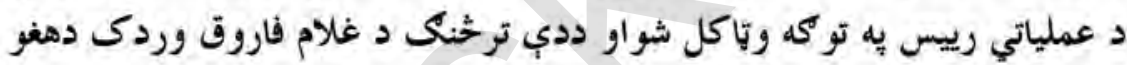

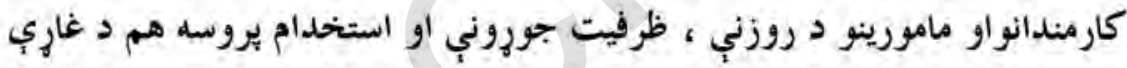

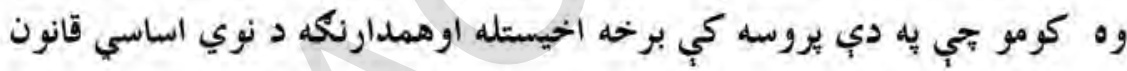

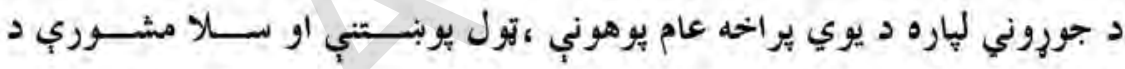

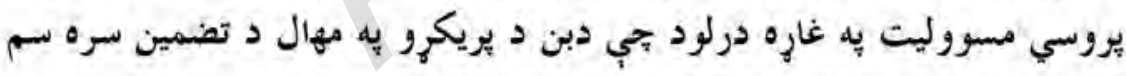

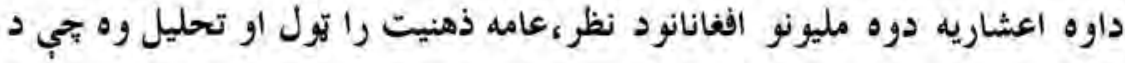

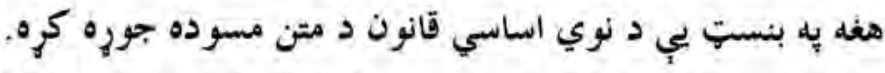

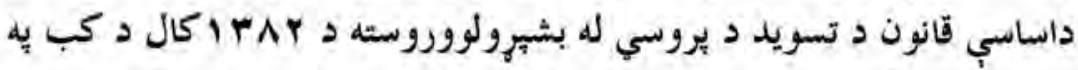

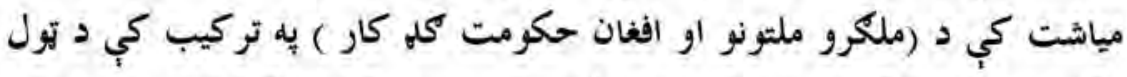

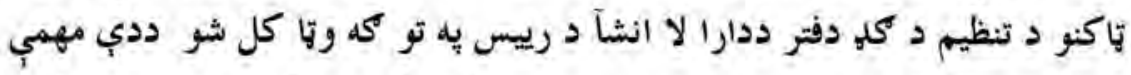

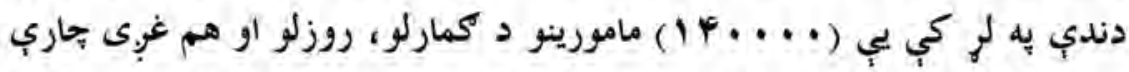

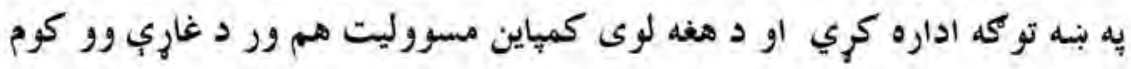




\section{$1 \wedge 1$}

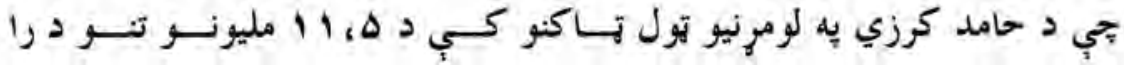

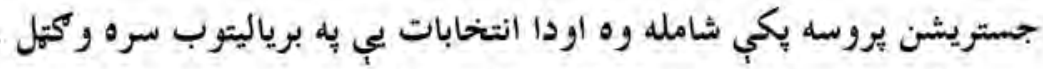

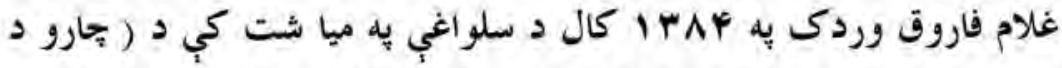

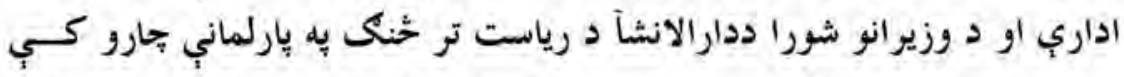

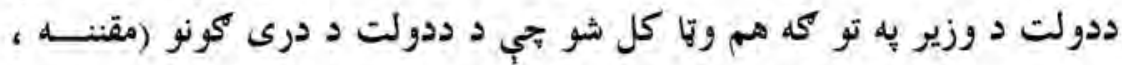

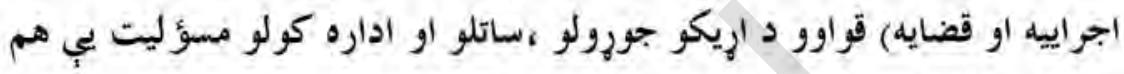
يه غارِه درلود.

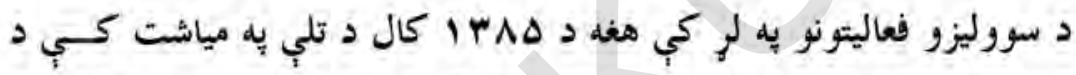

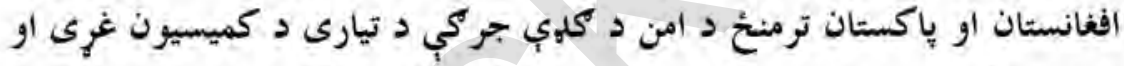

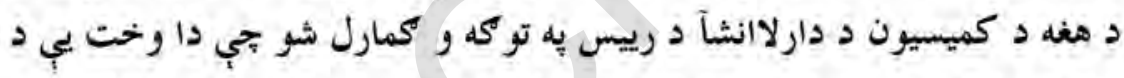

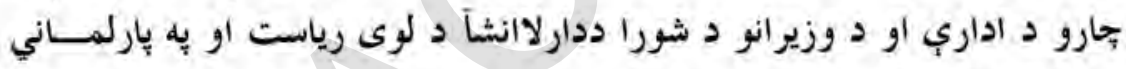

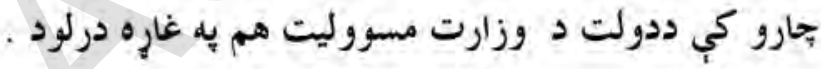

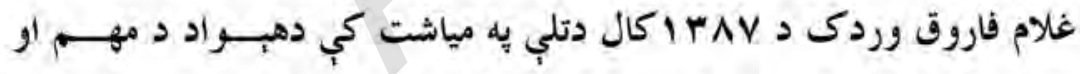

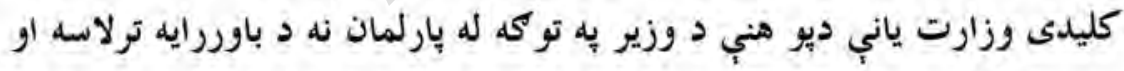

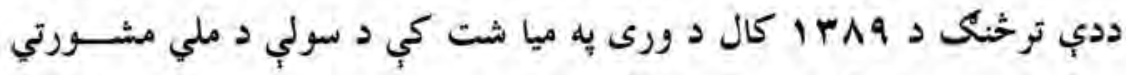

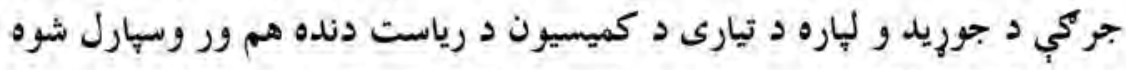

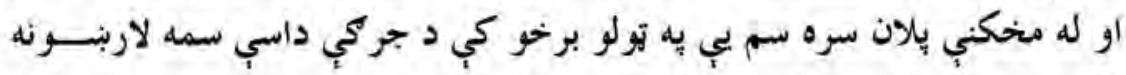

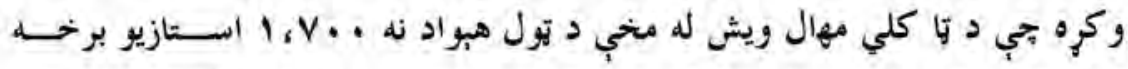

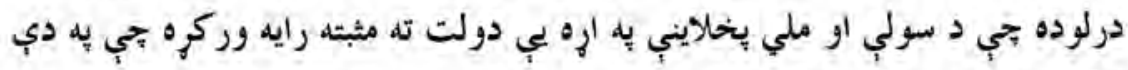

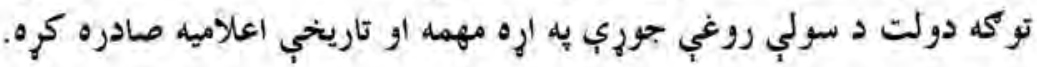


د هغه د ماموريت يه دوران كي د يو هني يه وزارت كي يه كمي او كيفــي لحاظ يه تولو برخو كي د يام ور داسي بد لونونه اويرمختكونه را منح ته شول

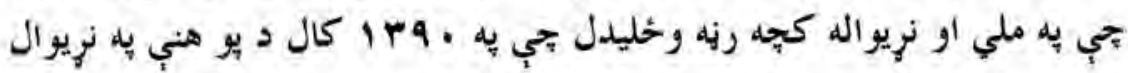
مشارت كي د افغانستان غريتوب يب غوره بيلكه كنلى شو.

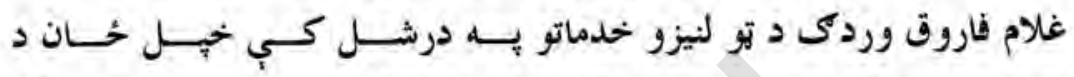
انجينرمحبوب خان (مابوب خان) اوزكريا خحان تو موقف يوري رسولى دي حـكه

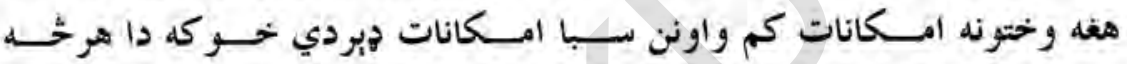
يرتله شى نود غلام فاروق وردك (توله) به بري درنده وي

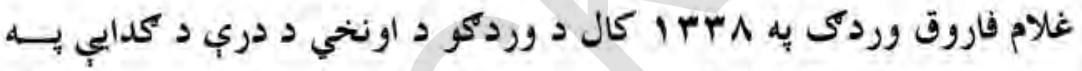

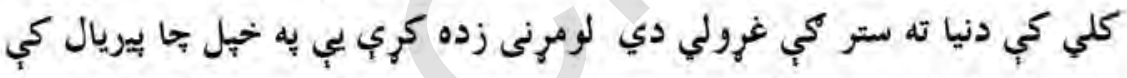

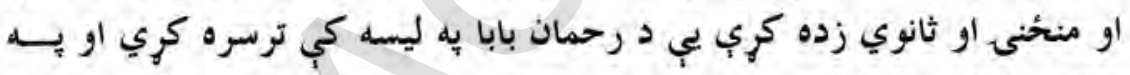

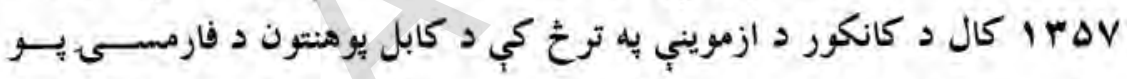

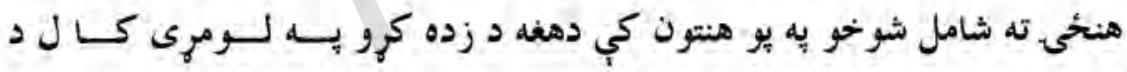

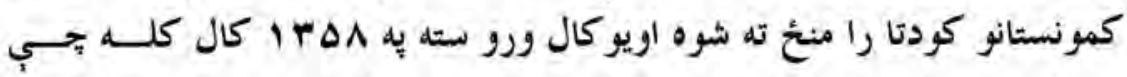

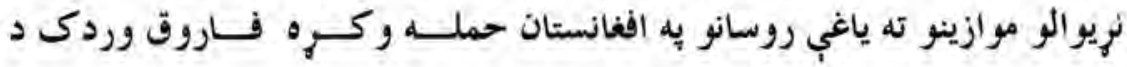

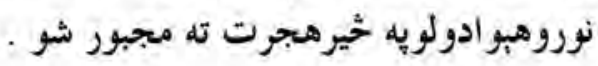




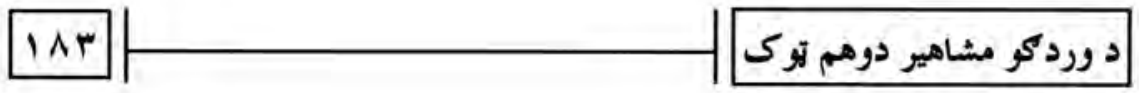

\section{غلام محمد (غمى) جهادي قوماندان}

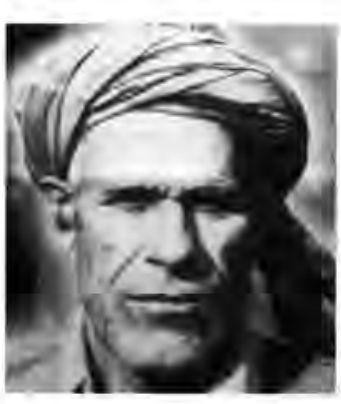

كله جي له هزاره قوم سره د ورودكو د خحيل منئي

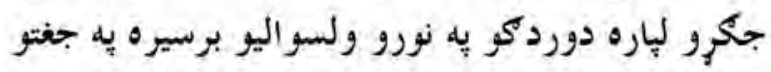

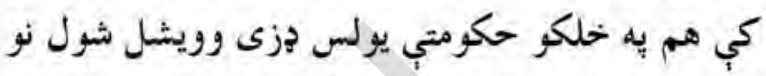

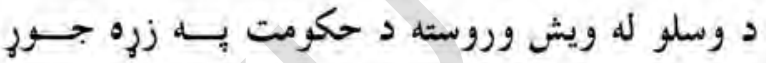

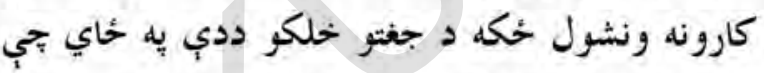

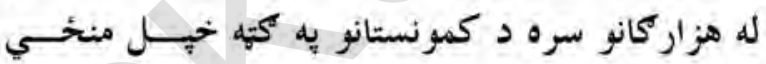

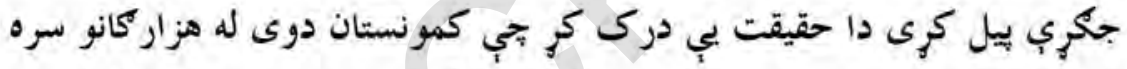

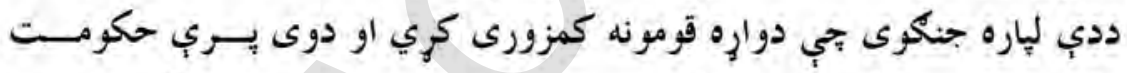

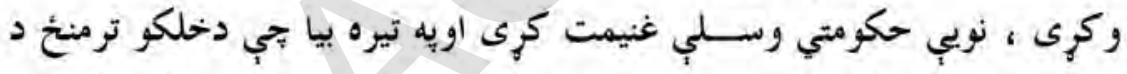

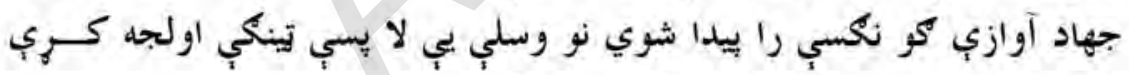
ترخو له كمونيستي حكومت سره يري وجنكيوب. نوبي.

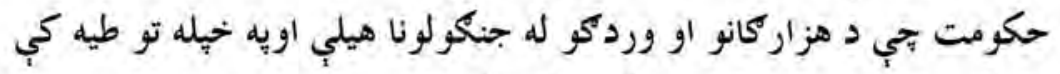

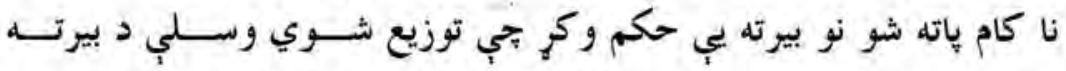

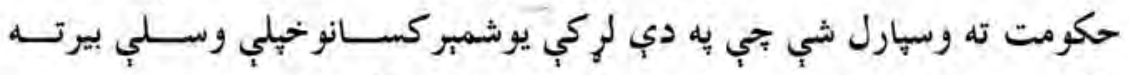

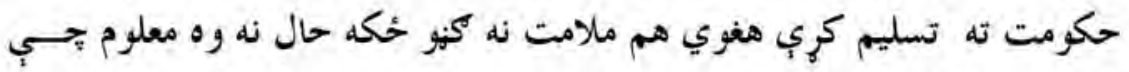
خه به را منحتَه كيري 
$1 \wedge \varepsilon$

د وردكو مشاهير دوهم توكى

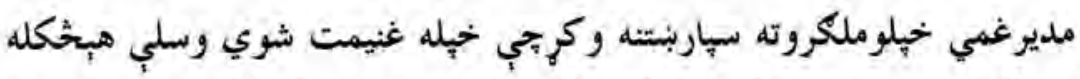
بيرته حكومت ته تسليم نكري حخكه تينك مصسم وو بحي له حكومت سره بـــه جنكي.ري

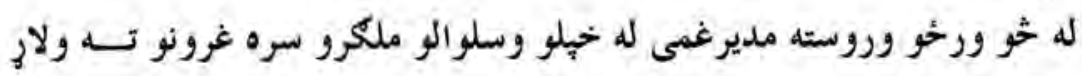

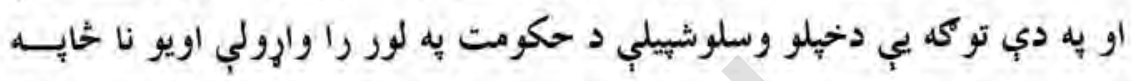

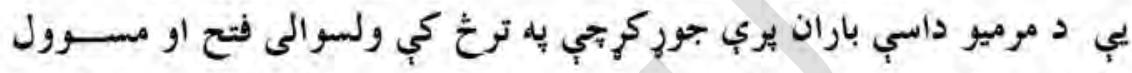

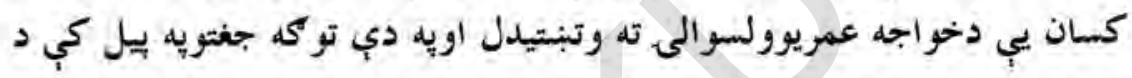
ملديرغمي او دهغه د مجاهدينو به لاس كبنسيوت .

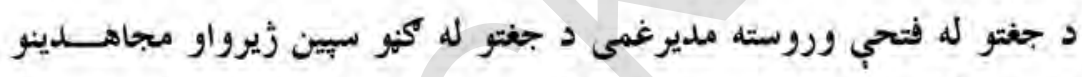

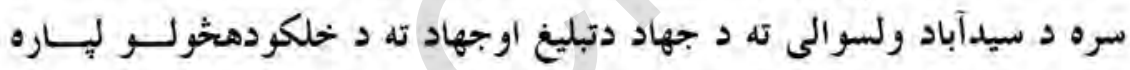
ولاراودهغه ولسوالى ديوشمبرعلماوراوسيبن زيروسره بي د باغك د كلي يه شا

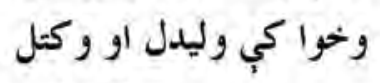
يه جغتواو وردكو كي دأوخت تقريبا نورو تنظيمونورجود نه درلود او يوازي د حزب ابلامي مجاهدين د اخو انيانو( اخوان المسلمين ) خه نامه د كوربت غره ته را غلي وو اوددغه ترخيك دمولوي محمد نبي له حركت سره هم خلكو ييرّند كلوي درلوده خيكه خه يخوا يب د عام ولس ترمنح يوخده جروي غزولي وي او د سعادت خيلو محمد نبي خحان يب كلك مخكنى مئعهد وو . د سيد آباد ولسوالى به ستره غونده كي دِبرى دسيمي هغه علما وو كلمون كرى وه جي له حركت انقلاب اسلامي سره بي اريكي درلودي . 
110

د وردكو مشاهير دوهم توكى

مديوغمى له غونلدي وروسته عجالتا دجغتو يه ولسو الى كي د حركت انقلاب اسلامي يه جو كات كي د عملي جهاد ذّكر ته را ووت او دجغتو يه ولسوالى كي د حركت انقلاب اسلامي ريس ملا يردل او نظامي قو اندان يب مديرغمى وتياكل شو ، د جهاد د بيل يه دي تودو شبو ورخو كي كمونستانود خلداي خحان (خـــر) وردكى يه مشرى د وردكو يو شمبر كابل ميشته مخور سبين زٔيري له كابل نـه

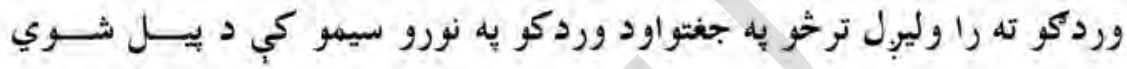
جهاد مخه دوب كري (1) ملديرغمي او د جغتر نورو سيين زيرو د هيئت غوبنــتئه ونه منله اوخبل مجاهدين يب دبركت د غا بنب له لاري غزني ته مارش اوهلته يب

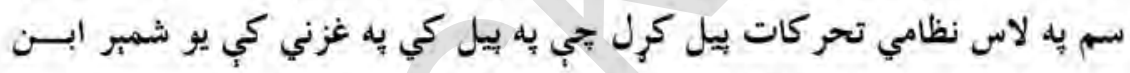

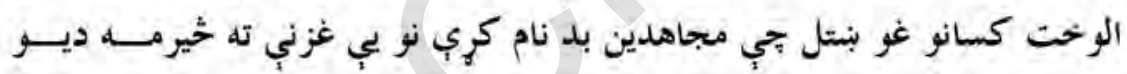
شمبر كليو لكه ده حاجى ، ده حخدايداد ، لاغريو د تالا كولو لياره رسى ترملا تولي او را دمخه شول خو كله بجي مل يرغمي بيه مو قع دهغوى دا هخده كثــف

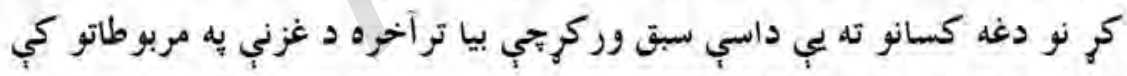
جا ورته عمل ته زره بنه نكره

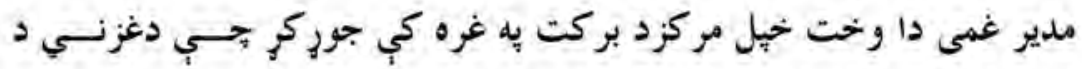

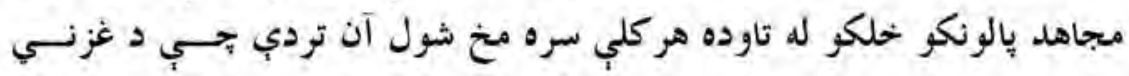
هندوان هم د هغه د ليدو لهاره راغلل خيكه هغوى هم له كمو نستانو نه د بورزوا

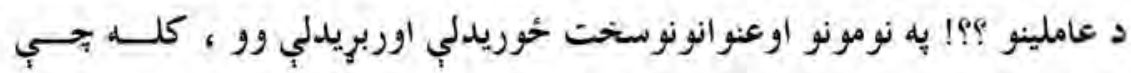
خلقي حكومت يه غزني كي د جهاد يه نيت د ملديرغمي يه را خر كهنديلدو يقينب

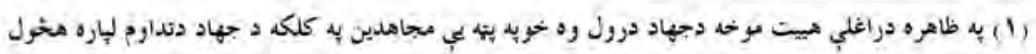




\section{$1 \wedge 7$}

\section{د وردكو مشاهير دورم تركى}

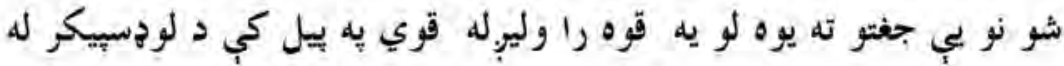
لاري جيفي وهلي او اعلانونه يب كول بجي مورجٍ له نور جا سره كارنلرو او يوازي مديرغمى اوله هزارجاتور اغلى (سيل جكرن ) مو يكار دي خح وروسته يب سنتي بد غونيو ته بلمبي ووهلي دوى لومرى له سيدي نه يه شيخ علي كي ددوى سيينه

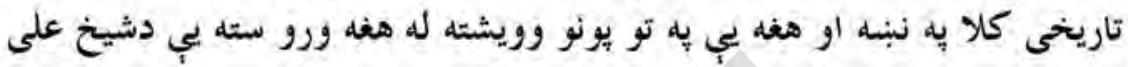
يه لور يه دبنّته كي تبانكونه را خوشي كرل ، كمونستان يه عصري وسلو سمبال

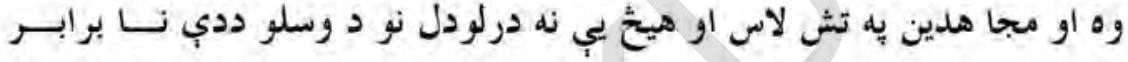

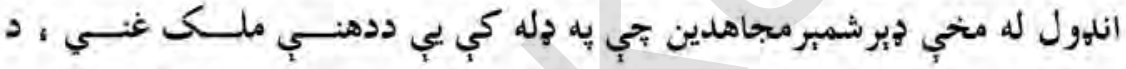
خدران عبدالمنان اويو شمبرنورتكره مجاهدين او غازيانو شهيدان شول . مديرغمي اوملكروبي ددوربين له لاري د فوي جنايات خارل خو يووخت يب وليدل بجي كمونستان ترسيينه كلا تاورا تاو شول اوله خودقيقووروسته يه منــيه تري ليري شول ، مجاهدينوو انكيرله اومديرغمي ته وويل : بنه دي كمرنســان

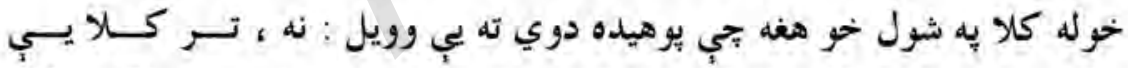

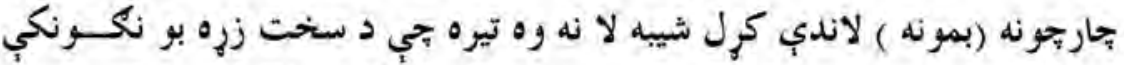

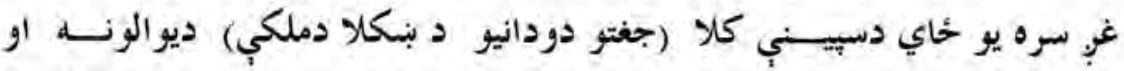

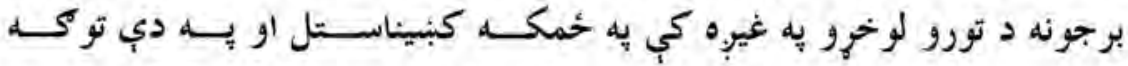

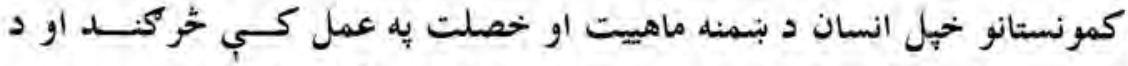
جغتو سراسر خلكو ته يب وروبنود ، د كوراوكالاد ريكيدو له امله ملير غمـى ناجار د هزارجاتويه لوركلهه وكره اوله كورنى سره هلته ميشت شول. 


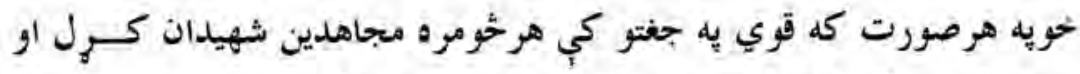

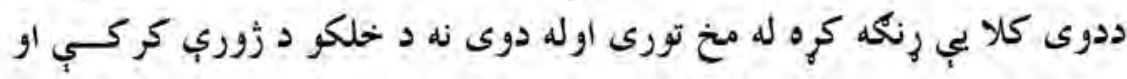
نفرت يرته نور خه يه لاس ورنغلل

دثه وخت يه تيريدو سره ددبنمن حملي لا يسبي قوي شوي اود قوي د بَّمن

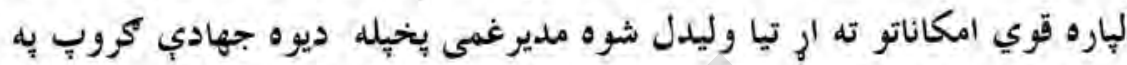

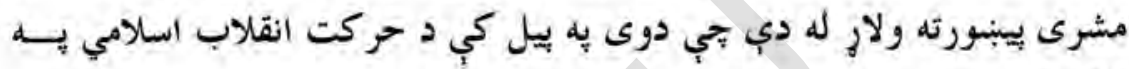
ليكو كي جهاد بيل كريى وو نولومرى هلته ورغلل خو دريغى نجي نوموري تنظيم

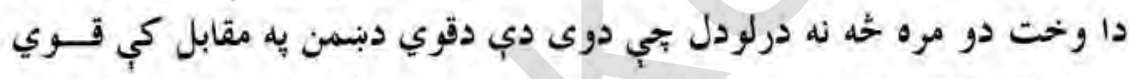
مسلح كرى كه خهه هم تولو تنظيمونو له ده غو بنتئه وكره جحي ددوى د تنظيم غريتوب ومني او له دوى سلاككاني يوسي خوخثكه بحي مديرغلام محمد غمى له بخو انه د بير سيد احمد كيلاني له كورنى سره د خهلوي اريكي درلودي او يخهيله

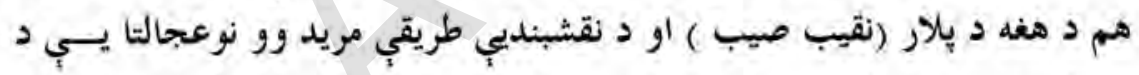
جا غو بنتنه ونه منله اود بيبر صيب د (محاذ ملي اسلامي ) په نوم نوي نشـــيل

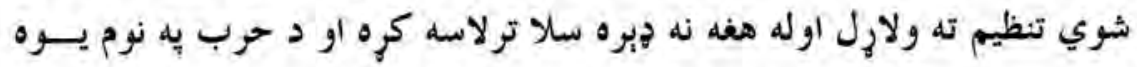

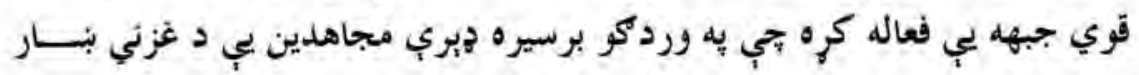
او د رشيدانو د ولسموالى. او سيدونكي وه .

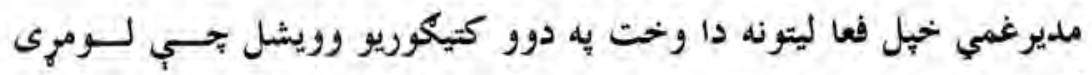
كتيكورى يب نظامي فعاليتونه وه جي عمليات به يجي كول ( نظاميان ) وه او بل يــي يوه لو يه قومي شورا را منتح ته كره جي د وردكو او نورو قومونو خيـلـل 


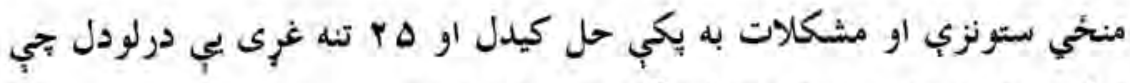

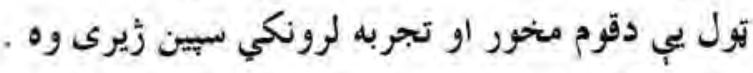

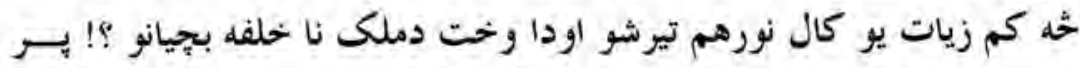

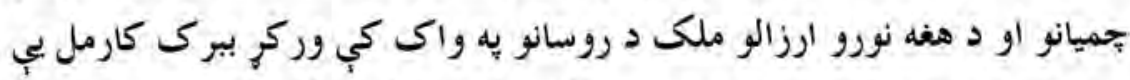

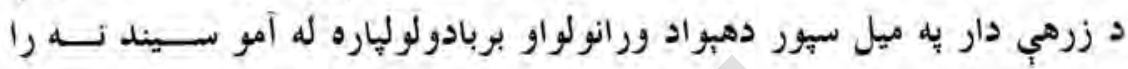

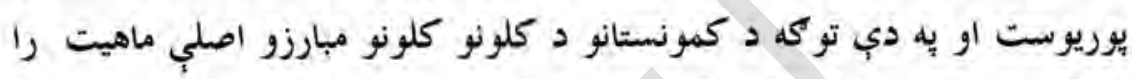

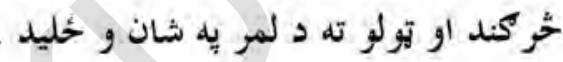

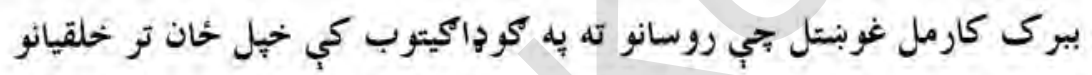

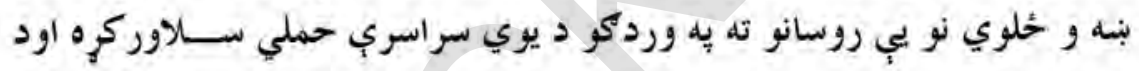

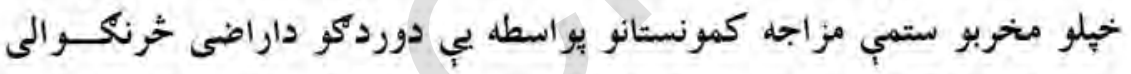

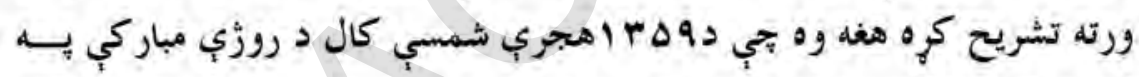

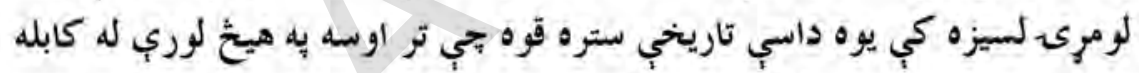
نه وه وتلب ، د وردكوخلور واره ولسواليو ته را وليربله .

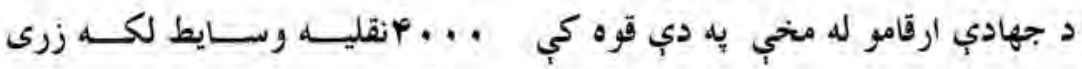

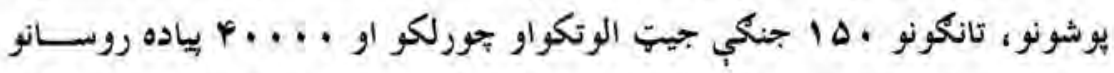

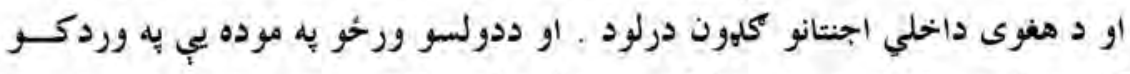

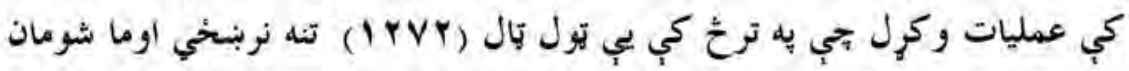

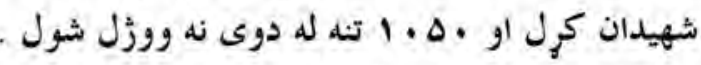

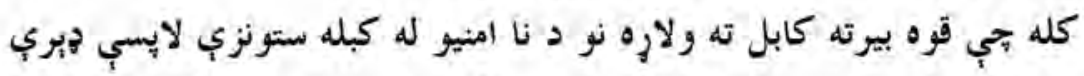

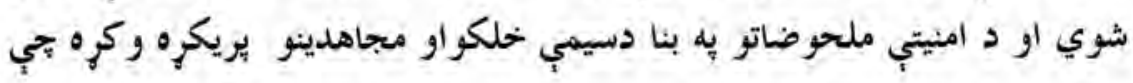


د ملديرغمي كلمه اوكورنى دي نور دهجرت وطن ياني ياكستان ته ولإِه شب (')

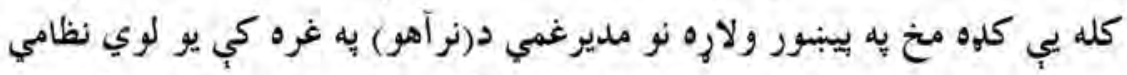
مر كز يرانيست او ددي تر خنك يب يه سيمه كي نظامي يوستي جوري كري او تينكى جهاد ته يب ملا وتوله يه رشيدانو كي يب جهادي ولسوالى جوره كري او او د

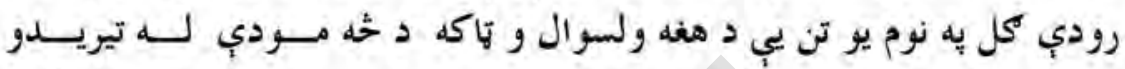
وروسته د ارتيا له مخي به به ب ا كال د محاذ ملي د تنظيم لخوا د فرقي تشكيل ورته منظور شواو يخهله مدير غمى د تورن جنرال يه رتبه كي د هغه قو ماندان

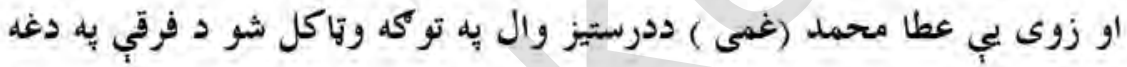

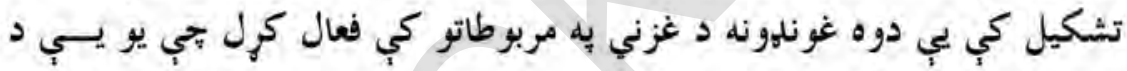

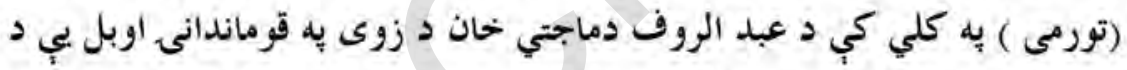

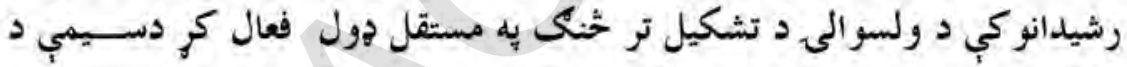
خلكو د نورو ستونزو دحل ترحنكى يي د هغوى صحي خدماتو ته هم ياملرنسـه وكره او د افغان جرمن د موسسي لخوا يجي يو مجهز كلينك فعال كر بجي دليرى

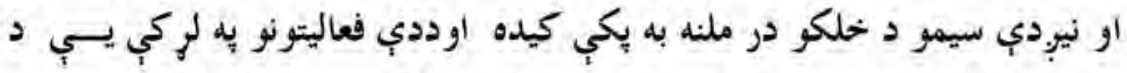

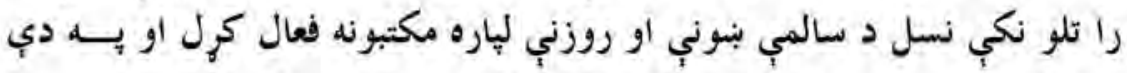

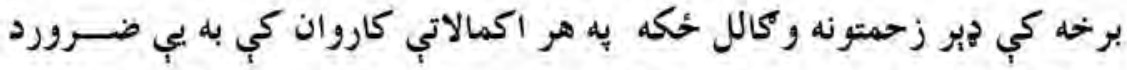
بنونحيو درسي مواد ديه لو مري كام كي د هجرت لله وطنه را بار كري وه.

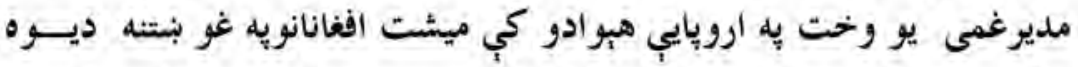
بلن ليك يه ترعُ كي جرمني ، هاليند او دفر انسي ته سفر وكرخيل نظريات او د

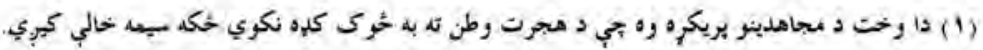




\section{9.}

د وردكو مشاهير دوهم ترك

افغان مجاهد ولس غو بي هغوي ته ورساو اوله يوي ميا شتي وروسته بيرتسـه خيل وطن ته راغي

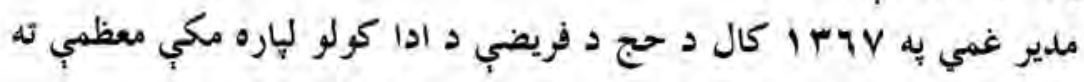

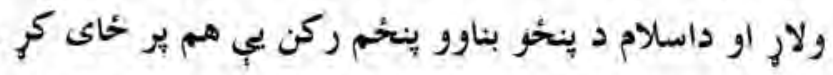

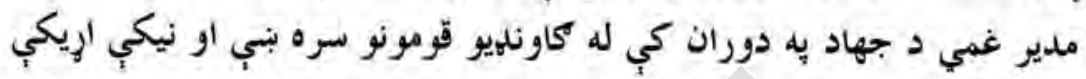
درلودي د جغتو يه لوديخ د هزاركمانو له علا وديني قوم سره بي هيخكله أر يكي

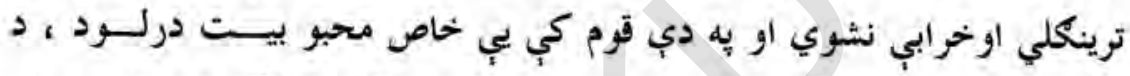

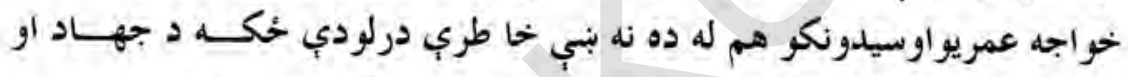
قدرت به وخت كي يب له دوي سره هيخ ستونزه او شكر رنجى را منتخ ته نشوه

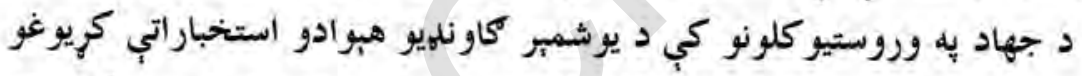

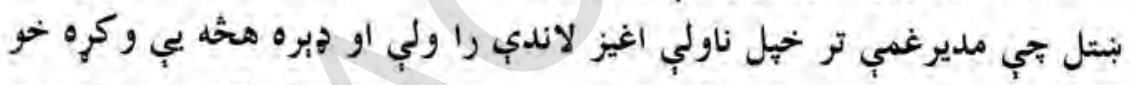

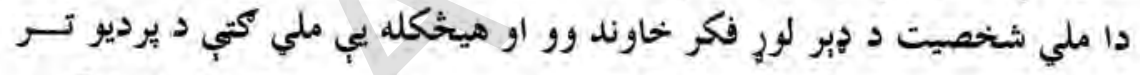

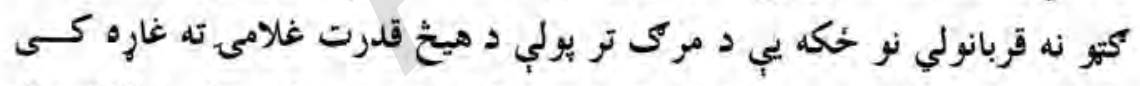
نبنوده هغه به تل ويل جي زه له يخو انه يو نظامي منصب دار يم او د الفغانستان له خحاوري سره مي زُمنه كري تجي هغه ته به صادق او وفادار اوسم .

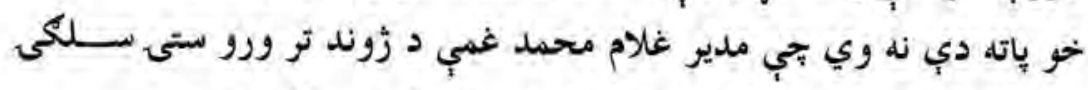

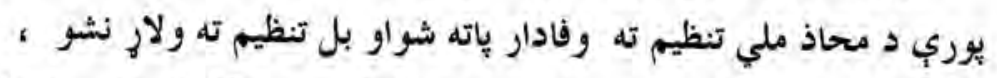

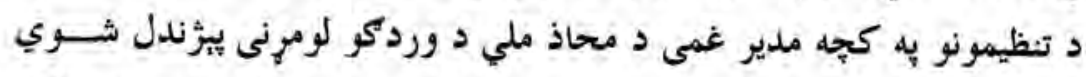
تكره او قوي قوماندان وو جي له وردكو ترميران شا بوري دلارويه سراستوكي 
تولوقومونو د جهاد له مماغه بيل ييزًانده او دخحدرانو قوم خو به د لارو بيه سرتول

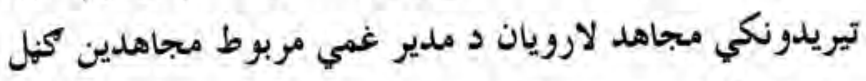

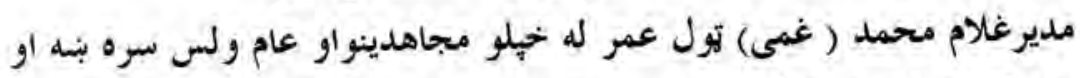

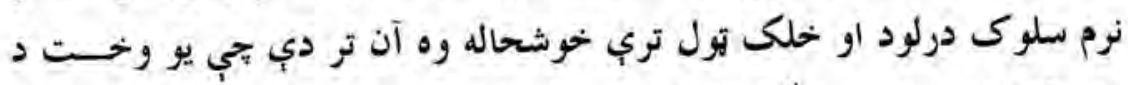

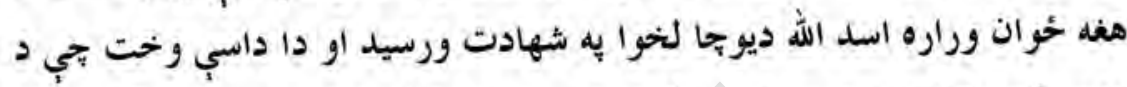

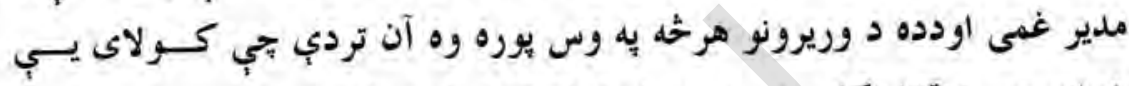

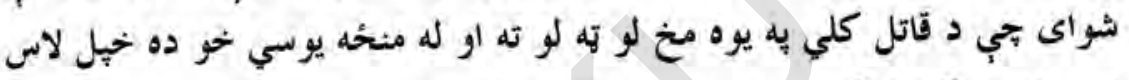

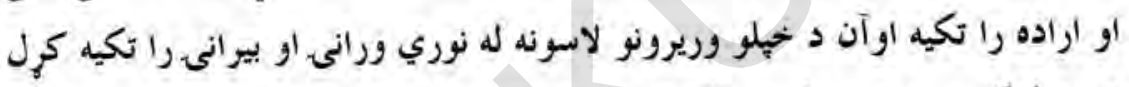

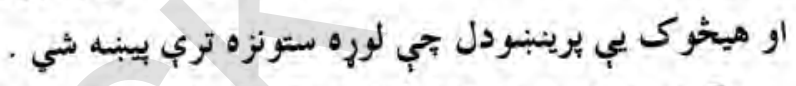

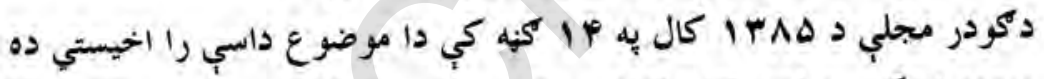

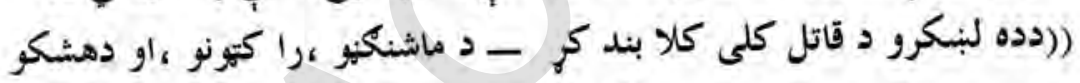
ليكي تري را وخر خيدي ، داسي انكيرل كيده جي كلى به د ده ده د اور اومكوليو

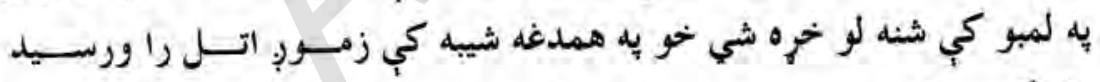

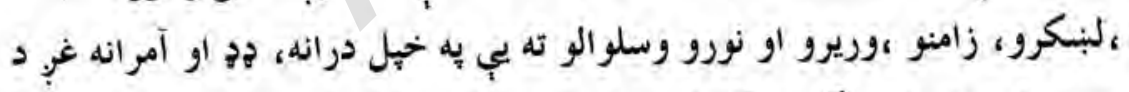

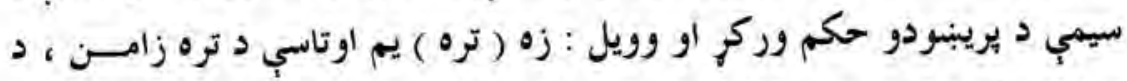

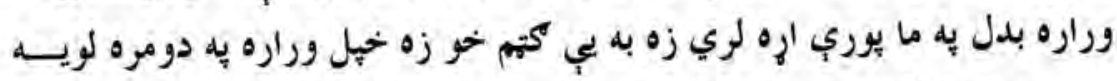

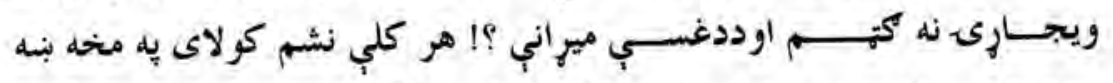

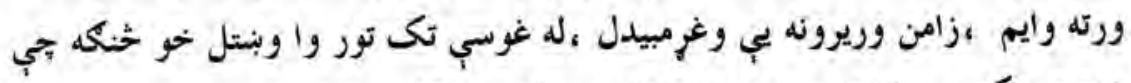

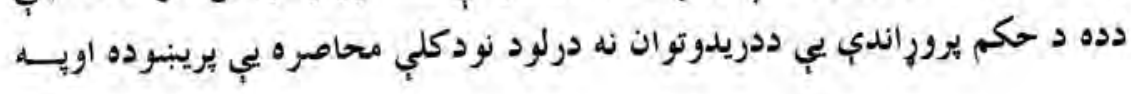




\section{$19 \%$}

دوركو مشاهير دوهم توكى

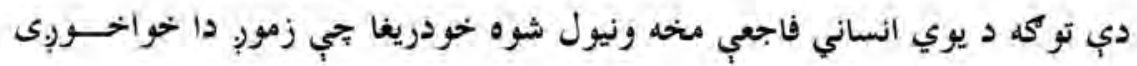

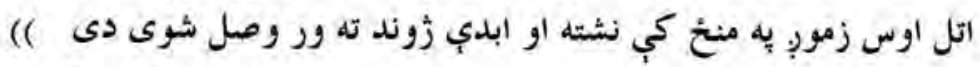

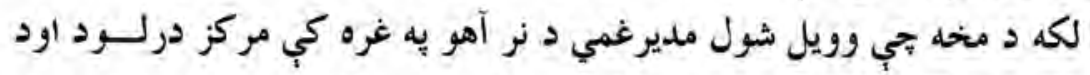

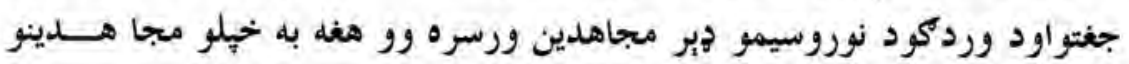

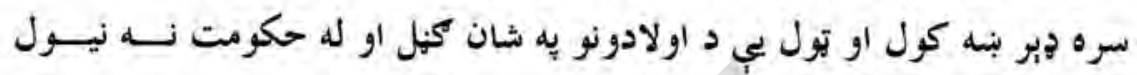

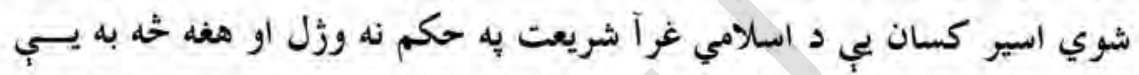
ورسره كول كوم بحي د الله (ج) او د الله (ج) د ربسول امر وو د جهاد يه لومريو كي جغتوته قوه را غله دده مجاهدينو د سيدي يه حنكل كي يو حكومتي منصب

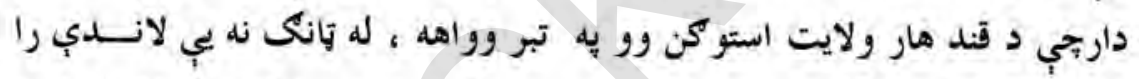
غوزار كر او ونيو كله تحي اسير ده ته ورو ستول شو نو سمدلاسه له اعدام نـهـ

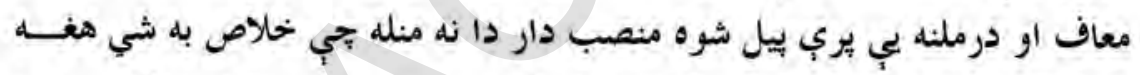

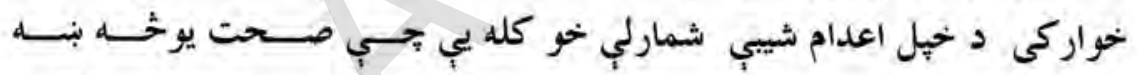
شونورخصت شو يه هغه منصب دار د ملدير غمى سلوكى دو مره بنه اغيز وكـــ

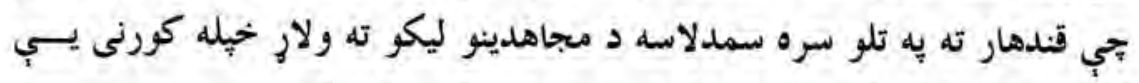
كويتي ته بوتله او لوي او يبرُندل شوي مسجاهد توي جور شو.

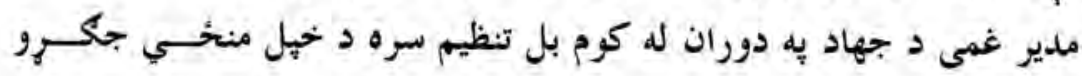
تاريخجه نلري . د جهاد يه ورو ستيو كلونو كي كله بيبنوركي تنظيمونوخيل كيفيت له لاسه

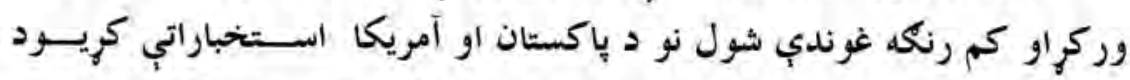

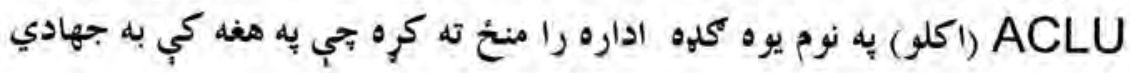




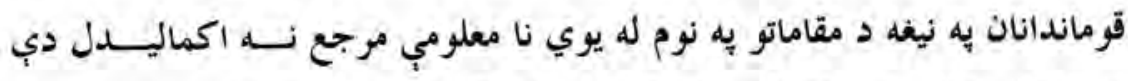

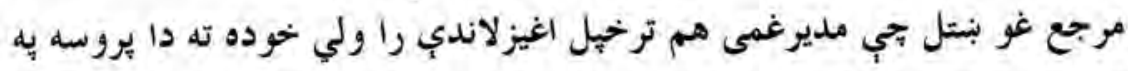

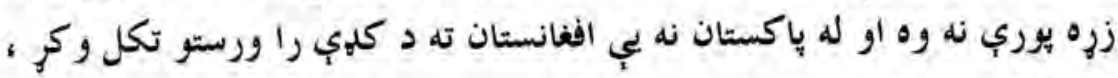

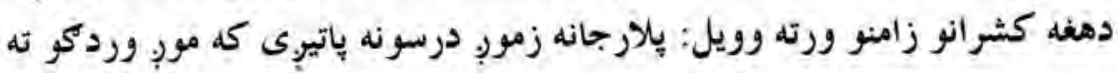

$$
\text { ولاه شو زموبج كالجونه به خثكه شي ، خو ده ورته وويل: }
$$

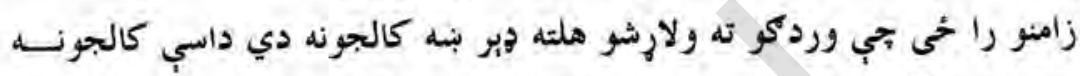

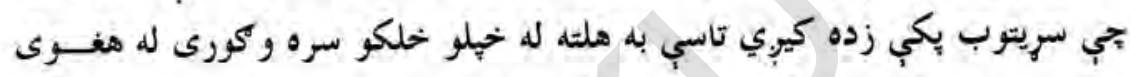

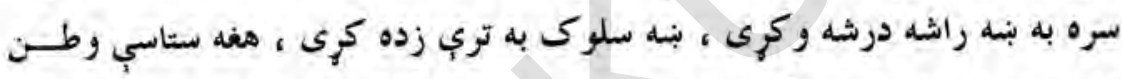
دي ، نو هماغه وه وحي كلره يب يه يوه محخ وطن ته را غله او به مجبورو شرايطو كي

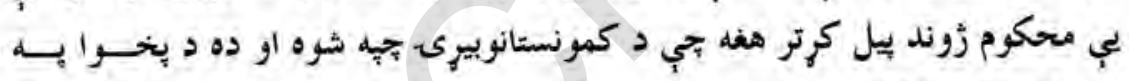
خير له خهلو خلكو سره عادي زوند بيل كر.

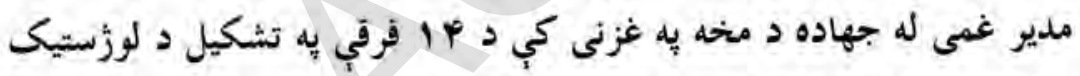

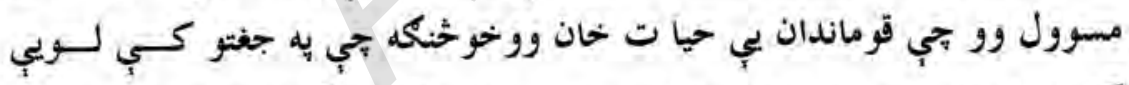
كورنى ته منسوب وو نوخوبنيده يب تجي د خجيل يلاراو نيكه دروازه يه غز ني كي هم وبلوي نو تل به يب د خلكو ستونزي له حكومت سره د وردكو ديوه وركيل به شان طرحه كولي او د خحل قوم بِه خدمت كي به تل له حكومت سره يه ذوغره كي وو ، يه هغه به تل هير خلك ديره وو ديك به بار اولنكر به جحالان ور نوله

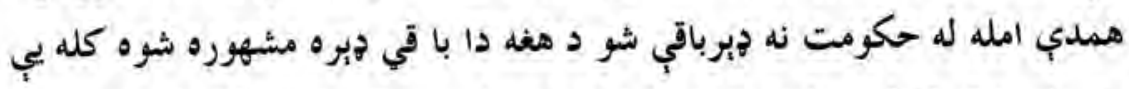
بي خبره تر تصفيب را ورسيده نو مديرغمي أر شو بجي خيل اقتصادي ملي دين

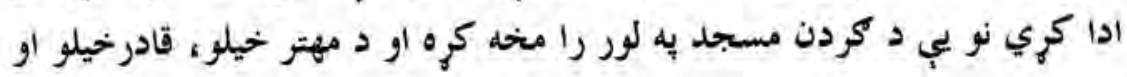


$19 \leq$

د وردكى مشاهير دوهم تركى

برغسون له كليو يب شا وخرا دوه سوه لاري لر كيى يوز اوخهيله با قبدارى يسي

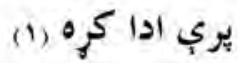

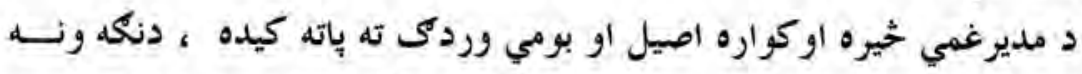

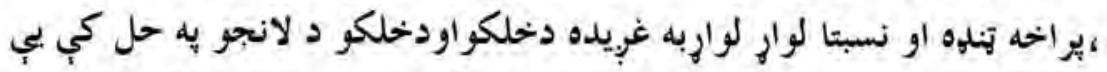

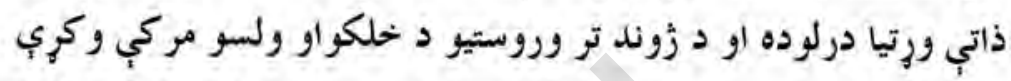

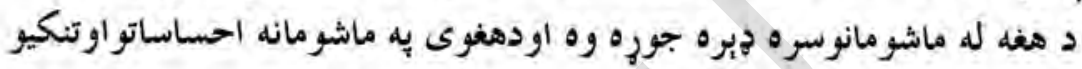

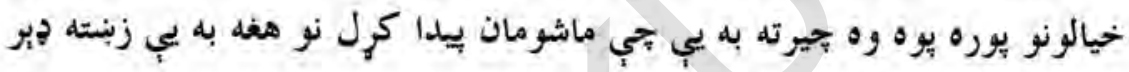

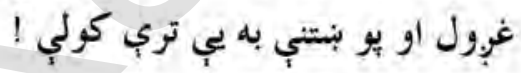

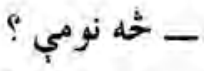

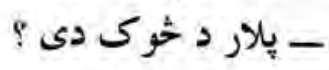

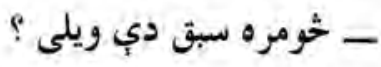

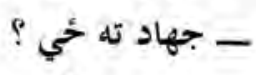

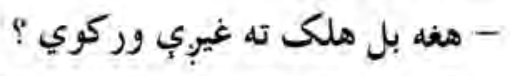

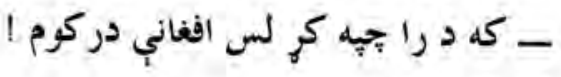
او داسي نور ب........

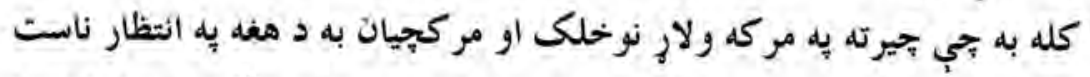

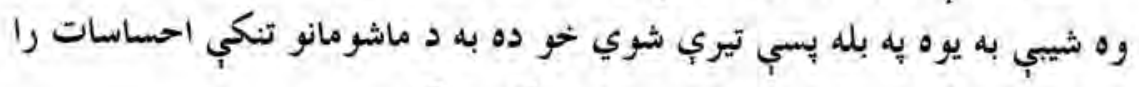

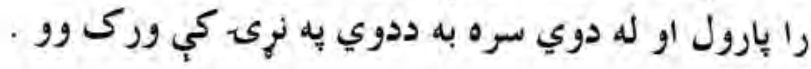

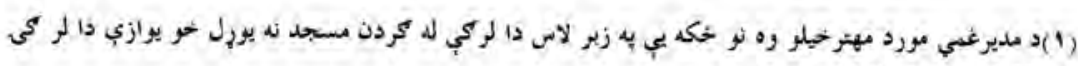

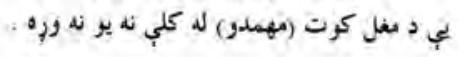




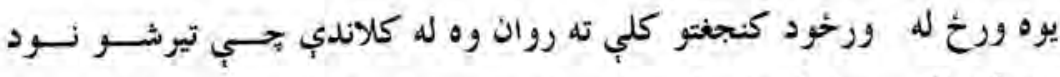

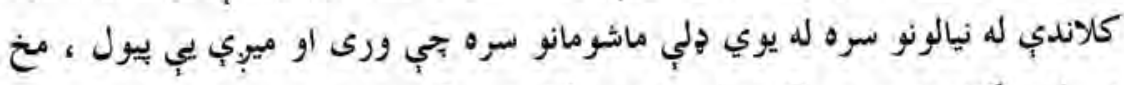

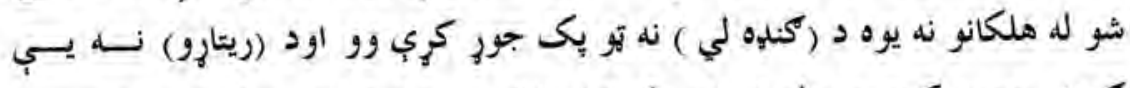

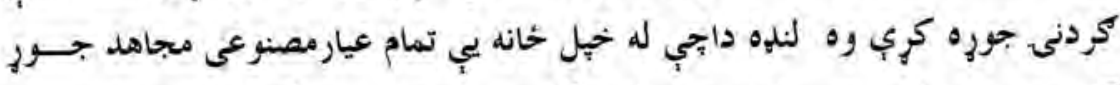

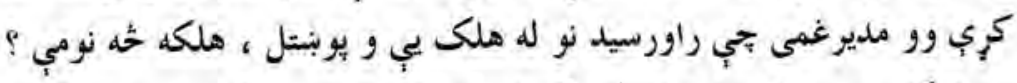

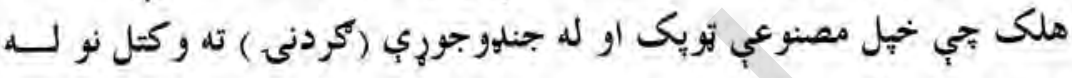

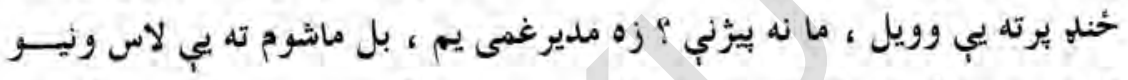
دا مي موستيال دي او نوم يبي عبد المتين دي ، د كنجغتو دي ، نورو هلكانو ته

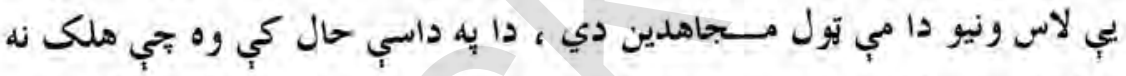
بوهيده بحي مخاطب لوري يب بخهله مديرغمى دي ، د مديرغمي له ستركو نرمي اوتودي او بنكي را رواني شوي نور يب خده ونه ويل اويه بتهه خوله مخ به كنجغتو g

د مديرغمي له خولي هيري معقولي روايت شوي خوترتول مشهروره معقوله بي دا وه جي ده به تل ويل : (هرخه زوال لري اوله منحخه خي ، خو يوازي هغه خه جي زوال نه لري او له منحُه نه خي ، تاريخ او د تاريخ خانه ده ، نو سري بايد

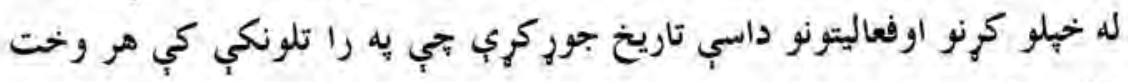
دو ستلو وروي ).

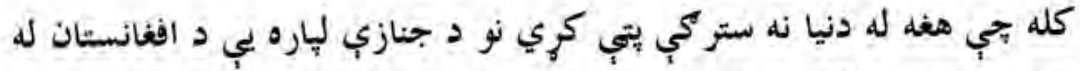

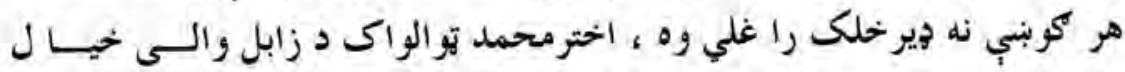

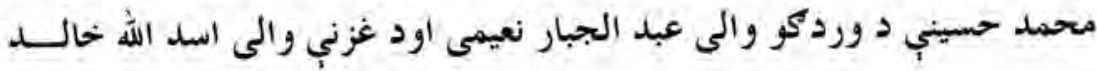




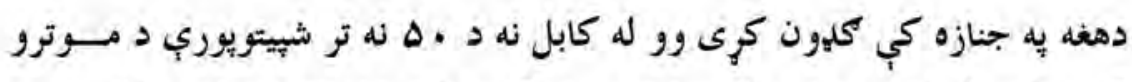
كاروان او له غزنى نه تر سلو موترو يوري كاروان د هغه جنازي ته را غلى وو

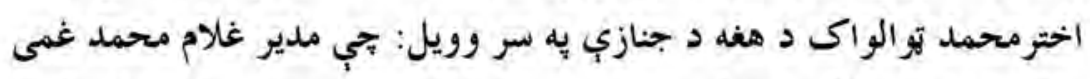
د وردكو مشر ثله بلكي د تولو يبنتنو مشر وو دهغه وفات داسي لويه ملي ظايعه ده جي بيا به هبخكله جبيره نشي ، نعيم كوخى هغه ته خحاص درناوى درلود او ويل به بي بجي دمديرغلام محمد غمي شخصيت اوقدر د وردكوخلكو ته دومره نه معلوميبوي لكه كوم جي دهفه قدر له وردكو د باندي له نورو خلكو سره دي. 


\section{غلام حيدرخان - - جرنيل}

غلام حيدرخان جرنيل د سيد آباد ولسوالى د توب د د كلب اوسـيدونكى وو

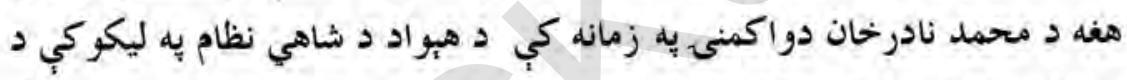

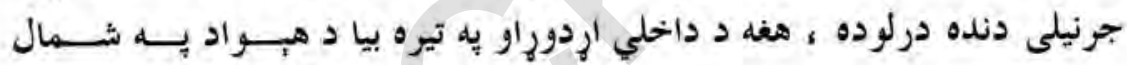

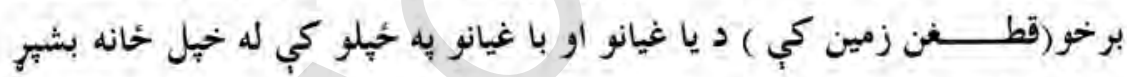

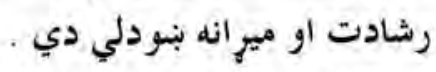

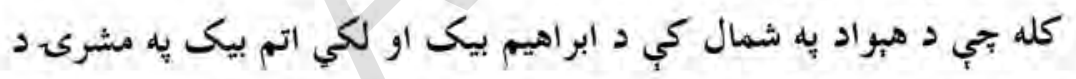

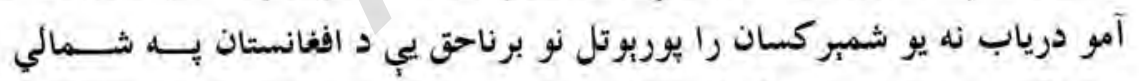

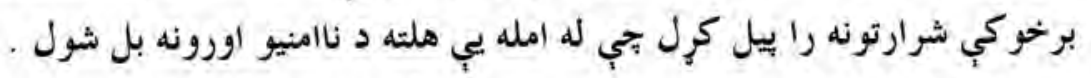

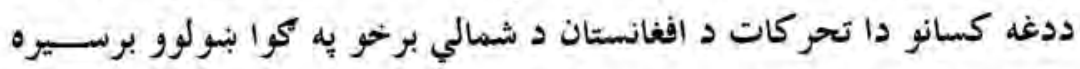

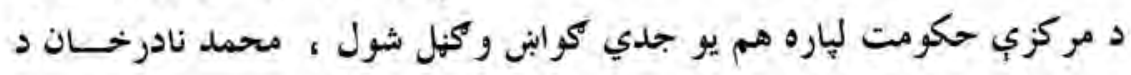

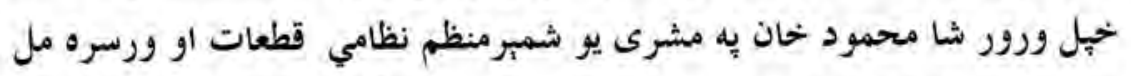

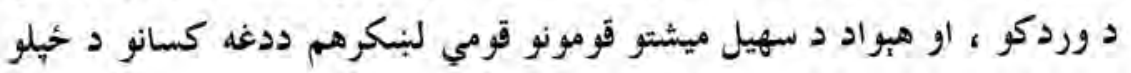

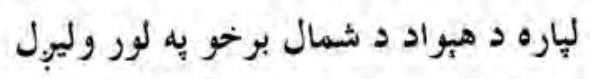


له كابل نه نويو راغليو قوتونو د غه اشراري ذي لكيى د آمو تر سيند يــوري و

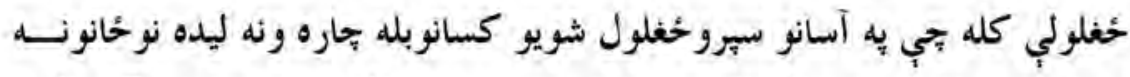

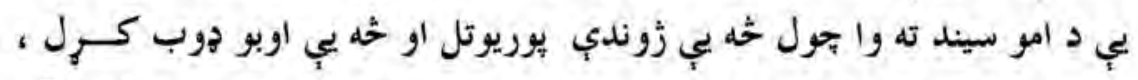

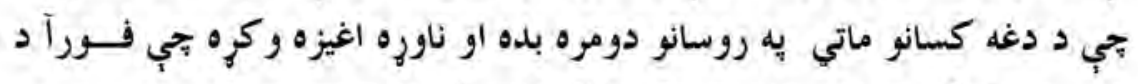

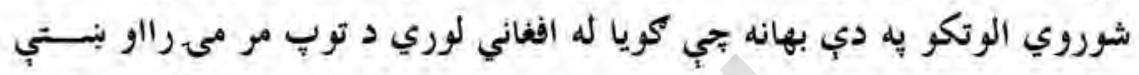
دي يه اففان قوتونو بمباري وكره خر بيا هم حذه يه لاس ور نغلل حيكه اشرار له يوي مني خيل شوي وره ه. جرنيل غلا م حيلدر خان د آشوب او فتني له خنثي كول وروسته د شمال له

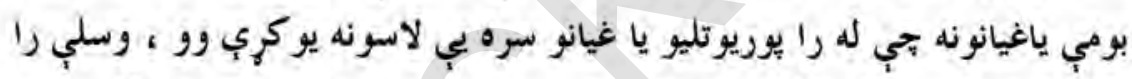

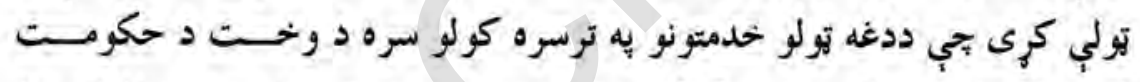
لخوا هغه د جر نيلي رتبه وركرل شوه ، ياته د نه وى جي دا وخت دو د الفغانستان

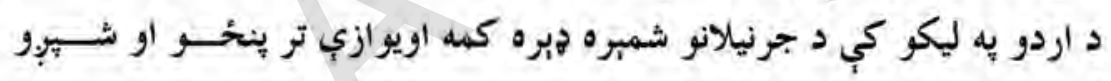
كسانو يوري رسيدل

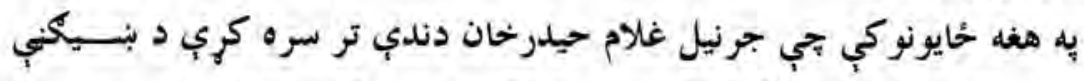
بيلكي يب لا تراوسه د خلكواويه هغه سيمو كي د استوكن منحتلفو قومونو ترمنغ

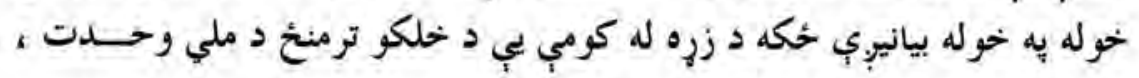

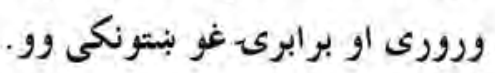

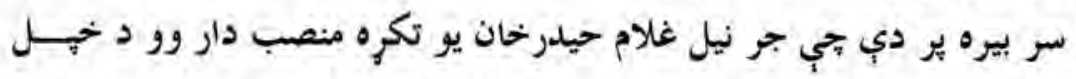

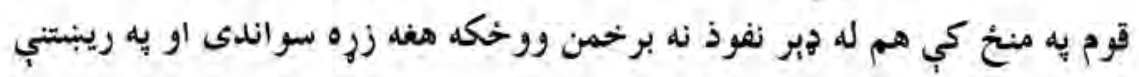


تو كه بخهيله سيمسه كي لكه د مخهه بحي وويل شول د خلكو ترمنح د يوالــي او

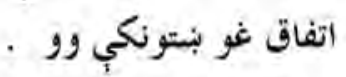
جر نيل غلام حيدرخان ورديى د عبد الحميد خسان زوى او د نيساز الله خسان

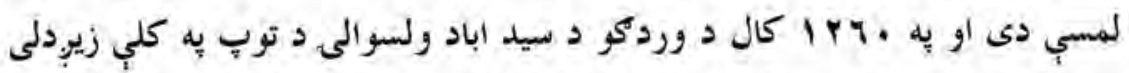

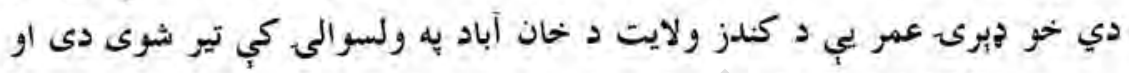

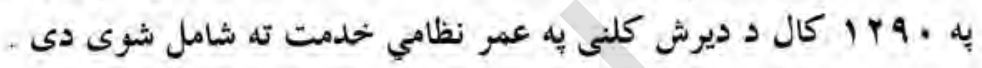

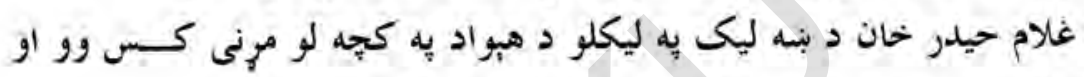

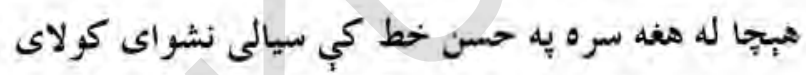

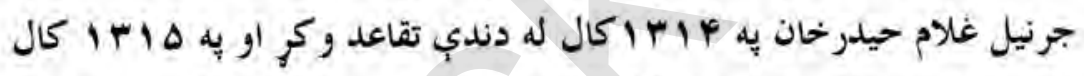

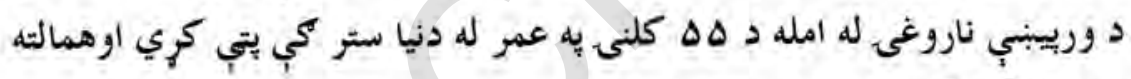

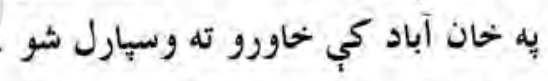

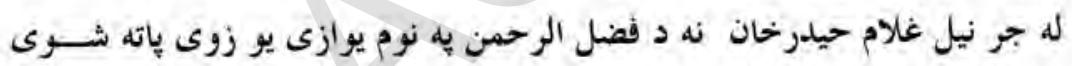

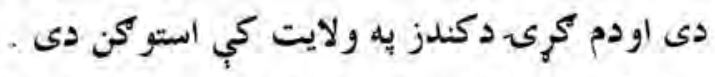

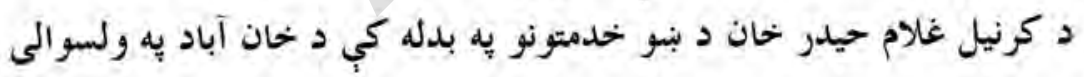

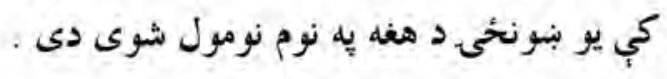




\section{غلام روحانى (ننكيالى) - قوماندان}

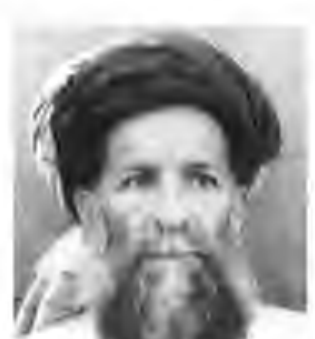

$$
\text { غلام روحانى (نككيالى) دحاكم غلام حضرت به زامنسـو }
$$

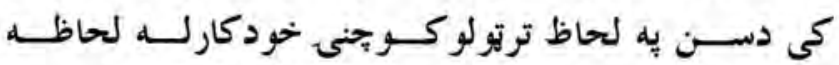

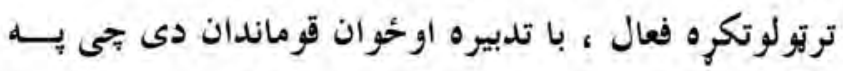

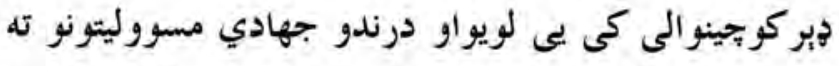

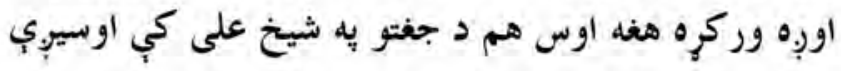

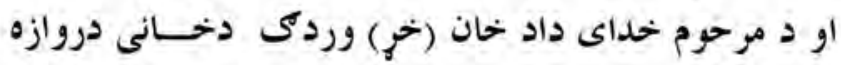

يب يرانيستي او فعاله ساتلي ده ه. 
$Y \cdot 1$

دور ورى مشاهير دوهم تو ك

نشكيالى د جهاد يه يبل كى دغارموغ د جبهاتو د اريكر مسؤول وو خبريالان

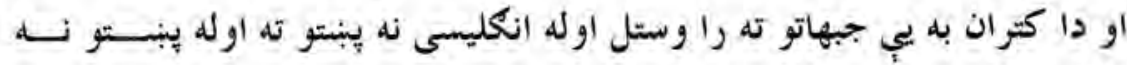
انكليسى ته ددوى خبري به يي زبارلي له دي جي دمسلحانه جهاد سره بي دي ديره

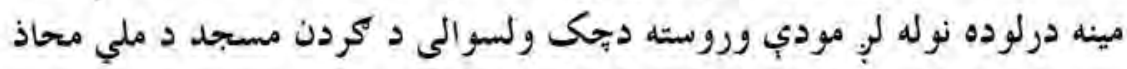
د جبهو مشرشو اوله هغه ورو سته كله بحى مركز يب د عربانو دخو اجه محيــات

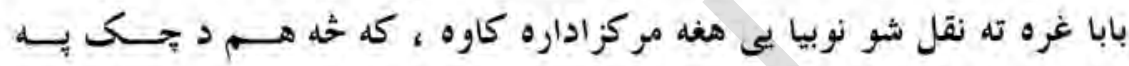

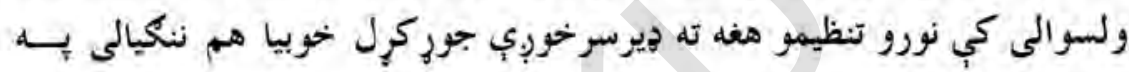
حوحله دا تولي ستونزي وزغملي . كله جي ددي ولسوالى د جبهاتو مسؤوليت وردغاري شو نودنوروجهـــادي

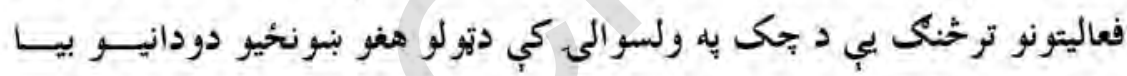

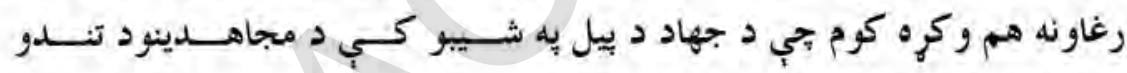
احساساتو له امله وران شوي وور . د نيكيالى مسؤ ليتونه هفه وخت درانه شول كلد بجى دكمونستانو دورو ختمه شوه اومجاهدين بريالى شول نود تنظيمونوترمنئ د بي باورى له امله د استعمارى

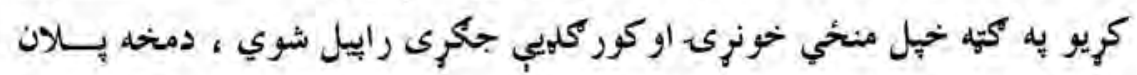

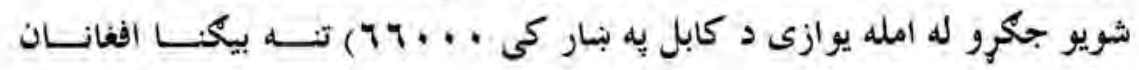
شهيدان شول . ش ش

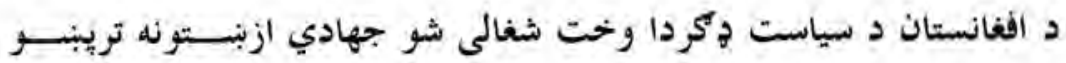
لاندي شول د رباني يه مشرى دمركزى حكومت نه د مجاهدينو او عام ولس تمه له وشــكيده اودهر ولايت مجاهدين د حُان يه غم كى شول . 


\section{r. r}

د وردكو مشاهير دوهم توكى

مولوي خالص يه غوخده تو كمه خيلومجاهدينوته بجي دا وخت ننكيالى هم د هغد تنظيم ته تللي وو، وويل : بجي د قرآن كريم حكم او زما فتوا داده بجي قاتل او

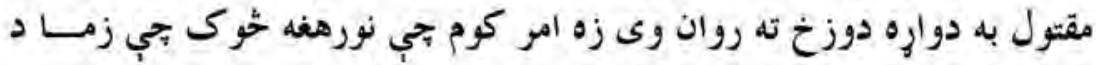
تنظيم مجاهدين دي له كابله ووزى اوخيلو سيمو ته د ولار شي . ننكيالى او ورونويب خجيل مجاهدين له كابل نه وايستل او يوازي يو مركزيب د افغانستان دعلومو اكازميى يه دفتر كي فعال يرينسود . لكه د مخه جي وويل شول مجاهدينويويربل باورله لاسه وركــــ او دجهــاد برحقه داعيه يب دزبنيو، سمتي ، ستمي ، قومي اوغير اسلامي كر ايشونو قربــانى كره يوبل ته يب د توطيويه جورولولاس يوري كر او جهاد يب له خيـلـل اصـلي مسير نه • צ' درجى منحرف كري د وينوتويولو ، توطيو جورولو او دبيكنا مركونو بازار تود وو ننكيالى به دا

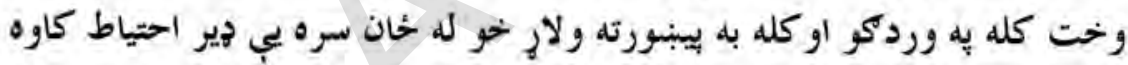

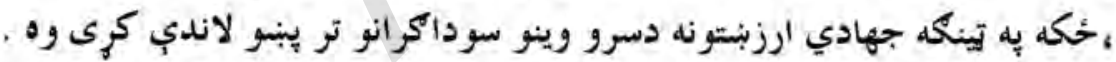
يوه بيلكه دلته را وريو د . rV I كال د جدي به مياشت كي نثكيالى له يببنور نه د وردكو يه لور راروان وه جي نا خايه د ننكرهار د درونتي له بند سره له يوه (نظامي كمين ته ورته يتّك سره مخ شو) له دغه ورخي د مخه او وروسته يه دي

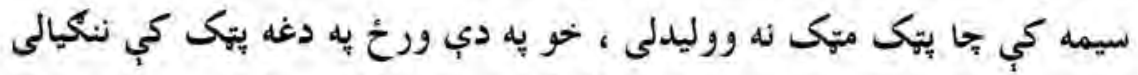
او مجاهدين يب ددي لياره (جي دوى خوكى دي ؛ ودرول شول ) او ورته وويل 


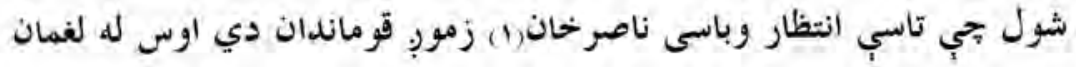

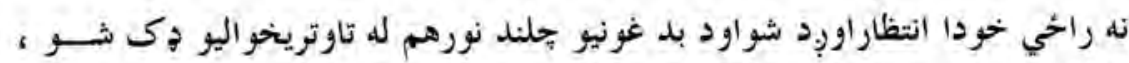

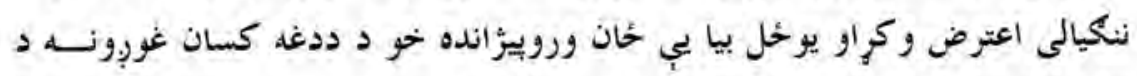

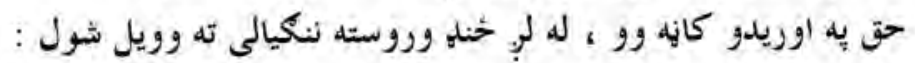

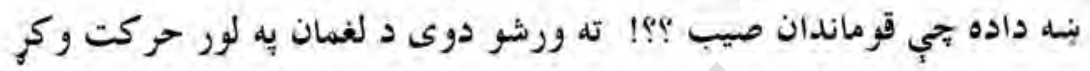

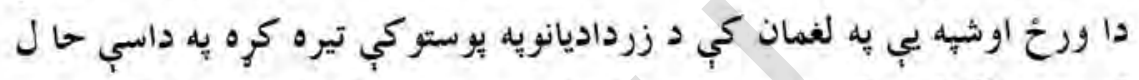

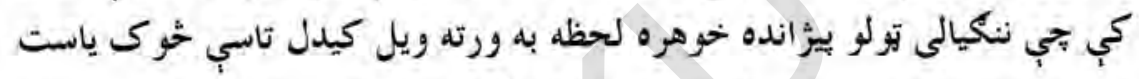

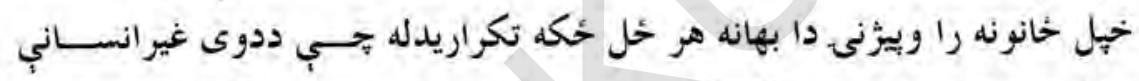

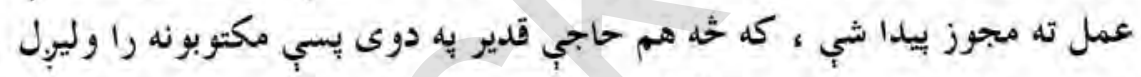

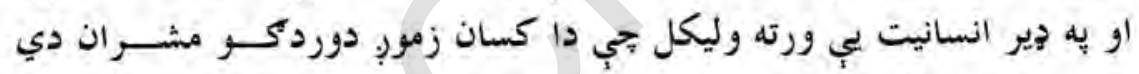

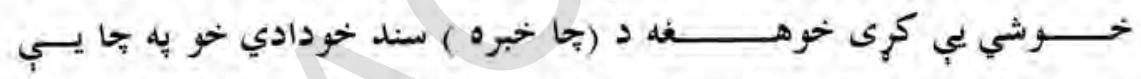

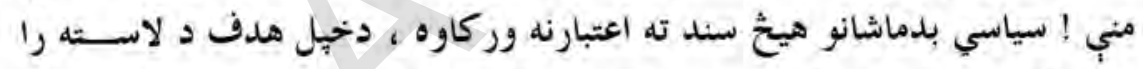

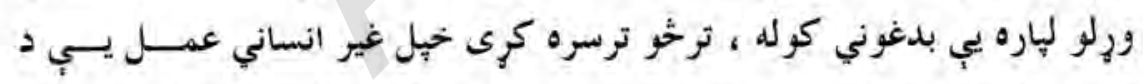

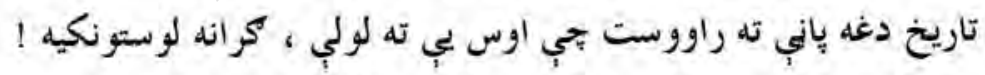

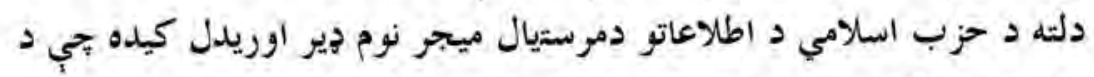

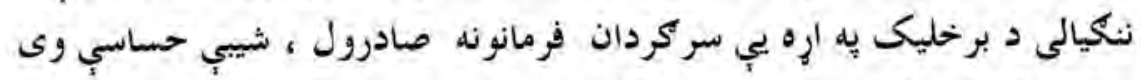

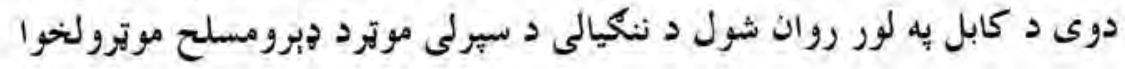


$r \cdot \varepsilon$

د وردكو مشاهير دوهم توكى

بلدركه كيده ، د موترو كاروان د خُخحي يله يه سيمه كي د اوسئى احمد شا

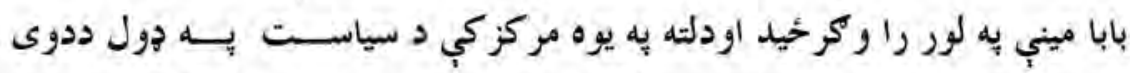
نومونه ثبت شول ، شيه بخه وه دمركي د دلالانو او دوينو د سوداكر انو ددود بيه

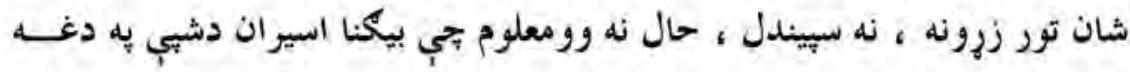

$$
\begin{aligned}
& \text { تورتم كي د كوم سيا جال به لوربيول كيري ؟ } \\
& \text { كيه كومله كنا ? } \\
& \text { يه كوم جوم }
\end{aligned}
$$

مكر كله به هم جيري كوم جانى او قاتل دالله ج له قهر اودتاريخ له قضــــاوته

$$
\text { وتبنتي تجي يه كومله }
$$

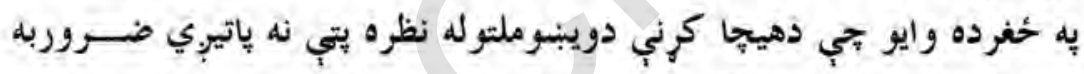

دهرجا به كرونونسالم اوعادلانه قضاوت ددوى لمسيانو اوكروسيانو ته ياتيروي . يه هر صورت ! د لوكرسيمه وه ددوى د سبرلى موترله نوروموترو نه تــرمخ

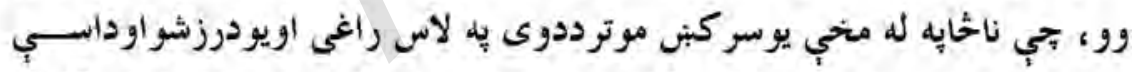

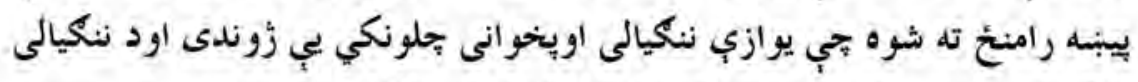
د كاردانو يه شمول نورسياره كسان تول له منحة ولارل . دوى روغتون ته ورسول شول له نيكه مرغه بجي ننكيالَّ ڤيه حال برابروو، خحو

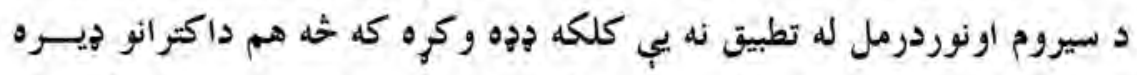

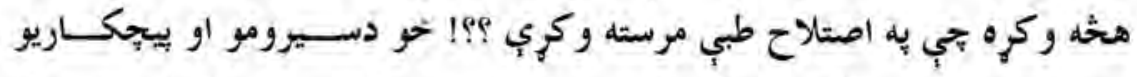

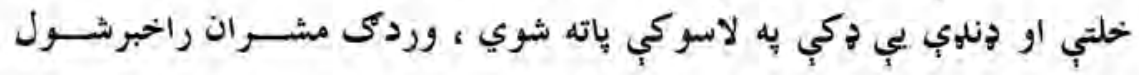


اوسر آنجام بنكارشوي مات وزرى مارغه له خو كسو شهيدانو سره مل له دام نه زوندى د جغتو يه لوري والوت

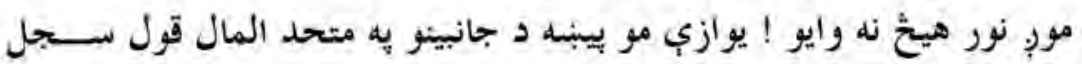
كره دا جي ولي ؟ قضاوت به تاريخ وكرى .

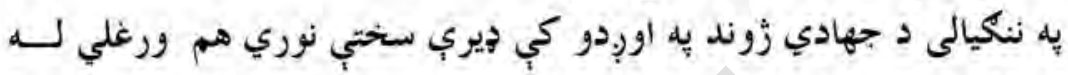

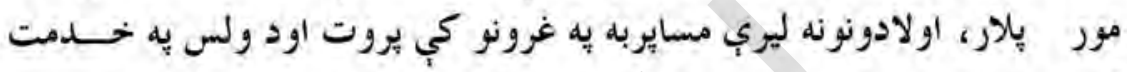

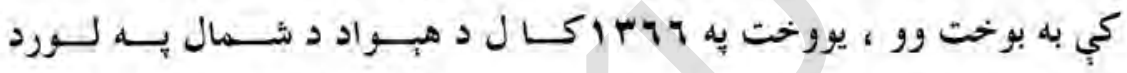
مسجاهدينوترمنحخ د يوالى اواتحاد د راوستو لهاره ولار ، دغوربند د فند قستان يه سيمه كي د حُيئو حُان غوبنتنوله لاسه دوي اونى. بندي وو له دغه بنديخاني نه

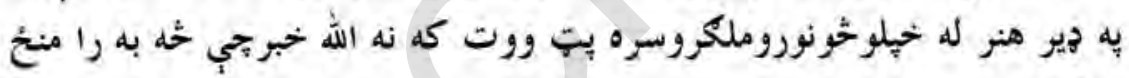
ته كيدل : د استاد ربانى د واكمنى يه مهال كله جي يه وردكو كي دوالى د دياكلو لياره

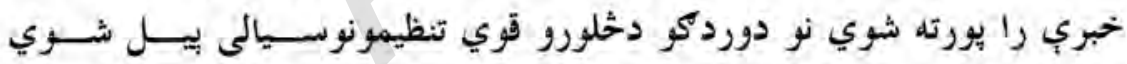

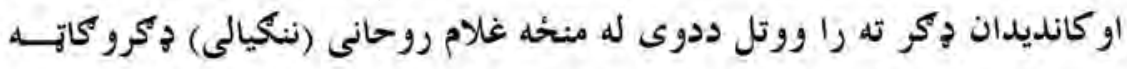
اودده انتخاب د كابل د و اكمنى لخوا يه رسميت هم وبيثرندل شو له راد يوكانو

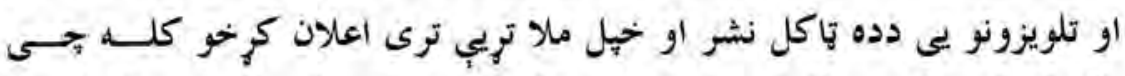
ننكيالى له مركزي حكومت نه دولايتي لكبنتونو لهاره امكانات تقاضا كرل نورد

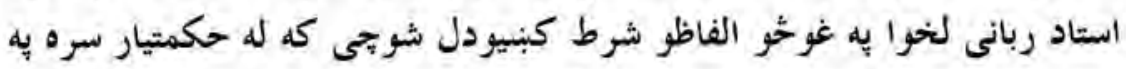

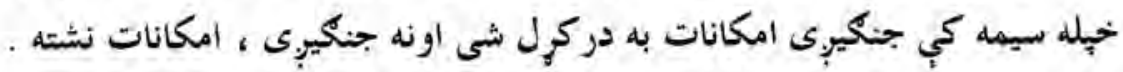


Y.T

د وردكو مشاهير دوهم توكى

كله بتي د رباني دجمهوري رياست غيرقانو ني دوره ختمه شوه له لوبر مودي

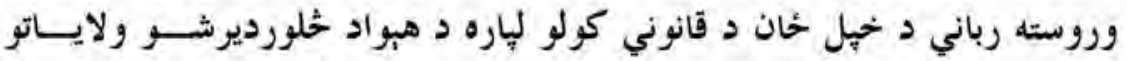

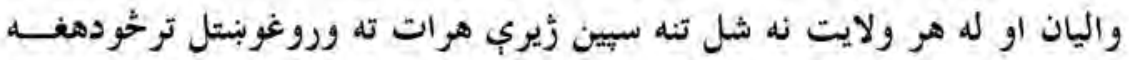
درياست جــمهوري موده وغــزوي ، يه دي غونلهه كي ننكيالى له ويري بيرته

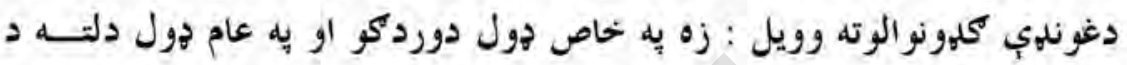

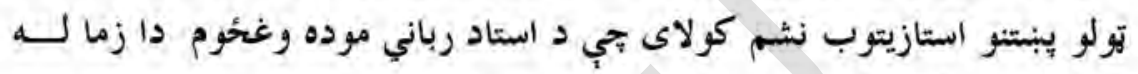
صالاحيت نه لوره خخبره ده . حيه دي غونلره كي يوازي هب تنه يبنتانه وو ، د ننكيالى يه همدي خبره غونلهه رجكه شوه او هو والى له خهلو سبين زيرو سره د خيل ولايت يه لوري ولار . دا وخت د حكمتيارصاحب او دو ستم ترمنئ د ربانى يه مقابل كى يو اتحاد هم جور شوى وو او دو ستم حكمتيارصاحب ته سلاه او مشوره وركري وره بحى كه برياليتوب غوارى نو لومرى بايد د لوكراو وردمى ولايتونه د نورو تنظيمونو له موجوديت نه تصفيه شى خواصله خبره دا وه بحي ددفه مثلث د دريـــو وارو ضلعو نه دهري يوي يه تطبيق كي د وردكو بربادي نغبنتي وه .

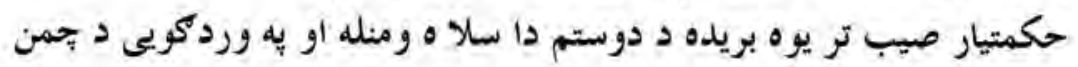
، قلم او ئورو زرداد يانو به ذريعه بِه حخينو سيمو كى نظامى تحر كات را يِيـل

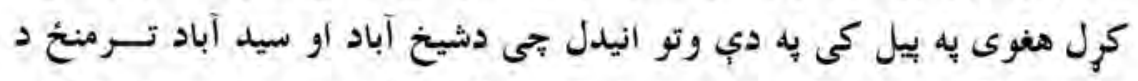
اتحاد اسلامى مربوط د (سي سى) غونله جرور كرى له هغه ورو سثه دا بلدغوني

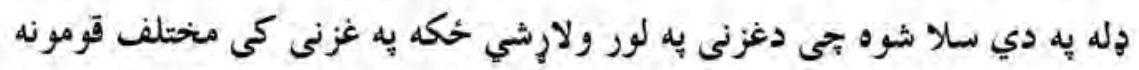

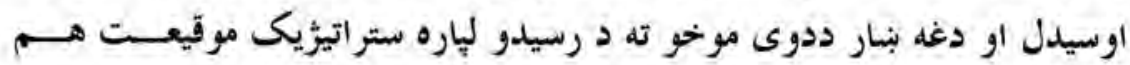


درلود ، دوى دغزنى والى قارى بابا ته اخطار ور وليوبه جى كه بجيري دسيمى

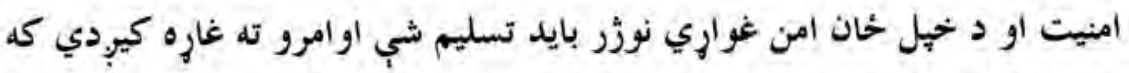

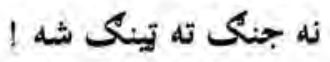

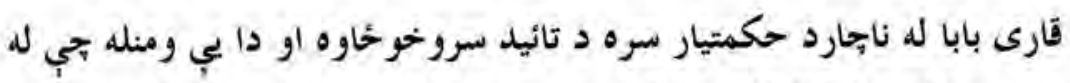

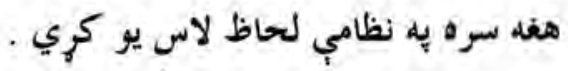

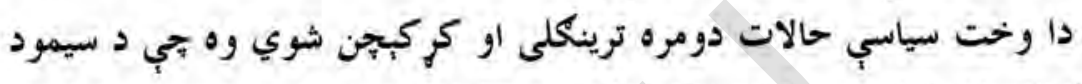

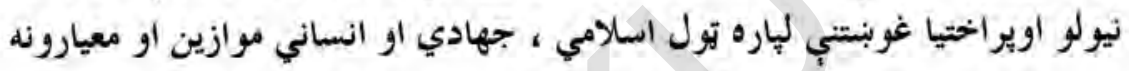

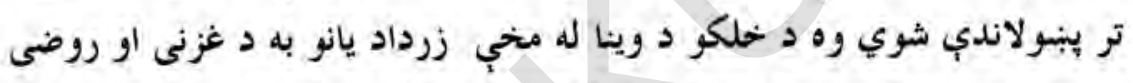

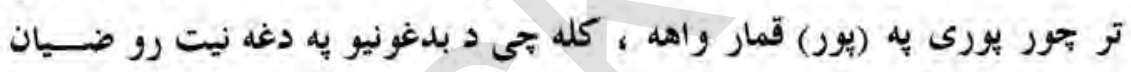

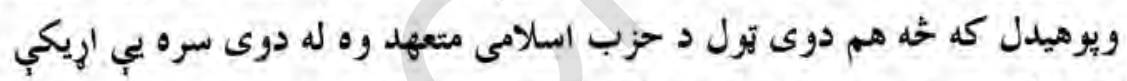

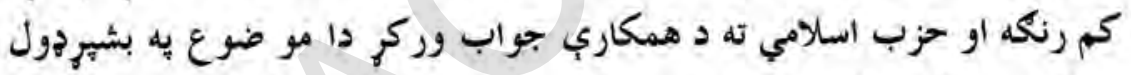
د طالبانو به كيهه وخرخيده

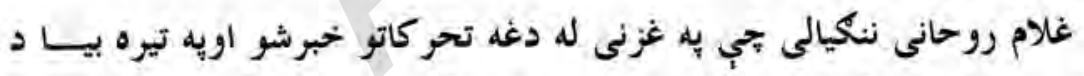

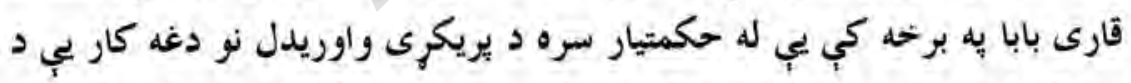

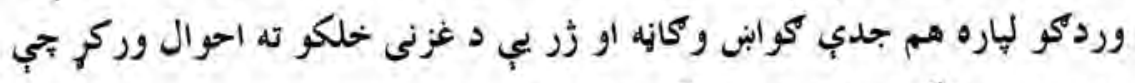

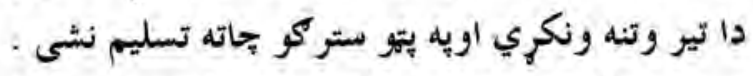

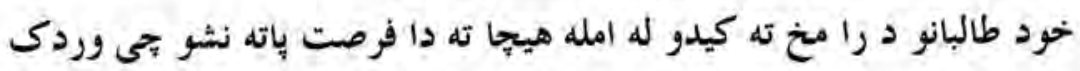

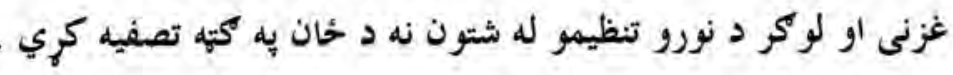

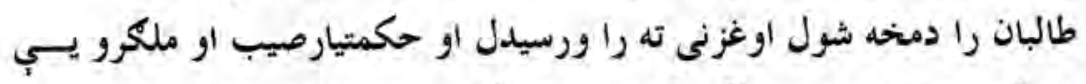

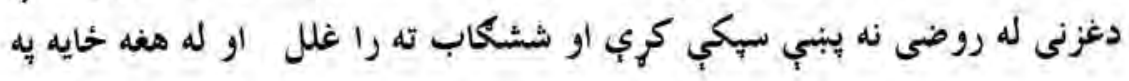


Y. A د وردكو مشاهير دوهم توكى

تراب دخهلي اصلى قراركاه ( جار آسياب ) يه لوري ولارل خكه دوى ويوهيدل

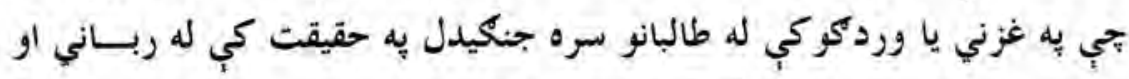

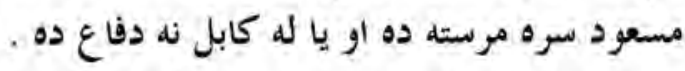

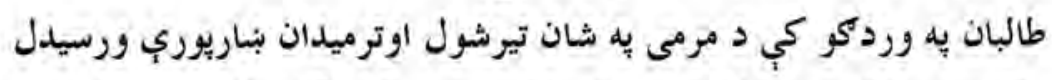

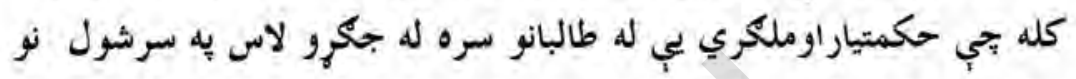

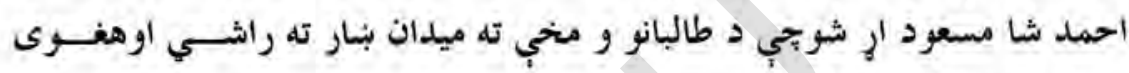

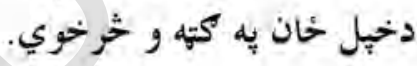
احمد شا مسعود طالبانو ته وريل

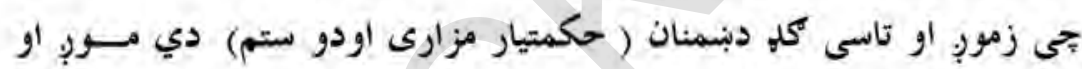

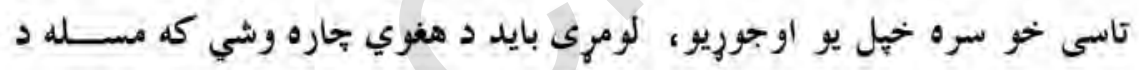

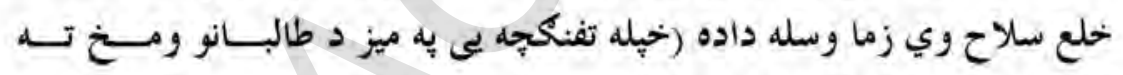

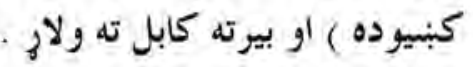

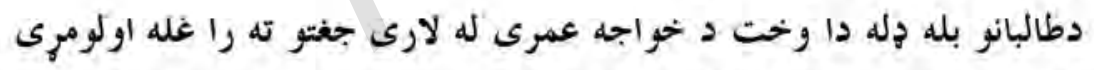

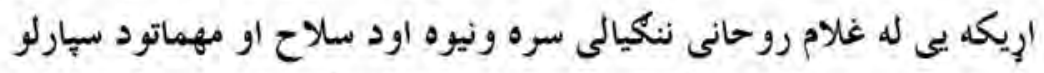

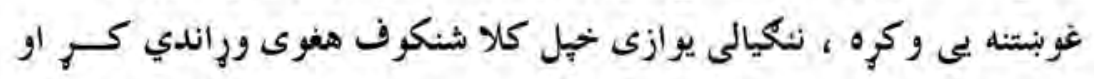

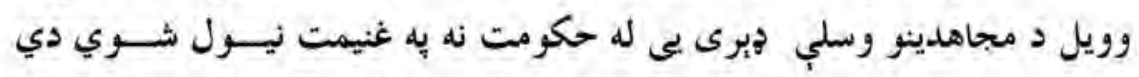

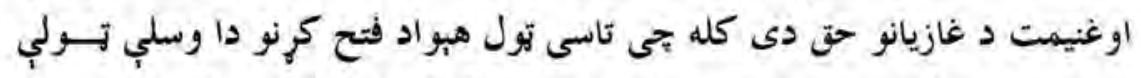

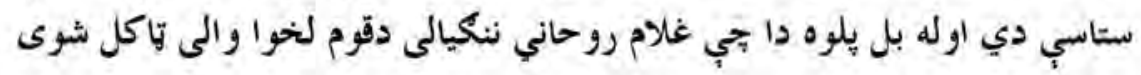

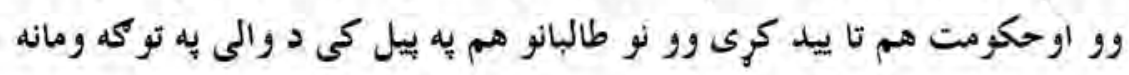


Y. 9

د وردكو مشاهير دوهم ثي ك

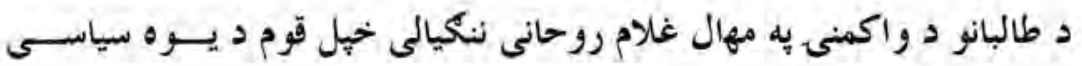

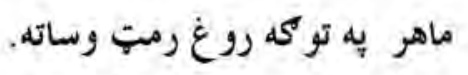

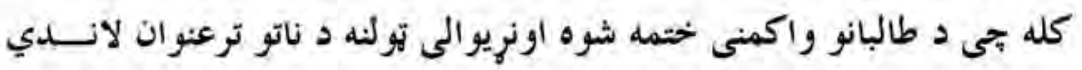

افغانستان ته راغله نويه هماغه يبل كي ننكيالى د جغتوله قوي اوهوبنياروسـيـين رُيرو يوه غونلهه را وغوبنته خو يريكره يه دي شوه جي نيكيالى ته وويل شول : ته له طالبانو دمخه د رباني دحكومت والى وى اوس بيرته رباني راغلى ته صــبر

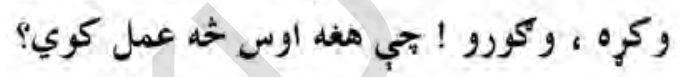

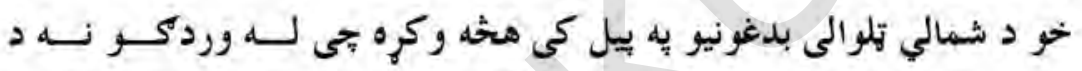

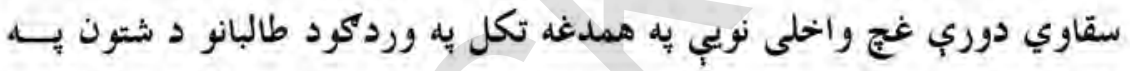

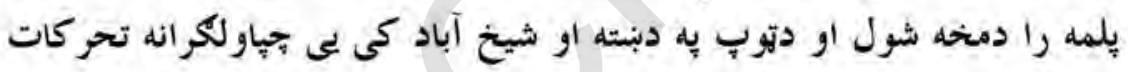

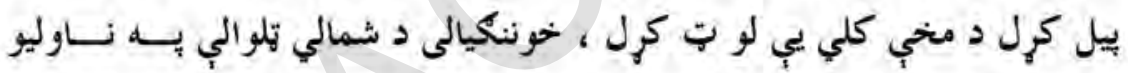
موخو و يوهيد اوله بشيرى ( تاريخي هو بنيارى او بيدارى نه يب كار واخيست)

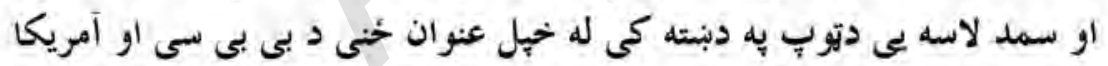
غو. له راديو كانوسره مركي وكري او يه خهلو مركو كي يب به غوخد توكه وريل :

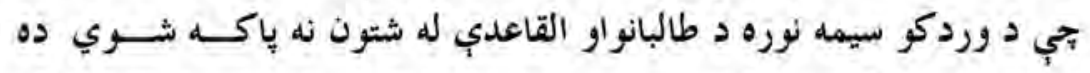

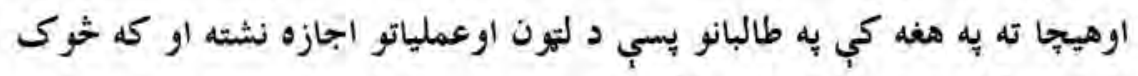

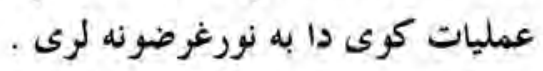

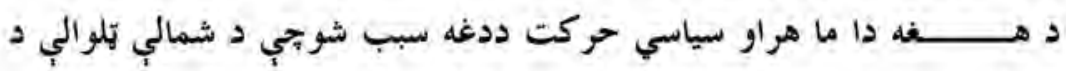
تاريخي غج اخيستي بهائه وركه شي كه حثه هم دولت دا وخت د مظفر الدين يمسـين 


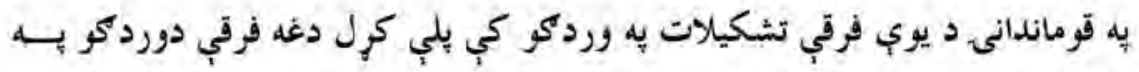

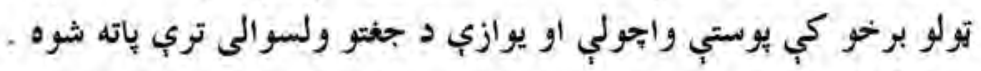

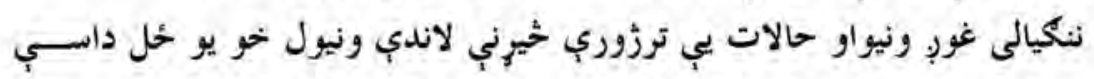

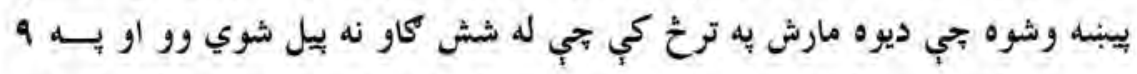

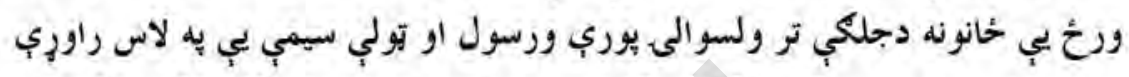

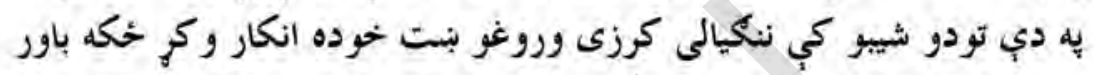

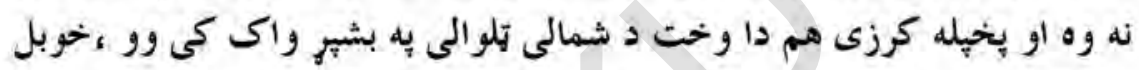

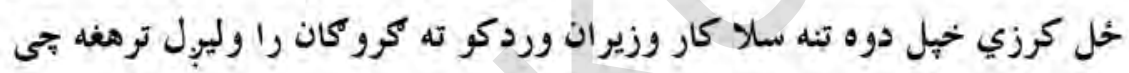

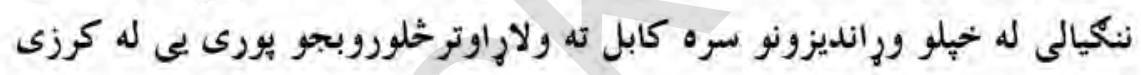

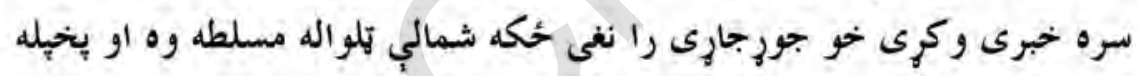

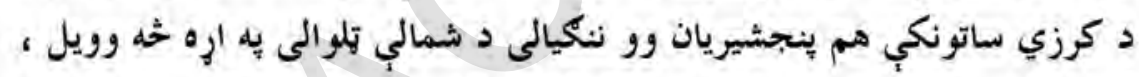

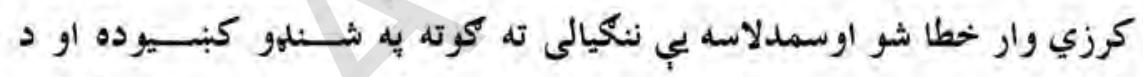

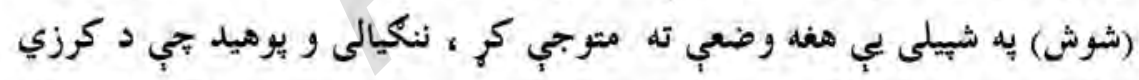

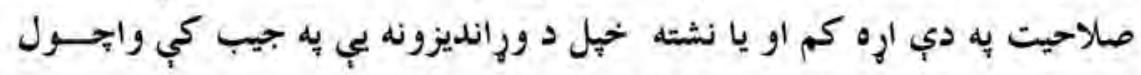

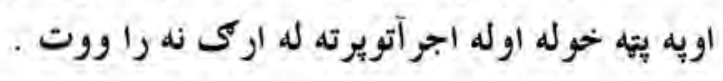

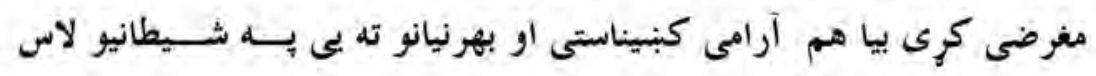

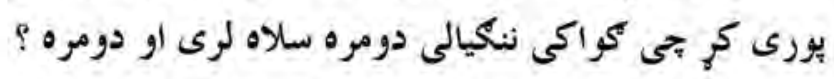

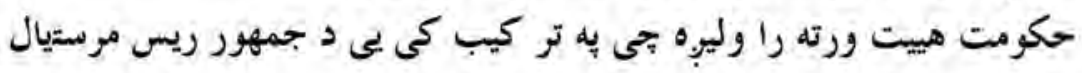

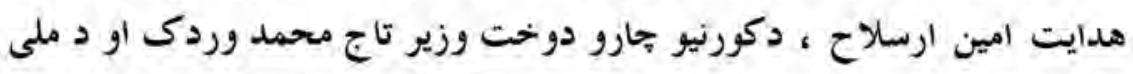

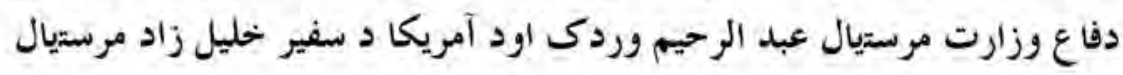




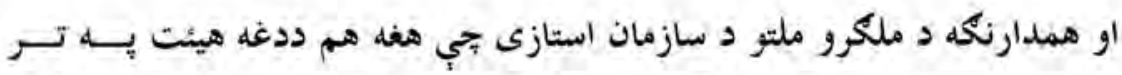
كيب كى وه له م . . هتنو بدركي سره ننكيالى ته ور وليزبل ددوى د ناستي حاى

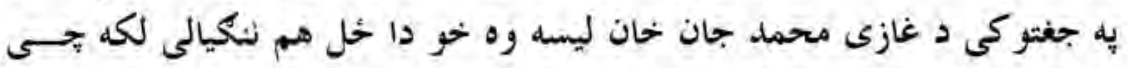
طالبانو ته يى ويلى وه دوي ته وريل : بيره مكوى سلاح توله خوندي اوكريسبند يه صندوقونو كى اجول شوي ده

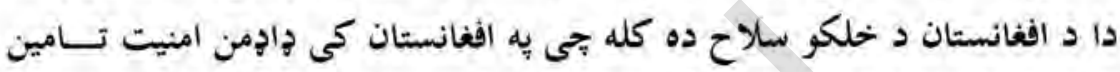
شو او د ملى د فاع وزارت اوكورنيو جارو د وزارتونو تشكيلات جـــوراو يـــه

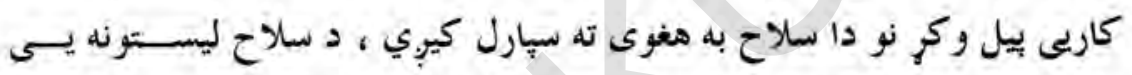
وركرل اويه دي تو كه د رواغلى هيئت او حكومت بهانه هم وركه شوه.

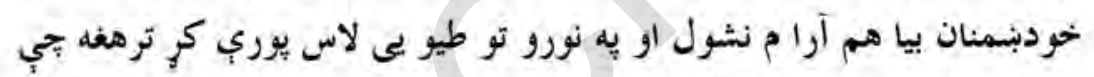

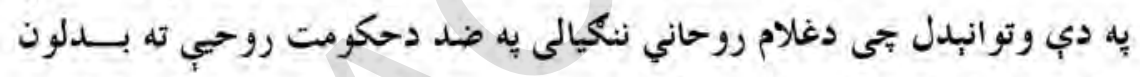

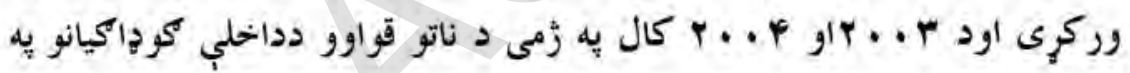

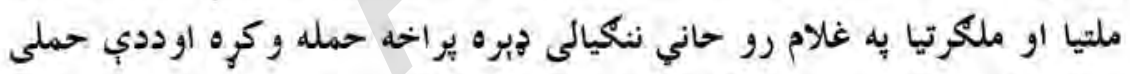
يه ترحُ كي غلام رو حاني ننكيالى كلا بند او د اولادونو تر مخ يب لاس ورباندي وترل شول اوله خلمور ويشتو ساتو وروسته بكيرام ته بوتلل شو او دده يه زركونو ميله وسلب او مهماتويى سره را تول او د سلطان له بند سره نيردي يبي وجول جى له امله يب د سلطان بند استنادي ديوالونو درزونه بيدا كرل او يه را تلونكى

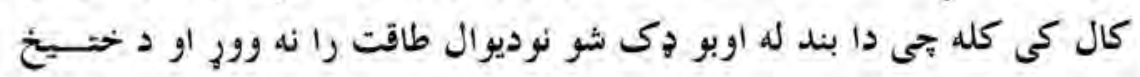

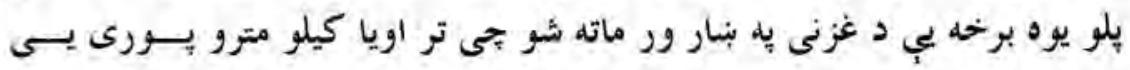




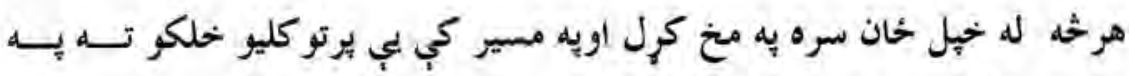

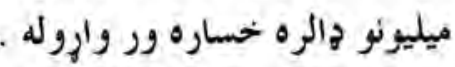

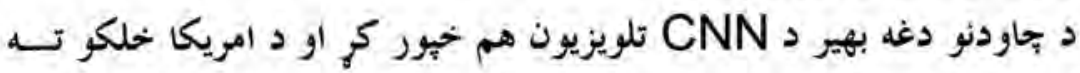

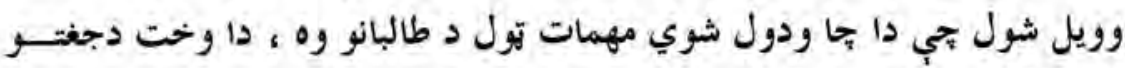

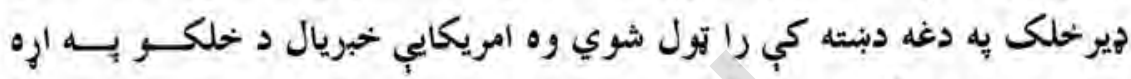

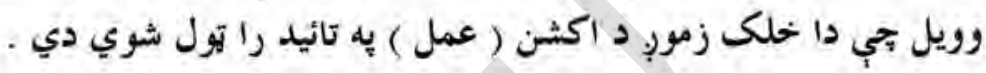

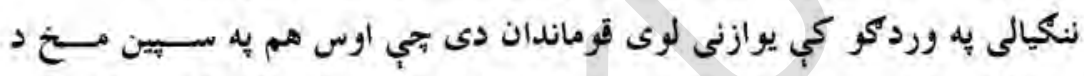

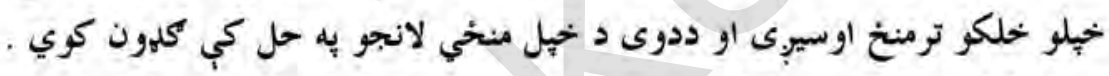

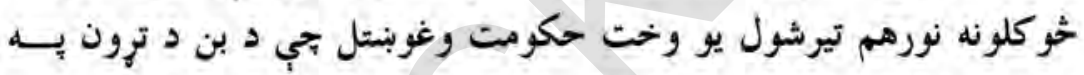

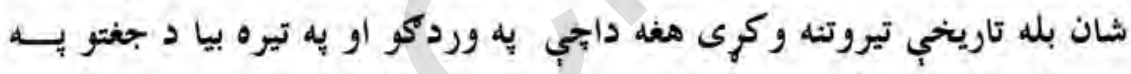

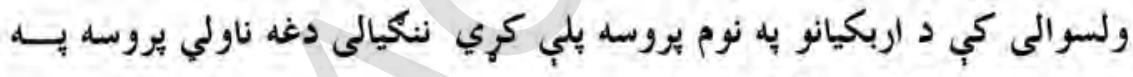
لاندي دلايلو كلكه رد كره ولهي

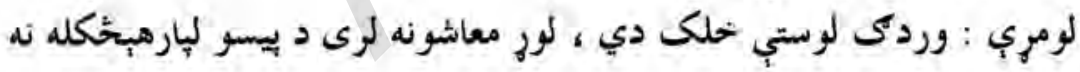

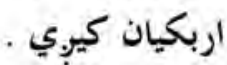

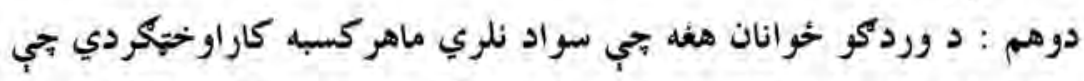

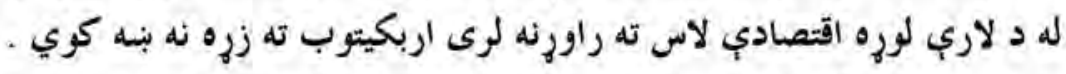

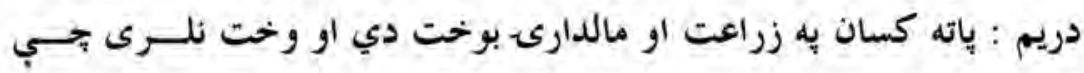

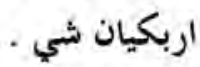

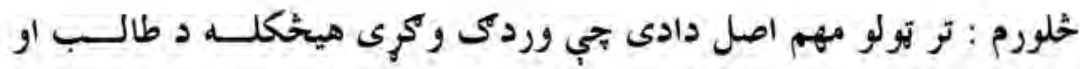

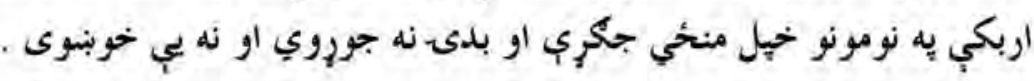




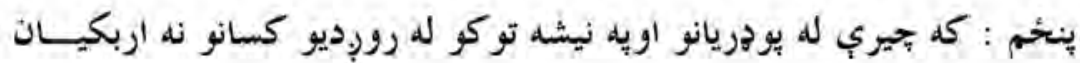
جوروى نو دا كسان به حتمى خيلي وسلي يه يوزرو تبادله كوي . د مغرضوكريو يه شيطانت بياهم دحكومتى مقا ماتو او (ناتو) زره نه صبريده او يه ننكيالى يب دوسلو درلودلو شك ور يوحَل به جغتوكي آوازه وانول شوه جى دجعفرخيلو له كلى كوم هلى يبريانو تبنتولى دي بـى شمبره مخلوق يى يه

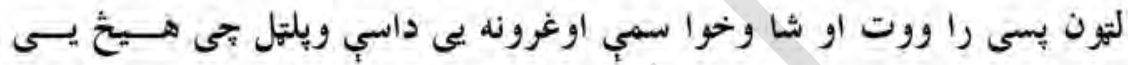

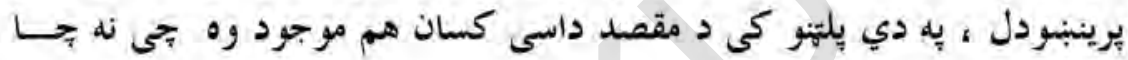
يبرّندل او نه يعى د مخه ليد لي وه له دغه كسانو سره تعليمى سبى هـــم وه او د

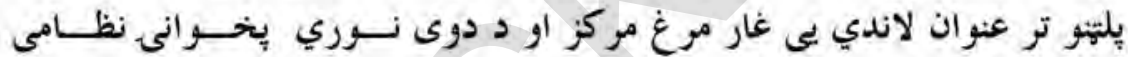

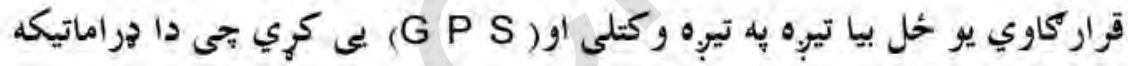

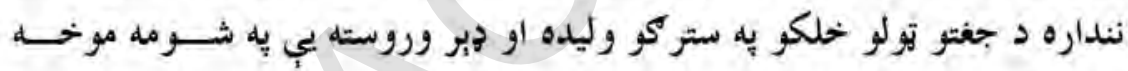
ويوهيدل .

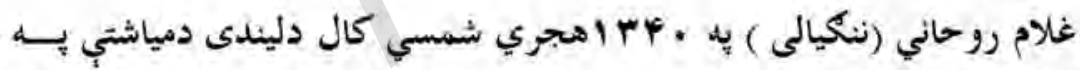

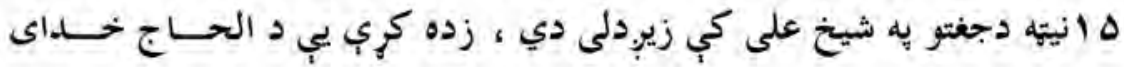

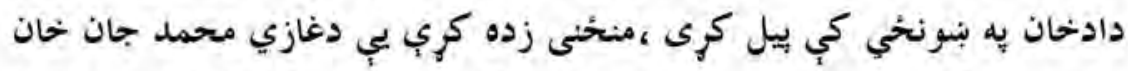
يه بنونحي كي ترسره كري او بيا وروسته د كابل دحبيبي له عالي ليسي نه فارغ

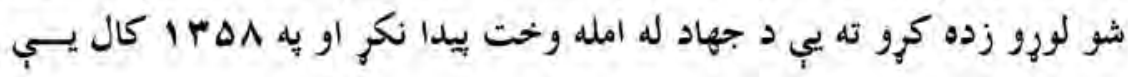
جهاد ته ملا وتركله 
ris

دوركم مشئهير دوهم توكى

\section{كمال خان - غازي (كمال خحيل )}

غازي كمال خان د اختر خان مشر ورور، وو او له احمد شا ابدالي سره هند

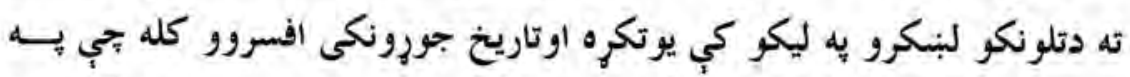

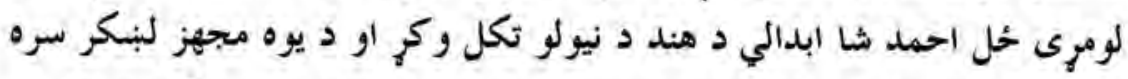

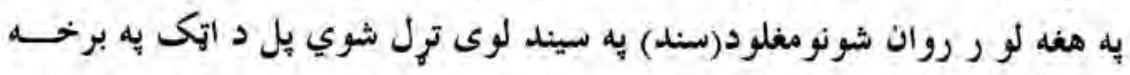

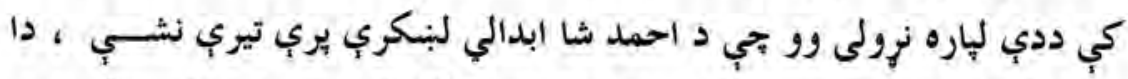

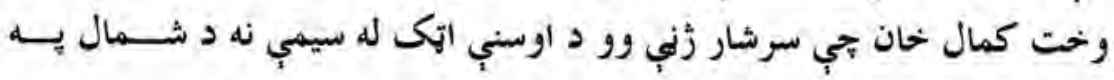


لورجيري جي ددواروسيندونود اتصال نقطه وه له هغه هم وري اندي تيرشــو لاره اوكودر يب معلوم كرل او بيا بي يه دواروسيندونو يلونه وترل او يه اساني ســـره

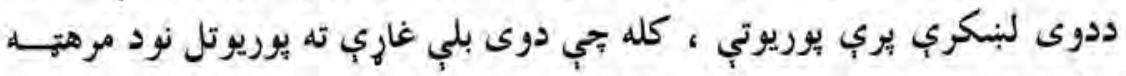
لبنكري هم را غلي وي او دواره لبنكري سره مخامخ شوي .

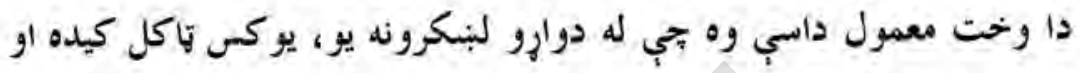

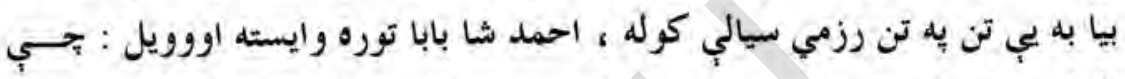
خوى به سيالى ته وراندي شي ، ذرّ كمال خان لاس يورته كر، احمد شا ابدألي ورته وويل: بي ته نوي حوان يب له مقابل لوري سره ستا داسيالي نا ممكنه ده !

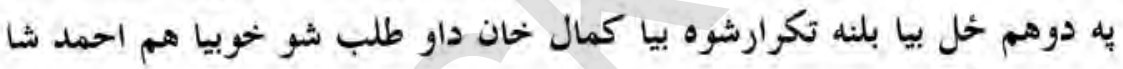

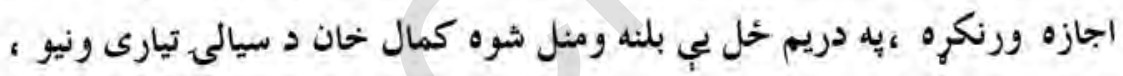
دوى دواره سره مخحامخ شول مرهيه بحي يهلو ان وواو يه فيل سيوروونو كمــا ل

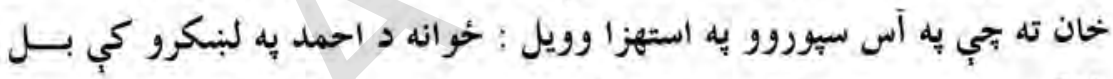
خو ثى نه وه بحي ته يب له ما سره سيالى ته را وليولي ، كمال خان ورته ووريل :

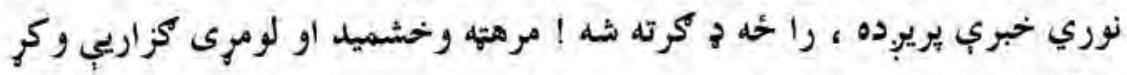
او كمال خحان د بريبنا به خير د آس سيني ته شو مرهتي يه خوشحالي خهيله توره

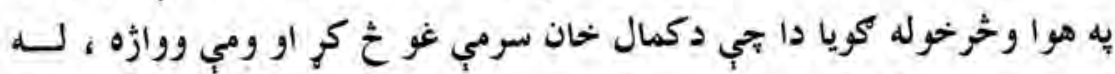

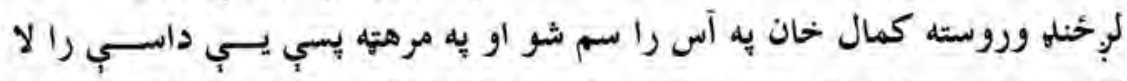

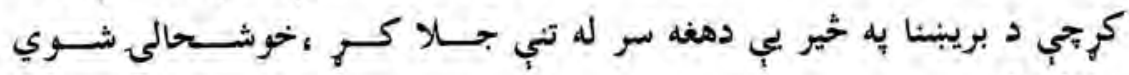
اوجكجكي احمد شا ابدالي د مرهيّه جوغه كمال خان ته وريه سركيره (1) 
اوبيا وروسته احمد شا ابدالي كمال خحان ته د ددغه خدمت او رشادت يـــه

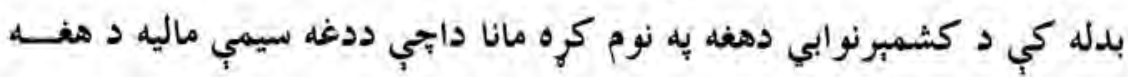
شوه او آن د لمسيانو تو زماني يوري يبي د دغه يه نوم دا ماليه وردكيو ته راتله

كما ل خان له هند د را ستنيدو يه مهال دوه هندوكورنى هم له خجل خحان سره وردكو ته راوستي تي ديوي كورنى مشر به زركرى ورته كوله اود بلب كورنى مشريب ( ميتر ) وو كمال خان دا وخت يه سنلماور كي اوسبده خوله هند نه د را تكى وروسته

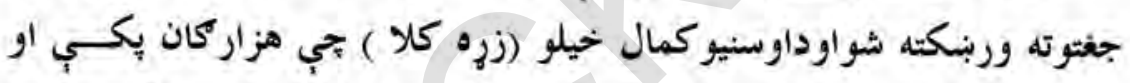
سيدل يه يسسو توي واخيسته او هغوى يب تري وايستل اويه دي توكه ورو ؛

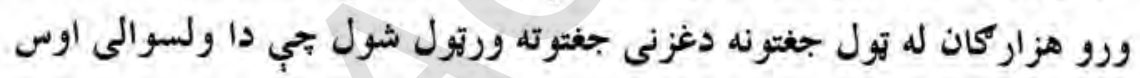
د(جمع جغتر) يه نوم ياديوبي تجب دا نوم هم اورجده فلسفه لري .

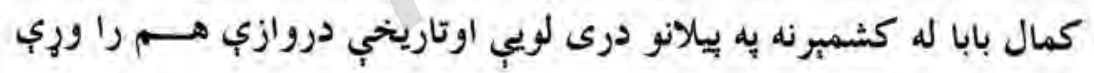

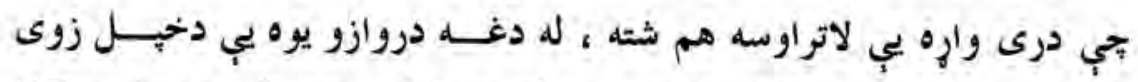
(مير سنت خان ) يه كلا كي او بله بي د كونلده قول د همزول بابا خيلو يه كلا كي بجي خيلب خورته يب وركري وه اودريمه بي به بيد مشيك كي يه يوه كلا كي اينبيودل شوي ده بي دا درى واره دروازي اوس هم موجودي دي.

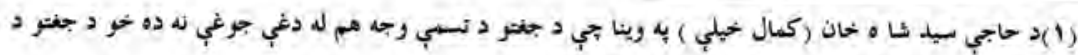

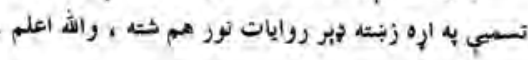




\section{Y IV}

د وردكو مشاهير دوهم تبوكى

غازي كمال خحان له دووميرمنونه اوه زامن درلودل جي مشريب عيد الله خان

(1) دوهم يب عثمان خحان دريم يب ميرسنت خحان اوخلورج يب دايم خحان ينتم يب كالاب خان او شيرجم او اوم يب د مير طهماس اوعلى كوهر يه نومونو

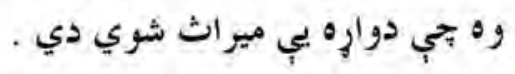

له غازي كمال خان سره هند ته د تلونكو لبنكرو هيه ليكو كي د هغه خـــاص

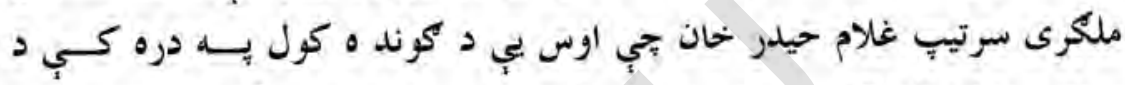

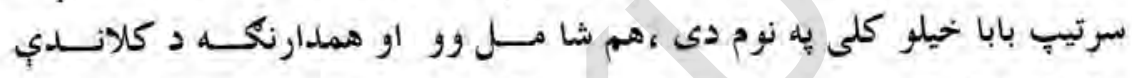
سليمان خان جي اوس يب د سليهنان بنماره كلى به نوم دى او د شيخ آباد زيسـن

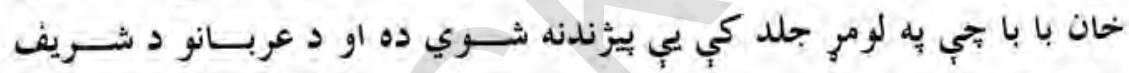

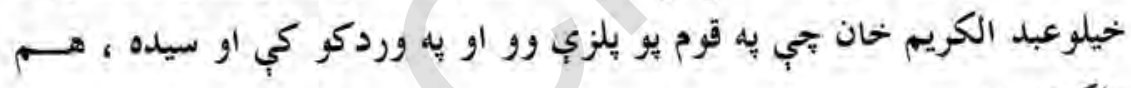
ملكرى و مانكو

د كمال خان يه اولادو كي ددايم خان له اولادي نه يو شمبر كورنى اوس هم

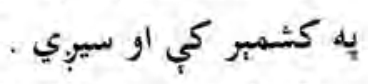

كمال خحان يه خوانى كي وفات شو اوريه جغتو كي د سلطان دبند يه سرهدير كي د سيدرسول آغا له قبر سره لند خحاورو ته سيارل شوى دى . 


\section{كرامت الله آخندزاده _- ـد طالبانو والى}

كله جي مجاهدينودهبو اد به كوتب ، كوتب كي بدغونيو او منحرفو اعمالوته

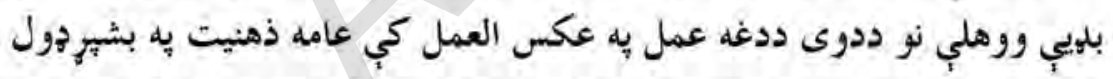

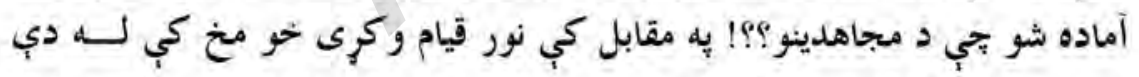

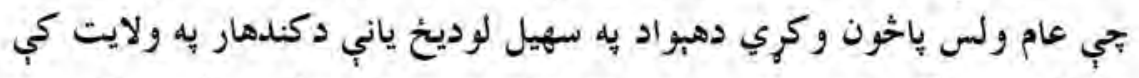

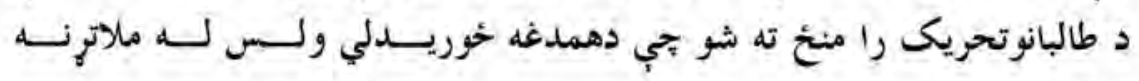

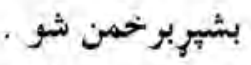

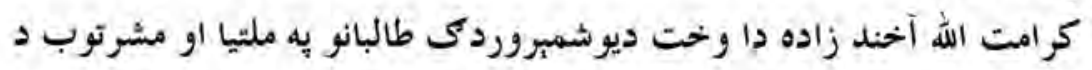

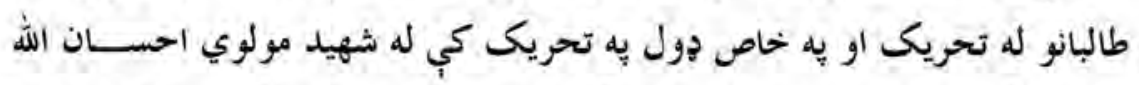

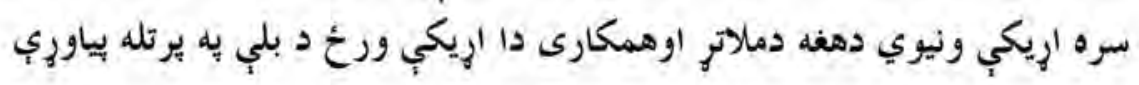


كيدي تر خو كرامت الله آخند زاده د طالبانو د تحريك د يو باوري شخصـيت

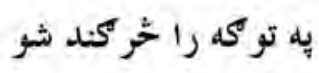

طالبان ورو، ورو له كندهار نه مخ دشمال ختيخ يه لور را دمخه كيدل ترخو

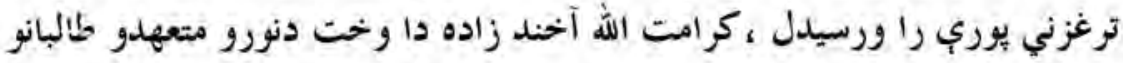

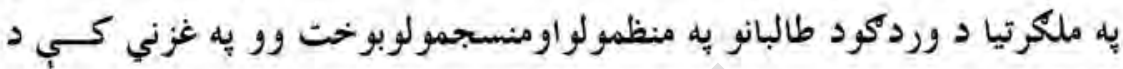

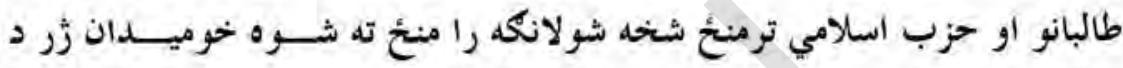

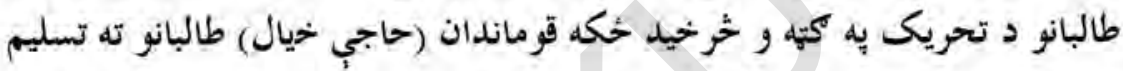

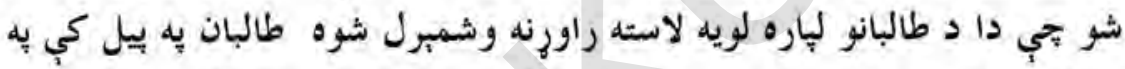

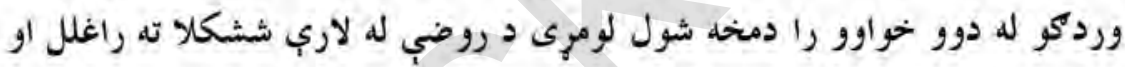

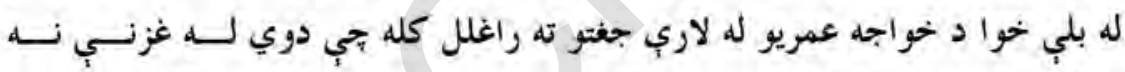

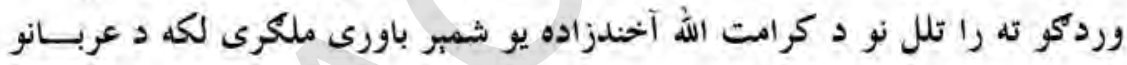

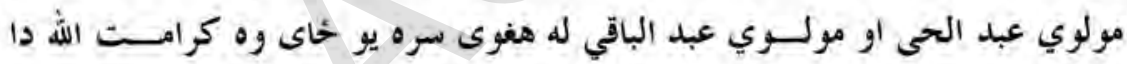

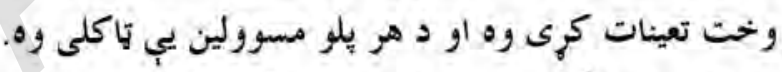

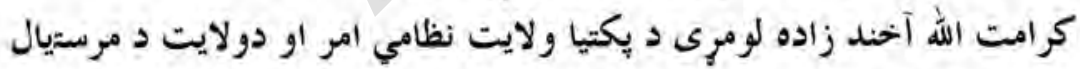

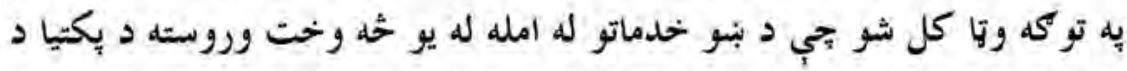

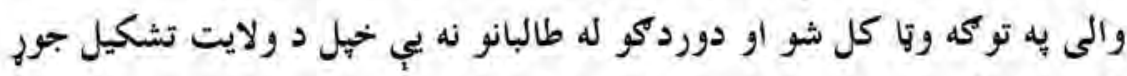

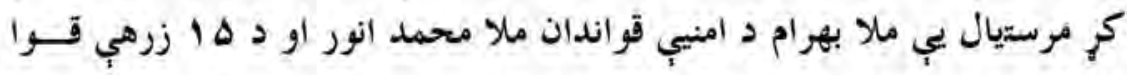

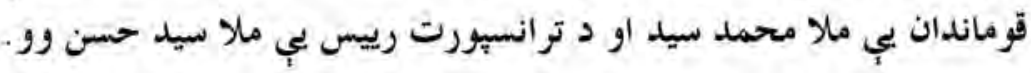


YY.

دوريكو مشاهير دوهم توكى

د كرامت الله آخند زاده دغه ماموريت تقريبا يو نيم كال دوام وكي كه خه هم د هغه طالبانو دا وخت يه لو كر كي هم فعاليت درلود او د يل قندهاري سيمه يب ساتله .

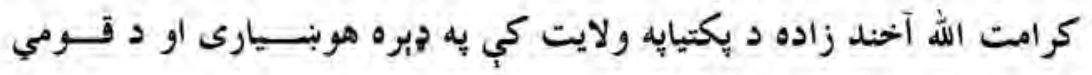
تزاكتونو د بشيررعايت به رونا كي خيل ماموريت به مخ يور . هغه سياست تجي كرامت الله آخند زاده د شرايطو يه نظر كي نيولو سره هغه

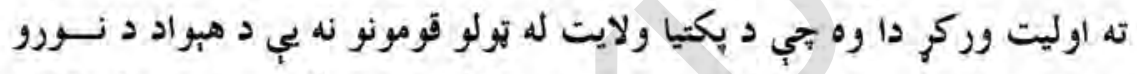

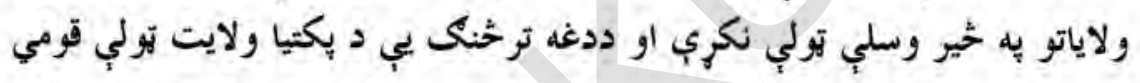

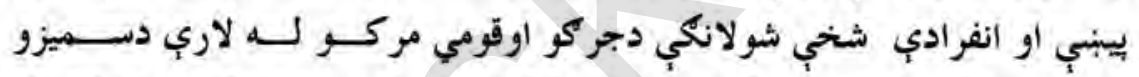

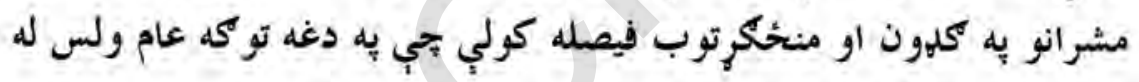

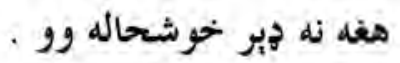

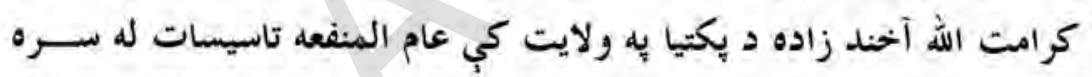
ورغول د ولايت مقام يب جوركر به نظامي برخه كي يب فرقه جوره كره او تول هغه وسا يط بجي خراب شوي وو لله سره جور او ترميم كرل .

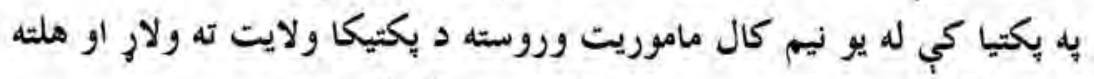

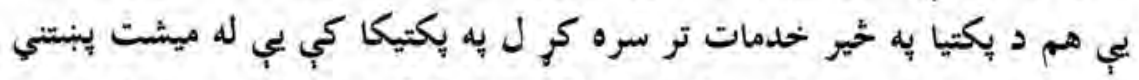
قومونو سره يه قومي جروكات كي جلند كاوه او خوكى تري ناراضه نشول .

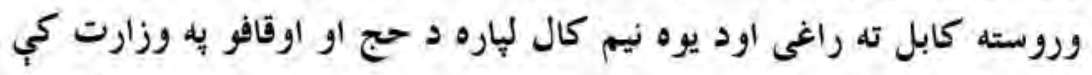
مالي او اداري معين وتاكل شو وروسته كله بحي افغانستان د ناتو داشغالكر انويه

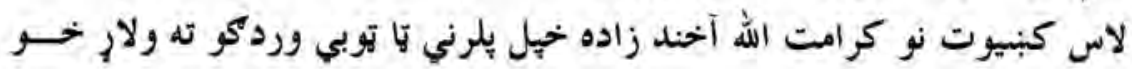




\section{rit}

\section{د وردكو مثاهير دوهم ترك}

زوند يب تريخ او كزاره يب سخته شوه خكله حكومتي جو اسيس دهغه يه لتهيه كي

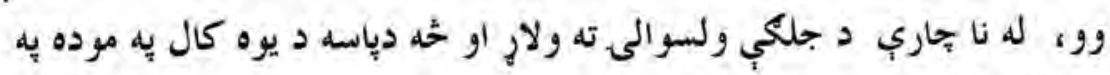
يوه كور كي بتي وو او وروسته بيا د حينو دوستانو يه مرسته مهاجر شو -

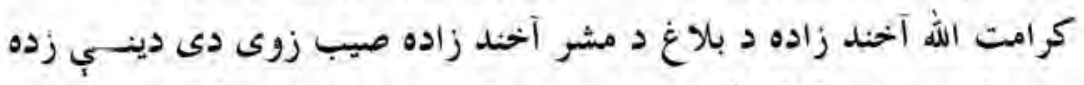

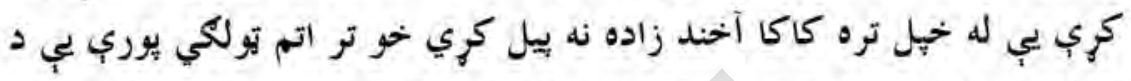
عربانو بنونخي هم لو ستي دي وروسته بيا دهجرت يه وطن كي د (زرينور) يسـ

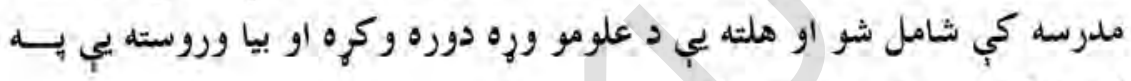
كويته كي لويه دوره تر سره كره .

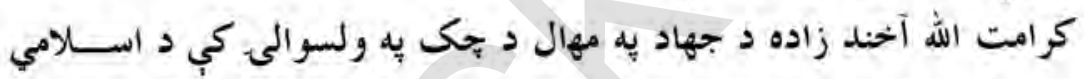

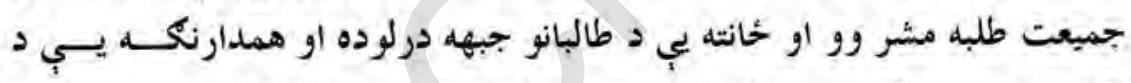

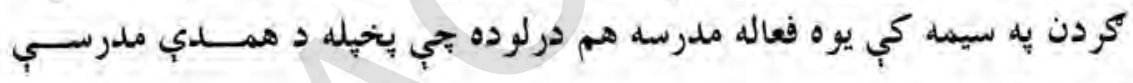
مدرس هم ورو - مان

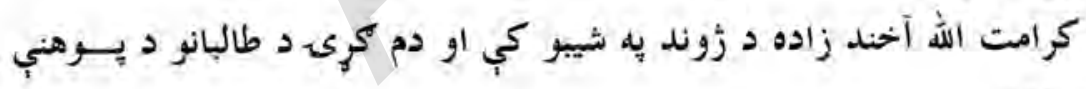
وزير دي. 


\section{كل الدين (عادليار) - جهادي ريس}

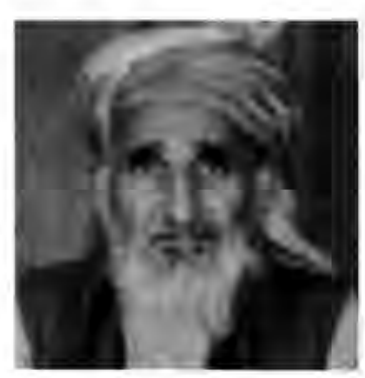

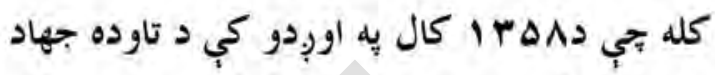
يه تودو شيبو كي د وروكو سيمي له كمونيستي عمالو

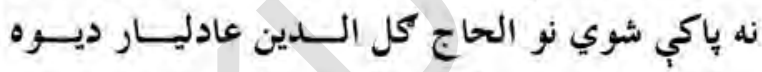

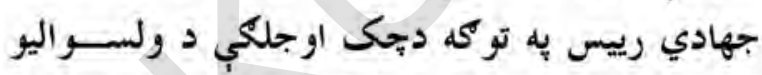

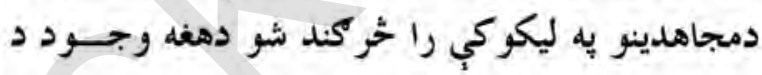
جهاد يه صفوفو كي ددي سبب شو بي د مجاهدينو تر منئ له احساساتى حركا تو او نورو ورته خيل سريواو افراط كريو نه مخنيوي وشي خيكه عادلياريه تنظيمب فعاليتونو برسيره د عام ولس يه زيرونو او دماغونو د

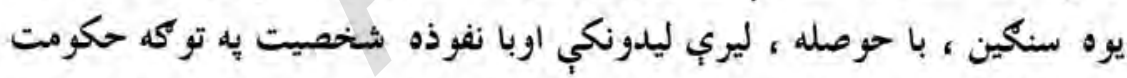
كاوه كه حثه هم هغه د حزب اسلامي تنظيم به جركات كي فعاليت درلود خود جِكى ،دايميردادو او آن تولو وردكو مجاهدينو ته د يـــوه مهربـــان شخصــيت سمبرل ور هغه د جهاد يه دوران كي د مجاهدينو او تنظيمونوترمنح هيثكلــه د تــاو

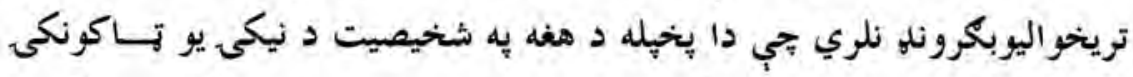

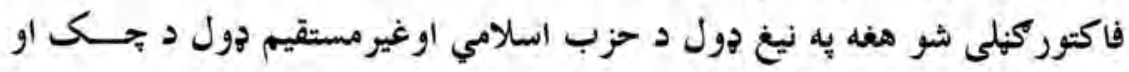
دايمير دادو د تولو مجاهدينو سمه او يه خاي رهبرى وكره . 
خو دريغا كله جي د تنظيمونو جه دننه كي لاسوهني را بيل شوي اود مســلمانانو ترمنح خود غرضه او نا مطلوبوعناصرويه فعاليت بيل وكر نوعادليارته دا تحركات دو د

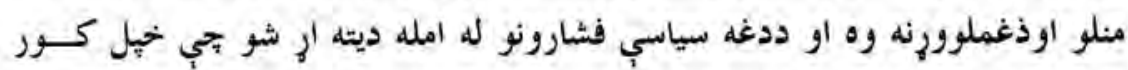

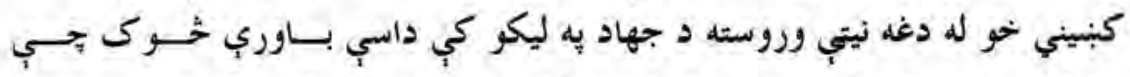
مجاهلدينوترمنخ ديوالى سمبول وى اودعادليار تشه يوي خوكه شي يبدا نشول . هفه نه يوازي دا بجي يوبا عزمه مجاهد وو بلكي يوخ ميرزا هم وو او ددغد تر

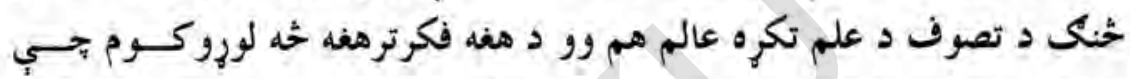

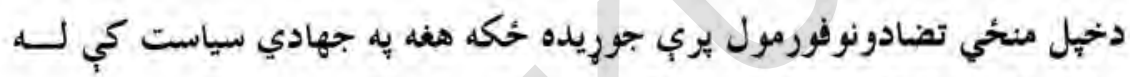
تنظيمي قومي او ربنيو تعصباتو او كينو نه يو بيزار شخصيت وو .

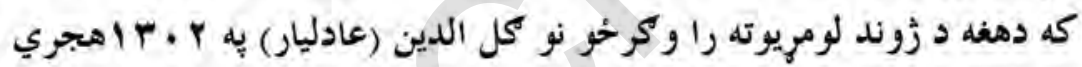

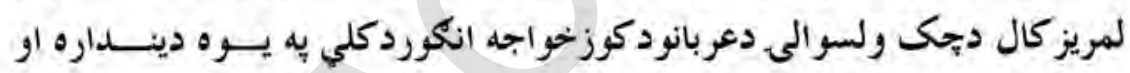
روحاني كورنى كي زيوبدلي دي د هفه د والد صيب مولوي غياث الدين ور اود

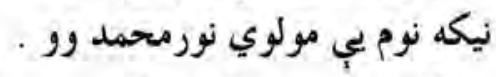
كل الدين (عادليار) كله بح د لوست جوكه شو نو والد صيب يب د عربانو

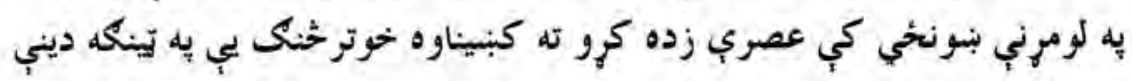

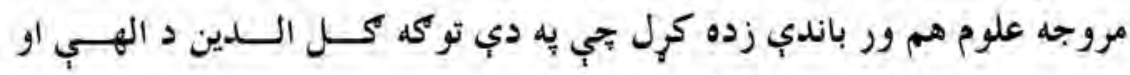
عصري دوارو علومو زده كونكي او طالب ور .

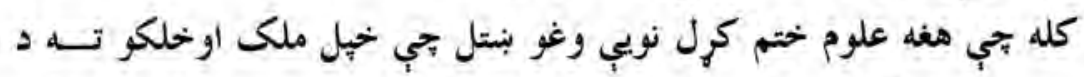
خدمت مصلدر وكئحي اوكار وكري نود مرحوم والى محمد السمعيل خحان مايار يه مرسته اولاربنسونه د لومرى حيل لِياره د اوسنى يكتيكا ولايت د شرني به لويه 


\section{PYE}

د وردكو مشاهير دوهم لوزى

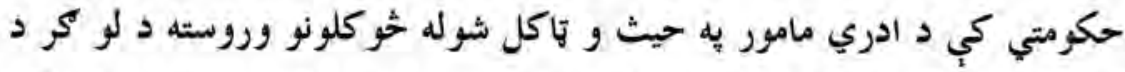

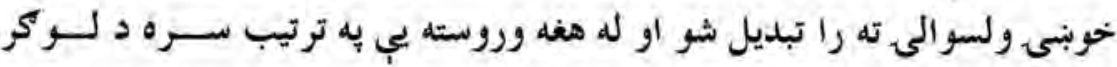

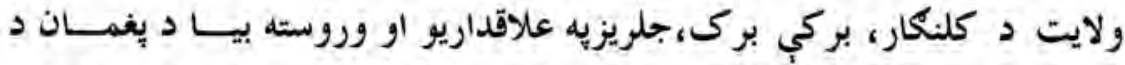
ولسو الى اداري مسؤل و تبا كل شو خودا وخت د يغمان ولسوال بحي يه خيانت كي يو وتلى او مشهوركس وواوعادليار له هغه سره د بلهو يه اخيستلو كي جوز

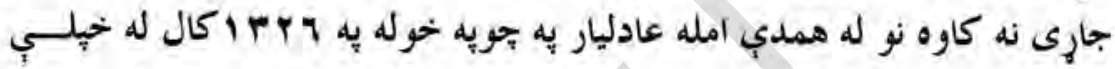
دندي سره مخه بنه وركهه او بيرته خجل كلي ته را غيى او دا وخحت د عربــانو د حوزي يو شمبر سبين زيري اومخور د بيداريو يه كلي كي سره رأتول شول او

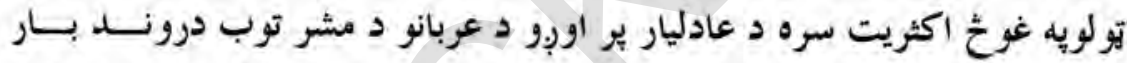
كبنيود جي له دغه نيتي وروسته دعربانو د كشالو يه حل فصل كي د هغه رول د د يوه منصف اوخو اخوربِى مشرله عنوانه يه بنسه شان وخليد خو له دي بحي حكومت ددا سي مخلصواو تو لنيزو شخصيتونو كوبنه كيدل

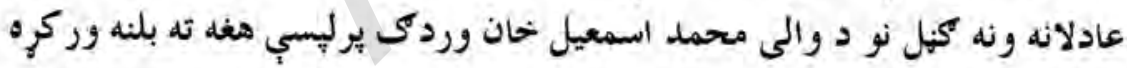

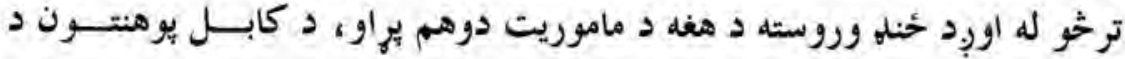

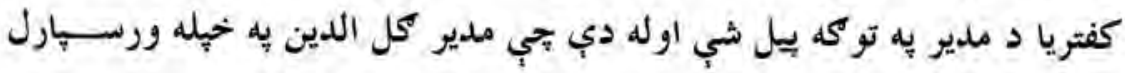

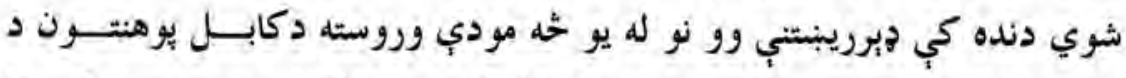
خدماتو دلوي ملدير به توكه يه دنده وكمارل شو بآي د كابل يه يو هنتون كي 12 ترتولو باوري ماموريت وو. كل الدين (عادليار) يه تولو ماموريتو كي د هايك نفسي ازموينه بريالى تيره كري وه نو له حُه مودي وروسته د تلداركاتو د عمومى مدير يه توكه وياكل شو 


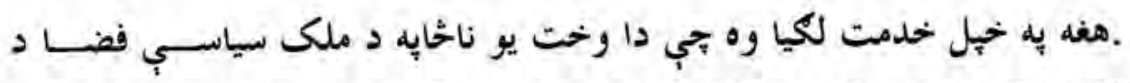

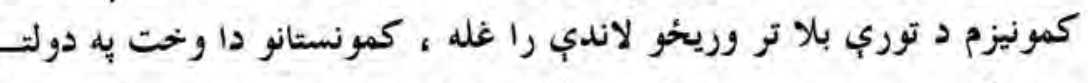

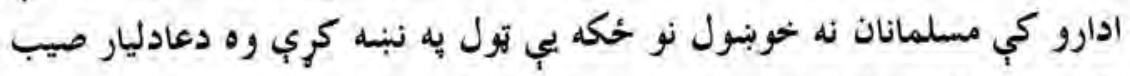

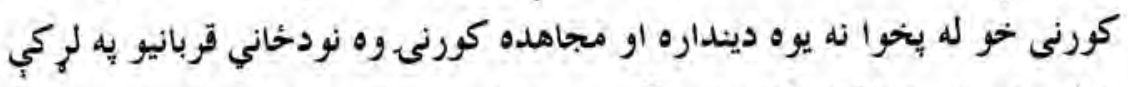

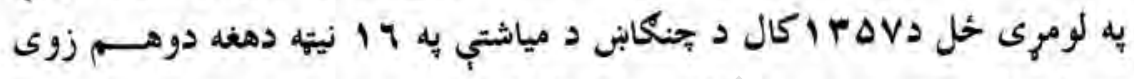

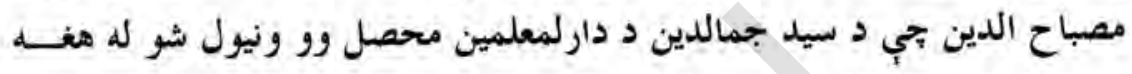

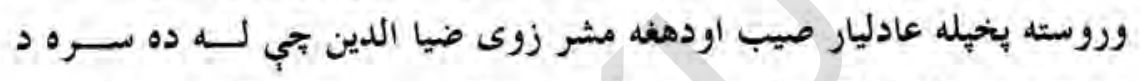

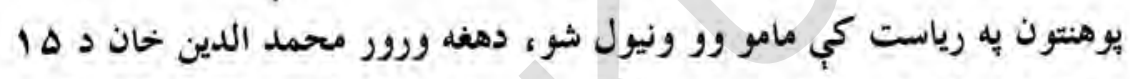

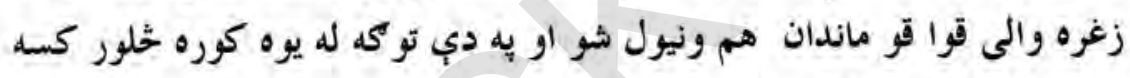

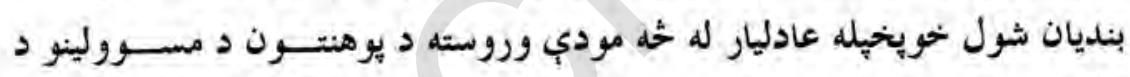

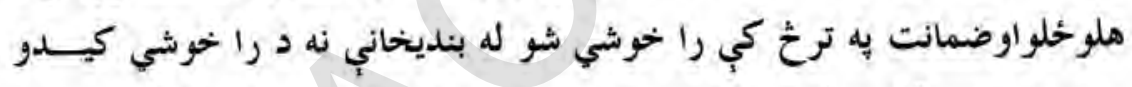

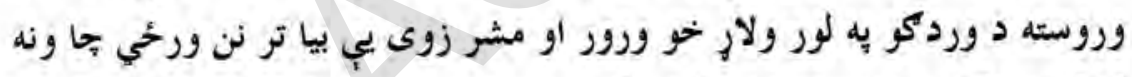

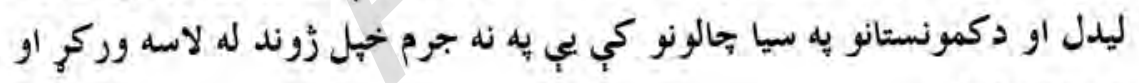
شهيدان شول . الون عاد ليار د نورو حوريدلو اومظلومو هيواد والو به شان د خحاني او مالي قربانيو به وركولو سره د ITVY

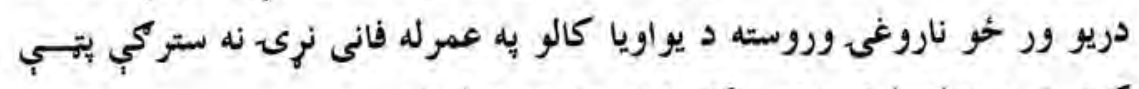

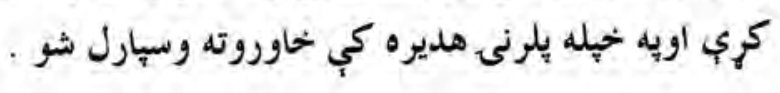




\section{محمد اكبروردك - داكتر}

داكترمحمداكبروردكى دطب يه برخه كـي يســ زيره

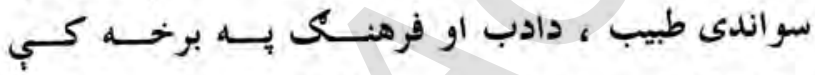

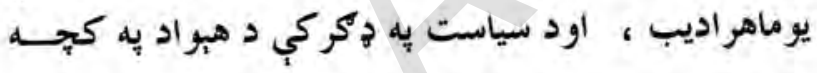
يو وتلي سياست مدار دي بحي يه خيله طبي رشته برسيره

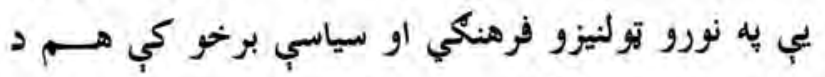

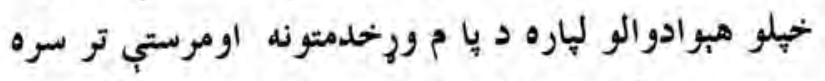
كري اويه يورتنيو دريو وارو برخو كي يل داخلي او بهرنى كجه يو بيرثندل شوي افغان دي .

كله تجي افغانستان د روسانو تر اشغال لاندي راغي نو داكتر محمد اكبــر

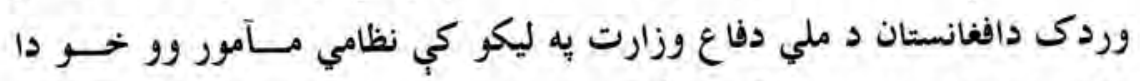

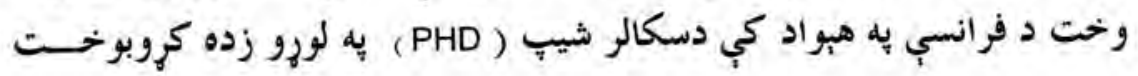




\section{r Y V}

دوروكي منشاهير دوهم تيوكى

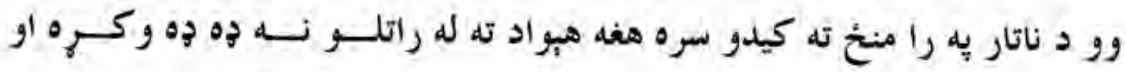
سمدلاسه يب دروسي اشغالكر انو يه وراندي دمرستو يه برابرولو دمجاهدينويسـه ملاتي لاس يورى كري تجي له لِّ مودي وروسته يب يه وردكو كي د مجاهدينو يو شمبر جبهي خه اقتصادي لحاظ يه ينبو ودرولي د محمد اكبروردكى كمونستان

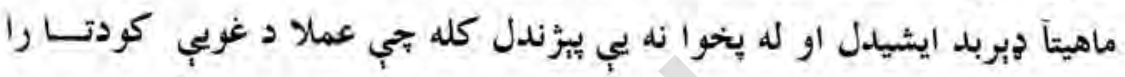

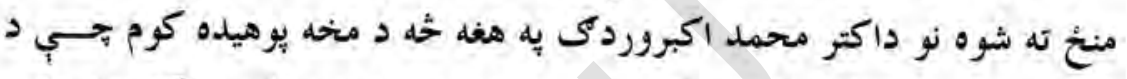

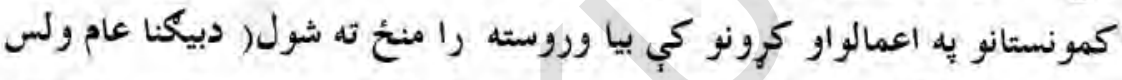
وزل ، بندي كول ، ترتل ، كلهوالى ته أرويستل او د هيواد دسياسي وضـعي

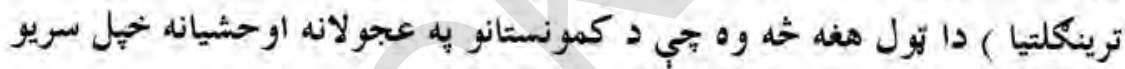

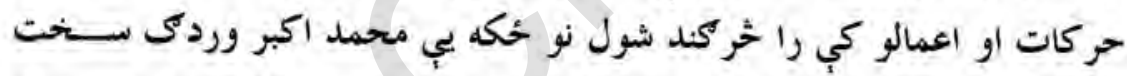

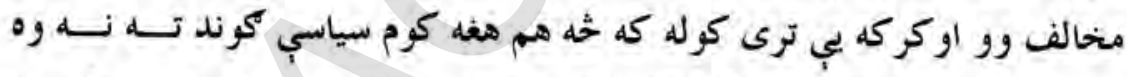
منسوب او تر هغه يب لور فكر كاوه كوم بجي د يوه كوند يا دلي يه مرام كي دا نفبنسل شوي ورى .

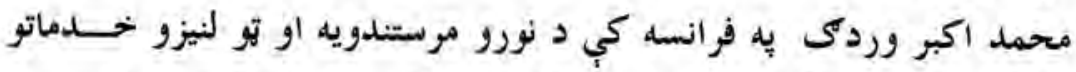

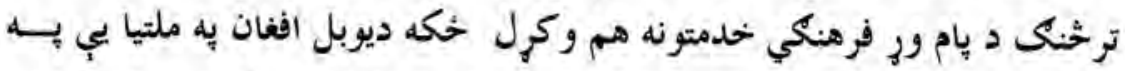

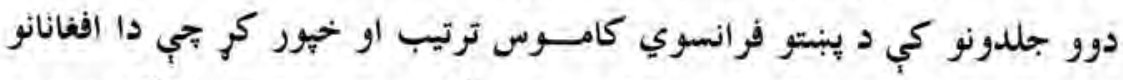

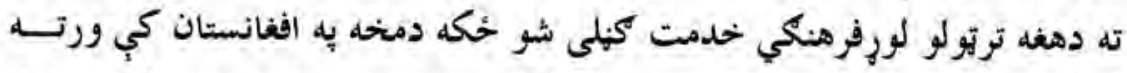
كام نه وو اخيستل شوي ، كله بجي دا ريكشينرى را بحاب شوي نو داكتر محمد

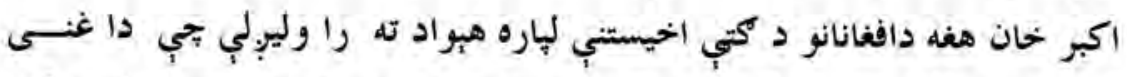

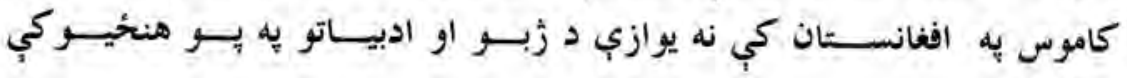


و كارول شو او كثيه تري واخيستل شوه بلكي د افغانستان د علومو به اكادمى. يبنتو تولنه او نورو علمي اوركانونو كي هم تري كار واخيستل شو - دوري

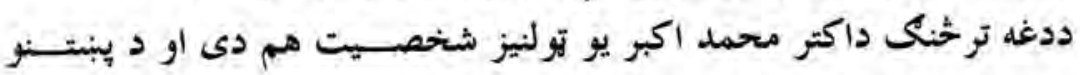

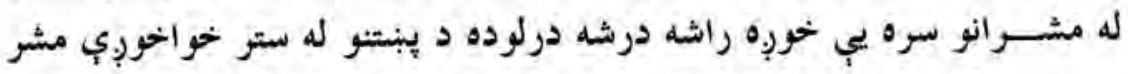

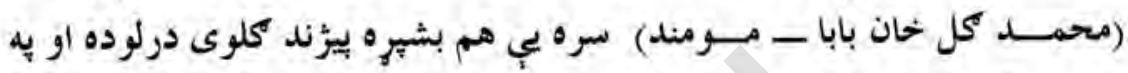

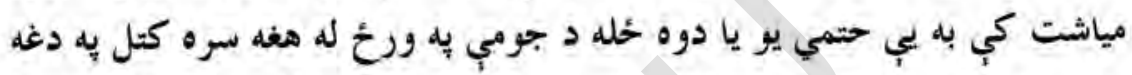
مجلسونو كي به اكثر ا ارســلان سليمي ، يوهاند صديق الله (ربنتــين) ، وياند

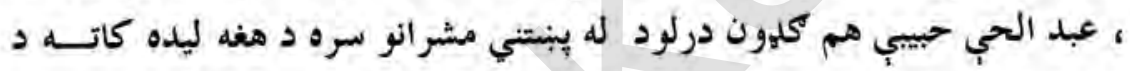
هغه د شخصيت يه جوربنت مثبت اغيز شيندله او هغه يب يه ملي يبا وري روحيه

داكتر محمد اكبر نه يوازي د بري ينبتونتخوا له مشرانو سره بلد او راشـــه

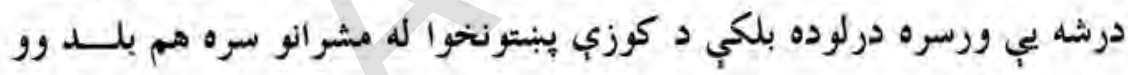
،اجمل ختبك يب يبرُانده او له هغه سره به يب تل بنبتني مجلسونه كول .

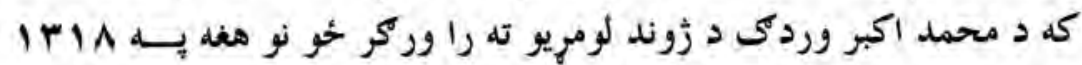
هجري شمسي كال د جغتو ولسوالى دو محمد قلي به كلي كي د محمدل عثمــان خان يه كورنى كي زيودلي اولوى شوي دى خرونكه جي دهغه مشر ورور وكيل

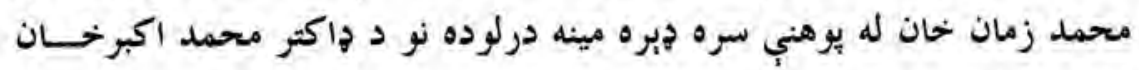
لياره دا بنه جائس وو جي د خحل مشر ورور يه هخونه د غازي محمد جان خحان

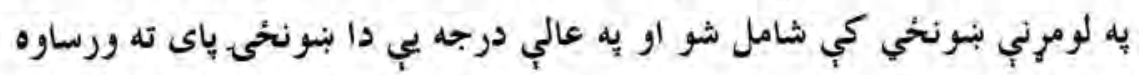

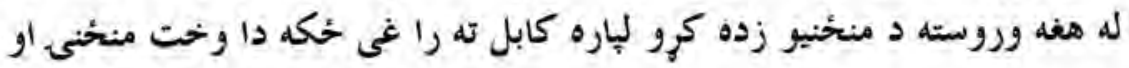




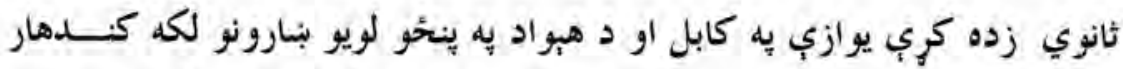

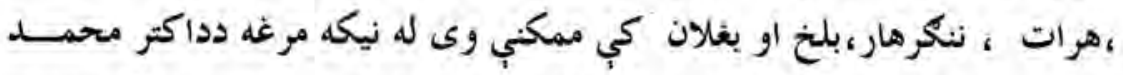

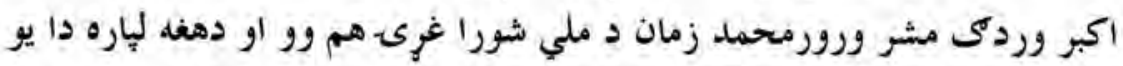

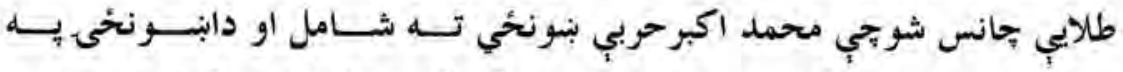

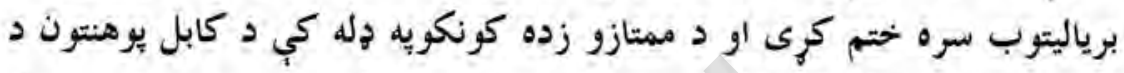

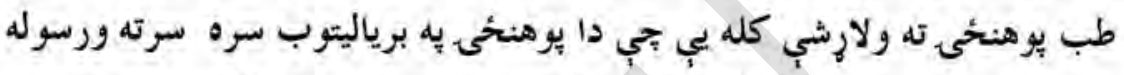

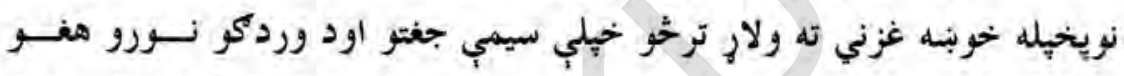

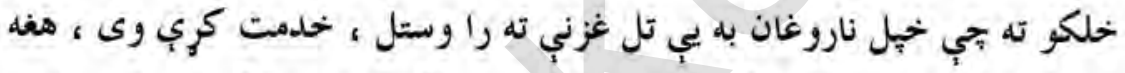

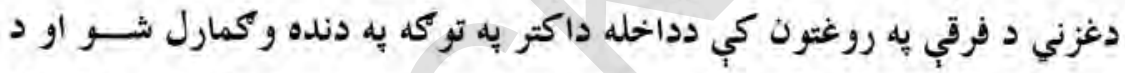

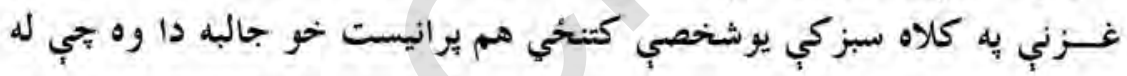

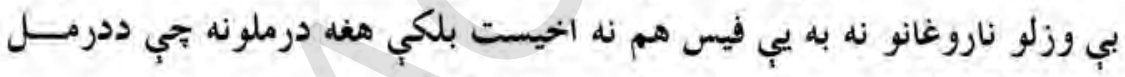

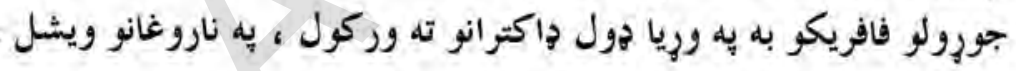

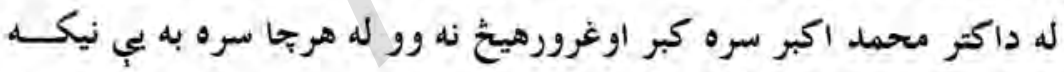

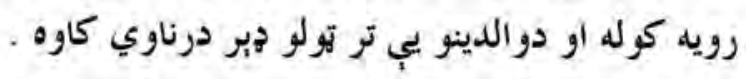

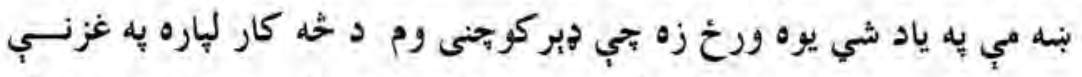

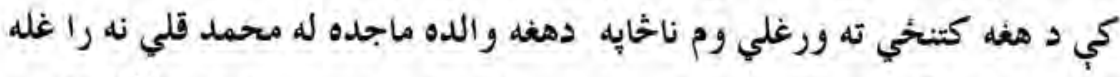

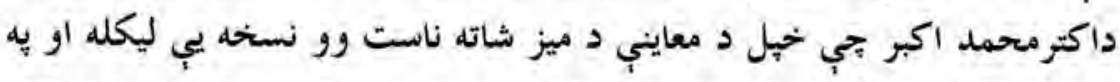

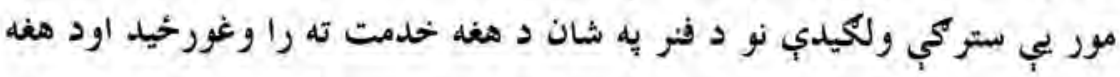

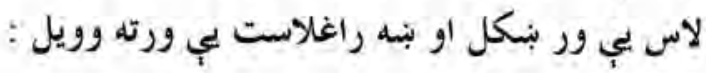


$\boldsymbol{r} \boldsymbol{r}$

دوركى مشاهير دوهم توى

هيخكله مي هغه صحنه له ياده نه خحي جي محمد اكبريب د مور خولي ته تيار سى ودريد او مورجاني يب يه آمرانه غوب خو يو بنتني ترى وكرى اوده به مهربانه لهجه هغه ته جوابونه وروكرحول ، بيا داكتراكبر د كوم بحا يو بنتنه تري وركي نو والدي يب ورته وويل او س بنه دي يرون سهارمي لجِخه سابه ورته ياخده كرل او هغه مي ور وليبرل نه مي هيريوي بجي زه ددوي خولي ته داسي ولارورم لكه د

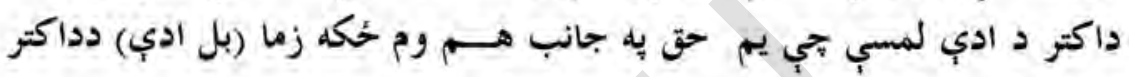
محمد اكبر د كاكا لوراود حاجي غلامحي الدين خوروه . يه هر صورت هاكتر محمد اكبر وردكى كله بحي د فر انسي هيواد ته ولارج نو

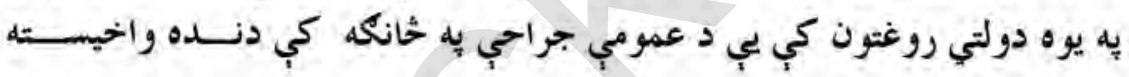
اوجِده كلونه يه دغه روغتون كي يه دنده بوخت وو، خو تقاعد شو هفه تو اوسه زوندي دي خو سيبن زيري شوي دى او كومه رسمي دنده هم نلري . داكترمحمد اكبر وردكى د جهاد يه تودو كلونوكي له نريوالو رسنيو سره د افغانستان دروانو ستونزو يه أره تل اورِدي مركي كولى او د خهم وخحت لِياره بي بي سي د هينتو يروكر امونو سياسي مفسر هم وو . 


\section{محمد اسحق نورى - ذخرجنرال}

هُكر جنرال محمد اسحق نوري د اففانستان دجهاد يه

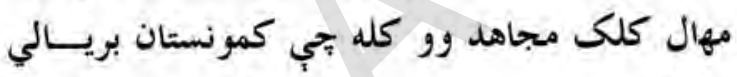

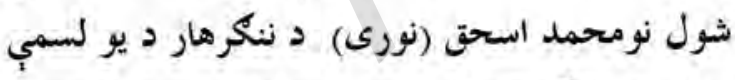

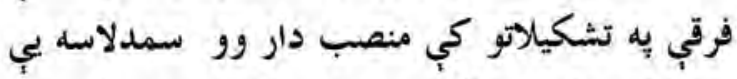

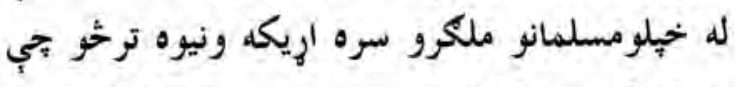

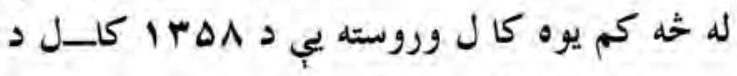

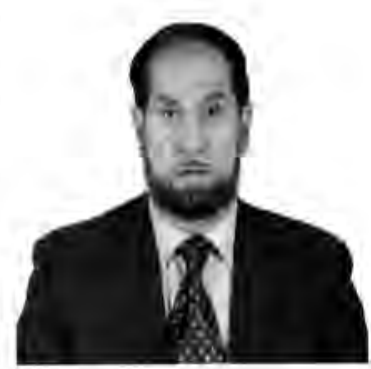

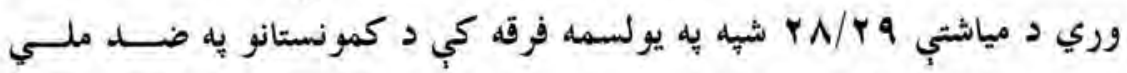

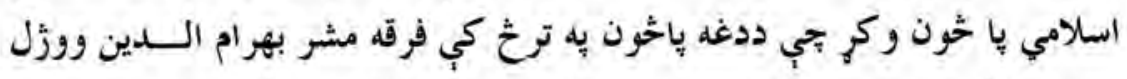

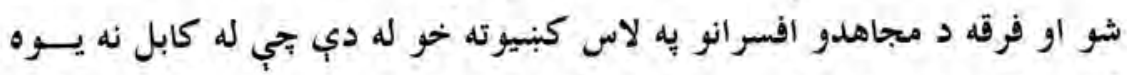

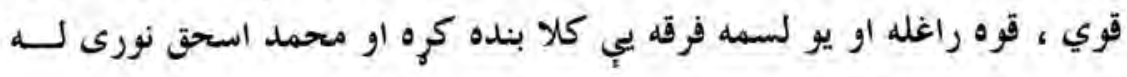




\section{rrr}

دودكي مشاهير دومم تئى

خيلو دولسو ملكرو سره يه دي وتوانيد بحي د خوريانيوولسوالى د يجهيرآكام يل سيـمه كي له مجاهدينو سره يوخاى ثي محمد اسحق او ملكُرو يمي خه دغه مركز كي له مجاهدينو سره له يوي مياشـــي تيرولو وروسته ديوه نظامي حركت يه ترع كي د يجبير آكام علاقدارى فـتح او

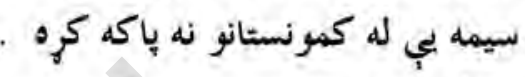
له يوخه وخت وروسته كله جي حكرمت د علاقدارى نيولو لياره تعرضسي قواوي راوليولي نو دوى د سهين غر، دغر ه له لاري د ياراجنار سيمي ته ولارل او يه دغه حخاى كي له خو مياشتو تيرولو وروسته يبنبور ته ولارل . محمد اسحق نوري دا وخت د بير سيد احمد كيلاني سره وكثل نجي دا كتينه دوغه سبب شوه بحي نوري د محاذ ملي تنظيم ته ولارشي . دا وخت د خحدرانو د مجاهد او باتور ولس له لوري د خوست هله دولتسي لهي

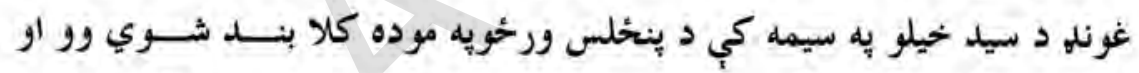
دولت يوه لويه قوه له كرديز نه د ستر كنلهو به لار ددغه غونله د خلاصون لِاره را وليوله جي د حخدراني مجاهدينو لخوا تار مار شوه او جير وسايط به خاى تري باته شول دا وخت د قوي د وسايطود نظم او ترتيب لياره ماهرو كسانو ته ارتيا

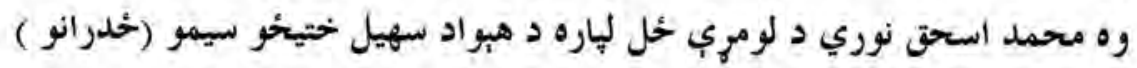
ته را غي هغه وسايط جي مجاهدينو وري وه به لطايف الحيل يي يوب را حاضر كرل او تول يب سره منظم او منسجم كرل او دودبنسمن سره د مقابلي لياره يسي

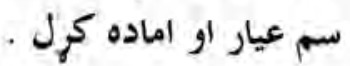


دزمي تيرولو لهاره بيرته يبنسور ته راغى دا وخت د افغانستان د ملي اسلامي

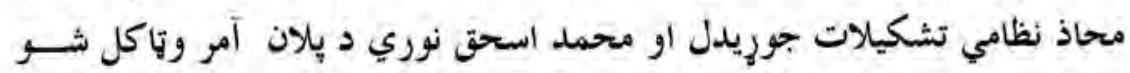

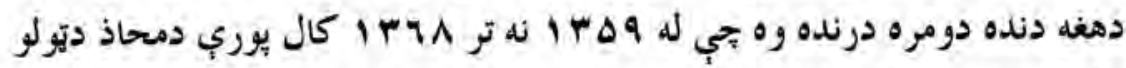

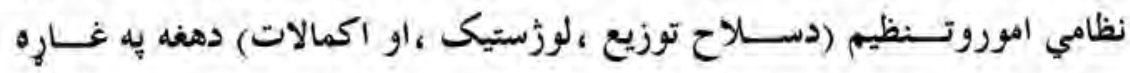

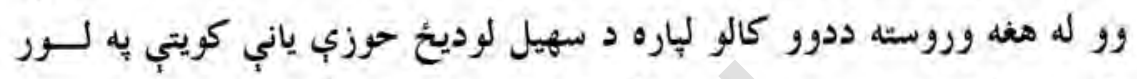
ولار او هلته د بيرصيب سيد احمد كيلاني د زوى (حامد آَال ) مرستيال وو . محمد اسحق نوري نه يوازي داجي به جهادي دفترونو كي يب دندي تر سره كري بلكي د جهاد تودو سنكرونو ته هم تللى دى دكونر، ننكرهار، خوست ،

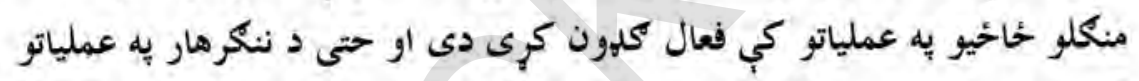

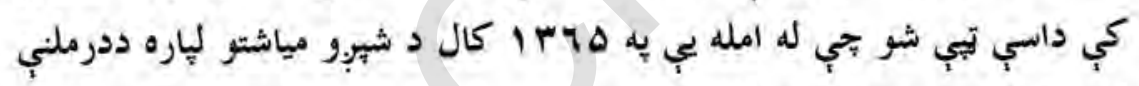
لياره د فر انسبي هيواد ته ولاهي .

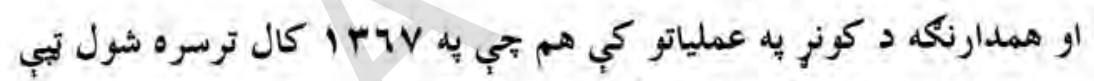

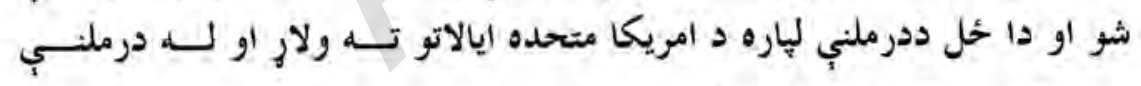
وروسته بيرته جهاد ته را ستون شو . هحمد اسحق نوري دهيواد به ختيحُو سيمو كي به جهاد سربيره د سهيل لودئح يه حوزو قندهار زابل اونورو سرحدى سيمو كي هم كرندى عمليات تر بـــره كري دي - ت

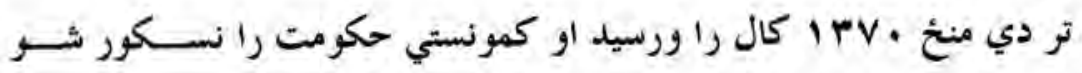
تنظيمونه كابل ته راغلل او محمد اسحق نوري هم د ملي محاذ له لوري د دملي

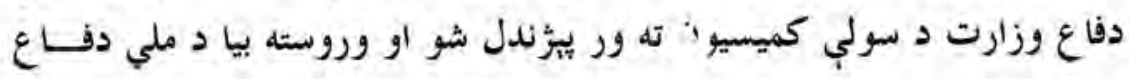


وزارت د مجاهدينو د حقوقو د اعادي يه ترخ كي د تورن جنرال رتبي ته تر فيع

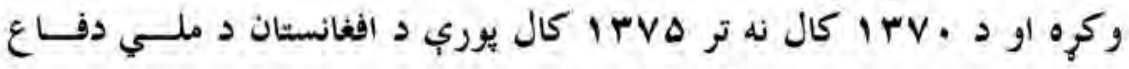

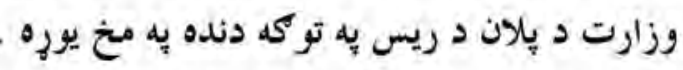
محمد اسحق نورى كله بحي د بلدخشان ولايت ته د مجاهدينو د وسايطو ديوي

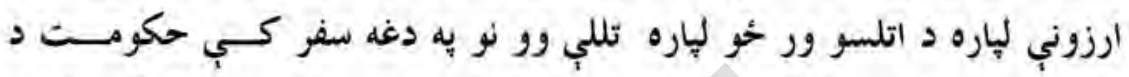
طالبانو د تحريكى يه لاس ورغى او محمد اسحق نوري د شا ه سليم لــ لاري بيرته يببنبور ته ولار او هلته د ملي اسلامي محاذ يه مركزي دفتركي د سلاكار

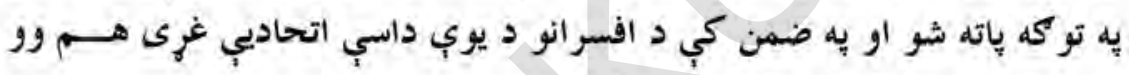
بجي مشر يب جنرال عبد الرحيم وردكى وو . د نويو الى تولني به راتكى سره دوى تول كابل ته راغلل او محمد اسحقى نــوري دا وخت دملي دفاع وزارت د تو يجي د عمومي قوماندان يه توكه يه دنده وكمارل

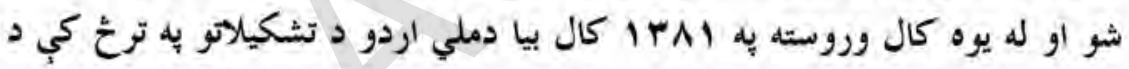

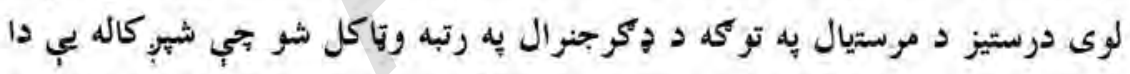

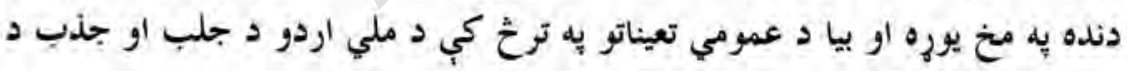
قـــوماندان به تو كه مقرر او تر نن يوري دا دنده يه مـخ ورئ .

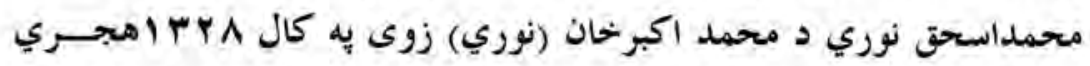
شمسبي دجدي يه ها نيّه د شنيز دملي خيلو دكلي د(اكبرخيلو ) يه محله كي

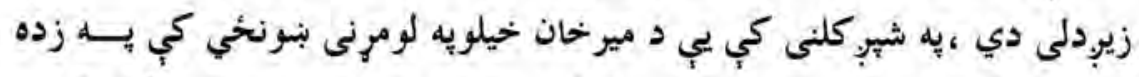

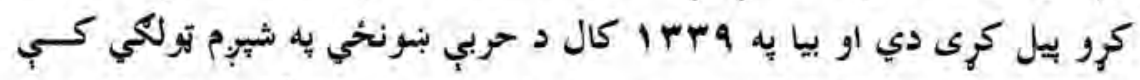

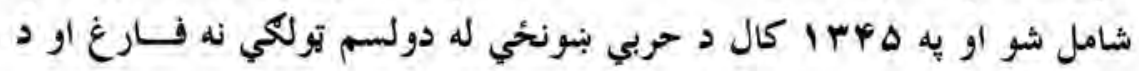




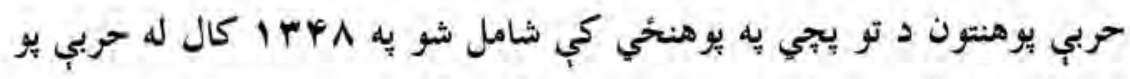

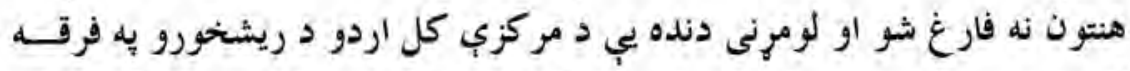

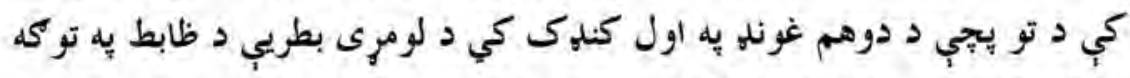

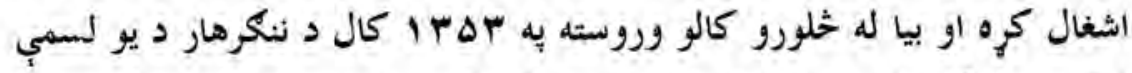

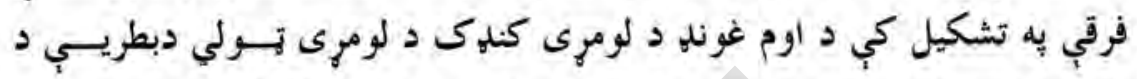

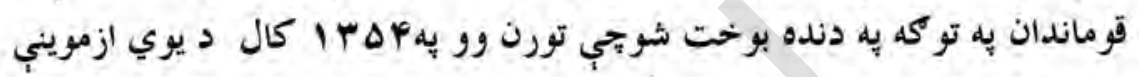

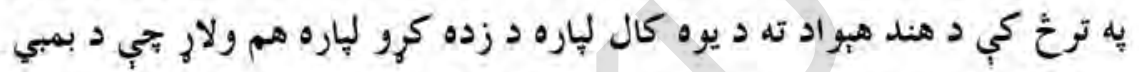

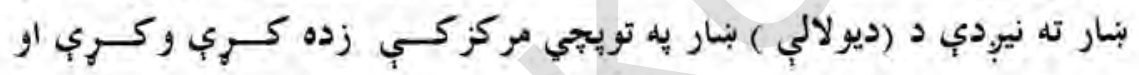

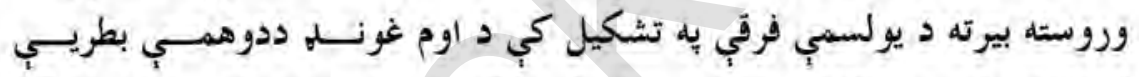

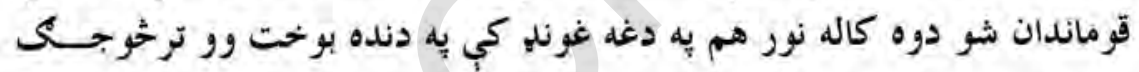
تورن شو . جُكرال جنرال محمد اسحق نوري يو آرام زره سو اندى ،صبوره او بي ضوره

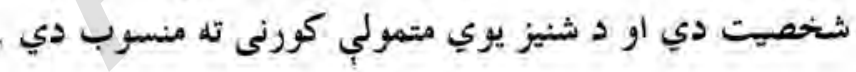




\section{محمد اسمعيل خان وردكى دهلهوكر هاكتر}

دهلهو كوددرملني هغه لومرنى طبي اله جي د افغان طبي الي به نوم يب نهيوال شهرت ومونداود نرى يه ذّبرو هيوادو او بلخاصه يه امريكا كي يــه كـــار

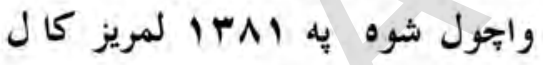
دلومرى خل لياره د داكتــــر محمـــــ

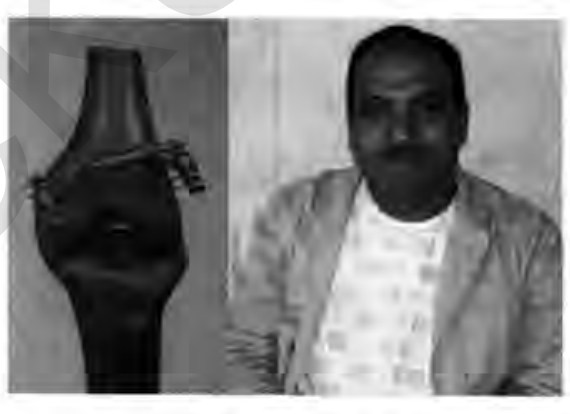

اسمعيل وردكى لخوا د كونلوي د ستركي ددرملني لياره را منئ ته شوه جي نن

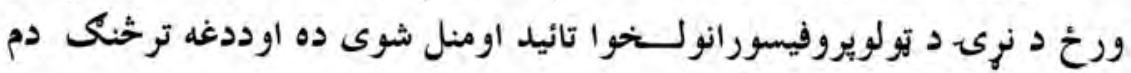
كرى محتمد اسمعيل وردكى دمروند د ماتوهلوركو د ارجاع او (جوسر) لهاره د دوهمي طبي الي يه اختراع هم بريالى شوي بجي ددي الي عملي كارونه خلاص اولومرنى بيراو يب نهايب شوي دي .

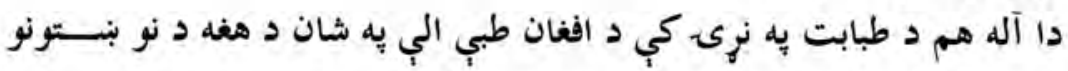
لويه او بريالى لاسته راورنه كنلى شو. 
دهلوركود ناروغيو يه درملنه كي د محمد اسمعيل خان وردكى دا رغنده او نوبنتكر كام او اقدام نه يوازي د هغه د يوهي او شخصيت د لورتيا سبب شوي بلكي يه نويواله كجه د الفغانستان د سرلوري سبب هم شوى دى دى .

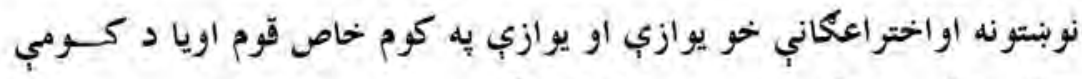

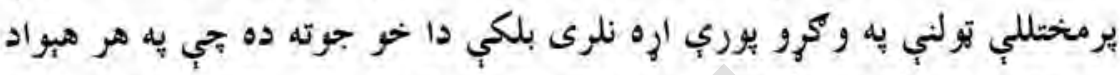
كي داسي نوبنتكراومتفكر مغزونه بيدا كيربي جي كه زمينه ورته مساعده شـي دي زونل هيه مختلفو سياسي ، نظامي ،طبي ، فرهنكي او اقتصادي برخوكي داسي به نيه زره يوري نو بنتونه را منح ته كولاع شي تجي نريوالوال ورته كوته يه غابن باته

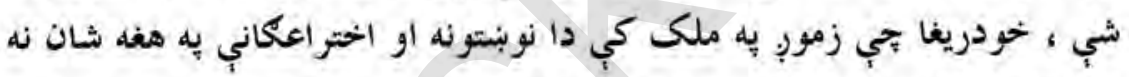

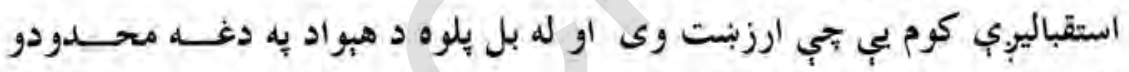

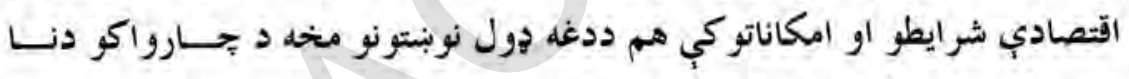

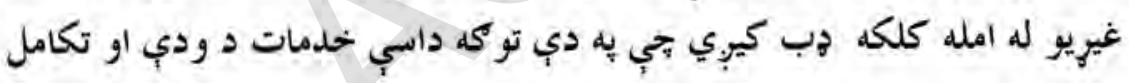

$$
\text { ورو ستي يزي او ته نه رسيوبي . }
$$

لكه بي دمخه وويل شول ددغه نو بنتونو او اغيزمنو طبي الاتو د اختراع يه

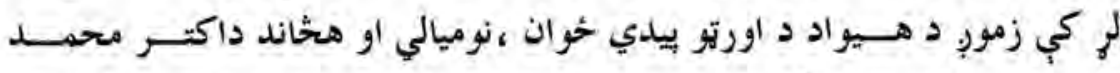
اسمعيل وروكى داسي آله را منتخ ته كره بحي نزيوال شهرت بي وموند اوخه موده د مخه او ما هجري شمسي كال د امريكا دمثحده ايالاتو د عــامي روغتيـا سرجينود اورتو ييدي يه هغه نريوال كنفر انس كي دا طبي آله ارزيابي اوبشيره بي

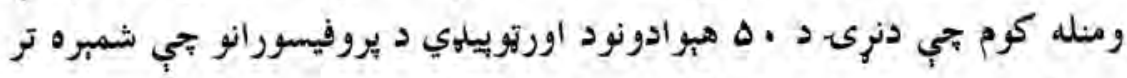

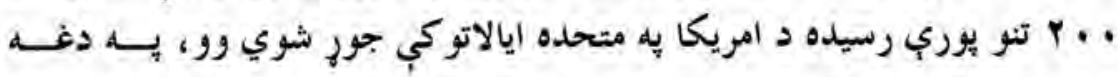




\section{rrA}

\section{د وروكو مشاهير دوهم تركى}

كنفر انس كي دا آله يه عملي زول وازمايل شوه او يه نويوال طبي زُورنال كي يب ثبت او را جسترو كره ه كله بحي ها إكتر محمد اسفعيل وردكى له آمريكا را وكرحيد نو دروان مــيلادي

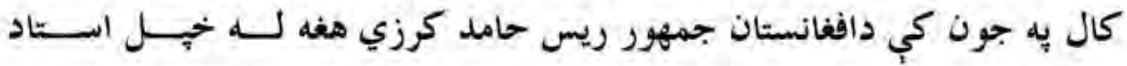
داكترعبدالرزاق سيا وش سره د بريال يه ملرالونو وويارل جي دا يه داسي حال ل كي وه جي محمد اسمعيل وردك كرزى ته دو افغان طبي الي يوه هيه طلا يوبنــل شوي نمونه هم ور والي كره بحي اوس د هيواد يه ملي موزيم كي ساتل كيبِي

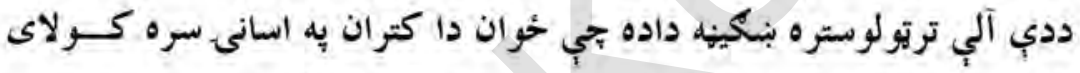
شي له هغه سره بلد تيا ييدا كري او يه اغيزمنه تو كه يي وكاروي .

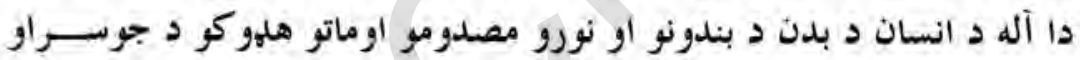

$$
\text { شيليز لياره كارول كيربي . }
$$

د مخه به داكترانو د بدن د ماتوهلهوكو دوه حملى د جراحي عمليات كول ياني

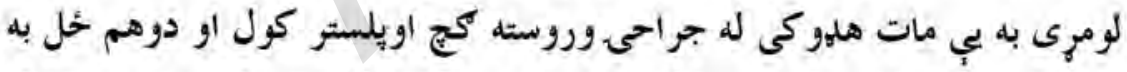
يبي اساسى عمليات بري ترسوه كول خو اوس ددي آلي يه تطبيق اواســعمال سره ناروغ له دوهم خحلى عمليات ته ارتيا نلرى خكهة به عمليات كي د يوه ذير

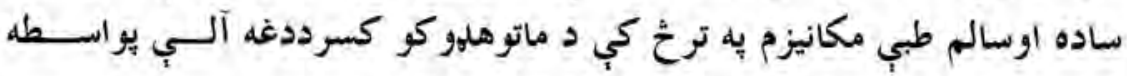
لومرى كنتروليوى او بيا دا عمليه بريالى تر سره كيري.

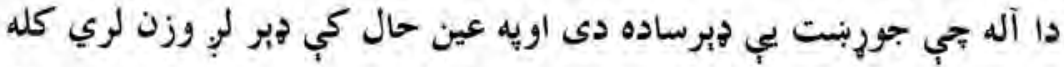

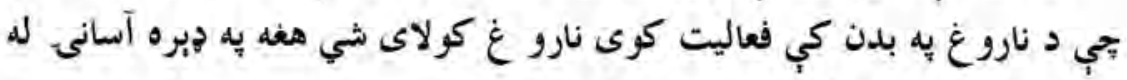
يوه حخايه بل حخاى ته له خحيل خحان سره يو سي . 
كه دداكترمحمد اسمعيل وردكى ددغه الئ تاريخي بكروند ته نظـــرواجور

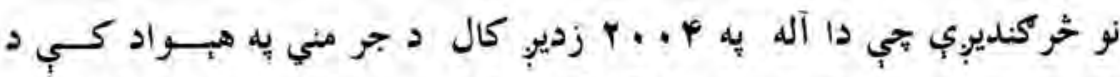

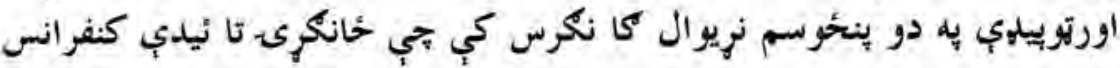
ورته نيول شوي وو هم ومنل شو.

محمد اسمعيل وردكى د اور تويدي يه برخه كي تر اوسه يه زركونو لوى او

وارهه دجراحى بريالي عملياتوثه ترسره كري دي خو دهغه تر تولو لوى عمليات د

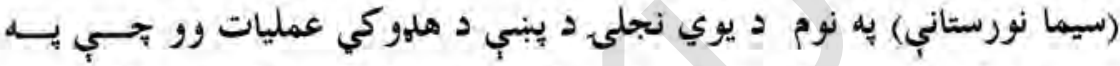
جومنى تركيه او نورو كاونلديو هيو ادونو كي يب درملنه نه وه شوي ، داكترانســ

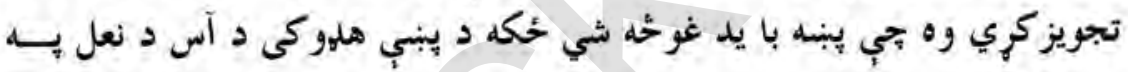
شان كوجٍ ووخو داكتر محمد اسمعيل يه بر ياليتوب سره دا يبنه ددو كســـروئو

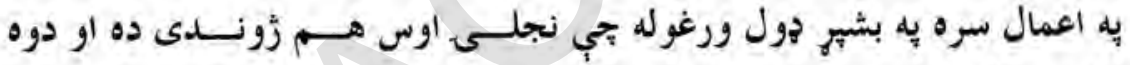

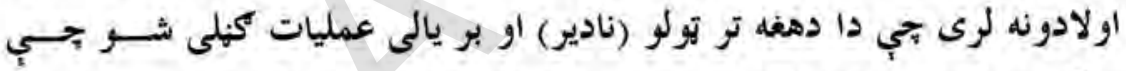
بيلكي د طبابت به نري كي ديري كمي اويا هم نه دي ليدل كيري

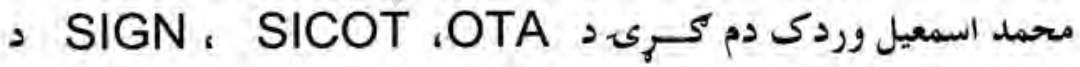
اورتو يبليوي د نريوالو انجمنونوغريتوب لري تجي له دي لاري يب يه مليونو دالره مرسته خيل فقير او ناداره ملك ته را جلب كري ده او همداريكه د اورتوييلى به نري كي دهغه دا خحمات ددغه سبب شوي تجي دم كريى ده امريكا له هيواد نه يه وريا توكه د سردار محمد داود خان له خلورسوه بستريز رو غتون ســره او همدا رنكه د شينو زاده له خصوصى روغتون سره جي داكتر محمـــد اسـمعيل وردى يه كي كار كوى يه وريا توكهد هلهوكرد كسر د ارجاع نور طبى سامان 


\section{$r \leq$.}

دوركو مشاهير دوهم توكى

آلات وركري جي ددب مرستو يه (كاور) كي د ننكرهار، جلال آباد ، شبرغان

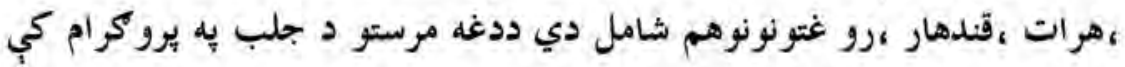

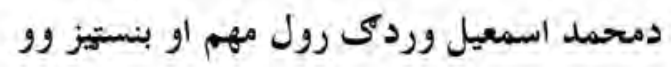

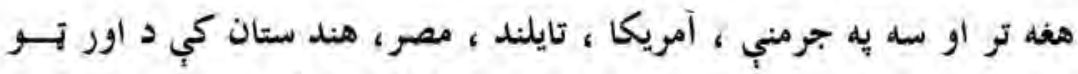

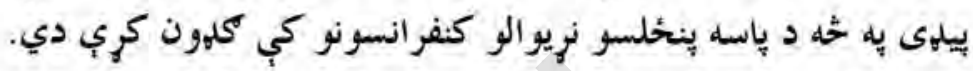

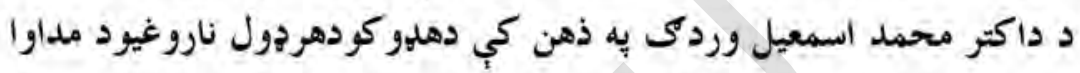

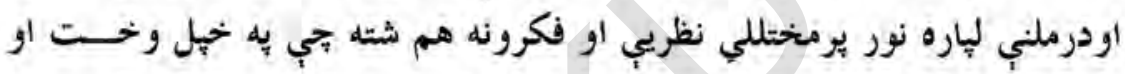

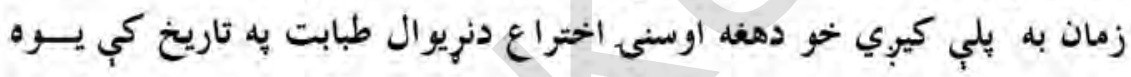

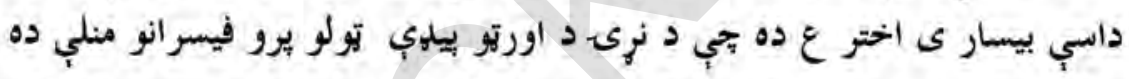

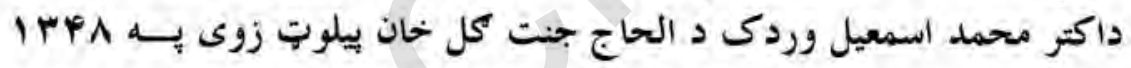

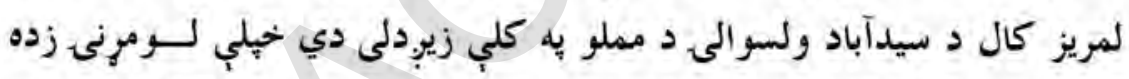

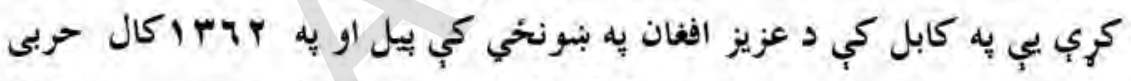

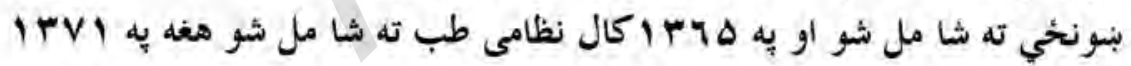

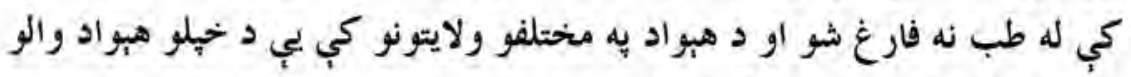

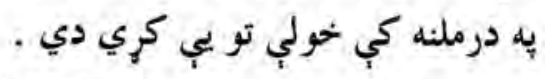

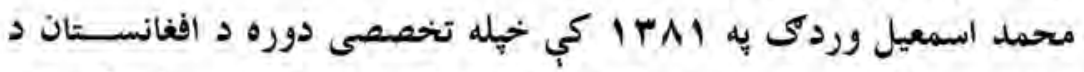

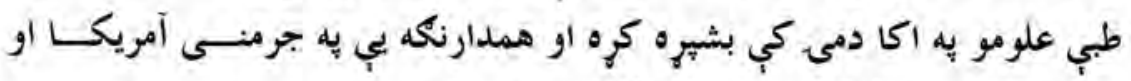
هندستان كي هم فوق تخصص ترينكونه ليدلى دي. 


\section{محمد غوث حكيمى - يوهاند هاكثر}

يو هاند دوكتور محمد غوث حكيمسى د اورجّو

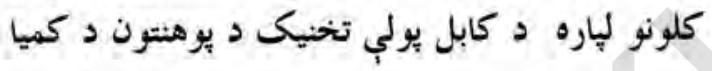

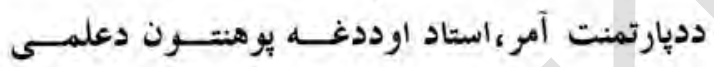
شوراغرئ باته شوي دي.

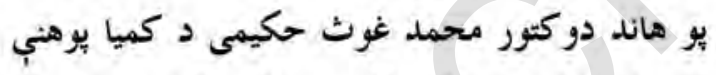

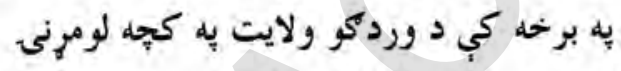

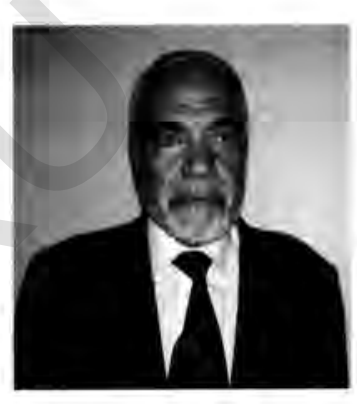

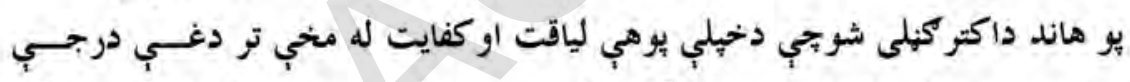

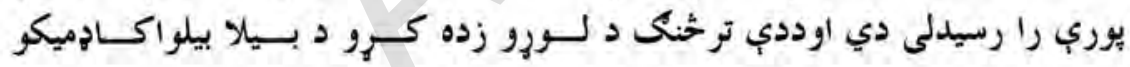

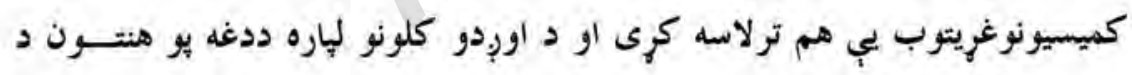
علمي مجلي مسوول مديرهم و .

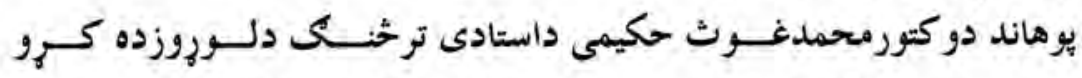

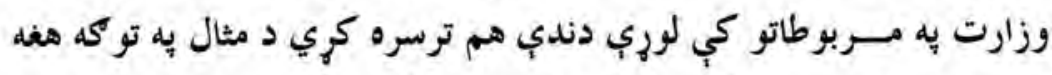

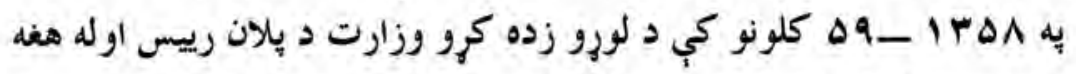

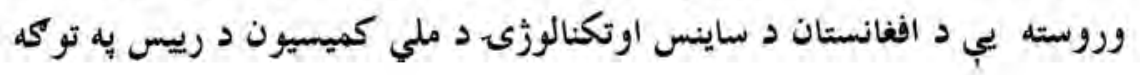


هم دندي تر سره كري دي او همدارنكه ددوو اورجدو دورو لباره يه انتخابي او

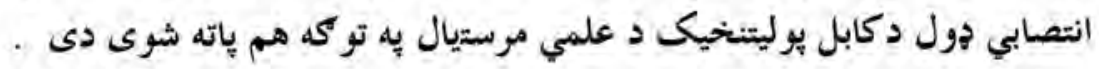

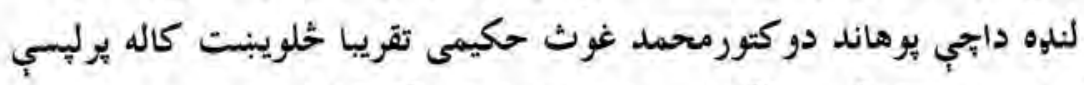

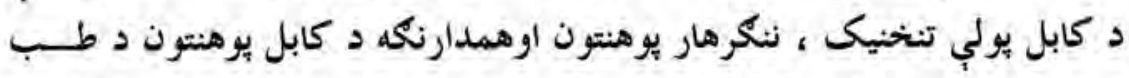

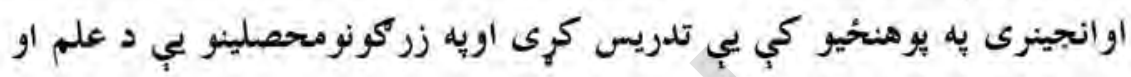

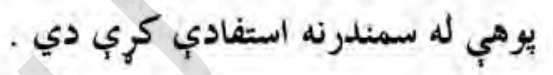

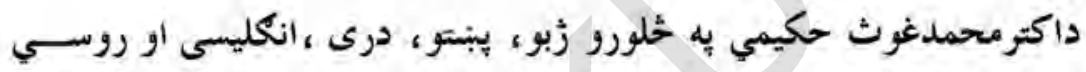

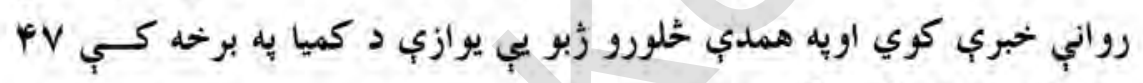

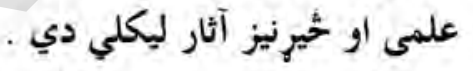

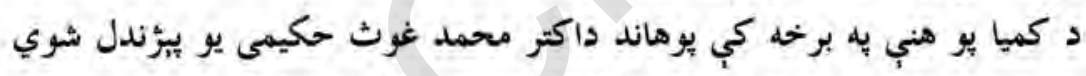

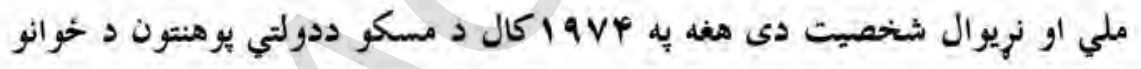

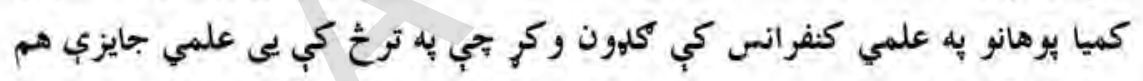

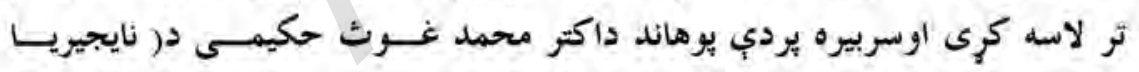

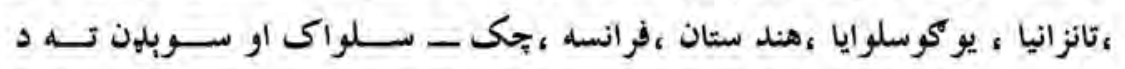

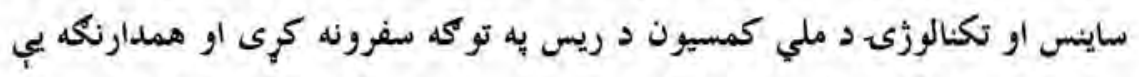

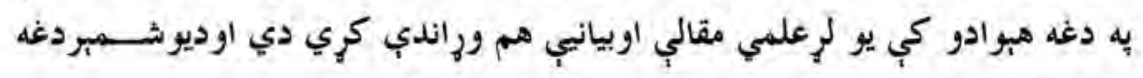

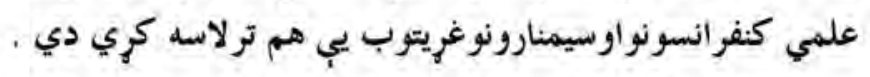

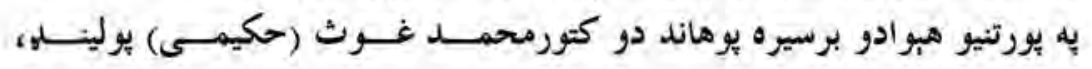

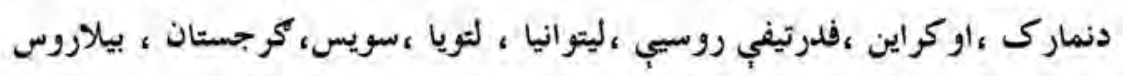

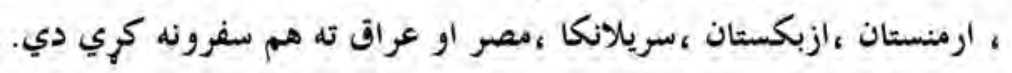


يوهاند دو كتور محمد غوث حكيمي دعلمي فعاليتونوترخنك د سره صليب ين بشـــردوستانه فعاليتونو كي هم ونلره اخيستى ده هغه ددغي نهيو الكى كوميتي لخوا

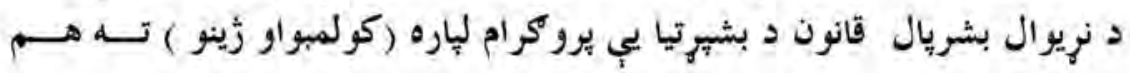
سفرونه كري او يه دي أره يب د فعاليت بشبهر اسناد يه لاس را وري دي .

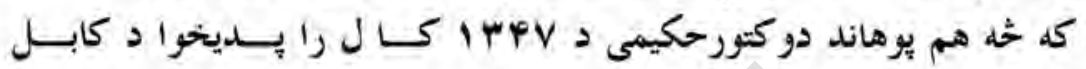

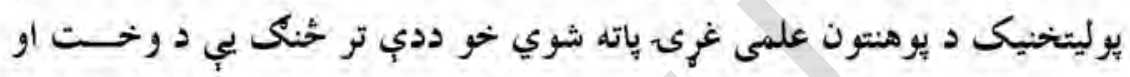

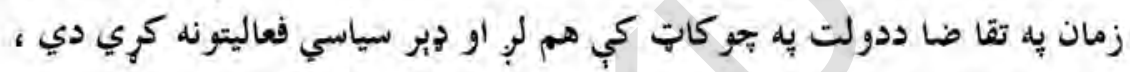

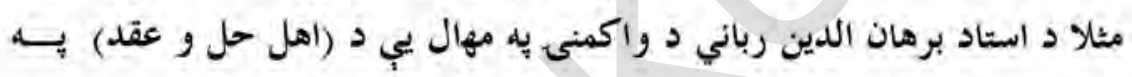
شورا كي هم كلمون كري او د اضطراري لويب جركي انتخابي غري هم وو. يوهاند دو كتورمحمد غوث (حكيمى) تل د قانون درناوى كرىى هغه هبخكله

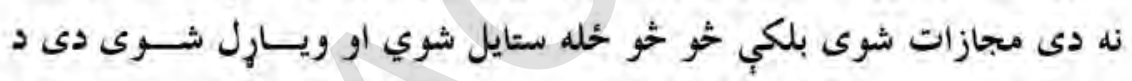

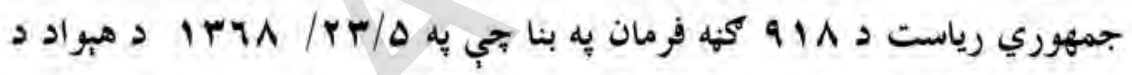
خهيلواكى د اويايمي كليزي د لمانحلويه مهال ملهال وركرل شو او همدارنكه د

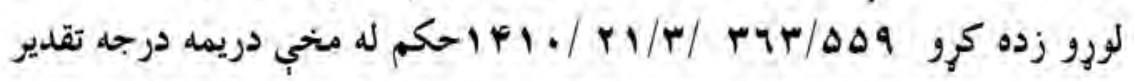

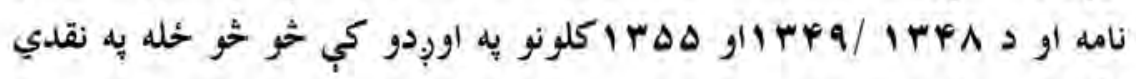
مكافاتو ويارل شوى دى .

كه د هغه دزوند لومريو ته را وكرئونويوهاند دو كتورمحمد غوث (حكيمى)

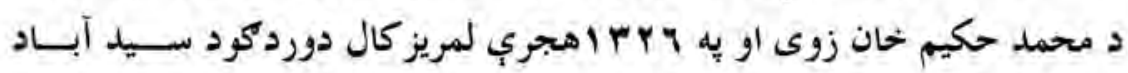
ولسوالى د (دره نورتنكى) د اميركال د كلي د رحمان خيلو په محله كي دنيا ته ستركي غرولي دي او لومرنى زده كري يب د خيلي سيمي يه بنهونحُي كي او لله 


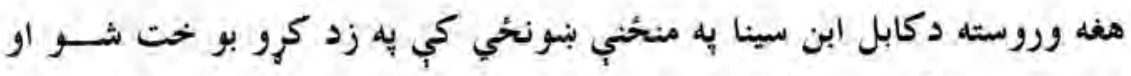

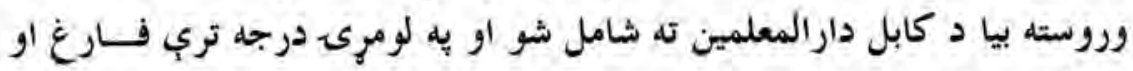

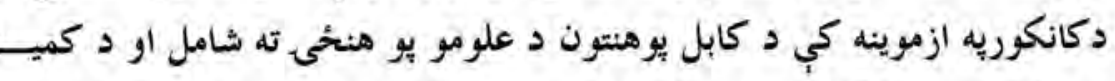

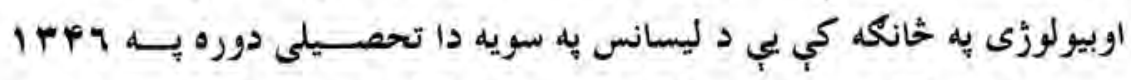

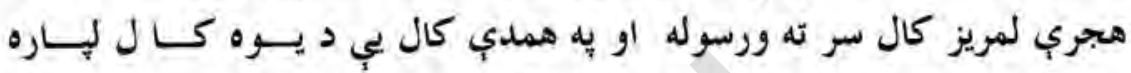

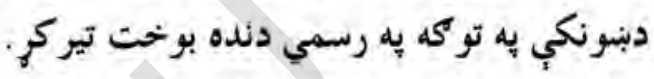

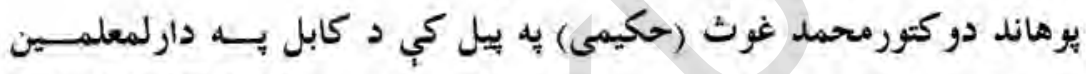

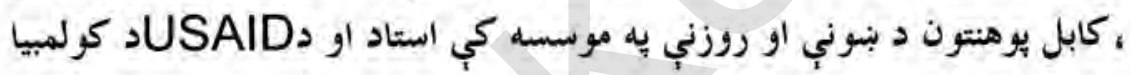

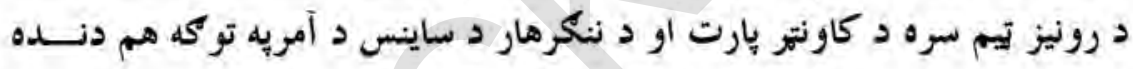

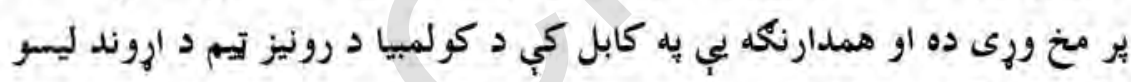

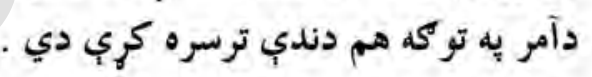

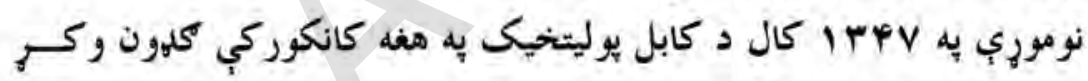

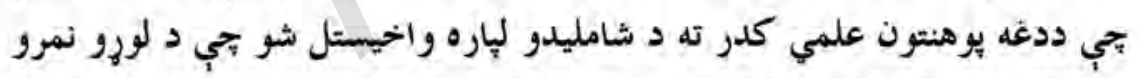

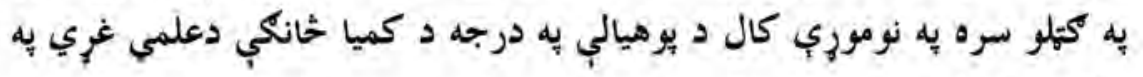
تو كهد ومنل شو. له دي تجي يوهاند دو كتور محمد غوث حكيمى له زده كرو سره بي كيجسي

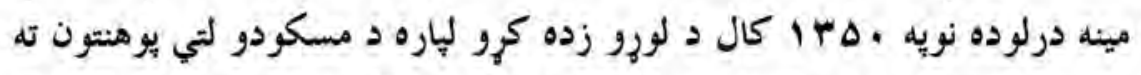

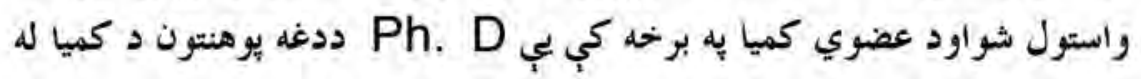

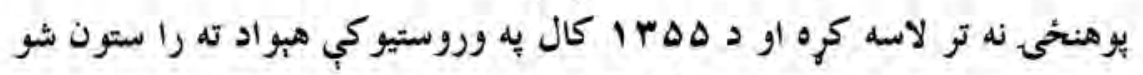

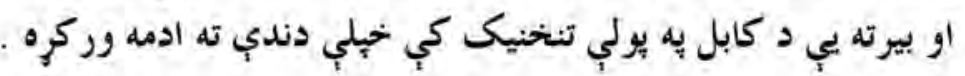


يو هاند دوكتور حكيمى يه هاب ال كال د بو هاند رتبي ته ترفيع كـري او

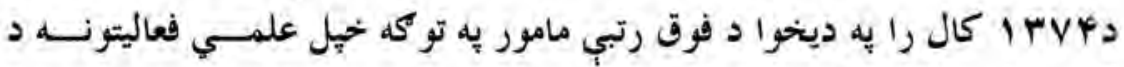

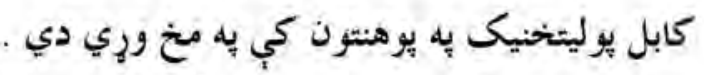
يوهاند دو كثورمحمدل غوث (حكيمى) يه هيواد كي دنيه او هم له هبــــاده دباندي حينو هغو كسانو ته تجي د ماشترى تحصلي دوره تر سره كري د دعلمـي

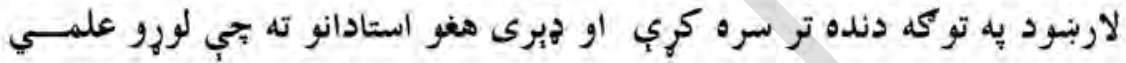

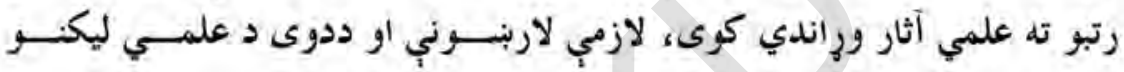
تصحيح او علمي لاربنسونه يب ورته كري ده .

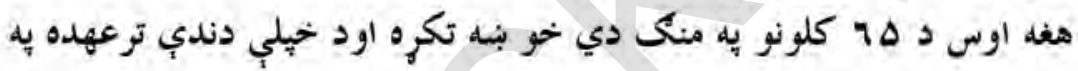
بنه برياليتوب سره وتلاى شي .

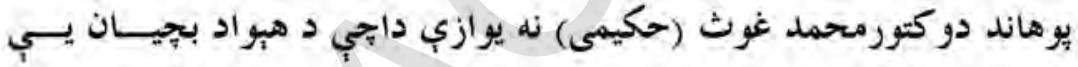
روزلي دي بلكي د خيلو اولادونو بنوني ، ووزني او يوهني ته يب هم مسوولانه

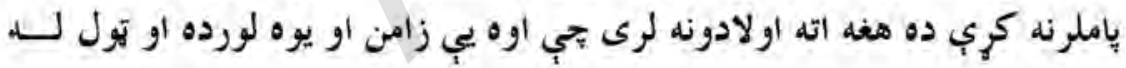
لورو زده كرو نه برخمن دي ديادوني ورده جي مشر زوى يب ماشترى يه ايتاليا

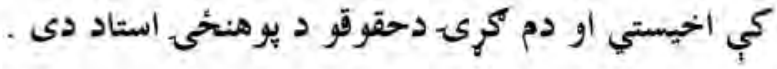
دوهم زوى يب د كابل طبي يوهنتون د ماشومانو دجراحى. د خانكي استاد دي. 


\section{$r \leqslant q$}

د وردكو مششاهير دوهم ترك

\section{محمد آصف وردى - خهلواك زورناليست}

محمد آصف وردك يه يـيل كي ملي ، اودم كرى نريوال زورناليست دى كه خهد هم د اسلامي انقلاب يه مهال يب اوجبه يه اورجه لله خيلو مجاهدو ورونو سره دجهاد يله تودو سنكرونو كي ستري شبي ورحَي هـــم

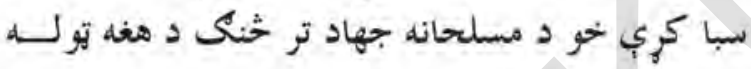

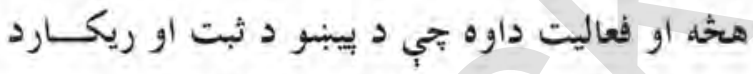

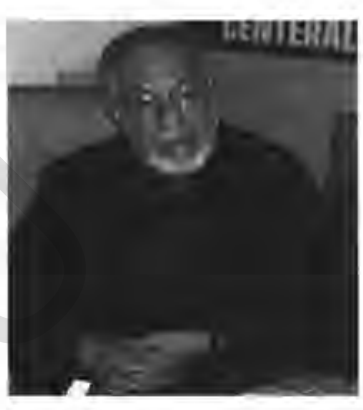
لِاره د جهاد تودوسنكرونوته نريوال زور ناليستان راوبولي اوهفوى ديته وهخوي يجي 2 رونسانودمظالمو ، بمباريو دهشتونو اونورو وحشتونو بيلكـي لـه نيسـردي ريكارد او د نريوالو سالم او عادلانه قضاوت ته يجي ور غبركي كري .

محمد آصف وردكى د كوم خاص جهادي تنظيم او يا كومي جلي غرى نه وور كه خذه هم ورونو ته يب د (محاذ ملي ) له تنظيم نه د تندر اوبرق يه نومونو دوي جبهي اخيستي وي بجي د روسانو تر وتو يوري يب عملا جهادي فعاليــت

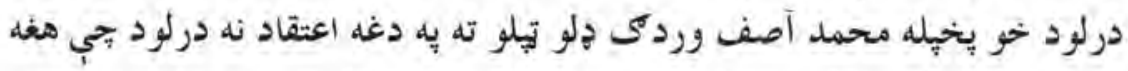
جيبر لوز ملي فكر درلود اوترل هغه مجاهدين بجي داسلامي داعيب تر جتر لاندي

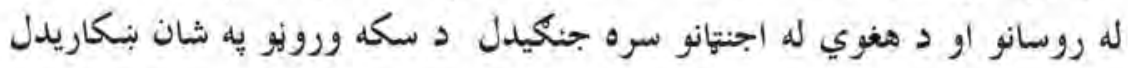

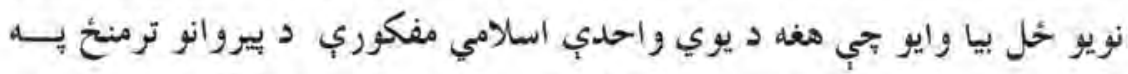
جالو باور نه دولود اودا بنسه نه ورته بنسكاريده تبي مجاهلينو د دولو او يا تنظيمونو 


\section{$r \leq V$}

دوركو مشاهير دوهم توكى

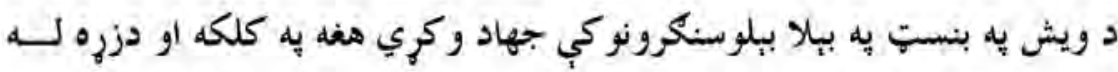
كومي د افغان مجاهدينو ترمنح د و وحلدت او يوالي غوبنتونكى اوله نفاق نه يسي كلكه كركه او نفرت درلودل اوتر آخــره د مجاهـــلدينو تــرمنئ د مينــي او وروركلوى د فضا د رامنحتّه كيدو ارمانجن وو. هغه فرهنكي فعاليتونه بحي محمد آصف وردكى د جهاد به مهال يه ملي كجه اوله جهاد وروسته يه نيويواله كجه تربره كري يه دوارو برخو كي يبي د افغانانو دردونه ، ستونزي ناخو الى را غبركى كري بجي اوس هم د هغه فرهنكي فعاليتونه

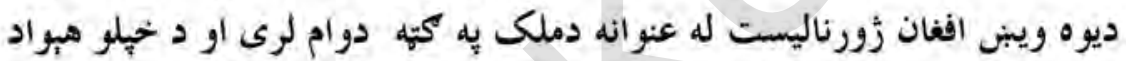

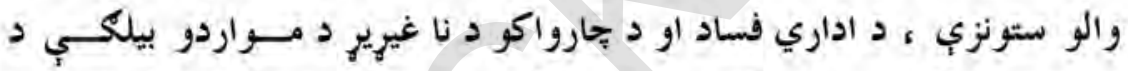
نهيوالو ستر كو ته ور غبر كوي د محمد آصف وردكى د فرهنكي فعاليتونو لريى

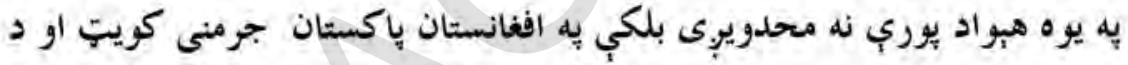
آَمريكا يه لاس انجلس كي دهغه د فرهنكي فعاليتونو لريى مخينه لرى . كله جي زمورج يوشمبرليكو الانواواديبانولكه خيرندوى الستاد حبيب الله رفيع ، محمد آصف صميم ، عبد الجليل وجدى ،شهرت نبكيا ل اوخينوبـــوروملي او فرهنكي شخصيتونود هجرت يه وطن (بينبور) كي فرهنكي فعاليتونه بيل كرل نو د (كوربت د فرهنكي تولني) يه نوم يب يوه يراخ بنستيه ادبي اوفرهنكي نهـيـاد را

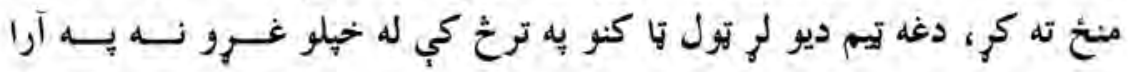
اكثريت سره محمد آصف وردك ددي تولبي د مشريه توكمه وبتاكه نو خيكه له دي وروسته ددي تولثي تول مالي لكبنت د محمد آصف وردكى يه غاره شو. 


\section{$r \leqslant \wedge$}

دوركو مشاهير دوهم توكى

دافغانستان يه ارهه ددي تو لني فعاليتونه د ارويايب تولني د ويبتيا سبب شول

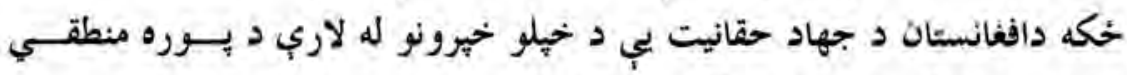
دلايلو به رنا كي د نريو الوسالم او عادلانه قضاوت ته ورغبركاوه .

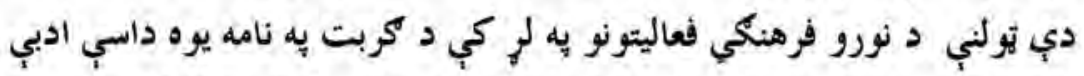
فرهنكي مجله خيروله بحي د مطلـالبو ديوخوالى او لور كيفيت له لحاظه يسي افغانستان د نورو مجلو ترمنيخ د مور لقب كتيلي وو .

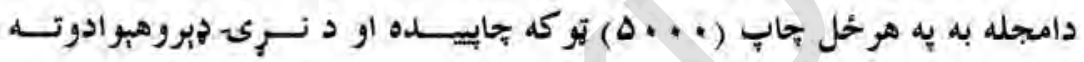
د(ميل) يواسطه استول كيده او ديرلوستونكي يب درلودل خثكه ددي مجلي قلمبـي

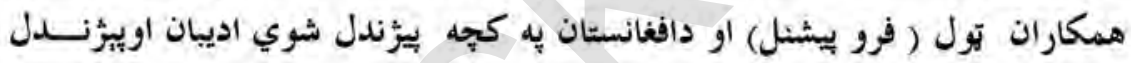
شوي علمي ملي شخصيتونه وه ، دوي تولو دافغانستان د روانو يبنــــو تحليـلـل او تفسير ته بشير لاس رسى درلود اوكره ادبي او سياسي حساب يري كيده .

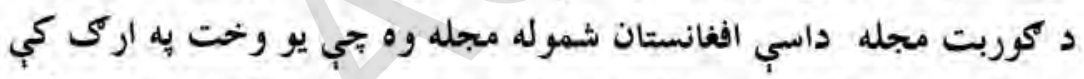

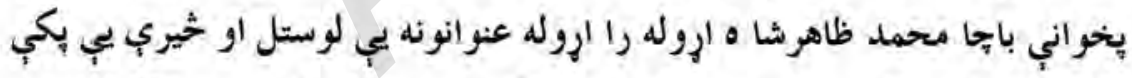

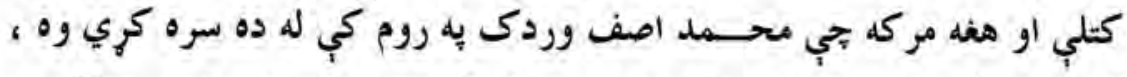
كتله إ نا خايه يب ترخوله ووتل ( بيه دي مجله كي خو تول جاب شوي مطالــبـ ينبتودي) محمد آصف ورد كى ورته وويل : اعلحفرتا ! خير كه دا مجله يه يبنستو خيره شي ، پيه كابل كي دم كريى تر

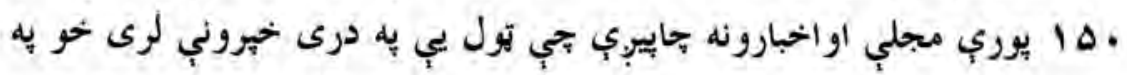
(ملي هيبتو زبه) هم بايد يوه مجله ولور، محمد ظاهرشا ددي خبري يه اوربدو سخت وخندل او د مجلي كتلو ته يب ادامه وركره . 
محمد آصف وردك له محمد ظا هرشا سره ذير له ئيردي يبرّندل اوخــورا يري كر ان وو ، يو وخت كله جي روم د ستميانو له لخوا كلا بئد شو او محمد ظاهرشا ته بِنستانه نه ور يريبنودل كيدل نو محمد آصــف وردكى وو جـــي

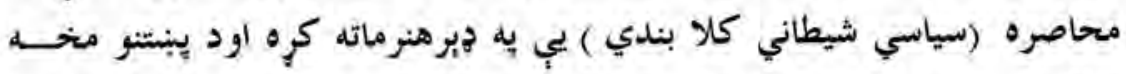
اولاره يب د محمد ظاهرشا يه لور ير انيستله بل حخل ستميانود المان اففان ميشت جا يبريال هم د جهاد ترعنر ان لاندي تر خيل ستمي نفوذ لاندي را ووست محمد آصف وردكى يو خل بيـــا ارشيــوبحي

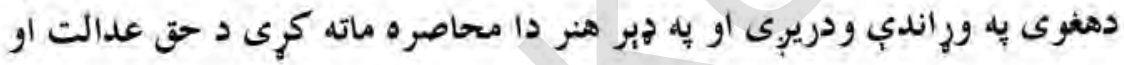

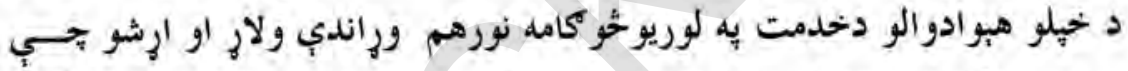
ديبنسورد هوربت دتولني يه شان يه جرمني كي هم يه شخصي لكبنست دخلكود

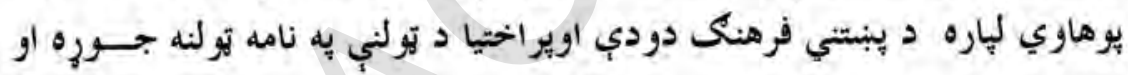

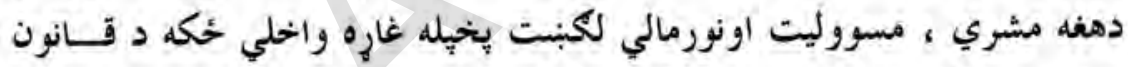

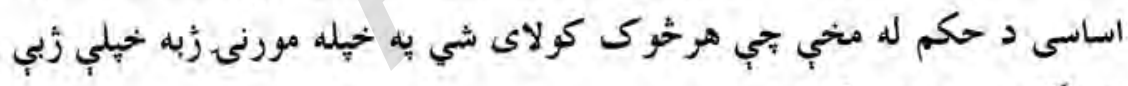
اوملك ته خدمت وركي .

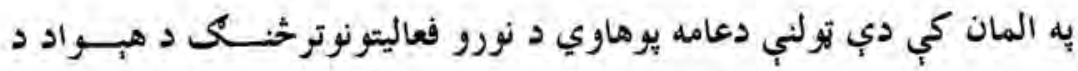
يبرّندل شويواو تكره ليكو الانو، شاعر انواوسياستو الولكه حسبيب الله (رفيع ) عبد

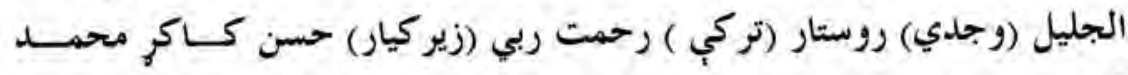
آصف صميم ، مجاوراحمد زيار او د الفانستان د ملي دفاع د وزارت د اوسني درستيزوال كريمي او داسي نورو اديبانويه لسكونو كثابونه جايول او خجيرول او وريا به يب به مينه والوويشل 
ro.

د وردكو مشاهير دوهم لَوك

همدا تولنه وره بي دكوربت مجله يب يه توله الرويا ، امريكا ، كانارا ،عربسى ملكونو اود سراسرى نرى يه ليري يوتو هيوادونو لكه نيوزرلند، استر ليا او يا

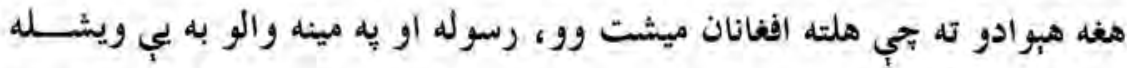

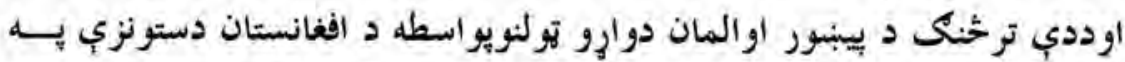
كتبه لاريونونه منظمول يه لاره به يب اجهول اونوري سياسي غونلهي به يب نيولي .

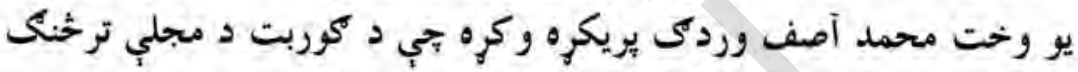

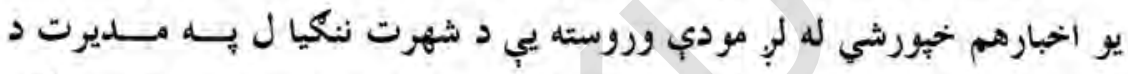
هبنداري به نوم يو اخبار له لندن نه خيوركي جي دكوربت مجلي رو حيه به يكي

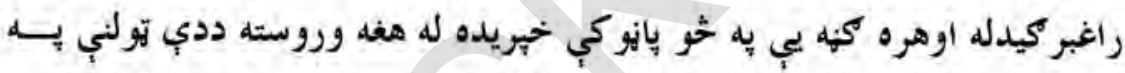

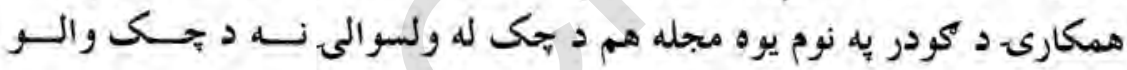

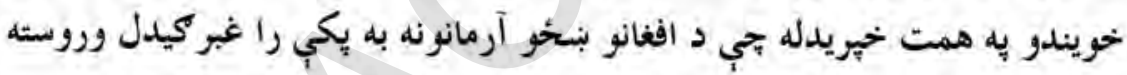
بيا دي تولني د ليب له مجلي سره هم هيره مادي او معنوى همكاري و كير .

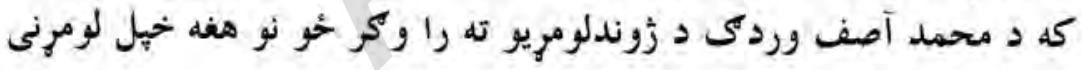

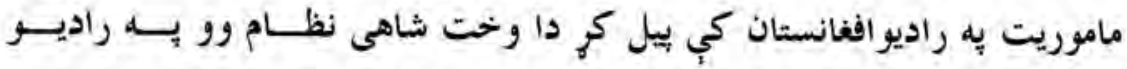
افغانستان كي يبنتو خهيروني ذِبوي لوبي اوتقريبا يه نشت حساب وي خو محمد آحف وردكى ينبتو خجروني به تولو برخوكي له دري خيرونو سره سيالي كري ،

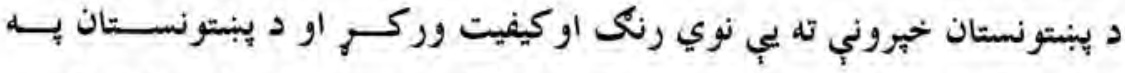

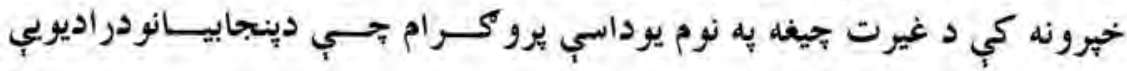

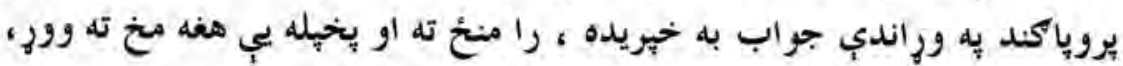




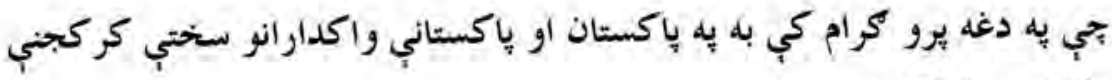

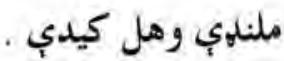

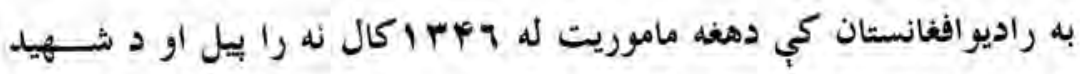

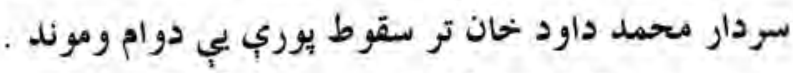

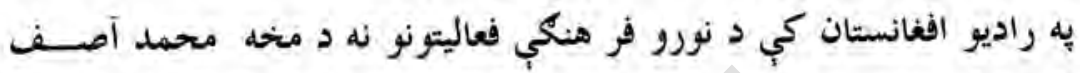

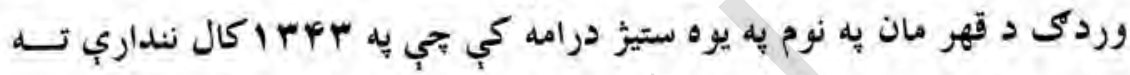

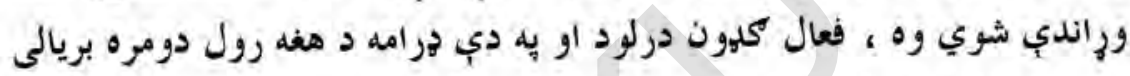

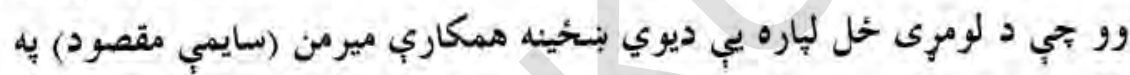

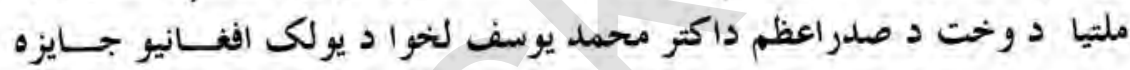

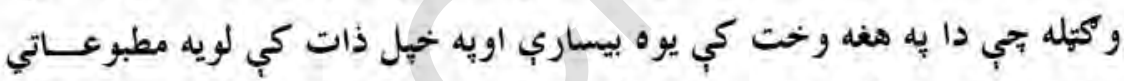

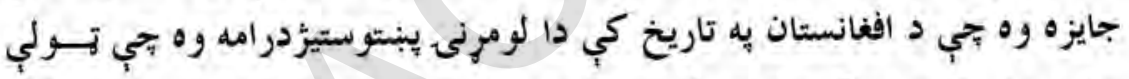

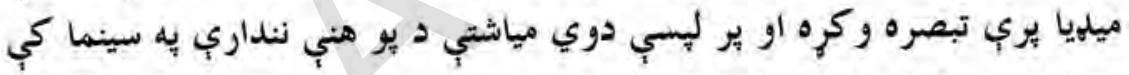

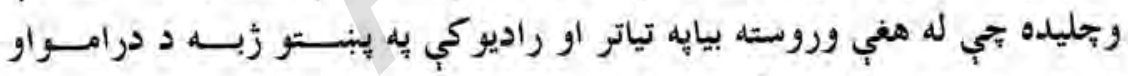

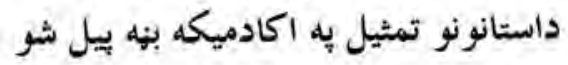

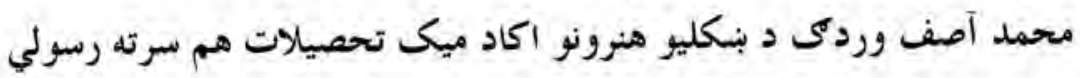

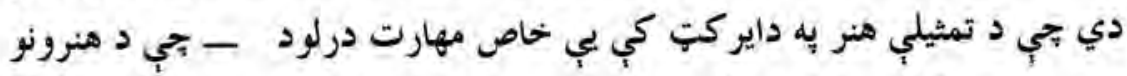

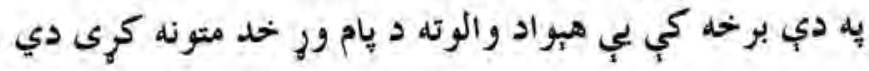

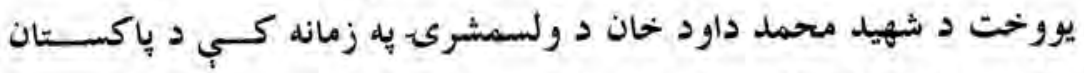

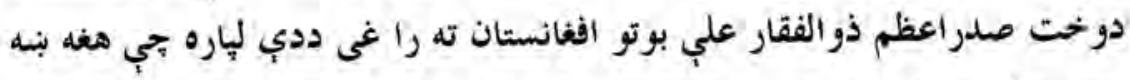

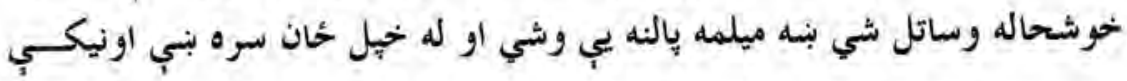




\section{ror}

\section{دوردكو مشاهير دوهم تئك}

خاطري يوسي نو يغمان ته بو تلل شو د يغمان يه سفركي له دوارو ولسميثــــرانو

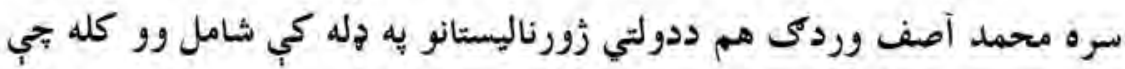

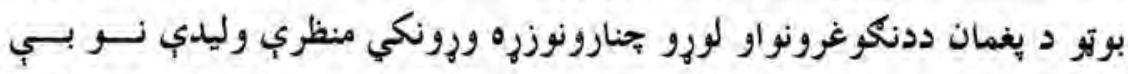
اختياره يج وويل : جي زه اوس ويوهيدم جي اففانان ولي دومره هسك غرورلوى ني ، بيا يب حاضرين مخاطب كرل او وويل : تاسي خو هيه جنت كي او سـيرِى دا لورغرونه دا ياكه او صافه هوا ،دا لور جنارونه كاشكي ما هم يه بإكستان كي داسي جنت خايونه در لودايى لنده داجي بوتو بنه ونازول شونو ددوارو حكومتونو يخوانى كرغيرني عقدي لجِ خه نرمي او نظرونه يب تريوه بريده يو بل ته لِ نيك شول .

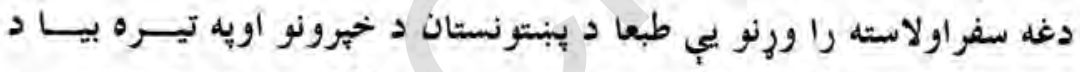
غيرت جيغي يه روحيه كي تعادلي بدلون راووست خيكه د غيرت د بجيغي يـهـ خاي جي مخكي محمد آصف وردك د ينجابيانو د بروياكندي خجيرونو يه ضد او

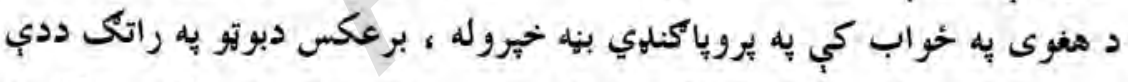

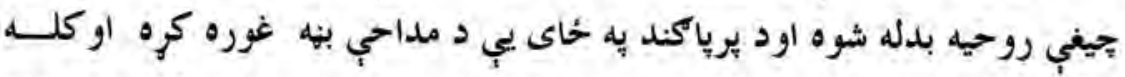
تي د مداحى مضمون دخيرولولياره د محمد آصف و متخ ته را ورل شو نو هغه

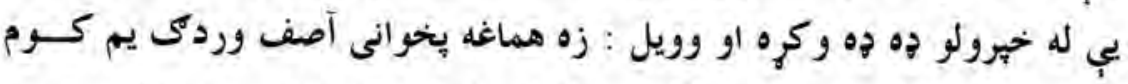

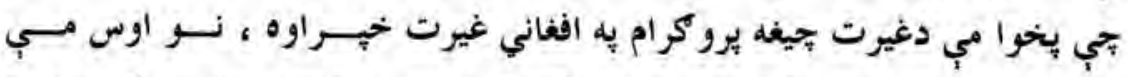
يخو انى غيرت او وجدان دا اجازه نه را كوي جي د بنجابيانو مداحي وكــرم زه خود ينجابيانو د ستر كو اغزى يم نو خحنكه به مي ذَبه او قلم دهغوى يه مداحى 
ror

د وردكو مشاهير دوهم توكى

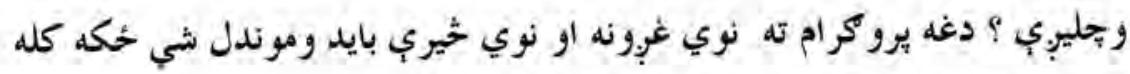

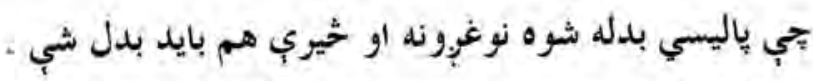

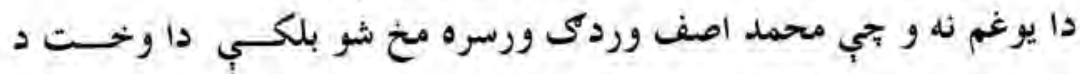
جمهور ريس محمد داود خان لخوا دا امر هم شوى و بحي قومي تخلصرنئ دي نور ليري كرى شى ، د محمد آصف تخلص وردك وو ، حيران شو بحي اوس خेه وكري

كه خه هم د يو خده وخت لياره يب د محمد اصف كاريز وال - جغتو وال

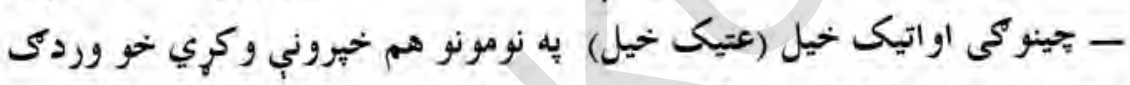

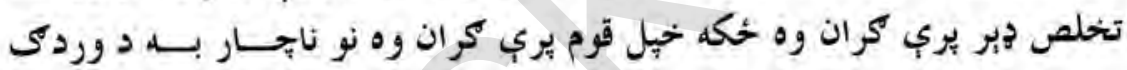
تخلص ترب استعمالبده . كله بي له ريا سيت جمهورى نه د قومي تخلصونو د بند والى يه ارهه دوهم او وروستي متحد المال مكتوب راورسيد نو محمد اصف وردكى مجبور شــو او

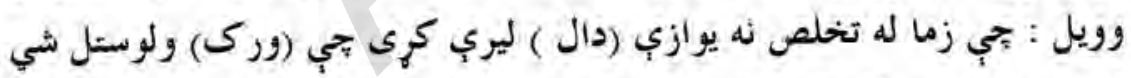

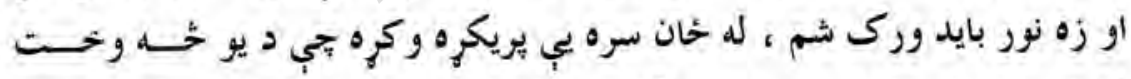

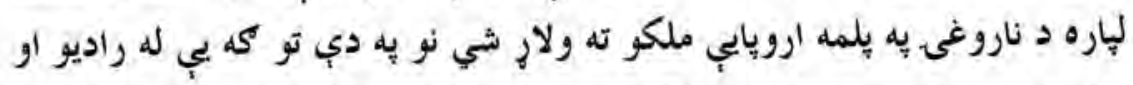

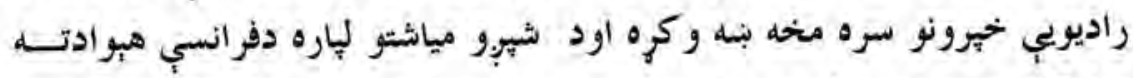

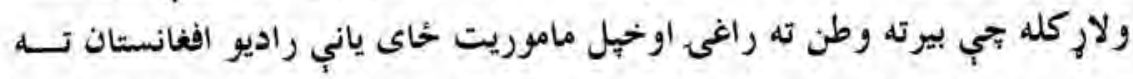
ورغى نو بهانه ورته جوره شوه د ناروغى اسناد يجي ونه مثل شول او به يوه رتبه

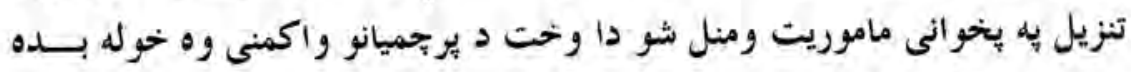

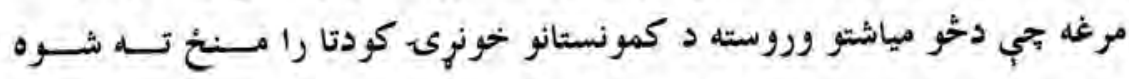


اومحمد اصف مجبور شو تجي بيرته د فرانسي هيواد ته ولارشي او به فرانسه كي

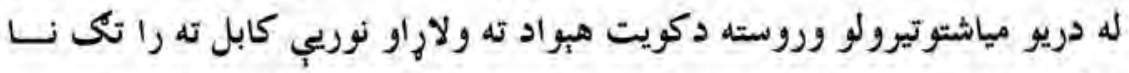

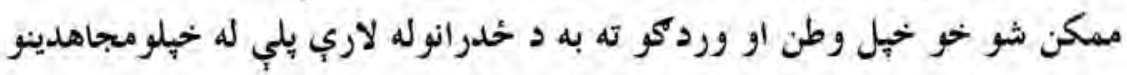

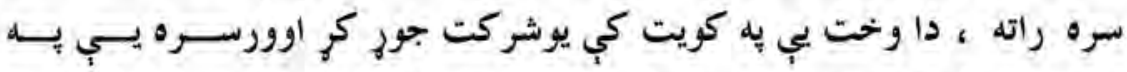

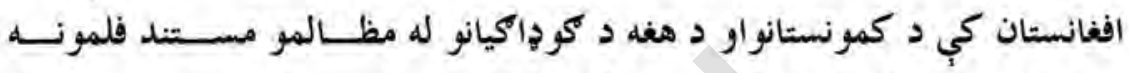

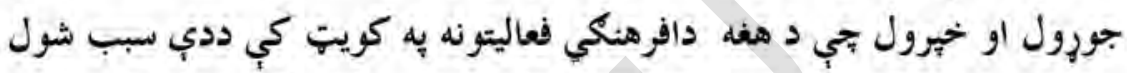

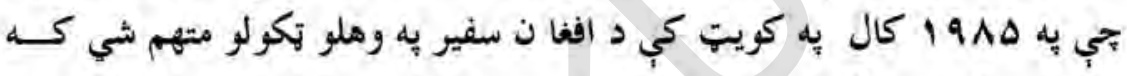
خه هم د كويت حكومت دا وخت افغانستان او دهغه سفير به رسميت نه بيرّندل

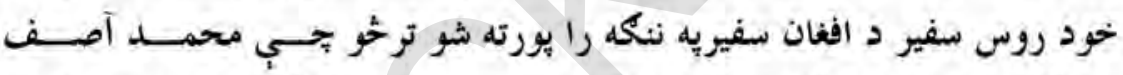

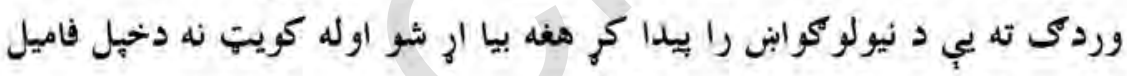

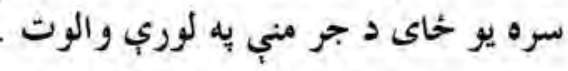

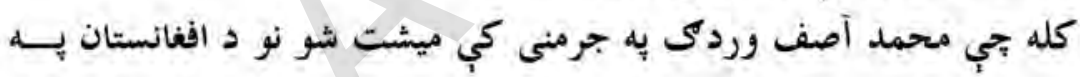

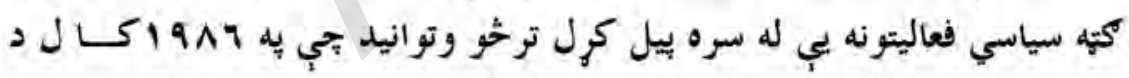

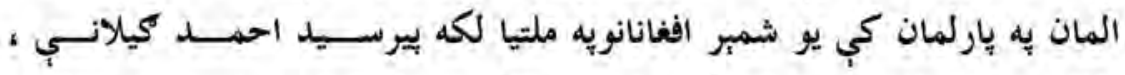

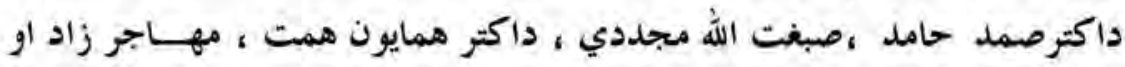

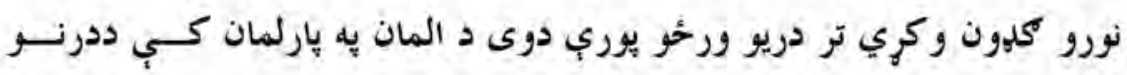

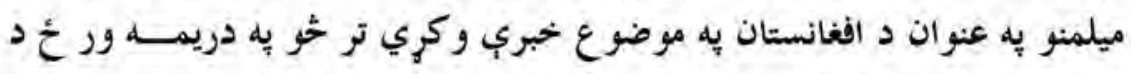

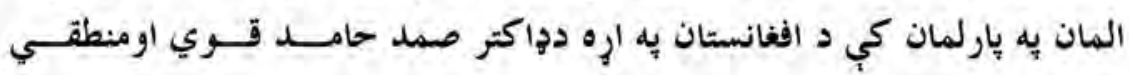

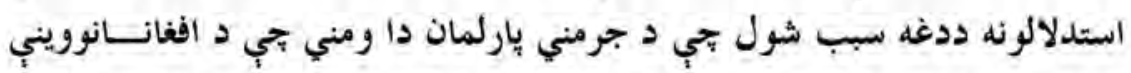

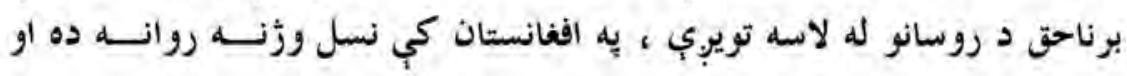




\section{roo}

د وردكو مشاهير دوهم توك

روسانو د تولو نريوالو موازينو خحلاف يه دغه ملك حمله كريى أو يه دي توكه د

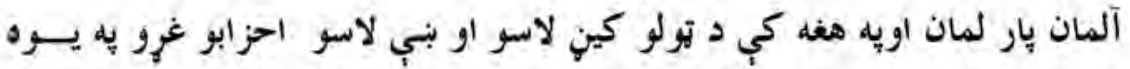
غرِّ دا ومنله جي د اففان مجاهدينو داعيه برحق ده .

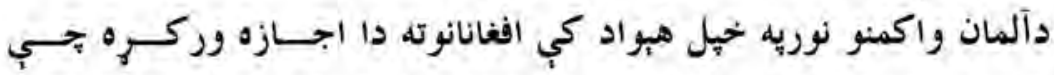
دروسانو يه ضديراخه اوقوي مظاهري وكري اوخيل غرِ اوجت كري دالمان يه

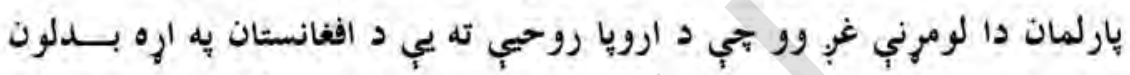
وركم اوويوهيدل بحي د روسانو لاسونه بِ افغانستان كي د بيكنا افغانانو يه وينو رنكى دي بايد نريوال كلك ملاتر يب وشي .

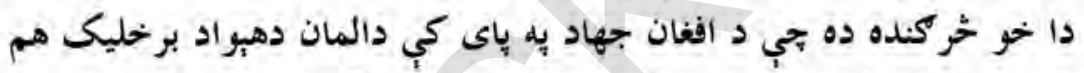

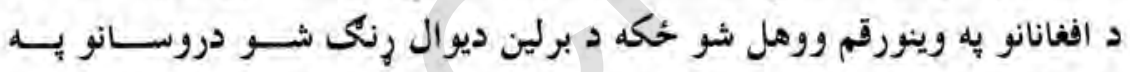

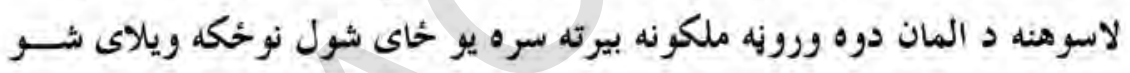

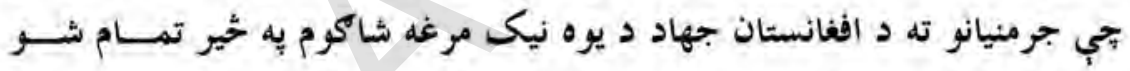
اودوى ته بي دلا برياليتوبونو درواز ي خحلاصي كري .

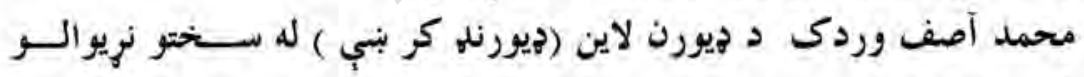

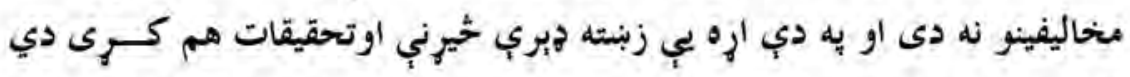

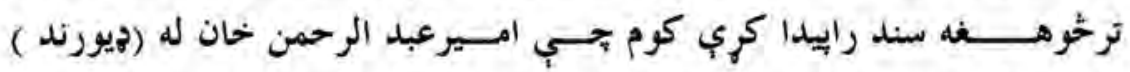

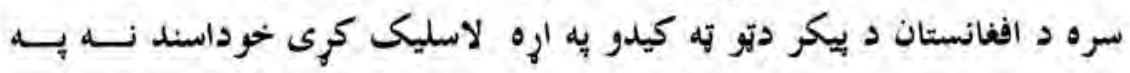
افغانستان ، نه يه هند ، نه يه الكلستان او نه هم دنرى يه كوم بل آرشيف كـي

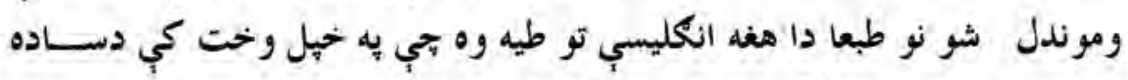

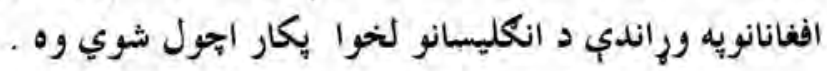


نو يه يورته دليل اود تاريخ يه منطق محمد اصف وردكى داتيك ترسيند بوري

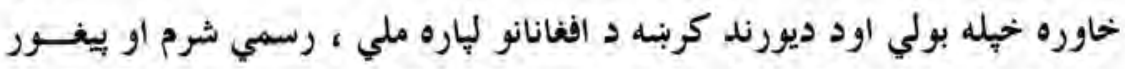

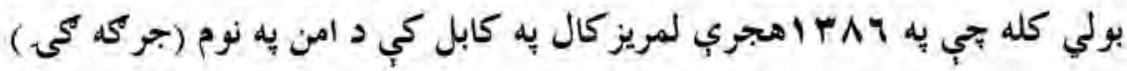

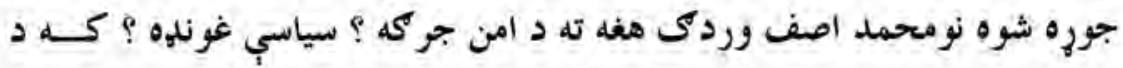

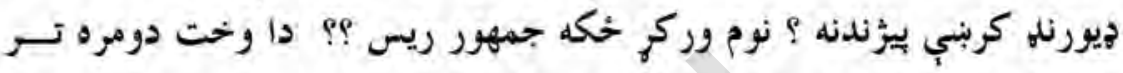

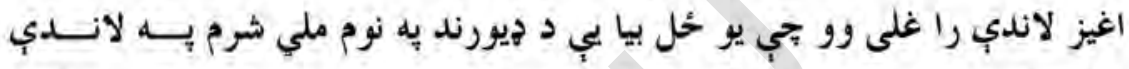

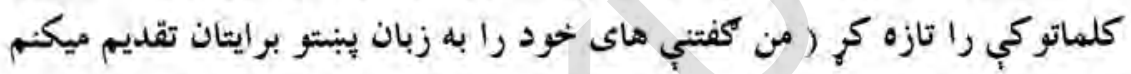

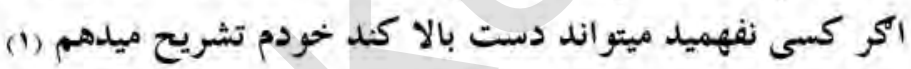

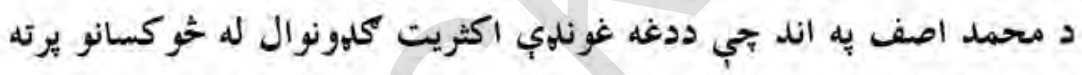

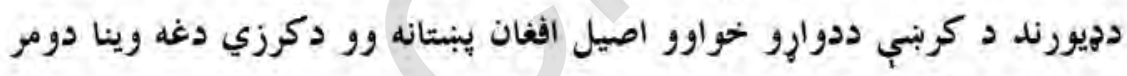

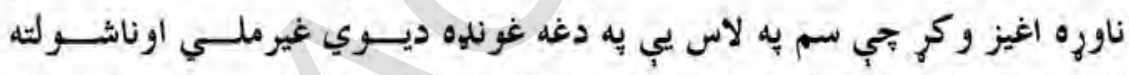

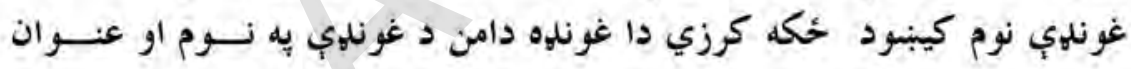

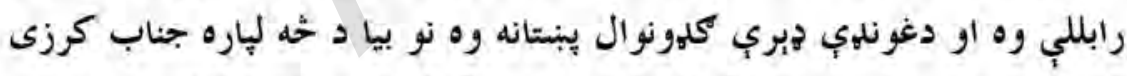

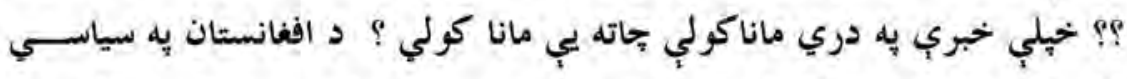

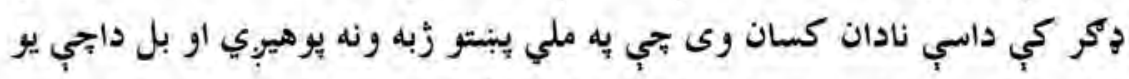

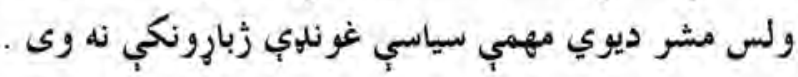

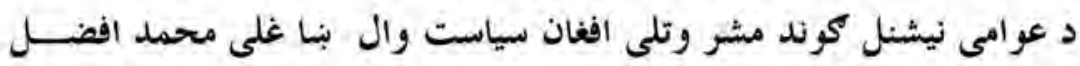

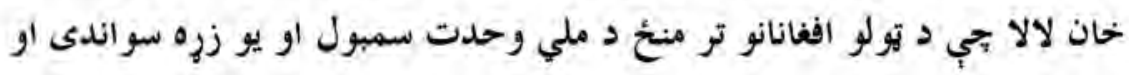

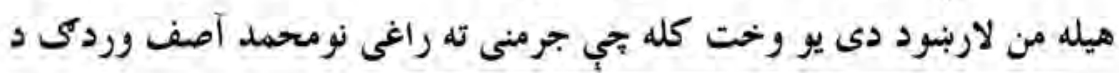




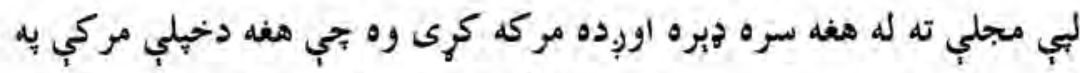
ييل كي ويلي وه ، وردك صيب!(خيل ملك اووطن افغانستان ته يه ويزه رواغلي يم ) بجي د خحان لا لا دغه خبري يه محمد اصف وردكى زيوه زوره اغيز ه وكره او د ديورن لاين خه اره د هغه يه ذهن كي نوي باب ير انيست ، اوله هفه ورونته محمد افضل لالا د محمد اصف وردكى د لومرى يو بنستي يه خواب كي ويلـي لئي وه جي يبنتانه شته اوقام نشته ، قام يه بهم ا زيديز كال انكريزانوويشلى دي

$$
\begin{aligned}
& \text { او د هغه خاوره يب هم ويشلي ده . } \\
& \text { د شاعر به قول : }
\end{aligned}
$$

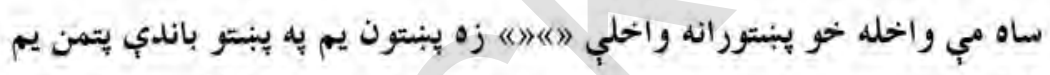

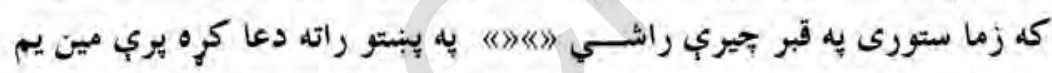

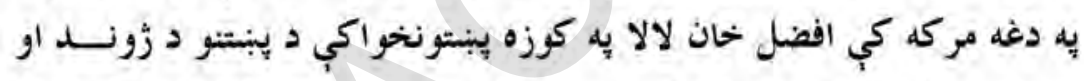
ستونزويه مختلفو ابعادو رنا واجوله خويه خو اشينى سره د خحان لالا دا مركه ددغه

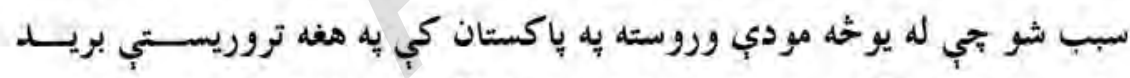

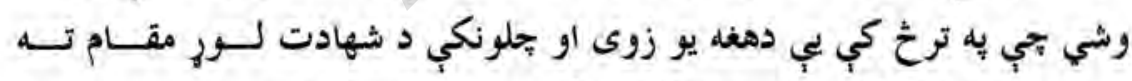
ورسيدل خو له نيكه مرغه نحان لالا الله (ج) بج كر خو سخت تيب او معيوب شو خوتراوسه زورندى دى . محد آصف وردكى هم تو اوسه د زورند يه شيبو كي دى د يَيام افغان يه نوم له هغه تلويزيون نه ملاته كوي كوم تجي د آمريكا له لاس آنجلس نه خبريوبي محمد اصف وردكى ددغه تلويزيون دافغانستان دبرخي مشر او دخيل ملت غوِ د دغــه

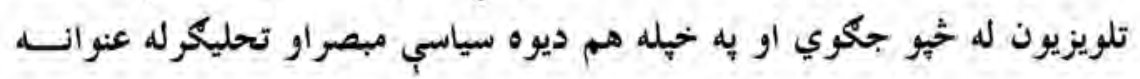


درسنيو او يه تيره بيا له خصوصي تلويزيونوسره مركي كوي او له جار او ويري

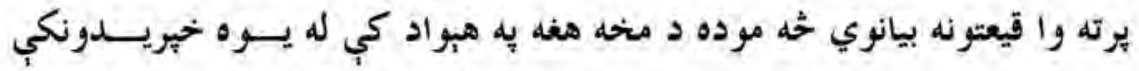

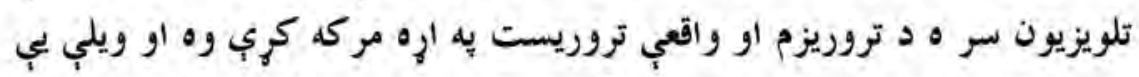

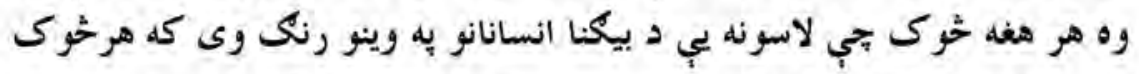

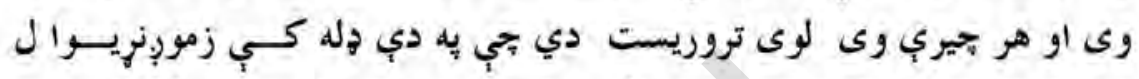

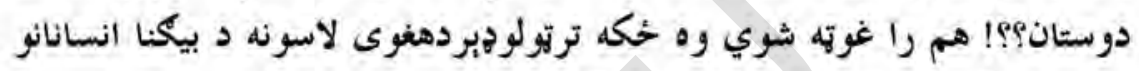

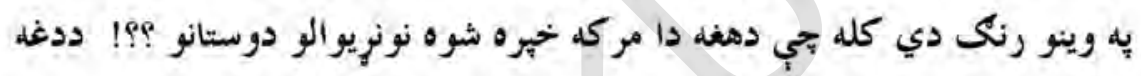

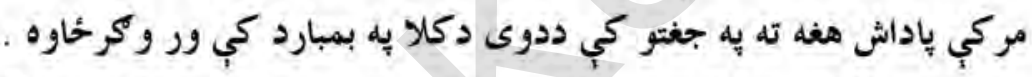

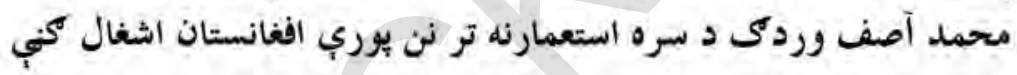

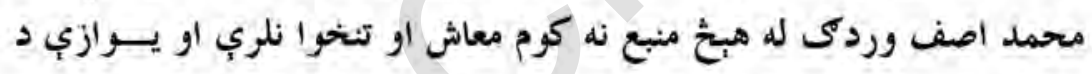

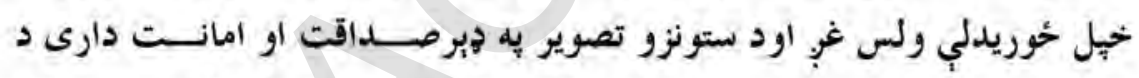

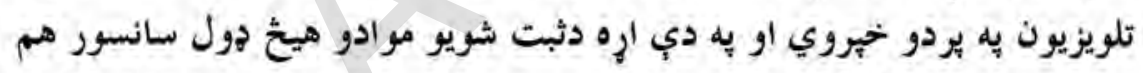

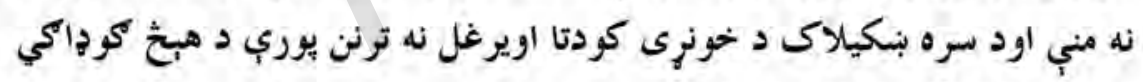

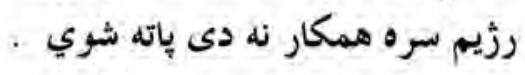

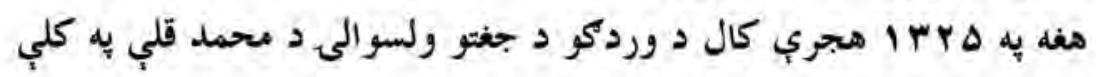

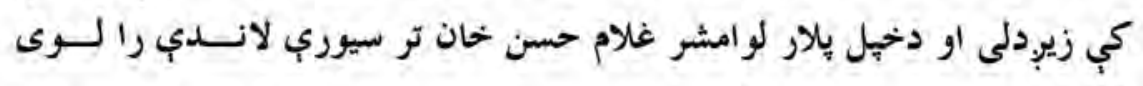
شوي دي . محمد آصف وردكى اوس بخيله د اتو اولادونو بلار دى بجي حينب يب يه ثمر

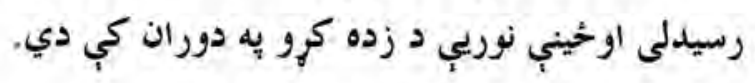




\section{محمل ابر اهيم 》حسن}

محمد ابراهيم 》احسن) د وردكو د مشاهيرو يه دِله كي

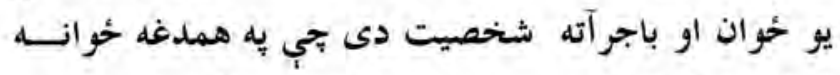

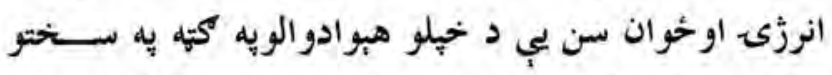
ستونزمنو شرايطو كي لوري او ور دندي تر سره كري، هغه

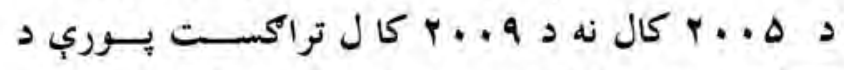
International Legal Foundation-Afghanistan (د افغانستان لياره نريوا ل حقوقي بنست) مشري كوله د دي موسسب دنده دا وه جي د هغو بي وسه او بي اسرب اففانانو لِاره تجي د بيلا بيلو جرايمــو د 
ارتكاب يه تور، تورن او يا هم مظنون يبرّندل شوي وو، يه محاكمو كي د وريا

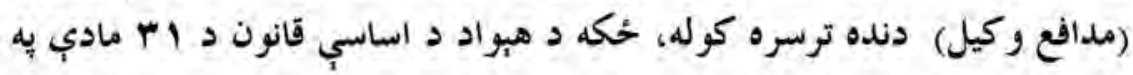

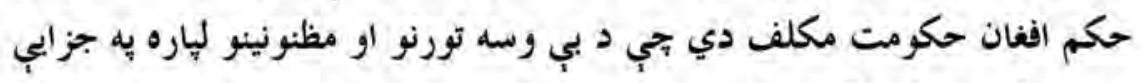
مسايلو كي مدافع وكيل ولري.

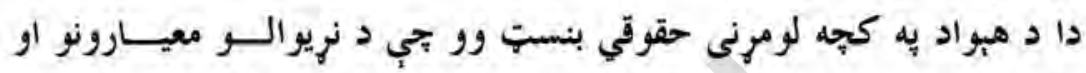

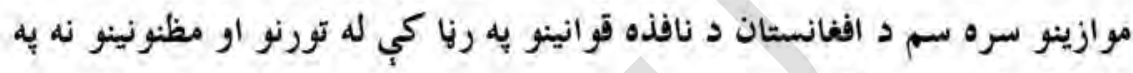
مسلكي هول دفاع كوله.

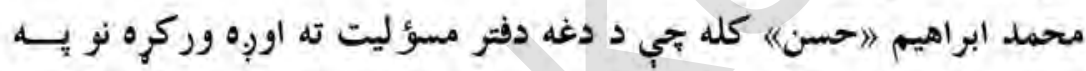

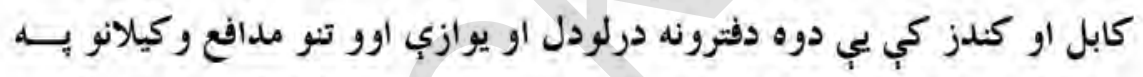

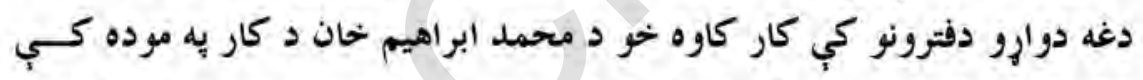

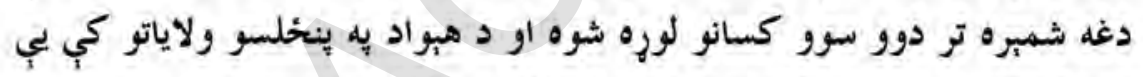

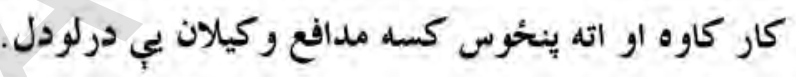

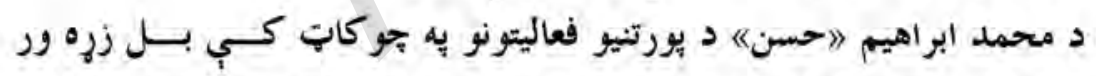

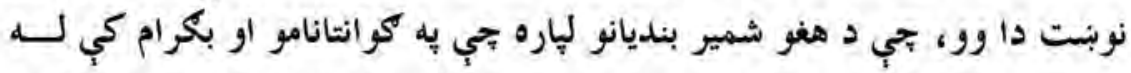

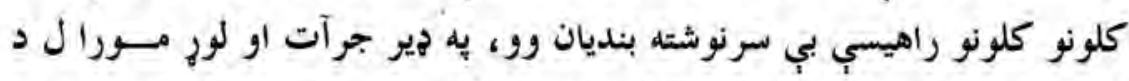

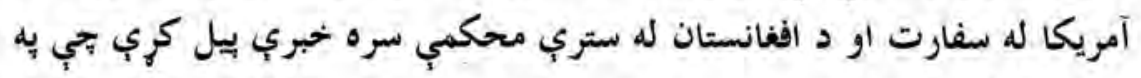

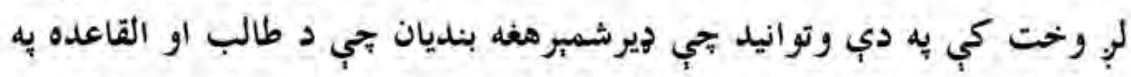

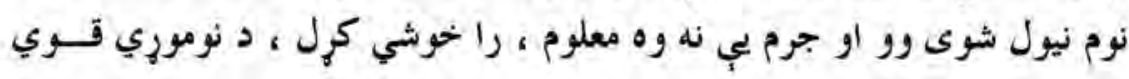

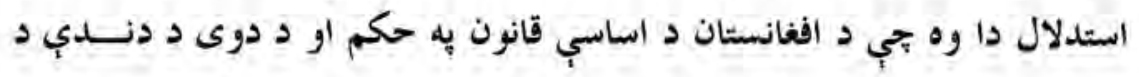


ايجاباتو له مخي دوى حق لري تجي كه طالب وي يا هرخوكى جــي بيكنــا وي تري دفاع وكري

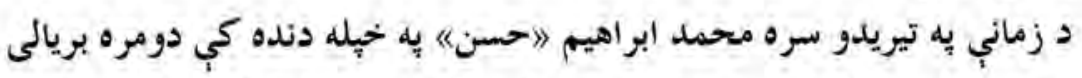

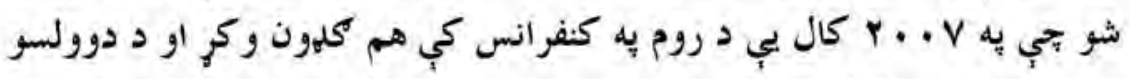

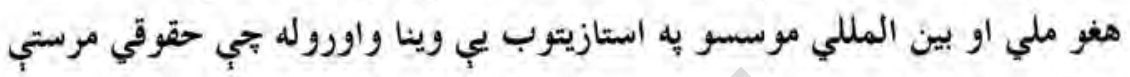

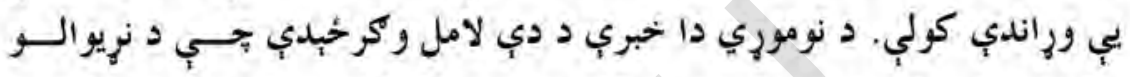

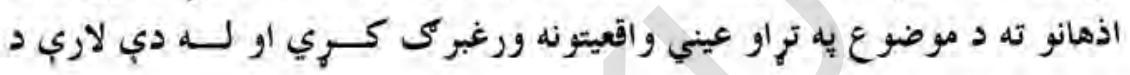
دونرانو باملرنه را جلب كري.

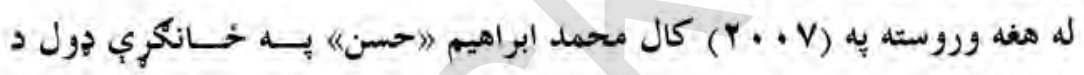

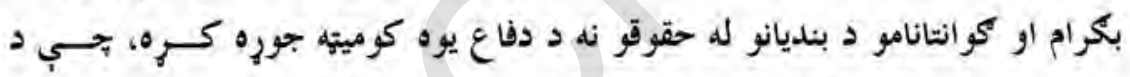

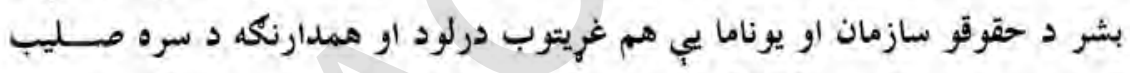

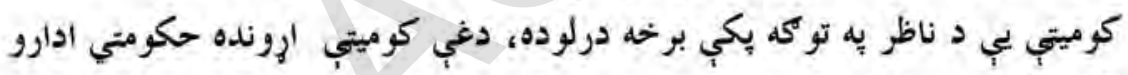

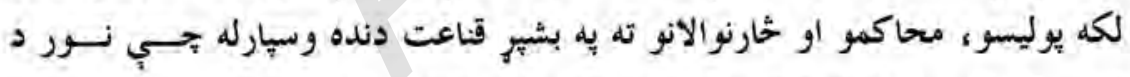

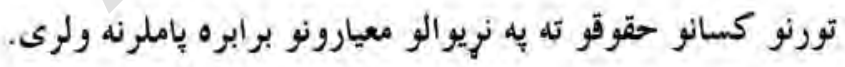

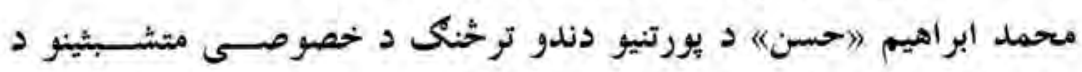

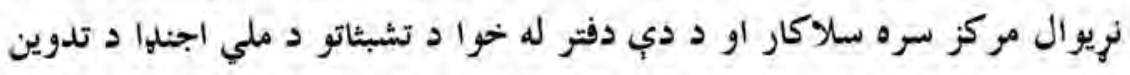

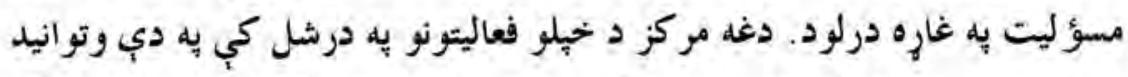

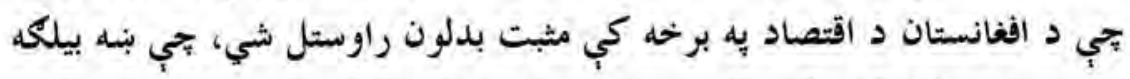

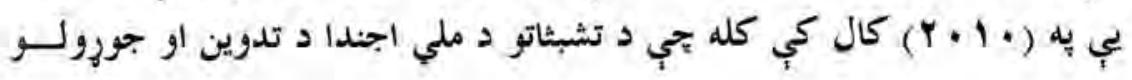




\section{FTr}

مسوليت ورد غاري وو نو هفه د هبواد د م . ما الفغان متشّــبثينو د ابــتازو نظريات سره راتول كرل.

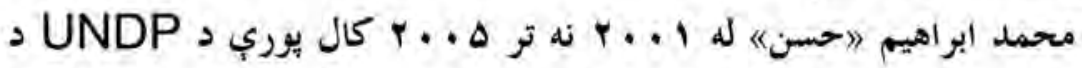
مختلفو يووزٔو مسؤليت يه غاره درلود بجي دعدلي او قضايب توينكونو او د بشر د حقوقر او وزارتونو سره د مرستو بروزي يكي شاملي وي.

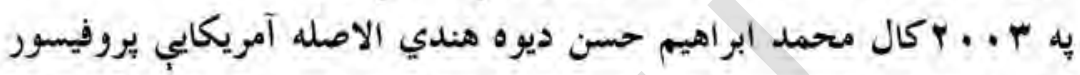
سره ديوي مياشتي لياره ايران ته ولار او هلته يب د مختلفو دولتي او ملدني تولنو

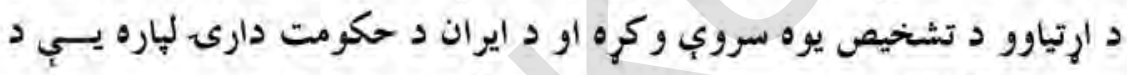

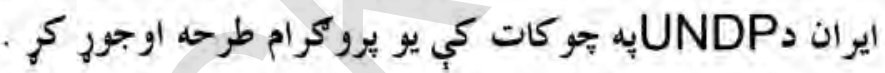
د طالبانو د واكمنى ير مهال محمد ابراهيم 》حسن) د ملكرو ملتونو د نشيه

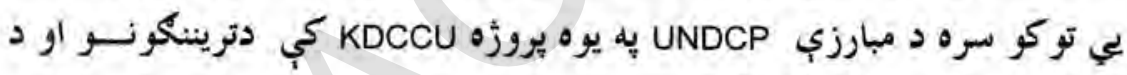
اداري مسؤل يه توكه كار كرى لون. به جرمن اكرواكشن كي يب د كور جورولو د يروزي د مسؤل يه توكه هم كارك كرى

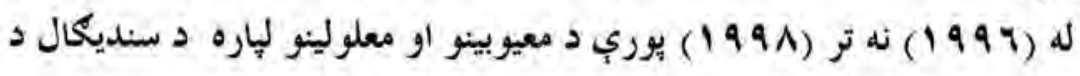
موسسب د كابل د دفتر مسؤل ورو. محمل ابراهيم 》حسن) د خيلو دندو يه بهيركي ديرستاينليكونه اخيستي او د نزى جيروهبوادولكه جرمني، فر انسي، تركيب، هندستان، عربي متحده اماراتو، ايتاليا، ايران او ياكستان ته يب رسمي سفرونه كري او يه مختلفو ملي او بــين المللي غونلهو كي يب برخه اخيستي ده. 
محمد ابر اهيم 》حسن) فرهنكي فعاليتونه هم تر سره كري، د هبو اد زيــات

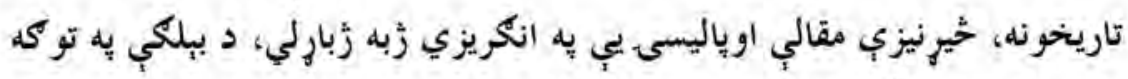
(تاريخ روزنامه نكارى اففانستان - ليكوال، محمدحليم تنوير) او خيني نور.

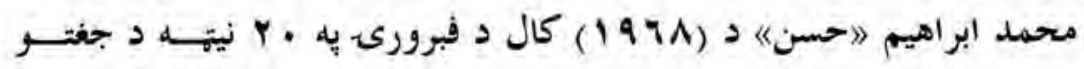

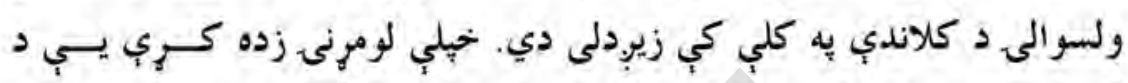

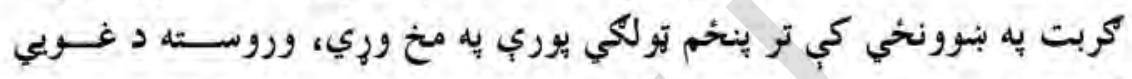

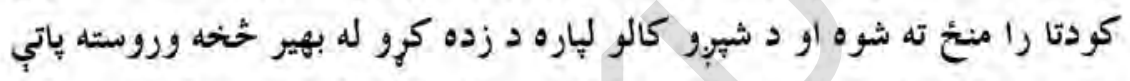
شو، بيا ياكستان ته ولارج او د صديق اكبر يه عالب لبسه كي به زده كرو ييل ورك او تردوولمسم تولكي يوري يب يه دغه لبسه كي زده كري وكري، وروسته يب د

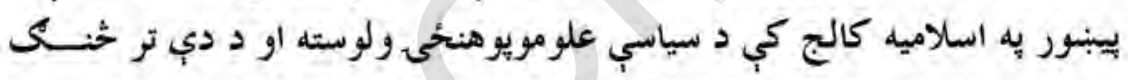

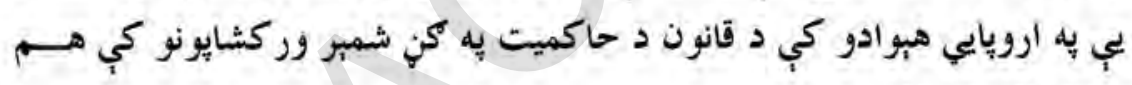
برخه اخيستي ده 


\section{ry}

دوردم مشاهير دوهم توكى

\section{مظفر الدين ( يمين) - قرماندان}

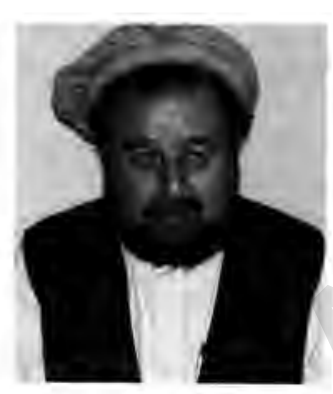

مظفرالدين 》 يمين 《 كله بحي له حربي يو هنتون نه فارغ شو نونومري يب ديري لوري وبي اولازمه خو داوه جي يه حربي يوهنتون كي د استاد يه تو كه يه كدر كي

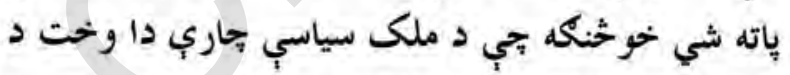

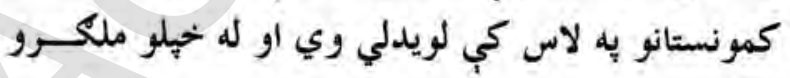

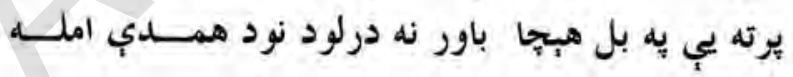

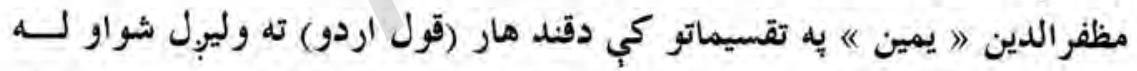

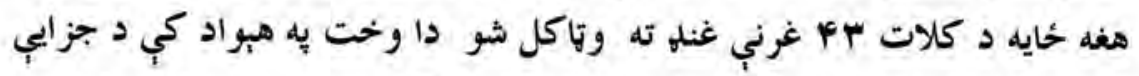
منصب دارانو لِاره دووغنلهونو ته منصبدار ليول كيدل جي يو يب د اسمارغرني

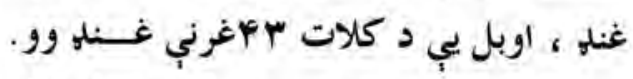

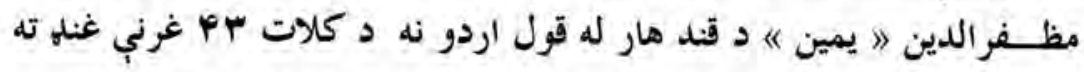

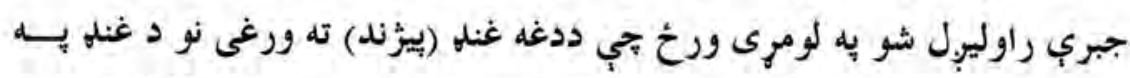

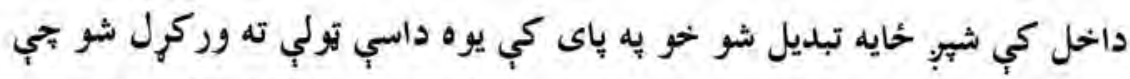
قو ماندان يب د يار محمد يه نوم ددغه غنله د حو انانو د سازمان منشي هم وو . 
مظفر الدين 》 يمين 《د دمونستانو تر تينكى نظر او نظارت لاندي بكار يـيـل

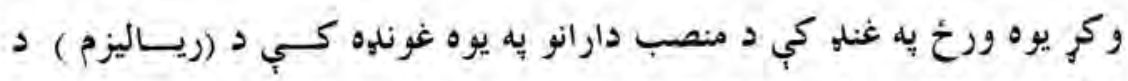

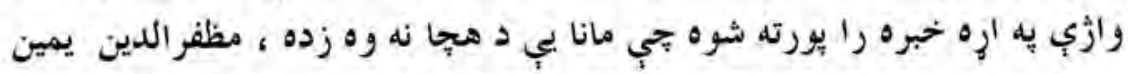

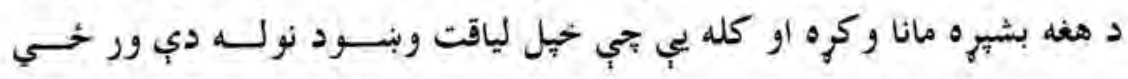

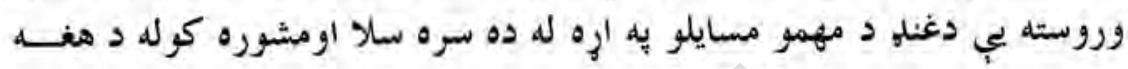

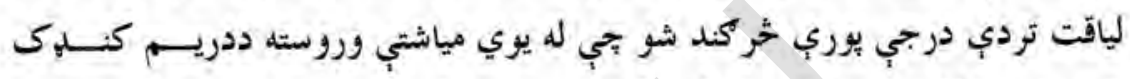

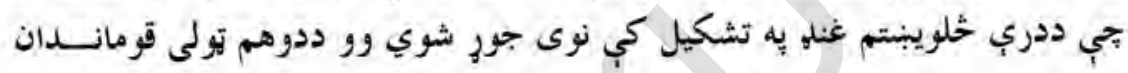

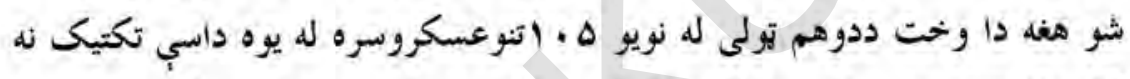

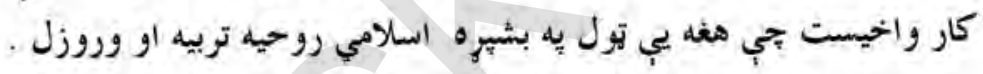

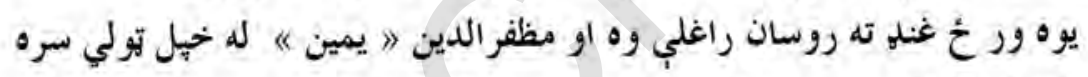

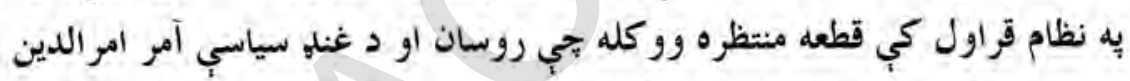

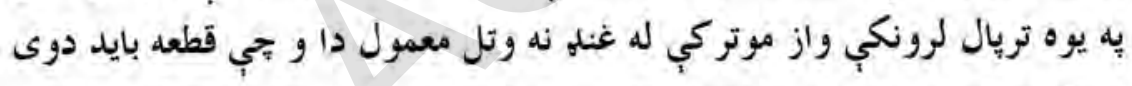

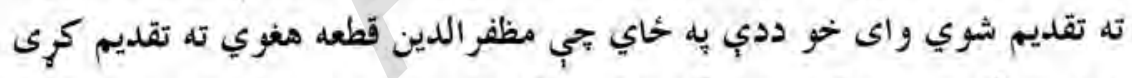

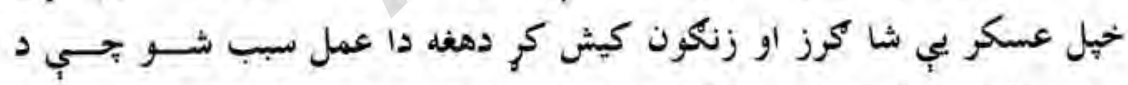

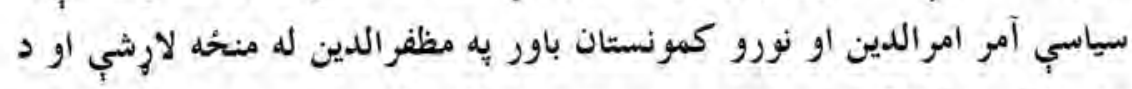

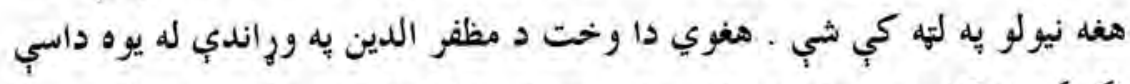

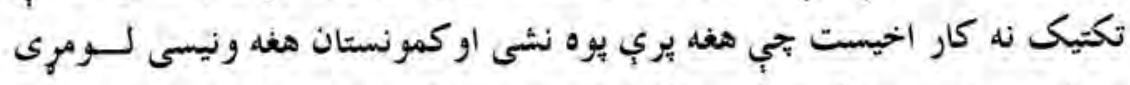

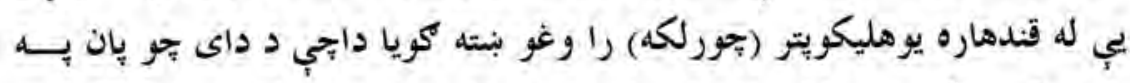

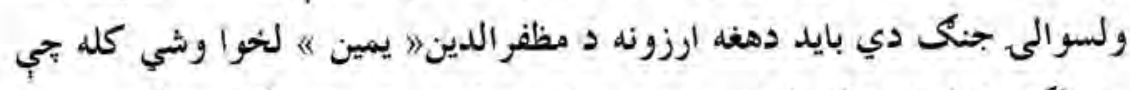

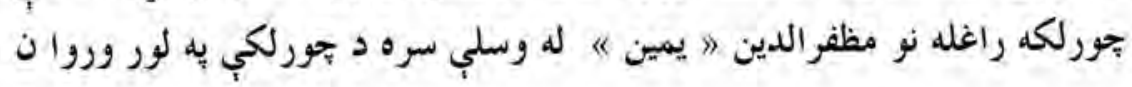




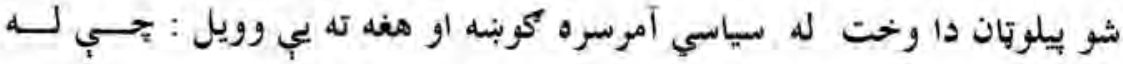

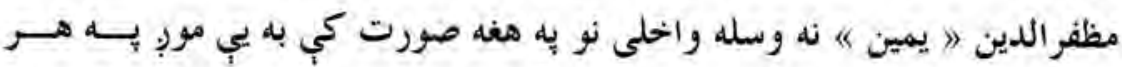

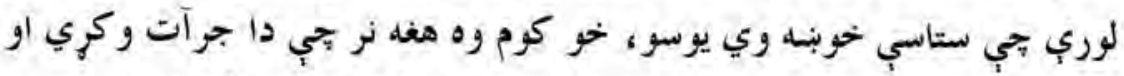

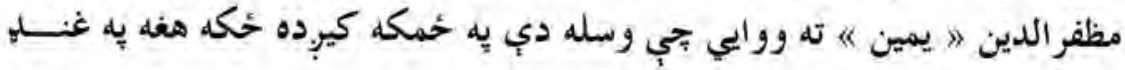
كي هبو يلويان درلودل ، يه نتيجه كي هليكويتر يرته له دي بتي ماموريت سرته ورسوي مخخ يه قند هار والوتى ، توطيه جحالانه وه ترخو يوه وروخ د موتريه سيرلى

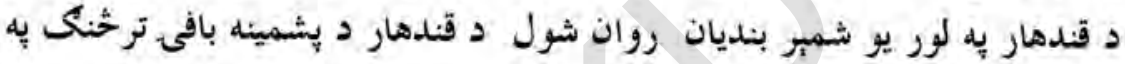

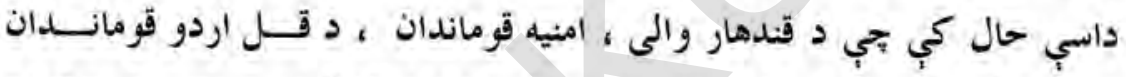
اونور تول دولثي لور يوري مامورين را وتلي وه د مظفر الدين 》 يمين 《ه موترهم دلته ودريد او مظفرالدين ثري را بنكته شو دامنيب قو ماندان يو نا خايه خيـلـ

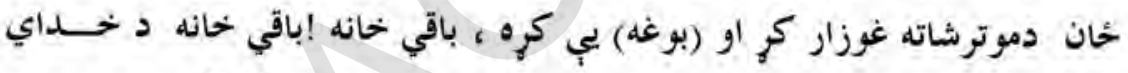
يار دي له مظفر الدين نه وسله واخله ، وسله ورسره ده ، مظفر الدين ” يمين "

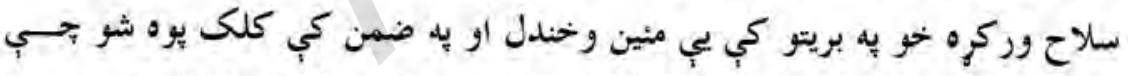

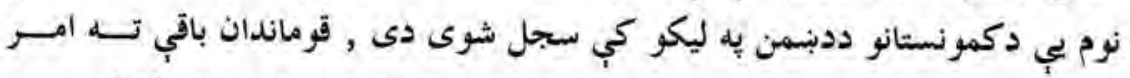

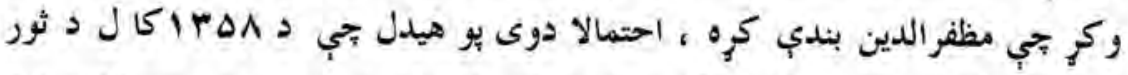

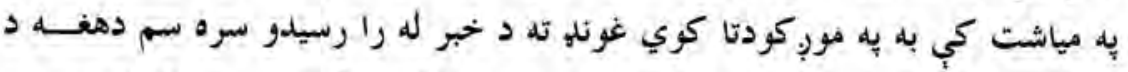

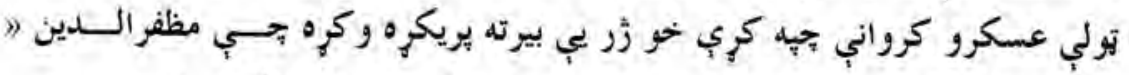
يمين " را خلاصيوي با يذ دهغه تر راتلو يوري (تولى) بنه او منظم وساتو.

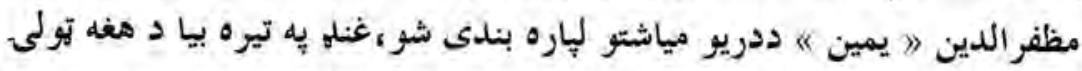
د له منحخه تلو يه حال كي شو كله بجي مظفر الدين له بندي خحاني را خحاص شـــو 
او خيل غونله ته راغى نونيم غنده يب د سرحد يه لور د جنيك لياره تللي وو اوله

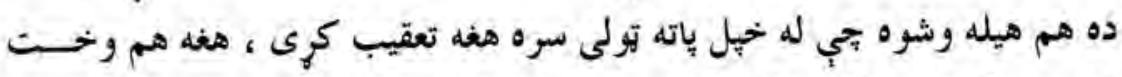

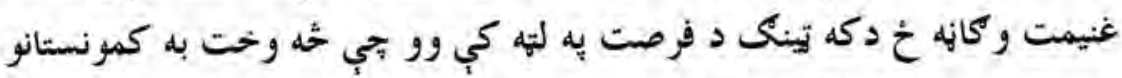

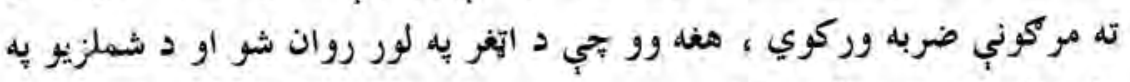

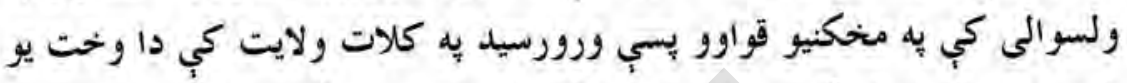

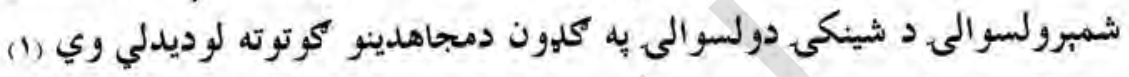
ياته دي نه وى مظفرالدين تجي كله له بند يخاني را خلاص شو نو له له مجاهدينو

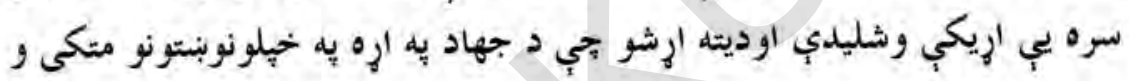

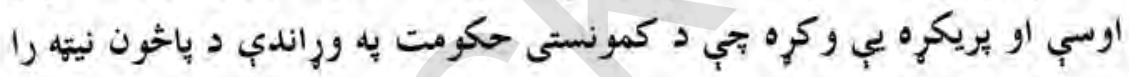

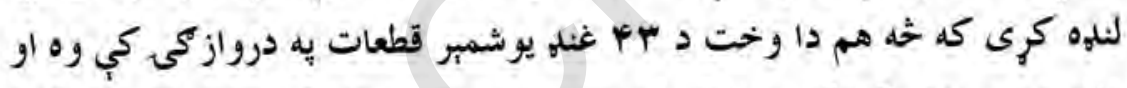

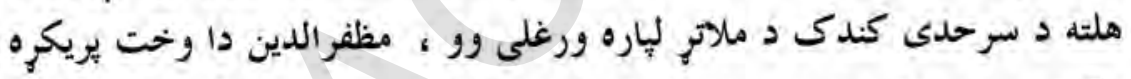

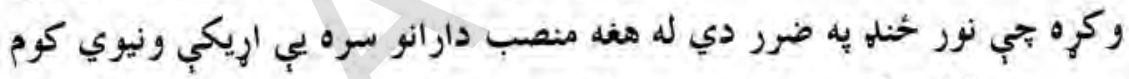

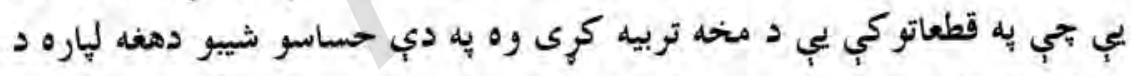

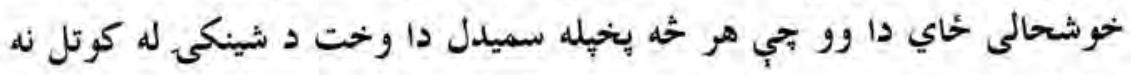

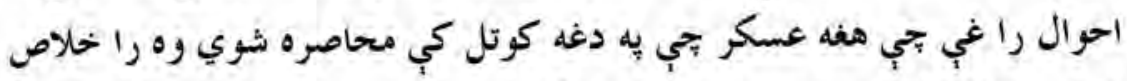

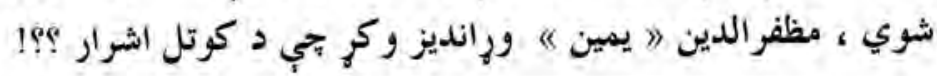

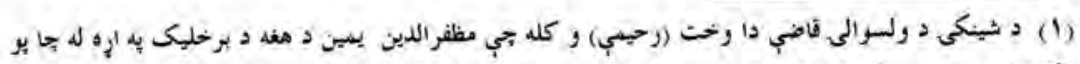

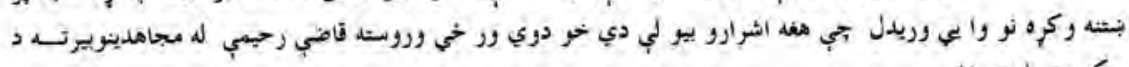

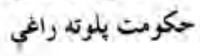


r.

د وروكو مشاهير دوهم توكى

زوندي نيول كيداي شي خويه دي شرط بجي ددغه كار لهاره با يد د معتملدو

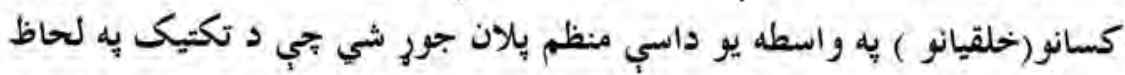
له هريلوه بشير وى هغه خلقيانوته وويل: نجي زه به كوتل كي تيجِه يه تيبره بلد يم ، خلقيان تول به دي تبكي سلا شول بي د شينكى ولسو الى يه دالان كي ددغه هالان د جورولو لياره را غونله شى دثينكى ولسوال مظفر الدين ته وويل آيا زه هم

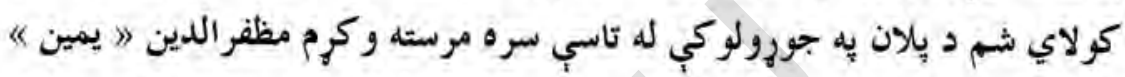
جي دا جانس له خدايه غوبنت هغه ته يب وويل : ولي نه إ خداي دراوله ، ددي وخت ولسم الان بايد تول فو خيان وي .

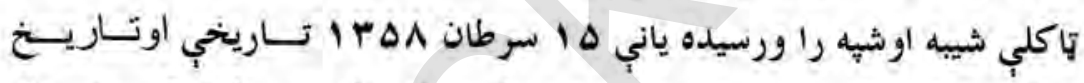
جورونكي شيه ديالان جورولو شيه ! دوى تول دو ولسو الىى يه سالون كي راتهـول

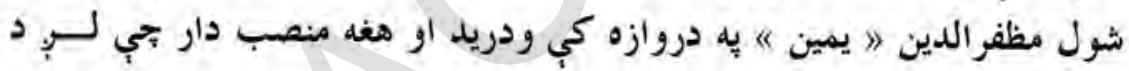
مسلمان شكى به هم يوي كيده سالون ته يب نه يريبنو د حكه بحي بيحايه ونه ورزل

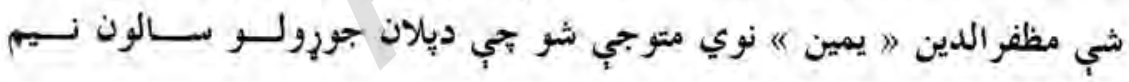

$$
\begin{aligned}
& \text { تريشيتول يوري جبه خحانه هم ده . } \\
& \text { ـ آه ، الله خيل فضل وكريل }
\end{aligned}
$$

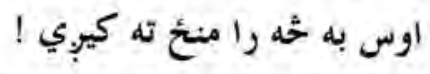

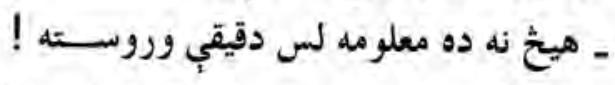
مركى يا زو ند؟ برى يا نا كامي ؟ يه دغه تولو يوازي مظفر الدين يو هيده او د دغه باوري ملكري إن 


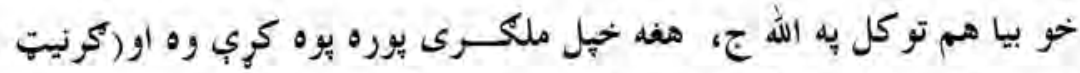

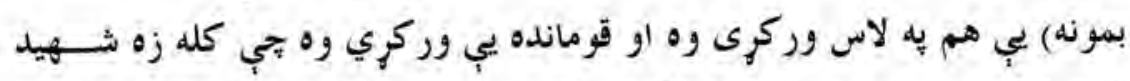

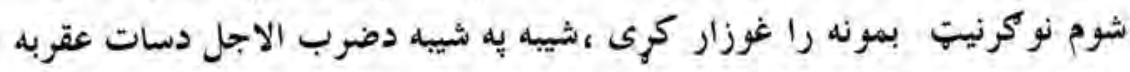

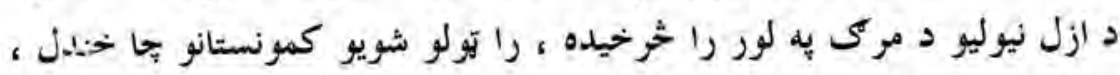

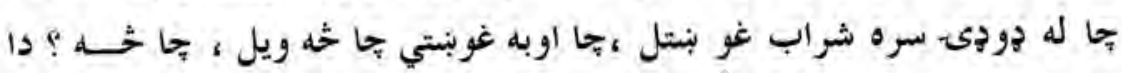

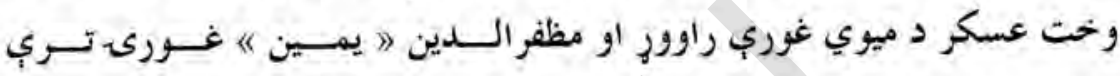

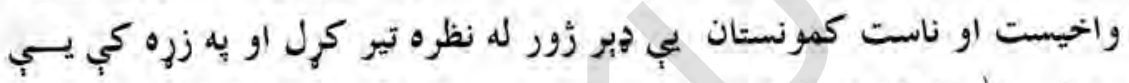

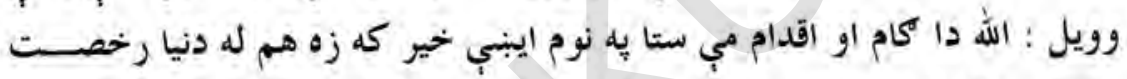

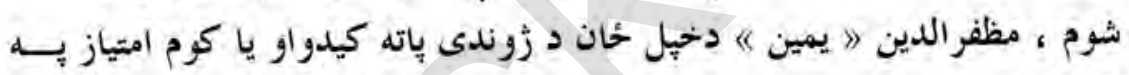

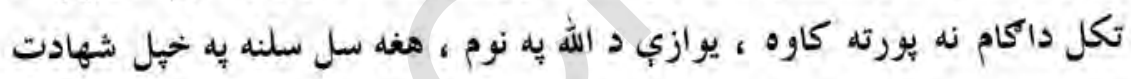

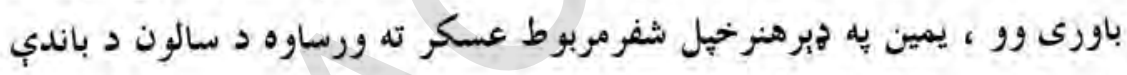

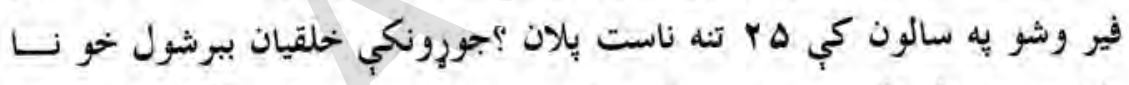

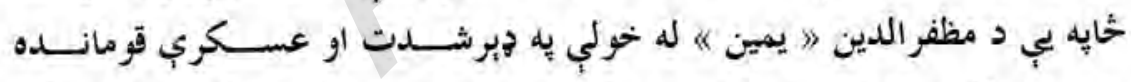

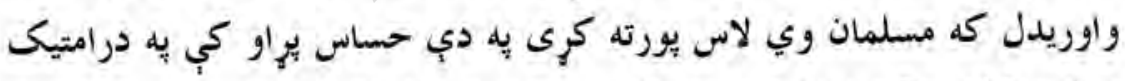

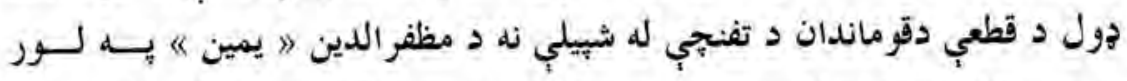

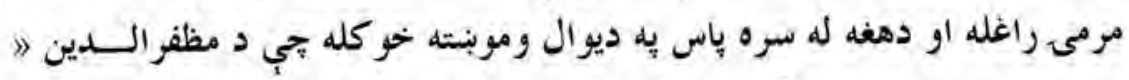

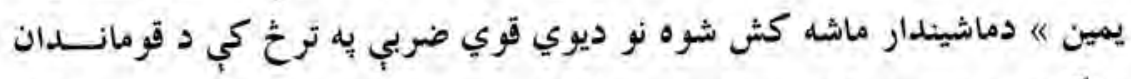

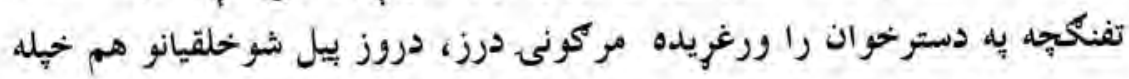

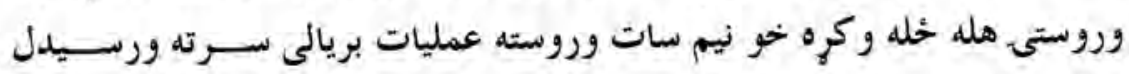

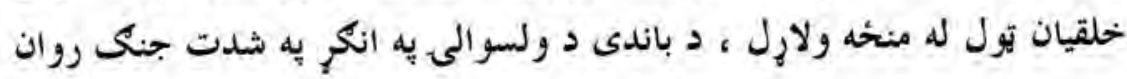


YV.

دوركو مشاهير دوهم تورى

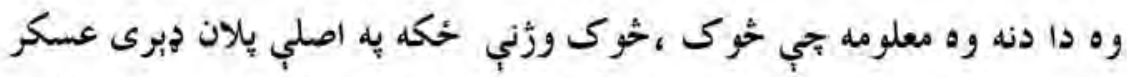
او منصب دار نه يوهيدل كله تجي دمطلب كسان له منحه ولارل نو مــفر الدين

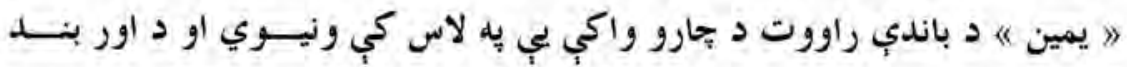

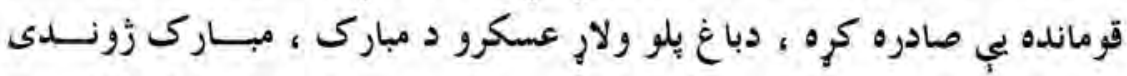
دوي اسلام ناري وركرى لوِ شيه وروسته يب تول جزتامونه سره را تول كرل ( ا وخت ددوى له مجاهدينو سره هيخ جول اريكه نه وه ) دوى اورونه بل كري إومجاهدينو هم اورونه بل كرل او يه دي توكه يب يو بل سره ويوهول بجي دواره خواوي نور مجاهدين دى مظفر الدين 》 يمين 《 مجاهدينو ته احوال وركر

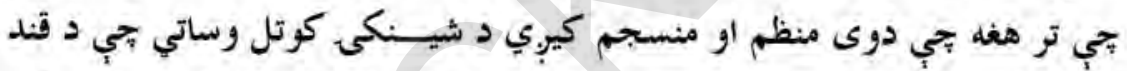
هاراوكلات نه تعقيبي قواوي رانثى كله بتي شيه سبا شوه مظفر الدين امر وكر

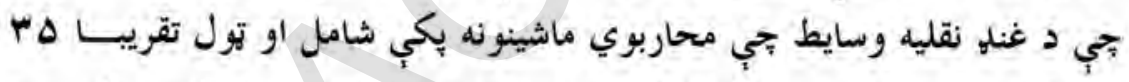

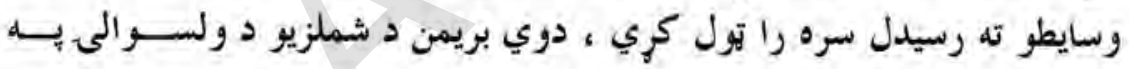

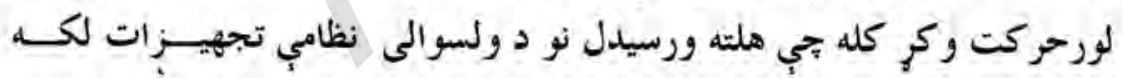

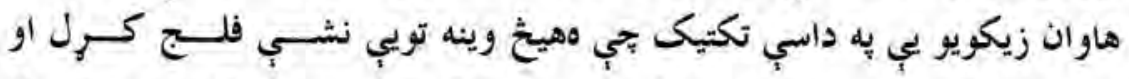
ولسوالى يب ونيوه او تول مسوولين يب ددروازكى د سرحلدى كندي هيه لور له له

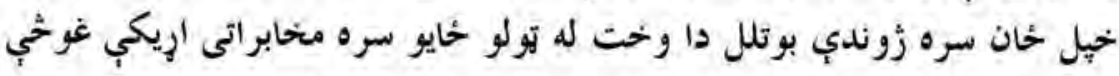
وي يوازي د تليفون له لاري يمين وتوانيل بجي دروازكىى له سرحدي كنله سرى سره اريكه ونيسي ، له نيكه مرغه دهغه كندئى د قوماندانى به قوار كاه كي كوشكه ظابط حفرت خحان هغه جي له مـ لـفر الدين 》 يمين " سره دمخه باوري تنظيم

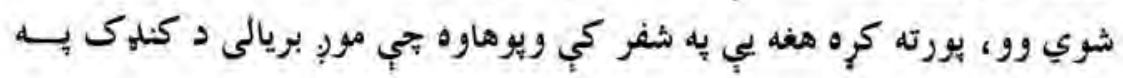


لور در روان يو تاسي خهيل تيارى ونيسى كله تجي دوى هلته ورسيدل قوماندان د

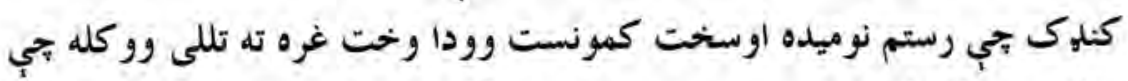

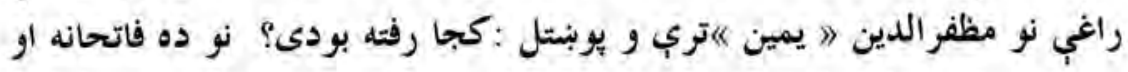

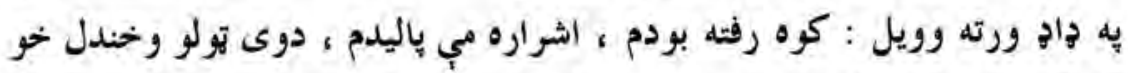

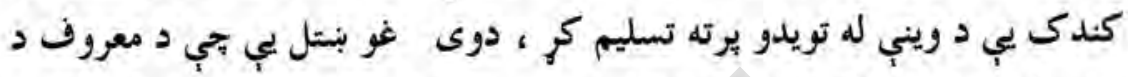

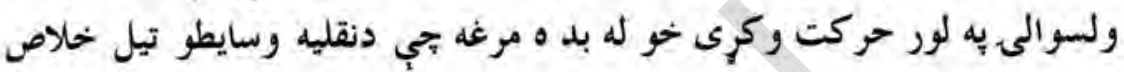

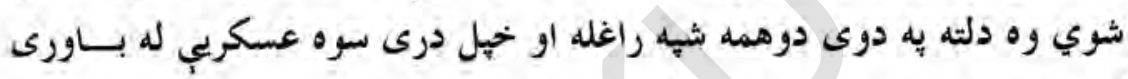

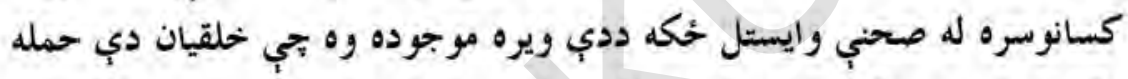

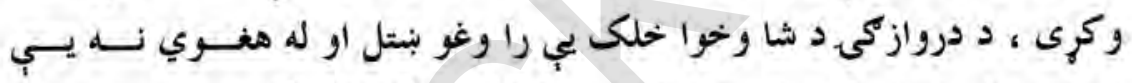

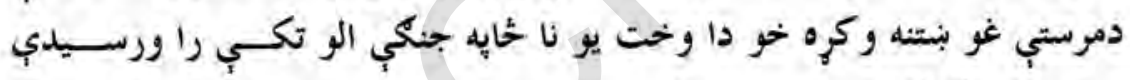

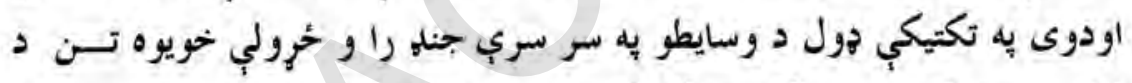

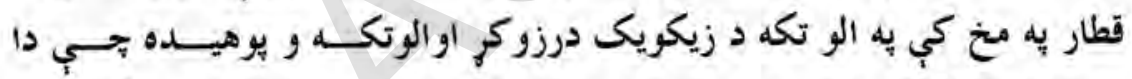

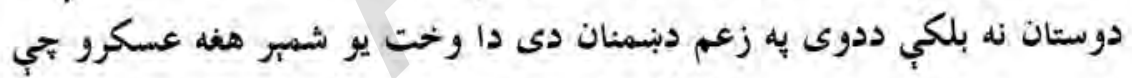

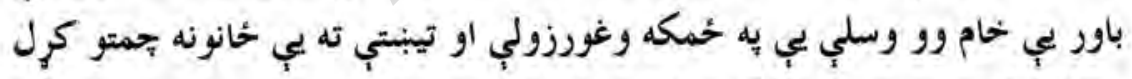

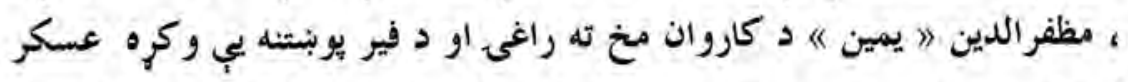

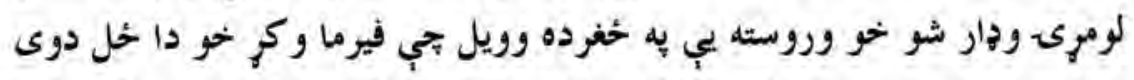

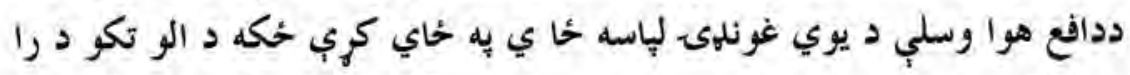

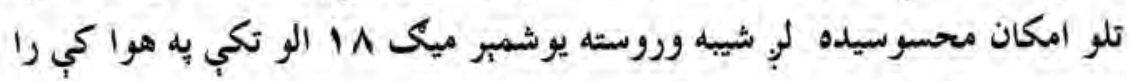

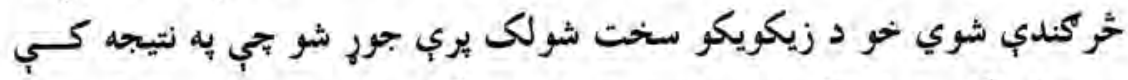

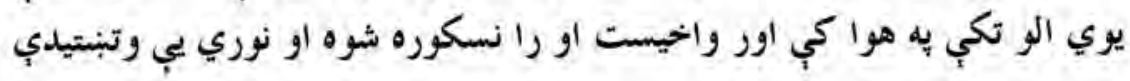




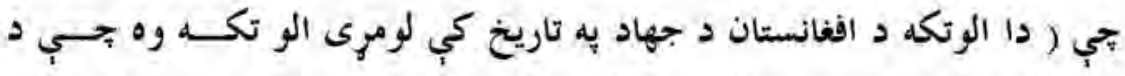

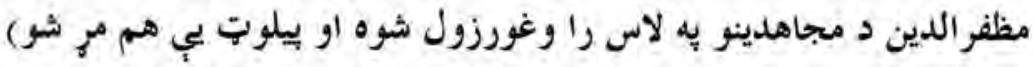

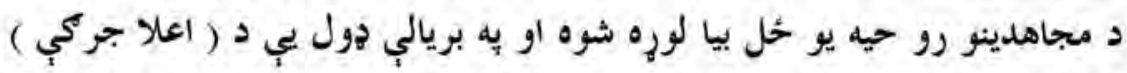

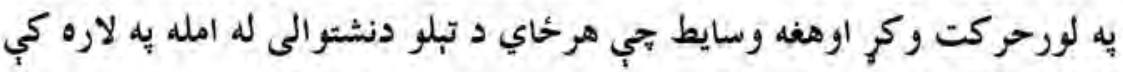

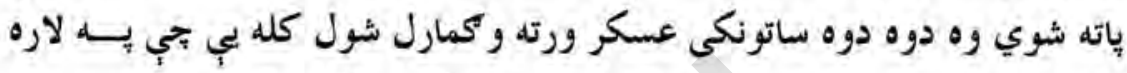

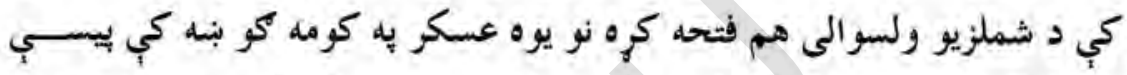

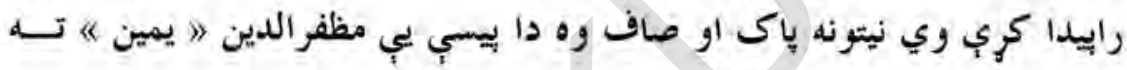

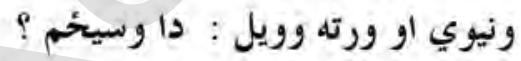

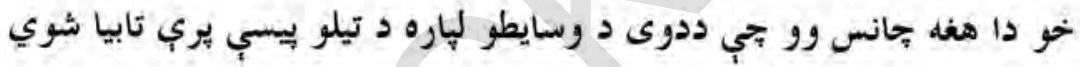

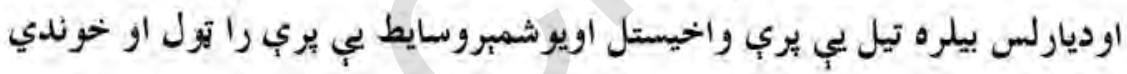

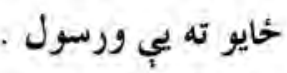

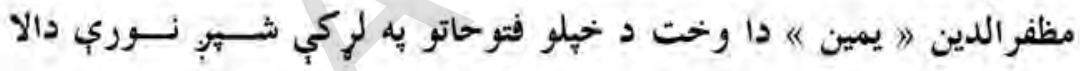

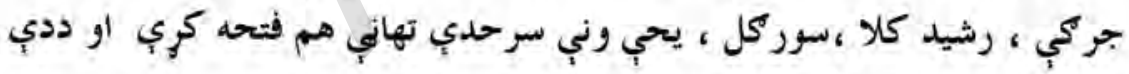

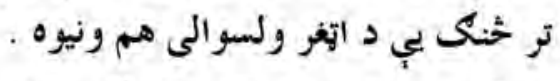

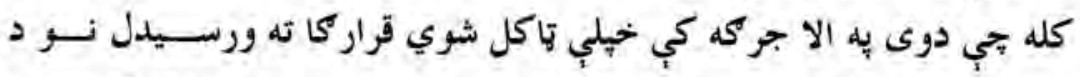

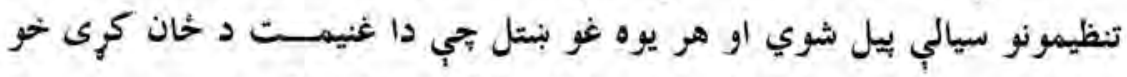

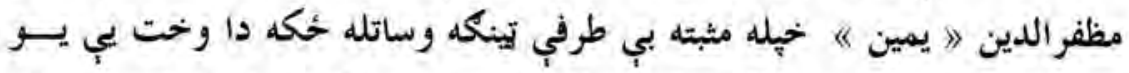

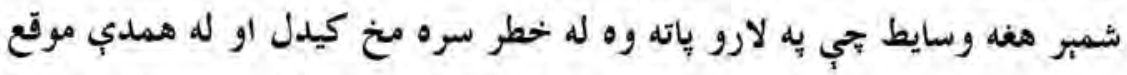

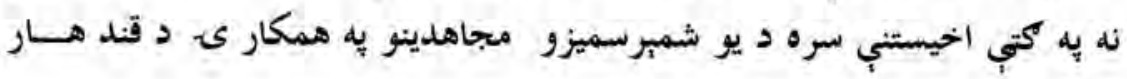




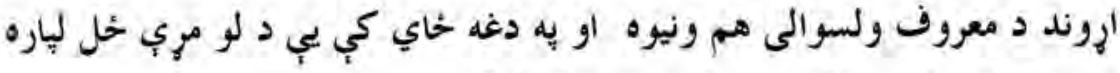

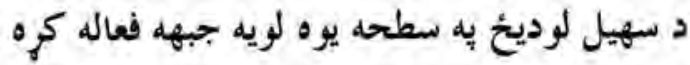

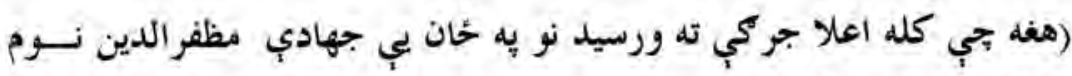

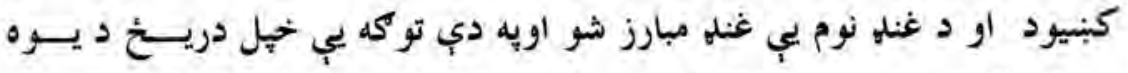

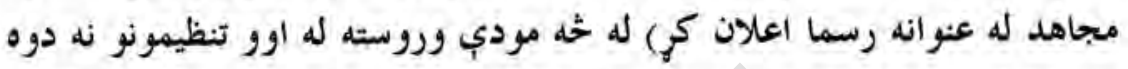

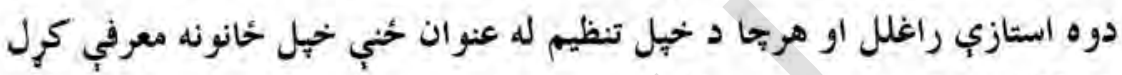

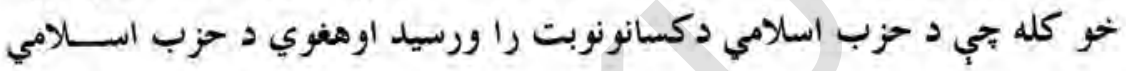

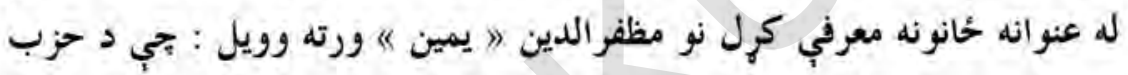

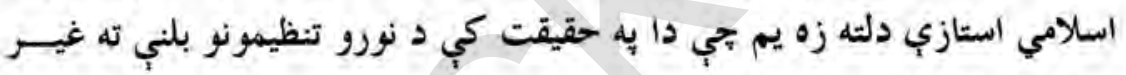
مستقيم جواب هم وو . مئل

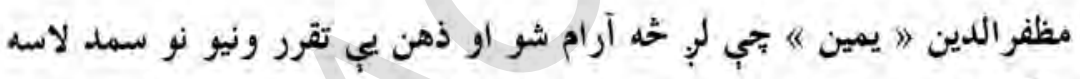

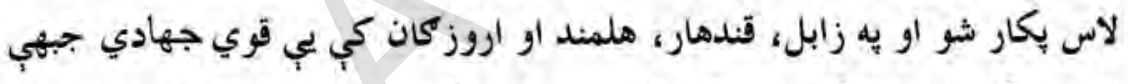

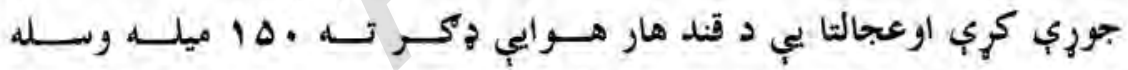

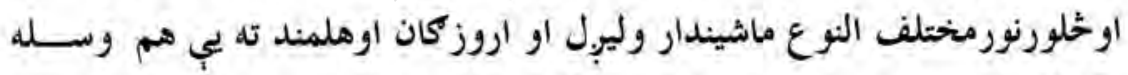

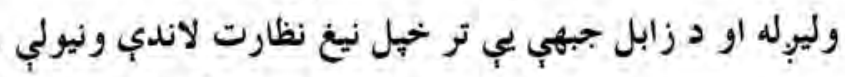

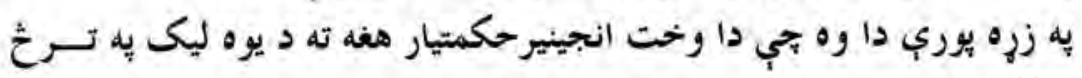

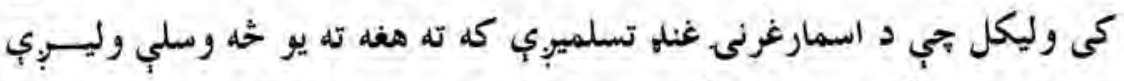

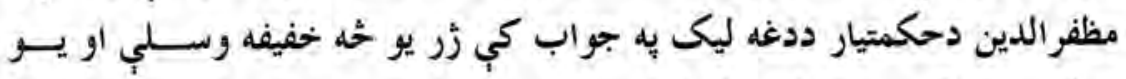

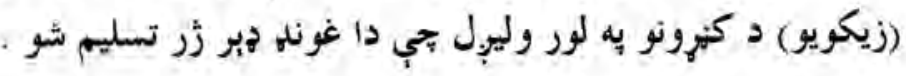


له دي وروسته د تنظيمونومشر ان داوخت يه كمين كي ناست اود مظفرالدين

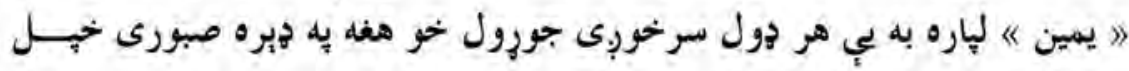

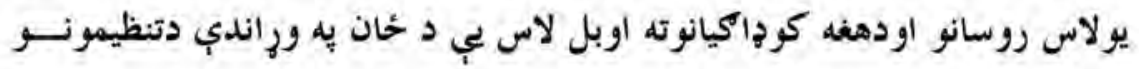
روانوتوطيواونسرخوبريوته نيولي وون.

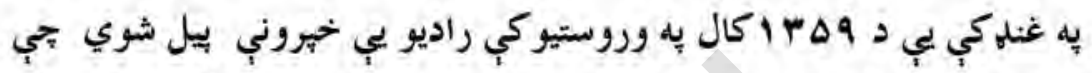
دا هم د مجاهدينولومرنى راديوكنلى شو جي دمجاهدينواو جهاد آرمانونه به كي را غبركيدل ددغه ترخنك دروسي اسيرانو لياره هم معئون جاييزيال را منئ ته شو دروسانو يه شمول نورجنكي اسيران هم تو آخره يه دغه غنله كي موجور وه د روسانوله جلي يوشمبريب مسلمانان او يو شمهير نور يب تر وروسته يوري يخهيله عقيده ياته شبول .

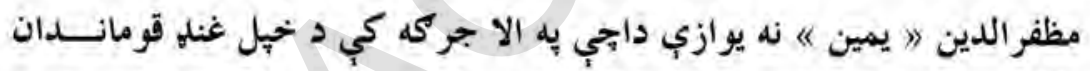

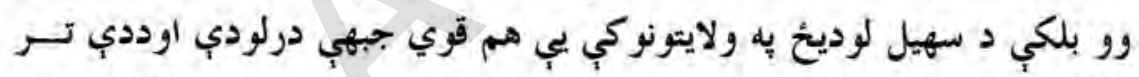

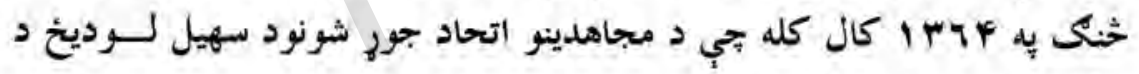
تولو جبهو درستيز وال هم وو . كله جي عبوري حكومت جور شو نو هغه يخهيله قرار كا كي يو قوي تعليمي

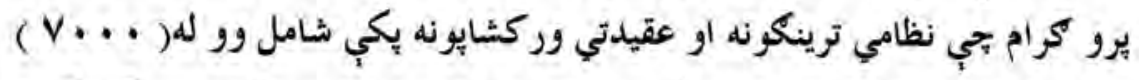

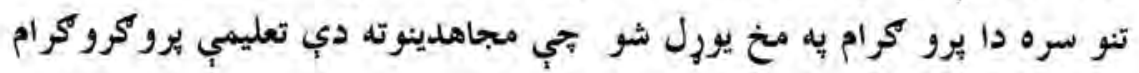

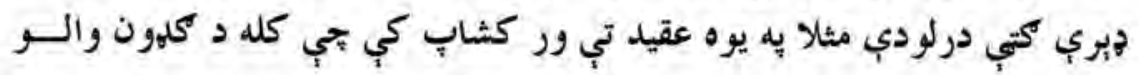

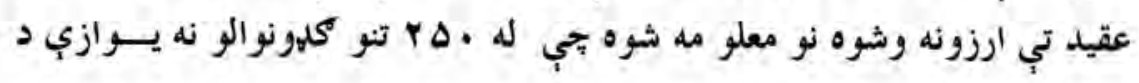


rVe دوركو مشاهير دوهم توكى

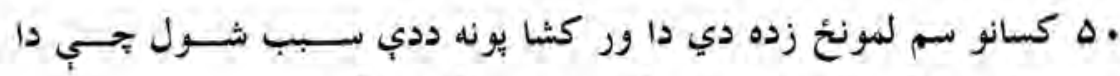

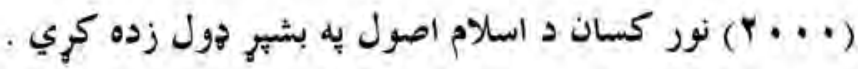

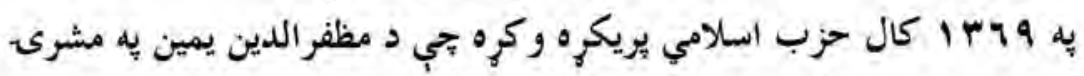
غند (مبارز) بايد يه فرقه مبارز بدل اوله (الاجركيّ) د كابل لوديخ ياني د وردكي ولايت ته را نقل شى د همدي يريكري يه بنا د وسايطو اونوروتجهيزاتو رانقلول

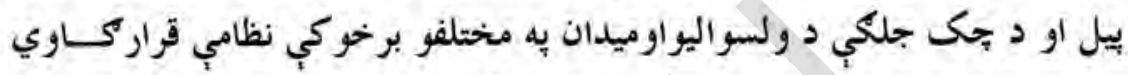
اونوري قوي شوراكاني جورى شوى ، يه جلكه كي يوه قوي قومي شورا جي يه

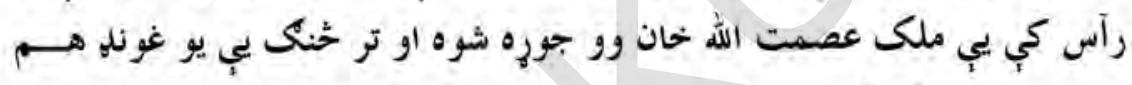
جورشو ، به كاوكوش اورد ميدان به سرخ بيد كى كي قوي قرار كاوي جوري شوى اويه سياب كي د ملك محمد شريف خان يه مشرى بحي دا وخت د قومي شورا ريس هم و يو مجهز غنه جورشو.

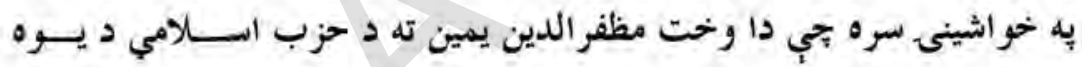
لورتبه كس لخوا تو صيه وشوه بي دسيمي د نورو تنظيمو اود حزب اسلامي

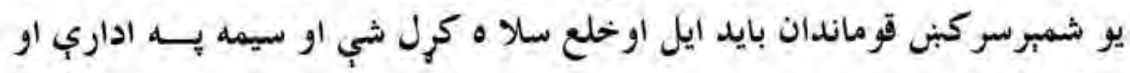

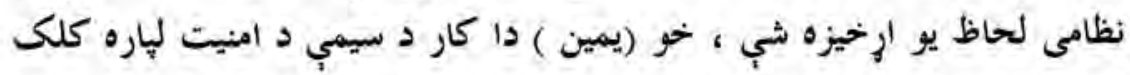

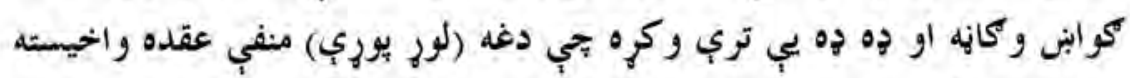

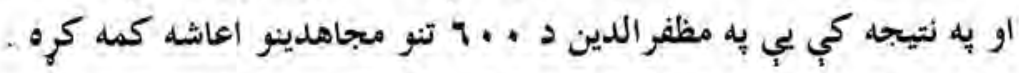
تر دي منخ د كابل د تسليمدو اوازي كونكسي را منئ ته شوى ارتيا وليدل شوه جي به بِينسور كي درهبر انو اوقوماندانو يوه كمره شورا جوره شي همداسي

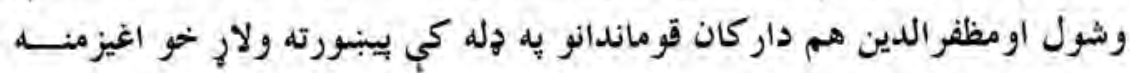


rVT

دوركو مشاهير دوهم توكى

يريكره ونشو خكه هغه كس بحي د رهبرى لياره وتياكل شو بشير ظرفيت او وريتيا

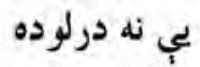

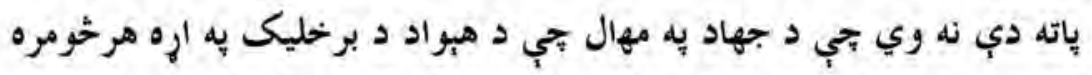

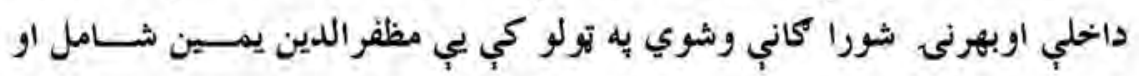

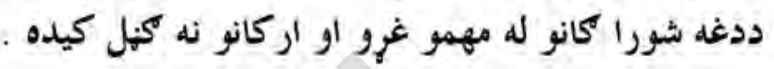

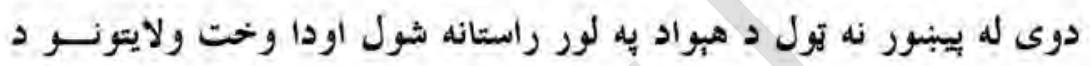

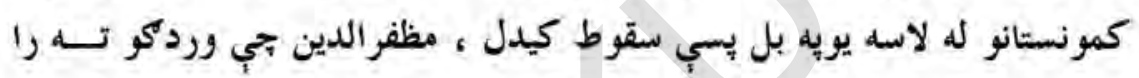

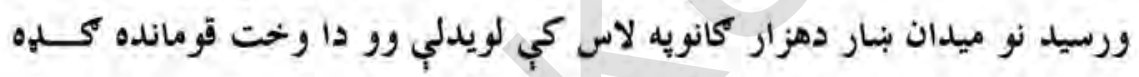

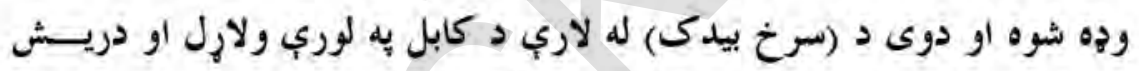

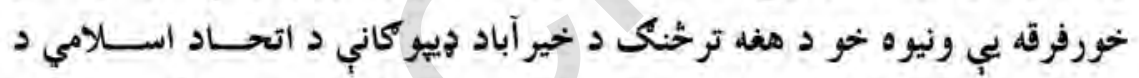

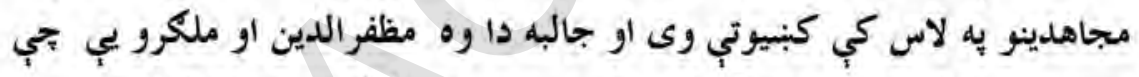

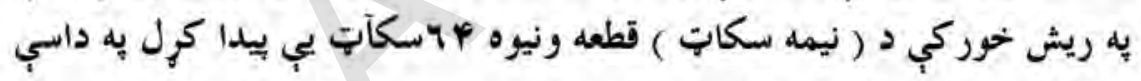

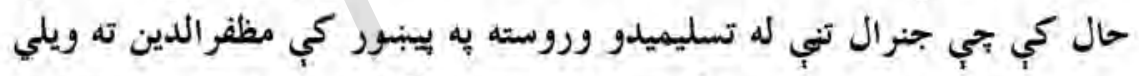

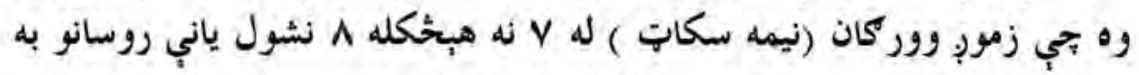

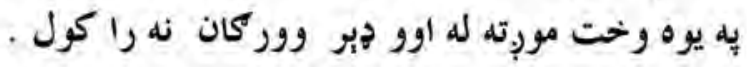

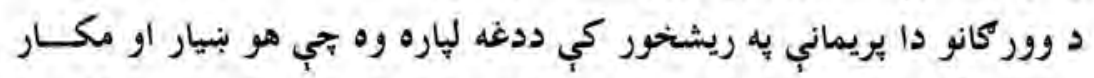

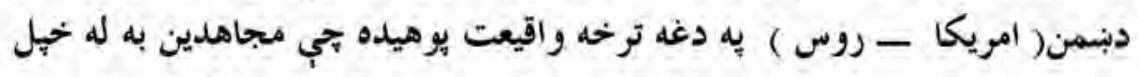

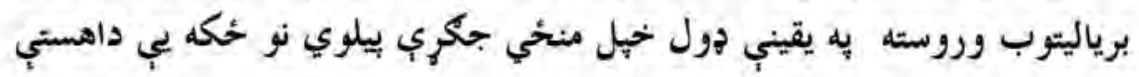

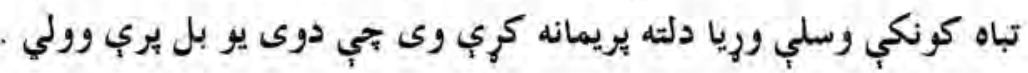


دا خوهم يه هر ترتيب ! ددغه نيمه سكات تو غونديو تر خنكى ما ضـــربه

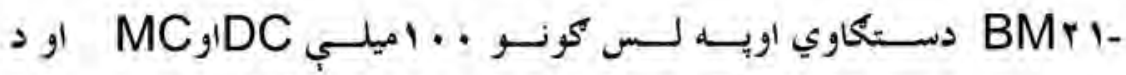

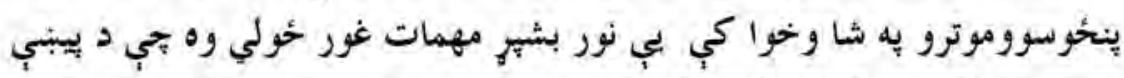
يه صورت كي دبنكيلو جلو يه كابل بنسار بنه زره يخ شى او مجاهدين يه اصلى خيره كابل بناريانو ته ور وخليوبِ . دا لويه تو طيه يه يقيني هول د كابل د ريكيدو لياره جوره شوي وه كله بحي

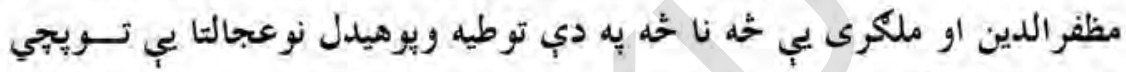
غياراو فعال نكر خو له يو خه حُنه وروسته ددوى لباره د تو يججي د قواوو به نوم يو تشكيل جور شو جي يه راس كي دي بلوته خلقي منصب داران او د شـــورا نظار خواته يه عين حركت يرجمي منصداران وتّا كل شول كه خهه هم د كابــل ورانولو ته دا وخت اكثرا د مليشوهفو ياته شونوهم زره بنه كرى ور كوم بحي د مجاهدينو توخنكى لوغبدل ، له يوي مياشتي سختو جكرو وروسته هـــيخ كــوم

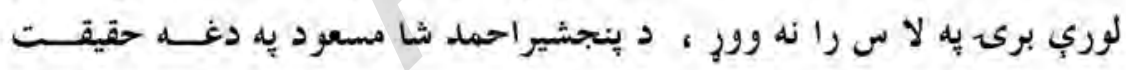

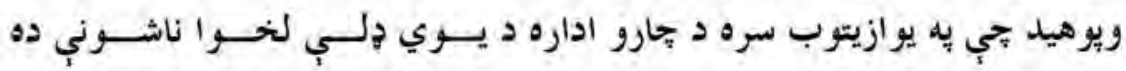
نوهرولايت ته احوال وركريجي د وزارت دفاع دتشكيلا تو لياره يـــو، يوقـــوي

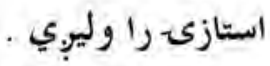

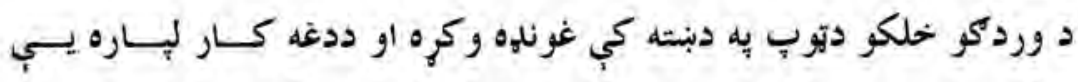
مظفر الدين (يمين ) و تباكه بجي وروسته بيا د تول ولايت يه كجه ومنل شو

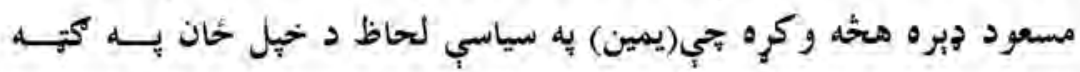




\section{rVA}

دو وركو مشاهير دومم توكى

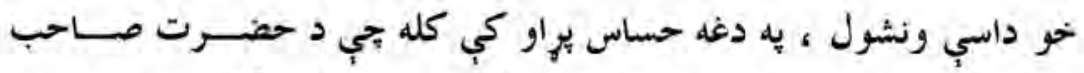
دوره مخ خه ختمبدو شوه نو حالات لايسب كر كيجن شول حخكه حضرت صيب

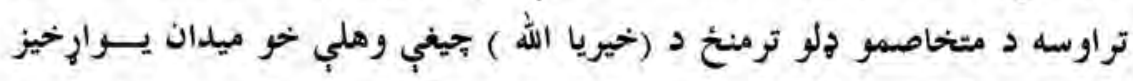

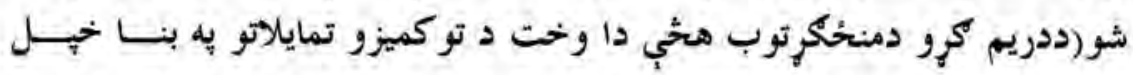
منحي جكرو ته يه هخو بدلي شوي ) او كابل يو حُل بيا د خيل منحجي خونريو

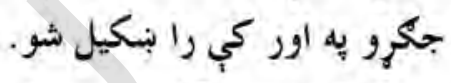

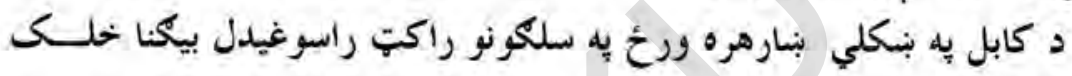

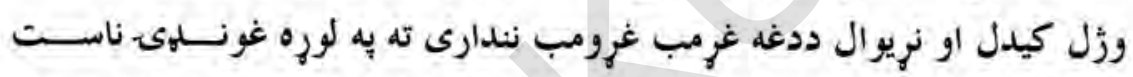
اويرته له دي تجي ميا نجيكري وكري سات يب تير اويه اصتلاح نصو ار يب ورته اجولي وه ننداره بي كوله .

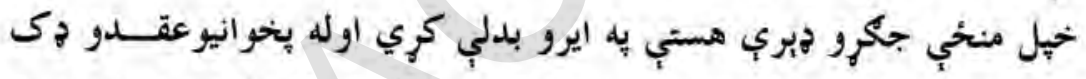

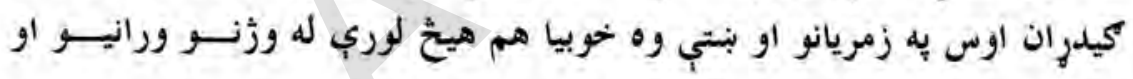
ويجارتياوو يرته كوم بري يه لاس را نه وورج ·

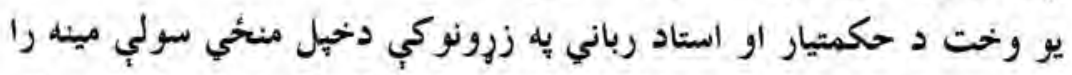
وتخنيده او تر منئ بي سووليز هيئات وكر حيدل را وكر حخيدل د ملا قات شئى

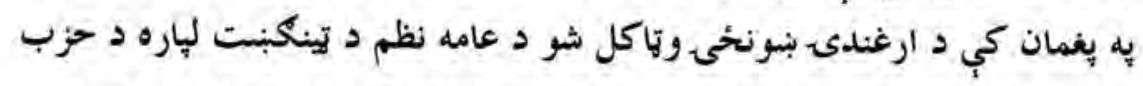

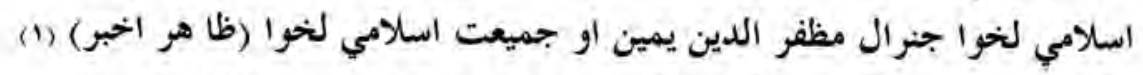
و تبا كل شول خودا وخت كوم راكت را غي او دا جلسه يب اخلالا ل 


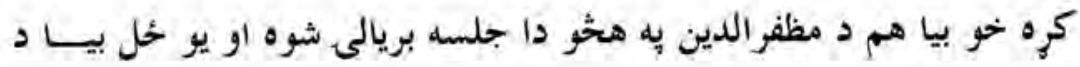

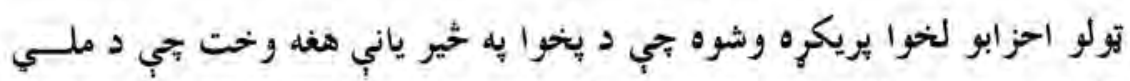
دفاع وزارت د ولاياتو د استازيو يواسطه اداره كيده ، با يد د ا حخل هم د احزابو د با صلاحيته استازيونه يو كميسيون جورشى اوددغه كميسيون به واسطه د ملي دفا ع وزارت بحاري اداره شي تجي د تنظيمونو داستازو نومونه يه لاندي خول ووه د حزب اسلامي حكمثيارلخوا مظفرالدين يمين. د جميت اسلامي لخوا احمد شا مسعود. د ملي محا ذ لخوا جنرال محمد اسحق نوري وردى لنو د اتحاد اسلامي لخوا جنرال سرا ج الدين دحركت محسني لخو اصادق ملدبر. دوحدت د حزب لخواها شمى د حركت انقلاب اسلامى لخوا واحديار و نجات جبهي لخوا ديدار شا ليزى كه خه هم د كمسيون رييس بخحيله استاد رباني وو خو له دوو دريو ناسـتو

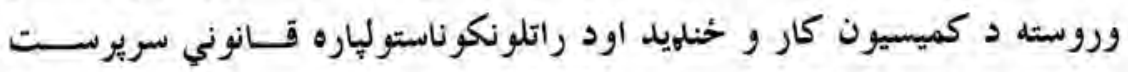
وتّاكل شو خوبيا يب كومه نتيجه ورنكره ، جنرال مظفرالدين دغه كار ته وتواكل شو دا هم ونه منل شوه حيكة د حزب اسلامي او جميعت اسلامي ترمثئ شديد مخالفت ددغه سبب شو جي دا انتصاب هم ونه منل شى حيكه د نورو تنظيمو د

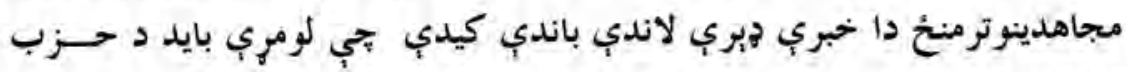
اسلامي او جميعت اسلامي سياسي روغه وكري او بيا يو دبل كسان خه مشـــرى 
५^.

دوردى مشاهير دوهم توكى

ومني ، جنرال مظفر الدين يه زيبر جرآت استاد رباني ته وويل : جي ســتونزه د

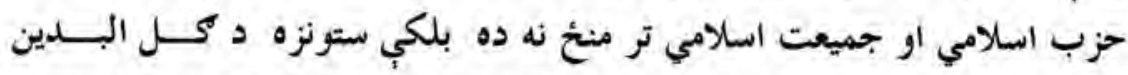
حكمتيار او احمل شا مسعود تر منئ ده لومرى بايد دهغوى ترمنئ روغه جوره

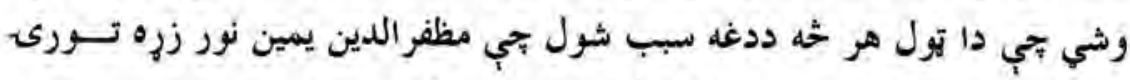

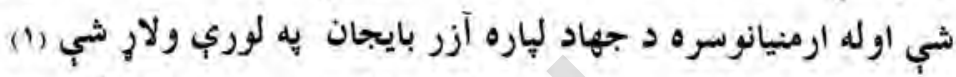

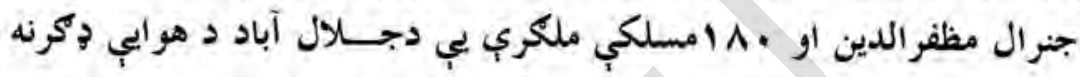

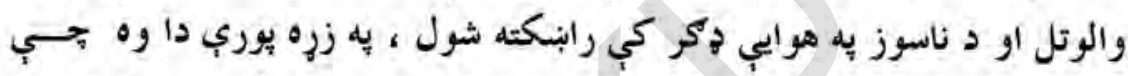
جنرال مظفر الدين د ورتك يه لومرى ورخ له ارمنيانو سره جكره بيل كره او له له

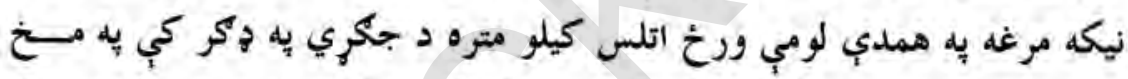

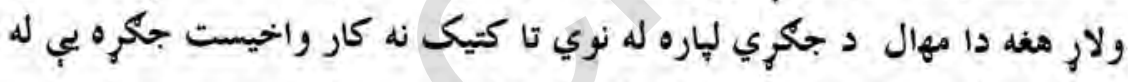
كليو نه دواكونواو ميدانونوته و ايستله اود خيل ماموريت تو وروستيو يوري يــي

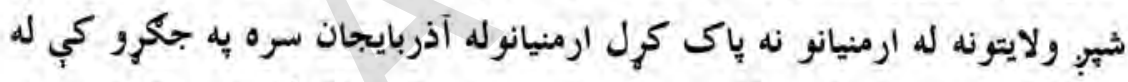

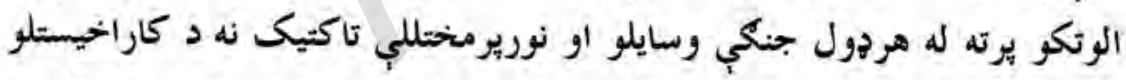

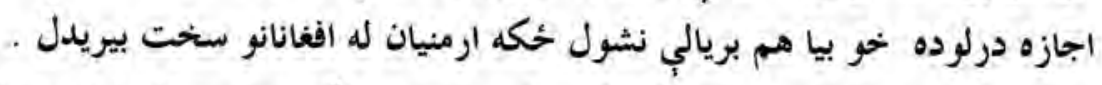
له شهبِور مياشتو وروسته مظفر الدين له يو شمبر ملكرو سره بيرته خيل هيواد ته را ستون شو او له راتكى سره سم دا وخت دحزب السلامي يو شمبر بي لي لي

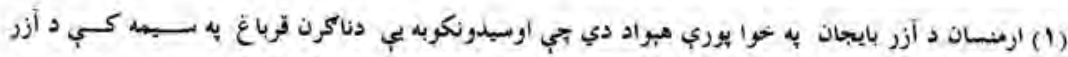

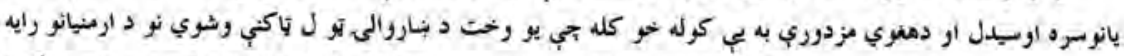

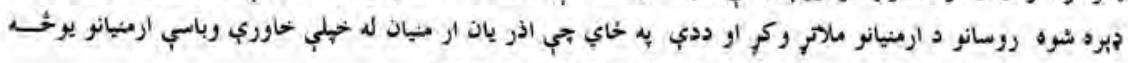

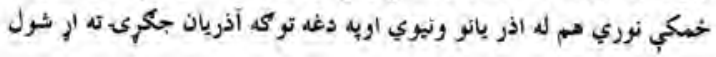


مسووليته كريو به وردئو كي داسي تحركات راييل كيرى وه بحي مطفر الدين

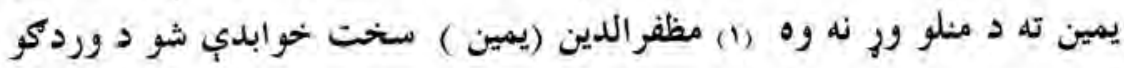

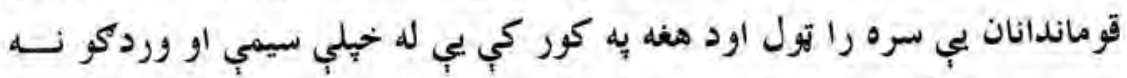

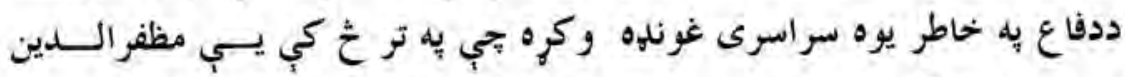

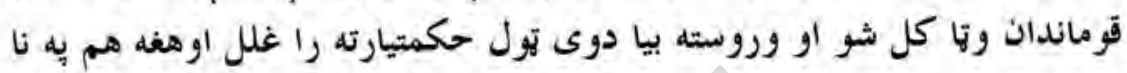

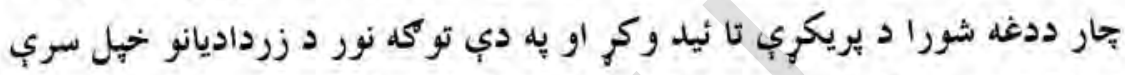

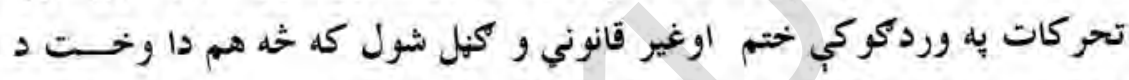

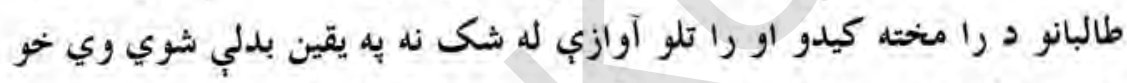

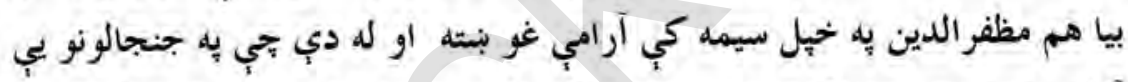

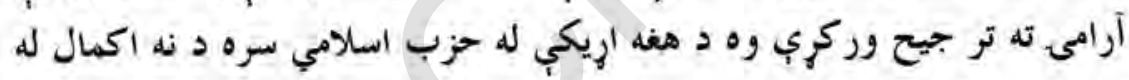

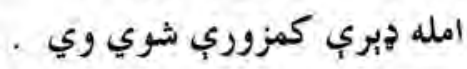

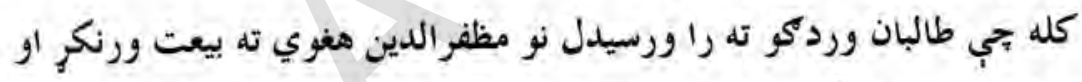

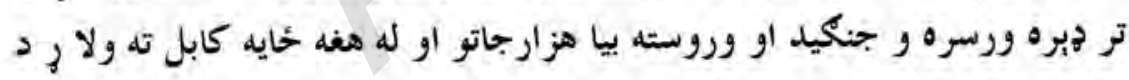

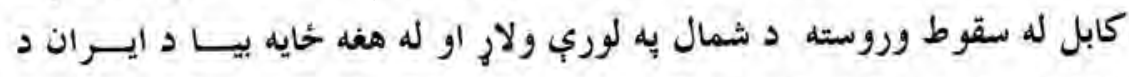

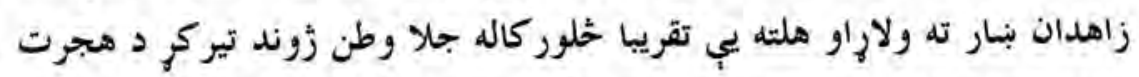

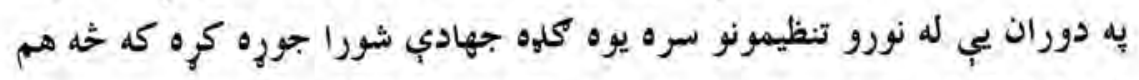

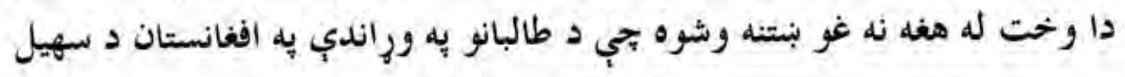

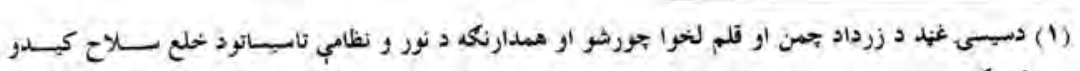
أوازي او كونكوسي مه وي 


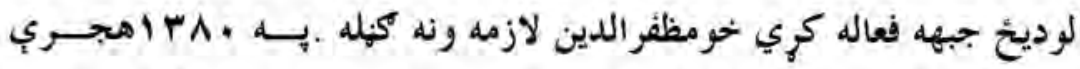

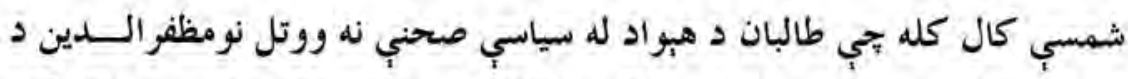

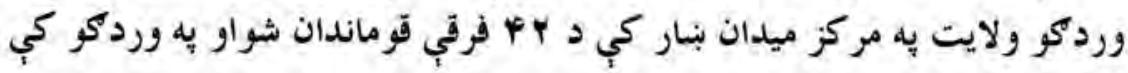

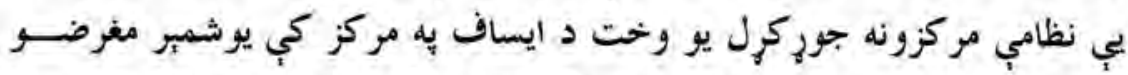

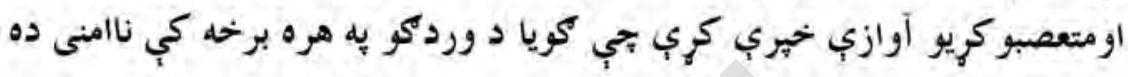

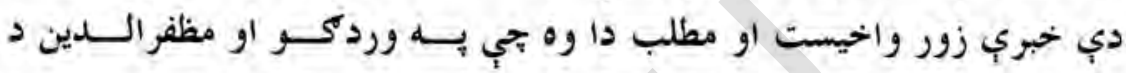

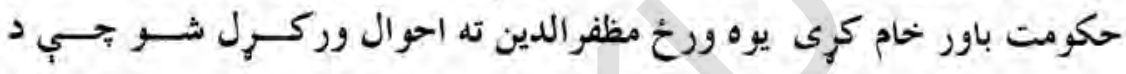

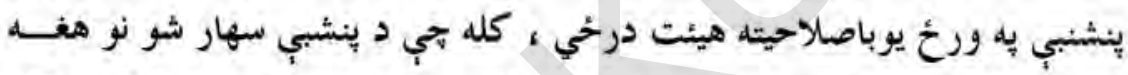

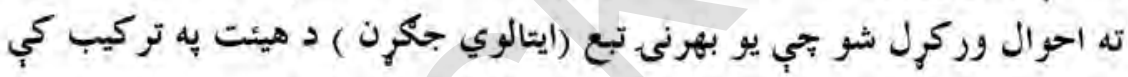

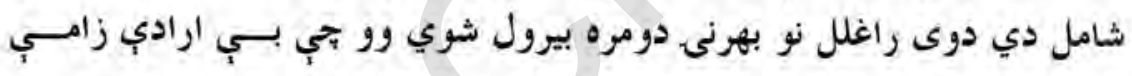

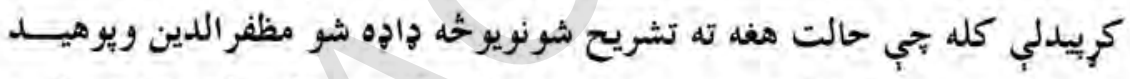

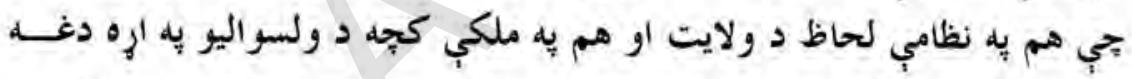

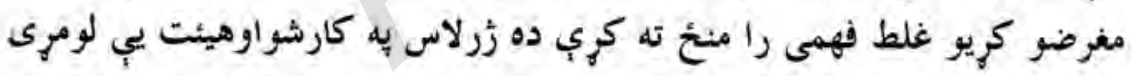

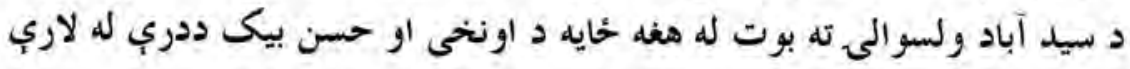

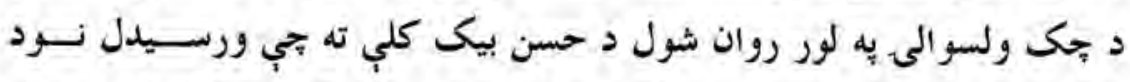

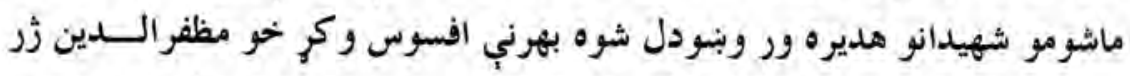

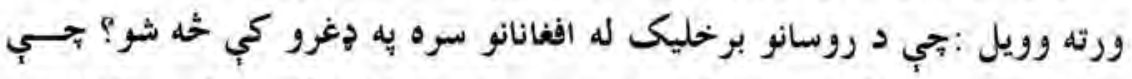

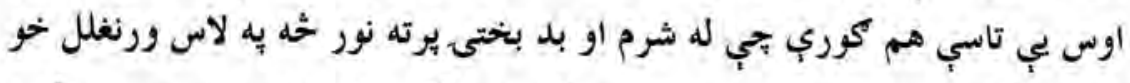

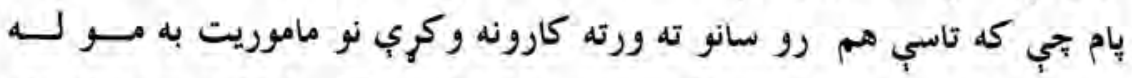
روسانو نه بد نام وى، دوى تولو وخندل او د قرباني دكلى له له لاري بوم اوله هغه 
<smiles>C1#CC#C1</smiles> 


\section{محمد فاروق وردكى \\ (Beau Wardak)}

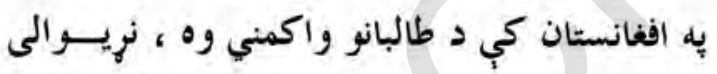

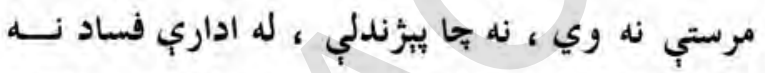

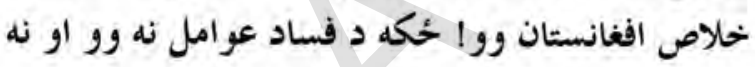

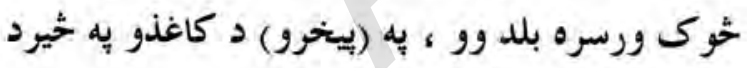

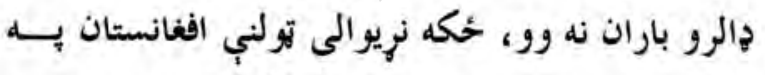

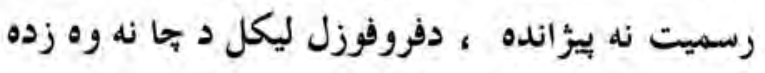

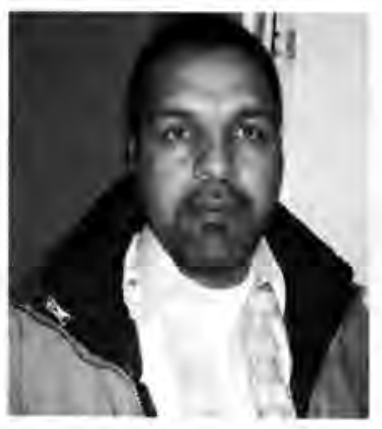

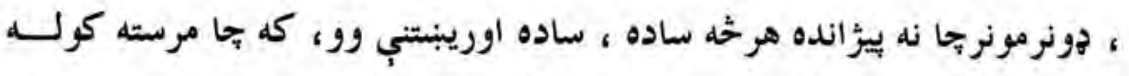

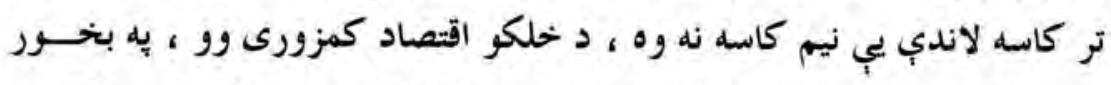

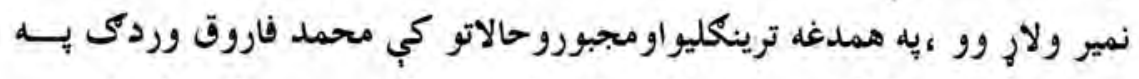

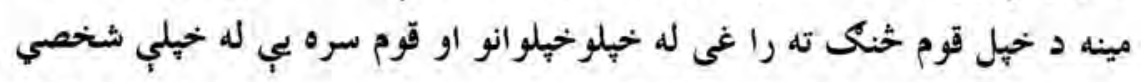

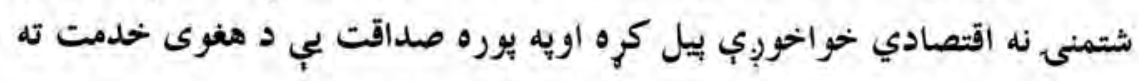




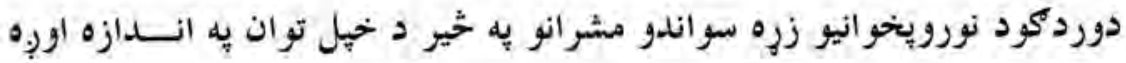

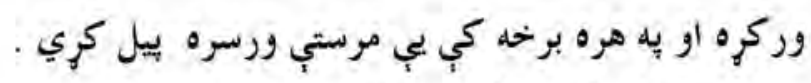

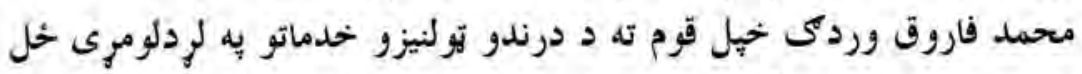

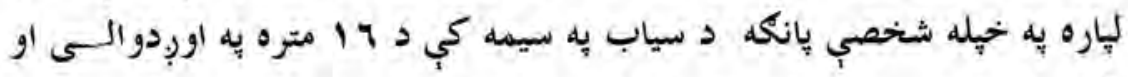

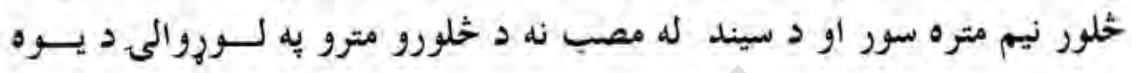

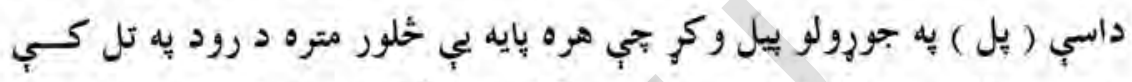

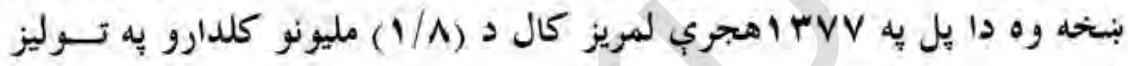

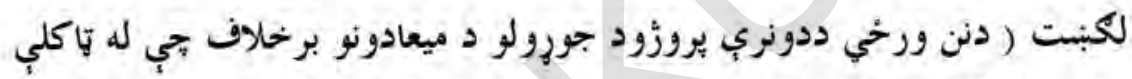

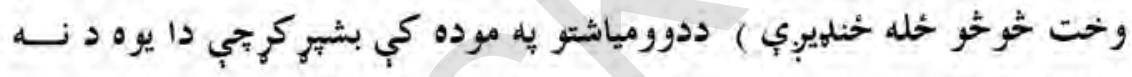

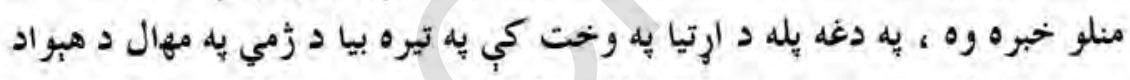

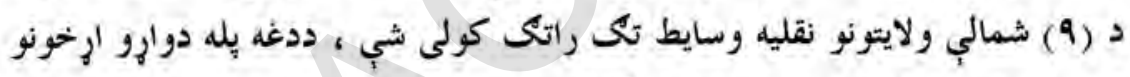

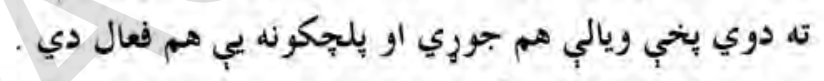

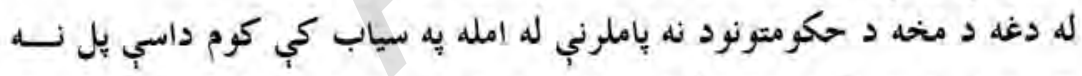

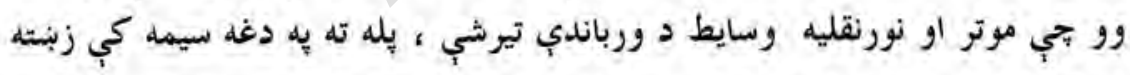

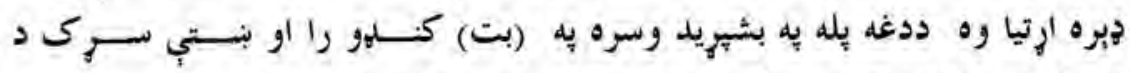

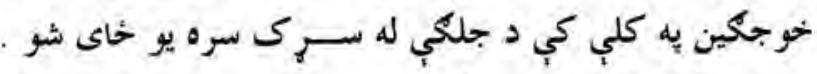

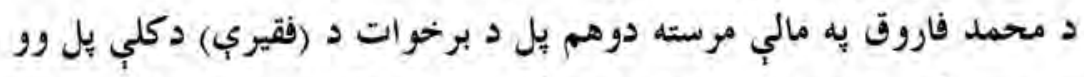

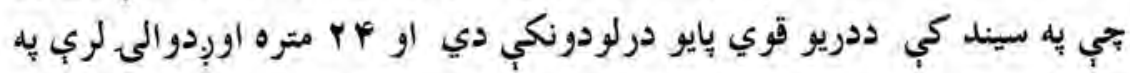

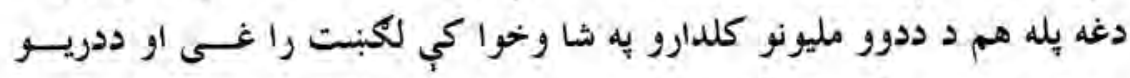

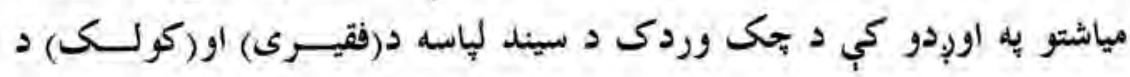




\section{Y 17}

دوركو مشاهير دوهم توكى

كليوترمنح وترل شويجي دا بيل هم د اليشنك او بك د يلونو ترمنح د يوه قوي

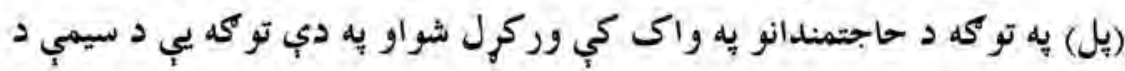
خلكو ستونزه كنترول كره

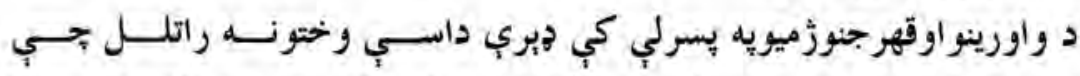

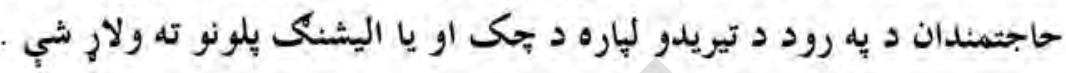

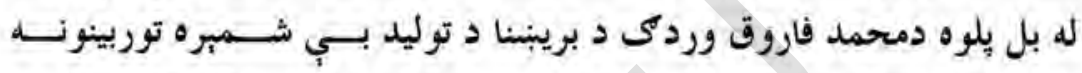
دبرخوات د نورخيلو او فقيرى يه كليو كي د ثرندو به خايونو كي او بريبنا يب

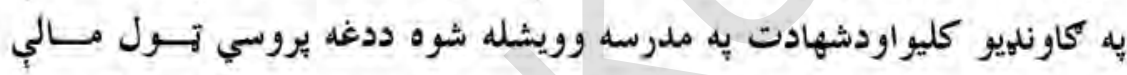

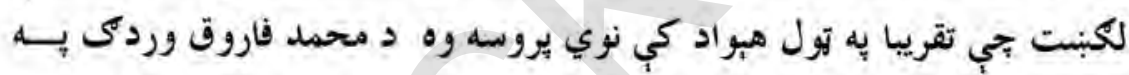
غاره ورو

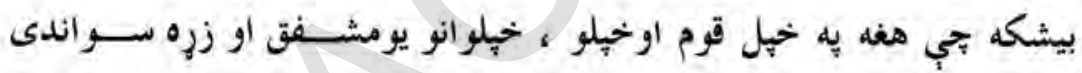
شخصيت وو او دى ، له هغه سره د ملاقات او خبرو اترو بر وخت به هرجا دا فكر كاوه جي له يوه داسي مهربان دوست سره مخ شوي تجي توله ياملرئه يــي

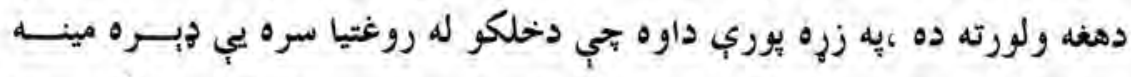

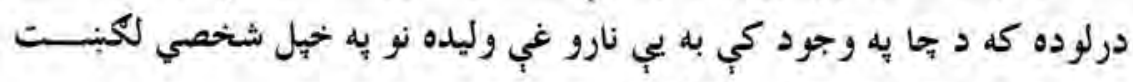

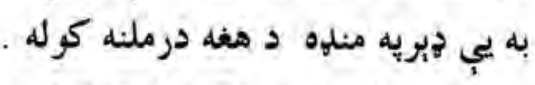

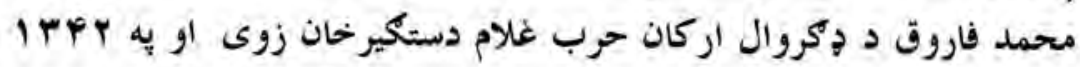

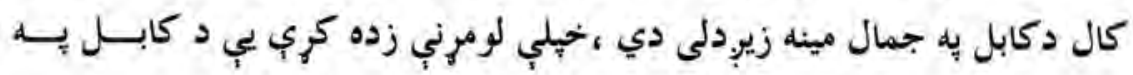

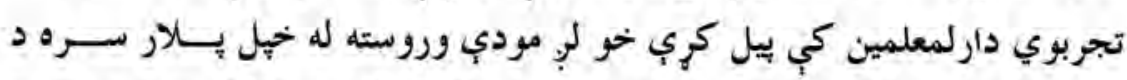

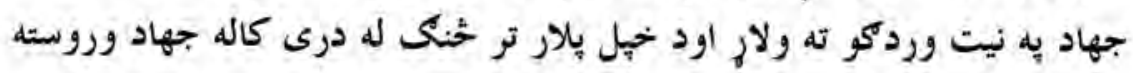


د هجرت وطن باكستان ته ولار اوبيا له يو خده مودي وروسته د آهريكا متحــــه

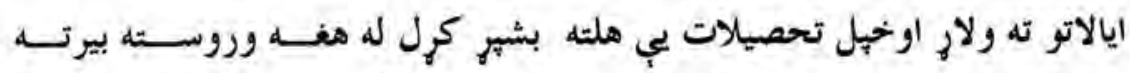

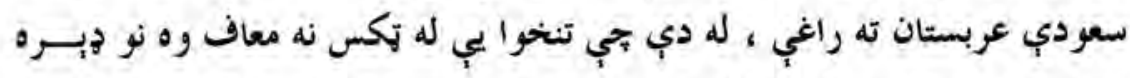

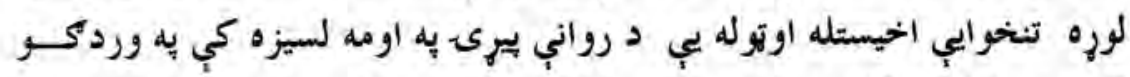
كي مصرفوله ، كله بحي هبواد د ناتود قواوولخوا اشفال شونو محمد فاروق وردك خهله د مرستو يروسه هغوى ته يريبنوده او بخهيله بي خيه سعودي عربستان كي د شاهي كورنى له يوي نجلي سره واده و كر او اوس همالته

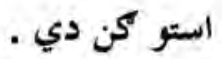
محمد فاروق وردى د محمد همايون ورديى ،محمد هارون وردى ،محمد

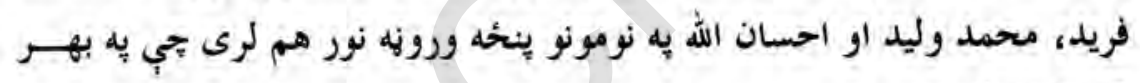

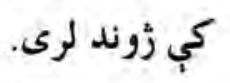

د محمد فاروق وروى له عربي ميرمني نه د و اده ثمره يو زوى او يوه لور ده . 


\section{محمد شريف خان - دسياب ملك}

ملك محمد شريف خان به 9 بr أهجري شمسب

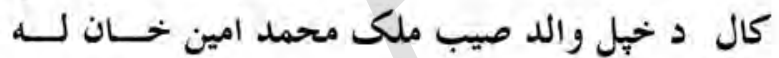

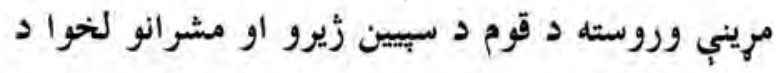

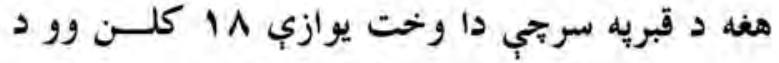

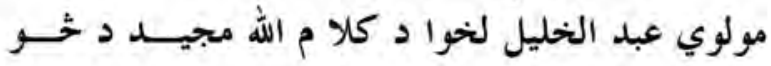
آياتونو يه قرائت اوددعايي يه لوستلو سيلو سره د خحيل قوم د

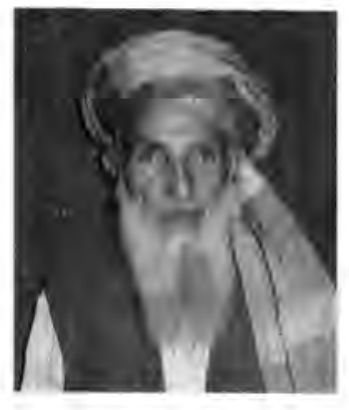

مشرى دستار ور وترل شو - ماتح

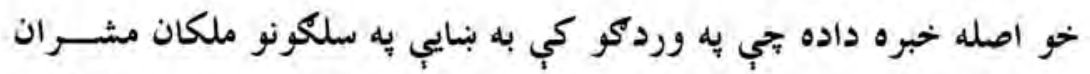
اونور ورته خحانان تير شوي وي خو ملكى محمد شريف خحان له دغه تولونه دمكرنو 


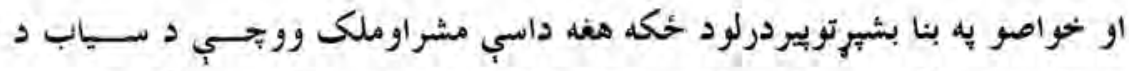
حوزي يه تولو كليوبرسيره يب ددايميردادو دهزاره قوم د زبور كليود ملكي دنده هم

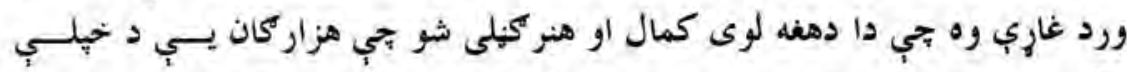

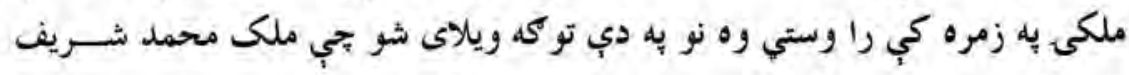

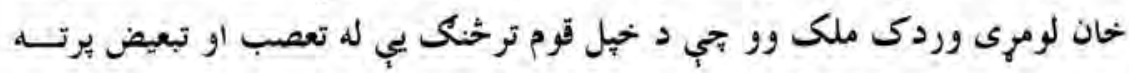

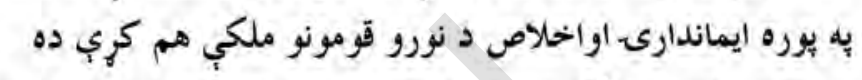

هغه جاجا تجي ملك محمد شريف خان بيرُ انده د هغوى متحد المال ويثا ده يخي

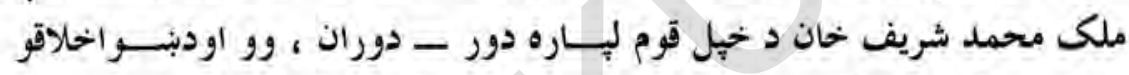

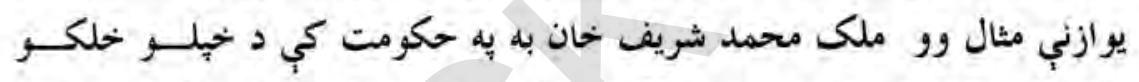
ملاتر كاوه دهغوى جيبونه بي خه حكومتي ليوانو نه ، توشيل داسي خحه تر اوسه د هغه لله ولس نه دى اوريدل شوى .

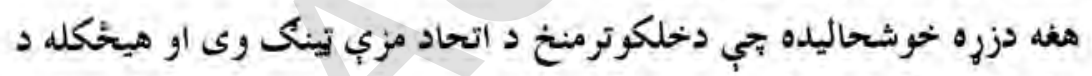
خيل قوم او خلكو تر منئ به تاوتريخو اليو نه وه راضى ، هغه خهله دا نيكه روحيه

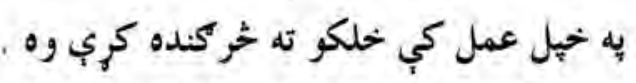

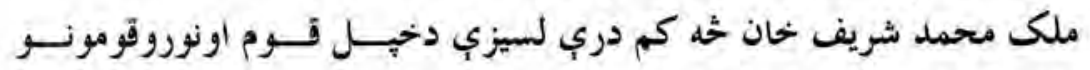

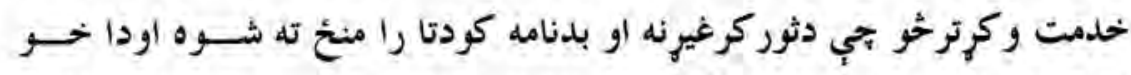
خركنده وه جي كمونستانو ملكان ، قومي مشران او نورولسي مخور د بورزوراد عاملينو يه ليكوكي شامل اود خيل حانونو سخت دبنمنان يب كنبل او مبارزه يبي له هفوي سره فرض كنيله نود ناباورى به دغه فضا كي ملك محمد شريف خان

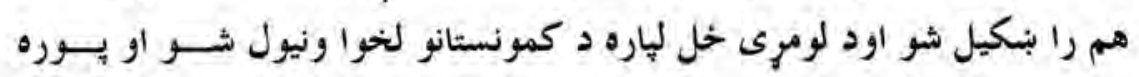




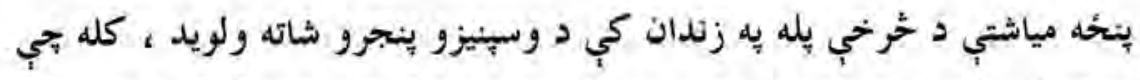

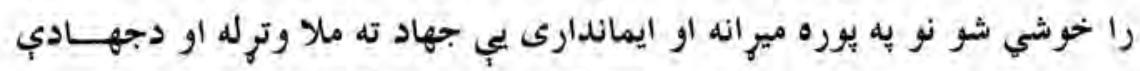

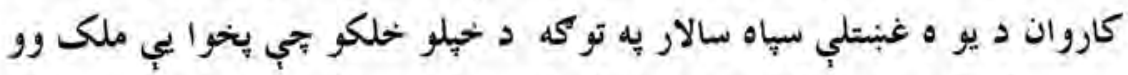

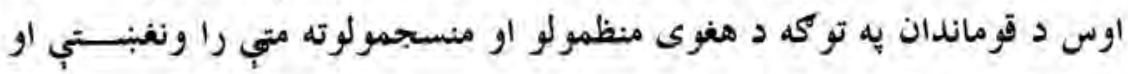
قوماندان شو. ملك محمد شريف خحان يه يوره صداقت او ايماندارىـد خحيل توان تر بريده

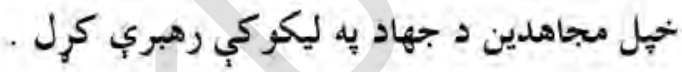

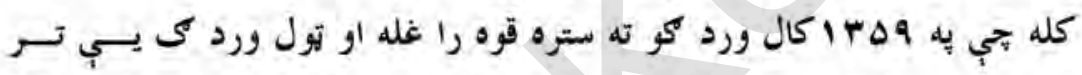

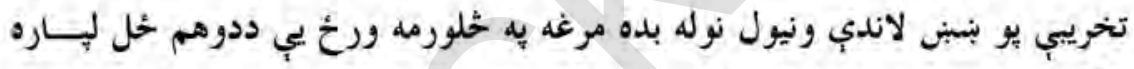

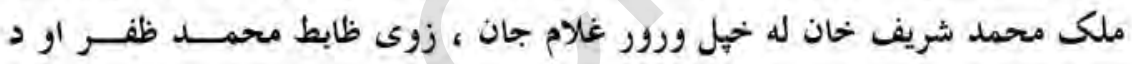

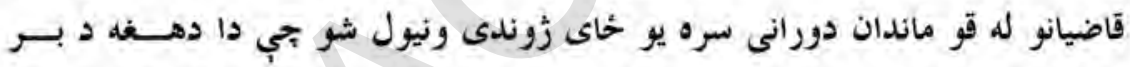

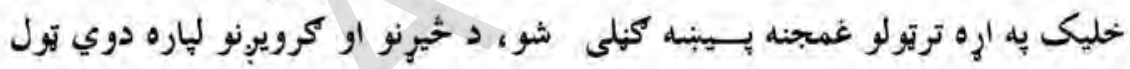

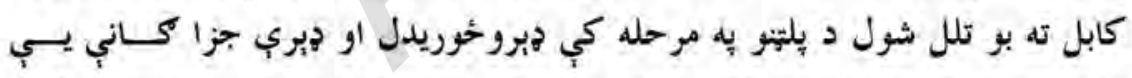

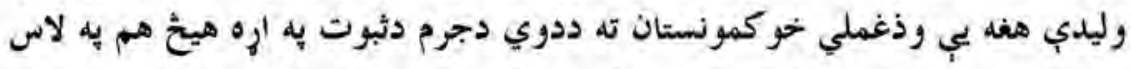

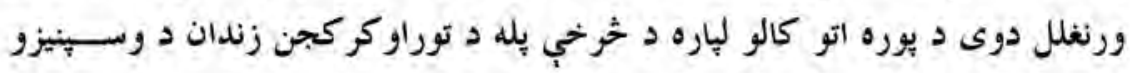

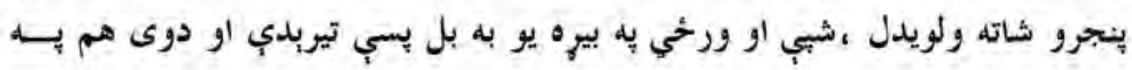

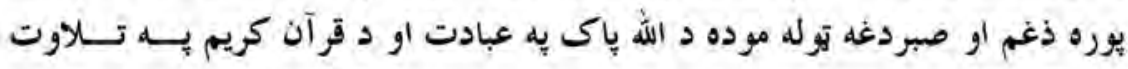

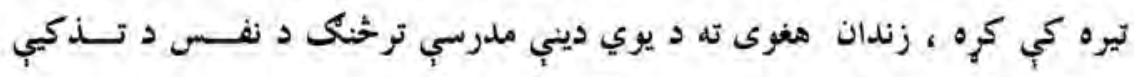

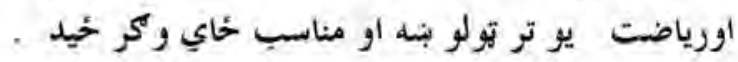




\section{+91}

دوردكو مشاهير دوهم توكى

ملك محمد شريف خان د بيباكه ،بي يروا ، بي رحمـله او بــي عــاطفي

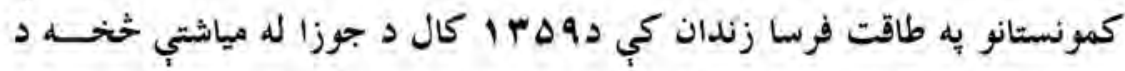
جو ا ا كال د كب تر مياشتي يوري يوره دوي مياشتي كم شيبر كاله بند تير كر

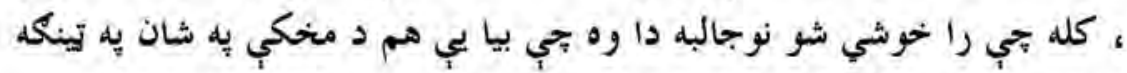
اراده د جهاد يه ليكوكي ودريد اودغه بهير ته يب ادامه وركره .

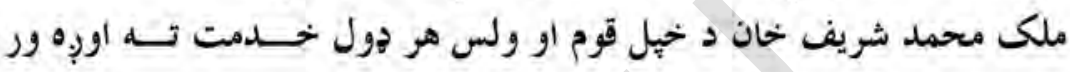

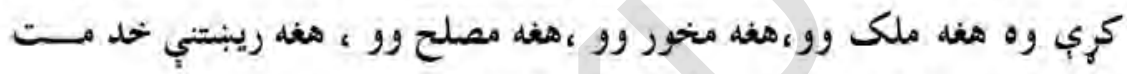
كار وو تجي د خحمتونو خو بيلكي يب يه لاندي هول راورو.

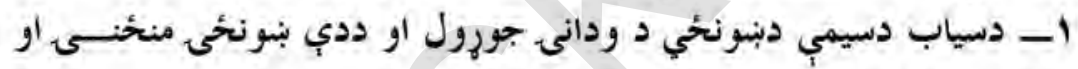

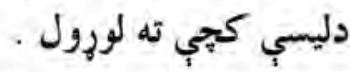

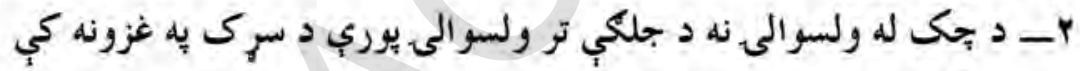
د ولسي خلكو يه هخونه او ملاتر يوره برخه اوونلهه اخيستل .

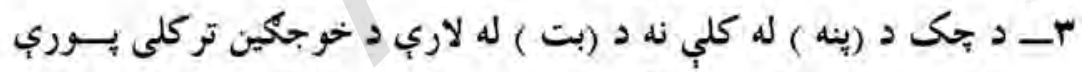
يه صعب العبوره اراضى كي د خلكو يه بشبه مرسته او همكارى دسرك غزول او جورول

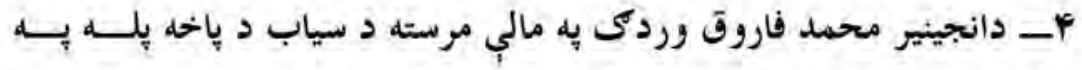
جورولو كي دهغه بشمه ونلوه او د عام ولس هخونه . هـ دخلكو يه مرسته دسياب به سيمه كي د فرعي لومرني بنونتحي او د هغه 
rar

دوردكو مشاهير دومم توكى

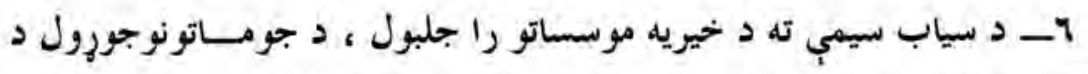

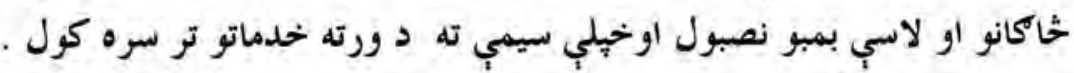

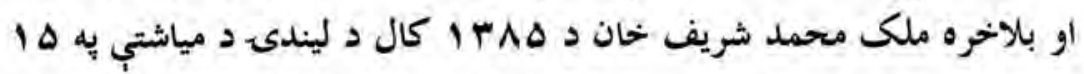

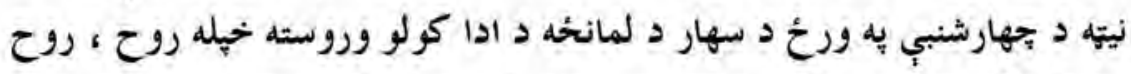

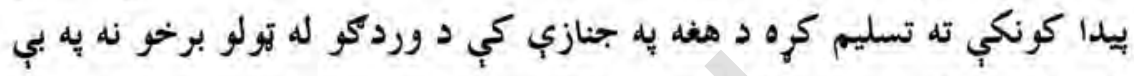

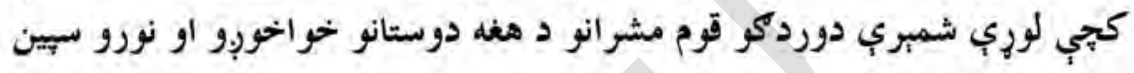

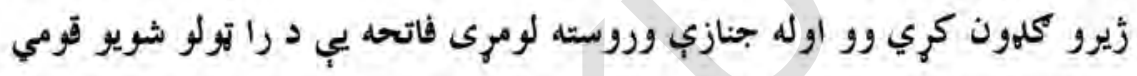

مشر انو لخوا وا خيستل شوه . 


\section{محمد ظا هرخان - السنك}

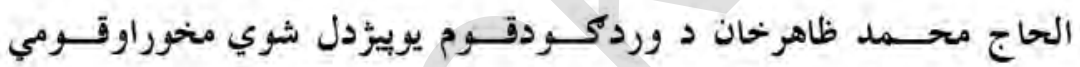

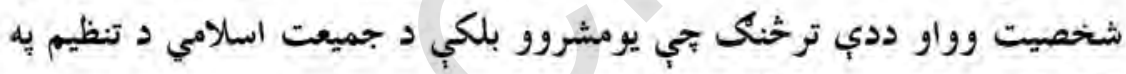

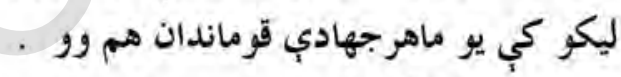

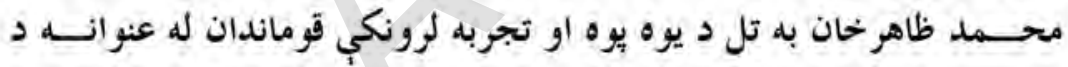

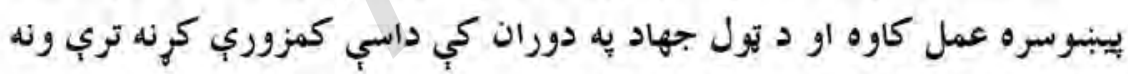

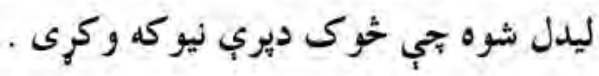

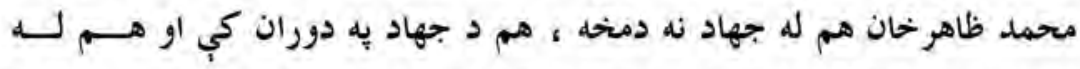

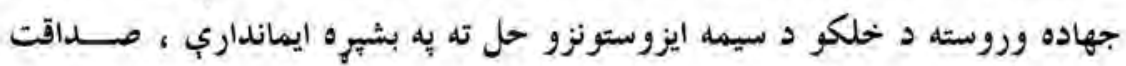

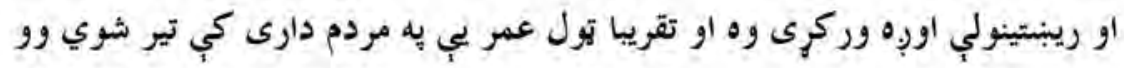

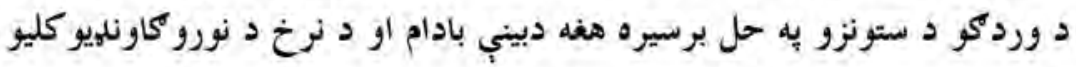

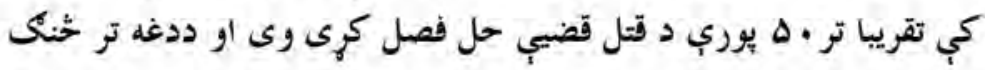




\section{ras}

كله بي د نرخ به ولسوالى كي د حزب اسلامي او اتحاد اسلامي ترمنيخ خيل

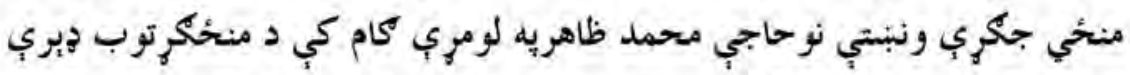

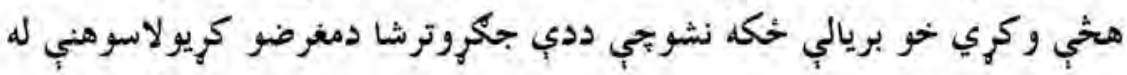

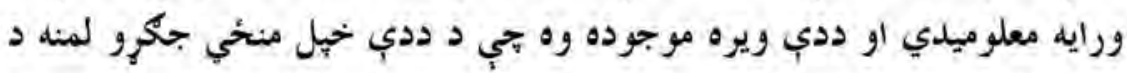

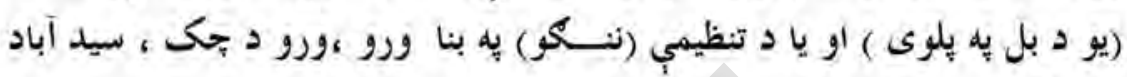

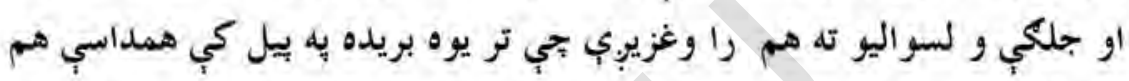
وشول.

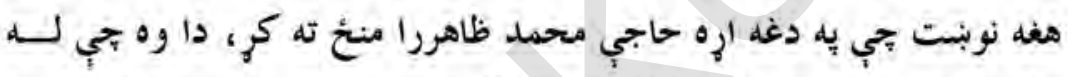

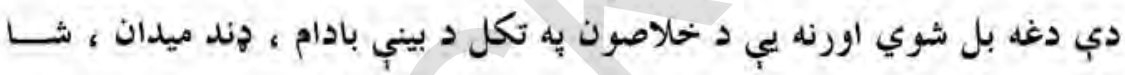

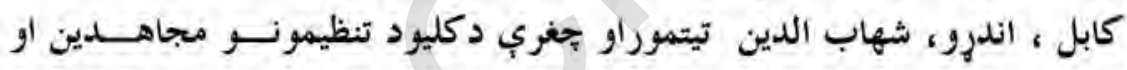

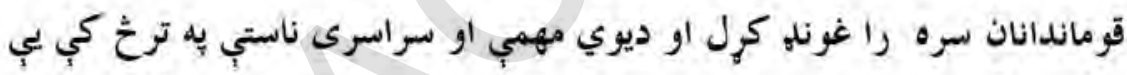

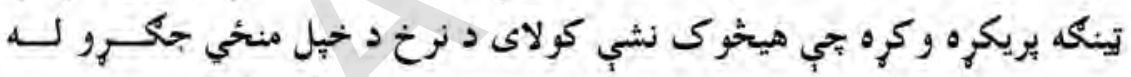

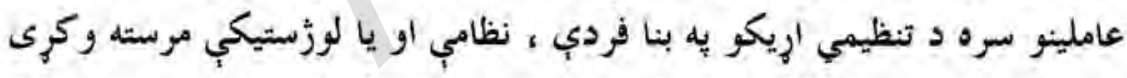

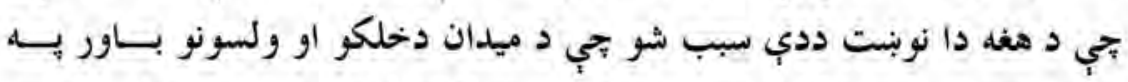

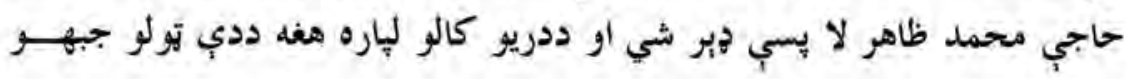
قو ماندان ويّاكي

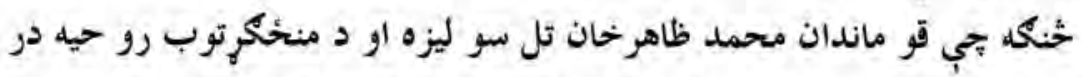

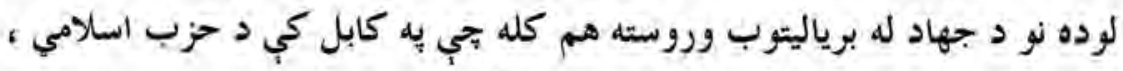

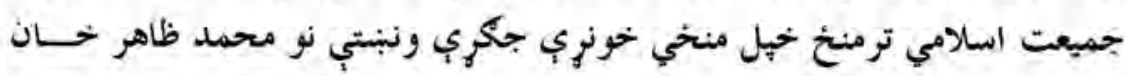

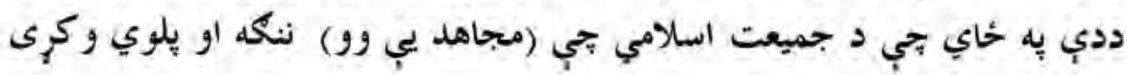




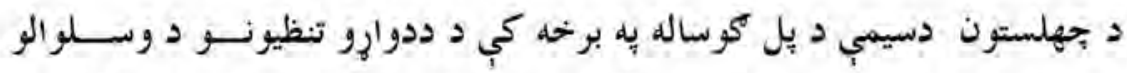

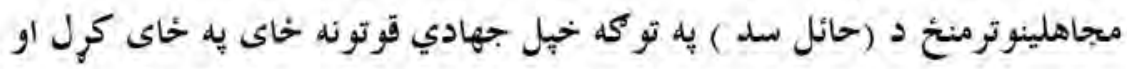

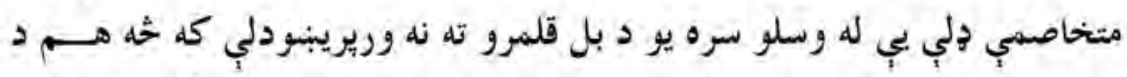

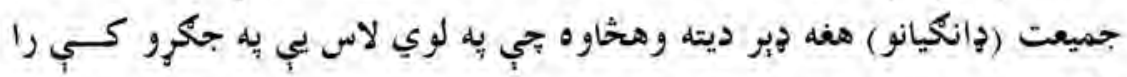

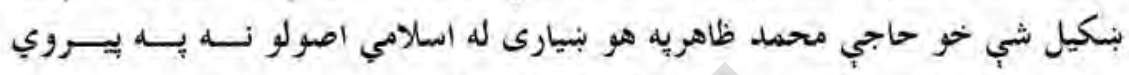

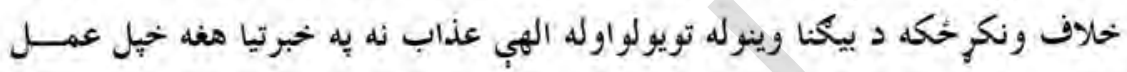

$$
\text { كنترول ورو تحلاون }
$$

كله جي حبل منخي جكري اوزبدي شوي او هيرو كسانود تنظيمو به ننكه برته

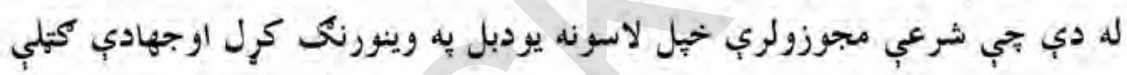

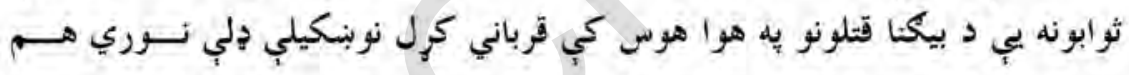

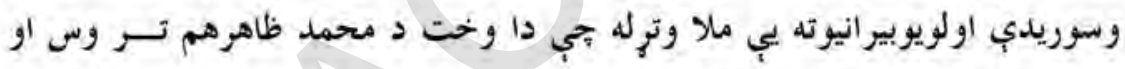

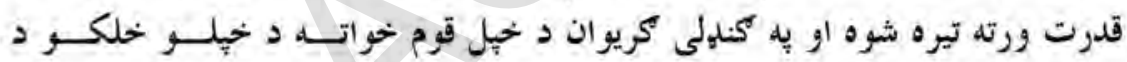

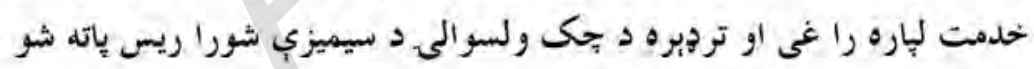

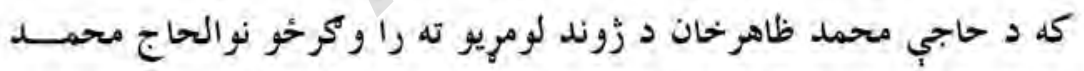

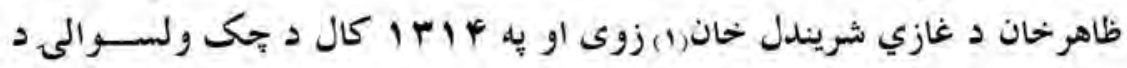

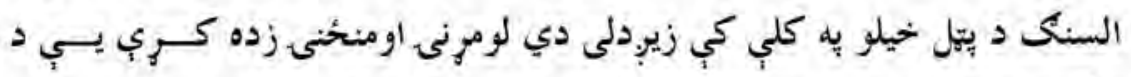

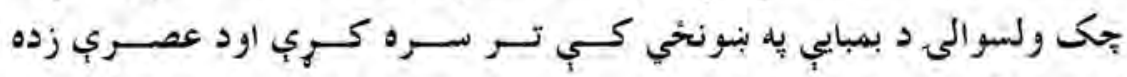

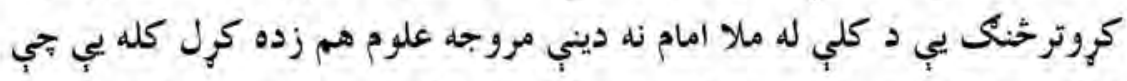

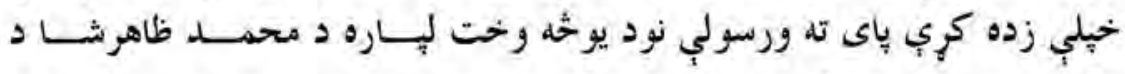

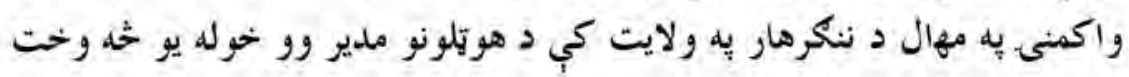


ورونته يب دا دنده يريبنسده او يه آزاد كارباريب ييل وكراود كريمي وردكى يه نوم يب د مسافرورلو راورلو يوه ترانسيورتي كمينىيب اداره كوله ، كله تحي يه افغانستان كي دو كمونستانو كود تا را منيخ ته شوه نومحمد ظاهرخان جيرزئرديوه حيركى قوماندان بيه توكه د جـى يه ولسوالى كي د جميعت اسلامي يه ليكوكي جهاد بيل كراو د نوموري تنظيم ديو شمبرجبهاتو دآمر يله تو كه يب خجيل جهاد ته

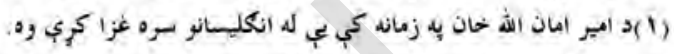

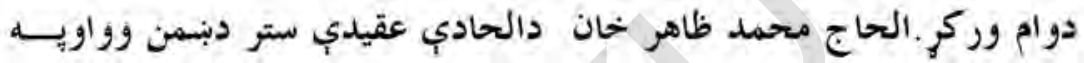

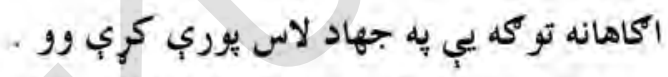

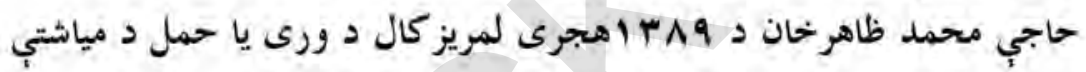

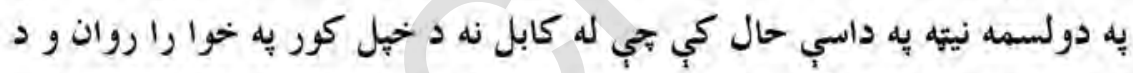

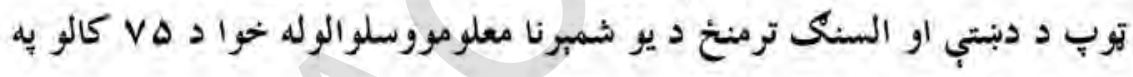
عمر شهيد كراى شو ل 


\section{محمد ميلروخان (بابا حيدر )}

محمد حيدرخان جي به (بابا حيدر) يب شهرت درلود

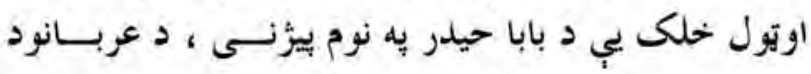

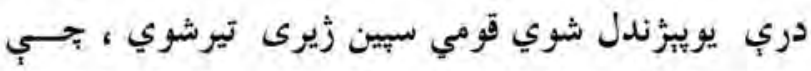

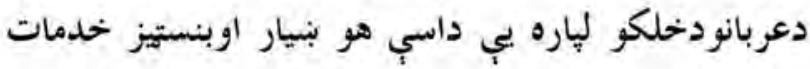

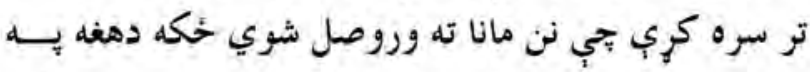

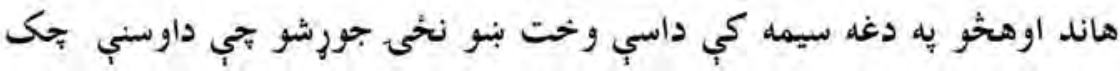

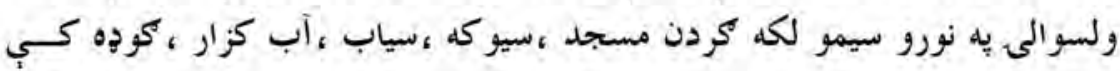




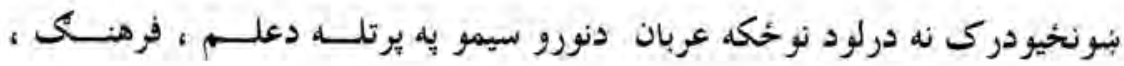

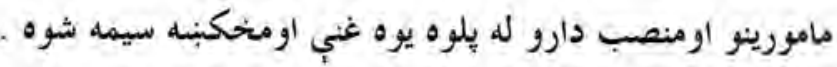

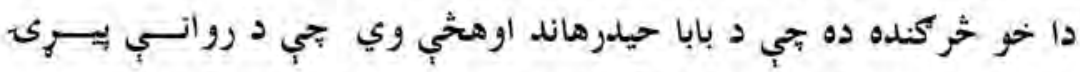

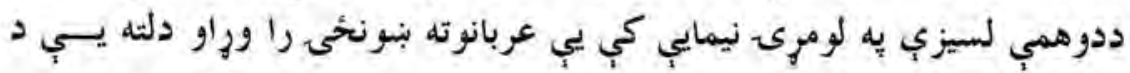

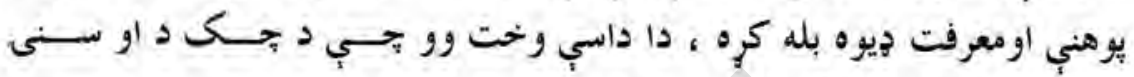

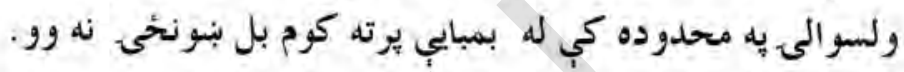

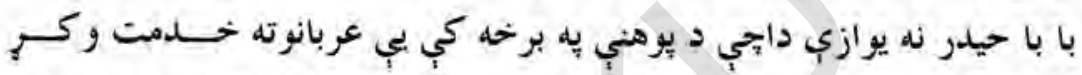

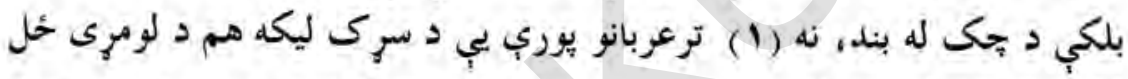

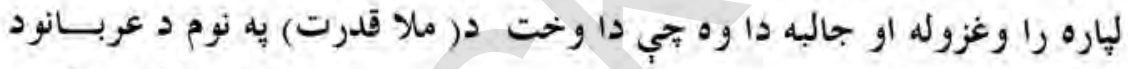

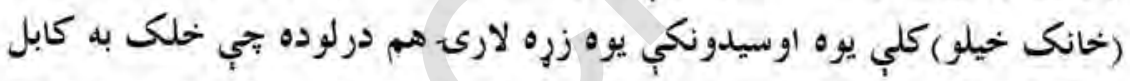
ته يكي تلل دا داسي لاري وه بحي تولو بيرزندله اونن هم د متل له مخي د هغه نوم دخلكو به خوله كي بيروت دي لهي

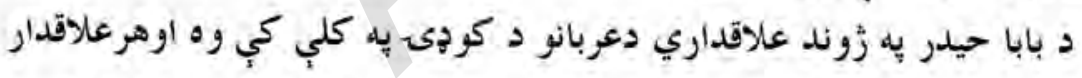

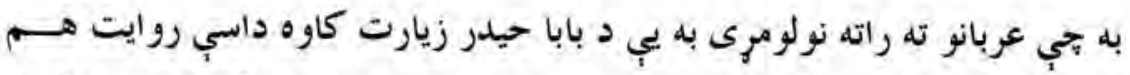

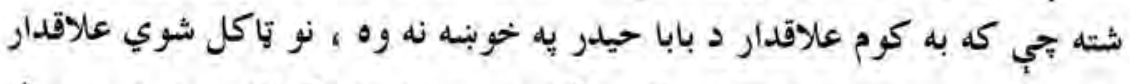
به د عربانو او دهغه يه مربوطاتو كي حكرمت هم نشواى كرلاي اودا هم معمول وه جي كله به علاقدار نه وو نو با با حيلدببه د علاقدار نايب وو. 


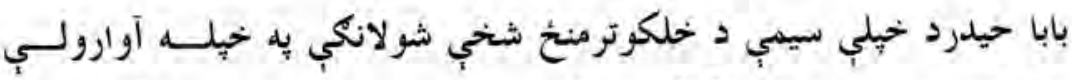

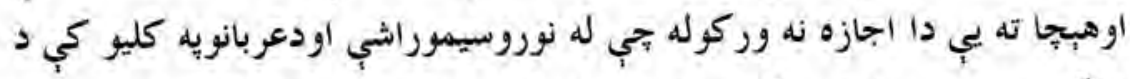

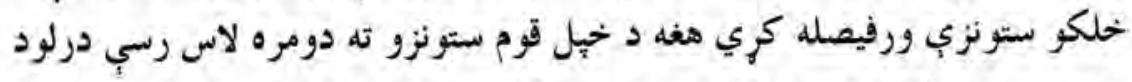

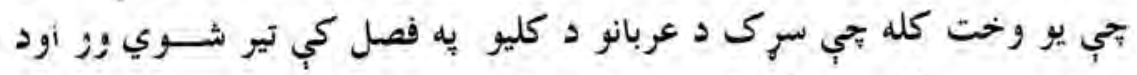

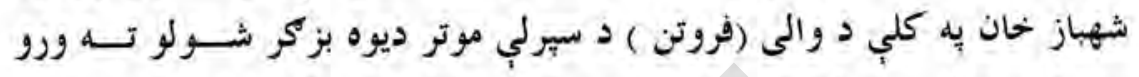

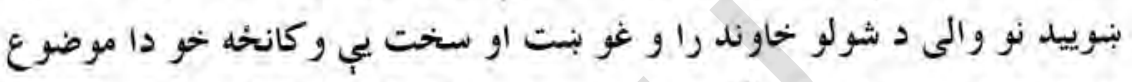

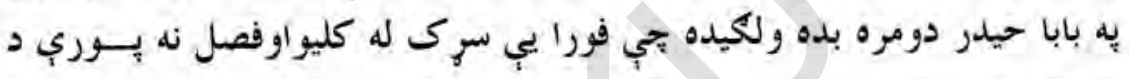

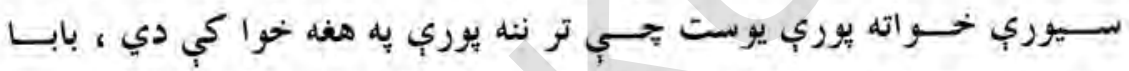

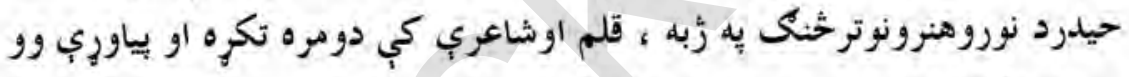

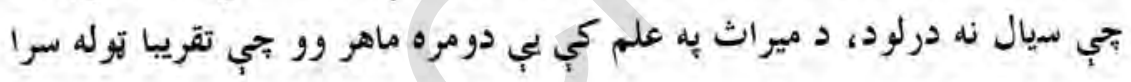

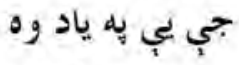

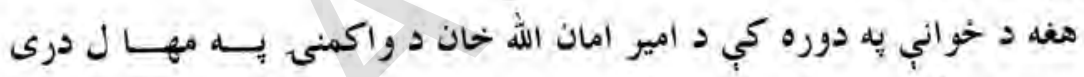

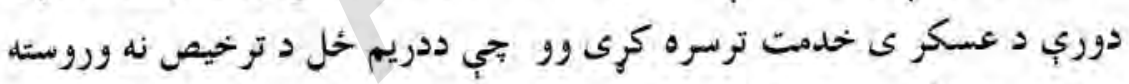

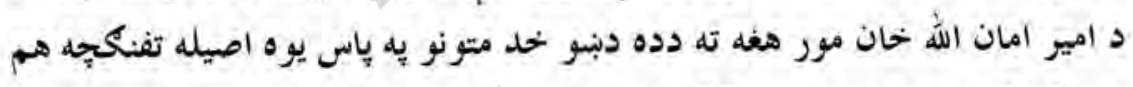

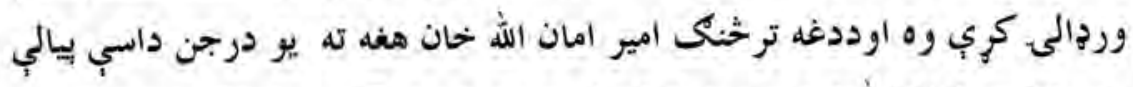

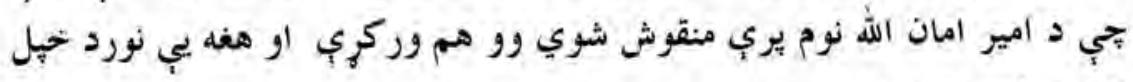

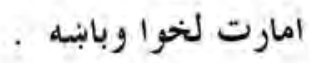

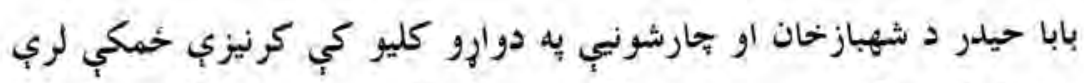

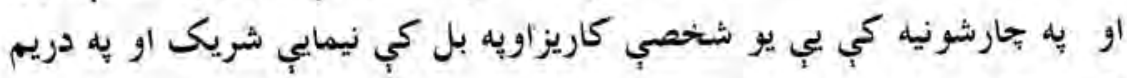

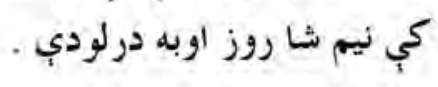


r..

د وردكو مشاهير دوهم توكى

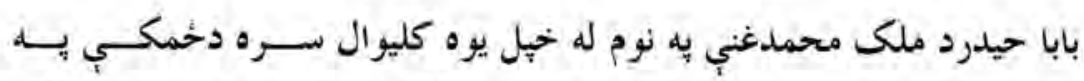

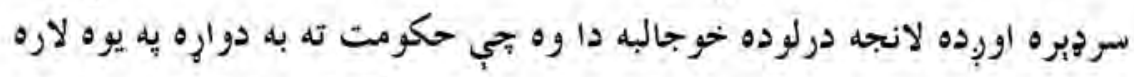
تلل او ددوو ورونو يه شان به يبي له يو بل سره عمل كاوه او له اوبردبي مـــودي لانجي ورو سته يب ييا سورليزه روغه جوره سره وركره .

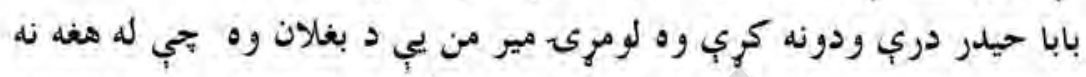
يي دملا مير حيدر ،رييس اسدالله ,ملدير عنايت الله ,او ومكروال محمد ولي خحان

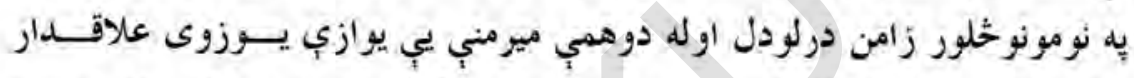
محمد ها شم وو او له دريمي ميرمني يب تبي د كنيكرودمحمد اكبرخان خوروره

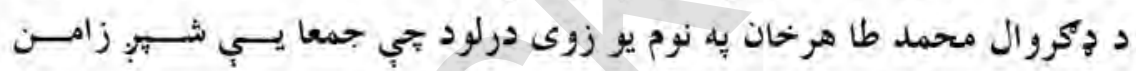
درلود 
$+1$

د وروكو مشاهير دوهم توكى

\section{محمد نعيم سليمي دكوار موسسي ريس}

داكترمحمد نعيم (سليمي ) دافغانانو لِيــاره د مرســـو

برابرولو(كوار) دموســـي عمومي ريس دى ، دغه موسسه

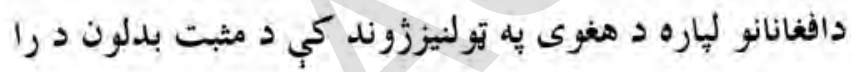
وستو يه خاطر يه اسنادو مستند دومره خدمات ترسره كري جي بنايب كومي بلي خيريه موسسب نه وى توسره كـري

اويوه يخو انى خدماتي موسسه ده هـ

د كرنب ، مالدارى ، اصلاح شويو تخمونو، كمياوي سري ، دميوه لرونكو

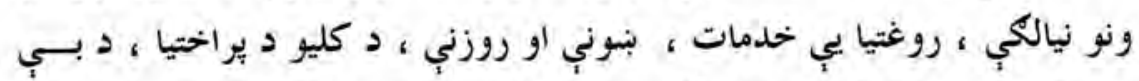
ربح قرضو يه وركولو اوهمدارنكه يه نورو القتصادي برخو كي د مرستو اعما ل ته د ها كالو را يه ديخوا به هر دول ستوثزمنو شرايطو كي اورجه وركـري ده 


\section{r.}

د وردكو مشاهير دوهم توكى

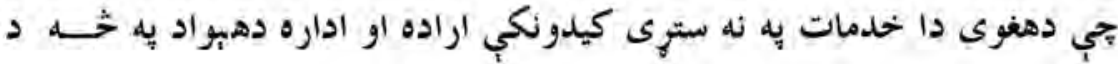
ياسه دوويشتو ولايتونو كي تر نن ورخي يوري دوام لري . كه جيري د كوار د موسسب دفعاليتونو يه وضاحت او جزياتو اروزنه وشي

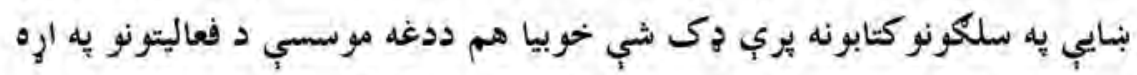

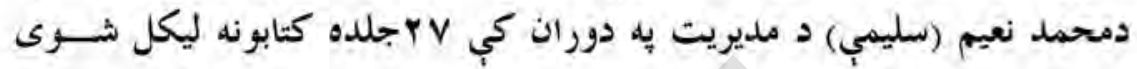
اوخياره شوي دي

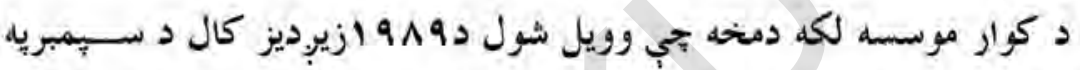
مياشت كي رامنتح ته شوي ده او بيه دغه موده كي يب د زوند يه مختلفو ابعادو

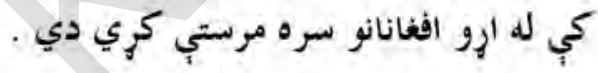

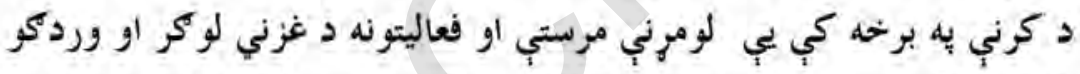
يه ولايتونو كي اعمال كري او يه دغه ولايتونو كي يب يه سلكونو كاريزورنه داوبو

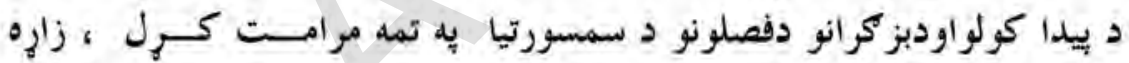

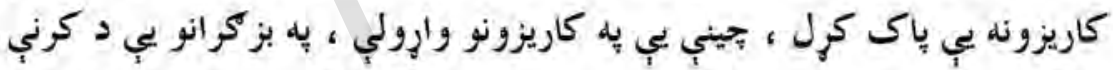
د مكانيزه كولو لهاره تراكتورونه وويشل ، د ميوه لرونكو ونو د ترويج لهاره بِي هلي حلبي وكري بزغلي يبي يه بزكر انو وريشل او ددغه ترخنك بي د كميــاوي سرى او اصلاح شويوتخمونو مرستي هم له بزكر انو سره وركري.

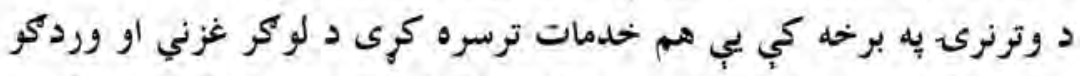

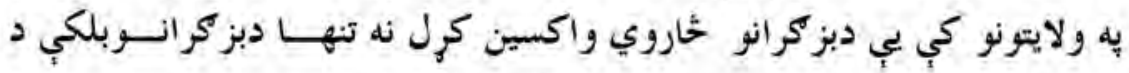
كوجيانو يه رمو يب هم واكسين تطبيق كريل . 
د بنوني او روزني به برخه كي يب هم خحدمات د هير بلدو نه دي دهبواد يـهن.

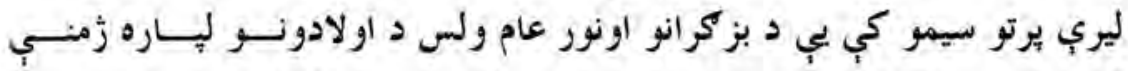

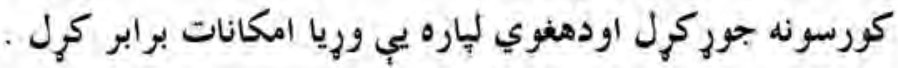

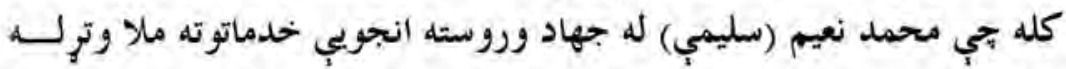

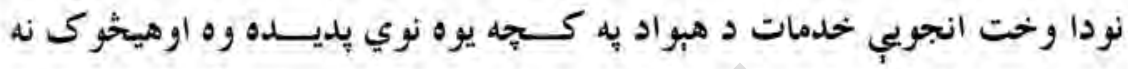

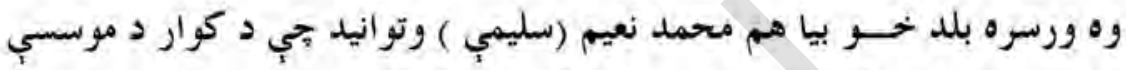

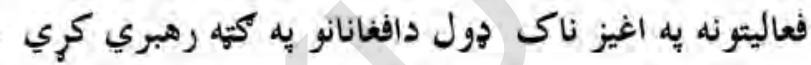

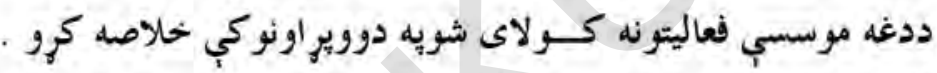

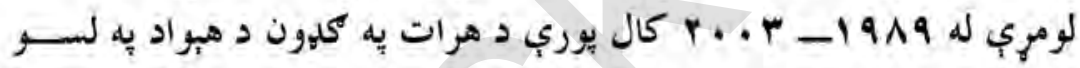

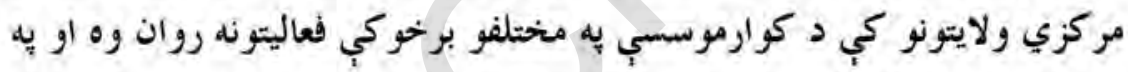

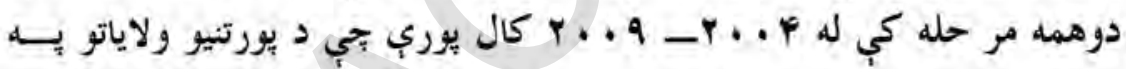

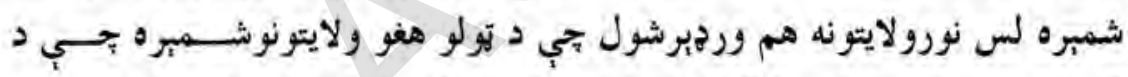

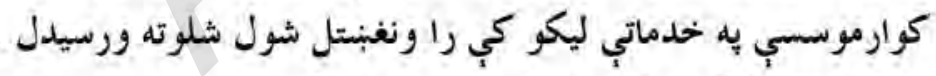

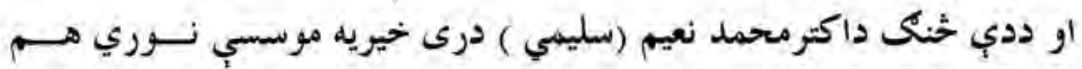
تاسيس كري بجي: اود كربت راديو تلويزيون اود تل هياتــه انكشــاف OSDR / STAR

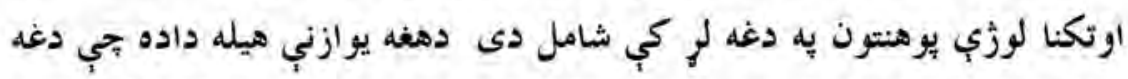

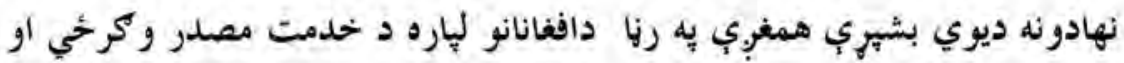

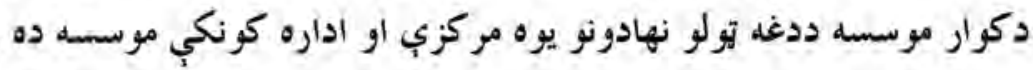


r. $\mathbf{E}$

دوردي مشاهير دوهم هوكى

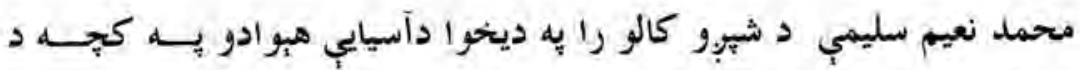

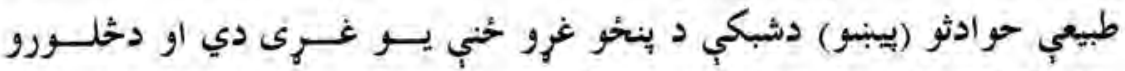

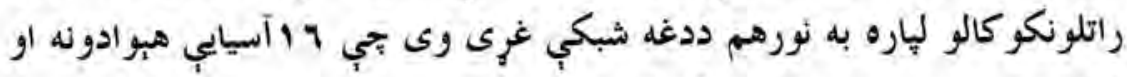

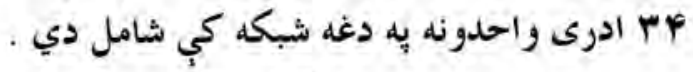

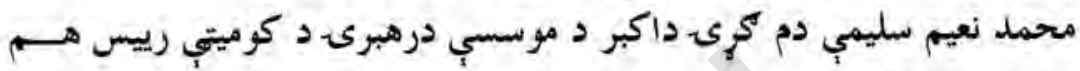
دي بجي به هغه كي VI ا ملي او نريوالى موسسي ثبت او راجسترد دي

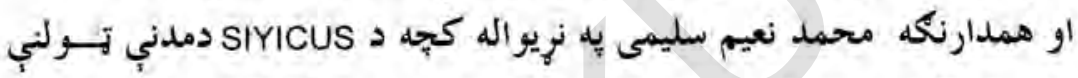
غوريتوب هم لرى او د افغان مدني تولني يه الستازيتوب يب له كرزي سره بــن ، جايان اوهاليند ته هم سفرونه كري دي د افغانستان د خلكو او د مدني ترلثو به استازيتوب بي انكلستان ،بلجـيميم

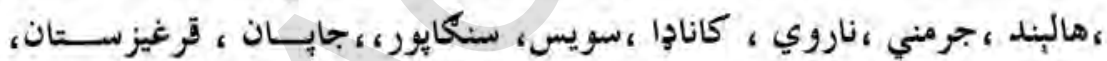
اندونيزيا ، تايلند ، ماليزيا ، نييال ،هندستان ، كمبوديا ايران او ياكستان ته هم سفرونه كري دي

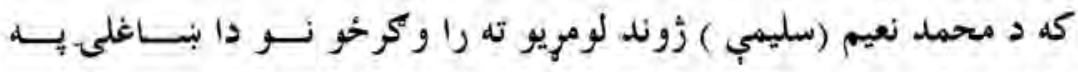

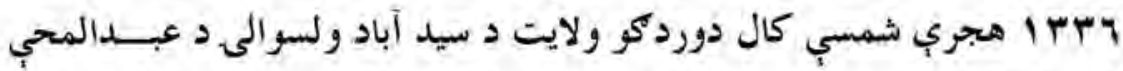
الدين يه كلي كي يه يوه رون آندي او مخوره كورنى كي زيودلى دي لومرنى او

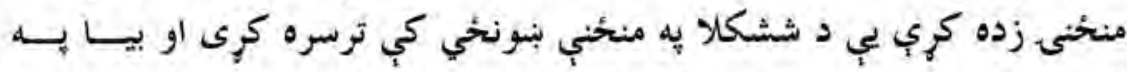
هاr ا كال د كابل د غازي له عالي ليسي نه فارغ شو .

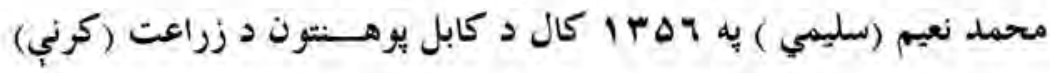


r.o

دوركو مشاهير دوهم توك

يو هنتحى ته شامل شواويه ه ه ا كال يب يه برياليتوب سره 12 يو هنخي سرته ورسوله هغه د يوهنتون يه دوران كي جي د كمونستانود وحسّت شبي ورخي وىى د كابل او يروان له مجاهدينو سره جهادي اريكي درلودي كله بجي له يوهنتون نه

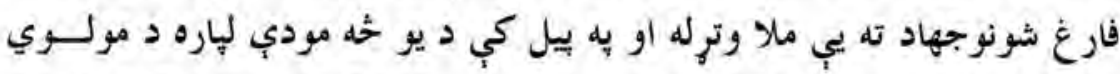
عبدالقديم آخند زاده تر قيادت لاندي د آبدري يه غره كي هم جهاد كري له هغه

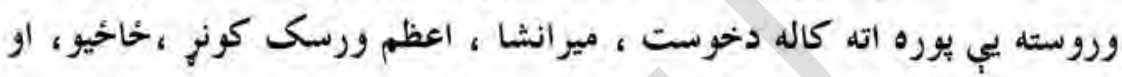
سبين بولدكى به سرحدي يولو كي د استاد سياف تر قيادث او د عبد الله خـــان وردك تو قوماندي لاندب عملي جهاد كري دي اوهمدارنكه به غزني او د بحك د مجاهديئو د صوفي بابا يه جبهه كي بي هم جهاد كري بجي يه دي تو كمه ويلاى شو جي محمد نعيم سليمي يو كلك مجاهد هم ورو .

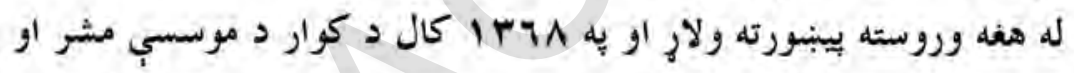

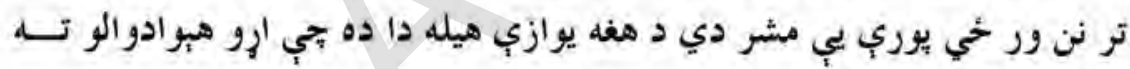
خدمت وكري او ترحنك يب د خهلو اولادونو بنسه روزنه او وارثى وكري. 
r.Y

د وروكو مشاهير دومم تئى

\section{محمد دين خحان - غازي}

غازي محمد دين خان به به ب الهجري قمري كال د كوز خوات د نوره خيلو

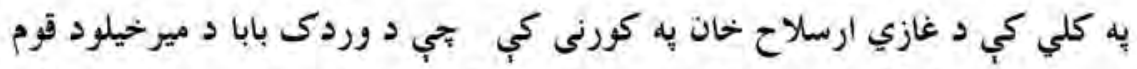

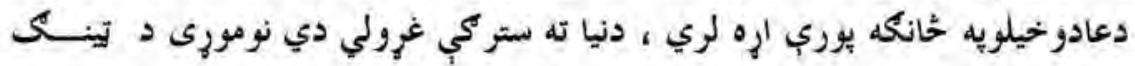

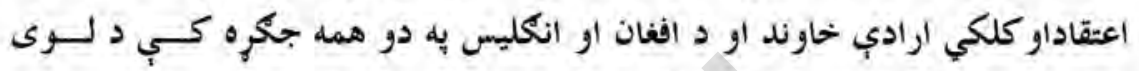

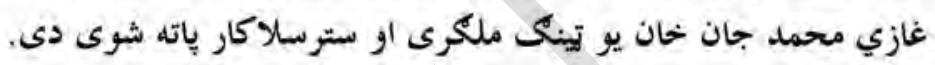

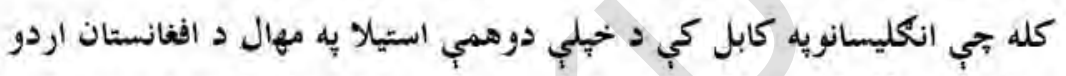

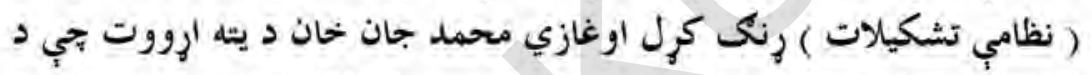

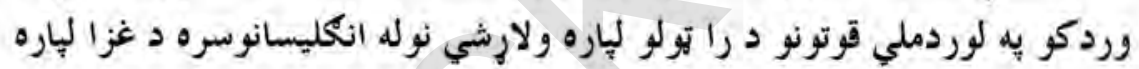

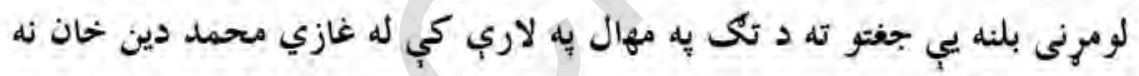

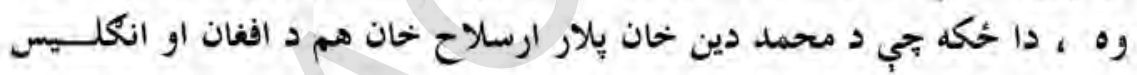

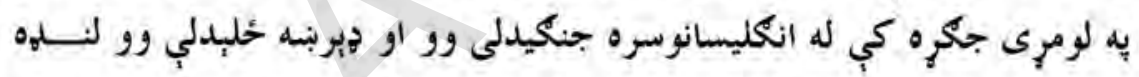

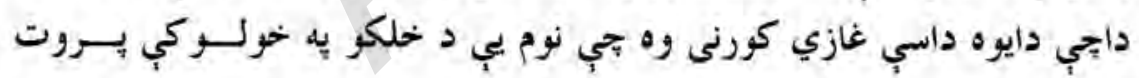
اوتولويبثرندله.

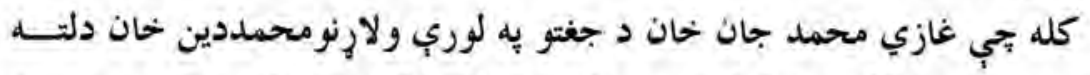

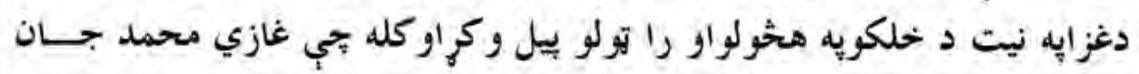

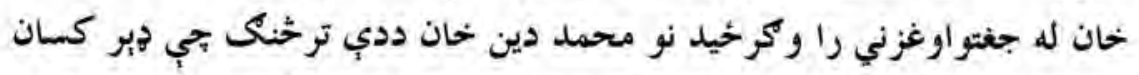

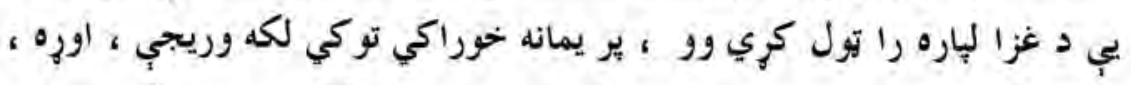

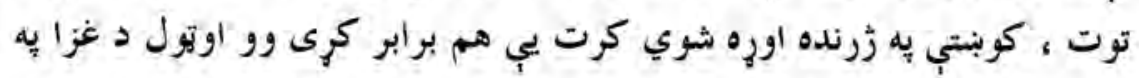

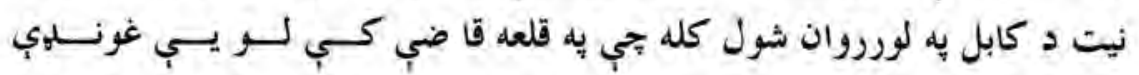




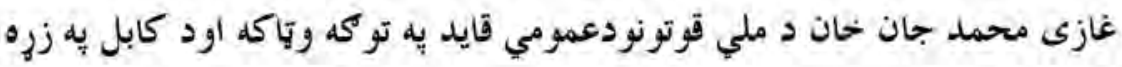

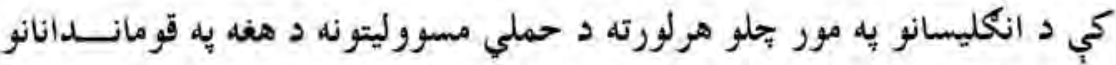
وويشل شول نو محمد دين خان هم يه يوه لوري خيل مسوروليت واخيست او به

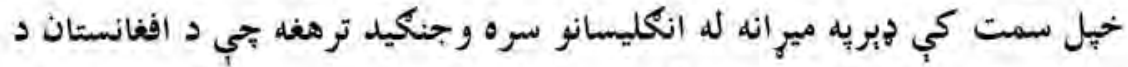

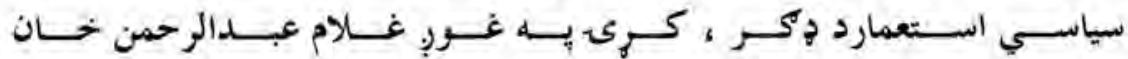
راخركندشواودانكليسانوزيه اشاره بي هغه ملي غازيان هب له انكليســانو ســره جنكيدلي وه د انكليسي استعماريه لاس د جوري شوي اوزجد مهالي سترا تيـرئ.

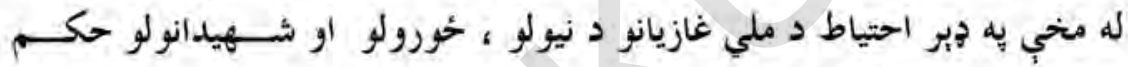

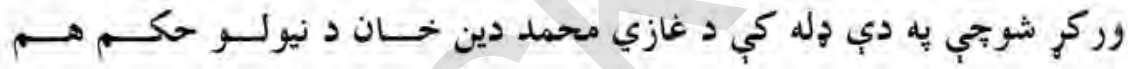
صا درشوي ورو ن غازي محمد دين خان يه نا خبرى كي د كوزخوات دنوره خيلويه كلي كـي ونيول شواو د شيخ يا سين يه حكومتى كي يب بندي كر ، د هغله كرنيزي حخمكي

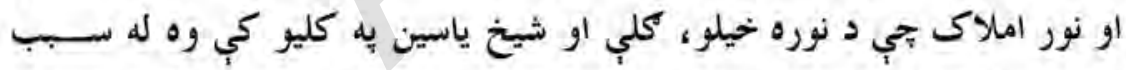
يرته ضبط شول ،غازي محمد دين خحان دا وخت د غازي محمد جان خحان دهغه دورور محمد افضل خحان او د نورو ملي غازيانو له نيولوكيــدوهم خبرشـــــا او وبوهيد بحي عبدالرحمن خحان له النكليسانو يرته ، د افغانانو اعتقادي ارز بنتونه يه

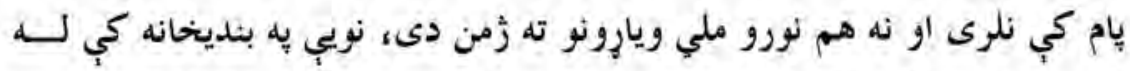

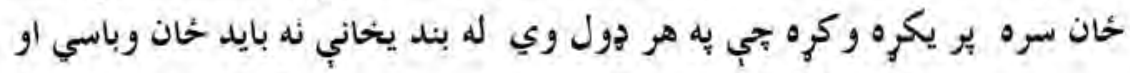
ووزي ، نو به همدغه تكل يب د بند يخاني د شا ديوا لل سورى كر او د د عبدالرحمن

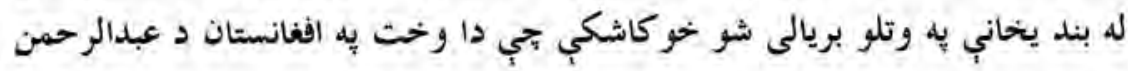


$\boldsymbol{r}, \Lambda$

د وردكو مشاهير دومم توكى

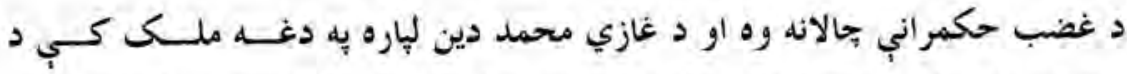

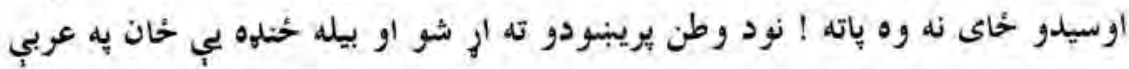

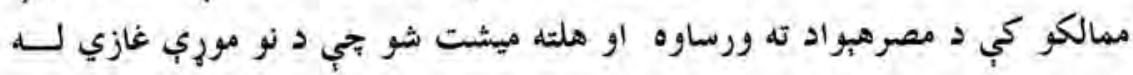

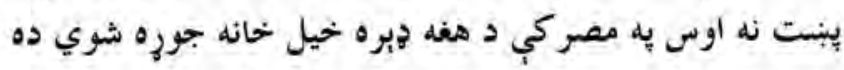

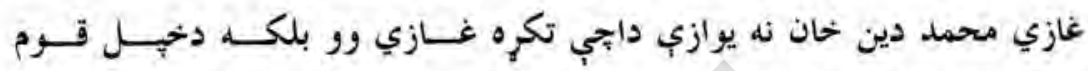

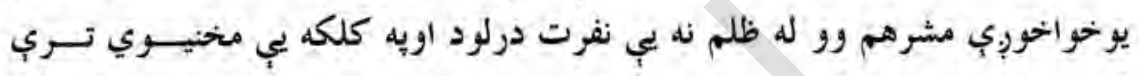

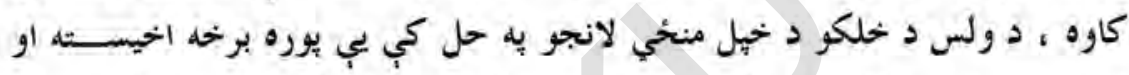

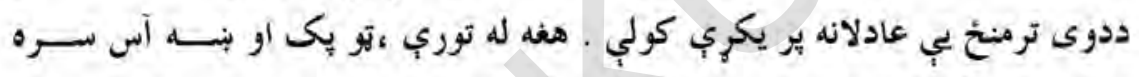
هبره مينه درلوده او تل به يب به رنكى سور آس خو بناوه اوساته ، وايب بحي غازي

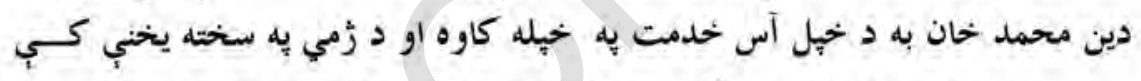

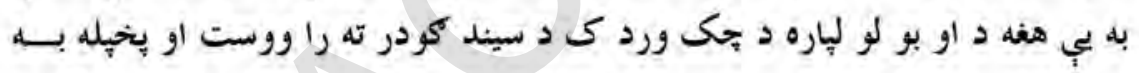

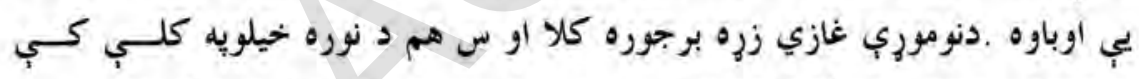
موجوده ، ده جي ديوالونه او يخسي يخ اوس د اوربنتونو له امله شريدلي دي. غازي محمددين خحان بجي كله د مصر يه لور روانيده نو دلته تري د مححمد امين خان (مشهور خيه امينو ) ، بهاو الدين خحان ، او شمس الدين خحان يه نومونو

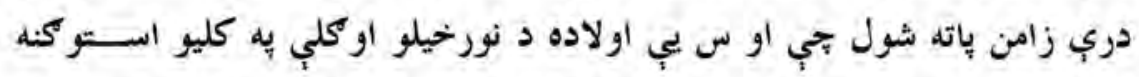
لري او ياته دي نه وي بحي دا له يبله يوه غازي كورنى وه نو د دورسانو د الستيلا يه مهال هم يه دي كورنى كي بنه تكره تكره غازيان اوقوماندانان مو جود وه. 


$$
\text { r.q }
$$

\section{محمد يحيى وردكى - د داكتر}

د جاكتر يحيى وردك يه دفتر كي تر هرخه د مخه د

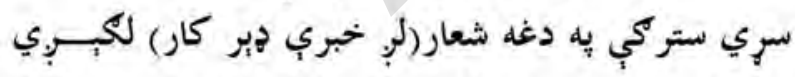

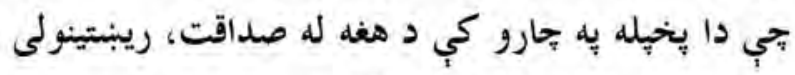
او كرئديتوب خخخه نمايندكي كوي. نوموري شعار د هغه د هر مامور د ميز د يانسه يه خدي

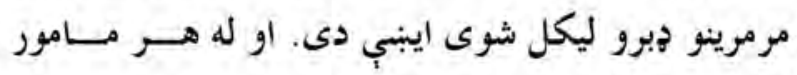

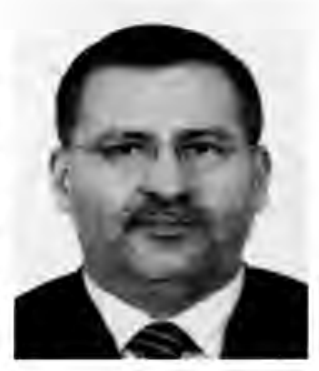
حخخه د خبرو يه خئى د كار غوبنتنه كوي. 
ri.

د وردكو مشاهير دوهم توك

جاكتر يجيى وردمى د لورو زده كرو يه وزارث كي د هير اد د شيبرو يوهنتونو

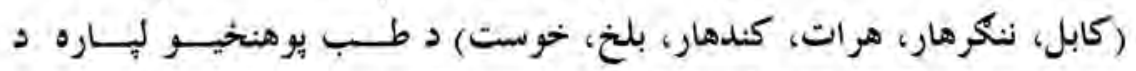
استادانو علمي كتابونه او خيّرنيز اثار د بوهي د كيفيت د لورولو او د محصلينو

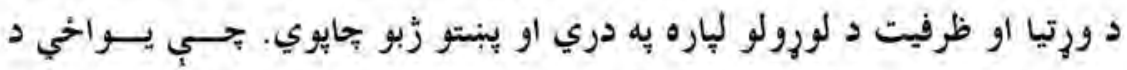

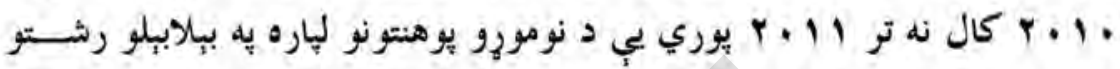

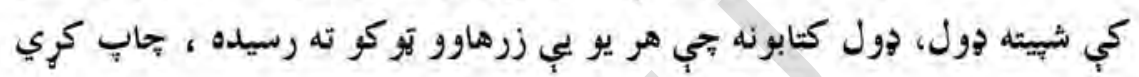

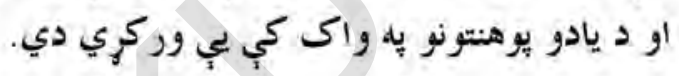

تر دي د مخه د الفغانستان د طب يوهنخيو محصلين او اســتادان ددربسـي

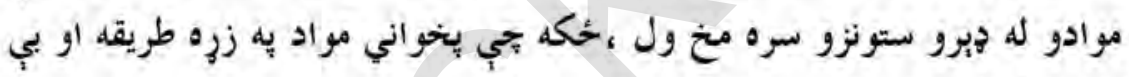
كيفيته كاغذ جاتخ او يه ورته ميتود تدريس كبدل.

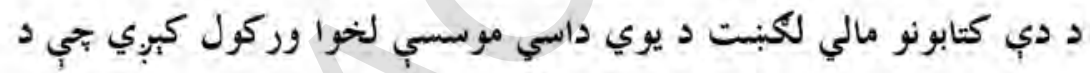

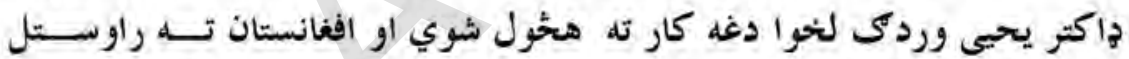
شوي ده. كه داكتر يحيى وردكى او د هغه نه سترى كبدونكي هثخي نه واى نو زمونج هبواد به يه طبي دُكر كي له داسي ستري علمي شتمنى تي د طبي كتابونو

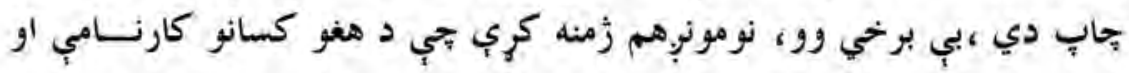

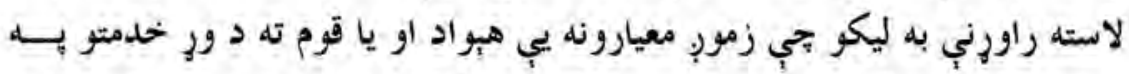

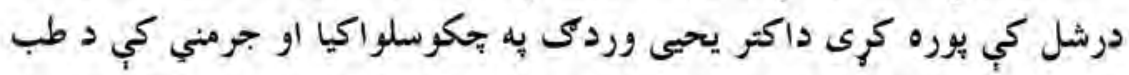

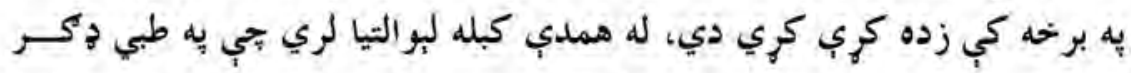

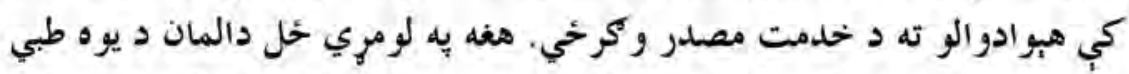
انستيتوت او افغان طبي يرسونل يه ملثيا د المان د اكازميكو همكاريو د تولني 


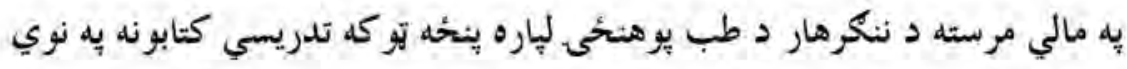

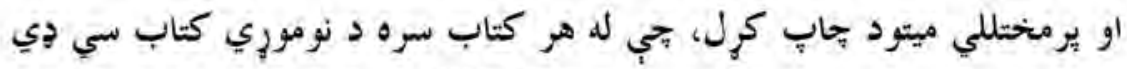

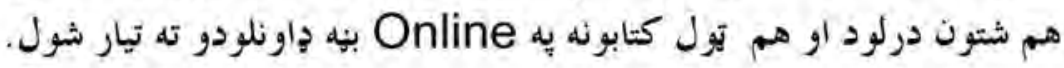

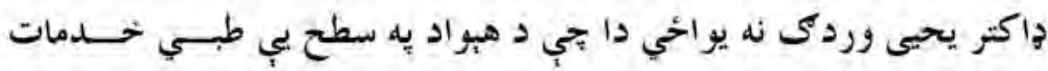

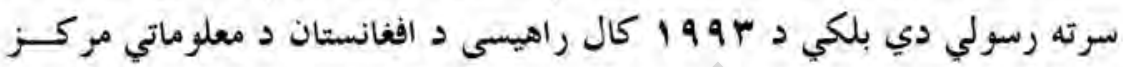

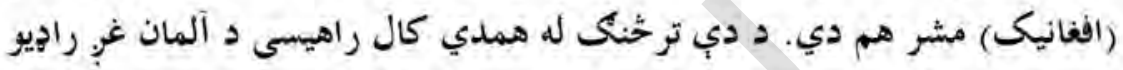

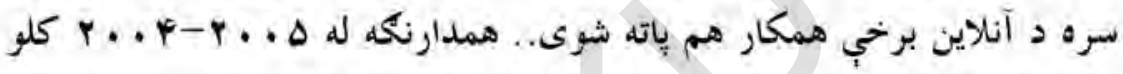

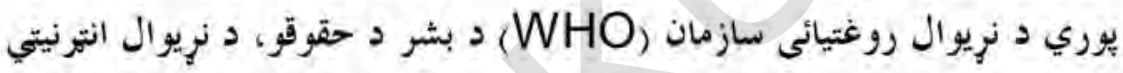

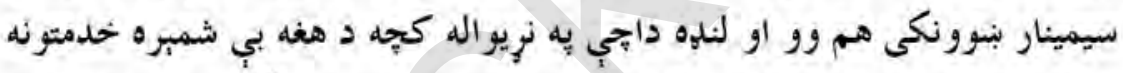

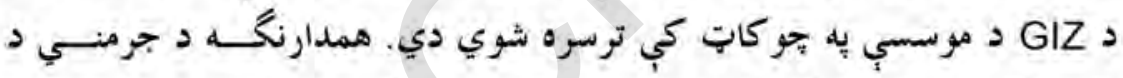

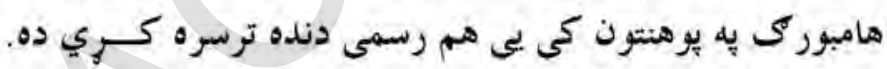

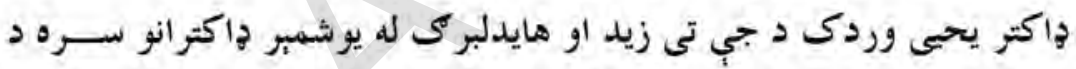

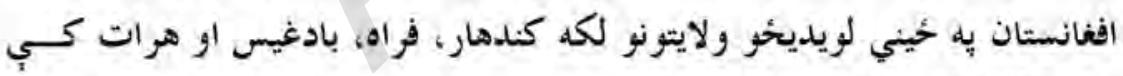
طبي حالات له نبدي خارلب او ارزولي.

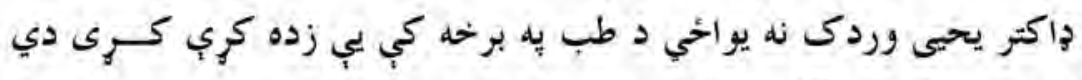

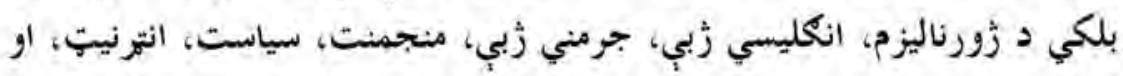

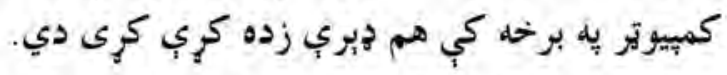

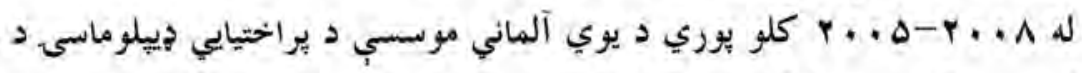

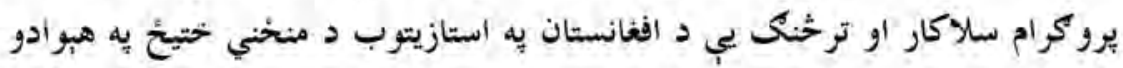

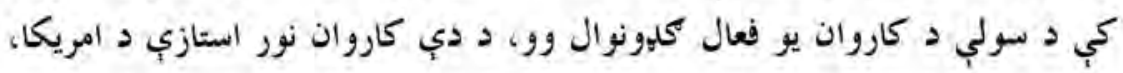




\section{Tit}

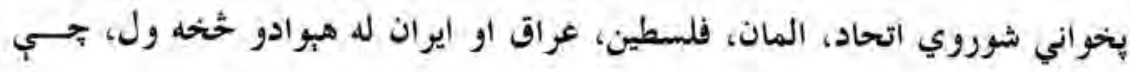

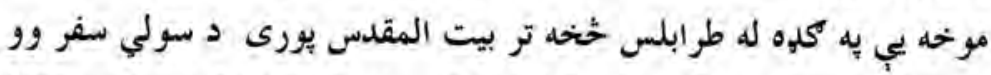

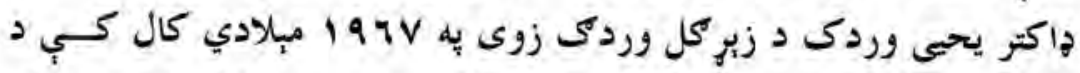

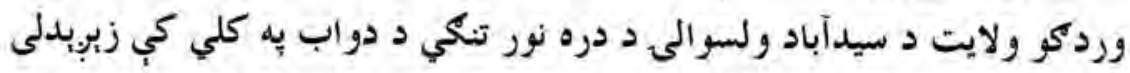

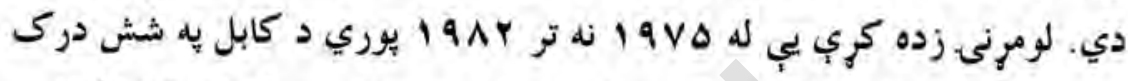

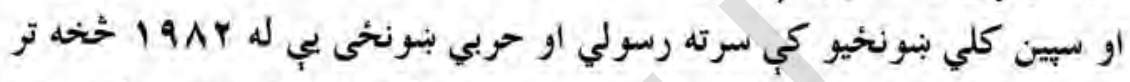

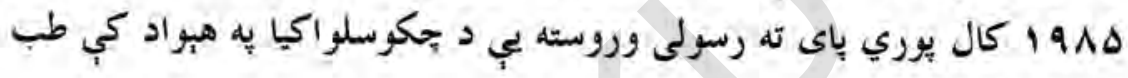
يوهنحئ لوستى ده.

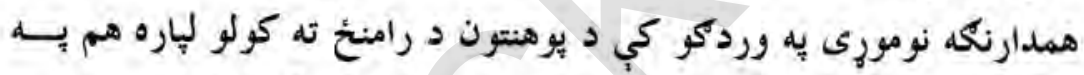

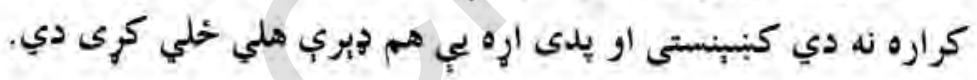




\section{محسن خان (طاهرى) - - وكيل}

2 سردار محمد داود خان د واكمنى يه مهــــ ل د

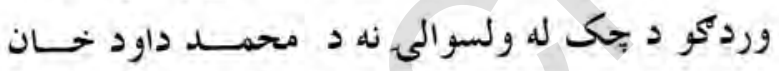

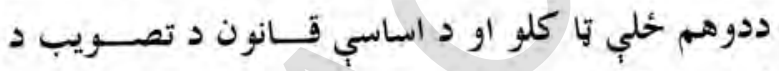

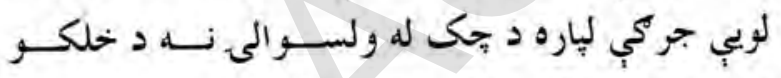

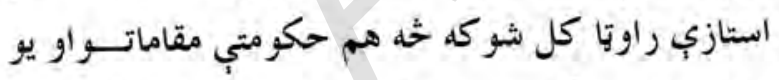

شمبر حخايب حكومت يلوه كريو دا وخت غوبنتل بحي د

جكى د وخت ولسوال دب لويب جركي ته ور ويبرّندل شي خو ملديرمحسن خان

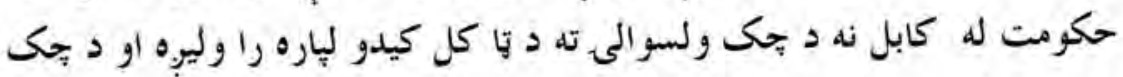

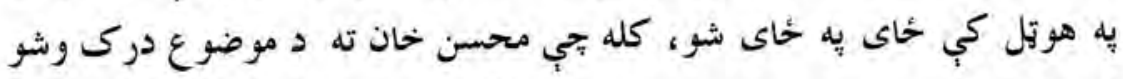

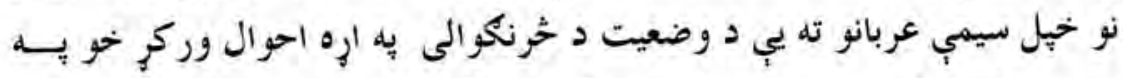

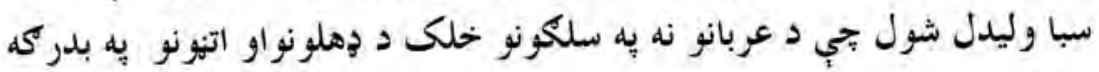

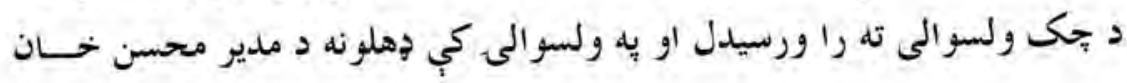


طاهرى يه يلوي ودرمبيدل وغرمبيدل ، ولسوال اوحكومت يلوه محدودو كسانو

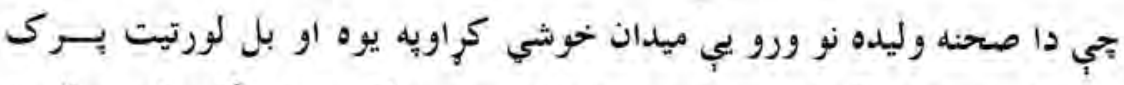

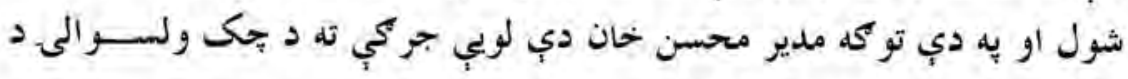

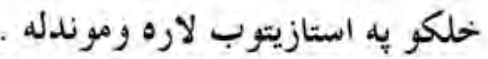

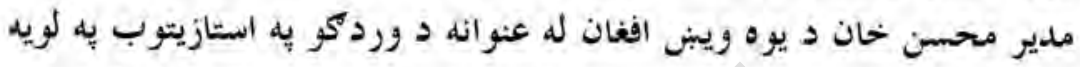

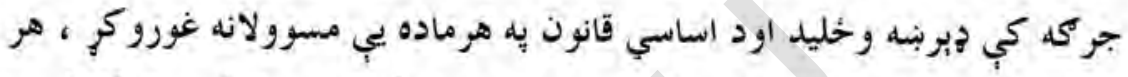

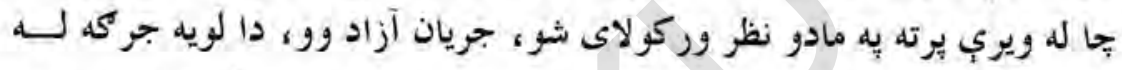

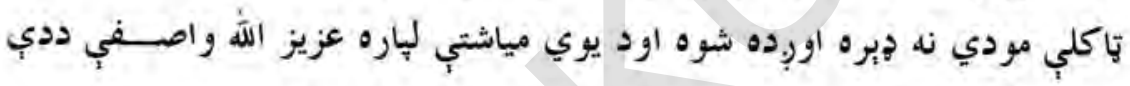

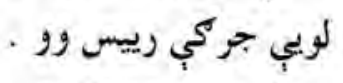

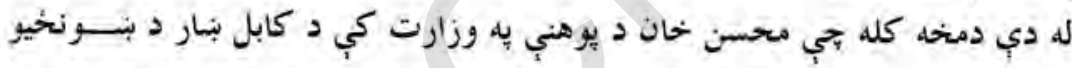

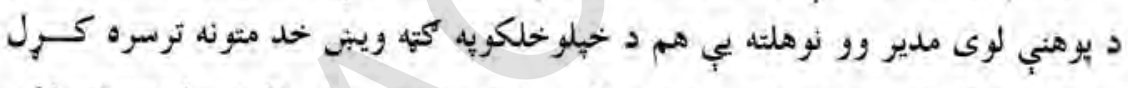

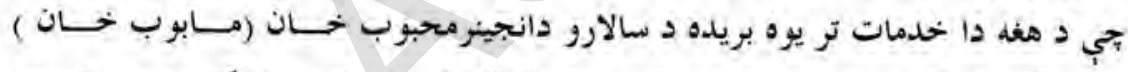

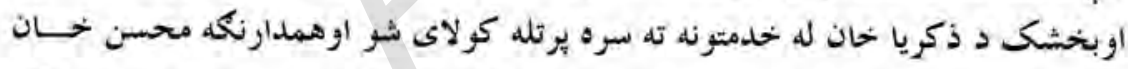

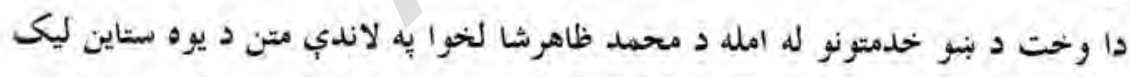

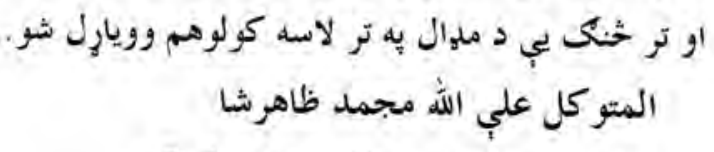

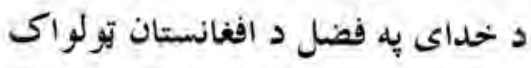

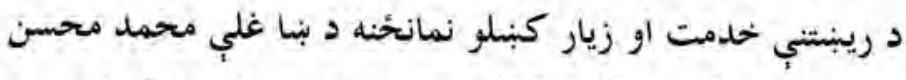

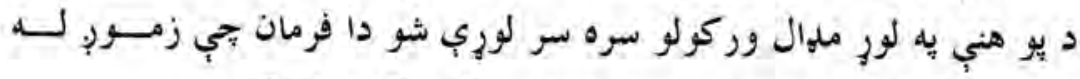

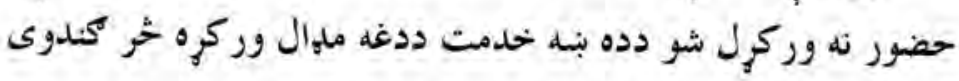




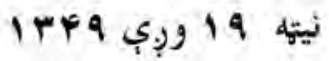

محمد محسمن وردى د يوهني وزارت يه مربوطاتوكي نوري دندي هم تــــ

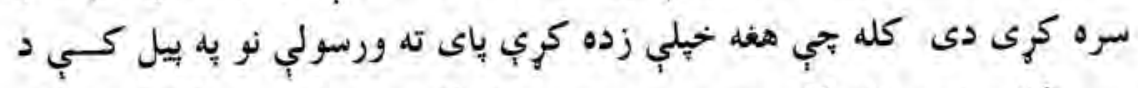
سبين كلب يه بنونتحى كي بحي يه ميرويس ميدان كي يب موقيعت درلود د دبنونكي

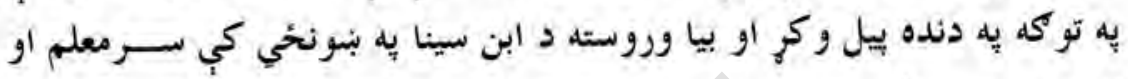

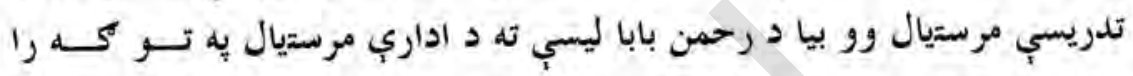

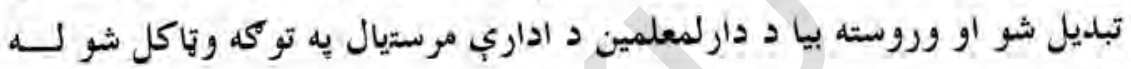

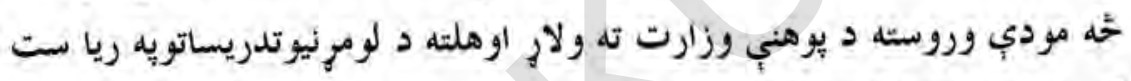

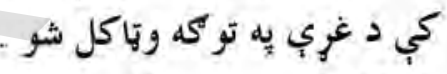

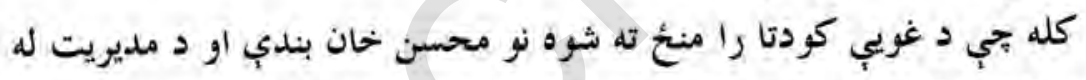
دندي كوبنه كريى شو خو د خحه وخت بند له تيرولو وروسته بيرته را خوشي شو

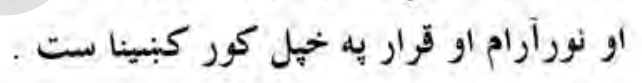
كله بجي د وردكوخلكو د كمونستانوية ضد وسلوال ياخون وركر اود ياخون

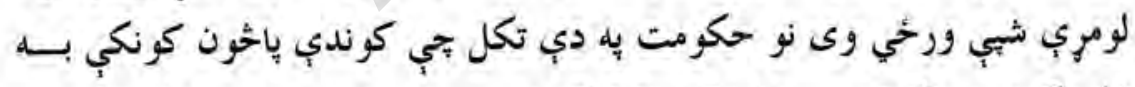

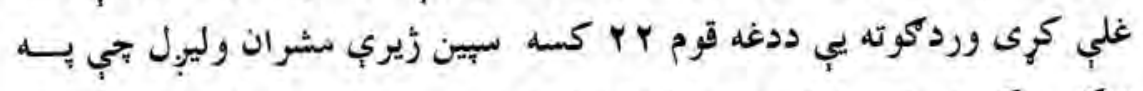

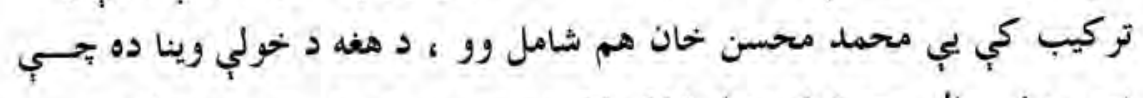

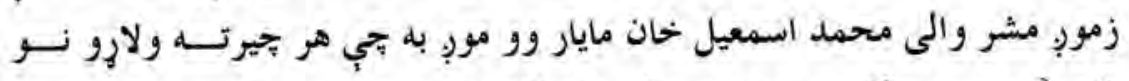

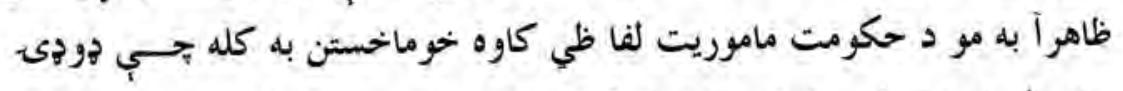

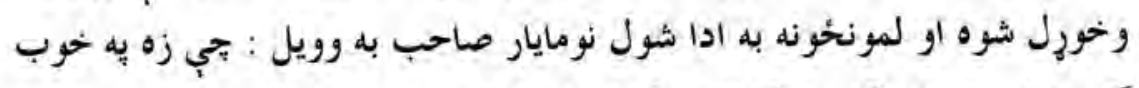

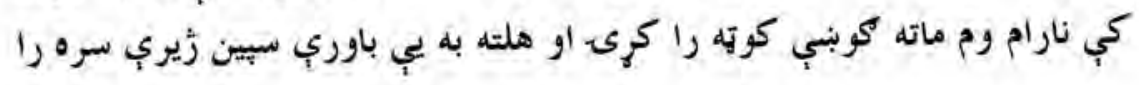


Fia

د وردكو مشاهير دوهم توكى

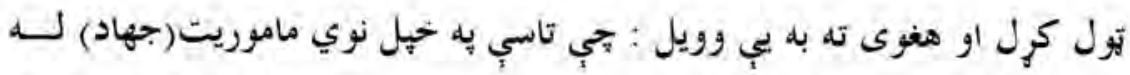

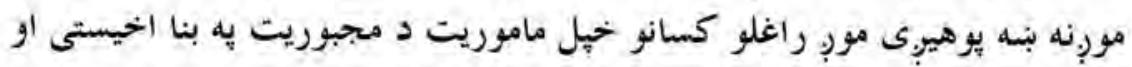

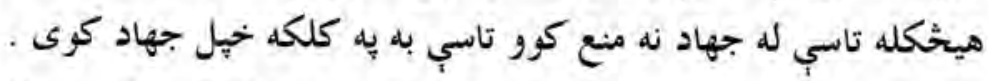

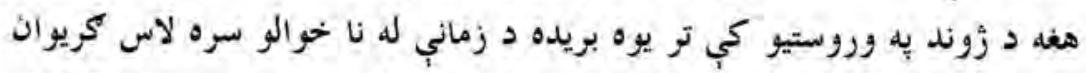

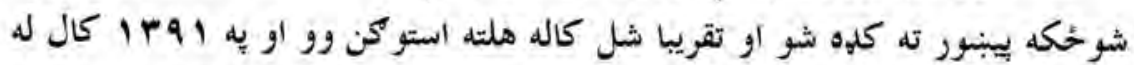

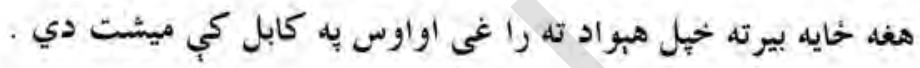

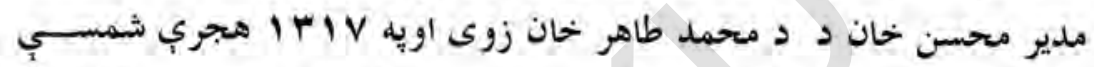
كال د عربانو د بيداريو يه كلي زيودلي دي خهيلي زده كري يب دسيمي يه لومبرنى

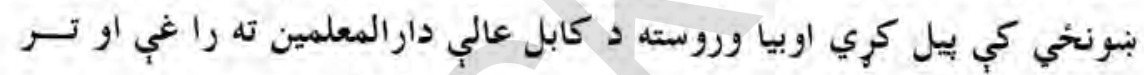

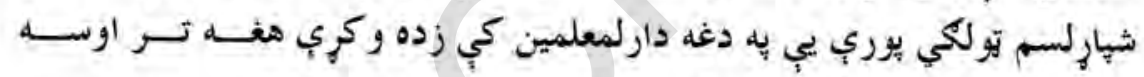
زوندي او د كابل يه قرغه كي او سيربي لوبي 


\section{محمد كريم مولوي - قوماندان}

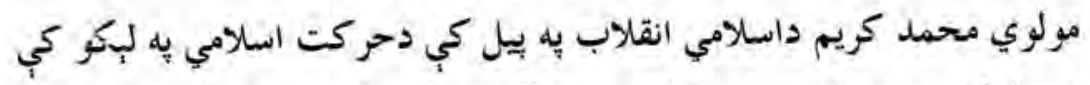

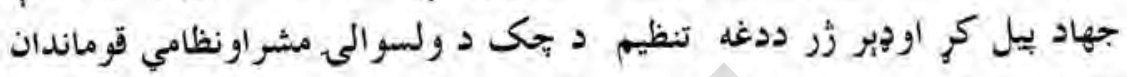

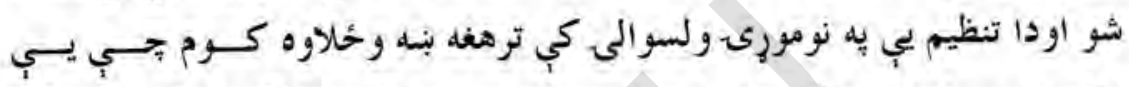

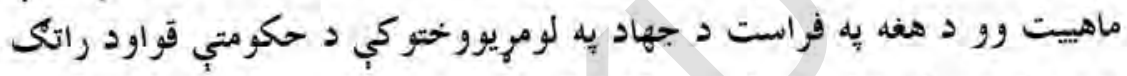

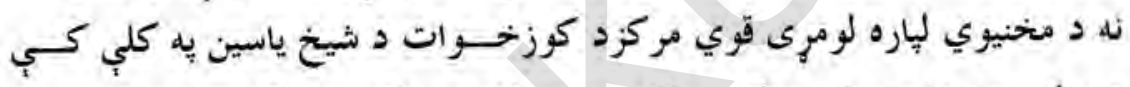

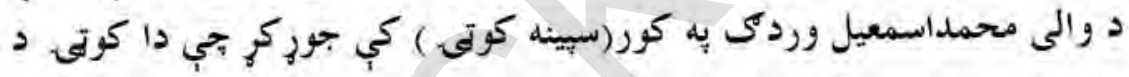

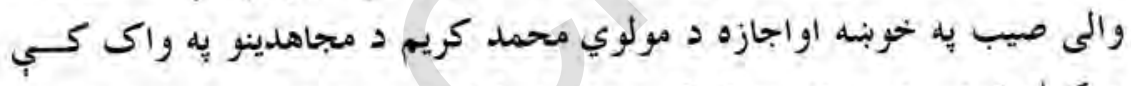

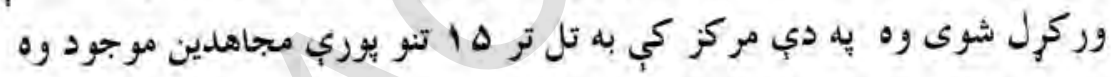

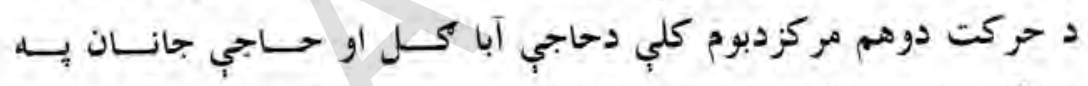

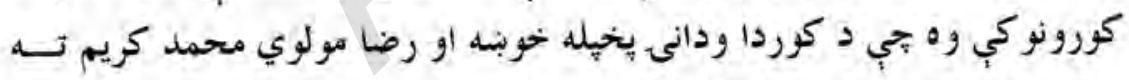

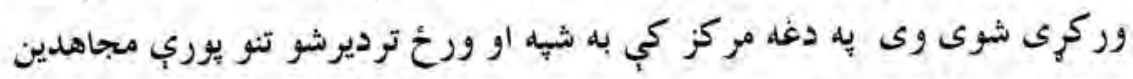

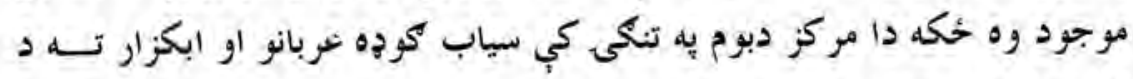

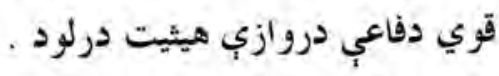

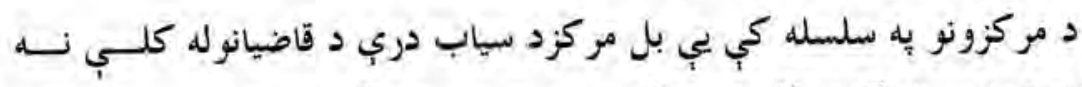

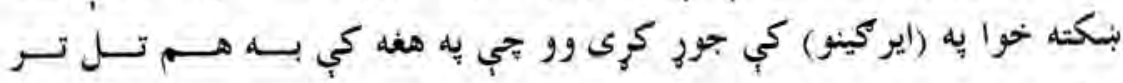
هاتنويوري مجاهدين موجود وه. 
بل مركزيب د سيوكي يه (سيينه كيجه نومى غره ) كي فعاليت درلود بهي يه هغه كي بله هم تر ها تثر مجاهدين حاضر وه ددي مركزونو د بنب اداري او لله ولس سره د اغيزمنوجهادى إريكو نيولــو لياره د حركت انقلاب اسلامي ستراوعمومبي مركزدعربانودجا رشونيب له كلي

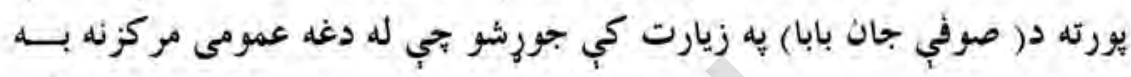
تول هغه مركزوئه اداره كيدل لحي يورته ذكرشول د صوفي جان بابا مركزديجى ولسوالى يه كجه د حركت انقالاب اسلامي عمومى مركزوو اود ضرورت اوارتيا يه وخت كي به له يورتنيو فرعى مركزو نه مجاهدين را توليدل او د جهاد ليكو ته به سوق كيدل .

مولوي محمد كريم به تل يه خهلو مركزونو كرحيده اوددوى له لوزيستيكي ستونزوبه بي خان خبر اوه اوخيل مجاهدين بي هيخكله نه احتياجول دجهاد له بهيرنه حُنه نه وه وتلي جي مولوي محمد كريم د حزب اسلامي ؛ جميعت اسلامي او محاذ ملي سره يو حخاي يو قوي ايتلافي تهاجمي مركز د بور يه كلي كي جوركرجي ددغه مركز داداري اوسوق واكى د قومي مشراودشورا

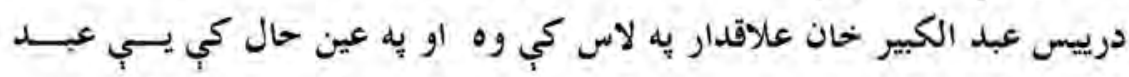
الكريم أخند زاده ،مولوي شرين (شجاعت) او قاضي نذيريب مرستيالان وه بحي دا كار محمد كريم يه نوبنت وو تجب له دغه كار نه غوره موخه دا وه بحي يخهيله

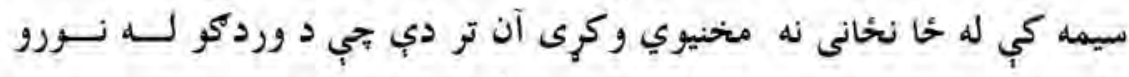
ولسواليو سره د خيل تنظيم به كجهه منظم تشكيلات جور كرل 


\section{riq}

د وردكر مشاهير دوهم لروك

خولالِبروخت يري تيرنشو بحي دغه يِياوري او با عزمه قوماندان يه مرموز جول شهيد شو.

د مولوي محمد كريم پيه شهادت ته يوازي دجيك ولسوالى د مجاهدينو زره وسويد اوخفه شول ، بلكي د تولو وردكومجاهدين يري ودرديدل د افغانســتان مجاهد يالونكي ولس به عام زول او د وردكومجاهلدين او نورعام خلك يه خحاص مول ددغه نوميالي به شهادت وحوريلدل د سيوكي يه سيمه كي اوس يره ليسه د هفه يه نوم ده بحي تو يوه بريده دهغه د جهاد او بنو حلدماتو بدله ور وكيرخول شوه . كه د هغه دزوند له جهاده نه د مخحه دوري ته يو حخغلنده نظروكرونو محمد كريم يوتكره عالم وو به اصول فقه، صرف نحوه كي بي غبنتلي لاس درلود هغه

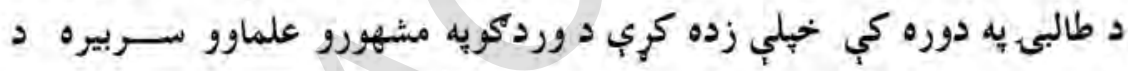
حضرت صيب د شلكر يه مشهوروه مدرسه (نورالمدارس ) كي جــي د غزئسي ولايت د ميري يه ولسوالى كي واقع ده، هم تر سره كري او هم يب د يغمان د مشهور عالم مولوي ملنك نه هم زده كري دي هغه كله بحي ملدرس شو نو خخهيله يب هم جِبر طالب العلمان و روزل (1) 


\section{(1) نصر الله (نقشبند) - مولنا}

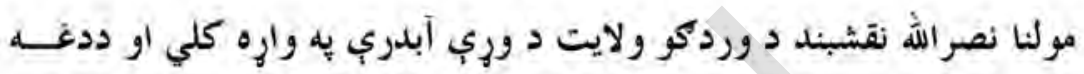

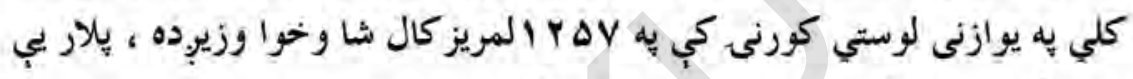

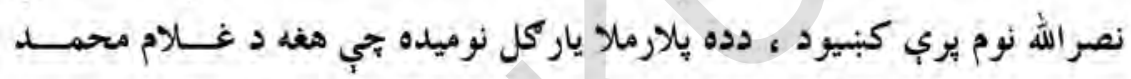

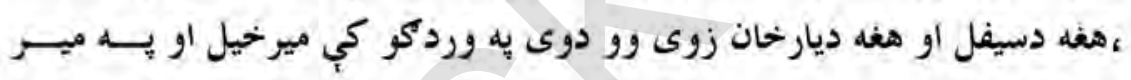

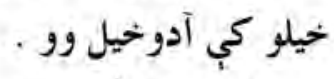

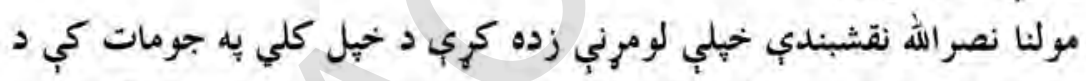

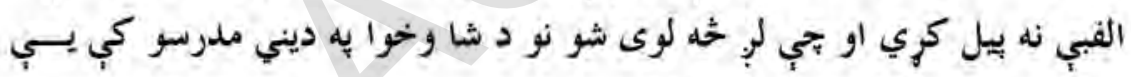
خيلي ديني زده كرو ته دوام وركر.

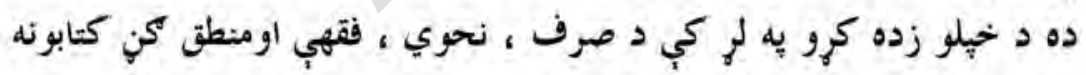

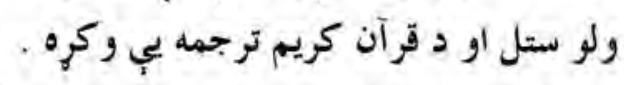

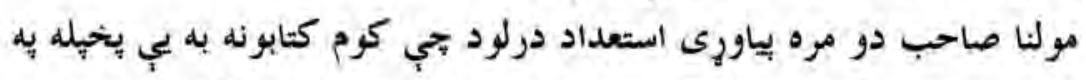

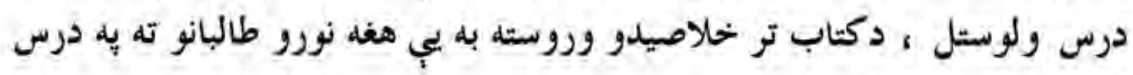
ويل او ورزده كول . دورن

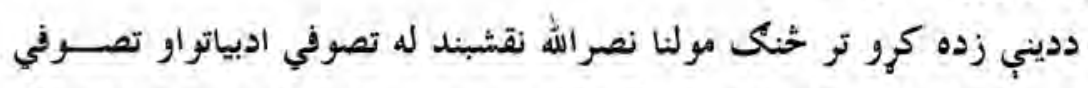

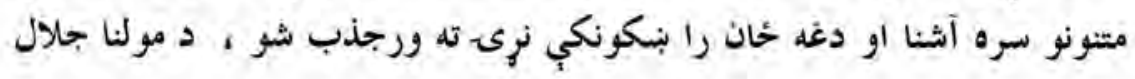


الدين بلخي مثنوى او د عبد الرحمن بابا ديوان دده معنوي غذا وكرحيدل اوتل

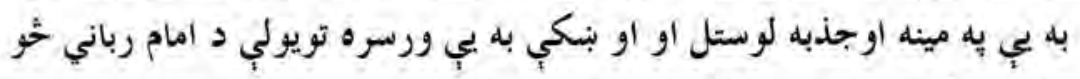

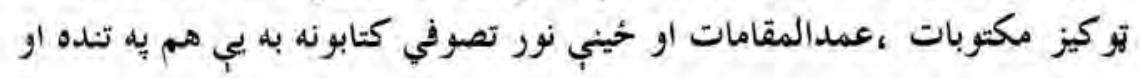
تلونسه لو ستل اوخو ندونه به يب تري اخيستل .

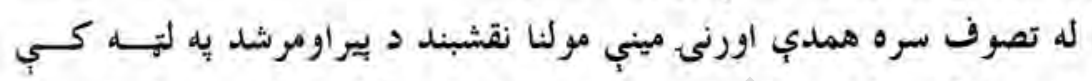
كراويه شل كلنى كي يب د وخت له نامتو نقشبند يب كورنى له يبرنور المشـيـايخ

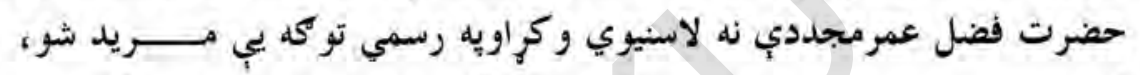

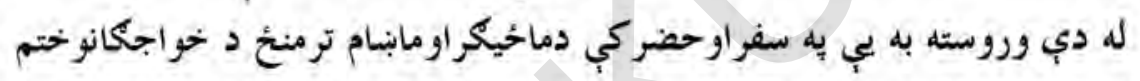

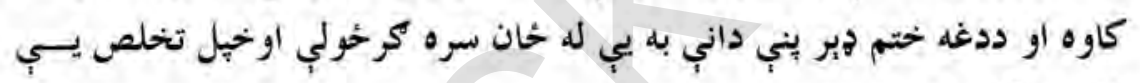
تقشبند كبنيود . له سير سفرسره مولنا وزبره مينه درلوده له كوم وخت نه بحي هغه رو حسـاني سفر يبل كر له ديرو كسانو نه بله يب د هند د مشهورويير انواوصوفيانو كيسـي اوريدي اوددوى له كراماتو اوخوارقونه به خبريده ددي لياره بحي داسي وليان او لويان له نيرِدي نه وويني نو د سفر موزي يبي به ببنسو كري إي او دهند د بيلا بيلـــ بنسارونو يه لور يب لاري تر ينسو كري يه دي له كي زيلي ،مدراس ، توردكن ، اجمير شريف او يه لاره يوتو بنارونو ته ولاريه بهاركي يبي يو داسي يير وليد بحي ني

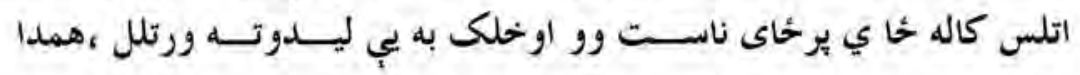




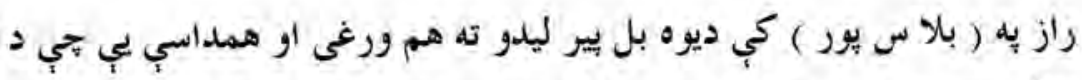

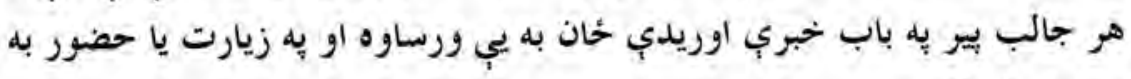
بي مشرف كيده

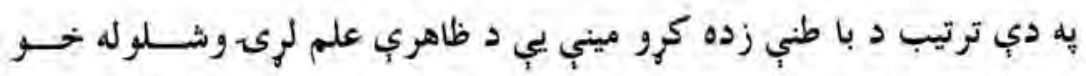

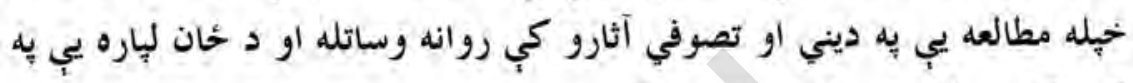

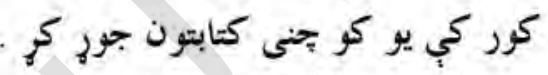

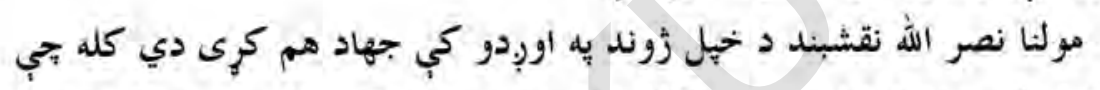

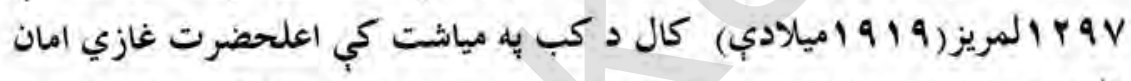

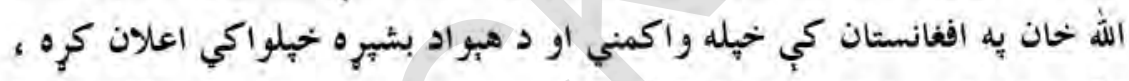

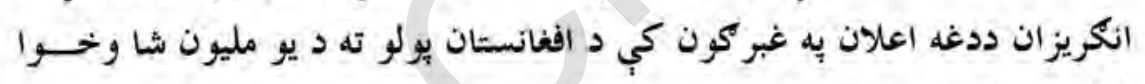

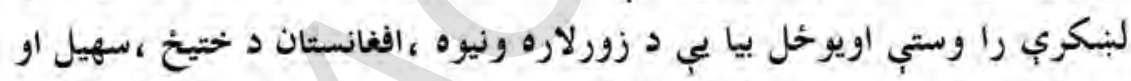

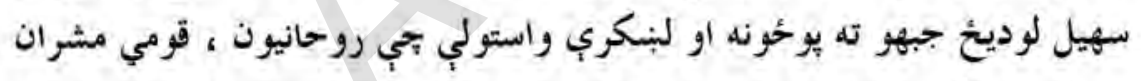

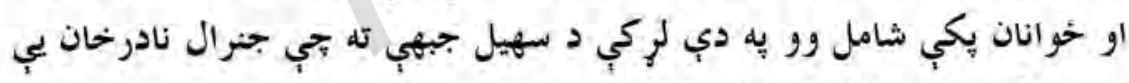

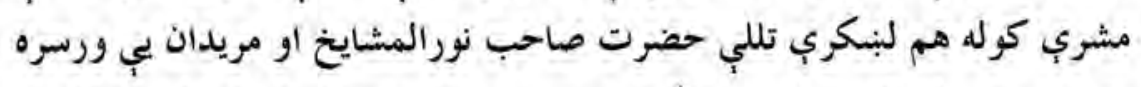

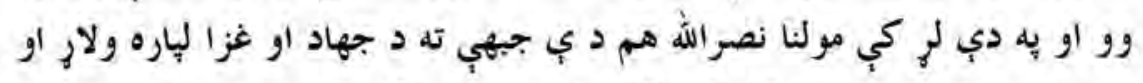

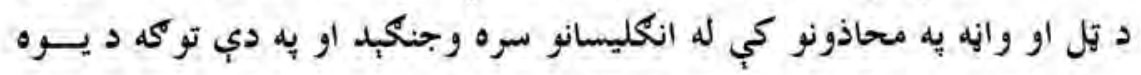

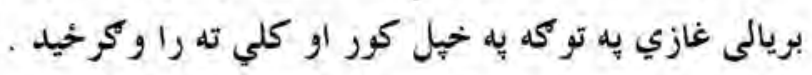

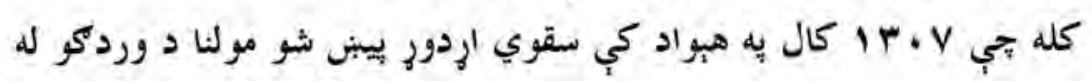

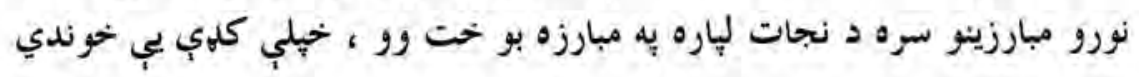




\section{rra}

د وردكو مشاهير دوهم توكى

حَاى ته بو تلي اوددي غايلي تر ختمبدو يوري يه مبارزه بو خحت وو او دهبواد د نجات يو بريالى مبارز ورو - ن

يه زره يوري ده جي مولنا نصر الله نقشبند به بجي كله هند ته له تلوســو ذوى روحاني سفرونه كول اود لويانو اووليانو يه دربارونو به حاضريده خو د خهيـل زوند او اولاد د نفقي بار هم ور يه غاره وو ثو يو وخت يب ددغه نبــفرونو يه

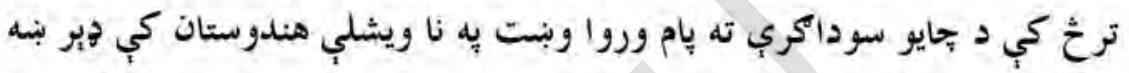

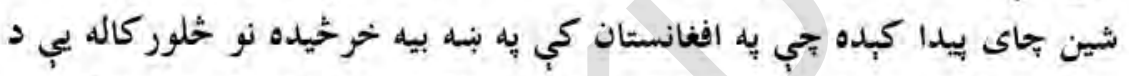

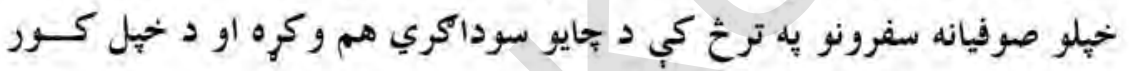
اقتصادي أرتياوي يب يري يوره كري ددغه هرخه تولوترخنك مولنا نصرالله (نقشبند) له تصوف او شعر، شاعرى

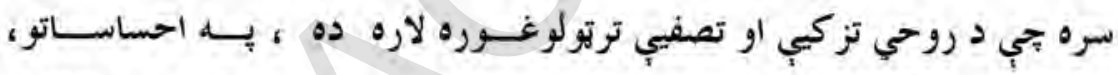

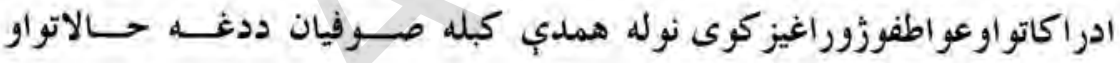
احساساتود خركندولو لهاره له شعرئه كار اخلي ، به ينحمه هجري قمري بيري كي يج حكيم ابو المجدد مجد بن آدم سنايي غزنوي او شيخ فريدالدين عطارد تصوف نازكى رمزونه او رازونه د مثنوي او شعر قالبو ته واجول او نور يبي خواجِه

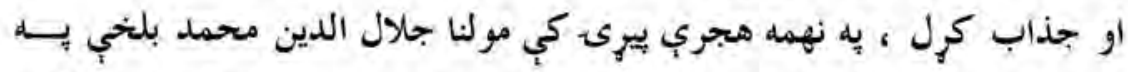
خِله نامتو مثنوي كي تصوفى خبري نوري هم مهيني ، شرينب اودل نشيني كري او به دي توتيب تصوف نور هم جلب او جذب ييدا كر ، يه يبنتو كي هم شيخ

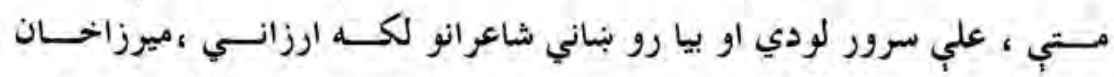
انصاري ، دولث لواني ،واصل او نورو او وريسي رحمان بابا ،كاظم خحان شيدا 
FYE

د وردكو مشاهير دوهم توكى

،حافظ اليوري او نورو كنو شاعرانو د تصوف ادبيات ايجاد او صوفيان يج بري

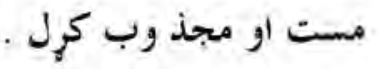

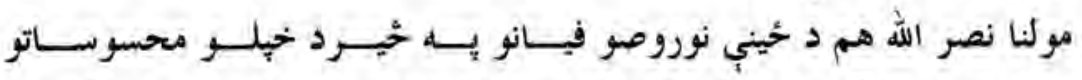

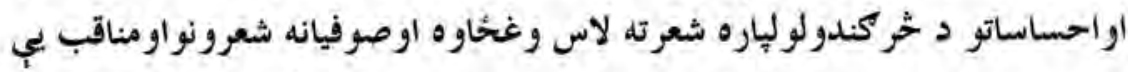

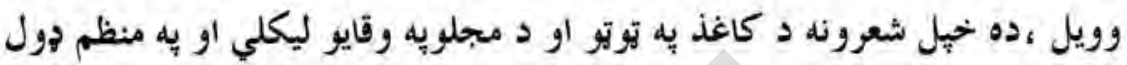

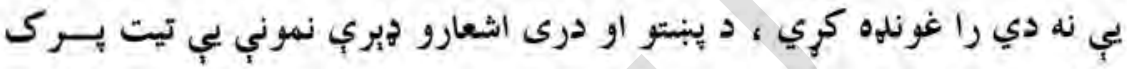

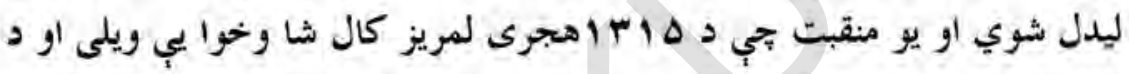

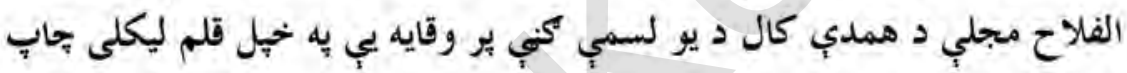
كرى دي دادي ستاسي وميخ تله يب ربدو

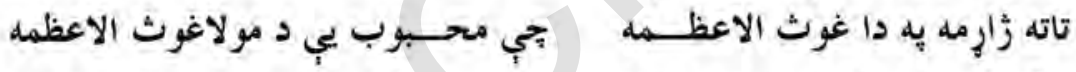

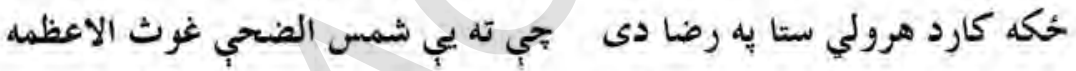

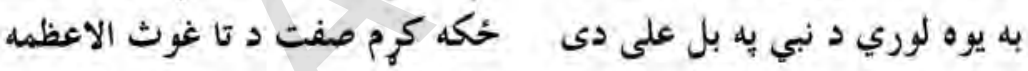

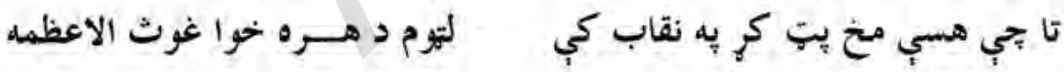

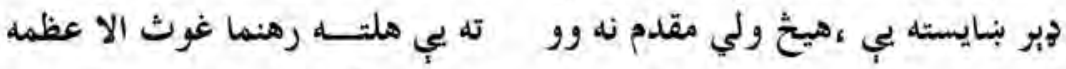

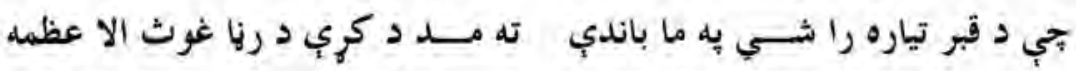

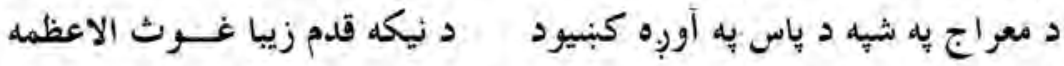

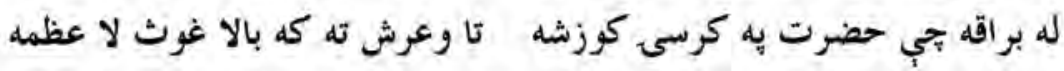

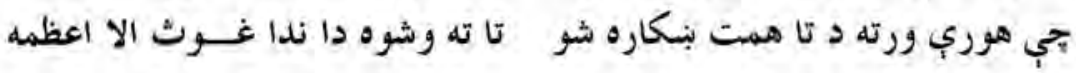

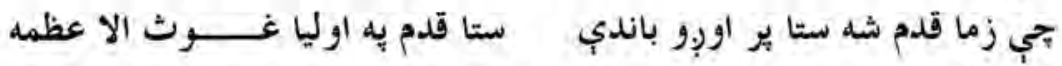

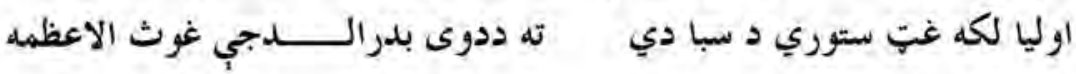


ني جي خو كى خاوري دستا ددريه سركا معزز به شــي سبا غوث الا عظمه

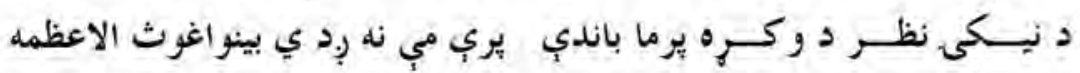
عرض مي وركره كريم خحاى ته دسيهز الىى كه هرخثيم روى سيا غوث الاعظمه

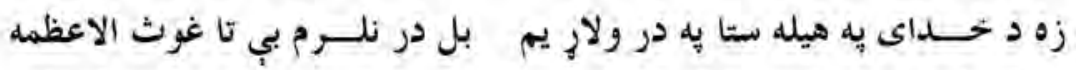

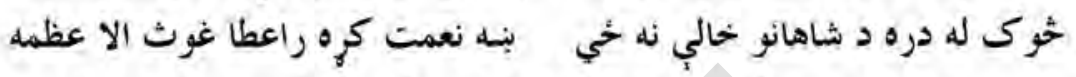
يو وار ماوته را يورته كره يه مينه دوارِه ستركي خوشنما غوث لاعظمه

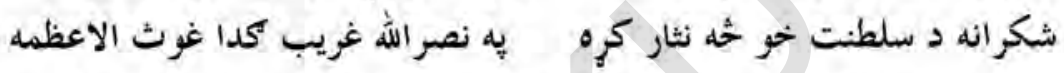

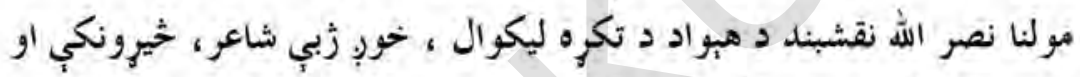

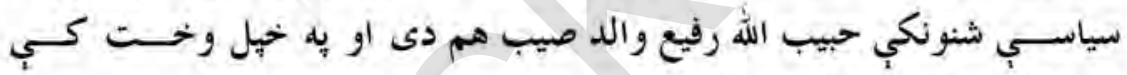
دوردكو د علماووترمنح د لوى باور جنبتن عالم تير شوى ، علماوو اونورعـام ولس به د هغه زيودرناوي كاوه .

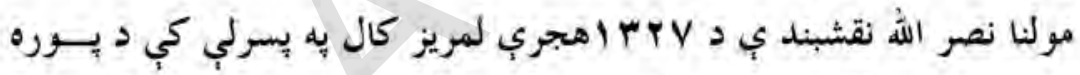

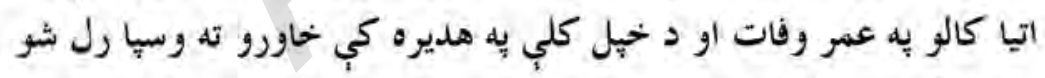
مولنا نصر الله نقشبند ي نه دري زامن باته شوي دي :

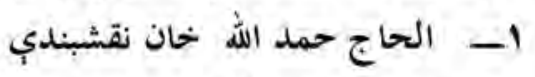

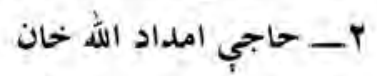

r- خيرندوى حبيب الله رفيع د هيواد نامتو ليكوال شاعر او خيرونكى. 


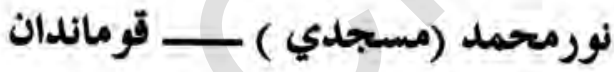

نورمحمد (مسجدي) د هيواد له نومياليوملي يوليسو نه وو، جي خيل تول عمريب د خلكود امنيت پيه تآمين

$$
\text { اود ملي يوليسويه روزنه كي تير كرى دي دي . }
$$

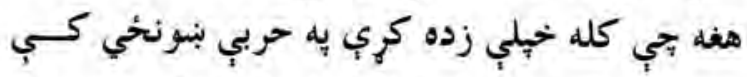

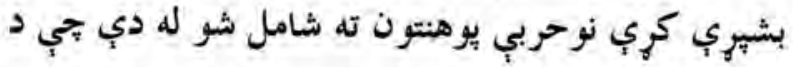

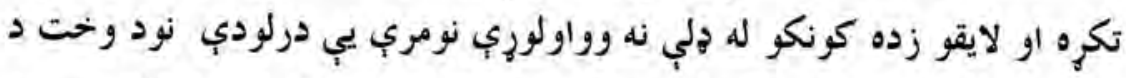

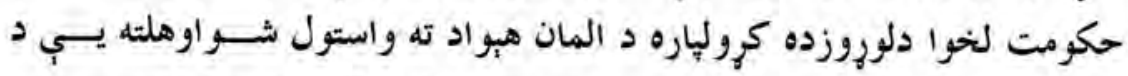
يوليسويه خانكه د لِّسانس تردرجي يوري تحصيلات وكرل او يه برياليتوب سره

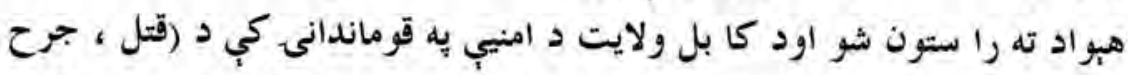

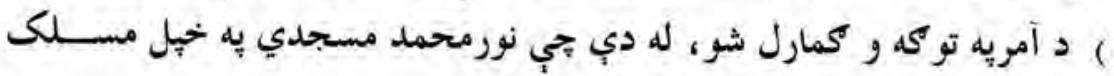




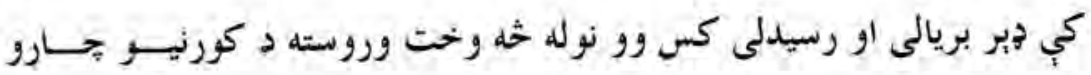

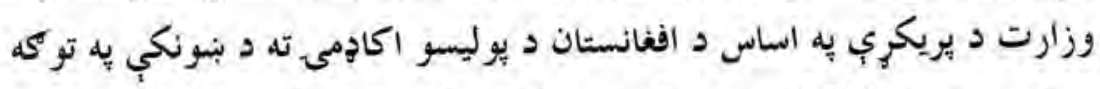

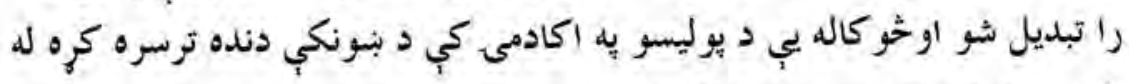

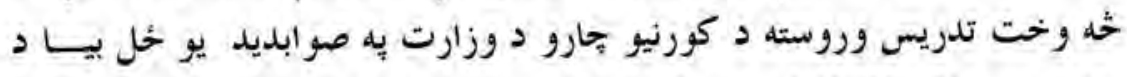

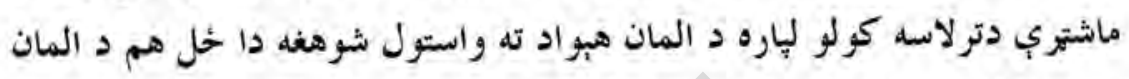

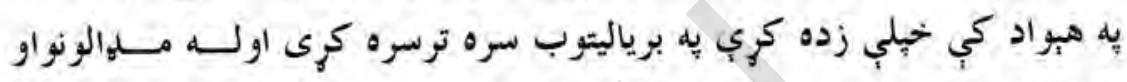

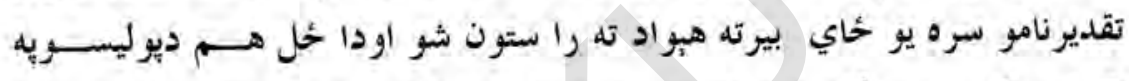

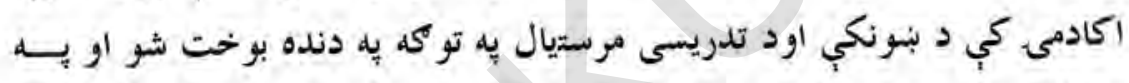

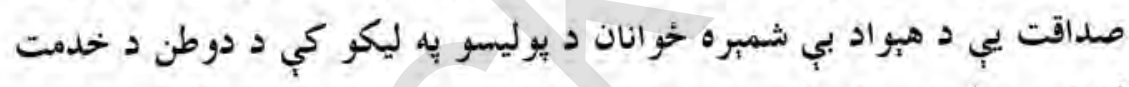

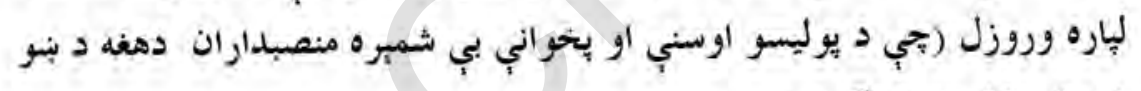
خدماتو شاهدي وركوي)

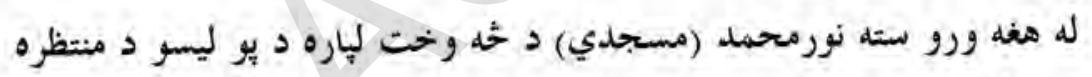

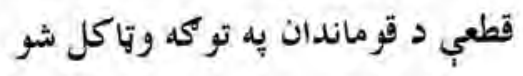

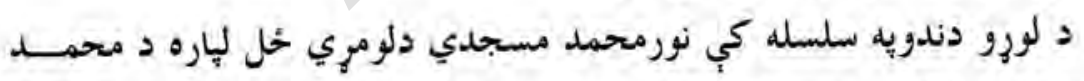

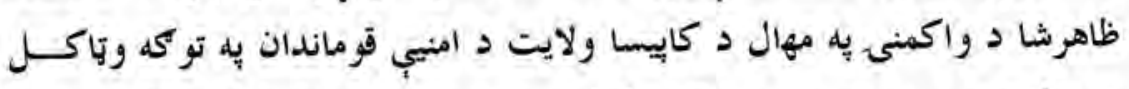

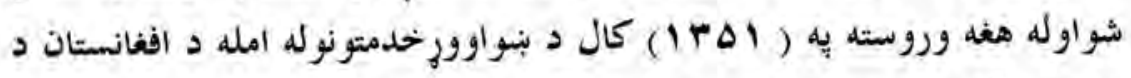

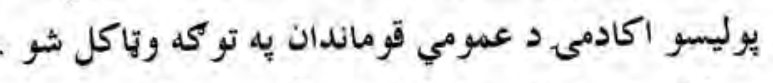

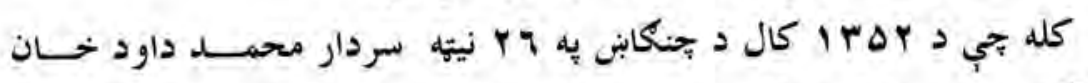

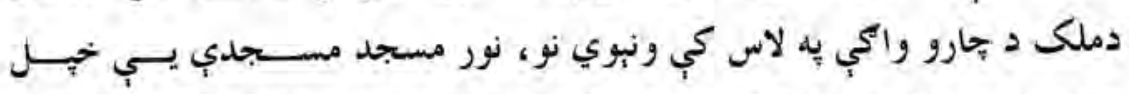

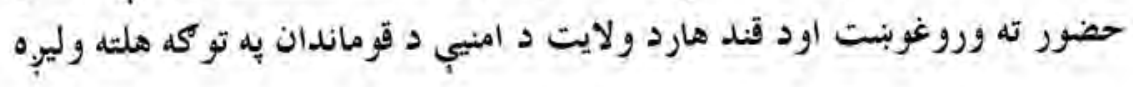


r

دوركى مشاهير دوهم ترك

نورمحمد مسجدي تواوبردي مودي يوري يه قند هاركي د امنيب د قوماندان

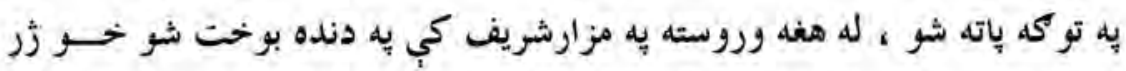
بيرته د امنيب د قو ماندان يه توكه غورات ته وليرلٍ شو خو كاله يب هلته تيركرل

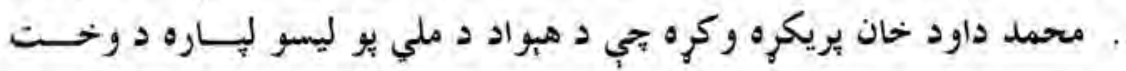
اوزمان له غوبنتنو سره سم يه ملي او نهيواله كجه نوي قوانين جوركري نو يبي نور محمد خحان مسجدي د غورله ولايث نه را وغوبنست اود يوليسو لِاره د قانون جورولو د كميسيون مثشر يب وتاكه ترخو د يو ليسو لياره يه نريوالومعيــارونود برابر قانون مسوده جوره شوه او دكورنيو جارو د وزارت مقام ته د نورو اجراتو لياره وراندي شوه .

له بلده مرغه دا وخت ديوشمبرسياسي بلدغونيو لخورا د افغانســــان قـــانوني

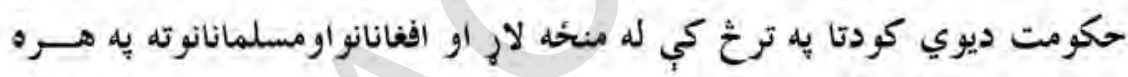
برخه كي د خطرزنك ورهل شو نورمحمد مسجدي له كمونستانو سوه ددندي له اجرا نه كلكه جه وه و كره أو

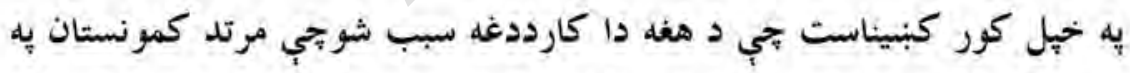

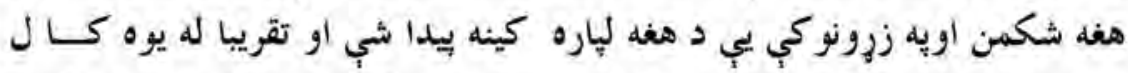

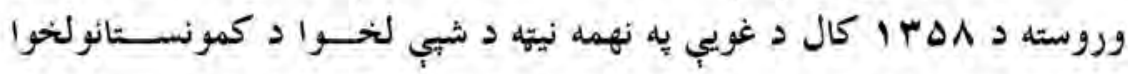

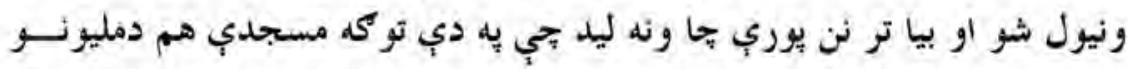
شهيدو هبوادوالويه دله كي د شهيدانو له قا فلي سره يو خاي شو.

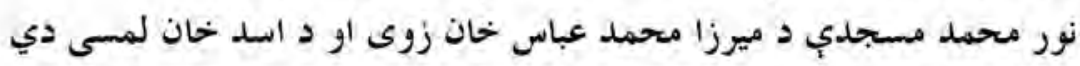

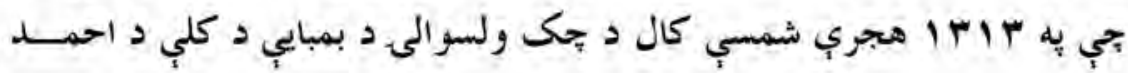


خيلو يه محله كي زيوبل دلي دي ، دهغه والد صاحب د محمد ظاهرشا يـهـ دوران

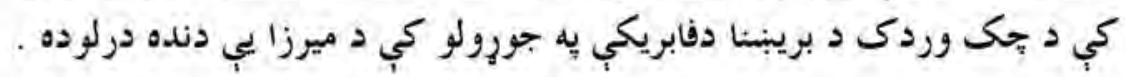

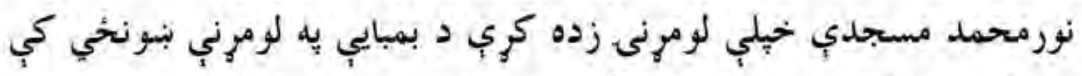

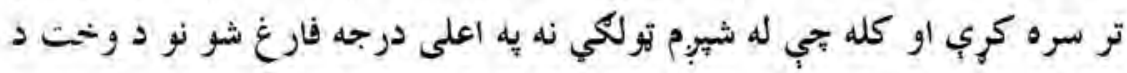

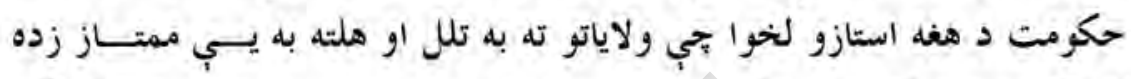

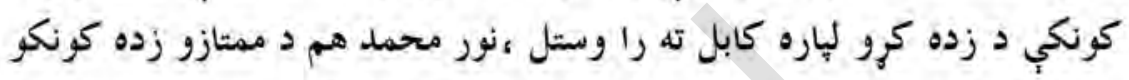

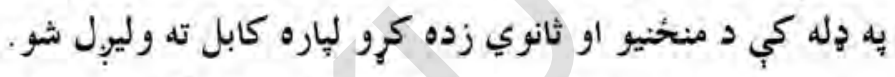

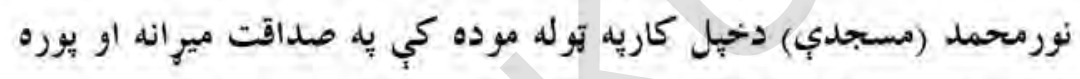

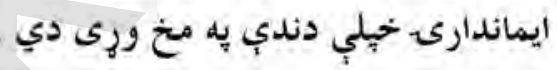




\section{هميشه كل - م قوماندان}

هميشه كمل د جميعت اسلامي د تنظيم د وردكــو د

سيد آباد ولسوالى قوماندان اومسوول وو .

كله تجي د ثور كودتا رامنحه ته شوه نوهميشه كال

د هرات ولايت د فرقي يه تشكيل كي د جكتررن دنده درلوده ،كودتا دهغه يه روحياتو د نورو مســلمانانويه

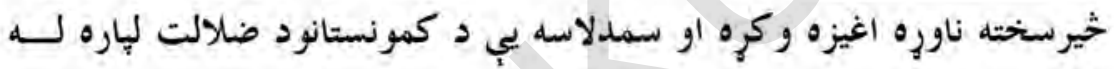

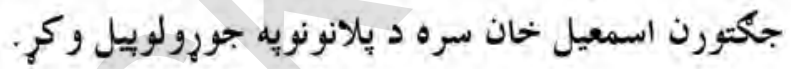

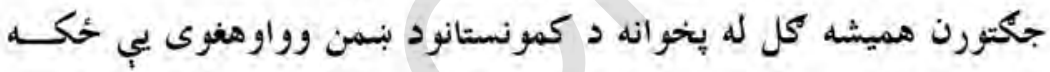

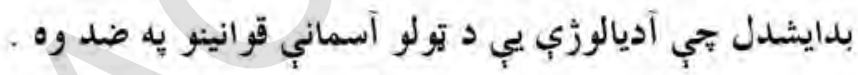
كه خه هم دهمدي كال د د ينكابن يه مياشت كي دهغه جكرنى ته د توفيع

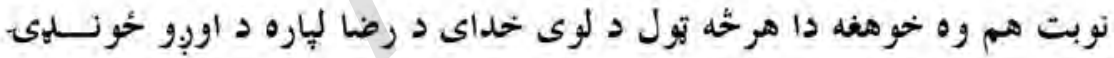
كرل او جهاد ته بي ملا وتئله .

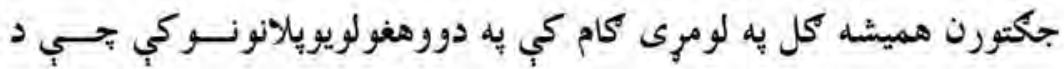
كمونست رزّيم د را يرزولو لِاره د هر ات يه فرقه كي طرحه شوي وه عمــلا

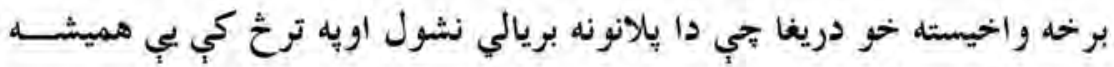
كل افشاً اودملك يريبنودلواو مسلحانه جهاد ته اروورت جكتورن له هرات نه لو مريى ايران او له هغه حخايه د هجرت وطن ته ولأر 
حُكه دا وخت يه وردكوكي د كمونستانو واكمني وه خوله لوبمودي وروسته

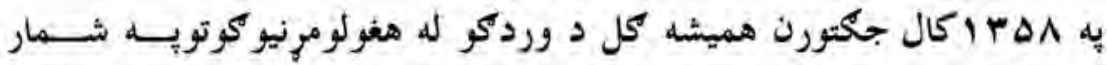

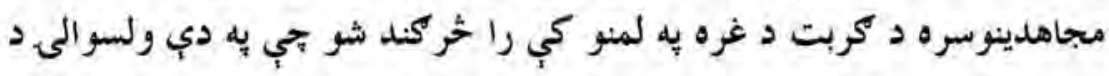
جهاد موسسين وه. جكتورن هميشه كل د عبد الله خان زوى او يه هب ها با هجري شمسي كال د سيد آباد ولسوالى د شنيز ددري د ملي حيلو د كلي يه يوه متلديثه كورنى كي

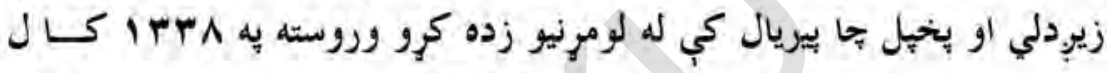

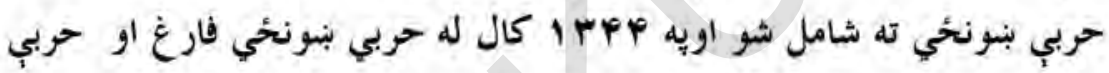

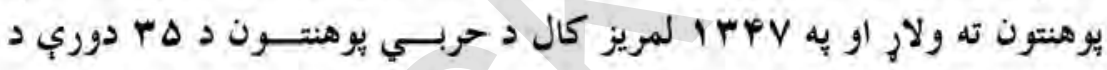

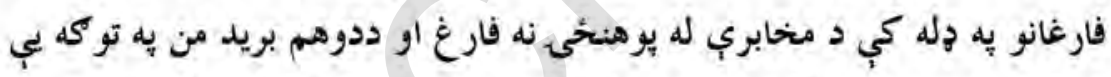

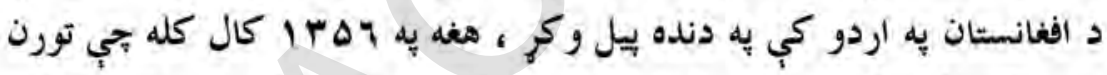

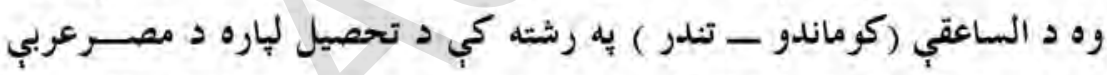
جمهوريت ته ولارج او د زده كروله بشهرولو وروبسته بيرته هبواد ته راغسيى او ديوه بريالي صا حب منصب يه تو كه يب د جكتورن يه رتبه د كوماندو د ه ه قطعي د مخابرب د آمر به تو كه وتاكل شو تر هفه هي د غويب خونرى كودتا را

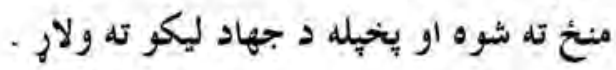

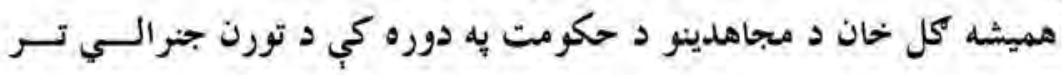

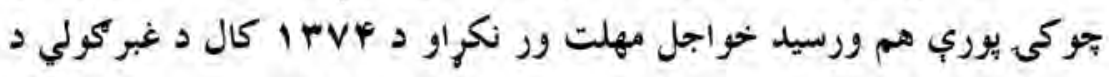

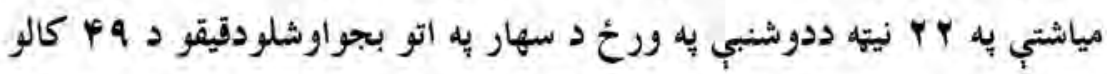
يه عمر د يوه نا حو انمردانه او غير عادلانه عمل يه تو خُ كي يه شهادت ورنسيد. 


\section{هم-تـت بابا}

هدــت بابا يه قوم آدين خيل ورد كى او دجفتو د محمد قلي دكلي نيكه د

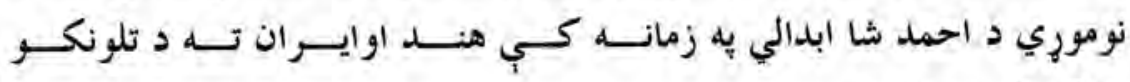

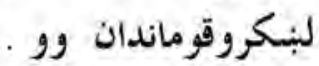

همت بابا نه يوازي يوتكره قوماندان تيرشوي بلكي فزيكل يوقوى اوغبنـــلي يهلوان هم تيرشوى دي ، له دي جي كلك همت ناك سري وو نوله احمد شا

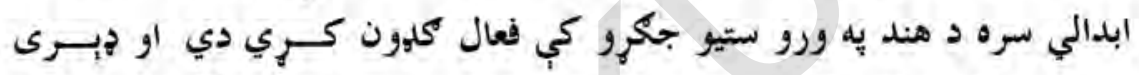

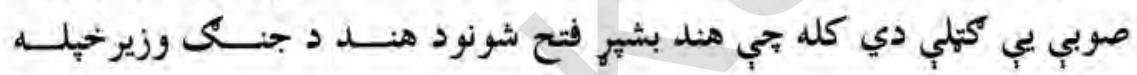

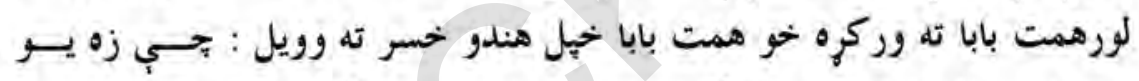

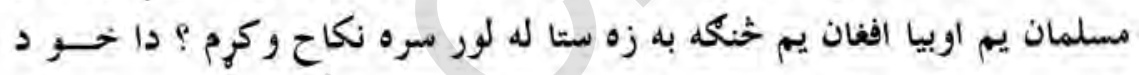
مذهب يه اختلاف ماته نه روا كيربي .

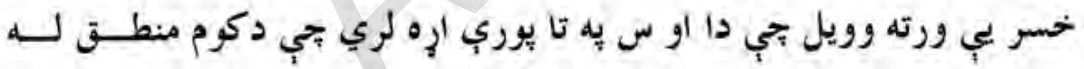
لاري زما لورخيلوديني اوملذهبي اصبولو ته يه اعتقاد قانع كولى شب ماخو دادي

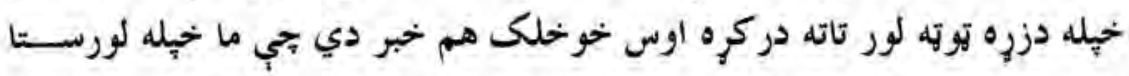
يه نامه مي كرى ده ، ، نوته اوس داسب بهاني مه جوروه جي ستا له ارزبنتونو سره

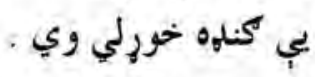

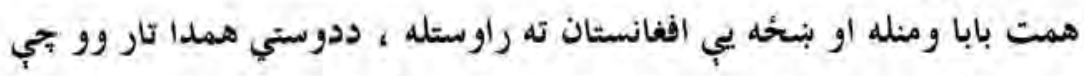

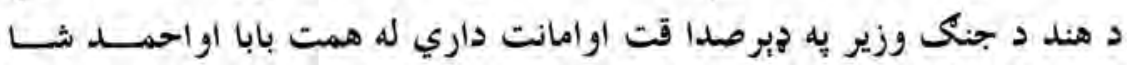
ابلدالي سره بيعت وكر او له دوى وروسته يبي له نيول شويو سيمو اوحايو نه يه رينتينولي حراست اوياسلاري وركره . 
هندو بنخخه كله بتي افغانستان تله را وستل شوه ، نوخلكو به همت بابا ته ويل

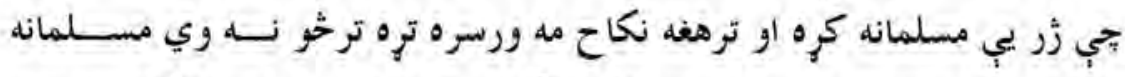

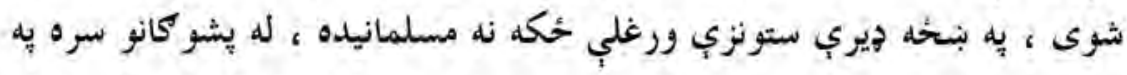

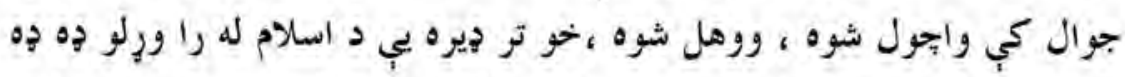
وكره ترهغه بحي به لطايف الحيل د منطقي دلايلو يه رنها كي د السالام يه سبيخثلي دين مشرفه او مسلمانه شوره خو بيا جيره تينكه مسلمانه وه . بل خل كله بحى همت بابا ايران ته به نظامي سفرولارنو تصادف د ايران د جنيك لئل

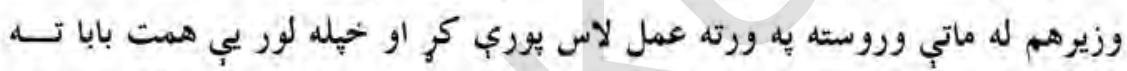
وريه نكاح كره خو د ايران د جيكى د وزيو دا عمل يوه خدعه وه نو خكه له دريو

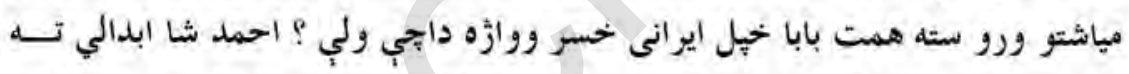

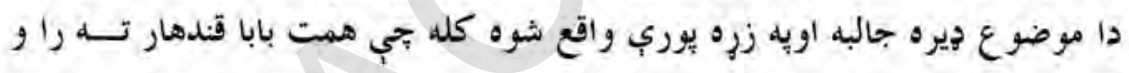

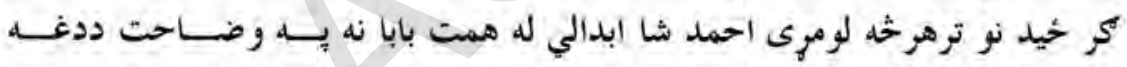

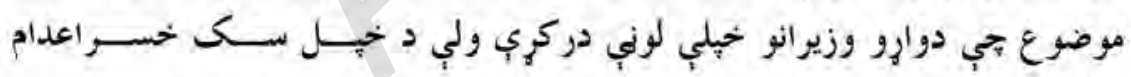

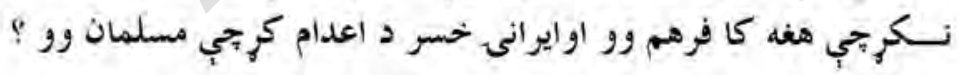
همت با با سخت وخندل او داحمد شا ابدالي ته يب وويل : عاليجنابه ! خبره يه كفراو اسلام كي نه وه ، خبره يه ربنتينولي او منا فقت

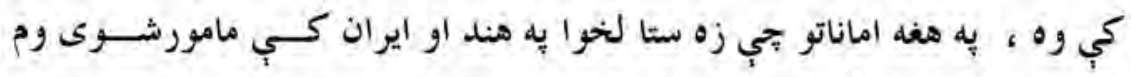
دهند د جنك وزيرلكه يجي تاسوهم شاهد واست يه يوره صداقت ،ايمانداري او ربنتينولىله مورج سره بيعت وكرخو د ايران د جنك وزيوبيا له ييل نه زموزج سره

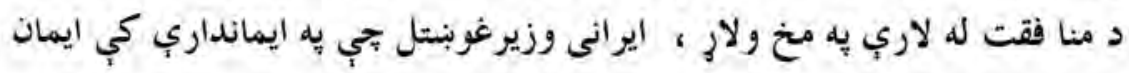


ret

دوركو مشاهير دوهم ثرك

تر يبنو لاندي كري او يه دو ستى كي (درز) رانه يورته كري نوخيكه مي مركر، لوريب هم يه منا فقت را كري وه او بيعت يب هم يه منا فقت را سره كري وو. هدت بابا د احمد شا ابدالي د حكومت يه ورو ستيو كي د هغه يه دربار كي

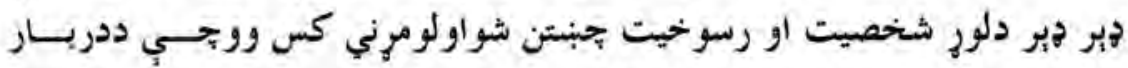

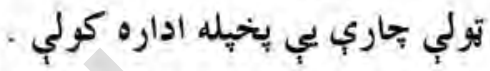
يوه ورخح له ورخود احمد شا ابدالي در بارته د باركزيود قوم يومقتدراومخور

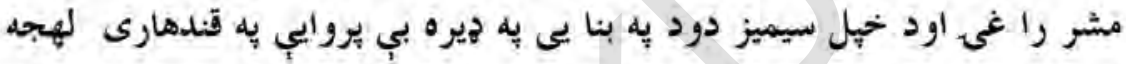
د احمد شا ابدالي يوبنتنه وكره او وريل امله (احمدشا) جيري دي ؟

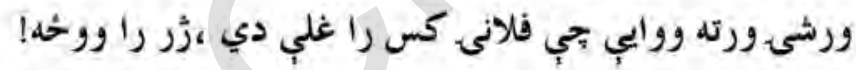

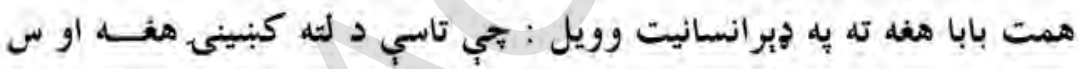

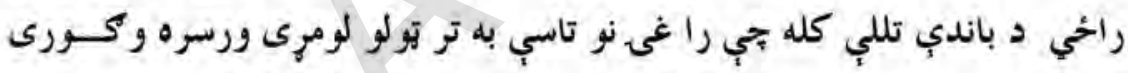
خو را غلي - خحان ؟ د خهلو فطري خواصو يه حكم يه دِبرلور آوازتول درباريان مخحطب كرل درحفلي دمور د....... رٔر هغه ته ورناري كرى دستركو يه رب كي دهمت بابا توري هوا وخيرله او دو ر اغلي بذغوني سرله

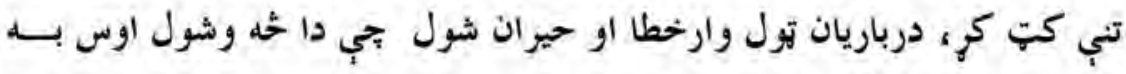
احمد شاه ابدالي خهه وايب؟ دا خو د باركزيود قوم مشر ور ، خو كله جي احمد شا ابدالي راغي او بيبنه يــي

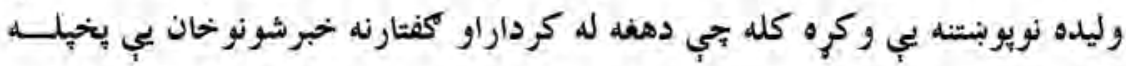




\section{rro}

د وردكو مشاهير دوهم توكى

ملامت و كانه او وويل : تجي د كور كلي جحمونه يه شا هي دربار كي ؟؟ ، بنسـه ده ، متاسبه سزا مو وركري ده.

له هغه ورو سته د احمد شا ابدالي له يلوه همت بابا ته د خحانى يو داسي فرمسـان

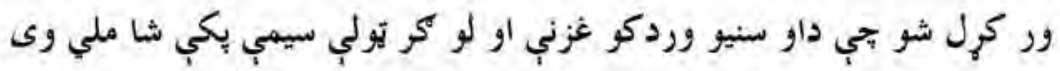

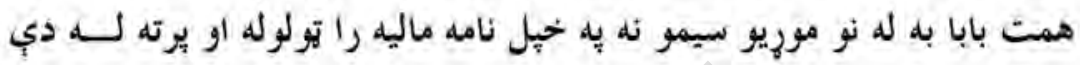
يجي مركزي حكومت ته بي وسياري توله بله بي يه خحله مصرفوله .

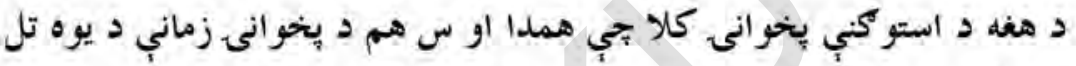

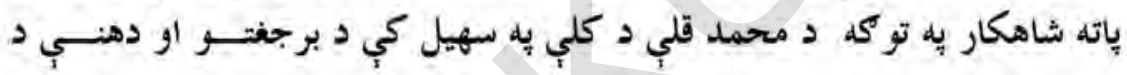
خورونو ترمنح مو قيعت لري ، مو جوده ده ، خو ية خواشينى سره جي دا كالا

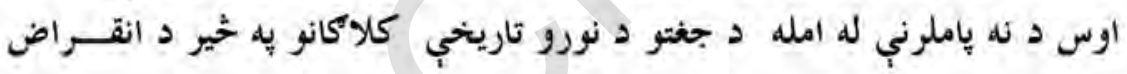

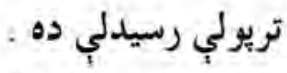
د همت بابا د يلار نوم قلندرخان و جي به سنلهاور كـي اوســيده او دوي ميرمني يب درلودي جي يوه بي كرانه او بله نا كر انه وه يوه ورخح احمدشا ابدالي

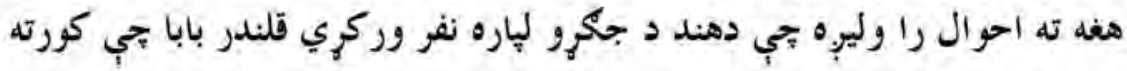
راغى نو له خهلوميرمنو سره يب سلا وكره بجي د كومي يوب زوى يب له احمد شا

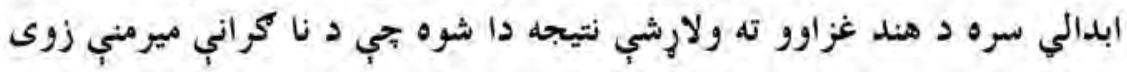
يب تجي همت نوميده له احمدثا ابذالي سره هند ته ولار ثي خو د هغه دا تلـلـل

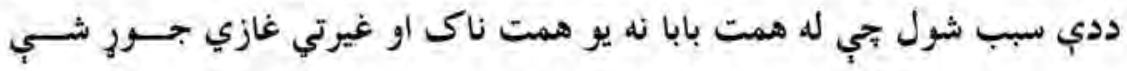
داسي غازي بحي كارنامي يب تل ياته د تاريخ يه يانو او د زبو يه سر زمزمه ثي. 


\section{داكتر عبدالوحيد (حسن)}

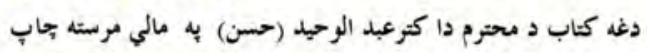

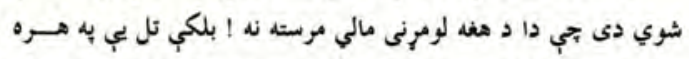

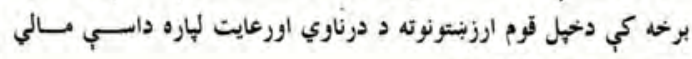

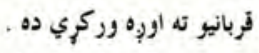

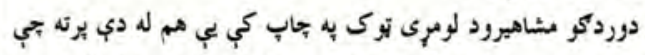

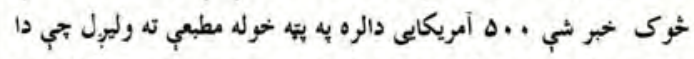

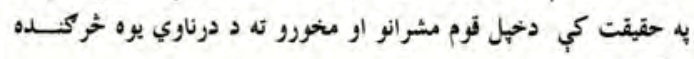
بلكه كنيلى شر.

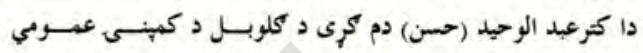

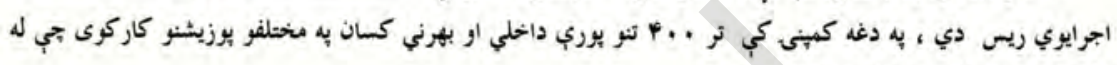

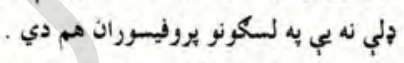

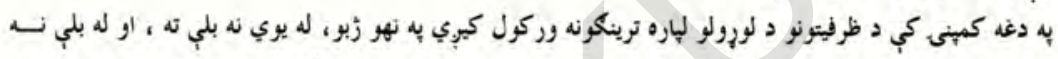

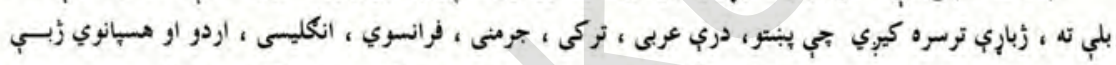

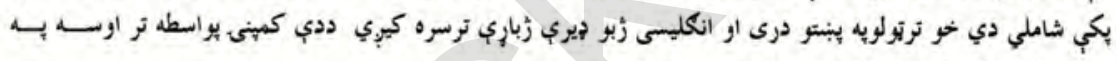

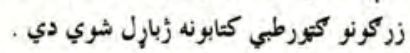

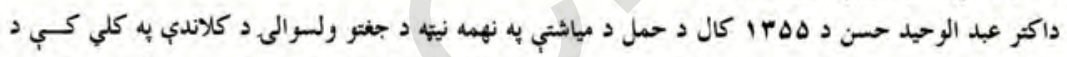

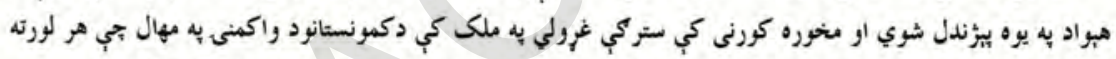

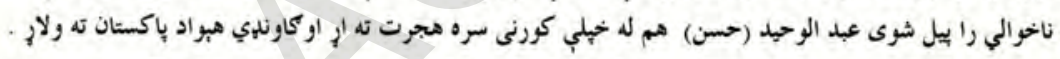

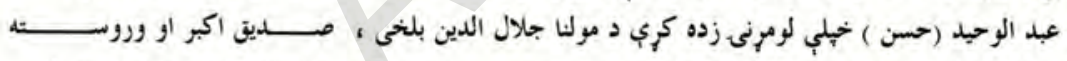

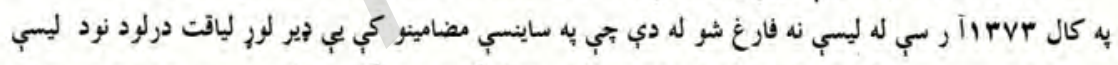

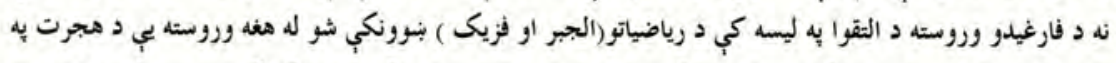

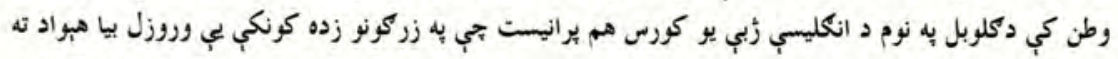

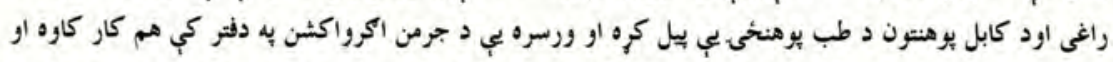

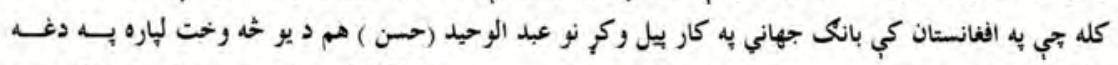

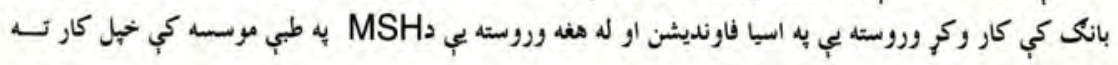

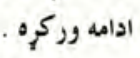

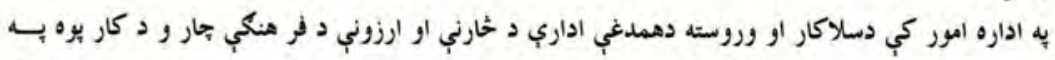

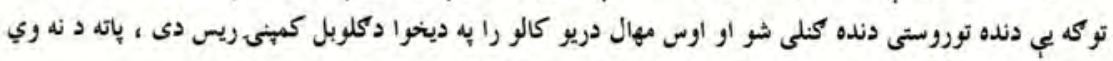

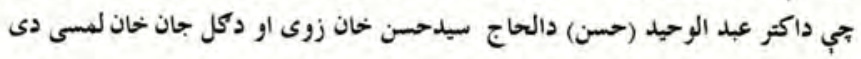




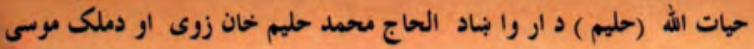

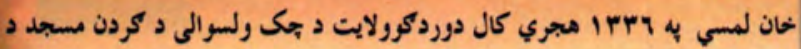

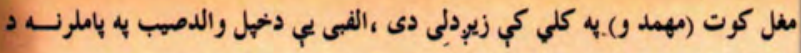

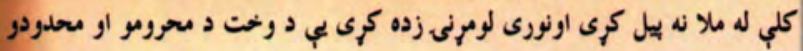

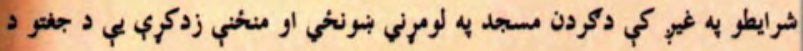

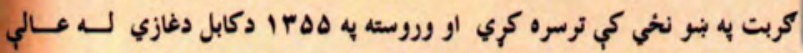

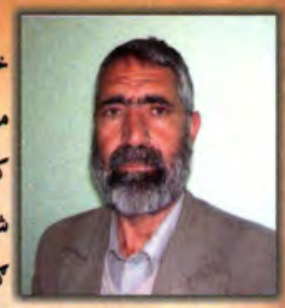

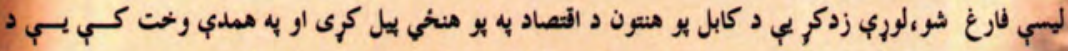

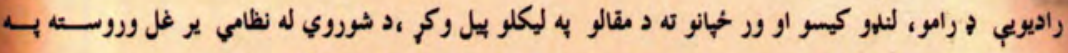

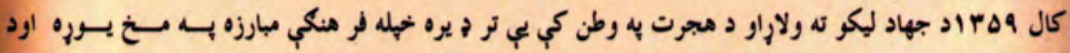

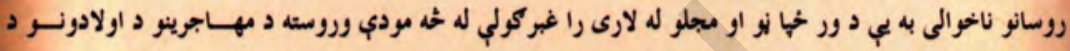

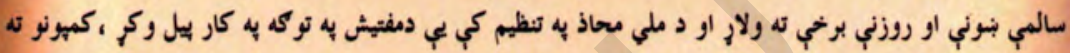

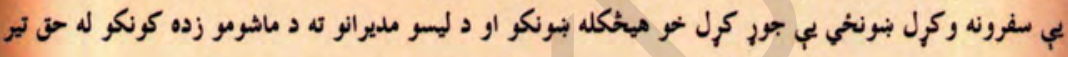

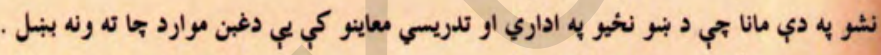

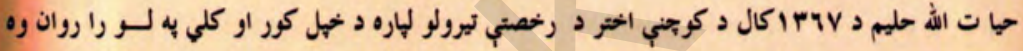

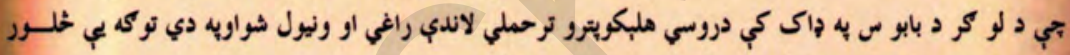

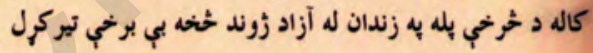

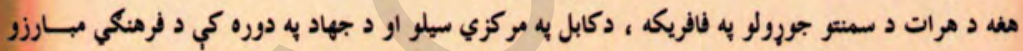

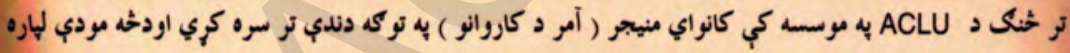

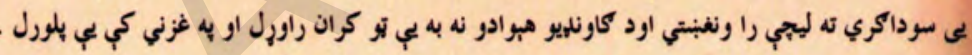

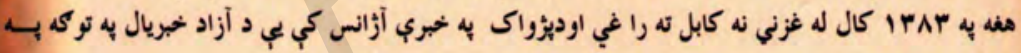

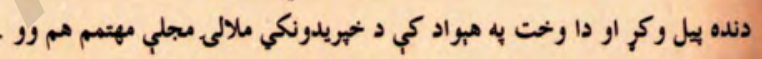

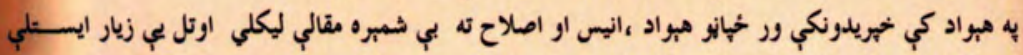

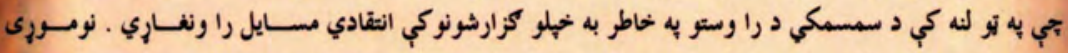

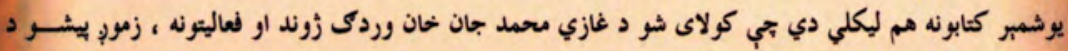

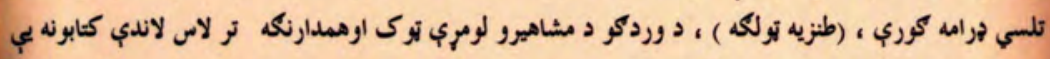

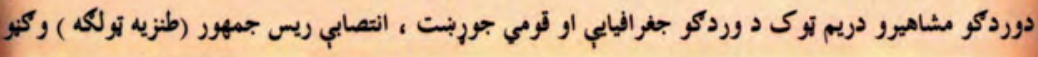

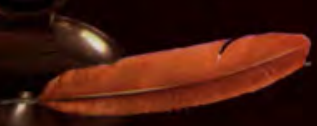

